DEPARTMENT OF THE INTERIOR

UNITED STATES GEOLOGICAL, SURVEY

GEORGE OTIS SMITH, DIRECTOR

Profegsional Paper 64

THE

\title{
YAKUTAT BAY REGION, ALASKA
}

\section{Physiography AND GLacial GeOLOGY \\ BY}

RALPH S. TARR

- AREAL GEOLOGY

BY

RALPH S. TARR AND BERT S. BUTLER

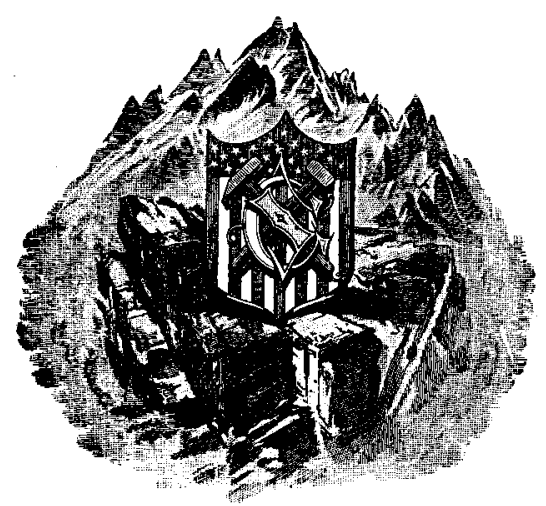

WASHINGTON

GOVERNMENT PRINTING OFFICE

1909 


\section{CONTENTS.}

Part I. Physiography and Glacial Geology, by Ralph S. Tarr.

Chapter I. General physiography

The coast and the mountains.

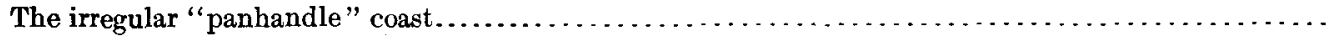

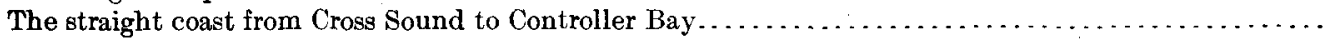

The mountains.

Yakutat Bay Inlet.

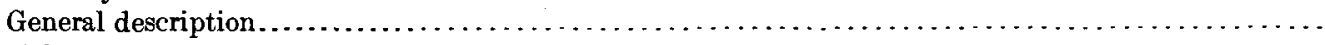

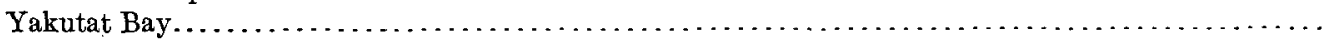

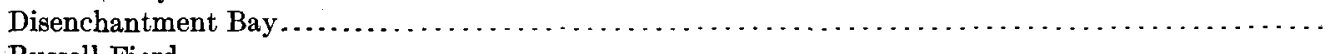

Russell Fiord.

Extent and character...

Northwest Arm of Rusell Fiord

Nunatak Fiord. . . . . . .

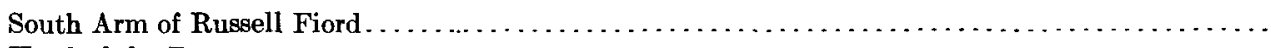

Head of the Bay...

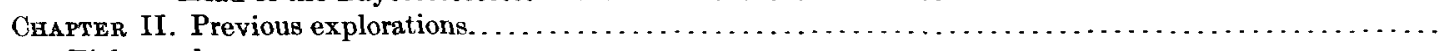

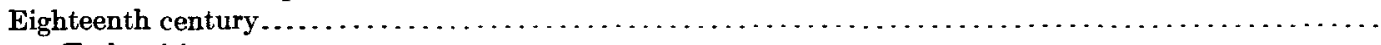

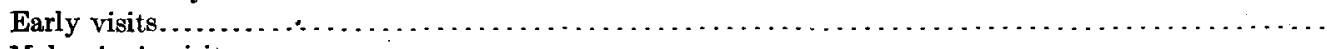

Malaspina's visit.

Puget's visit.

Position of Hubbard Glacier front in 1792 and 1794.

Russian occupation.

Nineteenth century

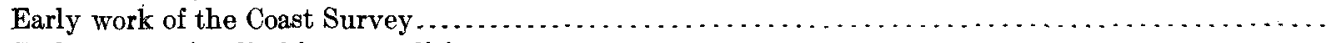

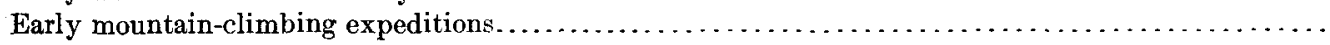

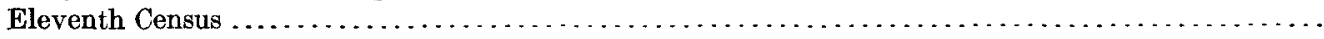

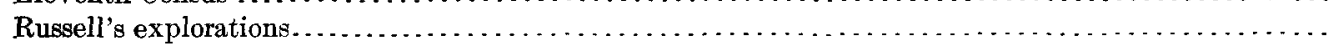

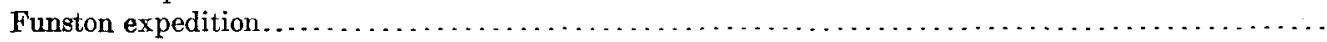

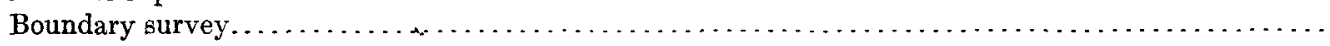

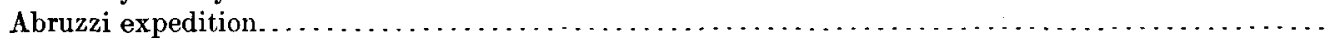

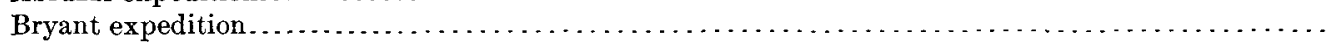

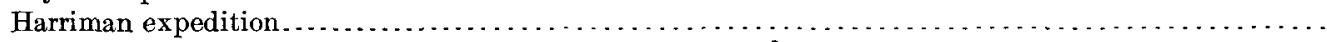

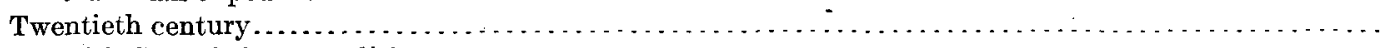

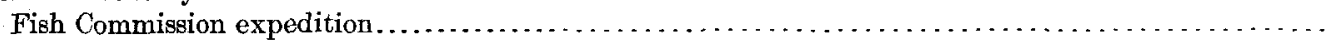

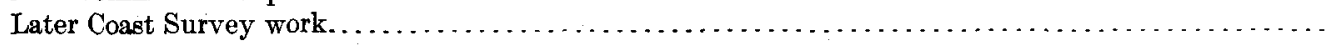

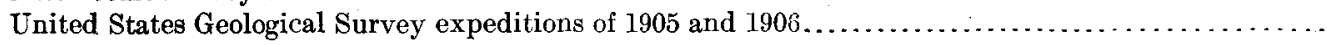

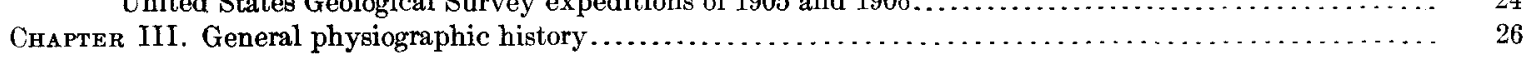

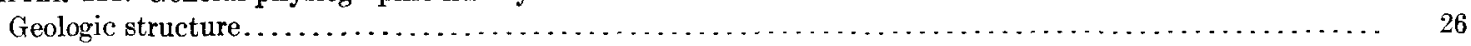

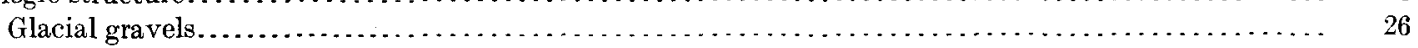

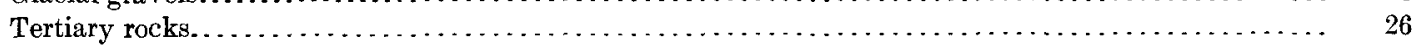

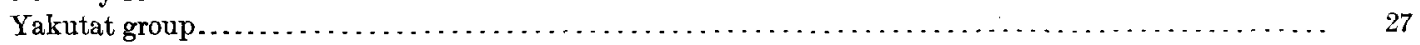

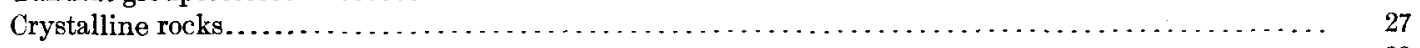

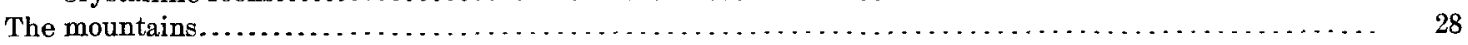

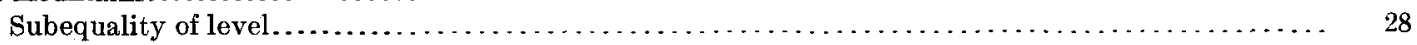

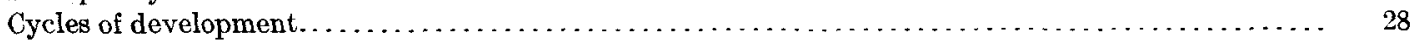

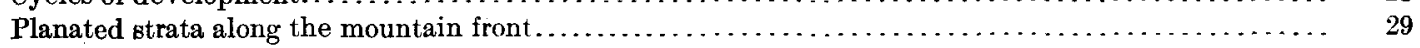

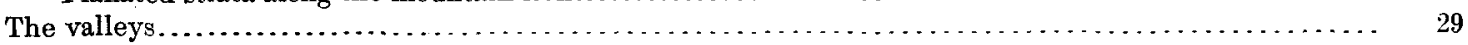

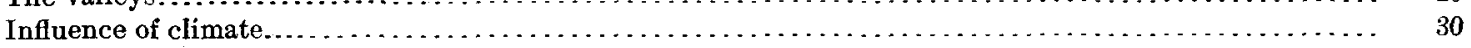

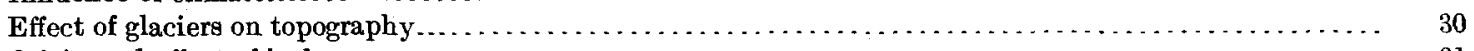

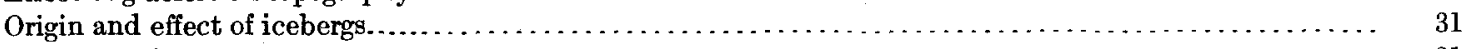

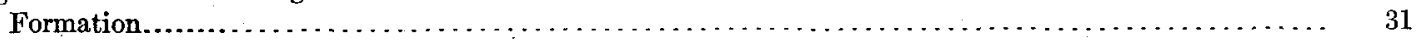

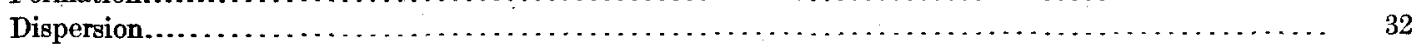

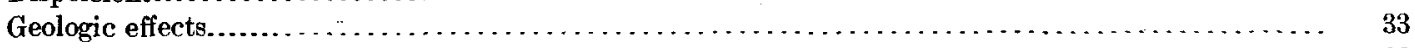

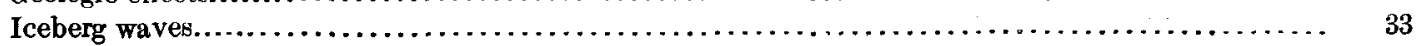




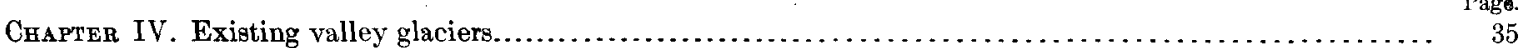

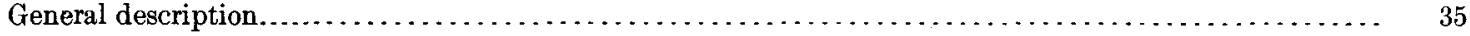

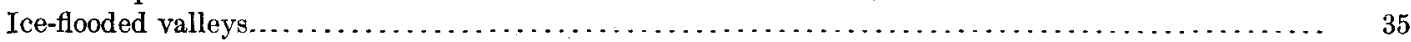

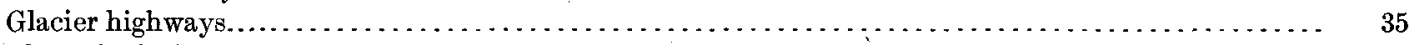

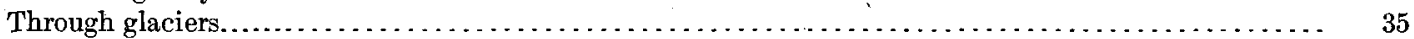

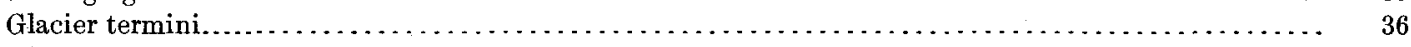

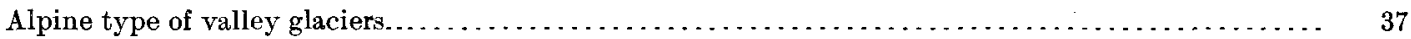

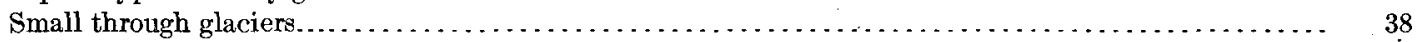

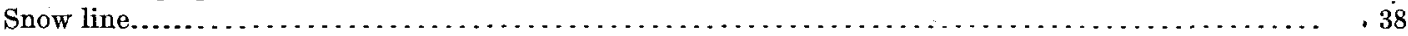

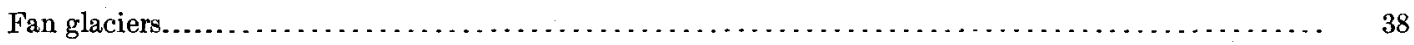

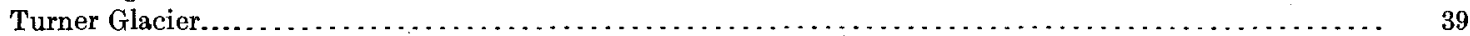

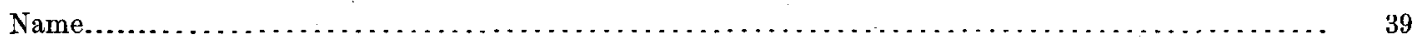

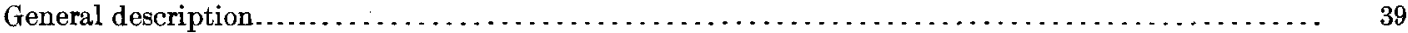

Fan-shaped terminus................

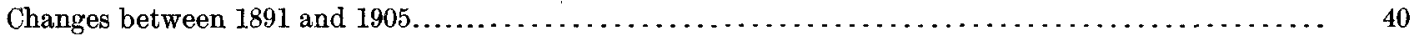

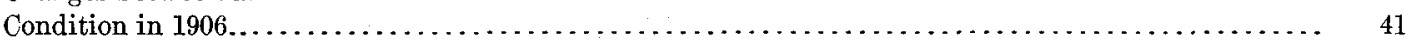

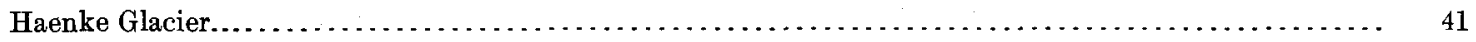

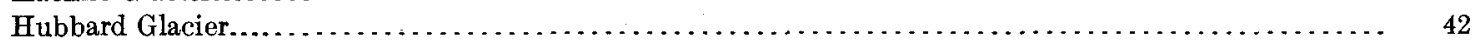

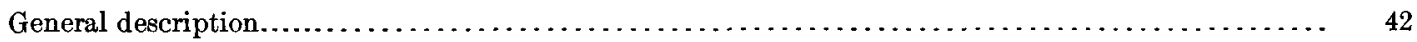

Relation to Variegated Glacier................................................... 43

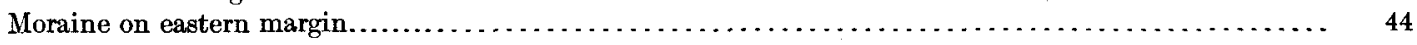

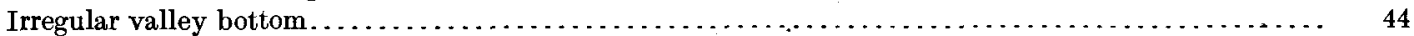

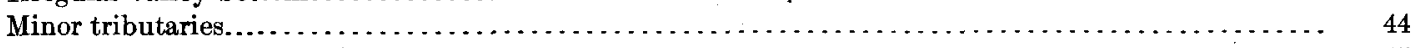

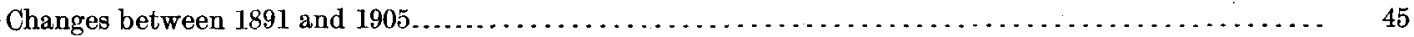

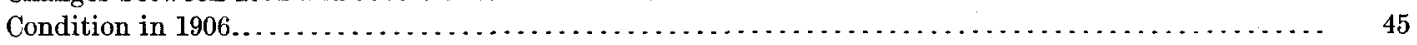

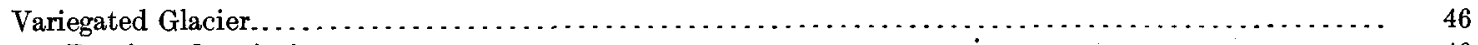

Previous descriptions. . . . . . . . .

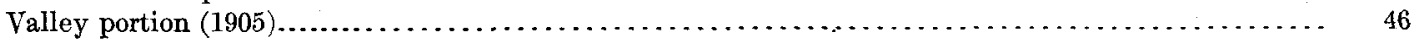

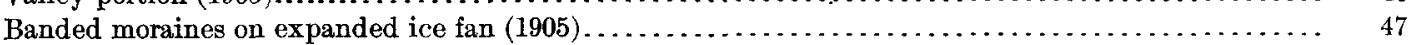

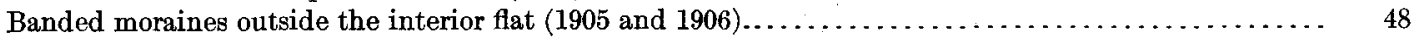

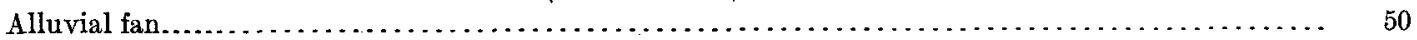

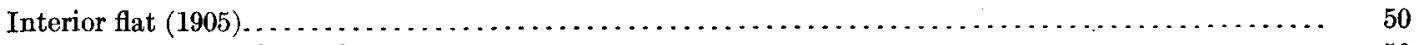

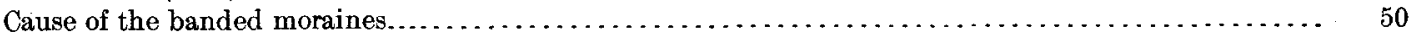

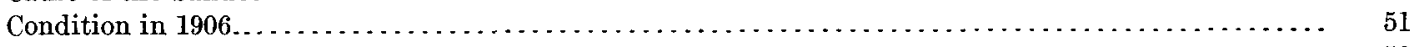

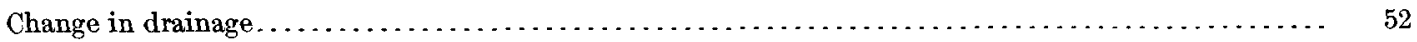

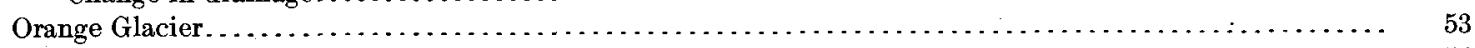

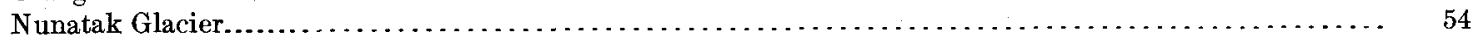

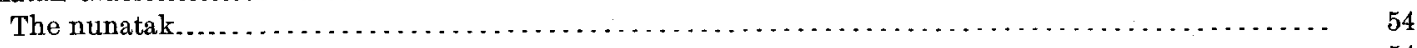

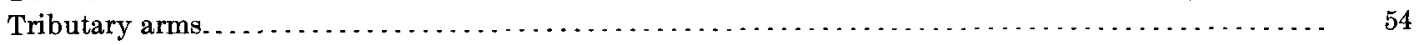

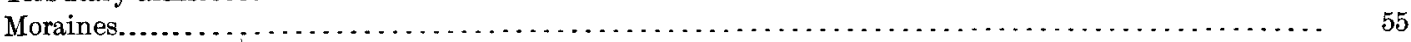

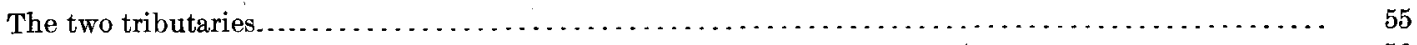

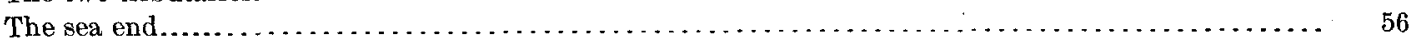

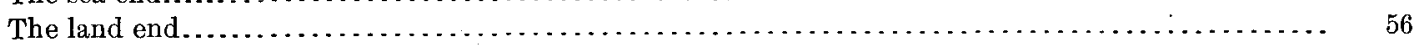

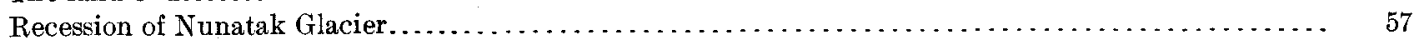

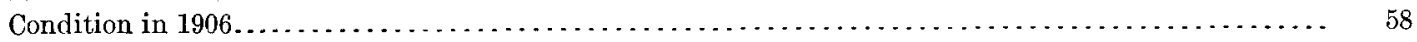

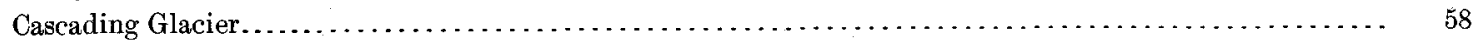

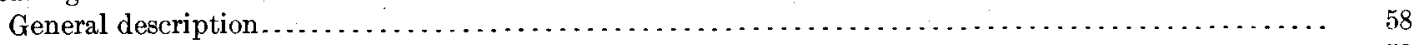

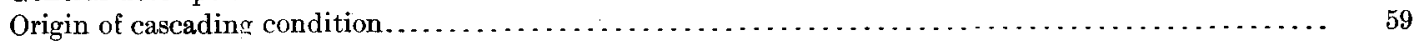

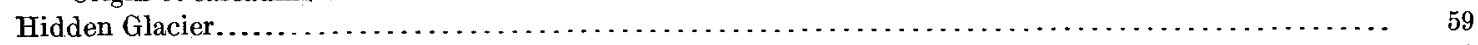

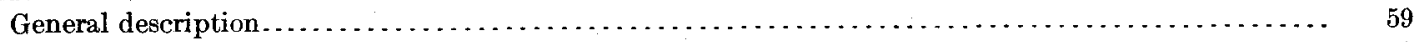

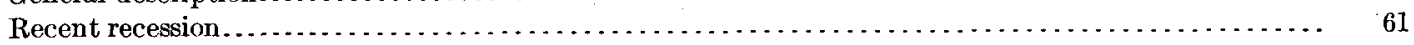

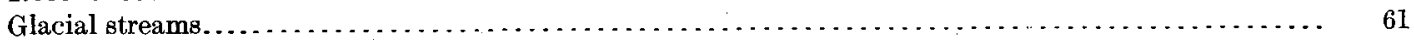

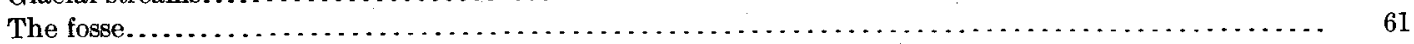

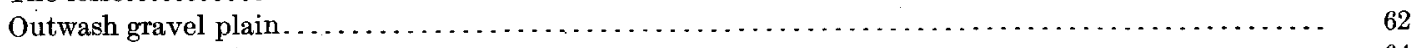

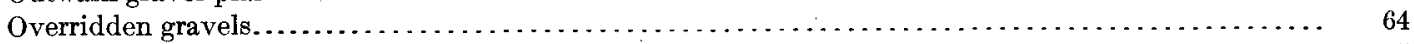

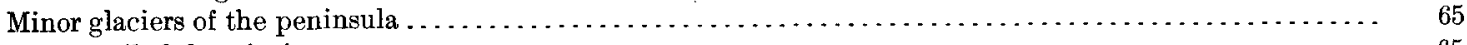

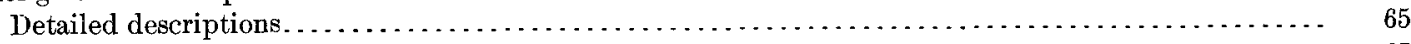

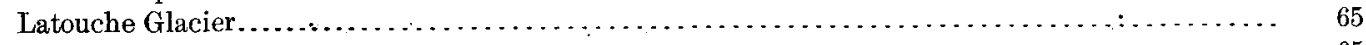

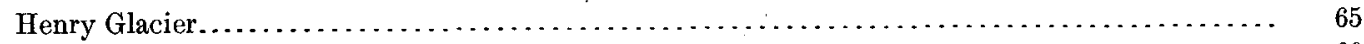

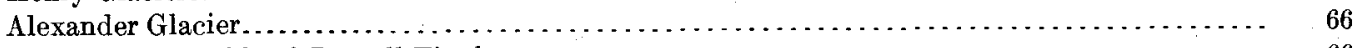

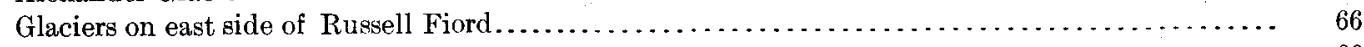

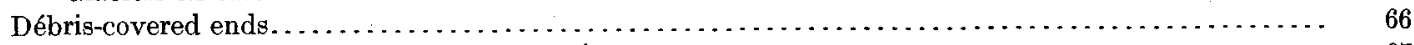

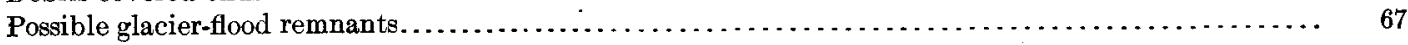


Chapter IV. Existing valley glaciers-Continued.

Fallen Glacier.

Page.

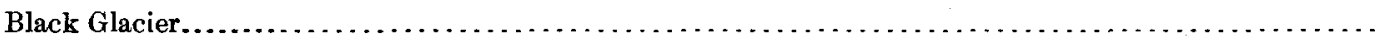

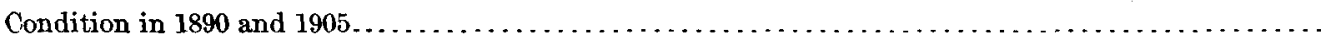

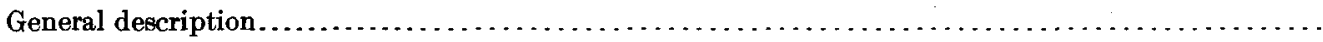

Glacial erosion.

Galiano Glacier.

Expanded ice bulb or fan

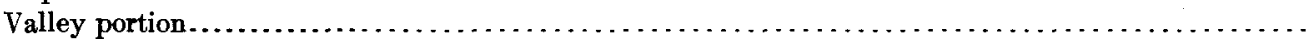

A valanches.

Changes in the glacier

Alder-covered moraine

Alluvial fan.

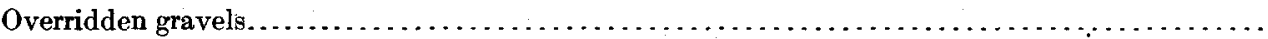

Former forest.

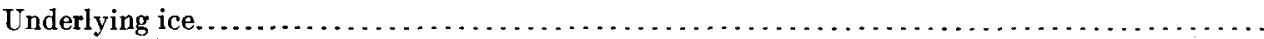

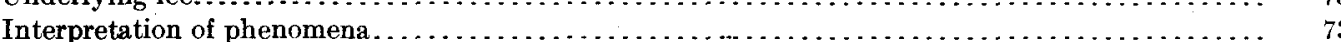

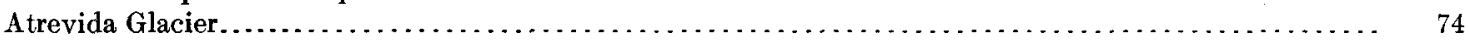

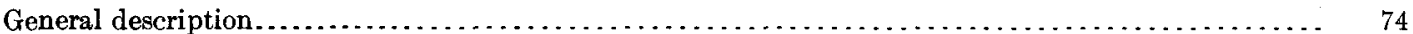

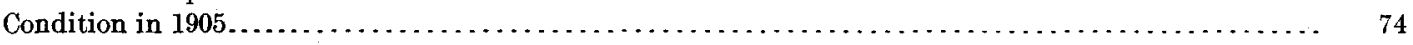

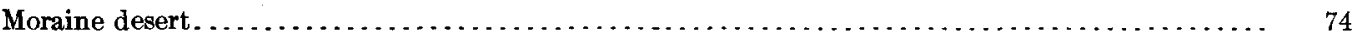

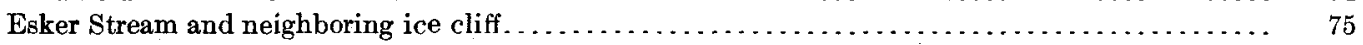

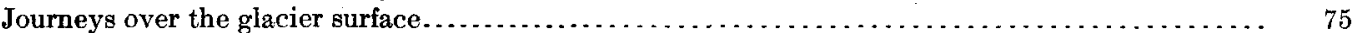

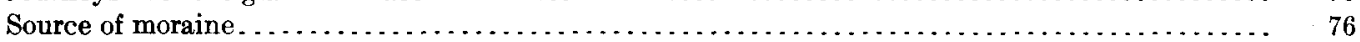

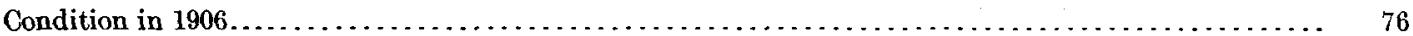

Interval between visits. . . . . . . .

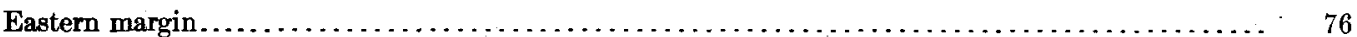

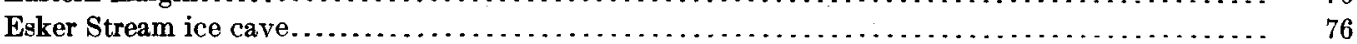

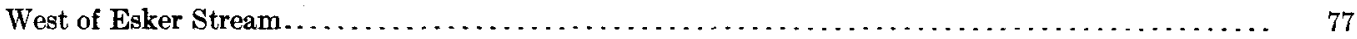

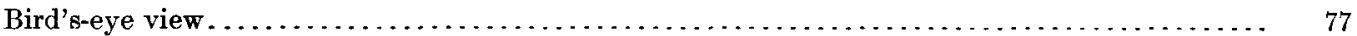

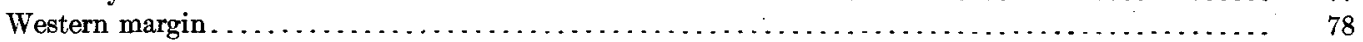

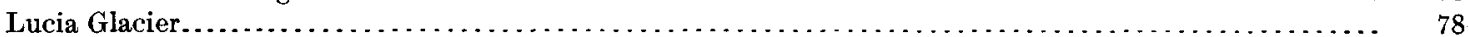

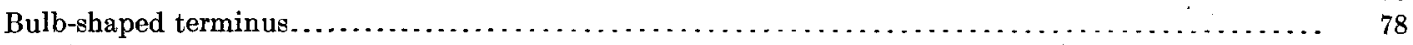

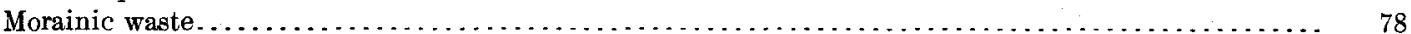

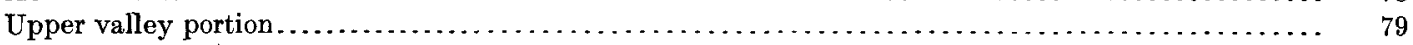

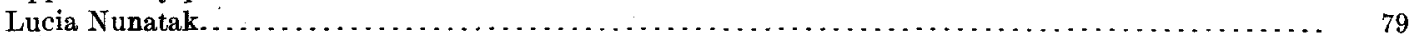

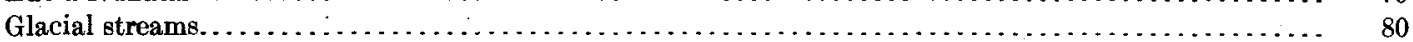

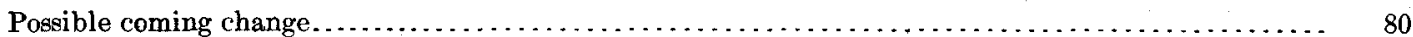

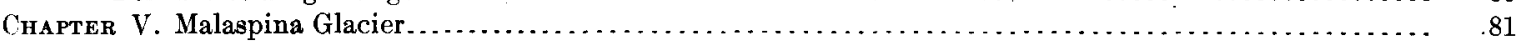

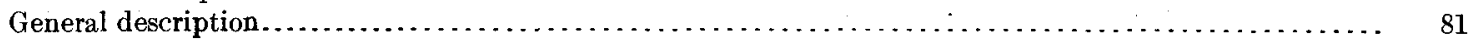

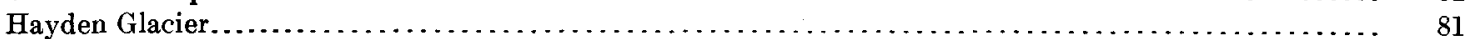

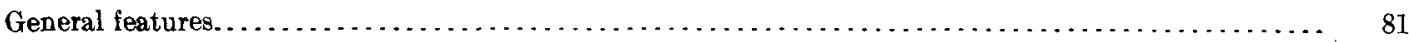

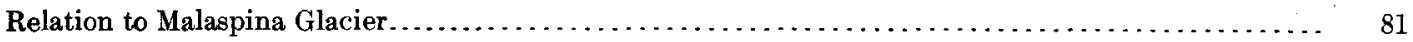

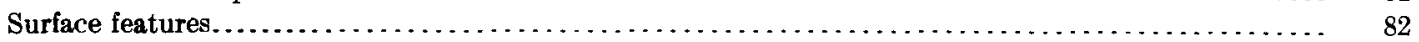

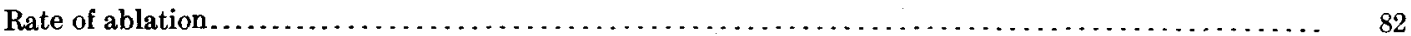

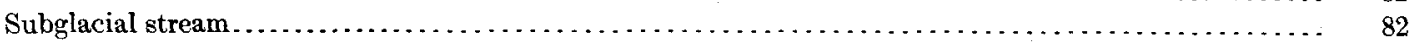

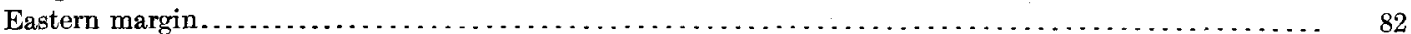

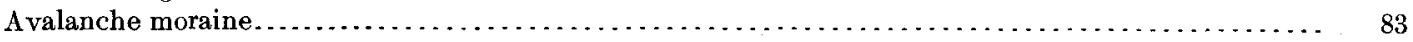

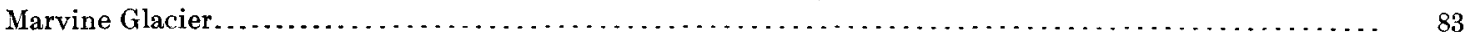

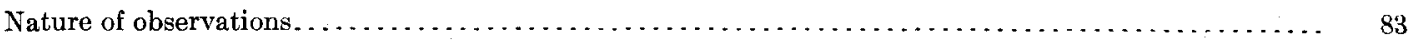

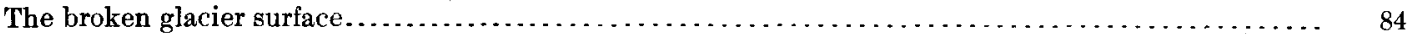

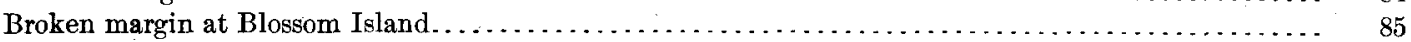

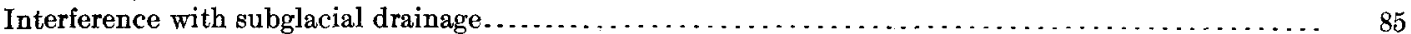

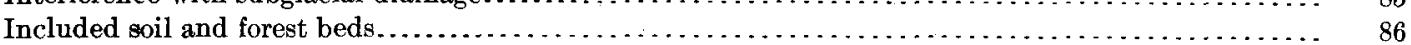

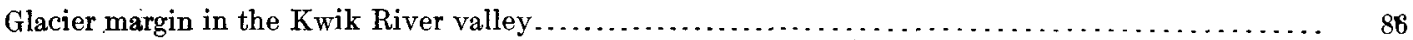

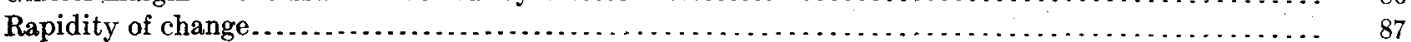

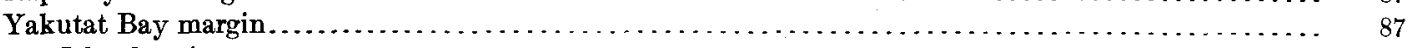

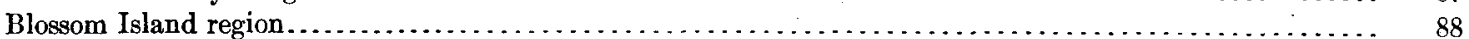

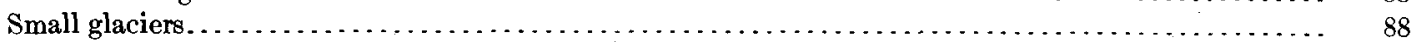

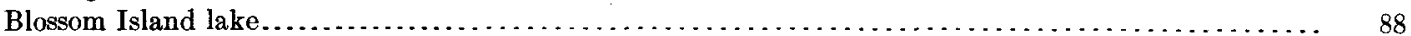

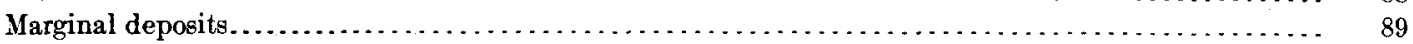

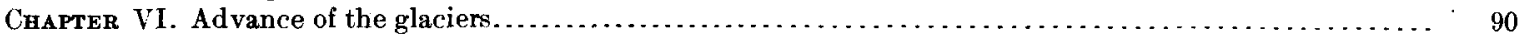

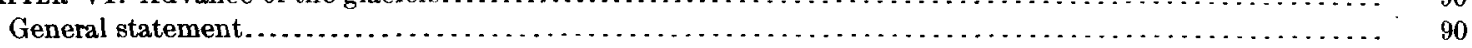

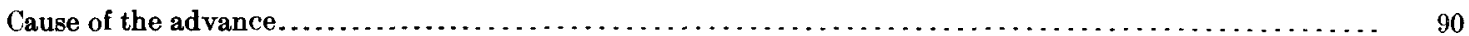


Chapter VI. Advance of the glaciers-Continued.

Cause of the advance--Continued.

Climate.

Uplift.

Change of grade.

Earthquake shocks.

Snow supply resulting from earthquake shaking

Statement of hypothesis.

Earthquakes.

Proof of unusual avalanches

Adequacy of the cause...

Probable effects of unusual avalanche supply

Lack of previous recognition of phenomenon

Possible application to other regions

Glaciers that are not advancing

Future condition.

Geologic effects

Possible economic effects.

Chapter VII. Morainic deposits of formerly expanded glaciers.

Evidence of former expansion.

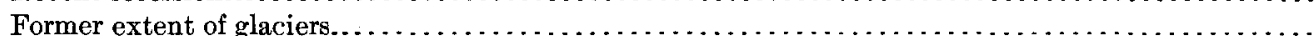

Yakutat foreland

General features.

A bird's-eye view

Foreland southeast of Yakutat

Foreland at head of Russell Fiord

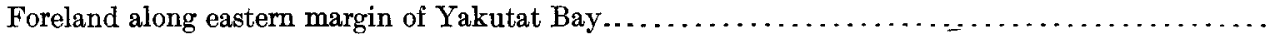

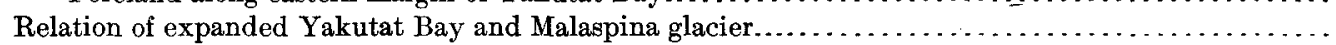

Origin of gravels.

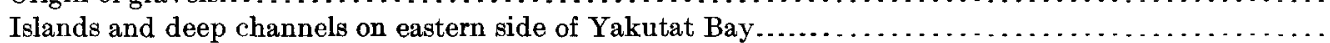

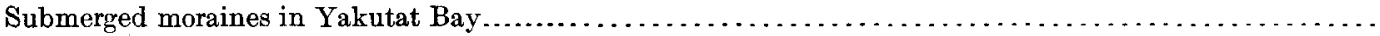

High-level moraines.

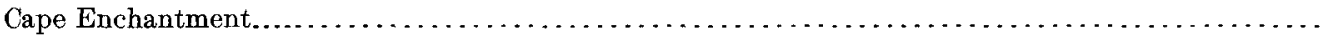

Point Latouche.

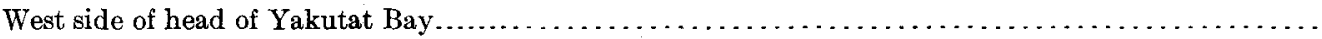

Terrace Point.

Floral Hills.

Blossom Island.

Mount Tebenkof.

Head of Russell Fiord.

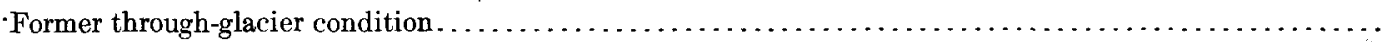

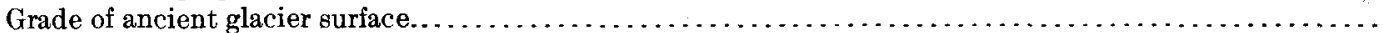

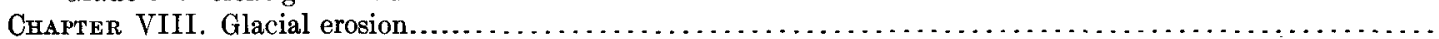

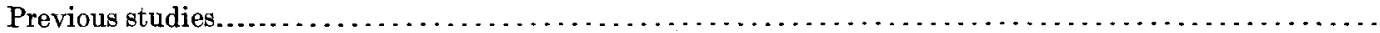

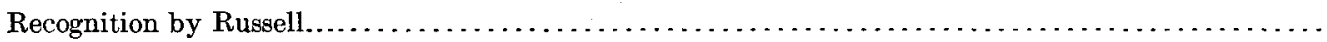

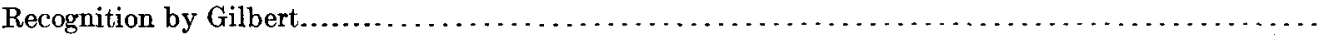

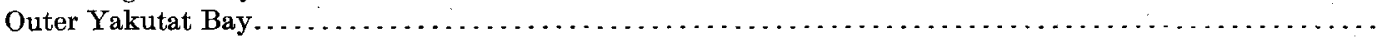

Disenchantment Bay

West side.

Calahonda Valley

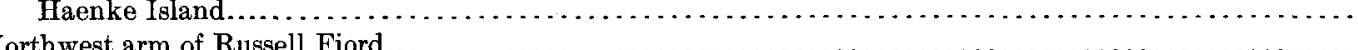

Nunatak Fiord

Significance of nunataks

South arm of Russell Fiord

Cascading glaciers.

Cirques.

Through valleys.

Y-shaped valleys ...

Alternative hypotheses.

Rejuvenation. 
Chapter VIII. Glacial erosion-Continued.

Alternative hypotheses-Continued.

Faulting.

Page.

Other hypotheses................ 117

Efficiency of glacial erosion . . . . . . . . . . . . . . . . . . .

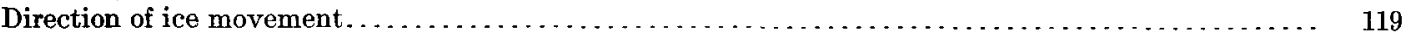

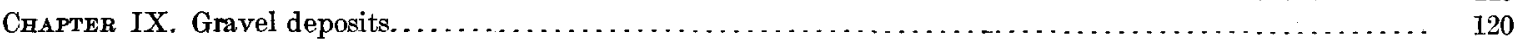

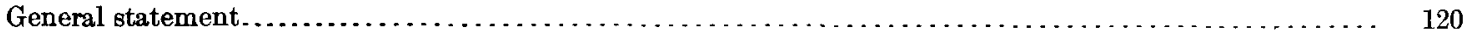

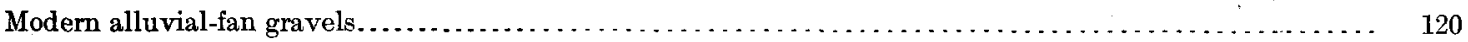

Alluvial fans $n$ Nunatak Fiord. . . . . . . . . . . . . . . . . . . . . . . . . . . . . . . . . . . 120

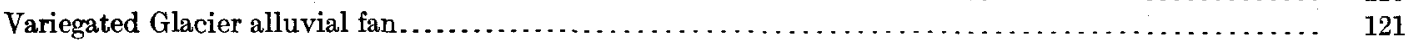

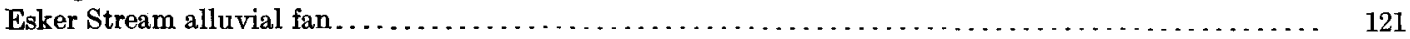

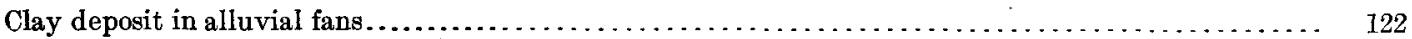

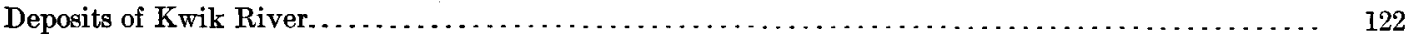

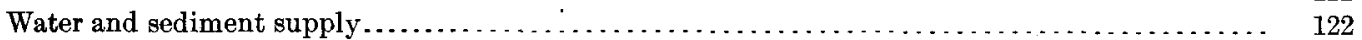

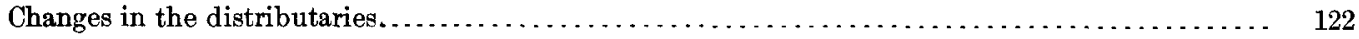

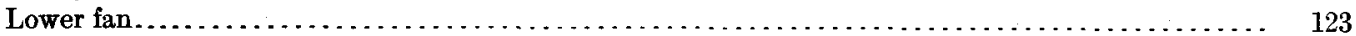

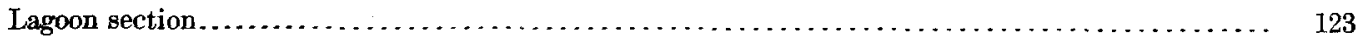

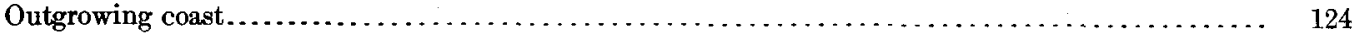

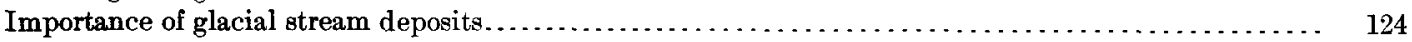

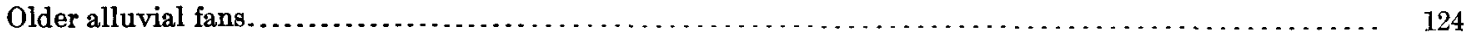

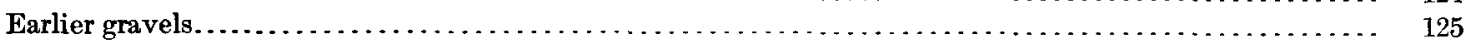

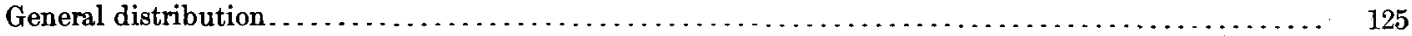

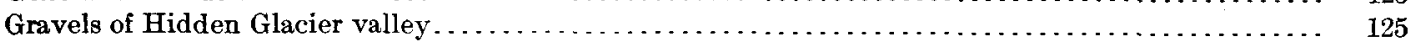

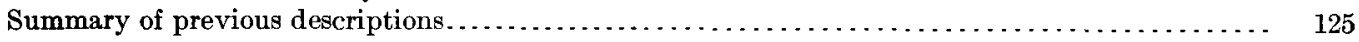

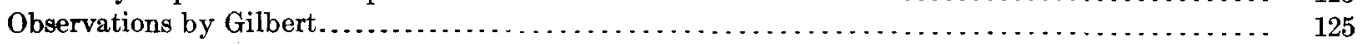

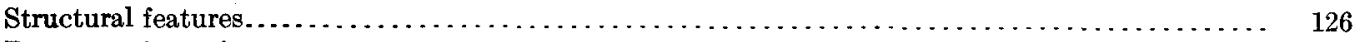

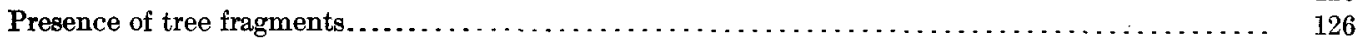

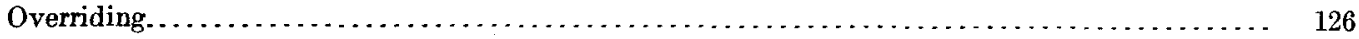

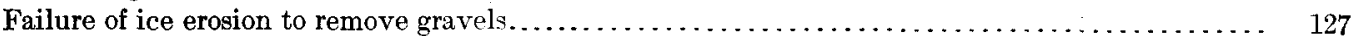

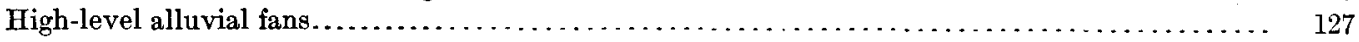

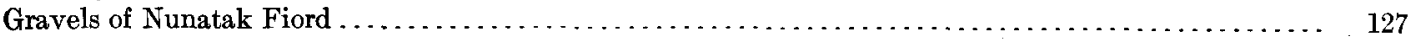

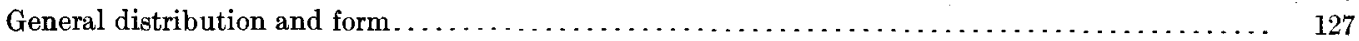

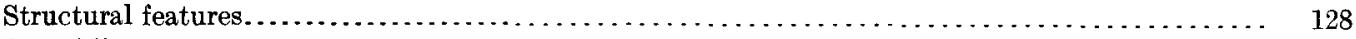

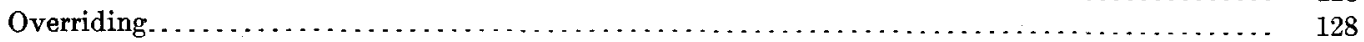

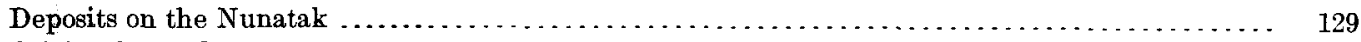

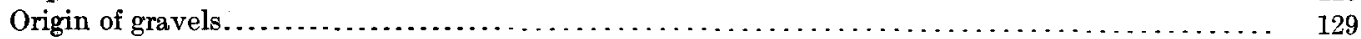

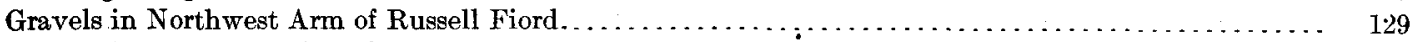

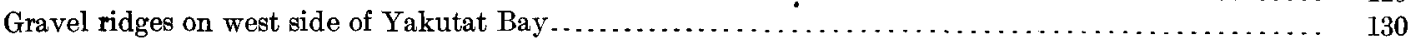

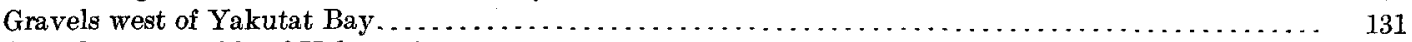

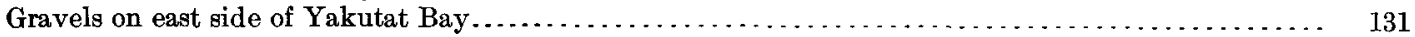

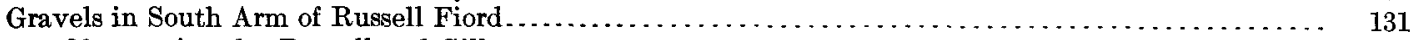

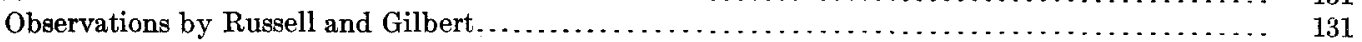

Overridden gravels.................................................... 132

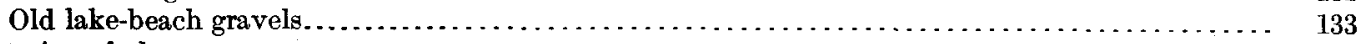

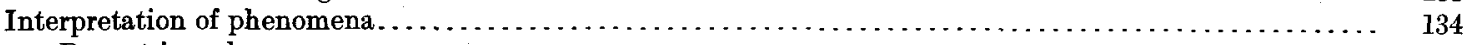

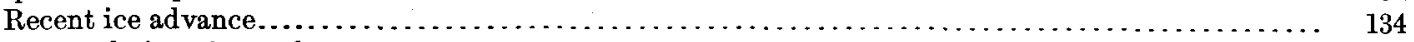

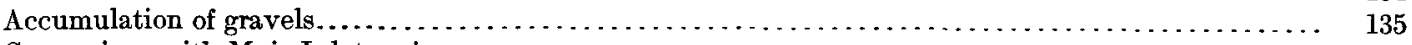

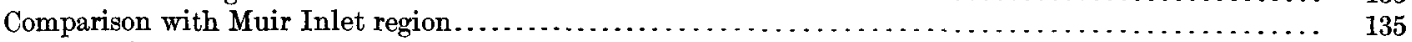

Causes of ice advance and recession........................................... 136

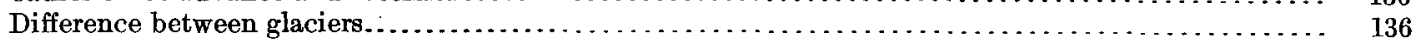

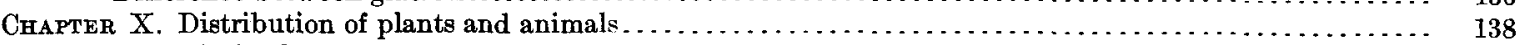

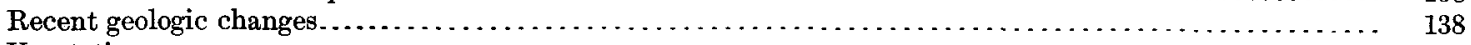

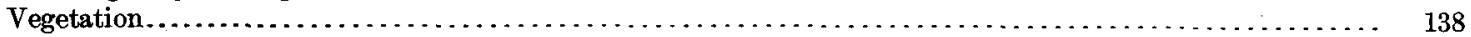

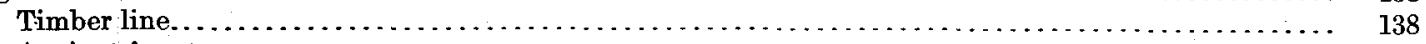

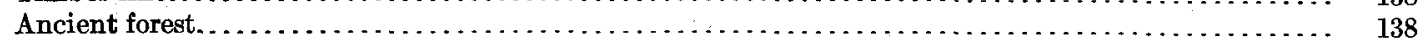

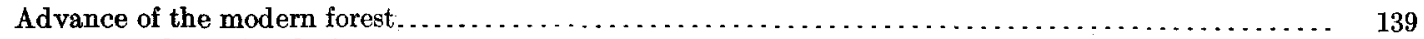

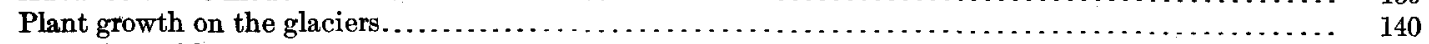

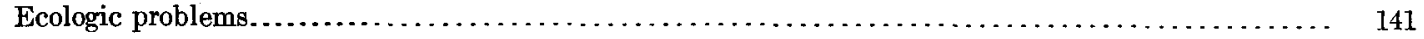

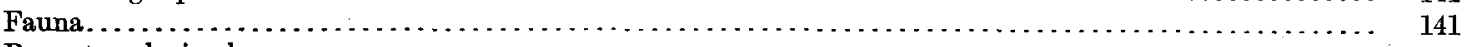

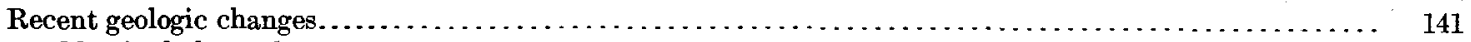

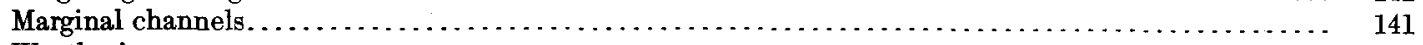

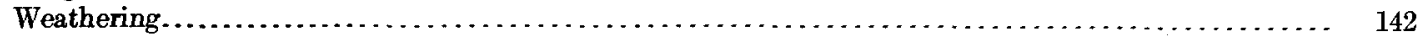

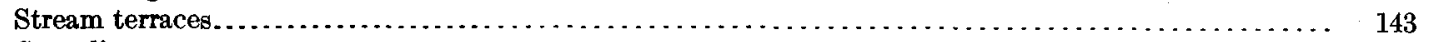

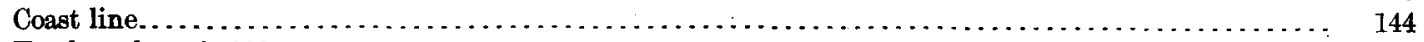

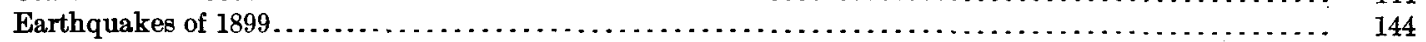


Geologic investigations

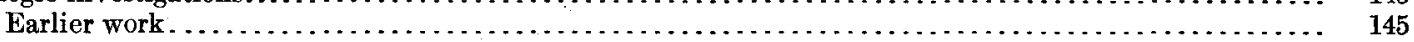

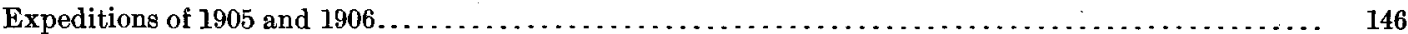

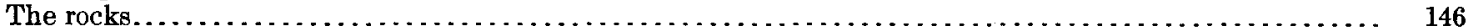

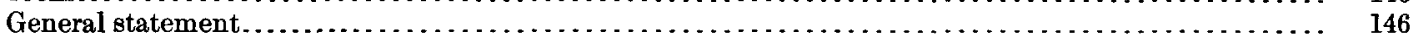

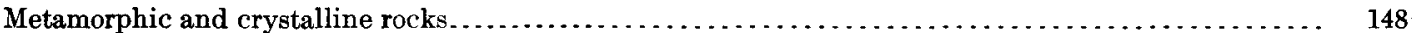

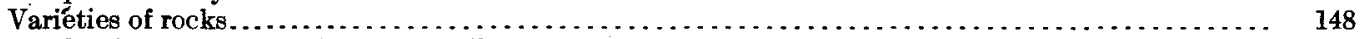

Hubbard and Variegated Glacier valleys $\ldots \ldots \ldots \ldots \ldots \ldots \ldots \ldots \ldots \ldots \ldots \ldots \ldots \ldots \ldots \ldots \ldots \ldots, 148$

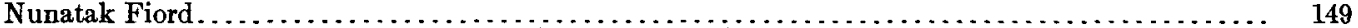

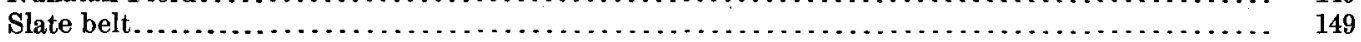

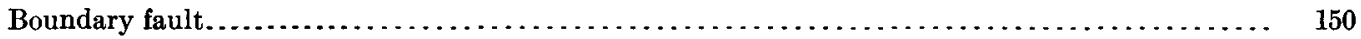

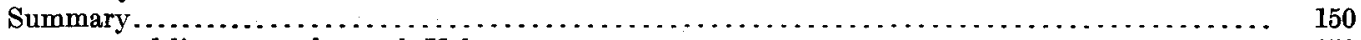

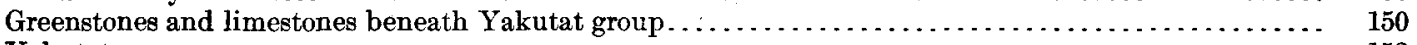

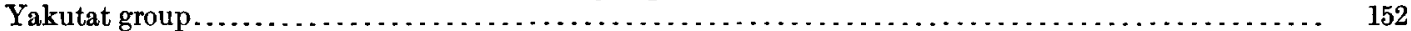

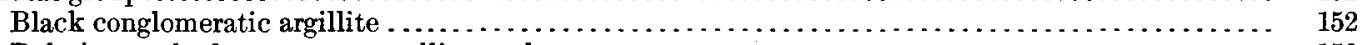

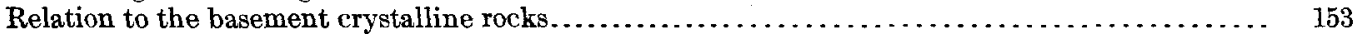

Massive conglomerates................................................. 153

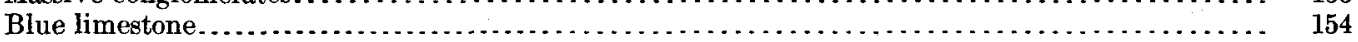

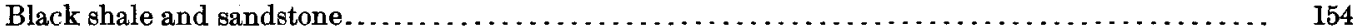

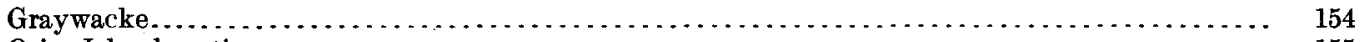

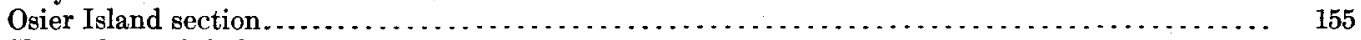

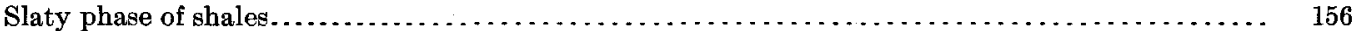

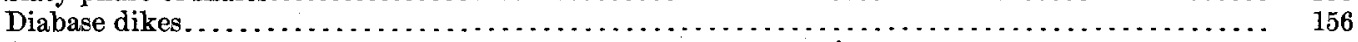

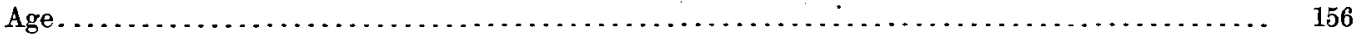

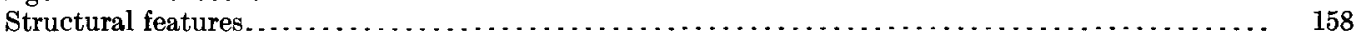

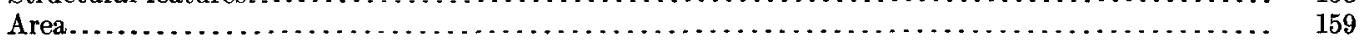

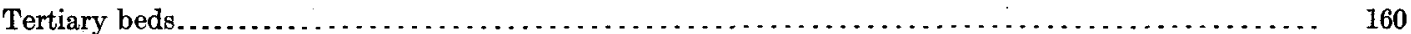

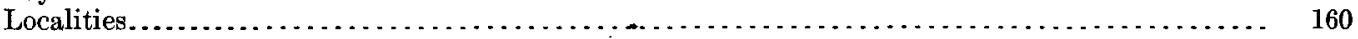

Sections............................................................ 160

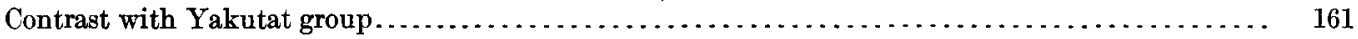

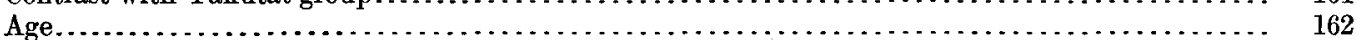

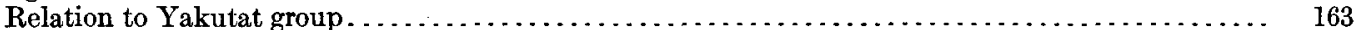

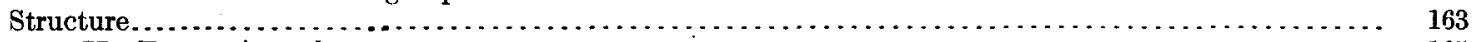

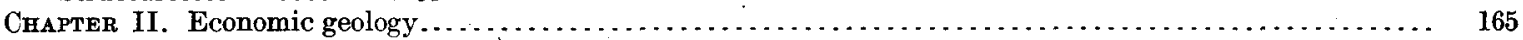

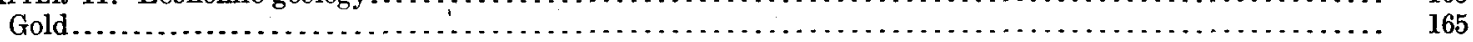

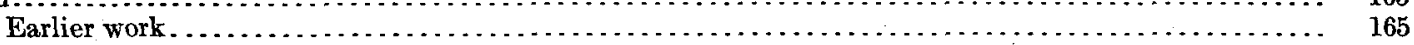

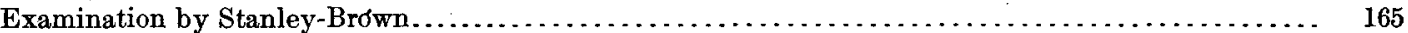

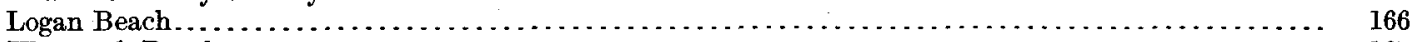

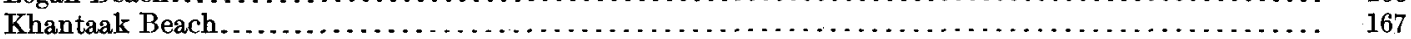

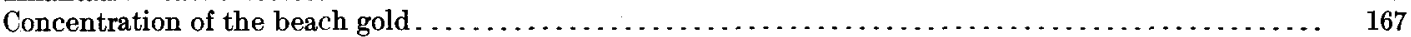

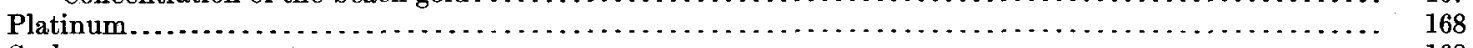

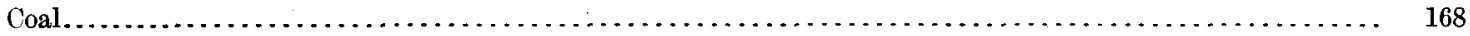

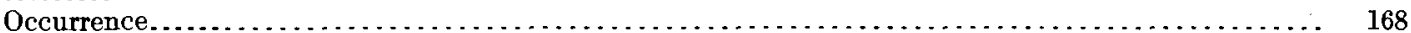

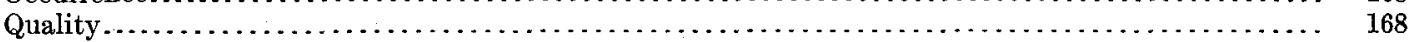

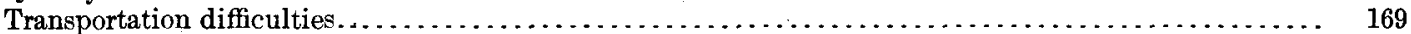

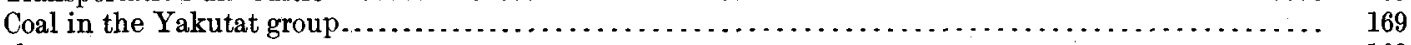

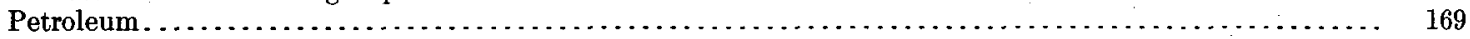

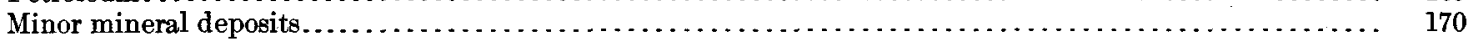

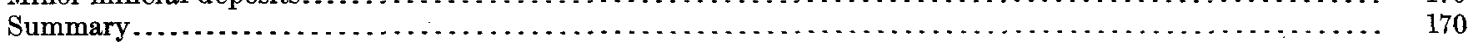

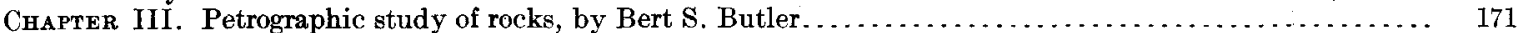

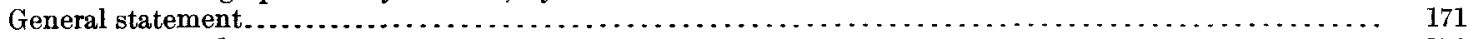

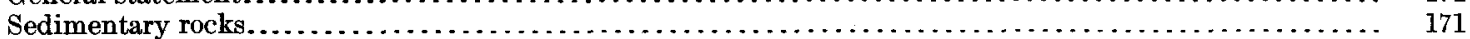

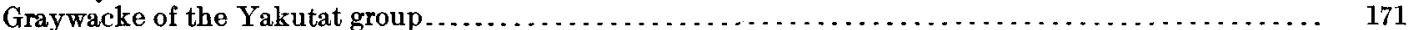

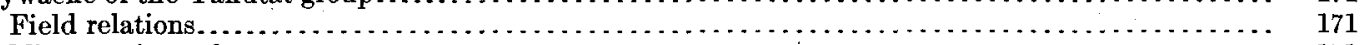

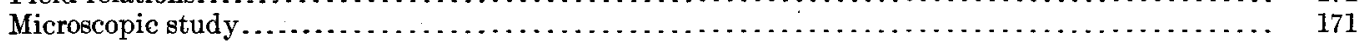

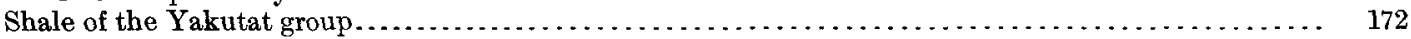

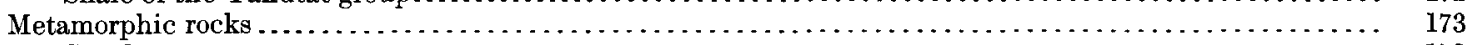

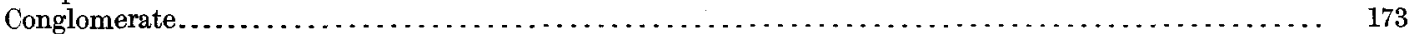

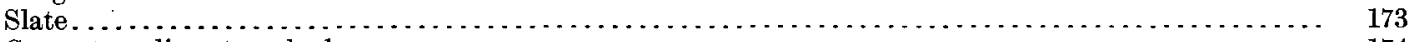

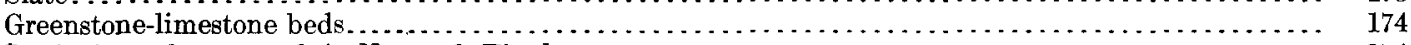

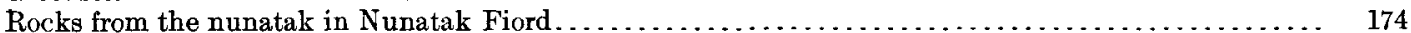

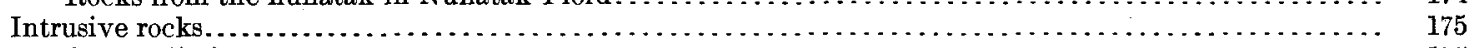

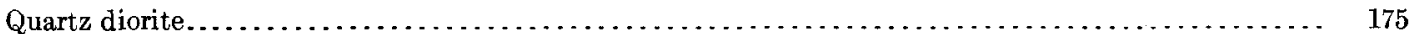

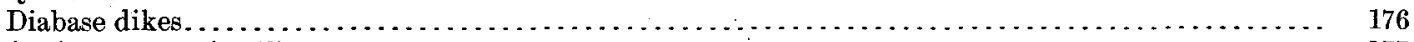

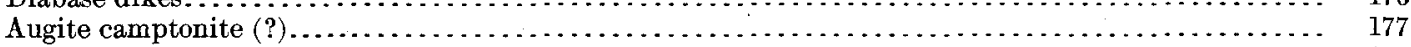

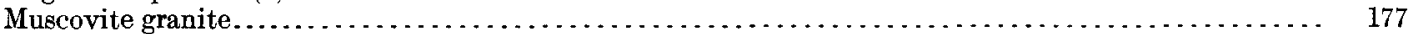

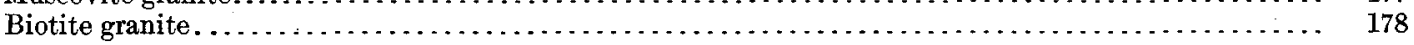




\section{ILLUSTRATIONS.}

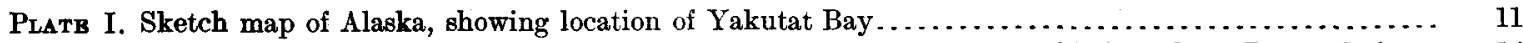

II. View of east side of Disenchantment Bay from elevated beach on west side just above Bancas Point. . 14

III. View looking east through Russell and Nunatak fiords, with Nunatak Glacier in the distance....... 16

IV. View looking south through South Arm of Russell Fiord, showing Yakutat foreland in distance..... 18

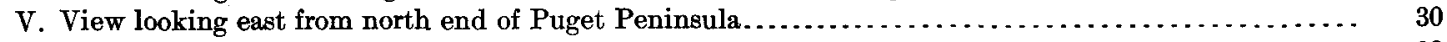

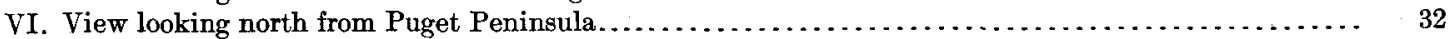

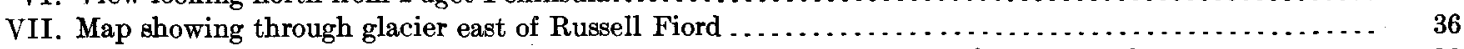

VIII. View looking east up the two branches of Nunatak Glacier from crest of the nunatak. ............. 36

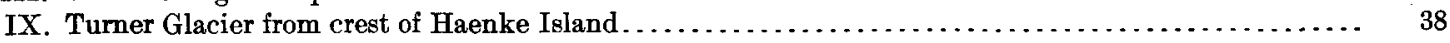

X. $A$, Panorama of Turner and Hubbard glaciers from south side of Turner Glacier; $B$, Eastern margin of Hubbard Glacier near emergence from mountain valley; $C$, Stagnant moraine-covered eastern

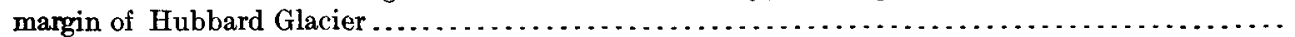

XI. $A$, Haenke Glacier and northern edge of Turner Glacier from point near summit of Haenke Island;

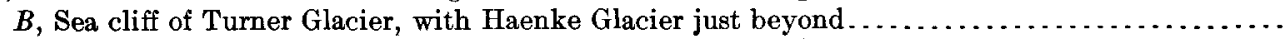

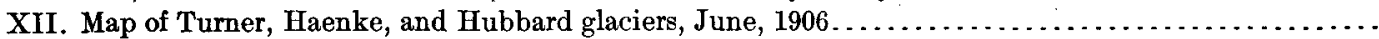

XIII. $A$, Northwest arm of Hubbard Glacier from the hill slope, 1,000 feet above Osier Island, June 21, 1899; $B$, Hubbard Glacier from same point as Plate XIII, $A$, July 3,1906 . . . . . . . . . . . . . . .

XIV. $A$, Hubbard Glacier from Osier Island, 1891; $B$, Hubbard Glacier from same point as Plate XIV, $A$, July 4, 1906 .

XV. $A$, Wasting lower end of valley portion of Variegated Glacier; $B$, Long-focus view of Variegated Glacier from Gilbert Point; $C$, Variegated Glacier from the southeast; $D$, Western or lower end of tunnel in

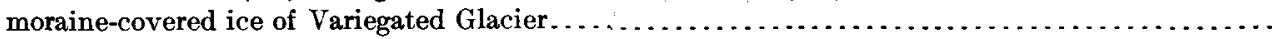

XVI. $A$, Panorama of interior alluvial flat from the green moraine of Variegated Glacier, looking west; $B$, Panorama of interior alluvial flat from inner portion of black moraine of Variegated Glacier........

XVII. $A$, View looking east up to the snow-covered divide of Orange Glacier along the medial moraine; $B$, Crevassed bulb of Variegated Glacier rising above interior flat. . . . . . . . . . . . . . . . . . . . . . . .

XVIII. $A$, Cascading Glacier from the nunatak; $B$, Land tongue of Nunatak Glacier from south side of the nunatak; $C$, Sea end of Nunatak Glacier from point near crest of the nunatak; $D$, Nunatak Glacier

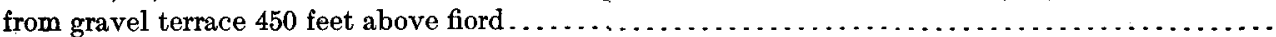

XIX. $A$, Sea end of Nunatak Glacier, July 5,$1906 ; B$, Sea end of Nunatak Glacier, June, 1899.........

XX. $A$, Débris-charged iceberg in Disenchantment Bay, bearing bowlders; $B$, View of end of Hidden Glacier, looking northeast; $C$, Ice cave near southern edge of Hidden Glacier, from which main stream

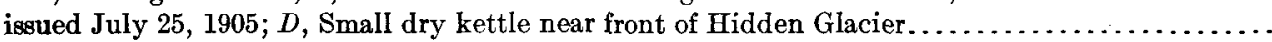

XXI. $A$, End of Hidden Glacier from gravel terrace on north side of valley, June, 1899; $B$, End of Hidden

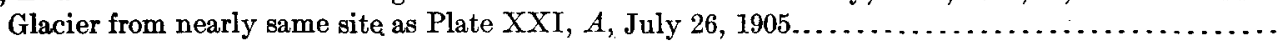

XXII. $A$, View looking west from Hidden Glacier, showing the fosse and the pitted plain; $B$, View looking

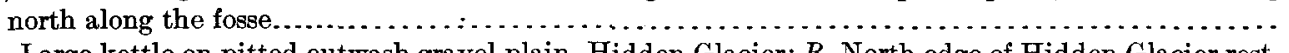

XXIII. $A$, Large kettle on pitted outwash gravel plain, Hidden Glacier; $B$, North edge of Hidden Glacier resting on older ice-eroded gravels.

XXIV $A$, Surface of Atrevida Glacier, showing area of crevassing, $B$, Point of emergence of Esker Stream, June 29, 1906; $C$, Margin of Atrevida Glacier west of Esker Stream; $D$, View looking down marginal valley of Hayden Glacier at southwest end of Floral Hills, 2 or 3 miles above point of emergence of Kwik River...

XXV. $A, B$, Panorama of Atrevida Glacier from crest of Amphitheater Knob.

XXVI. $A$, Long-focus view of crevassed surface of Atrevida Glacier, looking east from Terrace Point; $B$, Crevassed surface of Marvine Glacier from small glacier northwest of Blossom Island ...............

XXVII. $A$, A detail in the crevassed eastern margin of Marvine Glacier near Blossom Island; $B$, Moraine-covered

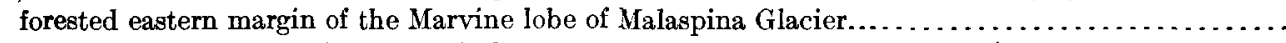

XXVIII. A, View showing Blossom Island Hill, the crevassed Marvine Glacier, and the faulted Hayden Glacier; $B$, Broken eastern margin of the Marvine lobe of Malaspina Glacier, from alluvial fan of $\mathrm{K} w i \mathrm{k}$ River; $C$, Blocks of ice protruding through the morainic soil and the forest cover, Malaspina Glacier. 
Plate XXIX. A, Moraine terrace in the amphitheater on Amphitheater Knob; $B$, Long-focus view of Calahonda Valley, from west side of Disenchantment Bay...

XXX. $A$, Two hanging valleys on northeast wall of Russell Valley, lying at different levels; $B$, Nearer of the two hanging valleys shown in Plate XXX, $A ; C$, Hanging valley on south side of Nunatak Fiord, just west of the nunatak; $D$, Hanging valley on south side of Nunatak Fiord, lying next east of valley shown in Plate XXX, $C$.

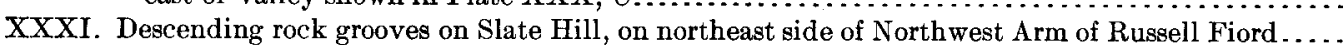

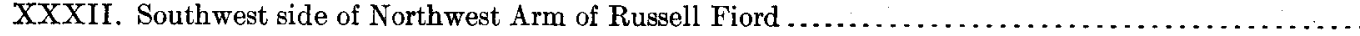

XXXIII. $A$, View looking up the broad glaciated valley shown in Plate XXX, $C ; B$, Lower part of Esker Stream alluvial fan

XXXIV, $A$, Dissected, ice-sculptured gravel benches on north side of Nunatak Fiord; $B$, Stream cut i overridden gravel bench on west side of Russell Fiord, just south of Cape Enchantment; $C$, Tree trunks standing in place in a clay layer in gravels on east side of Russell Fiord; $D$, Esker on overridden gravels south of Cape Enchantment, on west side of South Arm of Russell Fiord

XXXV. View from mountain slope on west side of South Arm of Russell Fiord, looking east............

XXXVI. $A$, View looking down marginal channel older than that shown in Plate XXXVI, $B ; B$, Marginal channel across spur of white granite south of terminus of Variegated Glacier..........

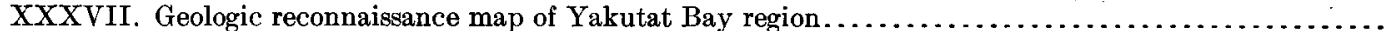

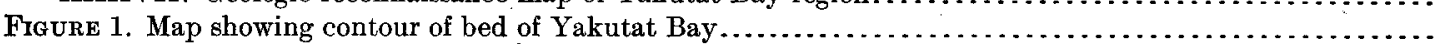

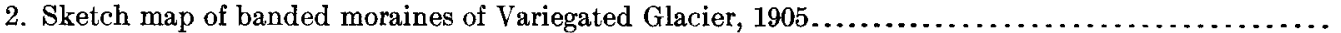

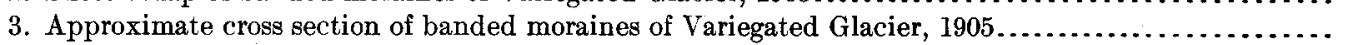

4. Gannett map of Nunatak Glacier, based on surveys in June, $1899 \ldots \ldots \ldots \ldots \ldots \ldots \ldots \ldots \ldots \ldots$.

5. Sketch map of Nunatak Glacier, from plane-table survey by B. S. Butler, August, 1905 .............

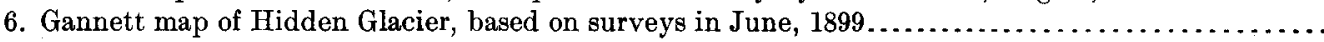

7. Sketch map of Hidden Glacier, from plane-table survey by B. S. Butler, July, 1905

8. Map of outer portion of outwash gravel plain, Hidden Glacier, showing position of delta margin in July, 1905

9. Map showing hypothetical former extension of glaciers during ice-flood stage, based on observations

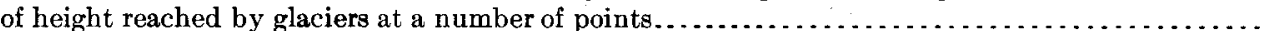

10. Section in gravels on southwest side of Northeast Arm of Russell Fiord, showing location of tree fragments. 
$=$ 


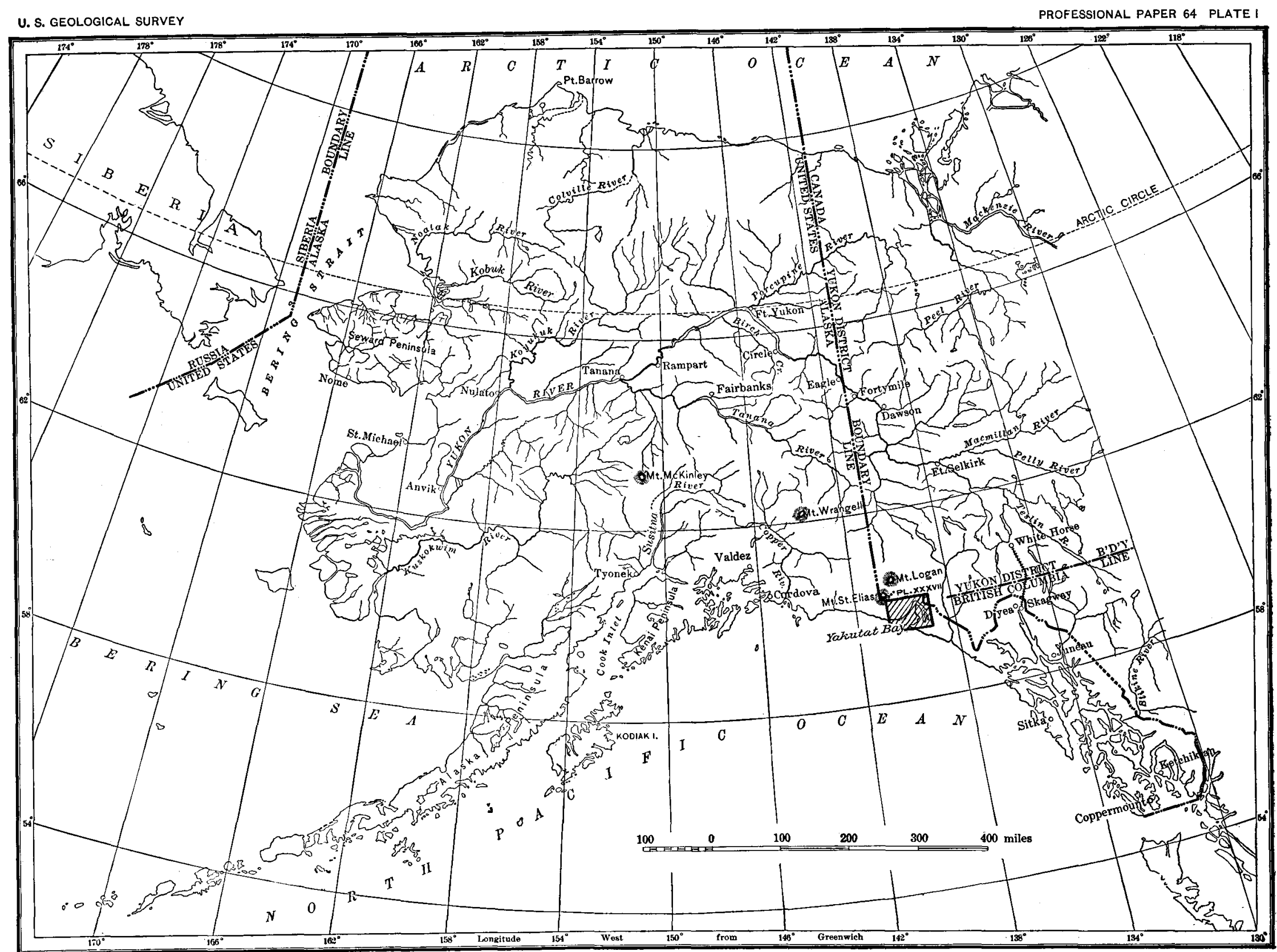

SKETCH MAP OF ALASKA, SHOWING LOCATION OF YAKUTAT BAY. 


\title{
THE YAKUTAT BAY REGION, ALASKA.
}

\section{PART I. PHYSIOGRAPHY AND GLACIAL GEOLOGY. ${ }^{\circ}$}

By Ralph S. TARR.

\section{CHAPTER I.}

\author{
GENERAL PHYSIOGRAPHY.
}

\section{THE COAST AND THE MOUNTAINS.}

The irregular "panhandle" coast. - - The coast of British Columbia and southeastern Alaska, or the "panhandle," is famous for its intricate maze of channels and outlying mountainous islands. It is possible to travel along it for a thousand miles, from Seattle to Cross Sound, by the widely famed inside passage to Alaska, without once going out into the open ocean. The region is everywhere mountainous, the walls of the fiords rise steeply from the water's edge, and the depth of the water is in places very great. Everywhere there are signs of powerful glacial erosion, both in the form of the smooth, rounded fiord walls and in the presence of perfect hanging valleys. ${ }^{b}$

The straight coast from Cross Sound to Controller Bay.-North of this irregular stretch the nature of the coast changes abruptly, and from Cross Sound to Controller Bay, a distance of about 300 miles, the shore line is notable for its regularity; but beyond Copper River Delta it again becomes irregular. About midway in this straight stretch of coast lies Yakutat Bay (Pl. I), the only notable break in the whole 300 miles. Two much smaller indentations occur in the coast south of this. The first of these, called "Dry Bay," has been so filled with delta deposits from Alsek River that it has been practically closed within the last century. The other, Lituya Bay, is so nearly shut in by a reef that it is difficult to enter except under favorable conditions of tide and waves.

Yakutat Bay therefore offers the only harbor on the entire stretch of straight coast line. It lies in latitude $59^{\circ} 40^{\prime}$ and longitude $140^{\circ}$ west, about 40 miles southeast of Mount St. Elias and therefore very near the point where the boundary line between Canada and Alaska turns abruptly northward.

Along the coast pierced by Yakutat Bay the lofty Fairweather and St. Elias mountains rise abruptly to great altitudes from a remarkably straight, seaward-facing front, and they are still in process of uplift. Bordering them is a lowland fringe, or coastal plain, of glacial débris, forming a foreland between the mountains and the sea. This foreland narrows from Yakutat Bay toward the southeast, disappearing before Cross Sound is reached. Down to it many glaciers extend from the mountains, and, by their melting, supply gravels for its farther extension. In the neighborhood of Yakutat Bay, on its southeast side, the growth of the fore-

a Special acknowledgment is due to Lawrence Martin for valuable assistance on the physiography and glacial geology in 1905, and to B. S. Butler for the same in 1905 and 1906. Many of the 1905 photographs were taken by Mr. Martin, and most of the 1906 photographs by 0 . D. von Engeln. In 1906 valuable assistance was rendered by R. R. Powers and J. L. Rich, the latter, among other services, making the map of Hubbard Glacier. Mr. Martin worked with me, especially on the problems of physiography and glacial geology, and has read this report, making many valuable suggestions. To him are due special acknowledgments.-R. S. T.

b Gilbert, G. K., Glaciers and glaciation: Harriman Alaska Expedition, vol. 3, pp. 139-161, 203-210. Tarr, R. S., Glacial erosion in A laska: Pop. Sci. Monthly, vol. 70, 1907, pp. 99-119. 
land has almost entirely ceased, though it persists as a witness to the former great extension of the ice sheets in this vicinity. On the northwest side of the bay, on the other hand, the foreland is still being rapidly built seaward by deposits from the great piedmont ice plateau of the Malaspina Glacier, which now stretches along the base of the mountains in the position occupied by the foreland farther southeast.

That the coast line over a large part of this foreland area is still growing outward admits of no doubt, and the soundings offshore indicate distinct shallowness for some distance. Near Yakutat Bay the 100-fathom line lies 50 or 60 miles from the coast; but beyond this line the ocean bottom descends to a depth of 1,500 to 1,800 fathoms in a distance of 25 miles. Farther south, along the irregular part of the coast, deep water exists much nearer the land; for instance, at Sitka the 100-fathom line lies only about 10 miles from the coast, and beyond it the ocean rapidly deepens.

From these facts it is evident that the region of coastal plain, with its straight coast line, differs from the irregular coast line farther south in the possession of a fairly broad continental shelf beneath the sea. If the foreland gravels could be removed from the straight coast, and the ice be melted out from the mountain valleys, it would without doubt be notably less regular than it now is; but even then it would present a striking contrast to the remarkably irregular coast farther southeast.

The mountains.-Roughly parallel to the coast rises the St. Elias-Fairweather chain, with a general northwest-southeast trend. In the neighborhood of Yakutat Bay the mountains rise abruptly from the inner margin of the foreland, reaching elevations of 2,000 to 4,000 feet in a few miles. The seaward front is very steep, and the mountain spurs are so truncated that they are brought into a remarkable alignment. This is especially noticeable southeast of Yakutat Bay; northwest of it the mountain face is much less regular, and numerous spurs project beyond the general front.

Near their seaward face, in the Yakutat Bay region, the mountains rise to no great height, the peaks rarely being above 5,000 feet in elevation; but back of this foothill section the peaks become rapidly higher, and a number of them rise more than 10,000 feet above sea level. Among the high peaks visible from Yakutat Bay are Mount Seattle (10,000 feet), Mount Hubbard (16,400 feet), Mount Vancouver (15,617 feet), and Mount Cook (14,700 feet). These all lie back from the ocean, being separated from it by the coastal-plain fringe and by an area of lower mountains, the foothill section of the main St. Elias chain, of which these higher peaks are a part. The foothills, if the lower mountains may be so called, are well developed in the neighborhood of Yakutat Bay, but their area narrows toward the northwest, and they practically disappear at Mount St. Elias, which rises abruptly out of the ice plateau to an elevation of 18,024 feet. This great rock pyramid, the whole of which is visible from the sea, is one of the most imposing mountain peaks in the world. Near it rises Mount Logan, in Canada, the second highest peak on the continent, which, though higher than St. Elias (19,539 feet), is far less impressive because partly cut off from view.

Even the foothill region has its snow fields and glaciers, but these are mostly small. The higher mountains are whitened with snow wherever it will cling, and the valleys are deeply filled with ice, which in many places advances either to the foreland or to the sea, giving rise to the largest glaciers on the American mainland. Of these the piedmont Malaspina Glacier, made by the coalescing of several valley glaciers at the mountain front, is far the greatest. Another, Hubbard Glacier, is one of the finest examples of tidal glaciers on the continent.

\section{YAKUTAT BAY INLET.}

\section{GENERAL DESCRIPTION.}

The Yakutat Bay indentation crosses the foreland and the foothills and extends to the very base of the main part of the lofty St. Elias chain. It then turns at a high angle and extends back through the foothill region and into the foreland, reaching within 12 or 13 miles of the sea, along a course roughly parallel to that by which it struck inland. The entire inlet 
has the shape of a bent arm; with the shoulder at the Pacific, the elbow at the point where the bay turns back toward the ocean, the forearm in the foothill region beyond this bend, and the fist beyond the mountain front at the head of the inlet, where it expands on emergence into the foreland. For most of the distance the coast line of this bay is very regular, and it has only one notable branch, which lies about a third of the way between the elbow and the fist.

Several names have been given to the different parts of the inlet. The outer portion, mainly in the foreland, is called "Yakutat Bay." Farther inland, where both shores of the bay are mountain walled, the name "Disenchantment Bay" is applied. The southward arm, beyond the bend, is called "Russell Fiord," and the single notable branch, which extends eastward from this, is called "Nunatak Fiord." These several sections will be described separately.

YAKUTAT BAY.

Between Ocean Cape and Point Manby, where Yakutat Bay branches off from the ocean, its width is about 20 miles; but at its head, where it merges into Disenchantment Bay, the width is less than 3 miles. For the first 18 miles the two shores are nearly parallel, extending approximately northeastward; but beyond this the eastern shore turns abruptly northward, causing a convergence which continues to the head of Yakutat Bay proper at Point Latouche. This northward reach of the eastern shore, which extends for about 15 miles, is bordered by the low mountains of the peninsula which lies between Russell Fiord and the YakutatDisenchantment Bay section of the inlet. The other shores of Yakutat Bay proper are all lowland.

On the northwest side of Yakutat Bay the shore line is everywhere made of débris supplied by glacial streams and worked over by the waves. In the region between Point Manby and the mouth of Kwik River the débris is brought by streams emerging from the Malaspina Glacier, whose margin lies a short distance back from the coast, being separated from it by a fringe of short, coalescing alluvial fans. Back of these fans the ice rises as a low cliff, everywhere (1905) covered by moraine, ${ }^{a}$ and for a part of the distance occupied by vegetation growing on the moraine. The largest streams are the Osar, Kame, and Kwik, and they, together with the smaller ones, are supplying so much sediment that the coast line is rapidly growing outward. It is a remarkably straight coast, with long, offshore bars, bluntly cusp shaped opposite the stream mouths and inclosing lagoons with shallow openings, difficult to enter by boat because of the surf which almost constantly beats on this coast.

Kwik River receives a notable proportion of its water and sediment from Lucia Glacier, which is not now connected with Malaspina Glacier. Like the other streams, it divides over its fan in a maze of distributing channel ways.

Northeast of the Kwik smaller glacial streams descend to the bay, one supplied from the eastern margin of Atrevida Glacier, another emerging from Galiano Glacier, and another from Black Glacier. By their deposits they extend the lowland fringe up to the very entrance of Disenchantment Bay. Beyond the fan of the Galiano stream the alluvial-fan fringe narrows rapidly, ending on the northern side of the alluvial fan of the Black Glacier stream. Here the mountains come down to the very coast, forming Bancas Point, the boundary on the west between Yakutat and Disenchantment bays.

Wherever conditions favor, there is forest growth on this lowland strip; but the sand bars, the swampy flats between alluvial fans, and the constantly shifting streams on these fans present unfavorable conditions for forest growth over a large part of the area. The spruce tree grows as far as Bancas Point, and the slopes of the foothills west of this are occupied by a spruce forest growth, grading upward into alder thickets.

The eastern shore of Yakutat Bay is divisible into two entirely different sections of nearly equal length. The outermost borders the low Yukatat foreland; the innermost, the mountains

a As noted later, this condition of 1905 was utterly changed in 1906 by the remarkable advance due to a forward thrust from the MarvineGlacier tributary. 
of the peninsula. The foreland section, nowhere rising more than 250 feet above sea level, is low and timber covered, the dense Alaskan forest of spruce and hemlock descending to the very sea. This part of the coast line is exceedingly irregular and is faced by a series of islands, the largest two of which are Khantaak, the southernmost, and Knight Island, the northernmost. Associated with these islands are numerous shoals and reefs; but there are also deep, navigable channel ways. This archipelago of islands and reefs gives rise to an intricate maze of narrow straits and broad, lakelike expansions, protected from the ocean surf that elsewhere beats incessantly on the shores of Yakutat Bay. These stretches of quiet water, bordered by forest-clad shores, look quite like the lakes in the forested region of Maine.

Nowhere on this shore were hard rocks found in either the foreland or the off-lying islands. Gravel bluffs occur wherever the waves have cut into the land; and for some distance back

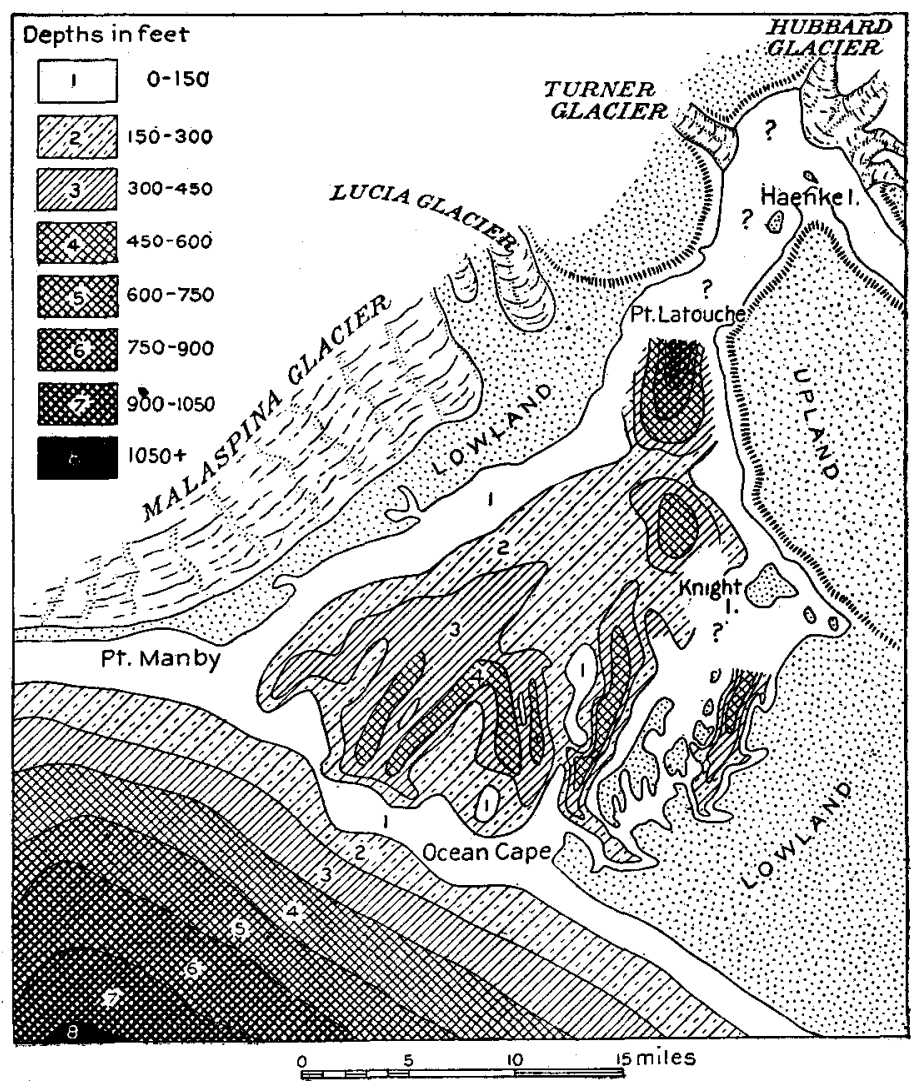

FIGURE 1,-Map showing contour of the bed of Yakutat Bay. (Gilbert, G. K., Glaciers and glaciation: Harriman Alaska Expedition, vol. 3, fig. 27.) from the shore, wherever visited, the topography was found to be distinctly morainic. Both on the islands and on the main Yakutat foreland there are numerous lakes and ponds occupying kettles in the moraine.

The northern part of the eastern shore of Yakutat Bay is a remarkably straight mountainous coast. There are no harbors, and, above Knight Island, no landing places except at times of greatest calm. Mountains rise abruptly to heights of 1,000 to 2,000 feet, and, in a distance of 3 or 4 miles from the coast, reach elevations of 3,000 to 4,000 feet. Six fair-sized streams descend through mountain valleys along this coast, three of them clouded with sediment from the melting glaciers at their heads. This mountainous coast is a direct extension of the mountain front, which rises abruptly out of the foreland, but which, in the neighborhood of Knight Island, turns northward at an angle of $30^{\circ}$ to $35^{\circ}$. This eastern, mountainous shore of Yakutat Bay, with truncated spurs, has distinctly the appearance of fault origin, as indicated by Russell. ${ }^{a}$

The importance of Yakutat Bay as a harbor has led the United States Coast Survey to make thorough soundings in a large part of the bay proper, but, unfortunately, not beyond Point Latouche. These soundings reveal some interesting facts concerning the topography of the bottom of the bay (fig. 1), the most notable being the presence of a slightly crescentic ridge at the outer margin of the bay, between Point Manby and Ocean Cape. In a number of places on this ridge the water is less than 10 fathoms in depth, and nowhere does it reach a greater depth than 14 to 16 fathoms. On both sides of this ridge the depth rapidly increases, and on the inner side there are a number of places within 2 or 3 miles of the ridge where the depth is from 70 to 96 fathoms. The soundings indicate decided irregularity of the bottom of the bay; but in general it may be stated that there is an area of considerable depth inside 


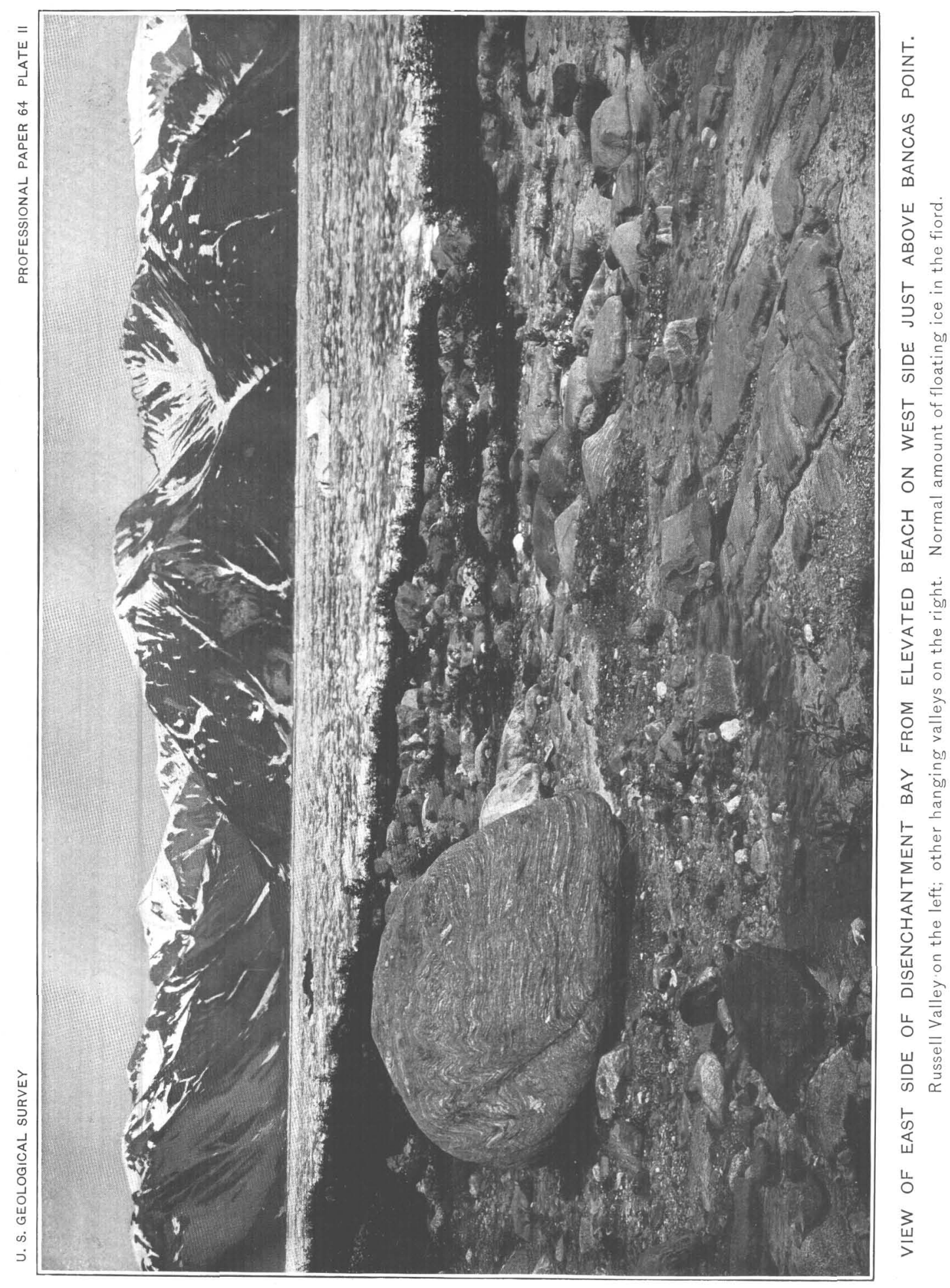


the ridge, then a rise in the neighborhood of Blizhni Point, followed by a decided increase in depth toward Disenchantment Bay.

In the outer part of Yakutat Bay, away from the archipelago, there is no sounding of more than 99 fathoms. On the rise near Blizhni Point most of the soundings are less than 50 fathoms, and only one is as great as 70 fathoms; but between this rise and Disenchantment Bay there are several soundings of more than 100 fathoms, and near Point Latouche is one of 167 fathoms, the greatest depth recorded in the inlet.

The greatest irregularity in the submarine topography of the bay is found on the eastern side, where, although there are numerous low, flat islands and extensive shoals, there are also great depths. For example, within $1 \frac{1}{2}$ miles of the northern end of Khantaak Island 105 fathoms is recorded. Between the archipelago of islands and Yakutat foreland soundings of more than 100 fathoms are numerous. In fact, outside of Blizhni Point, the deepest water in the bay (109 to 111 fathoms) is found among the islands within one-fourth mile of the shore. The narrow channel way between Knight Island and the peninsula is also deep, showing soundings of 69 fathoms. These remarkable depths within the archipelago, and between it and the mainland, constitute the most notable features in the topography of the outer bay. They present a striking contrast to the levelness of the surface of the broad foreland and of the islands.

The shoals in Yakutat Bay are the seat of growth of abundant kelp, which is always found floating in the bay and stranded on the shore, in distinct contrast to the conditions in other parts of the inlet, where kelp is never found.

\section{DISENCHANTMENT BAY.}

Disenchantment Bay, as the Yakutat Bay inlet is called north of Point Latouche, is bordered on the east by the steep hills of the peninsula and on the west by the main mountain front. Its coast is precipitous and through nearly its entire length it is a true mountain-walled fiord. The two mountain walls approach each other at Point Latouche almost at right angles, and Disenchantment Bay enters between them with a nearly north-south axis. Its shores are nearly parallel and from $2 \frac{1}{2}$ to 4 miles apart.

On the east side the mountains rise abruptly to a height of 2,000 to 3,000 feet. They are breached by several valleys, two of which are of large size and head back near the center of the peninsula, with small glaciers at their head. These two valleys have the characteristic forms resulting from glacial erosion, being broad and $U$-shaped, with hanging tributary valleys and bottoms graded up by deposits of gravel supplied by the glacial streams (Pl. XXIX, $B$ ). Their mouths are occupied by broad deltas over which the glacial streams flow in several distributaries. Probably they themselves hang above the submerged floor of Disenchantment Bay.

The western shore, above Bancas Point, is straight and steep, and four small cascading glaciers nestle in steep, cirquelike hanging valleys on the mountain face. North of these is a broad valley down which extends the large Turner Glacier, which enters the bay, and discharges icebergs from its sea face (PI. IX). Within its mountain valley this glacier is more than a mile wide, but in the fiord it expands into a foot of about twice that width. Still farther north two smaller glaciers descend nearly to the sea; their ends are moraine covered and they are faced by alluvial fans which are being built out into the fiord. ${ }^{a}$

The head of Disenchantment Bay is bordered by the ice cliff of the great Hubbard Glacier, which, for a distance of about 4 miles in an air line, rises approximately 250 feet above the water. (See Pls. X, $A$, XIII, and XIV.) The terminus of this glacier is greatly crevassed, and its sea cliff is very irregular; the ice front, with all its sinuosities, measures between 5 and 6 miles. From it icebergs are being constantly discharged, and these, together with those from Turner Glacier, so fill the bay with floating ice, especially on the western side and between Hubbard and Turner glaciers, as to make navigation difficult even in a small rowboat.

The procession of icebergs streams down the western side of Disenchantment Bay, forming a barrier of drifting ice (Pl. II), which interferes with navigation as far as Blizhni Point. Most

a This description was written before the summer of 1906. During that summer it was found that one of these glaciers, the southern, had advanced and united with Turner Glacier, as described later. (See pp. 41-42.) 
of these icebergs melt in the bay, very few escaping into the open ocean. The outgoing tidal current, being down the west shore, ordinarily prevents the spread of the ice to the eastern side of Yakutat Bay, and icebergs are rarely seen on that side.

About halfway up Disenchantment Bay is Haenke Island, which rises 520 feet above sea level. It is a rounded, ice-scoured, rock island about half a mile in length. Somewhat more than a mile north of Haenke Island are two low reefs, rising about to high-tide mark, which were uplifted during the earthquake of 1899.

The steepness of the shore line and the absence of kelp indicate deep water in this part of the fiord; but the Coast Survey has not extended its soundings beyond Point Latouche. In 1890, however, the Corwin sailed up to the front of Hubbard Glacier, and Russell ${ }^{a}$ states that soundings between Haenke Island and the ice foot found depths of 40 to 60 fathoms.

The ocean swell sweeps into Disenchantment Bay, but during the summer is not felt with marked intensity beyond Points Latouche and Bancas, though the exposed southern shore of Haenke Island is frequently surf-bound. In place of ocean surf are waves formed by the discharge of icebergs from the cliffs of Hubbard and Turner glaciers, and the waves thus generated break all along the shores of Disenchantment Bay, but with special intensity near its head. From Haenke Island to Osier Island iceberg waves are almost constantly breaking upon the shore.

RUSSELL FIORD.

Extent and character.-At Osier Island the bay turns at a high angle, extending southeastward almost parallel to the mountainous east coast of Yakutat Bay. From this point on to the head of the bay the name Russell Fiord is applied to the inlet. The division between Disenchantment Bay and Russell Fiord on the northern side is the projecting point of Hubbard Glacier; but if the ice could be removed from the valley the inlet would doubtless extend several miles farther northeast. Russell Fiord is more diversified than the other parts of the bay, and four different sections may be readily recognized, as follows: (1) The straight northwestern section between Osier Island and Cape Enchantment, known as the Northwest Arm; (2) an eastern arm, Nunatak Fiord; (3) a long, somewhat irregular section which may be called the South Arm; and (4) the expanded Head of the Bay, or the fist-shaped area where the fiord extends beyond the mountains into the foreland. These several sections will be considered in the order named.

Northwest Arm of Russell Fiord.-The walls of the Northwest Arm of the fiord are nearly parallel, and, taken as a whole, extend in a very straight line for 12 miles. The straightness of the fiord is particularly noticeable on its northeastern shore, which becomes uneven only where alluvial fans project into the fiord (Pls. III, XXXI). The northwest end of this side of the coast is made up of alluvial fan and morainic deposits for about 4 miles southeast of Hubbard Glacier. There moraines and fans are associated with two glaciers, the Variegated and the Orange, which descend through mountain valleys and spread out at the mountain base, coalescing with Hubbard Glacier. Southeast of this section, to the mouth of Nunatak Fiord, there is a straight coast line of slate rock, fronted by a narrow beach. The mountain wall rises with fairly steep slopes to an elevation of about 2,000 feet, and its sides are smoothed and grooved by glacial erosion. About midway down this coast there is an excellent example of a hanging valley with its mouth about 1,000 feet above the fiord; behind it rises Mount Stamy ${ }^{b}$ (4,689 feet). No glaciers are visible on this side of the fiord southeast of Variegated Glacier.

The coast line of the southwestern side of the Northwest Arm is much less regular than the northeastern, but the mountain wall itself is almost as straight, the irregularities of the coast being due to low-lying masses of rock outside the mountain base (Pl. XXXII). Of these the most prominent are two elongated hills, with axes nearly parallel to the fiord, whose northern terminus has been named Marble Point. These hills are made of crystalline rock, in distinct contrast to the sedimentary beds which form the adjacent mountains. Among these crystalline rocks is a white marble, which appears prominently at a number of places, including Marble Point. This point is joined to the mainland by alluvial fans. It is here that this arm of the fiord is narrowest,

$a$ Russell, I. C., An expedition to Mount St. Elias, Alaska: Nat. Geog. Mag., vol. 3, 1891, p. 100. $b$ Named after Russell's companion, Thomas P. Stamy, in his boat trip up the fiord in 1891. 


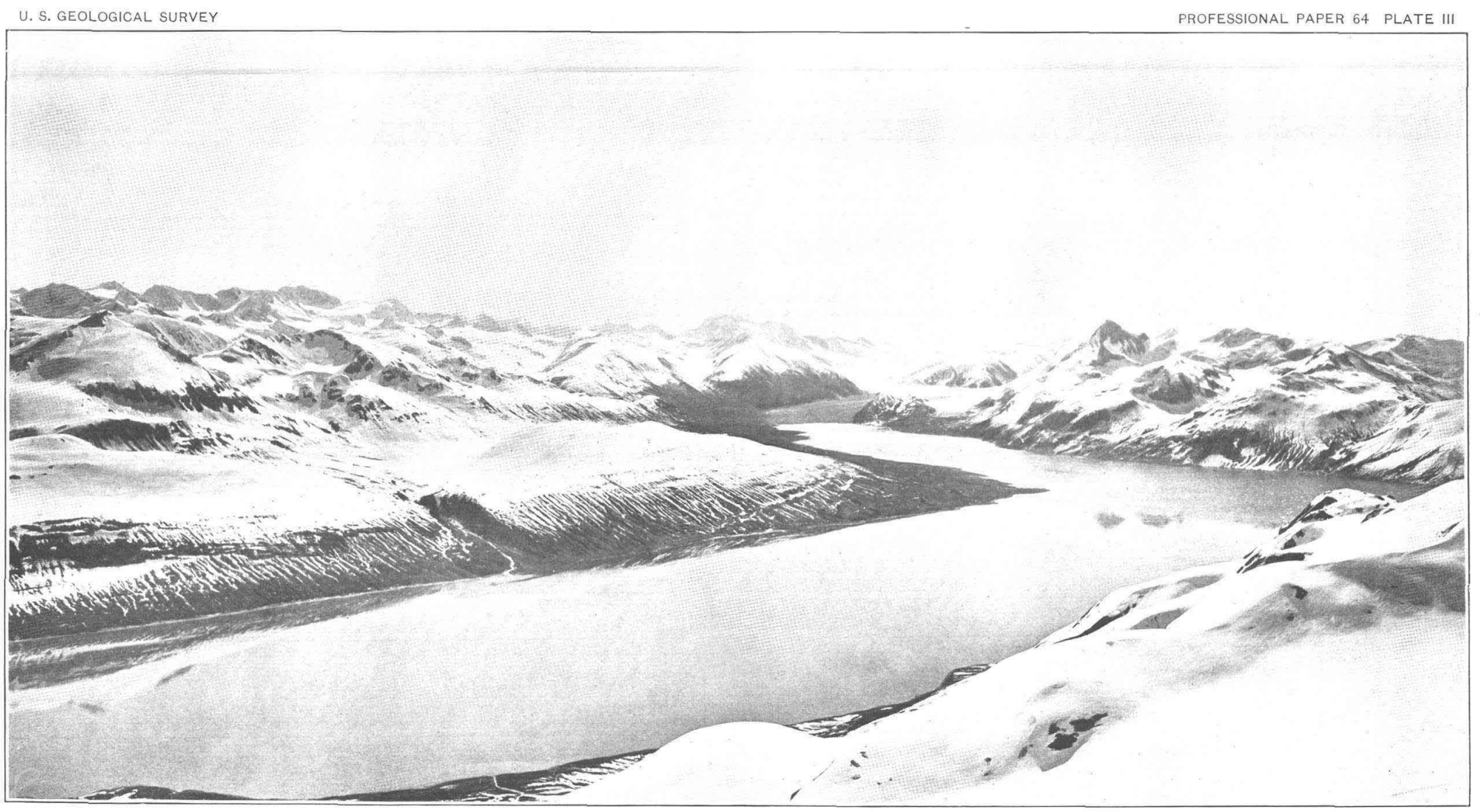

VIEW LOOKING EAST THROUGH RUSSELL AND NUNATAK FIORDS, WITH NUNATAK GLACIER IN THE DISTANCE.

The smoothed glaciated slate coast of the north side of the northwest arm of Russell Fiord on the left. Photograph by Brabazon, Canadian Boundary Commission. 
being about $1 \frac{1}{4}$ miles in width; but nowhere in this section of Russell Fiord is the width greater than 2 miles.

At the extreme northwest end of Russell Fiord a low island, Osier Island, lies just off the mountainous tip of the peninsula. It is joined to the mainland at low tide by a gravel bar sprinkled with bowlders that have drifted there in floating ice. A few hundred feet north of this island is a low reef, almost submerged at high tide.

The southeast end of this stretch of the fiord, called Cape Enchantment by Russell, is composed of crystalline rock ( $\mathrm{Pl}$. XXXVII). At its tip is a small, rounded, ice-worn island of crystalline rock connected to the mainland by a beach which, before the earthquake of 1899 , was covered by water at high tide. It is now reported by the Indians to be above the water at all times except the very highest spring tides. Views from this point and from the mountains back of it are among the grandest in the fiord, furnishing ample warrant for the given name by Russell. From it one may look northwestward to and beyond Hubbard Glacier, eastward to Nunatak Glacier, and southward beyond the head of the bay to the Pacific, seeing in each direction a series of grand mountain and glacier panoramas.

The southwest wall of the fiord rises precipitously, through much of its distance by inaccessible cliffs. The two highest peaks are Mount Alexander ${ }^{a}\left(3,828\right.$ feet) and Mount McCarty ${ }^{b}$ (3,534 feet). Three small glaciers descend in mountain valleys from the shaded northeast slopes, terminating far back from the sea in pronounced hanging valleys. The middle and largest of these has been named Alexander Glacier.

The waters of the Northwest Arm are dotted with icebergs, partly derived from Hubbard Glacier and swirled into it by tidal currents, but mostly coming from Nunatak Glacier at the head of Nunatak Fiord, from which there is a constant outmoving procession of bergs. The exact depth of the fiord is not known, but to all appearances it is great.

Nunatak Fiord.-Nunatak Fiord, the only large branch of the entire inlet, is at present between 8 and 9 miles in length. Nunatak Glacier, which forms the head of the fiord (PI. III) has gone back more than a mile since the Boundary Commission map was made in 1895, so that the fiord is now being rapidly lengthened ( $\mathrm{Pl}$. XIX). It is about 2 miles wide at its mouth, but narrows toward its glacier head, where the width is approximately 1 mile. Here the ice cliff rises to a height of about 200 feet, actively discharging, from its crevassed face, bergs which keep the fiord constantly littered with floating ice (PI. XVIII, $C$ ).

Nunatak Glacier divides into two arms (Pls. VIII, XVIII), the larger ending in the ice cliff just mentioned, the smaller passing down a valley behind a rock hill, or nunatak, and ending in a land tongue on the south side of this nunatak. The valley in which this glacial distributary terminates extends westward along the mountain base to the fiord. Therefore at this point there are two nearly parallel valleys, one with its bottom an unknown distance below sea level, the other entirely above the level of the fiord, the wider north trough, presumably the seat of most active ice movement, having been deepened far below that of its weaker neighbor, which hangs above it where the two valleys reunite below the nunatak. The hill between these two troughs rises to a height of 1,410 feet near its eastern end, but descends rapidly toward the west and is faced in that direction by a long tail of less resistant rock.

The two sides of Nunatak Fiord possess very different topographic characteristics. The northern side, almost up to the very edge of the ice, is moderately sloping and shows much gravel and moraine extending to a height of 1,000 feet and in some places even higher. One broad valley on this side extends down to the fiord with moderate slope, and is occupied through its entire length by a glacier discharging both ways, the northwest end terminating in Orange Glacier, in Russell Fiord, and the southeast end in a moraine-covered tongue which reaches to within about a mile of Nunatak Fiord. Smaller glaciers occupy tributaries of this through glacier valley.

a Named for Benno Alexander, the Alaskan pioneer and poet, who was in Yakutat Bay in 1897 with the Duke of Abruzzi, and whose efficlent help did much to render the two Geological Survey expeditions successful.

$b$ Named after Nell MeCarty, one of Russell's companions on his boat trip to the head of the fiord in 1891 . $74228-$ No. $64-09-2$ 
East of this valley, up to and beyond the end of Nunatak Glacier, the northern wall of the fiord rises steeply, though broken at one point by a U-shaped valley, which ends on the mountain wall as a distinct hanging valley about 1,000 feet above the water, and which is occupied by a glacier with a moraine-covered end (PI. XIX).

The southern wall of Nunatak Fiord is everywhere steep, and in most places actually precipitous. The highest point on this side of the fiord is Mount Drajer (5,525 feet). There are four pronounced mountain valleys, all hanging at elevations of more than a thousand feet above the fiord, and these, as well as the smoothed, striated, spurless slopes, testify to recent powerful glacial erosion. Three of these hanging valleys contain glaciers, only one of which, the easternmost, extends beyond the lip of the valley. To the latter, which passes out of its hanging valley and descends the mountain slope below the lip in a series of ice cascades, Gilbert gave the very descriptive name of Cascading Glacier (Pl. XVIII, $A$ ).

South Arm of Russell Fiord.-From Cape Enchantment and Nunatak Fiord the South Arm extends 17 miles to the head of the bay. Both sides of this fiord are irregular, the eastern more so than the western (Pl. IV). From Cape Enchantment southward to Cape Stoss the western shore is almost everywhere bordered by gravels. This is due (1) to a number of streams descending from the peninsula and building alluvial fans with gravel abundantly supplied by the melting of the small glaciers at their heads; and (2) to the fact that along this coast there are extensive gravel terraces deposited during a period of earlier ice advance. - Only in a few places do the mountain walls descend directly to the South Arm on this side; but back of the gravels the mountains rise precipitously almost everywhere. In the valleys there are numerous small glaciers, all moraine covered at their ends and rapidly receding. "Of these the largest, named in order from north to south, are McCarty, Hendrickson, Rasmusson, ${ }^{a}$ and Hoorts. One or two of these descend to within 1 mile or $1 \frac{1}{2}$ miles of the fiord. The valleys occupied by these glaciers are all hanging, but most of them are at elevations of only 100 or 200 feet above the surface of the fiord.

The eastern side of the South Arm is more precipitous and rises to greater height, reaching an elevation of 6,250 feet in Mount Unana and of 5,600 feet in Mount Ruhamah. For nearly a third of the distance the mountains rise directly out of the fiord, but in the southern two thirds there is prevailingly a fringe either of alluvial fan or of gravel terrace. There are two indentations on this side of the fiord. Seal Bay, the northernmost, is mountain walled, but has at its head a gravel delta built of the outwash gravels supplied from the melting of Hidden Glacier, which terminates about 2 miles from the sea, at the head of the delta, at an elevation of 150 feet. Several miles south of this is a small bay which I have named Shelter Cove. ${ }^{b}$ This cove is made by a low knob of rock connected to the mainland by a terrace of glacial gravels. . It is here that the Yakutat Bay inlet is narrowest, being somewhat less than a mile in width; but nowhere is the South Arm very wide, being generally not more than 1 mile or $1 \frac{1}{2}$ miles across, though expanding to a width of about 3 miles opposite Seal Bay.

On the north side of Seal Bay there is a hanging valley with a cirque glacier at its head, and on the south side there are two others with glaciers at their heads. South of Shelter Cove there are two hanging valleys occupied by good-sized glaciers.

South Arm of Russell Fiord comes to an abrupt end where the mountains meet the foreland previously described (p. 11). Cape Stoss, a low island joined to the mainland by an elevated beach, marks the end on the west side, as does a small bay on the east side. Into this bay are poured the waters of a torrent fed by the melting of a glacier which descends the mountain front east of the fiord.

Head of the Bay.-The expanded head of Russell Fiord, which has a width of 3 to 4 miles, is bordered by a very irregular shore line, much more irregular than the map indicates, consisting for a great part of the distance of gravel cliffs and headlands with intervening bays. The forest comes to the very edge of the gravel bluffs.

a Named after Rev, E. A. Rasmusson, of the Yakutat Mission, to whom thanks are due for many favors and much assistance in connection with the two Geological Survey expeditions.

$b$ It was in this bay that Russell took shelter when overtaken by a storm in his passage up the fiord. 


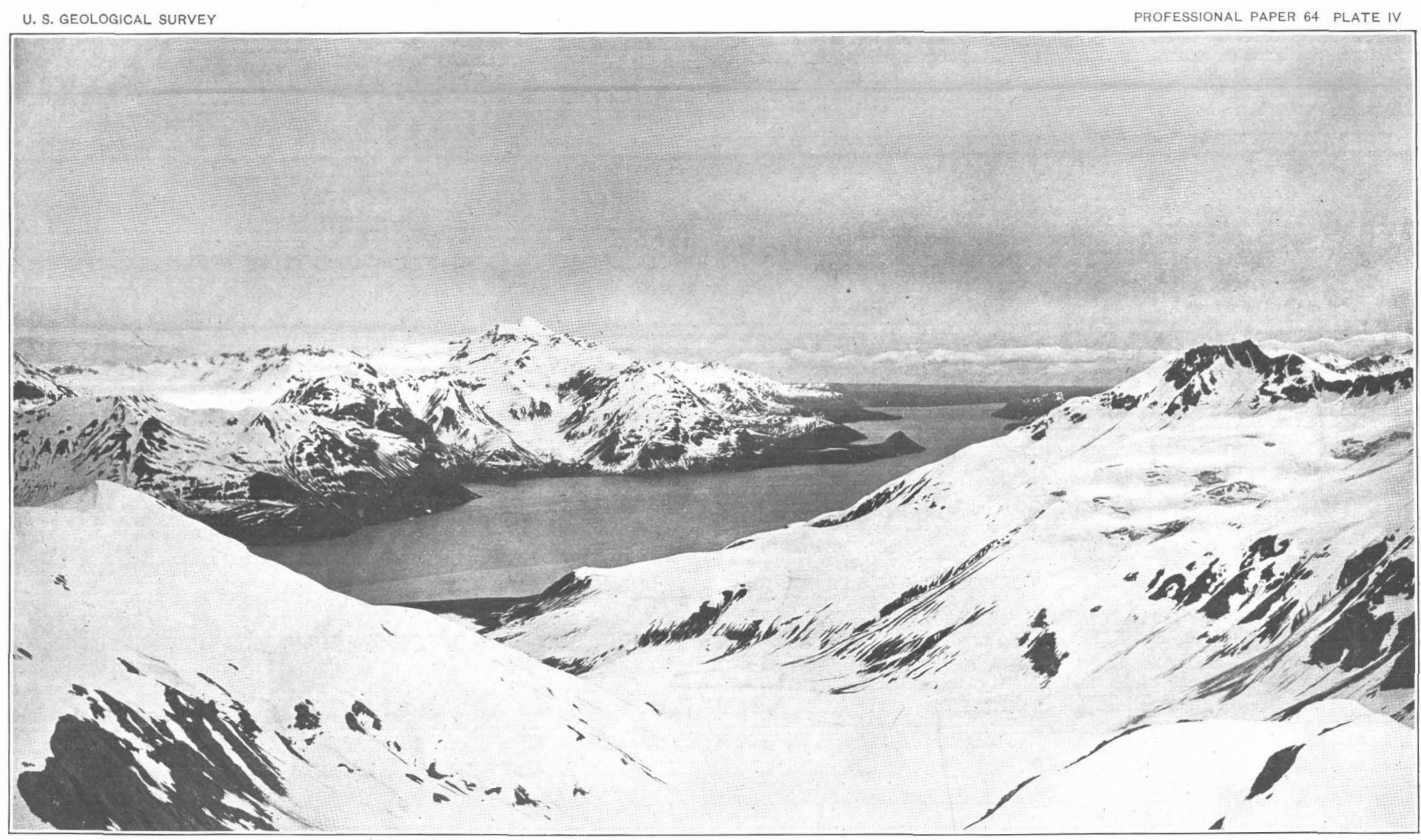

VIEW LOOKING SOUTH THROUGH SOUTH ARM OF RUSSELL FIORD, SHOWING YAKUTAT FORELAND IN THE DISTANCE. Seal Bay and basin of Hidden Glacier on the left; Russell Cove farther up the coast. Photograph by Brabazon, Canadian Boundary Commission. 
$\therefore$ 
On the east side a low buttelike hill rises above the level foreland a mile or two back from the shore. It is evidently a rock island in the gravels and moraines of the foreland. The shore of the fiord nearest to this butte reveals low rock cliffs. On the western side of the head of the bay there are also rock outcrops, forming headlands between small bays, and in some cases the shores of the bays as well.. These rock outcrops are all low and are covered by the gravels and moraines of the foreland, which nowhere reach a height of more than 250 feet and are usually much lower.

This part of the fiord resembles the archipelago on the eastern side of Yakutat Bay and presents a striking contrast to the rugged topography in the rest of the fiord. It has every appearance of being the site of an expanded ice foot of the great glacier which once occupied Russell Fiord. The irregular outline of the ice contact, as molded in the moraines, has been greatly modified by powerful wave action, here made possible, as nowhere else in the fiord, by the strong winds which are able to sweep its whole length; but some of the irregularity is still preserved in the form of bays and headlands, and in one place by an island which lies a little more than one-fourth mile from one of the headlands.

The head of the bay is only 13 or 14 miles by air line from Yakutat, though it is fully 75 miles by water, through all of which the largest steamers can sail. 


\section{CHAPTER II.}

\section{PREVIOUS EXPLORATIONS.}

\section{EIGHTEENTH CENTURY.}

Early visits.-Bering sighted Mount St. Elias in $1741 ;^{a}$ and in 1778 Capt. James Cook sailed past the entrance of Yakutat Bay, naming it Berings Bay, mistaking it for the bay in which Bering had anchored.

In 1786 La Pérouse ${ }^{b}$ cruised off Yakutat Bay and sent an officer into it in search of an anchorage. The officer reported that there was no suitable place, a statement difficult to understand in the light of our present knowledge. To this bay La Pérouse gave the name of Baie de Monti, in honor of the officer who first landed. The map in the atlas accompanying his book is the first one on which the position of Yakutat Bay is given.

The following year Capt. George Dixon ${ }^{c}$ explored and gave names to several parts of the bay. ${ }^{d}$ Dixon also made the first soundings in this bay, and in his description says that the harbor, to which he gave the name Port Mulgrave, is "entirely surrounded by low, flat islands, where scarcely any snow could be seen, and well sheltered from any winds whatever." He also describes the natives and their mode of living. Captain Douglass anchored in Yakutat Bay in 1788 , but has left no special description of the region.

Malaspina's visit.-In 1792 Malaspina, ${ }^{e}$ an Italian in the service of Spain, was sent with two ships, the Descubierta and Atrevida, to test the accuracy of a report that the western end of the famed Northwest Passage lay in the neighborhood of Yakutat Bay. The eastern shore of the bay was explored and an excursion was made into Disenchantment Bay as far as Haenke Island. One part of Malaspina's description of this exploration is of particular importance since it has been believed to indicate that Disenchantment Bay, as far as Haenke Island, was at that time occupied by an extension of Hubbard Glacier with Turner Glacier as a tributary. This description, as reproduced by Russell from a translation made by Robert Stein, of the United States Geological Survey, was as follows:

An observatory was established on shore, and some absolute altitudes were taken in order to furnish a basis for the reckoning of the watches; but the great concourse of Indians, their importunity and thievishness, made it necessary to transfer all the instruments on board. Still, the latitude was determined, the watches were regulated, the number of oscillations made by the simple pendulum was observed, and the height of Mount St. Elias was measured, being 6,507.6 varas $[17,847$ feet] above sea level. The launches being ready, put to sea on July 2 with the commander of the expedition, in order to reconnoiter the channel promised by the opening, similar to that depicted by Ferrer Maldonado in his voyage; but the small force of the tide noticed at the entrance, and the indications of the natives, made it plain not only that the desired passage did not exist there, but that the extent of the channel was very short; which was also rendered evident by the perpetual frost covering the inner west shore. The launches anchored there, having penetrated into the channel with great difficulty, the oars being clogged by the floating masses of snow; they measured a base, made some marks, gathered various objects and stones for the naturalists, and, having reached the line of perpetual frost, returned to the bay where they had anchored.f They there observed the latitude to be $59^{\circ} 59^{\prime} 30^{\prime \prime}$, and six azimuths of the sun, which gave the variation of the needle as $32^{\circ} 49^{\prime}$. Before leaving that anchorage the commander buried a bottle with record of the reconnoissance and possession taken in the name of the king. They called

$a$ In the report of his first expedition to Mount St. Elias (An expedition to Mount St. Elias, Alaska: Nat. Geog. Mag., vol. 3, 1891, pp. 58-74) the late Prof. I. C. Russell presented a full and carefully prepared abstract of the literature relating to this region up to that date. I have briefy abstracted parts of this account and have added an outline of the work done since 1890 .

$b$ Voyage de La Pérouse autour du monde, 4 vols. and atlas, Paris, 1797, vol. 2, pp. 130-150.

$c$ The voyage around the world; but more particuiarly to the northwest coast of A merica, performed in 1788-1789, in the King George and Queen Charlotte, Captains Portlock and Dixon, London, 1789.

d Baker, Marcus, Geographic dictipnary of Alaska (2d ed., by James McCormick): Bull. U. S. Geol. Survey No. $299,1906$.

e Galiano, Dionisio A Icala, Relacion del viage hecho por las goletas Sutil y Mexicana en el año de 1792 para reconocer el estrecho de Fuca, with atlas, Madrid, 1802, pp. 112-121.

$f$ On the coast of the mainland east of Knight Island.-I. C. R. 
the harbor Desangaña (Disenchantment Bay), the opening Bahia de las Bancas, and the island in the interior Haenke, in memory of $\mathbf{D}$. Tadeo Haenke, botanist and naturalist of the expedition. On the third day they set out on their voyage to Mulgrave, where they arrived on the 6th, after reconnoitering various channels and islands north of that port and mapping them.

Puget's visit.-In 1794, two years after Malaspina's visit, Capt. George Vancouver ${ }^{a}$ also explored Yakutat Bay. The Discovery, under the immediate command of Vancouver, passed the entrance of the bay without stopping; but the Chatham, in charge of Peter Puget, anchored there and Puget carried on important explorations. He went in boats up the bay and found ice barriers in the vicinity of Haenke Island where they had been reported by Malaspina. The result of this exploration is stated in the following words:

Shortly after noon the boat that had been sent to explore Digges's Sound (Disenchantment Bay) returned, and Mr. Puget became informed that it was closed from side to side by a firm and compact body of ice, beyond which at the back of the ice a small inlet appeared to extend N. $55^{\circ} \mathrm{E}$. about a league. $b$

Position of Hubbard Glacier front in 1792 and 1794.- To Russell and others these statements have seemed to indicate that in 1792 and 1794 Hubbard Glacier extended as far as Haenke Island. Our work has led us to question this interpretation of the statements of these early explorers. Evidence of three kinds opposes this conclusion. In the first place the region between Haenke Island and Hubbard Glacier is occupied by vegetation of far more mature development than that in Nunatak Fiord, which has unquestionably been recently occupied by a. glacier. The more rapid return and development of this vegetation in Disenchantment Bay would be difficult to explain. Secondly, there are no lacustrine deposits or shore lines in the Northwest Arm of Russell Fiord, as there should have been if Hubbard Glacier swept past Osier Island, and as there are in the South Arm, into which, during a recent expansion, Nunatak and Hidden glaciers have extended. Thirdly, the elevated shore lines in Disenchantment Bay (raised during the earthquake of 1899) are seemingly as perfectly developed above Haenke Island as below it, and far too strongly developed for wave work of a single century.

After a careful examination of the two accounts, the conclusion that the glacier reached as far as Haenke Island does not seem necessary, even if warranted. The explorers speak of a "compact body of ice" and "the line of perpetual frost." It is to be noted that the Malaspina account speaks of "perpetual frost covering the inner west shore." It is evident that by this at least, is meant floating ice such as to-day forms a continuous barrier along that coast of such compactness as to render the pushing of a boat through it very difficult, especially early in the season when the broken ice is more or less compactly frozen into large masses, as it is late in June and early in July, the season of both the Malaspina and Puget visits.

The chronicler of the Malaspina expedition speaks of the "oars' being clogged by the floating masses of snow" (ice?) as they are even to-day on nearing Haenke Island, where the bay is sometimes almost completely closed with a great mass of floating glacier ice. He says "having reached the line of perpetual frost." This certainly can have no other meaning than floating ice, for no small boat could have gone up to an ice cliff discharging icebergs as Hubbard Glacier does to-day. Even if they had done so, it seems inconceivable that explorers with such a novel experience should have failed to even mention it, although stating other details of a trivial nature. Surely they would have been sufficiently impressed by a great ice cliff 3 miles long and 250 feet high, which was constantly discharging icebergs with a noise like thunder and huge outrushing waves, to have at least mentioned the fact.

Nor is Puget's account more convincing. To-day the bay at Haenke Island is frequently "closed from side to side by a firm and compact body of ice" through which a boat is pushed with great difficulty. He says that "back of the ice a small inlet appeared to extend N. $55^{\circ} \mathrm{E}$. about a league." With Hubbard Glacier as the "firm and compact body of ice" it is difficult to see how such an inlet could exist here; but if the ice described is floating ice, such an "inlet" might well exist. In fact, to-day, between Haenke Island and the peninsula there is quite

a A voyage of discovery to the northern Pacific Ocean and around the world, 1790-1795, new ed., 6 vols., London, 1801; vol. 5, pp. 348-409.

$b$ Vancouver's Voyage, vol. 5 , p. 389

c Tarr, R. S., and Martin, L., Position of Hubbard Glacier front in 1792 and 1794: Bull. Am. Geog. Soc., vol. 39, 1907, pp. 129-136. 
commonly a lane of water, with little floating ice, even when the passage at Haenke Island is closed.

From these and other facts, ${ }^{a}$ therefore, it is believed that both explorers encountered floating ice and declined to push through it. The "inlet" they saw was that between Haenke Island and the peninsula. Their failure to push farther in is readily understood by one who is familiar with the ice in this bay when at its worst. Frederick Funston, ${ }^{b}$ whose later career in the Army leads one to believe that he would hardly overstate the difficulties of navigating this ice-covered water, says: "Canoeing in Disenchantment Bay was attended with much labor and no little peril, as we were constantly in danger of being crushed in the floating ice which filled the bay at all times." The captain of the Alaskan steamer Santa Ana, accustomed to navigating the icedotted waters of Icy Straits, took the survey party into Disenchantment Bay with instructions to land it on the west side. When he saw the band of "perpetual frost covering the inner west shore" he declined to land us as instructed, saying that it was impossible to push a boat through the ice and that he would not try. That it was not impossible is proved by the fact that the survey party did go through it the next day; but it took hours of hard work and was attended by not a little danger to the heavily laden boats.

Russian occupation.-The Russians built a fort at Yakutat in 1795, and from that time till the date of purchase of Alaska by the United States trading with the Indians was carried on more or less continuously, this bay being an important source for the skins of the sea otter. ${ }^{c}$ Little was added to our geographic knowledge as a result of this occupation, though Tebenkof ${ }^{d}$ gives some description of the mountains and bays in the vicinity of Yakutat.

\section{NINETEENTH CENTURY.}

Early work of the Coast Survey.-The Coast Pilot for $1869^{e}$ contains some information concerning the conditions in Yakutat Bay as then understood. In 1874 (May 21-26) the United States Coast Survey carried on a survey in Yakutat Bay ${ }_{,}^{f}$ in which the elevation of Mount St. Elias was determined and geologic and geographic data were gathered. Supplementary to this report is a description of the St. Elias region in the Pacific Coast Pilot, ${ }^{g}$ in which the existence of Malaspina Glacier is announced and its name given to it. When seen in May, 1874, the entire surface of the glacier was so covered with snow that its true nature was not recognized; but in June, 1880, a later month, when much of the snow had melted, its true character was discovered and for the first time announced. Charts of the region were issued by the United States Coast Survey on the basis of this work by Dall and Baker.

Early mountain-climbing expeditions.-The New York Times expedition in 1886 and the Topham expedition in $1888^{h}$ endeavored to ascend Mount St. Elias and explored part of Malaspina Glacier, but their descriptions add. nothing to our knowledge of that part of the Yakutat Bay region with which this report deals.

Eleventh Census. - In the volume on Alaska in the Eleventh Census of the United States Eliza R. Scidmere (p. 53) and Henry Boursin (p. 230) mention the Yakutat region briefly, speaking specifically of the economic deposits.

Russell's explorations.-Far the most important explorations in the Yakutat Bay region were those conducted by the late Professor Russell in 1890 and 1891. Although he failed in the central object of his explorations-the ascent to the summit of Mount St. Elias-Russell brought back a wealth of geographic and geologic material, the most noteworthy part being his description of the conditions in and around Malaspina Glacier and his exploration of what is now known as Russell Fiord.

a See Tarr, R. S., and Martin, L., Position of Ilubbard Glacier front in 1792 and 1794: Bull. Am. Geog. Soc., vol. 39, 1907 , pp. 129-136.

$b$ Contr. U. S. Nat. Merbarium, vol. 3, 1895, p. 327.

c Dall, W. H., Alaska and its resources, 1870, pp. 316-333. For further bibliographic reference see Dall, W. H., and Baker, M., Partial list of charts, maps, and publications on Alaska and the adjacent region: Pacific Coast Pilot, Coast and Inlets of Alaska, 2d ser., U. S. Coast Survey, 1879, pp. 225-375.

d Atlas of the northwest coast of A merica from Bering Strait to Cape Corrlentes and the Aleutian Islands, etc., St. Petersburg, 1852.

- Davidson, George: U. S. Coast Survey, Pacific Coast, Coast Pilot of Alaska, from southern boundary to Cooks Inlet, pt. 1, pp. 137-140.

$f$ Dall, W. H., Ann. Rept. Coast Survey for 1875, appendix 10, pp. 157-188.

g A laska, pt. 1, Washington, 1883, p. 212.

$h$ See references in Russell, I. C., An expedition to Mount St. Elias, Alaska: Nat. Geol. Mag., vol. 3, 1891, pp. 73-74. 
On his first expedition, in $1890,{ }^{a}$ Russell made a boat trip to Haenke Island on July 3 , and late in September he went up Disenchantment Bay in the revenue cutter Corwin to a point beyond Haenke Island where he could look into the eastern extension of the fiord now bearing his name. So far as known the Corwin was the first vessel to navigate these waters.

In his second expedition, in 1891, Russell began his explorations from the Pacific side of Malaspina Glacier near Yahtse River; but in the autumn, on his return from the mountain, he skirted the margin of Malaspina Glacier from the Yahtse to the Kwik and thence onward to the mouth of Disenchantment Bay. In this, as in his first expedition, Russell gathered data of the highest value concerning Malaspina Glacier. ${ }^{b}$

After reaching Disenchantment Bay he made a boat trip to the very head of the inlet between September 5 and 14, this being the first expedition through the whole length of the fiord of which we have a definite record. Undoubtedly the Indians were familiar with the entire inlet, for they now go freely to its head; and Russell says ' that John Dalton, with a single' companion, is reported to have made a trip to the head of the bay a few years earlier. Of the inlet now called Russell Fiord, Russell says: ${ }^{d}$

No other inlet on the wild Alaskan coast is more picturesque or more beautiful. It recalls the splendors of Lynn Canal, but added to the charm of vast snow-covered ranges is the variety and novelty of glacial scenery, which is fully as attractive as that of Glacial [Glacier] Bay, which is already famous.

The observations which Russell made on these expeditions are of such high importance that his work will be referred to in detail at numerous places on succeeding pages. In addition to the two full reports referred to above, he has published several articles on special phases of the work.e

Funston expedition.-In 1892 Frederick Funston spent the season, from May 19 to September 4, in Yakutat Bay on a botanical expedition. ${ }^{\prime}$. Funston collected plants and material for a description of the general condition of the flora as far up the bay as Haenke Island. He also crossed over to the west shore opposite Point Latouche. His collection included 154 different species.

Boundary survey.-In connection with the international boundary dispute, an excellent topographic map of Yakutat Bay and vicinity was made on the basis of a photographic survey conducted by A. J. Brabazon in 1895, the commissioners being W. W: Duffield, superintendent of the United States Coast Survey, for the United States, and W. F. King, chief astronomer, for Canada. This map was of great use in the Geological Survey expeditions, and is employed as the base for the general maps of the region that accompany this volume. The photographs upon which this survey is based are of excellent character and have been of much value in the study of the physiography of the region. Some of them are reproduced in this report. This survey ranks with the Russell and Gilbert explorations as one of the most important geographic expeditions to Yakutat Bay.

Abruzzi expedition.--In 1897 Prince Luigi, Duke of the Abruzzi, made Yakutat Bay the base for his ascent of Mount St. Elias. The report of his expedition ${ }^{g}$ contains much general information about the region, particularly a description of the conditions on Malaspina Glacier, and it includes some exceedingly fine photographs by Vittorio Sella.

Bryant expedition.-In 1897, also, H. G. Bryant, of Philadelphia, made a traverse across Malaspina Glacier from Osar River to the Samovar Hills and up Agassiz Glacier to Newton Glacier. Unfortunate circumstances prevented him from continuing his journey toward the summit of Mount St. Elias. He has not as yet published any account of his observations.

a Russell, I. C., An expedition to Mount St. Elias, Alaska: Nat. Geog. Mag., vol. 3, 1891, pp. 53-203.

b Russel, I. C., Second expedition to Mount St. Elias: Thirteenth Ann. Rept. U. S. Geol. Survey, pt. 2, 1892, pp. 1-91.

cIdem, p. 84.

d Idem, p. 90.

e Russell, I. C., Explorations in Alaska: Am. Geol., vol. 7, 1891, pp. 33-38. Origin of the gravel deposits beneath Muir Glacier, Alaska: Am. Geol., vol. 9, 1892, pp. 190-197. Mount St. Elias and its glaciers: Am. Jour. Sci., vol. 43, 1892, pp. 169-182. Malaspina. Glacier: Jour. Geol., vol. 1, 1893, pp. 219-245. Bull. Am. Geog. Soc., vol. 28, 1896, pp. 217-228. Glaciers of North America, 1897, pp. 92-127 and 150-153. Also popular articles in Century Magazine for 1891 and 1892.

$f$ Contributions from U. S. Nat. Herbarium, vol. 3, No, 6, 1895, pp. 323-353. Field report by Frederick Funston; botanical deseription by. F. V: Coville.

g Filippo de Filippi, The ascent of Mount St. Elias by H. R. H. Prince Luigi A medeo di Savoia, Duke of the Abruzzi, 1900 . 
Harriman expedition.-In 1899 the Harriman Alaska Expedition entered Yakutat Bay in the steamer George W. Elder and, under the pilotage of a Yakutat Indian, sailed to the ve.y head of the bay, being the first ship to do this. The expedition remained in the inlet from June 19 to 23 , and on its return, July 23, again steamed into the mouth of the bay. The accounts of the results of this expedition into Yakutat Bay so far published are scattered through four volumes. John Burroughs gives a general description ${ }^{a}$ of the bay and John Muir of the glaciers; ${ }^{b}$ C. V. Grinnell describes the summer sealing village; ${ }^{c}$ Charles Keeler furnishes a description of the birds of Yakutat Bay; ${ }^{d}$ B.E. Fernow briefly describes the forests; ${ }^{e}$ and Henry Gannett $f$ briefly describes the geography of the region, for the first time applying the name Russell Fiord to that part of the inlet of which Russell was the first explorer. Instead of giving a new name to the fiord beyond Osier Island, Russell had called it all Disenchantment Bay; but Gannett states: "We have rechristened it, in honor of its discoverer and first explorer, Russell Fiord."

B. K. Emerson ${ }^{g}$ and E. O. Ulrich ${ }^{h}$ contribute a discussion of the geology of the region which adds materially to our knowledge. But so far as this paper is concerned, by far the most important result of the Harriman Expedition is contained in the report on glaciers by Gilbert; ${ }^{i}$ who photographed and studied, while Gannett mapped, the four largest glaciers. Gilbert's descriptions and discussions, which are of the highest importance, will frequently be referred to on later pages.

\section{TWENTIETH CENTURY.}

Fish Commission Expedition.-The United States Fish Commission sent an expedition to the Yakutat Bay region in July, 1901.j One party, in charge of Lieut. Hugh Rodman, made a traverse from Yakutat to Dry Bay, partly by canoe, through the sloughs along the seaward margin of the Yakutat foreland. Another party, in charge of Ensign C. R. Miller, went to the head of Russell Fiord, thence by canoe down Situk (See-tuck) River across the foreland and on to Yakutat. The reports of these expeditions, which are accompanied by a map, ${ }^{k}$ give the best description of the foreland so far published.

Later Coast Survey work.-A general description, with sailing directions for outer Yakutat Bay, was given in the Coast Pilot for $1901,{ }^{l}$ revised from the statement in the Coast Pilot for 1891. ${ }^{m}$ An excellent chart (Chart No. 3455) of the outer bay was published by the United States Coast Survey in March, 1901. A Boundary Survey party, in charge of Fremont Morse, was at work in the inlet in the summer of 1906, locating boundary peaks and making a series of photographs suitable for use in map construction.

United States Geological Survey expeditions of 1905 and 1906.-The expeditions on which the present report is based were made in the summers of 1905 and 1906, as part of the work of the Alaskan division of the United States Geological Survey.

A grant of money obtained from the American Geographical Society made it possible to attach Lawrence Martin to the expedition of 1905 as special assistant in physiographic and glacial geology. B. S. Butler, the second scientific member of the 1905 party, was regular geologic assistant. The other members of this expedition were Benno Alexander, cook, and two natives, T. J. Henry and Moses Kinkuski, boatmen. Landing at Yakutat, June 23, 1905, the expedition proceeded by boat to various points on the shore, occupying in all twenty camp sites, traversing almost the entire coast line, and making numerous short expeditions into the interior. The season closed September 4 .

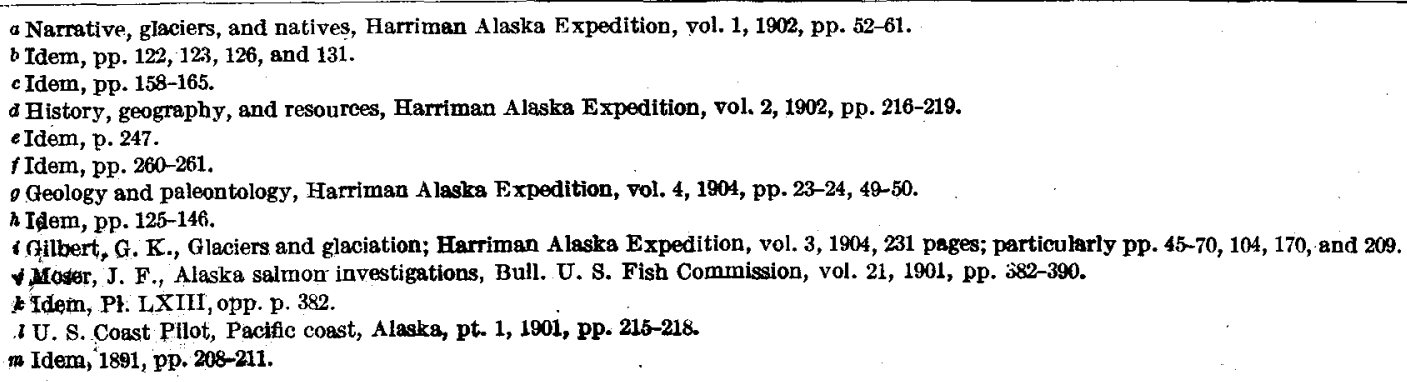


The expedition of 1906 included, besides myself, B. S. Butler, O. D. von Engeln, J. L. Rich, and R. R. Powers as scientific assistants, Benno Alexander and W. Thompson as packers, a Japanese cook, and six Indian packers. The work extended from June 23 to August 29. The plan was to cross Malaspina Glacier from east to west, but the advance of glaciers between 1905 and 1906, described in a later chapter, prevented the execution of this plan, and the party was unable to go farther northwest than Blossom Island. One boat trip was made to the head of the bay in June, and another later in the season as fat as Orange Glacier. Besides shorter trips, a reconnaissance was made up the Kwik Valley across Hayden Glacier to Blossom Island, and thence back across Hayden and Lucia glaciers to Terrace Point on the western margin of Atrevida Glacier.

In addition to this report the following articles have been published on certain phases of the work of these expeditions:

Tarr, R. S., and Martin, L., Recent change of level in Alaska: Science, vol. 22, 1905, pp. 879-880.

Observations on glaciers and glaciation at Yakutat Bay, Alaska: Bull. Am. Geog. Soc., vol. 38, 1906, pp. 99-101.

Glaciers and glaciation of Yakutat Bay, Alaska: Bull. Am. Geog. Soc., vol. 38, 1906, pp. $145-167$.

Recent changes of level in the Yakutat Bay region, Alaska: Bull. Geol. Soc. America, vol. 17, 1906, pp. $29-64$.

Recent change of level in Alaska: Geog. Jour., vol. 28, 1906, pp. 30-43.

Position of Hubbard Glacier front in 1792 and 1794: Bull. Am. Geog. Soc., vol. 39, 1907, pp. $129-136$.

The Yakutat Bay earthquakes of September, 1899 (in preparation; to be published by the U. S, Geological Survey).

Tarr, R. S., The Yakutat Bay region: Bull. U. S. Geol. Survey No. 284, 1906, pp. 61-64.

- The advancing Malaspina Glacier: Science, vol. 25, 1907, pp. 34-37.

Glacial erosion in Alaska: Pop. Sci. Monthly, vol. 70, 1907, pp. 99-119.

Second expedition to Yakutat Bay, Alaska: Bull. Geog. Soc. Philadelphia, vol. 5, 1907, pp. 1-14.

The Malaspina Glacier: Bull. Am. Geog. Soc., vol. 39, 1907, pp. 273-285.

Recent advance of glaciers in the Yakutat Bay region, Alaska: Bull. Geol. Soc. America, vol. 18, 1907, pp. 257-286.

Some phenomena of the glacier margins in the Yakutat Bay region, Alaska: Zeitschr. für Gletscherkunde, vol. 3,1908 , pp. 81-110. 


\section{CHAPTER III.}

\section{GENERAL PHYSIOGRAPHIC HISTORY; ORIGIN AND EFFECTS OF ICEBERGS. GEOLOGIC STRUCTURE.}

The region traversed by the Yakutat Bay inlet is complex in its geologic structure, and a full discussion of the geology must be postponed. In general, the geologic formations of the region are four in number, each with its own area and its own type of structure. Named in order of age from youngest to oldest these formations are (1) the glacial gravels; (2) the Tertiary rocks; (3) the Yakutat group; and (4) the crystalline rocks. (See geologic map, Pl. XXXVII.) These will be briefly considered separately.

GLACIAL GRAVELS.

Gravels, accumulated during a greater advance of the ice, occur at various points around the inlet; but the most extensive and typical area lies outside the mountain front, forming the coastal plain, or Yakutat foreland, already mentioned. These deposits vary in character, ranging from distinct moraines to alluvial fans of outwash gravel and sand, and they differ in age, some having been laid down at a not very remote period of former extension of glaciers, others being very recent. They present many interesting features, a discussion of which is undertaken in Chapter IX.

The total depth of these deposits is unknown, though in places they are more than 100 feet thick. Nor, over most of the area, is the nature of the underlying platform known. At the head of Russell Fiord, for a mile or two outside the mountain front, the gravels rest on a low platform of crystalline rock, but these low rock outcrops end abruptly near an old fault line, along which slight additional uplift took place in 1899, and on the seaward side of which no bed rock has been found. The fault line at this point does not pass along the exact base of the mountains, as it does farther to the northwest between Russell Fiord and Yakutat Bay.

\section{TERTIARY ROCKS.}

Just outside the mountain base, about 3 miles from the shore on the west side of Yakutat Bay, there are some relatively low outcrops of sandstone, shales, and clay, bearing lignite coal, which are tentatively assigned to Pliocene age. These beds do not occupy an area of sufficient size to form a notable part in the physiographic problems of the region.

The exact relation of these rocks to the older beds which form the neighboring mountains could not be determined with definiteness. They were traced to a point within less than a quarter of a mile of the older beds of the Yakutat group, and, for a number of reasons, it was inferred that the two belts of different age are separated by a line of faulting. While the rocks of the older Yakutat group are greatly folded and faulted, the Tertiary beds, with entirely different strike, are both less indurated and far more uniform in structure. The close approach of two such different formations, with entirely different dips and strikes, does not, of course, demonstrate a fault line; but in a region where other evidence proves the presence of numerous lines of faulting, both in past times and at present, this is a most natural inference from the conditions.

Although seen in only an exceedingly small area, this formation has decided interest because it has been uncovered by comparatively recent recession of the glacier, and may form a large part of the platform on which rests the 1,500 square miles of ice forming the plateau foreland of Malaspina Glacier; in fact, it may also underlie the gravels of the foreland on the east side of Yakutat Bay. 
YAKUTAT GROUP.

The mountains between the foreland and the Northwest Arm of Russell Fiord are made up of a complex formation to which the name Yakutat system was given by Russell. Rocks of this same type form all the mountains examined to the west of Disenchantment Bay, at least as far as Marvine Glacier; all of the peninsula between Russell Fiord and Yakutat Bay; and all the mountains on the east side of the South Arm of Russell Fiord. In other words, in this region rocks of the Yakutat group constitute the mountains in what has been designated the foothill section of the main St. Elias Range, now named Brabazon Mountains.

In the region occupied by the Yakutat group there are some areas of crystalline rocks which apparently form the basement on which the Yakutat rocks rest. Among these are granite, diorite, and white crystalline marble; but so far as was observed these crystallines form a distinctly minor feature in the area occupied by the Yakutat group. This is unquestionably true along the coast line, and was found to be the case wherever examination was made in the interior; all parts of this, however, could not be reached, and in many cases it was necessary to draw inferences from the topographic form, from the stream pebbles, and from the moraines of the glaciers, all of which indicate relatively unimportant areas of crystalline rock within the boundaries of the region dominated by the Yakutat rocks.

Resting on these crystalline rocks is the Yakutat group, a series of massive black conglomeratic argillite, black shale, thin-bedded black shales and sandstones, and a coarse-bedded gray indurated graywacke. There are also areas of a coarse conglomerate whose pebbles, often reaching the size of bowlders, include many older crystallines.

These strata, including both the crystalline basement and the sedimentary rocks of the Yakutat group proper, are folded and faulted in a most intricate manner. There are numerous great overturned S-shaped folds, and apparently also extensive overthrust faults. In addition to these greater disturbances there is a remarkable complex of minor folding and faulting, oftentimes resulting in a veritable brecciation and kneading. There is scarcely an outcrop on the shores of the fiord which does not show both folding and faulting; and usually a number of folds and faults appear in every outcrop a few yards square. Subsequent to the deformation dikes have been intruded.

The complexity of this disturbance of the strata has made it impossible to even estimate the thickness of the beds. It has also given rise to great and confusing variations in dip and strike.

The rocks of the Yakutat group, especially the graywacke, disintegrate readily and are rapidly crumbling away. Extensive talus slopes occur in favorable situations and are rapidly growing by the frequent fall of rock fragments. In spite of its massiveness, the graywacke, which contains much feldspar, both plagioclase and orthoclase, yields readily to the weather; but along the coast it resists the mechanical vear of the waves much better than the soft, thinbedded black shale.

\section{CRYSTALLINE ROCKS.}

While the southwestern shore of the Northwest Arm of Russell Fiord is made of the Yakutat rocks and basement crystallines, the northeastern shore includes only crystalline rock. Along the immediate shore the rock is all slate, with strike roughly parallel to the axis of this arm of the fiord. Back from the shore, however, there is a complex of crystallines, including granite and other plutonic rocks, and a variety of gneisses and schists. Accompanying this change in geologic structure is a decided increase in the height of the mountains, as well as in their ruggedness. There is also much less talus, and evidently far less rapid denudation, due to the greater induration of these igneous and highly metamorphosed rocks.

The slate members of the crystalline belt cross Nunatak Fiord near its mouth and extend thence into the valley of Hidden Glacier. Near the shores of Nunatak Fiord the unmetamorphosed black shales of the Yakutat group were traced up to the slate strata. This contact, together with the fact that the two very different beds have different dips and strikes, proves that the Yakutat and crystalline rocks are separated by a fault. A continuation of this fault 
line would extend southeastward through the Hidden Glacier valley, and northwestward along the lower arm of Russell Fiord. It is inferred, therefore, that the Northwest Arm of Russell Fiord is situated along a fault line between these two widely different geologic formations.

\section{THE MOUNTAINS.}

SUBEQUALITY OF LEVEL.

Back of the foreland the region is everywhere mountainous, rising to elevations of 3,000 to 5,000 feet in the foothills section occupied by the Yakutat group, and from 5,000 to 16,000 feet in the area of the crystalline rocks. There is no abrupt topographic change between these two divisions of strata, but, instead, a rather rapid increase in elevation and ruggedness (Pls. $\mathrm{V}, \mathrm{VI}$ ). In the low mountain mass of the peninsula there is a certain subequality of elevation among the mountain peaks which gives to the upland surface an appearance that might lead to its being interpreted as an uplifted and dissected peneplain. Numerous peaks rise to nearly the same level, and some are capped by the graywacke, some by the black shale.

Evidence is elsewhere presented ${ }^{a}$ to show that this mountain region is in a state of present growth, and that upward movements occurred as recently as 1899 ; moreover, that these movements were differential. Assuming this to have been the mode of uplift, and the abundant faulting of earlier date so indicates, it is questionable whether any recognizable remnants of an earlier peneplain would be left. The measure of subequality which is exhibited in the peaks seems capable of explanation in three other ways, as follows:

The weak graywacke and the friable shale, which constitute the bulk of the rock in the area of the Yakutat group, apparently possess nearly the same power of resistance to the weather, and therefore tend to be lowered at a nearly uniform rate under similar conditions of exposure. That the thin-bedded black shale and sandstone, weak though they are in ability to resist the mechanical action of waves, do possess about the same power of resistance to the weather as the massive graywacke, is proved by the fact that they cap many mountain peaks, as in the Mount Tebenkof region.

A second cause for subequality of the peaks is the former and long-continued presence of great ice sheets. Although these were slowly lowering the valleys by glacial erosion, their upper surfaces acted as temporary base levels down toward which the higher peaks were being worn by nivation, cirque recession, and weathering, and below which the lower peaks, covered by snow, could not be further reduced. It is conceivable that, if such conditions lasted long enough, mountain tops originally of very diverse heights might be reduced to a subequality of level.

A third possible aid in the reduction of peaks toward a uniform level is the adjustment of equilibrium by shattering along minor lines of faulting during the tilting of the major blocks. The full importance of this process can not be specifically stated as applied to the problem in hand; but the evidence in this region is clear that it was a phenomenon of importance during the faulting which caused the earthquakes of 1899 .

\section{CYCLES OF DEVELOPMENT.}

Although the presence of an tiplifted peneplain does not seem to be capable of demonstration here, and in fact appears to be rather doubtful, the evidence is clear that this region has undergone denudation for a long period. Omitting from consideration the crystalline area, whose history has been much more complex, involving more than one earlier period of deformation, it appears that the major folds produced $b_{y}$ the intense folding and faulting and igneous intrusion, to which the Yakutat beds have been subjected since their deposition unconformably on the crystalline rocks, have been so profoundly eroded that no observable relation whatever remains between these initial forms and the present upland topography.

The present-day growth of the mountains is along lines of faulting which cut obliquely across the complex structure of the older uplift, resulting in a greatly folded and faulted mountain region subsequently broken into blocks which are now being tilted.

a Tarr, R. S., and Martin, L., The Yakutat Bay earthquakes of September, 1899. (In preparation.) 
The facts stated clearly prove at least two cycles in the development of the foothill portion of this mountain range. Further, there is evidence that this double history represents only the latest stages of mountain growth in this region, and that it followed a complex earlier history in which crystalline rocks alone were involved. That the two deformations were separated by a long erosional interval is proved by the truncation of the overturned folds; and it is possible that this erosion interval lasted long enough to permit the reduction of the area to the condition of a peneplain before the uplift that resulted in the present carving of the fiords. But, as stated above, it has not been possible as yet to find evidence that demands this explanation.

\section{PLANATED STRATA ALONG THE MOUNTAIN FRONT.}

There is one point which may possibly bear upon this question. It has been stated that underneath the foreland, at the head of Russell Fiord, low rock outcrops extend for fully 2 miles from the mountain front. These rock outcrops, rising to a nearly uniform elevation, are clearly planed-off remnants of former mountainous land. Two hypotheses in explanation of this condition suggest themselves: (1) That this planed-off area is a remnant of an ancient peneplain which, in this section, has not been uplifted by the recent faulting, and that it is, therefore, to be correlated with the upland subequality of peaks; or (2) that the low rock outcrops represent a plain of marine denudation formed before the glaciers built the Yakutat foreland, the mountain face being primarily a wave-cut cliff of enormous size.

No facts were discovered which would establish one or the other of these hypotheses, though the fact that the fault line lies on the seaward side of this planed-off bench favors marine denudation rather than peneplanation. There is nothing impossible about such a wave-planed bench. Reusch has postulated such marine denudation to account for the great cliffs, the strip of coast plain, and the low islands of the Norwegian coast. Farther south in Alaska, however, Gilbert ${ }^{a}$ interprets the low coast plain and the off-lying islands as part of a peneplain due to subaerial and not to marine denudation.

\section{THE VALLEYS.}

The mountains of the Yakutat Bay region are deeply dissected by a system of valleys of very peculiar character. The bottoms of the larger valleys lie below sea level-at one point at least 1,000 feet below-while their walls rise abruptly more than 2,000 feet above sea level. The walls are often remarkably straight, and in some instances coincide with demonstrable fault lines, notably in the case of the eastern shore of Yakutat Bay and of both shores of the Northwest Arm of Russell Fiord. On the other hand, many of them, for example the South Arm of Russell Fiord, extend across structure lines and form a network of troughs which bears little resemblance to the pattern of valleys produced by normal mountain drainage. In form also they are peculiar, being broad and U-shaped, with tributaries commonly hanging.

Some of these features are unquestionably due to glacial erosion, as is shown in the chapter on glacial erosion (pp. 107-119); others are doubtless due to preglacial drainage development; but it seems impossible to completely block out the main preglacial drainage lines without the postulation of faulting. There is a peculiar rectilinear arrangement of the valleys, especially noticeable in the branches of the fiord, which seems to demand such an explanation.

Although I am convinced that much of the topography is the direct result of faulting and of glacial erosion, I am not able to go as far as Russell went in the following quotation: ${ }^{b}$

The St. Elias Range is young; probably the very youngest of the important mountain ranges on this continent. No evidences of erosion previous to the formation of the ice sheets that now clothe it have been observed. Glaciers apparently took immediate possession of the lines of depression as the mountain range grew in height, and furnish a living example from which to determine the part that ice streams play in mountain sculpture.

That there was profound denudation before the glaciers took possession of the region is indicated by the truncated folds and by the valley system on the peninsula, which is distinctly a sy tem of mountain drainage lines, later occupied and profoundly deepened and broadened by ice.

a Gilbert, G. K., Glaciers and glaclation: Harriman Alaska Expedition, vol. 3, 1904, pp. 123-139.

b Russell, I. C., An expedition to Mount St. Elias, Alaska: Nat. Geog. Mag., vol. 3, 1891, p. 191. See also Mount St. Elias and its glaciers: Am. Jour. Scl., vol. 43, 1892, p. 175. 


\section{INFLUENCE OF CHIMATE.}

The waters of this part of the Alaskan coast are influenced by a warm ocean current, and the prevailing winds are from the ocean. These conditions tend to produce both an equable and a rainy climate. The tendency toward equability is interfered with in the mountains by elevation; but on the foreland at their base the summers are cool and the winters not very severe. The tendency toward dampness is greatly increased by the steeply sloping mountains and by the presence on them of snow and ice, which, chilling the damp winds that rise over them, induce precipitation. The result is a very rainy climate.

Funston ${ }^{a}$ says that in 1892 , between May 19 and September 4, a period of one hundred and seven days, there were but twenty-four wholly without rain. The records of the Abruzzi expedition ${ }^{8}$ show an excess of cloudy weather and precipitation both at Yakutat and on Malaspina Glacier. No other numerical data are at hand, but the excessive dampness of the summer climate and the heavy summer snows in the mountains were abundantly evident during the two seasons of the work of the Geological Survey.

The two nearest stations at which rainfall records have been kept are Nuchek to the west, at the mouth of Prince William Sound, and Sitka, about the same distance to the southeast. At the latter station the precipitation is about 88 inches a year; at the former, 190 inches. ${ }^{c}$ The heaviest precipitation occurs in the fall and winter months, naturally as snow, even in the lower levels. From this it will be seen that even if the precipitation on the ocean-facing mountain slopes of Yakutat Bay is much less than it is at the sea-level station at Nuchek, the annual snowfall there must still be enormous.

The climate varies decidedly in short distances. It was frequently cloudy and rainy on the foreland when it was clear in Disenchantment Bay; and fog was often present on Malaspina Glacier when the weather was clear in Yakutat Bay. It was, of course, also true that the mountains were frequently clouded when the sky was clear along the shores of the fiord. Even in the most favorable spots, however, an abundance of rain fell along the coast in the summer of 1905 , and still more in 1906.

Of the winter conditions in Yakutat Bay I have no definite knowledge, though there can be no doubt that the winter snowfall in the mountains is very heavy (Pls. V, VI) under the favorable conditions of steady damp ocean winds, blowing against lofty snow-covered mountains. Even in summer heavy falls of snow frequently whiten the mountain peaks and higher slopes. It is this combination of conditions which gives to this part of the Alaskan coast its immense glaciers, the largest and most extensive on the American continent.

\section{EFFECT OF GLACIERS ON TOPOGRAPHY.}

Although the full discussion of glaciers and their effects is taken up in other sections, an outline of the physiographic history of the region would be incomplete without noting the present occurrence and past important effects of glaciers in this region. Permanent snow fields occur at all elevations above 3,000 feet (Pls. V, VI, XI), and in protected spots at much lower heights. From the more extensive of these snow fields small glaciers descend from low elevations and larger ones from the higher mountains, in the latter case deeply filling all the larger valleys with actively moving glaciers, some of which, as already noted, descend to the sea. This condition of ice-filled valleys forms one of the most prominent features of the present topography, a large percentage of the area studied being submerged beneath glaciers or snow fields. The glaciers are, however, mere remnants of former ice floods which reached out to the very mouth of Yakutat Bay.

The topography of the region has been profoundly modified by the action of these glaciers in two ways-by erosion and by deposition. The major effect of deposition is found on the Yakutat foreland, though minor deposits occur throughout the area, and in many sections are

a Contributions from U. S. Nat. Herbarium, vol. 3, No. 6, 1895, p. 328.

$b$ The ascent of Mount St. Elias, 1900, pp. 194-213.

c Abbe, Cleveland, jr., in Brooks, A. H., Geography and geology of Alaska: Prof. Paper U. S. Geol. Survey, No. 45, 1906, p. 165. 


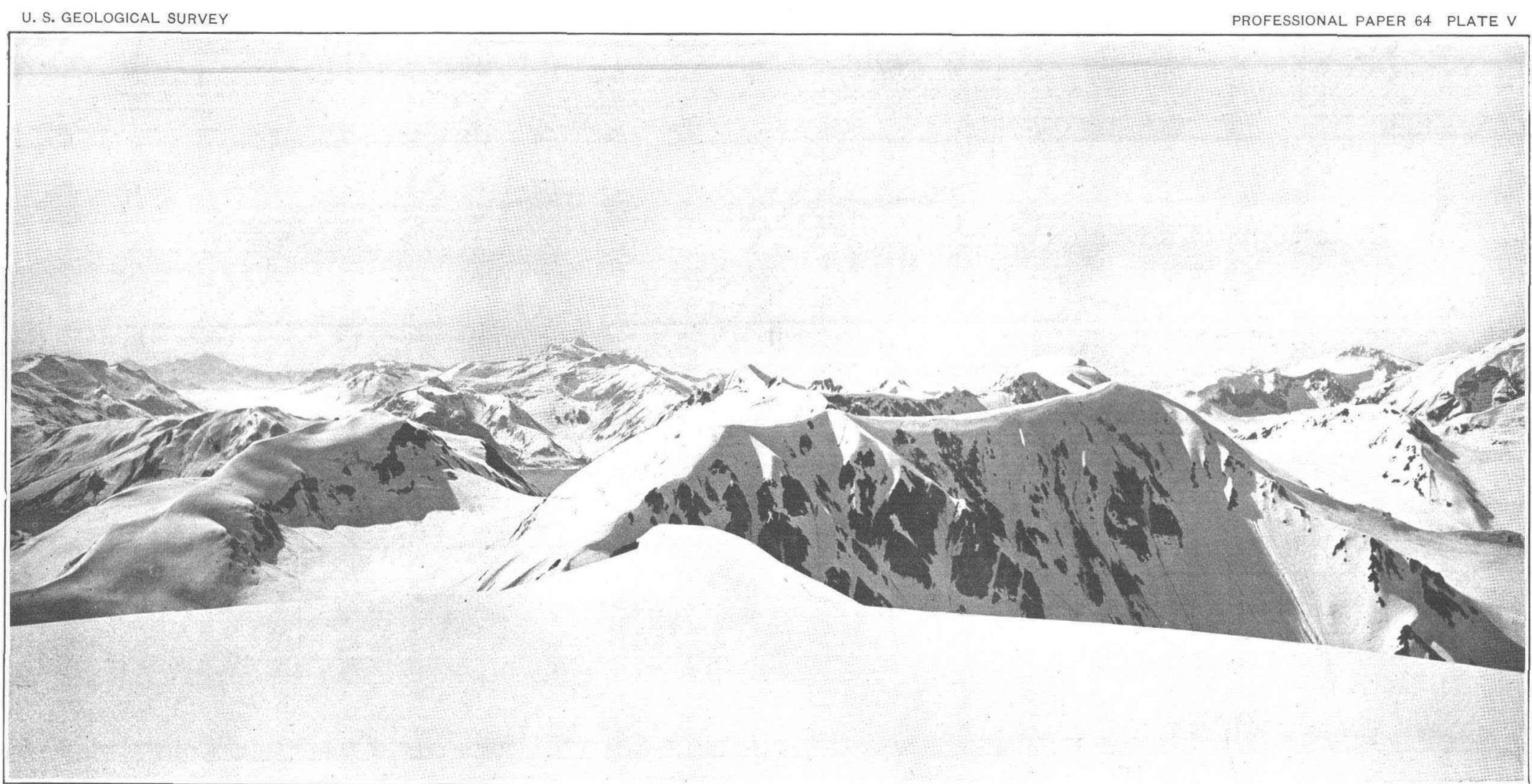

VIEW LOOKING EAST FROM NORTH END OF PUGET PENINSULA.

Showing subequality of many of the mountain peaks, but much diversity of elevation. heavy burden of snow and great snow fields: in the distance, on the left, the valley deeply filled with ice of the Hidden Glacier. Photograph by Brabazon, Canadian Boundary Commission. 
still accumulating. Throughout the inlet the effect of glacial erosion is seen both in the main fiord and in all the minor valleys studied. By it the fiords have been broadened and deepened; the tributary valleys have been truncated and left hanging above the main valleys; the valley walls have been steepened and straightened; divides have been lowered,forming through valleys; and where the ice currents have caused the necessary variation in erosion nunatak knobs have been left, forming a characteristic feature of the otherwise smooth fiord troughs. These effects of ice erosion are among the most striking features in the topography of the region.

\section{ORIGIN AND EFFECTS OF ICEBERGS.}

FORMATION.

Three of the glaciers, to be described later, the Turner (pp. 39-41), the Hubbard (pp. 42-46), and the Nunatak (pp. 54-58), are at present advancing actively into the fiord, terminating in ice cliffs with a total frontage of 7 or 8 miles, from which icebergs are being almost constantly discharged. The greatest discharges come from Hubbard Glacier, but both Turner and Nunatak supply large numbers of icebergs.

The discharge of a great many icebergs was witnessed, some of them from excellent points of observation near at hand. Far the greater number of the falls consisted of a crumbling of the crevassed ice above the water level, giving rise to ice cascades, at a distance resembling falling water. Such discharges produce very small fragments. In other cases large masses fell forward from the ice cliff, producing great commotion in the water near the glacier front.

Occasionally masses of ice rose from beneath the water at a considerable distance from the ice front. Russell describes the latter condition and postulates a projecting ice foot extending fully a thousand feet in front of the ice cliffs. He gives a graphic description ${ }^{a}$ of the formation of such icebergs, which are sometimes 200 to 300 feet in diameter, and usually much larger than those falling from the face of the cliffs. Some of these large icebergs rise 40 to 50 feet above the water.

Bergs immediately in front of the glacier are prevailingly either white, blue, or black in color. The white bergs are derived from the ice walls above the sea; the blue ones, which are often a beautiful Antwerp blue, rise from below the water; the purely black icebergs, which are by no means uncommon, rise mainly from the base of the glacier, though a few fall from the débris-covered portions of the ice front.

In his description of Muir Glacier, Reid ${ }^{b}$ postulates conditions exactly the opposite of those which Russell infers; that is, instead of a projecting ice foot Reid assumes that there is a projecting ice cliff. Only a few icebergs from Muir Glacier are discolored with débris, and Reid suggests that the discolored bergs mentioned by Russell came from the débris-covered parts of the glacier.

My observations were in harmony with those of Russell. In several instances blue ice was seen to rise from beneath the water, though none was observed to rise as far away from the ice front as Russell states. The abundance of débris-charged icebergs near Hubbard Glacier is far too great to be explained by supplies from the very small and almost stagnant débris-covered margins, or from the limited areas of medial moraine. Moreover, the blue bergs are exceedingly abundant near the glacier, and too numerous to be accounted for by melting and overturning so soon after their discharge. Furthermore, the great amount of ice which falls from above water indicates a rapid recession of that part of the cliff, far more rapid than the rate at which melting would be expected to cause the submerged part of the ice to recede.

Three conditions favor the projection of a submerged ice foot, as follows: (1) The warmer water at the surface of the fiord, causing undercutting of the ice there; (2) the crevassed, weathered, and thereby weakened upper portion of the glacier; (3) the attack of waves, especially those generated by the iceberg falls. The combination of these conditions would

a An expedition to Mount St. Elias, Alaska: Russell, I. C., Nat. Geog. Mag., vol. 3, 1891, pp. 101-102.

$b$ Studies of Muir Glacier, Alaska: Reid, H. F., Nat. Geog. Mag., vol. 4, 1892, pp. 48-49. 
tend to produce a projecting ice foot, and the facts observed indicate the presence of such a submerged foot in this region.

The normal condition of iceberg discharge from these glaciers may be best stated by giving a description of an actual instance of the calving of large icebergs which were seen to fall from the south side of the Nunatak Glacier ice cliff. First a small piece fell from the face; then a pinnacle at the ice front rose 50 to, 100 feet, reaching well above the surface of the glacier; it then slowly turned over into the fiord, sending a large fountain of water to a height of 75 or 100 feet. Immediately following this another ice mass, clear and blue, arose from beneath the water's surface, throwing it into renewed and still greater commotion, which lasted fully five minutes as the berg rocked to and fro. A great series of ring waves spread out for nearly ten minutes, causing a heavy surf on the coast to a distance of at least $1 \frac{1}{2}$ miles from the glacier. Prior to this fall there was almost no floating ice in front of the glacier; five minutes after the discharge of the iceberg there was a ring of very muddy water in which floated several thousand icebergs of small size and six gond-sized ones, all clean and free from drift. The ring of icebergs kept spreading until it reached both shores, advancing a half mile in each direction in about twenty minutes. (See Pl. XVIII, D.) The larger bergs, one of which was more than 100 feet long, rose at least 30 feet above the water.

In the warm summer air the blue icebergs quickly whiten; in one case such a berg, whose discharge was witnessed from the front of Nunatak Glacier, became completely whitened in less than twenty-four hours. One peculiar feature, especially in the neighborhood of Hubbard Glacier, is the frequent presence of iceberg breccias, sometimes composed of a number of small bergs piled together, sometimes due to the presence of a number of small ice fragments on a larger berg. These iceberg breccias evidently originate in two ways. Some are due to the sliding down of small fragments from the ice front upon large bergs at the base; but most are caused by the huge, swirling waves caused by the formation of large icebergs, and notably by those rising from beneath the water. When such waves are generated the surface of the fiord near the center of disturbance is raised in a series of huge ring waves, which, breaking against the larger icebergs, often throw spray completely over their tops, and readily toss the smaller ice fragments upon them. Even at the distance of a mile from the ice front these waves are sometimes alarming, and close to the glacier it is doubtful if a small boat could live during their passage.

\section{DISPERSION OF ICEBERGS.}

The icebergs discharged from Nunatak Glacier form a steady stream of floating ice in Nunatak Fiord (Pl. XXX, D). Some are moved by tidal currents up Russell Fiord, large ones being occasionally seen almost at the head of the inlet. Most of the icebergs, however, float out of Russell Fiord and join the much larger procession from Hubbard Glacier. Disenchantment Bay is ordinarily greatly encumbered with floating ice (Pls. II, IX), and the discolored bergs so closely resemble reefs, when seen from a distance, that one of the early explorers (Malaspina) called this deep bay the Bay of Shoals (Bahia de las Bancas), doubtless mistaking the numerous bergs for small islets. Below Bancas Point the stream of icebergs remains on the west side, though here and there a piece of ice is found well out in the bay. Of this condition the United States Coast Pilot says" "Ordinarily it banks on the western shore of the bay as far south as Blizhni Point. Occasional pieces find their way as far south as Ocean Cape and Point Manby, and scattering pieces are usually found in the body of the bay."

That so little of the floating ice, so abundant in Disenchantment Bay and including so many good-sized icebergs, should find its way to the mouth of Yakutat Bay is remarkable. It is evidently due in part to the influx of warm water from the ocean, and in part to the stranding of the bergs in the shallow water and on the beach along the western side of the bay. Grounded icebergs lie off shore in great numbers south of Bancas Point, and the beach

a Pacific coast; Alaska, pt. 1, 1901, p. 215. 


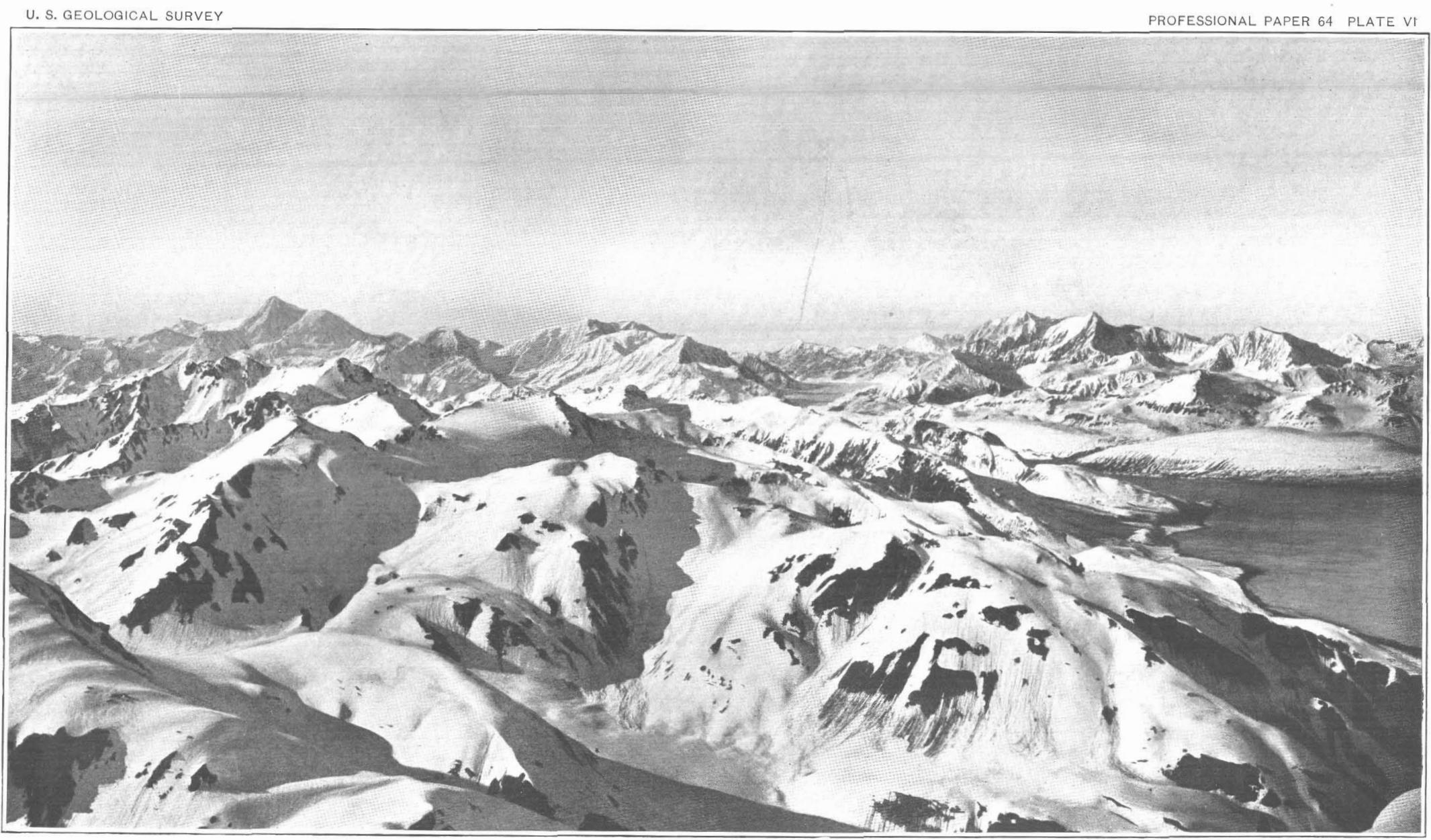

VIEW LOOKING NORTH FROM PUGET PENINSULA. Russell Fiord on the right, bordered on the north by the straight slate coast. Showing rough subequality of mountain peaks and rise of the crests in the
crystalline belt to the north; also vast extent of snow fields. East arm of Hubbard Glacier in valley near center. Photograph by Brabazon, Canadian
Boundary Commission 
there is often completely covered with iceberg bowlders, forming such a barrier that the landing of a boat is difficult, especially when the surf beats on the iceberg-strewn shore. The number of stranded bergs increases after a period of high waves. This is due to the fact that, because of the shoal water, the waves advancing on this coast are transferred into breakers before reaching the beach, and the breaking waves carry the ice blocks up on the beach.

GEOLOGIC EFFECTS OF ICEBERGS.

The icebergs are doing geologic work of importance. The discharge of a large iceberg stirs up the bottom deposits; this being proved by the presence of muddy water after an unusually heavy fall. The waves generated by iceberg discharge perform important work of erosion on the coast. The bergs which run aground must also do notable work of erosion. Those that are thrown upon the beach, in addition to leaving a trail as they are driven over the sand, stir up the beach deposits as they are rocked back and forth in the surf. Frequently the icebergs rest in holes which they have bored into the beach, and which are partly due to the deposit around them. Where the number is not too large the stranded icebergs apparently increase the activity of the waves by breaking them up into swirling surf currents of great velocity; but where they are very abundant they serve to effectively protect the coast by acting as a breakwater.

One of the most important geologic effects of icebergs is that of transportation of sediment. Only a very small proportion of those from Nunatak Glacier are débris-laden, but those from Hubbard Glacier include a large number so charged. Some of these are perfectly black with débris, but commonly they are only partly discolored. In some cases good-sized bowlders are seen either in or on the floating ice. (See Pl. XX, A.) A count of the débris-laden icebergs stranded on a section of the beach between Esker Stream and the Kwik Delta showed that one in every five of the larger icebergs could be classed as dirt-laden, not including under this term those bergs which had only minute quantities of débris. The amount of rock material thus contributed to the bottom of the fiord and to the beaches where the icebergs are stranded must form a very notable addition to the accumulating sediments.

ICEBERG WAVES.

Gilbert ${ }^{a}$ oalls attention to the evidence of iceberg-wave erosion on Osier Island. This evidence is very clear, consisting of a wave-cut bench about 5 feet above the zone of present wave attack. South of Osier Island also, for a distance of a mile or two, there is a rock cliff with its base about 6 feet above the reach of the highest waves, and with a continuous beach extending from it to the present storm beach. No evidence could be found that this condition was due to an uplift of the land.

Study of the elevated shore lines of the inlet yielded further indication of the importance of iceberg-wave erosion. The most prominent elevated beach in the whole region is that which lies on the west side of Disenchantment Bay, between Turner Glacier and Bancas Point, where, at present, iceberg waves are frequent and powerful and where they must have been far more active at the time of the greater extension of neighboring glaciers. On Haenke Island the narrowest elevated wave-cut rock bench is that on the south side, which faces the most open water and which is reached by ocean surf even in summer. But by far the best elevated rock bench is on the northern side of the island, out of reach of ocean surf, but facing Hubbard Glacier; and the bench on the western side, facing Turner Glacier, is more pronounced than that on the eastern side, which is turned away from the glaciers.

In Nunatak Fiord, just west of the nunatak, there is a wave-cut cliff whose base is 2 or 3 feet above the present storm beach; and on the northern side of this fiord, nearer the glacier, there is a wave-cut cliff in the moraine 5 feet above high-tide mark. It is possible that these two instances in Nunatak Fiord are due to uplift of the land, though no confirmatory evidence of uplift could

$74228-$ No. $64-09-3$

a Gilbert, G. K., Glaciers and glaciation, Harriman Alaska Expedition, vol. 3, p. 69. 
be found; and in view of this fact, together with the neighborhood of Nunatak Glacier, it is inferred that these phenomena are due to iceberg wave work.

The calving of a large iceberg causes a profound disturbance of the fiord waters, sending out a series of waves whose effect on the neighboring coast must necessarily be important. From twenty to twenty-five large waves were counted accompanying a single iceberg discharge of moderate size; and in addition there were numerous smaller waves. At a distance of a mile or a mile and a half from the glacier the larger waves produce a surf of such violence that it is often difficult to land a boat even on a beach, while landing on a rocky shore seriously endangers the boat. These iceberg discharges recur with great frequency, and rarely half an hour elapses in which good-sized waves are not breaking on the coasts near one of the glaciers. Even at present the shores of Osier Island and the point back of it receive a vigorous surf from this source; and iceberg waves from Hubbard Glacier break effectively on the coast of Russell Fiord as far southeast as Marble Point, and in Disenchantment Bay beyond Haenke Island. In diminished intensity they are felt even as far south as Point Latouche.

Since all of the tidal glaciers, and others as well, once extended farther out into the bay, sections of coast now remote from the ice front, like Osier Island and Haenke Island, must have formerly received much more violent surf. Moreover, the discharge area of these expanded glaciers was larger, so that the iceberg waves were both more numerous and, being nearer, more effective than now. It seems evident, therefore, that the phenomenon of high-level benches described above could well be caused in the way suggested by Gilbert for Osier Island. 


\title{
CHAPTER IV. \\ EXISTING VALLEY GLACIERS. \\ GENERAL DESCRIPTION.
}

\author{
ICE-FLOODED VALLEYS.
}

When, in 1891, Russell stood upon Russell Col, on a northern shoulder near the summit of Mount St. Elias, he looked northward over a view which he describes in the following words:

What met my astonished gaze was a vast snow-covered region, limitless in expanse, through which hundreds and perhaps thousands of barren, angular mountain peaks projected. There was not a stream, not a lake, and not a vestige of vegetation of any kind in sight. A more desolate or more utterly lifelese land one never beheld. Vast, smooth snow surfaces without crevasses stretched away to limitless distances, broken only by jagged and angular mountain peaks. * * * The view to the north called to mind the pictures given by Arctic explorers of the borders of the great Greenland ice sheet, where rocky islands, known as "nunataks," alone break the monotony of the boundless sea of ice. The region before me was a land of nunataks. $a$

The maps of the Boundary Commission (see Pl. VII) show that the condition described prevails at least from Alsek River to Mount St. Elias. The mountain slopes, where not too steep, are snow covered, and all the valleys are deeply filled with streams of ice (Pls. V, VI). No one has yet explored this region, and therefore the details of its ice drainage can not be stated; but from the Boundary Commission's photographs and maps and from long-distance views obtained in the summer of 1905 it is evident that this mountain region is flooded by ice, giving rise to what is truly an ice-drowned topography, from which valley glacier tongues extend toward and, in some cases, to the sea.

\section{GLACIER HIGHWAYS.}

It is possible to go from one glacier to another across broad snow-covered ice divides. For example, it is said by prospectors that one could start from the terminus of Yakutat Glacier, whose end rests on the foreland east of Yakutat, and, ascending to a broad ice divide, pass on down into the Alsek Valley by one of several courses, or, continuing northwestward, descend either to the terminus of Hidden Glacier or to that of Nunatak Glacier, or even northwest to Hubbard Glacier. In fact, several years ago some of these glaciers were actually used as highways by scores of prospectors as a means of entrance to the Alsek Valley, some going to the head of Russell Fiord and ascending a glacier (called "Fourth Glacier"), which comes down to the foreland just east of the fiord, others going from the head of Nunatak Fiord up Nunatak Glacier (called "Third Glacier"). (See Pl. VIII.) The ruins of a store at the head of Russell Fiord and the remnants of sledges at the base of the nunatak in Nunatak Fiord and of boats at the landing place, near by are relics of these days of over-ice travel.

THROUGH GLACIERS.

Such a condition of ice flood, drowning the valleys and rising high on the slopes of the mountains, which project as nunataks above the glaciers, is so different from that of the normal valley glacier that it seems to demand a special name; it is therefore proposed to apply to it the name "through glacier," taking as a type the glacier system which lies between Russell Fiord

a Russell, I. C. Second expedition to Mount St. Elias; Thirteenth Ann. Rept. U. S. Geol. Survey, pt. 2, 1892, p. 47. 
and Alsek River (Pls. VII, VIII). By the term "through glacier" is meant a continuous icefilled valley from the terminus of one glacier to that of another, across a flat divide from which, in some area of indefinite location and extent, ice drainage flows in both directions. Where well developed, as it is east of Russell Fiord, the through-glacier condition forms an intricate maze of broad rather flat epped glaciers of moderate slope, which so submerge the mountains as to give them the appearance of a drowned mountainous land, like the island-skirted coast of southeastern Alaska.

The striking character of the through-glacier condition attracted the attention of Vancouver more than a century ago. ${ }^{a}$ He says: .

The interruption in the summit of these very elevated mountains [the Fairweather Range southeast of Yakutat Bay] mentioned by Captain Cook was likewise conspicuously evident to us as we sailed along the coast this day and looked like a plain composed of a solid mass of ice or frozen snow inclining gradually toward the low border, which from the smoothness, uniformity, and clean appearance of its surface conveyed the idea of extensive waters having once existed beyond the then limits of our view, which had passed over this depressed part of the mountains until their progress had been stopped by the severity of the climate, and that by the accumulation of succeeding snow, freezing on this body of ice, a barrier had become formed that had prevented such waters from flowing into the sea. This is not the only place where we had noticed the like appearances; since passing the icy bay mentioned on the 28th of June other valleys had been seen strongly resembling this, but none were so extensive, nor was the surface of any of them so clean, most of them appearing to be very dirty. I do not, however, mean to assert that these inclined planes of ice must have been formed by the passing of inland waters thus into the ocean, as the elevation of them, which must be many hundred yards above the level of the sea, and their having been doomed for ages to perpetual frost, operate much against this reasoning; but one is naturally led on contemplating any phenomenon out of the ordinary cause of nature to form some conjecture and to hazard some opinion as to its origin, which on the present occasion is rather offered for the purpose of describing its appearance than accounting for the cause of its existence.

In the type case of the through glacier the divide areas rise only about 3,000 feet above sea level. The glaciers are fed in part by small valley tongues descending from the nunataks and the inclosing mountains, in part by snow slides from these mountains, but in large measure from direct snowfall upon the broad, flat ice surface itself. The movement is evidently slow, and since so much of the surface lies above the snow line, waste from ablation amounts to almost nothing. Because of the slow movement the surface is not greatly crevassed, thus rendering these glaciers excellent highways; but near their termini, where they pass out from the mountains, the motion is often so accelerated as to cause profound crevassing. Since so much of the through glacier lies in the zone of rapid accumulation, morainic deposits are covered beneath the snows of successive seasons and do not appear until the zone of wastage is reached. There the rock débris appears in the form of lateral and medial moraines and, to a lesser extent, as minor accumulations over the whole surface of the glacier.

.While the type of these through glaciers is located east of Russell Fiord, it is probable that the same condition is present among the higher mountains to the north. The Boundary Commission map shows that Hubbard Glacier receives some of its supply from ice-flooded regions of similar character; but without further exploration and mapping an exact description of this region is impossible.

\section{GLACIER TERMINI.}

On descending from the divide areas these through glaciers assume the characteristics of normal valley glaciers, which in many cases they retain to their very termini, where they end in low ice cliffs on the land, often completely covered beneath morainic accumulations. Hidden Glacier ( $\mathrm{Pl}$. XX, $B$ ) may be taken as a type of this condition, though its terminus is not moraine veneered. In favorable situations other larger tongues end as tidal glaciers with ice cliffs; Nunatak (Pl. XVIII, $C, D$ ) and Hubbard (Pl. XIII) glaciers are of this type. Still others, on passing out beyond the mountain front, expand to form fan-shaped piedmont ice plateaus. There are a number of illustrations of this type, on a small scale, in this part of Alaska, but the best example is Malaspina Glacier, formed by the coalescing of numerous 


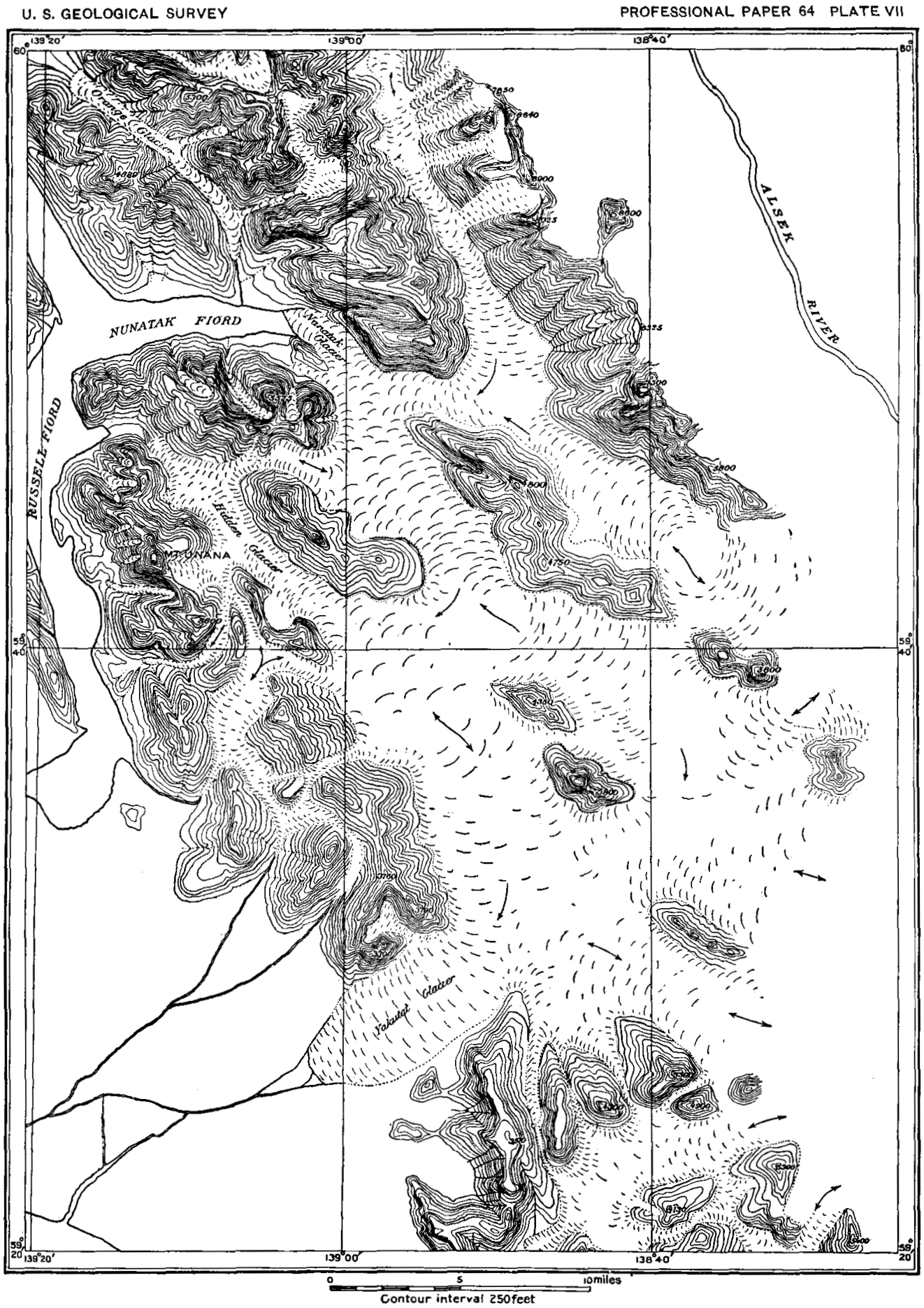

MAP SHOWING THROUGH GLACIER EAST OF RUSSELL FIORD.

Based on the Bcundary Commission map. 
$\longrightarrow$ 


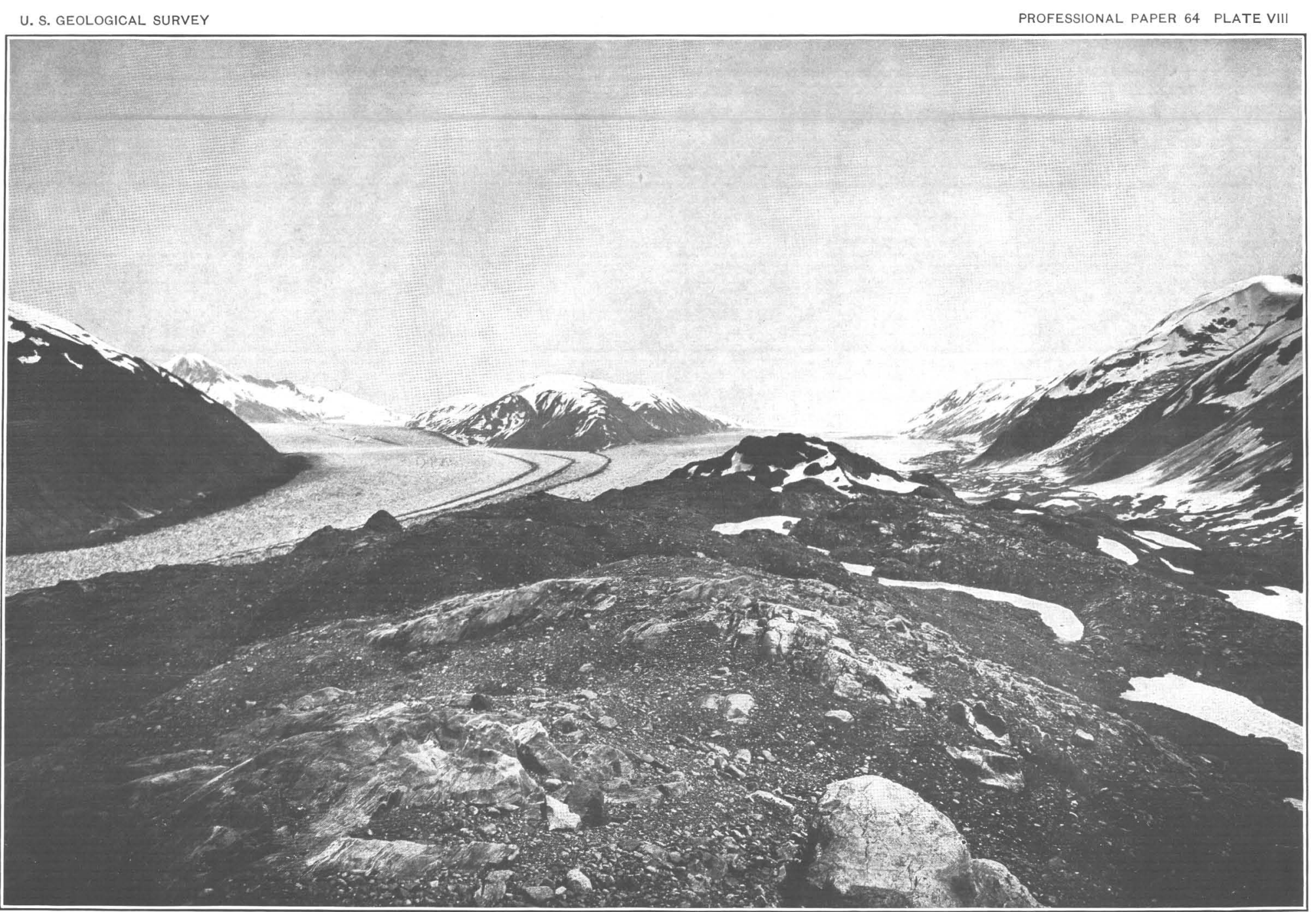

VIEW LOOKING EAST UP THE TWO BRANCHES OF NUNATAK GLACIER FROM CREST OF THE NUNATAK. July 5,1906 , it was possible to travel to the Alsek River valley across the broad ice divide. 


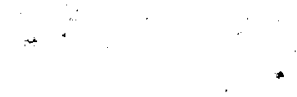


valley glaciers, some of which are the termini of through glaciers. In a former period of greater extension of glaciers in this region the expanded piedmont foot of through glaciers was much more extensive than now and occupied areas now free from ice.

It is a notable fact that the piedmont type of glacier extends much farther out from the mountain base than do those glaciers which are tidal. This is not in all cases due to an excess of supply from the glaciers which feed the piedmont expansions. In Hubbard Glacier, for example, the ice supply is unquestionably great, coming from numerous tributaries and from lofty mountains; yet its terminus is back well within the mountains, while some very small glaciers, like the Atrevida, extend beyond the mountain face and expand in moraine-covered, fan-shaped, piedmont areas.

It seems probable that the chief cause for this difference in position of the ice fronts of the two classes of glaciers is the action of the fiord water, which operates to cause relatively rapid recession in two ways-(1) by melting, breaking away, and removal of the ice front, and (2) by the prevention of marginal accumulations of protecting moraine, thus greatly accelerating ablation. A thin ice foot on the land may become covered with moraine and even with forest, and become so blanketed that it remains unmelted for half a century; but an ice cliff rising above fiord waters can develop no such condition.

\section{ALPINE TYPE OF VALLEY GLACIERS.}

Besides the large glaciers, which are mainly fed from the great ice accumulations back in the mountains, there are numerous small independent valley glaciers of the ordinary alpine type. These vary in length from a few hundred yards to 5 or 10 miles. Some of them are fed from extensive snów fields and by numerous small tributaries, and fill deeply fairly large valleys through which they move actively. Many of the larger descend beyond the mountain front and expand in small piedmont ice fans.

One characteristic of these glaciers, as well as of some whose supply comes from the ice floods back in the mountains, is the almost universal condition of débris-covered termini where . ending on the land (Pls. XVI, XXV). As pointed out by Russell, ${ }^{a}$ these Alaskan glaciers present. a striking difference in condition above and below the snow line. Rock fragments concealed in the névé region are concentrated by ablation near the terminus so as to form sheets of débris, often miles in extent, which almost, if not entirely, conceal the ice on whose surface the morainic débris rests. Some of this concentrated débris is doubtless supplied by the uprising ice currents near the terminus; but a large proportion of it is derived from the upper ice, into which it has been incorporated in the névé area. It begins to appear at the lower limit of permanent snow. In the presence of these extensive areas of débris-covered ice the Alaskan glaciers differ markedly from the normal valley glacier type as illustrated by the glaciers of the Alps. This subject will be more specifically discussed under the individual glaciers.

Some of the smaller glaciers occupy steep valleys in which it seems almost impossible for them to remain. In fact, one of these, more than a mile in length, slid out of its valley while the survey party was in the fiord, and for this reason the valley was named Fallen Glacier Gulch. Other small glaciers occupy cirques; and still others, forming mere shrunken remnants of former large valley glaciers, extend from the steep mountain slopes only part way down the valleys they once completely filled. These glaciers are specially well developed and numerous in the low mountain area of the peninsula.

Another type of valley glacier in this region is that which partly or completely fills the hanging valleys. In some cases these exist only as small remnants at the heads of hanging valleys; in others they extend almost or quite to the lip of the hanging valley; in still others, like Cascading Glacier (Pl. XVIII, $A$ ), the ice passes over the lip and descends part way down the steepened wall of the main valley; and in some cases the glaciers not only spill over the lip of the hanging valley, but descend the steep slope and join a larger glacier in the main trough. 
SMALL THROUGH GLACIERS.

In several instances even small valley glaciers head back upon low ice divides, from which the ice drainage extends in both directions. This condition is illustrated both in the peninsula and in the low mountains north of the Northwest Arm of Russell Fiord (Pl. XVII, A). These glaciers illustrate a late stage in the type of the through glacier, the final stage being apparently illustrated in Dying Glacier, described by Reid. ${ }^{a}$ This glacier, which is about 3 miles long, slopes both eastward and westward, and has moraines running from end to end. It has no real feeders, although a tributary joins it on the south. It is evidently the remnant of a much larger glacier, similar to some of the through glaciers of the Yakutat Bay region, and is rapidly melting away.

\section{SNOW LINE.}

The snow line in this region is extremely variable in elevation. In protected places, where snow has slid down in great quantities, patches remain at sea level throughout the summer. On the shady northern slopes of the mountains the snow line is much lower than on the sunny south side; it is higher on the ocean side than in the interior; and it is evidently lower on the mountains north of Malaspina Glacier, where the ice plateau cools the air, than on the mountains of the peninsula.

Russell ${ }^{b}$ states that the snow line on Hayden Glacier is at an elevation of 2,500 feet. . East of Point Latouche, on a small glacier (the Latouche) in a deep north-south valley protected from the sun during most of the day, the snow line on August 12, 1905, was found at an elevation of 1,850 feet; but on a ridge just south of this there was no snow at an elevation of 2,900 feet, except in small patches where it had been protected from melting, although there were excellent places for the preservation of snow if its crest were below the snow line. Funston $^{c}$ states that the tree line extends up to 3,000 feet on the southern slopes of Mount Tebenkof near the south end of the peninsula, where the mountains come nearest to the ocean. Under such variable conditions it is manifestly impossible to give an accurate average snow line for this region; but in general it may be stated to be between 3,000 and 3,500 feet in the southern half of the peninsula, descending gradually toward the northeast, north, and northwest.

\section{FAN GLACIERS.}

In a number of places a cause for the formation of glaciers was witnessed which demands special description, and for this I select one instance, that of a small glacier in the amphitheater just northeast of Amphitheater Knob, between the Atrevida and Galiano Glacier valleys. Here a steep, narrow, mountain valley, a veritable chute, extends up to a snow-capped mountain crest. The slope is so steep that snow shoots down this valley, but at the base the slope abruptly changes to an almost level surface, due to the presence of a high level moraine terrace formed during the former presence of glaciers.

The sliding of snow down this natural chute has built a snow fan fully half a mile in length, from the apex to the outer rim, and three-quarters of a mile around the periphery. Its outer margin is at an elevation of 1,800 feet. The snow in this fan has accumulated to such a depth as to form a true glacier, with glacier ice and even small crevasses. The fan bears a fringe of avalanche moraine a quarter of a mile in width, on which there is almost no vegetation.

To such glaciers I have applied the name "fan glacier." The fan glacier is quite different in character from the talus glacier, of which there are also many examples in this region. The fan glacier can develop only under peculiarly favorable conditions of steep, narrow, chutelike valleys terminating on fairly level ground and at proper elevations for the formation of ice, but with a sufficient snow supply to overcome melting and to cause growth season by season. The

$a$ Reid, H. F., Studies of Muir Glacier, Alaska: Nat. Geog. Mag., vol. 4, 1892, p. 36.

$b$ Russell, I. C., An expedition to Mount St. Elias, Alaska: Nat. Geog. Mag., vol. 3, 1891, p. 111.

c Funston, Frederick, Contributions from U. S. Nat. Herbarium, vol. 3, No. 6, 1896, p. 328. 


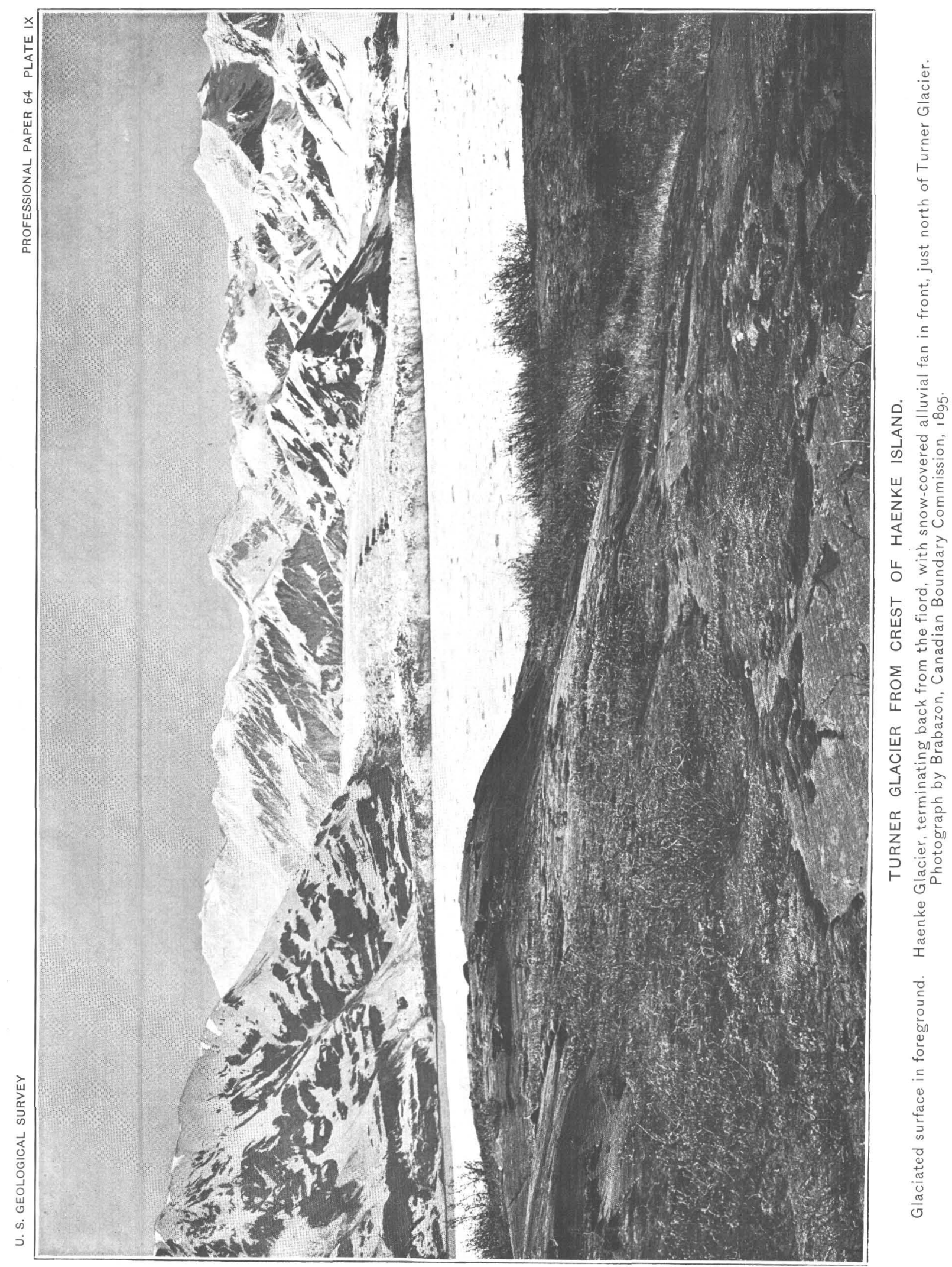


process of formation is analogous to that by which glaciers are formed in cirques, but the form is distinctly different because the supply is derived from a narrow chute, below which it spreads out in a fan.

\section{TURNER GLACIER.}

NAME.

Turner Glacier was first described briefly by Russell ${ }^{a}$ under the name of Dalton Glacier, and was again mentioned by him under the same name in the report of his second expedition to Mount St. Elias. ${ }^{b}$ It appears as Dalton Glacier on the United States Coast Survey chart (No. 8455) and on the Boundary Commission map. To the prospectors who go up the bay it is known as First Glacier. Baker ${ }^{c}$ says that this glacier was named Turner Glacier "by Russell, in 1891, after John Henry Turner, of the Coast Survey, who was engaged in Alaskan surveys from 1888 to 1892 . Russell had, in 1890 , called this Dalton Glacier, after John Dalton, a well-known frontiersman. By the Coast Survey it was called Duffield Glacier, after the superintendent, and later by the same Survey called Sumner or Dalton Glacier." Russell states ${ }^{d}$ that "the United States Board on Geographic Names has for sufficient reason authorized the substitution of the name of J. H. Turner for the name originally given by me."

GENERAL DESCRIPTION

The most complete published description of Turner Glacier is that by Gilbert.e Both Russell and Gilbert photographed it from the crest of Haenke Island.

The glacier enters Disenchantment Bay near its head (Pl. XII), descending from an unknown source near Mount Cook, through a deep mountain valley more than a mile in width (Pl. IX), whose inclosing walls rise to elevations of 5,000 to 6,000 feet. As far as its course can be seen in this valley, the slope is moderate and fairly uniform, while the ice is badly crevassed, indicating rapid movement. The glacier extends beyond the mountainous west wall of the fiord and, expanding, enters the sea. Where it passes from its mountain valley into that of the fiord the slope changes abruptly (PI. $\mathrm{X}, A$ ), and for a distance of one-fourth to one-half mile the glacier is greatly steepened, having an angle of slope estimated to be as much as $25^{\circ}$, whereas above this the inclination of the glacier surface is apparently not more than $10^{\circ}$.

Gilbert interpreted this increase in the glacier slope as the result of the hanging-valley condition, and $I$ coincide in this interpretation. When Hubbard Glacier extended farther down the fiord, receiving Turner and other glaciers as tributaries, ice erosion along the main axis of the fiord, by the strongest ice stream, must have deepened Disenchantment Bay far in excess of the deepening of the smaller Turner Glacier valley, which it thus left hanging. If recession of the glaciers in this bay continues, the time should come when the slope over which Turner Glacier now descends will form the lip of a valley well above the bottom of the fiord, and possibly even above the water surface.

That the ice on this steepened slope is not very thick is indicated by a large bulge, or domeshaped elevation, much crevassed in a massive way, which lies about half a mile back from the terminus of the glacier and about midway between the medial and south lateral moraines. This is interpreted as a higher portion of the valley bottom, marking the site of an unborn nunatak.

FAN-SHAPED TERMINUS.

Below its steepened slope the ice expands into a much-crevassed fan, with nearly horizontal surface, extending to the edge of the ice cliff, which rises about 200 feet above the waters of the fiord. $f$ It was impossible to determine whether the levelness of the ice foot was due to flotation,

a Russell, I. C., An expedition to Mount St. Elias, Alaska: Nat. Geog. Mag., vol. 3, 1891, pp. 98-99.

$b$ Russell, I. C., Second expedition to Mount St. Elias: Thirteenth Ann. Rept. U. S. Geol. Survey, pt. 2, 1891, p. 84, Pl. XX.

c Baker, Marcus, Geographic dictionary of Alaska: Bull. U. S. Geol. Survey No. 299, 1906, p. 414.

d Russell, I. C., Glaciers of North America, 1897, p. 93.

$e$ Gilbert, G. K., Glaciers and glaciation, Harriman Alaska Expedition, vol. 3, pp. 66-69.

$f$ In 1899 Gilbert estimated the height of the ice cliff of the Turner Glacier to be 220 feet on the average; in 1905 our measurement with Locke level from the shore just south of the glacier places the elevation of the cliff at 200 feet. 
as suggested by Gilbert, or whether it was the result of resting on a nearly horizontal valley bottom. If the former is the case, the fiord at this point must be about 1,500 feet deep. Soundings will readily decide the question. With a depth of more than 1,000 feet not far away, near Point Latouche, that of 1,500 feet near Turner Glacier might well exist, especially since it lies directly in the path which the great Hubbard Glacier must have followed when it extended through the bay.

A glacier, on emerging from its mountain valley, if left free, as it is when terminating on level land, expands into a fan-shaped terminus; but where the end is in the deep waters of a fiord, melting and iceberg formation check the full development of the fan. It is for this reason that the expanded terminus of Turner Glacier has the form of a truncated fan, being cut off along its seaward face. As a result of this truncation, there is a long, fairly straight ice cliff, terminating on both ends (in 1905) in winglike, moraine-covered points which rest on the land. From the tip of one wing to that of the other the distance is about $2 \frac{1}{2}$ miles, fully 2 miles of which is ice cliff.

From this cliff bergs are being steadily discharged (Pl. XI, B), and they, together with those from Hubbard Glacier, form a heavy stream of floating ice along the front of Turner Glacier and the coast south of it, making access to the glacier by sea very difficult and often almost impossible. It was only by dint of hard work that the Survey party was able to push through it to a point within half a mile of the southern edge of the glacier.

Rather pronounced lateral moraines fringe both sides of Turner Glacier and cover the tips of the two winglike ends. The lateral moraine on the south side is compound, and beyond it there are two parallel lateral moraine bands, neither very wide nor very distinct. There is also a pronounced medial moraine, whose source lies far back in the mountains, being hidden from view by a bend in the valley. Between the medial and the southern lateral moraines there are other narrow, thin bands of débris; but between the medial and the northern lateral moraines the ice is quite free from surface débris, and the frontal cliff reveals clear, pure ice. Even in the southern half of the glacier the area of clear ice greatly exceeds that which is moraine covered.

From the southern edge the ice cliff rises rapidly, reaching a maximum elevation within a little more than a quarter of a mile (Pl. XI, $B$ ) and maintaining a moderately uniform level to the northern wing. Although the ice cliff is fairly straight in general, in detail its outline is sinuous, consisting of a series of slightly projecting points and moderate reentrants. That part of the cliff which reaches farthest into the fiord is not in the middle of the glacier, but in its southern half.

The crevassed surface and the frequent discharge of icebergs prove that the glacier is moving rapidly, though it was not practicable to make observations to determine the exact rate. Even the débris-covered southern point is in motion, for its ice is badly crevassed.

\section{CHANGES BETWEEN 1891 AND 1905.}

The Survey party was able to reoccupy the exact site from which Gilbert took his photograph in 1899 and to find the approximate site used by Russell in 1891; but the growth of alder on Haenke Island since 1891 made it impossible to identify the exact site of the latter. Photographs taken from these points unfortunately came out so badly that they can not be reproduced and published herewith to show the changes that have occurred.

As compared with Russell's photograph of 1891, the condition in 1905 showed a distinct recession. The moraine-veneered tip, as well as the edge of the clear ice of the southern wing, had receded 200 or 300 yards, and the northern wing showed equal recession. The center of the glacier, near the medial moraine, had evidently receded as much as a quarter of a mile between 1891 and 1905, this recession in the middle being brought out prominently by the more direct course of the medial moraine. Between 1891 and 1905 there had, therefore, been a decided recession of Turner Glacier, both on the ends and in the middle. Russell's picture further shows more moraine on the southern half of the glacier than was present in 1905, but this may be due to difference in the season, for his picture was taken on September 5 and mine 


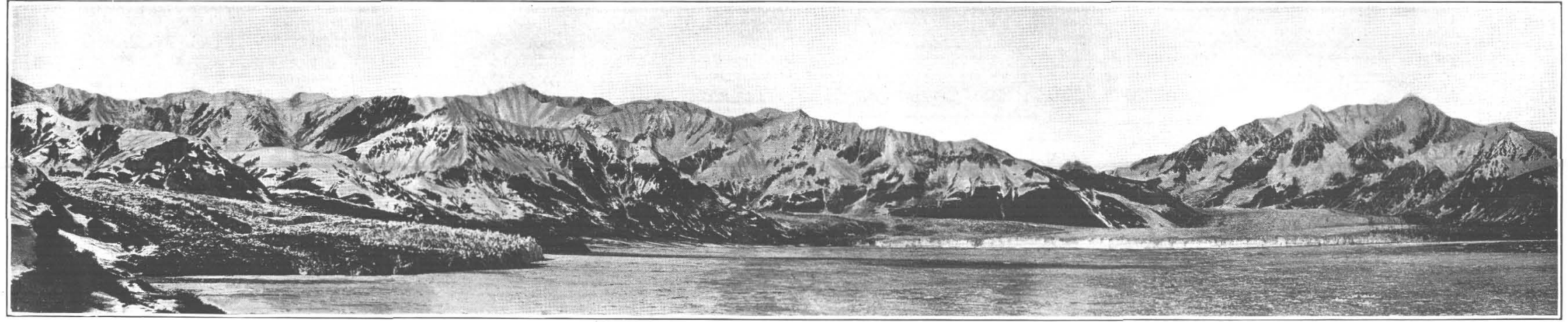

A. PANORAMA OF TURNER AND hubBard GLACIERS From SOUTH SIDE OF TURNER GLACIER.

Showing the steepened slope and flat foot of Turner Glacier, its crevassed surface, ice cliff, and moraine-covered southern wing. The black point just beyond Turner Glacier is the end of Haenke Glacier, which in August, 1905 , ended on the land a mile back from its present terminus. Hubbard Glacier in right-hand
half of view. Photograph taken June 28,1906 .

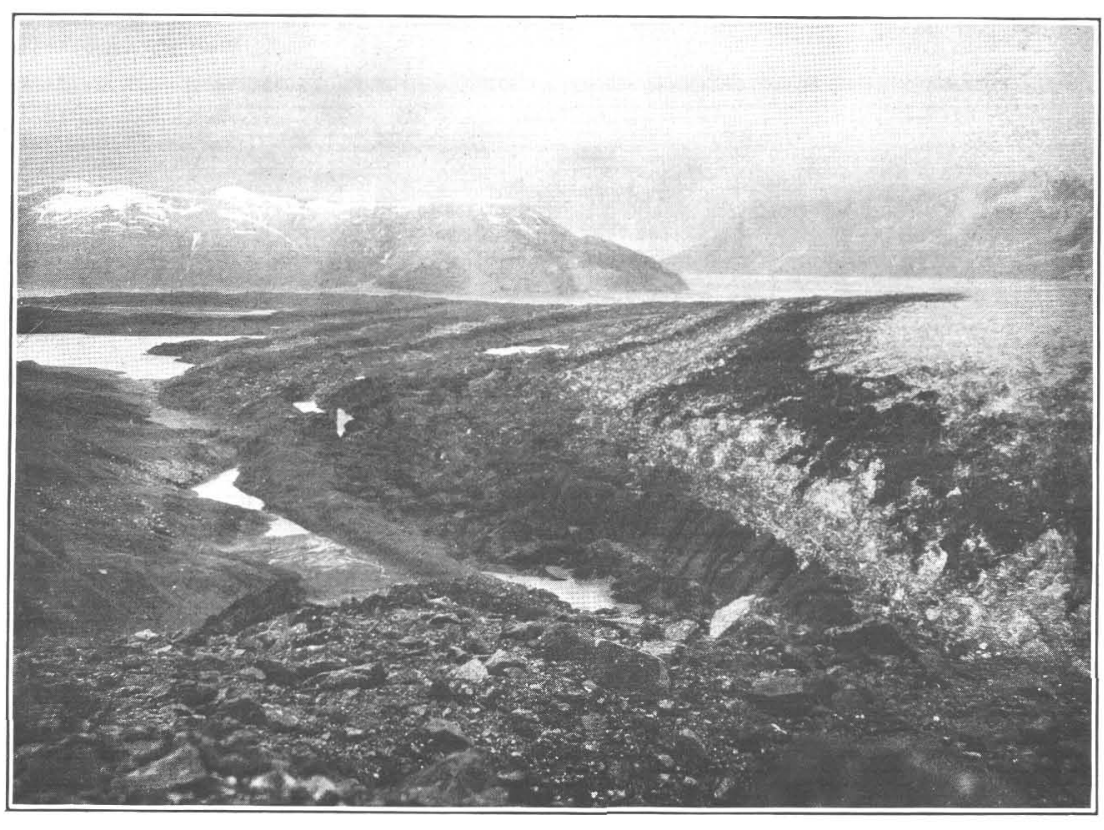

B. EASTERN MARGIN OF HUBBARD GLACIER (ON RIGHT) NEAR EMERGENCE FROM MOUNTAIN VALLEY.

Showing swinging of lateral moraines westward away from the Variegated Glacie bulb, with which it is coalesced just beyond the marginal lake. Interior flat of Variegated Glacier visible beyond the marginal lake. Photograph taken July 5 ,

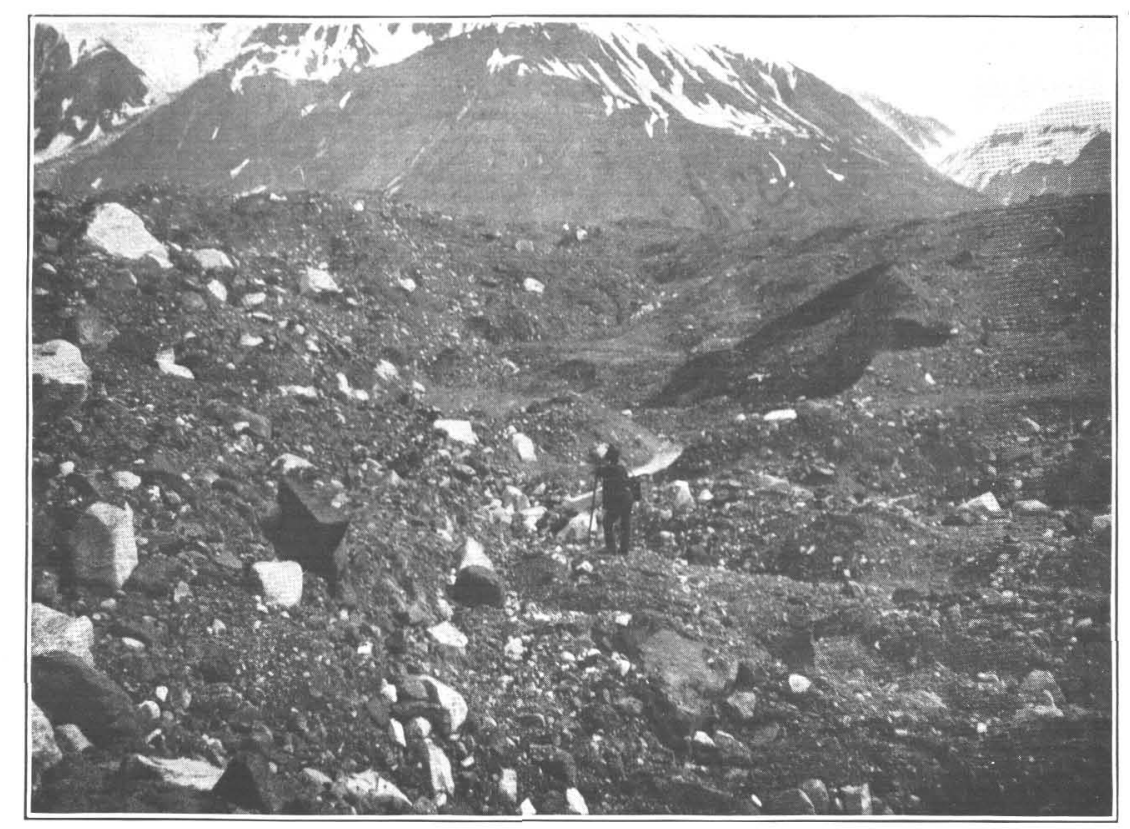

C. STAGNANT MORAINE-COVERED EASTERN MARGIN OF HUBBARD GLACIER.

Slumping so rapidly that no vegetation grows. Photograph taken July 5, 1905. 
on August 13; it is probably due, however, to the condition pointed out by Gilbert, namely, a more direct course of the ice in the southern half of the glacier, for a comparison of the Russell and Gilbert photographs shows that in 1891 the lateral moraine swung farther southward than in 1899 .

A comparison of the conditions in 1905 with those seen in the photograph taken by Gilbert in 1899 gives a very different result. Recession in the middle of the glacier, as indicated by the positions of the ice front at the medial moraine, is very noticeable, showing that fully two thirds of the recession since 1891 took place between 1899 and 1905. On the other hand, the winglike expansion on both sides of the glacier shows a distinct advance, the northern wing (both the clear and the debris-covered ice) extending fully a quarter of a mile farther out in 1905 than it extended in 1899 , and the southern wing also showing a distinctly noticeable advance, though one of less extent, being not more than 100 or 200 yards.

Thus Turner Glacier, which, as Gilbert pointed out, shows recession between 1891 and 1899, and which, by the above comparison, shows net recession between 1891 and 1905, has between 1899 and 1905 advanced distinctly in its northern and southern wings, although its center does not extend so far into the fiord as it did either in 1899 or in 1891 . This anomalous condition of advance on the wings and recession in the center is difficult of explanation. The only hypothesis that suggests itself is that it is the result of the earthquake shocks of 1899 , which in this vicinity must have been very pronounced, since an elevated shore line, raised more than 40 feet above the fiord, extends right up to the glacier. The shattering of the ice by the earthquake may have made the central portion weaker and more open to recession, while the great mass of snow, which was doubtless avalanched down upon the glacier during the earthquakes, may possibly have caused the advance noticed in the wings.

That the recent history of Turner Glacier has in general been one of recession is proved by the condition along its southern margin. Just beyond the moraine-covered tip of the southern wing there is a low moraine almost free from vegetation and apparently with no ice left in it. It seems probable that this moraine marks the site of the end of the southern wing when Russell photographed it in 1891, for it is in the proper position for this interpretation. A short distance beyond this moraine, and also not far above the present glacier surface, good-sized alders grow, proving that the glacier has not recently been much higher than at present. The age of these alders was not definitely determined, but they are estimated to be not less than twenty years old. No spruce trees have advanced to within several miles of Turner Glacier.

\section{CONDITION IN 1906.}

The above description applies to the condition of Turner Glacier as observed in July and August, 1905. No pronounced change was detected in June, 1906, although the position of the medial moraine indicated a slight forward movement in that part of the glacier. A most astonishing change, however, had occurred in a small glacier just to the north of the Turner, which in the interval of ten months had advanced into the fiord and become joined with Turner Glacier, as is described below.

\section{HAENKE GLACIER.}

The maps of the Boundary Commission and those of the Gannett survey, published in Gilbert's book, ${ }^{a}$ show two small valley glaciers terminating about a mile from the shore and faced by alluvial fans reaching the fiord (Pl. XII). No name has previously been applied to either of these glaciers, but for the southern I propose the name Haenke Glacier. The valley occupied by Haenke Glacier lies about half a mile north of the northern edge of Turner Glacier (Pl. IX), the other glacier about a mile farther along the coast. I saw these glaciers, in 1905, from Haenke Island and from several points in the fiord, and was convinced that they were then essentially stagnant at their lower ends, which were completely covered with black shale fragments.

a Gilbert, G. K., Glaciers and glaciation, Harriman Alaska Expedition, vol. 3, PI. VIII. 
In June, 1906, the northern glacier had advanced somewhat, but still rested on the alluvial fan well back from the coast. Some crevassing was visible, but I could not be certain that there was more than in the previous summer. Haenke Glacier, however, had pushed forward over its entire alluvial fan, expanding beyond the mountain front, much as Turner Glacier does, and had adranced boldly out into the fiord (Pl. XI, B) and coalesced completely with Turner Glacier, extending the ice cliff of that glacier fully a mile to the north (Pl. XI, $A$ ).

This remarkable advance of Haenke Glacier for more than half a mile in the brief period of ten months was accompanied by pronounced crevassing. The surface, which in 1905 was even, and, so far as could be seen from a distance, entirely unbroken, was now transformed to a perfect labyrinth of crevasses extending from the ice cliff as far up the mountain valley as the eye could reach. There was not a very active discharge of icebergs from this newly formed ice cliff, a condition possibly due to its resting on the bottom, shallowed by the deposits of the glacial stream which formerly entered the bay at this point.

Although Haenke Glacier was badly crevassed, little of the morainic cover had disappeared into the ice even as late as August. Its surface was therefore still black, making it difficult to photograph it clearly from distant points. This condition furnishes further proof of the recency of the advance; but it is to be noted that at this point melting is greatly retarded by the local rigor of the climate. Bounded on the south and north by extensive ice cliffs, backed by snow-covered mountains, and faced by a continuous stream of floating ice, the climate of the shore between Hubbard and Turner glaciers is so chilled that snow still remained on the alluvial fans at sea level as late as July.

\section{HUBBARD GLACIER.}

GENERAL DESCRIPTION.

Hubbard Glacier, the largest in the fiord, was discovered and first described by Russell in $1890 .^{a}$ It was also described by Gilbert in the report of the Harriman Alaska Expedition. ${ }^{b}$ Both Russell and Gilbert included, as part of Hubbard Glacier, a stagnant ice mass adjoining it on the southeast. For reasons stated later, I believe this to be a separate ice mass and have given it the name Variegated Glacier.

Thus limited, Hubbard Glacier front is somewhat more than $3 \frac{1}{2}$ miles across when measured in a straight line from northwest to southeast. But owing to minor irregularities, and to the fact that the glacier projects farther into the fiord in the middle than on the sides, the total length of the ice front along all the sinuosities is $4 \frac{1}{2}$ or 5 miles. Throughout the entire distance the ice front is a cliff rising above the waters of the fiord, almost everywhere to an elevation of 250 or 300 feet (Pls. XIII, XIV). From this ice cliff bergs are being constantly discharged, every part of the ice front apparently being in active forward motion except the débris-covered margins.

With two broad arms sweeping down through rugged mountain valleys and uniting near the sea to form a broad expanse of ice, broken by a labyrinth of crevasses and with a surface nearly free from débris, Hubbard Glacier is one of the most magnificent on the North American continent. There are numerous points from which it may be seen to excellent advantage, Haenke Island giving one of the least impressive views because from it a part of the glacier is hidden. The view from Osier Island is grand (Pl. XIV), but better still is the panorama from the site of Gilbert's photograph a thousand feet above Osier Island (PI. XIII). Nowhere, however, does Hubbard Glacier appear in fuller grandeur than from the mountain slope just south of Turner Glacier (Pl. $\mathrm{X}, A$ ). An impressive view is also had from the moraine between Hubbard and Variegated glaciers, back where the northern arm of Hubbard Glacier comes out of its valley. Though no ice cliff is seen, an even stronger impression of the irresistible forward movement of the ice is gained by looking across the ice fall, up the northwest arm of the

$\alpha$ Russell, I. C., An expedition to Mount St. Elias, Alaska: Nat. Geog. Mag., vol. 3, 1891, pp. 99-100; see also Second expedition to Mount St. Elias: Thirteenth Ann. Rept. U. S. Geol. Survey, pt. 2, 1892, p. 85.

$b$ Gilbert, G. K., Glaciers and glaciation, Harriman Alaska Expedition, vol. 3, 1904, pp. $63-66$. 


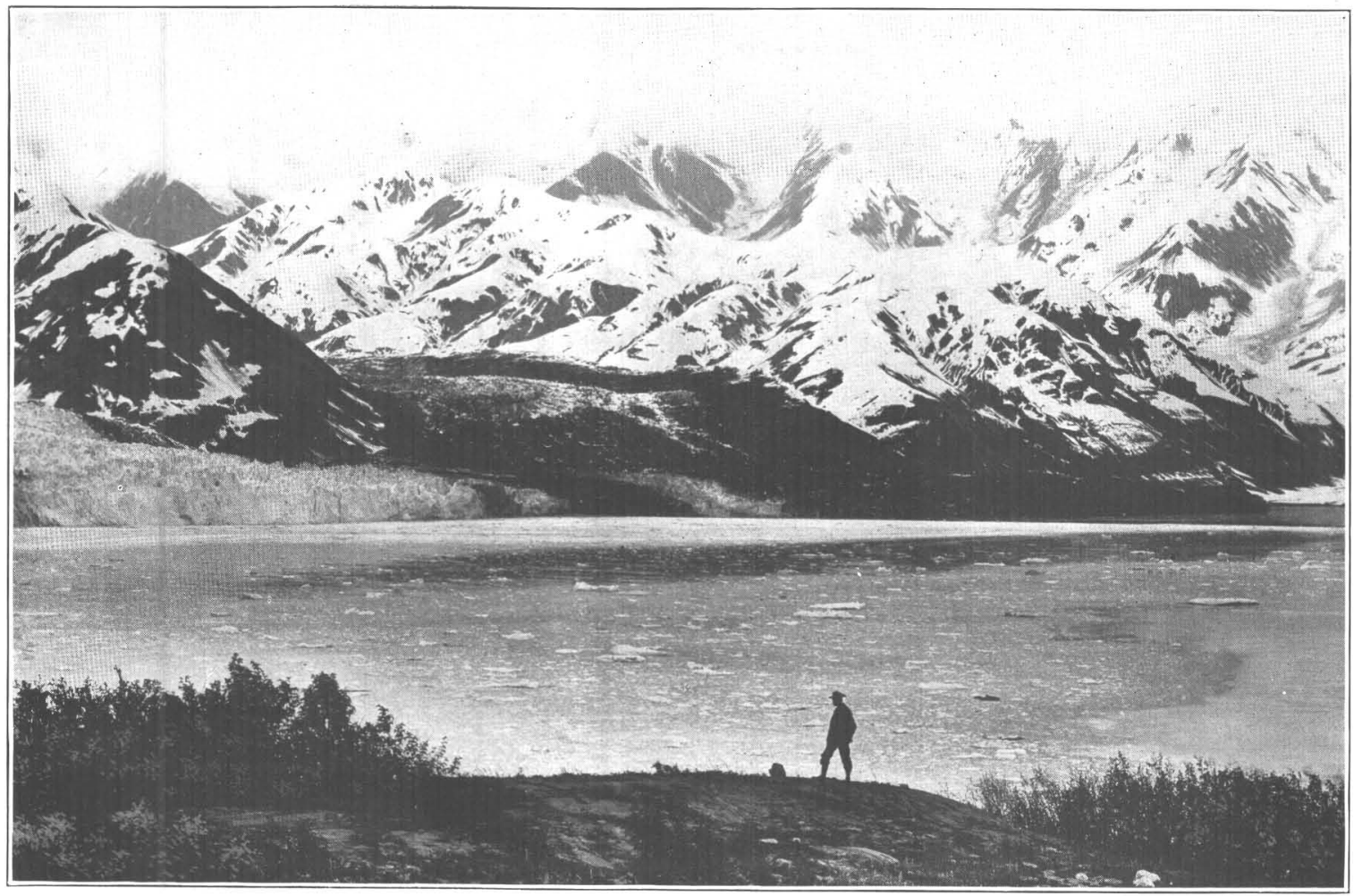

A. HAENKE GLACIER AND NORTHERN EDGE OF TURNER GLACIER FROM POINT NEAR SUMMIT OF HAENKE ISLAND.

Photograph taken with long-focus lens, June 21, 1906. The two glaciers are united, and the north end of Haenke Glacier extends almost to the right edge of the view, the entire front being in the fiord, whereas in August. 1905, it ended within the mountain valley. Surface of Haenke Glacier discolored by black shale of the Yakutat group.

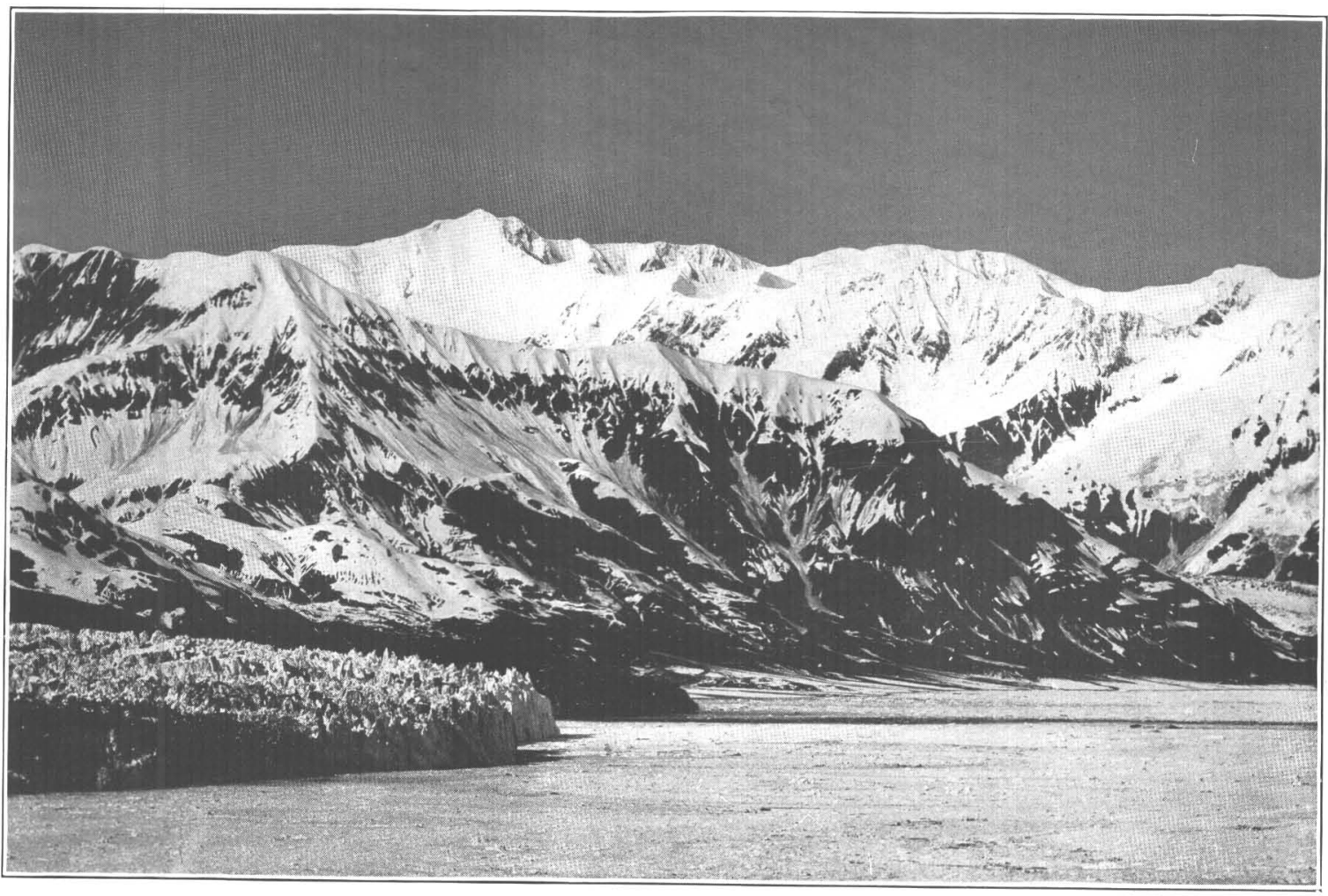

B. SEA CLIFF OF TURNER GLACIER, WITH HAENKE GLACIER (THE BLACK POINT) JUST BEYOND.

Looking north from south side of Turner Glacier. Photograph taken June 28, 1906. 

U. S. GEOLOGICAL SURVEY

PROFESSIONAL PAPER 64 PLATE XII

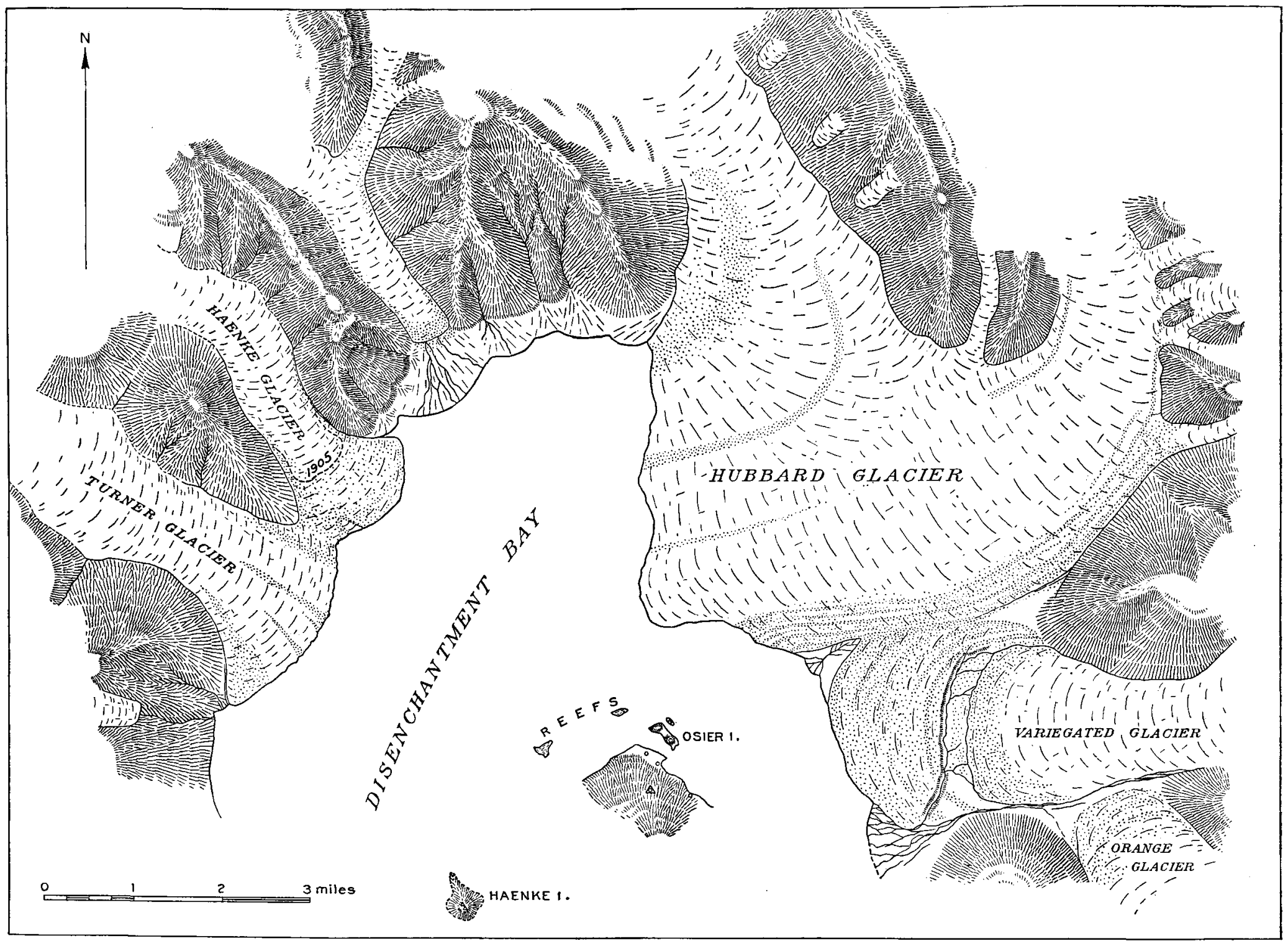

MAP OF TURNER, HAENKE, AND HUBBARD GLACIERS, JUNE, 1906.

By J. L. Rich. Dotted portion of Haenke Glacier has advanced since August, 1906. Moraine-covered areas dotted. Crevassed ice indicated by short lines parallel to axis of glacier. 
glacier, across more than 6 miles of shattered, glistening ice pinnacles, broad seracs, and yawning crevasses. It would be next to impossible to cross this shattered ice stream, which is moving imperceptibly, though irresistibly, to the great ice cliffs at the sea front.

The smaller of the two arms which unite to form the lower Hubbard Glacier comes from the northwest, the larger from the north. No one has ever explored the sources of these two arms, but according to the Boundary Commission map they are supplied from the great ice-flooded valleys back in the St. Elias chain. Numerous tributary glaciers are seen to descend to these two arms, and doubtless there are many more between these and the snow-field source.

Within the mountains both arms of the glacier have a moderate grade, estimated, where seen, to be not more than $5^{\circ}$, but abruptly increasing to fully twice this amount where the arms emerge from their mountain valleys; below this steeper slope the slightly expanded ice foot becomes approximately horizontal, with a gently undulating, crevassed surface. The steepened slope from the mountain valley to the main fiord valley corresponds to the step already described in the Turner Glacier valley and is interpreted here, as there, to be the result of the hanging condition of the tributary valleys.

Where the northwest arm of Hubbard Glacier descends over its steepened slope there is a slight bulge, apparently marking the site of a buried elevation on the valley bottom. There is, in fact, a large patch of débris-covered ice below this bulge, indicating that rock is near the surface, for there is no other visible source for the débris, and it is the only dirt-covered portion of the glacier away from the moraines. This area appears in the earlier photographs by Russell and Gilbert, but its true character is much better seen from near Turner Glacier than from the points where these earlier photographs were taken.

Both arms of the glacier are bordered by pronounced lateral moraines, and the northwestern arm has a medial moraine. The west lateral moraine of the northern arm comes down to the ice foot parallel to the medial moraine (of the northwestern arm), and enters the sea near it. The distribution of these moraines clearly indicates the direction of ice motion. The two arms of the glacier approach each other nearly at right angles, but the moraine of the northern arm extends straight away to the fiord, whereas the medial moraine of the northwestern arm is bent sharply and pursues a course to the fiord nearly at right angles to its course above the bend (PI. XIII, $A$ ).

These facts make it evident that the northwestern tributary is relatively weak and that the northern arm of the glacier dominates. The same conclusion is drawn from the fact that, after descending the step, the northern arm of the glacier fans out slightly. When viewed from near Turner Glacier, where the whole front of the Hubbard is clearly visible with almost no effect of foreshortening, it was estimated that along the sea front the distance between the eastern margin of the northern arm and the point where its western lateral moraine enters the fiord is fully one-half more than the width of the glacier where it leaves its mountain valley. It was also estimated that this part of the glacier front forms fully two-thirds of the whole ice cliff. The northern arm is undoubtedly the larger and main glacier, and the northwestern arm the tributary.

\section{RELATION TO VARIEGATED GLACIER.}

The main northern arm of Hubbard Glacier comes down directly toward the stagnant ice area to which we have given the name Variegated Glacier; but, although the region occupied by this stagnant ice is low and, so far as the visible topography shows, open to ice invasion, Hubbard Glacier turns away from it and for a large part of the distance has no ice connection with it. From this it is inferred that there is a deep trough down which Hubbard Glacier passes, thus leaving uninvaded the flat occupied by Variegated Glacier, which at a higher stage of the ice was tributary to this main arm of the Hubbard, but now barely coalesces with it.

An expedition was made along the southeast margin of Hubbard Glacier to the point north of Variegated Glacier where the first tributary enters. Near the sea the stagnant Variegated Glacier and the Hubbard are distinctly disconnected, the moraine of the Variegated being separated from the moraine-covered margin of the Hubbard by a V-shaped bay filled with 
outwash gravels which are not now being actively deposited. This line of division between the two ice masses extends back for about half a mile. Viewed from a distance, where the general relation of moraines can be seen, the appearance is decidedly that of two distinct glaciers; and even in passing over the moraine-covered area the arrangement of the morainic bands leads to the same conclusion. (See pp. 47-51.)

The actual condition is evidently that of a stagnant, bulb-shaped expansion of Variegated Glacier which Hubbard Glacier approaches, and even touches, but then turns away from, bending toward the west $(\mathrm{Pl} . \mathrm{X}, B)$. The two undoubtedly coalesce beneath the moraine, though it is certain that both the ice and the moraine owe their present position to independent sources, and that Hubbard Glacier in no way perceptibly influences the ice movement or distribution of moraines in the area occupied by the Variegated Glacier bulb. And it is equally certain that Hubbard Glacier is not influenced by Variegated Glacier, its former tributary, now almost cut off from it. Where the two glaciers come in contact the moraines are very different, that on the Hubbard being red in color and that on the Variegated being composed largely of black hornblendic gneiss. Farther back toward the mountains the line of separation between the two glaciers again becomes distinct, and the valley between them is occupied for a part of the distance by a series of marginal lakes $(\mathrm{Pl} . \mathrm{X}, B)$.

\section{MORAINE ON EASTERN MARGIN.}

The crevassed southeastern margin of Hubbard Glacier is greatly discolored by a series of parallel morainic bands, swinging westward after emerging from the mountain valley ( $\mathrm{Pl}$. $\mathrm{X}, B)$. At one point the upturning of débris-charged basal layers brings to the surface a badly crevassed blackened band of ice which, owing to the protection of its débris, melts less rapidly than the neighboring clear ice, and therefore stands up in the form of a ridge. Beyond this, toward the center of the glacier, the ice is so greatly crevassed that travel across it would be extremely difficult if not impossible.

Where Hubbard and Variegated glaciers are in contact the ice surface is covered with moraine, often so deeply as to completely hide the ice (Pl. $\mathrm{X}, C$ ), though stagnant ice is occasionally revealed in crevasses and in steep cliffs at whose base ponds are often found. Even where the ice is not visible its presence is indicated by slumping of the surface, by emergence of springs, and by general absence of vegetation. Usually we could thrust our ice axes down to solid ice, showing that the moraine veneer is thin on the average; but even this thin veneer is very effective in protecting the glacier from melting, while the thicker areas so protect the ice as to cause it to stand up as prominent, moraine-covered ridges.

IRREGULAR VALLEY BOTTOM.

That Hubbard Glacier is passing over an irregular bottom near its southern margin is proved by the undulating surface. In fact, at one place the bottom irregularities have caused a broad, saucer-shaped depression, fully 250 yards in diameter and 100 feet deep, out of which the ice rises, giving a local downstream ascent to the glacier surface.

\section{MINOR TRIBUTARIES.}

The minor tributaries to Hubbard Glacier descend with steep grades, often cascading (Pl. XIII); and some of them have an abrupt descent at the terminus, as if emerging from hanging valleys. The large tributary on the western side of the northern arm is sunk in a valley which has every appearance of being ice eroded, though far less so than the main valley; and the same appearance is presented by other tributaries. The first small tributary entering from the east descends a high mountain valley by a very steep grade and joins the main glacier in an area of abundant crevasses. It does not appear to deflect the ice of Hubbard Glacier at all, but the moraine which covers its terminus is deflected downstream parallel to the Hubbard Glacier margin, finally becoming a stagnant wedge. This tributary, therefore, has an independent existence even after coalescing with Hubbard Glacier, and has the appearance of a tributary about to be dismembered from the main ice stream. 


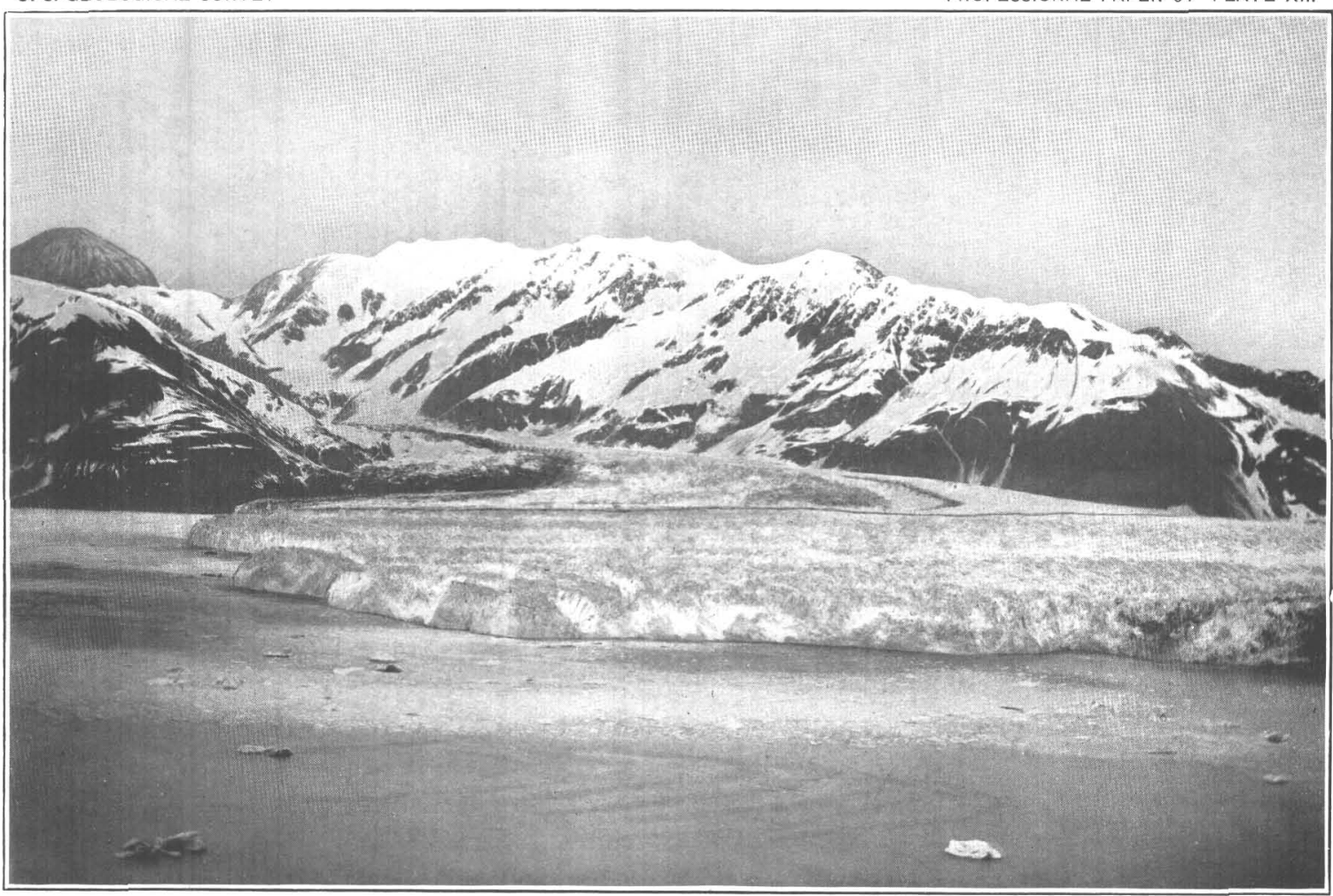

A. NORTHWEST ARM OF HUBBARD GLACIER FROM THE HILL SLOPE, 1,000 FEeT ABOVE OSIER ISLAND, JUNE 21, 1899.

Showing bend of medial moraine, where the two arms of the glacier join. Photograph by G. K. Gilbert.

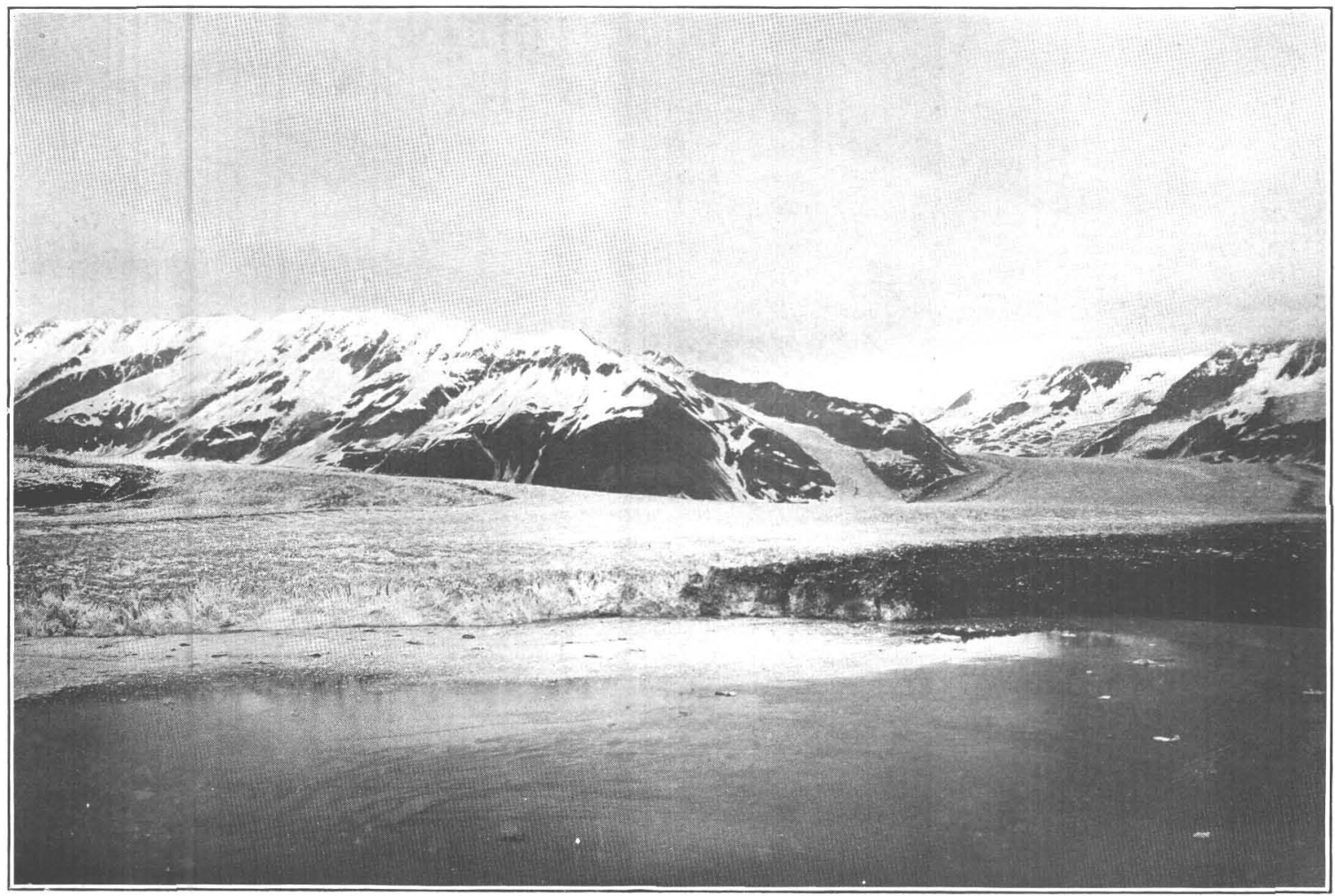

B. HUBbard GLACIER FROM SAME POINT AS PLATE XIII, $A$, JULy 3, 1906.

The elbow of the lateral moraine is noticeably farther east (to the right) than in the 1899 view. 
CHANGES BETWEEN 1891 AND 1905.

The stagnant, moraine-covered ice near the southern margin of the glacier and the abandoned moraines on the mountain slopes between Hubbard and Variegated glaciers all prove recent recession of the ice. Alders are growing on the older, higher moraines, but on the lower ones there are no woody plants, and on the very lowest only a scattered growth of annual plants. This proves that recession has been in progress for a long time and that the ice has only just left some of the lower moraines.

Gilbert ${ }^{a}$ pronounced Hubbard Glacier to be in recession in 1899, but our study of the Russell and Gilbert photographs from the sites where they were taken gives conflicting results as to the changes since then. Two of Gilbert's pictures were taken from the beach at the southern margin of Hubbard Glacier, looking along the sea cliff. While it was impossible to find the exact view points of these pictures, they were located approximately; and from no place could the same relation of points in the background be obtained and yet the ice front be brought out as far as it stood at the time of Gilbert's photograph. From this it seems necessary to conclude that the southeastern part of Hubbard Glacier has receded perceptibly since 1899. While a statement of the exact amount of the recession can not be made, its minimum is certainly several hundred yards. This recession may be the result of the 1899 earthquake, which, according to the report of prospectors camped near by at the time, dislodged great quantities of ice from the Hubbard Glacier. front.

Views from Gilbert's photographic site above Osier Island (PI. XIII, $A$ and $B$ ), and from Russell's Osier Island site (PI. XIV, $A$ and $B$ ), yield convincing evidence that the northwestern part of Hubbard Glacier has advanced both as compared with 1899 and with 1891 . In 1905 our photographs from all these points were unfortunately failures; but, poor though they are, they show this advance. Photographs taken in 1906 (Pls. XIII, $B ; \mathrm{XIV}, B$ ) are used here for comparison with the Russell photograph of 1891 (Pl. XIV, $A$ ) and the Gilbert photograph of 1899 (Pl. XIII, $A$ ).

The evidences of the advance are of three kinds-(1) as seen from Haenke Island, the western margin of the glacier, where it rests on the land, is evidently several hundred yards farther out than it was in either 1891 or 1899 ; (2) as viewed from Osier Island the western point of the ice cliff is farther out in the fiord by several hundred yards than it was when Russell photographed it in 1891; (3) as seen from the crest of Haenke Island in 1905 and above Osier Island (Pl. XIII) the bend in the medial moraine of the northwestern arm extended fully a quarter of a mile farther southeast than in 1891 and several hundred yards farther than in 1899 .

From these facts it appears that while the southern and larger portion of the Hubbard Glacier front is receding, the northwestern part is advancing. For a time the cause of this condition was in doubt. It did not seem probable that it could be assigned to waning activity of the northern tributary, thus giving to the northwestern tributary freer and more independent motion. This explanation might have accounted for the southeastward advance of the medial moraine, but it did not seem competent to account for either the projection of the ice cliff or the advance of the western margin of the glacier. Later study of the region (in 1906), and especially the discovery of the remarkable advance in some of the glaciers of the region, while others, even closest neighbors, showed no change, threw a new light on the phenomenon. A full discussion of this point is for the present deferred; but as applied to Hubbard Glacier it may be stated that it now seems highly probable that the avalanching of snow during the 1899 earthquake caused an advance in the northwestern arm of the glacier, but that the forward movement has not yet begun in the northern arm.

CONDITION IN 1906.

Like Turner Glacier, Hubbard Glacier showed no pronounced difference in 1906 from its condition the previous summer, thus contrasting very distinctly with the smaller glaciers on either side. Comparison with the photographs of 1905 indicates a slight advance in the

a Gilbert, G. K., Glaciers and glaciation: Harriman Alaska Expedition, vol. 3, 1904, pp. 63-66. 
western half. There was much more floating ice in the bay, and the discharge of icebergs was more frequent than during the visit of 1905, suggesting an increased activity; but whatever advance there has been is not to be compared with the great forward push of Haenke Glacier.

\section{VARIEGATED GLACIER.}

\section{PREVIOUS DESCRIPTIONS.}

Adjoining Hubbard Glacier on the southeast, in 1905, was a stagnant, moraine-covered ice mass which Russell describes as follows: ${ }^{a}$

A débris-covered glacier, so completely concealed by continuous sheets of stones and earth that its true character can scarcely be recognized, descends from the mountains just east of Hubbard Glacier. It is formed by the union of two principal tributaries, and, on reaching comparatively level ground, expands into a broad ice foot, but does not have sufficient volume to reach the sea.

In the report of his second expedition, ${ }^{b}$ after better opportunities for observation, Russell declares that this glacier is confluent with the Fiubbard, and this is the conclusion of Gilbert. ${ }^{c}$ For reasons stated above (p. 43), while I am convinced that the two ice masses are in actual contact for part of the distance, I believe them to be essentially independent, and have therefore proposed the separate name Variegated Glacier for the stagnant, piedmont ice mass which adjoins Hubbard Glacier on the southeast.

From all the views obtained of it in 1905, we inferred, with Russell and Gilbert, that Variegated Glacier was fed by two tongues; but in 1906, on a journey over the eastern glacier, I found that while it barely coalesced with Variegated Glacier for a short distance, the two were quite independent, the stagnant, piedmont area being entirely supplied and dominated by the north arm. For this reason the name Variegated, which in 1905 was applied ${ }^{d}$ not only to the stagnant terminus, but also to what appeared to be the eastern arm, must now be restricted to the stagnant area and to the glacier north of it. The new name, Orange Glacier, is proposed for the glacier east of the stagnant ice area.

\section{VALLEY PORTION (1905).}

Variegated Glacier heads back in an unknown source among the mountains, descending in a serpentine course through a deep valley with walls greatly steepened by glacial erosion. We went several miles up this glacier, to an elevation of about 2,100 feet; beyond which there are numerous tributaries descending steep mountain valleys. At this elevation there is little ablation, and a short distance above it snow remains on the ice in the middle of August. The ice here was crevassed somewhat, but nowhere sufficiently to interfere seriously with walking. The grade varied from $7^{\circ}$ to $10^{\circ}$, and in cross section the surface was nearly level, though descending slightly toward the margins. Neither lateral nor medial moraines were visible in the upper part of the valley.

Lower down the valley the crevassing decreased and the grade became much less steep, being even reversed in places near the mouth of the mountain valley. Ablation also increased, and the ice was rapidly melting, furnishing a perfect illustration of the wasting away of an inactive valley glacier $(\mathrm{Pl} . \mathrm{XV}, A)$. Both lateral and medial moraines appeared, and in the lower valley portion the glacier surface was strewn, and in places almost covered, with angular rock fragments.

In a number of places bands of rock fragments appeared at the surface along the outcrop of flow lines in the ice. One of these, near the middle of the glacier, was fully half a mile long, and so covered the ice with fragments of red gneiss as to form a prominent red ridge rising 10 feet or more above the glacier surface. The fragments were all so angular that they were interpreted as the reappearance of surface débris, incorporated in the ice farther up the glacier and brought again to the surface by ablation.

a Russell, I. C., An expedition to Mount St. Elias, Alaska: Nat. Geog. Mag., vol. 3, 1891, p. 100

$b$ Russell, I. C., Second expedition to Mount St. Elias: Thirteenth Ann. Rept. U. S. Geol. Survey, pt. 2, 1892, p. 85.

$c$ Gilbert, G. K., Glaclers and glaciation, Harriman Alaska Expedition, vol. 3, 1904, p. 63.

$d$ Tarr, R. S., and Martin, L., Glaciers and glaciation of Yakutat Bay, Alaska: Bull. Am. Geog. Soc., vol. 38, 1906, pp. 147-149. 


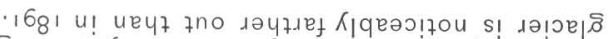

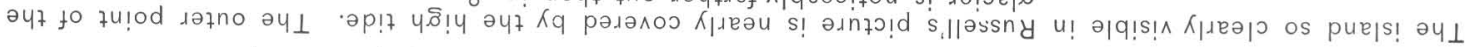
'906เ '†

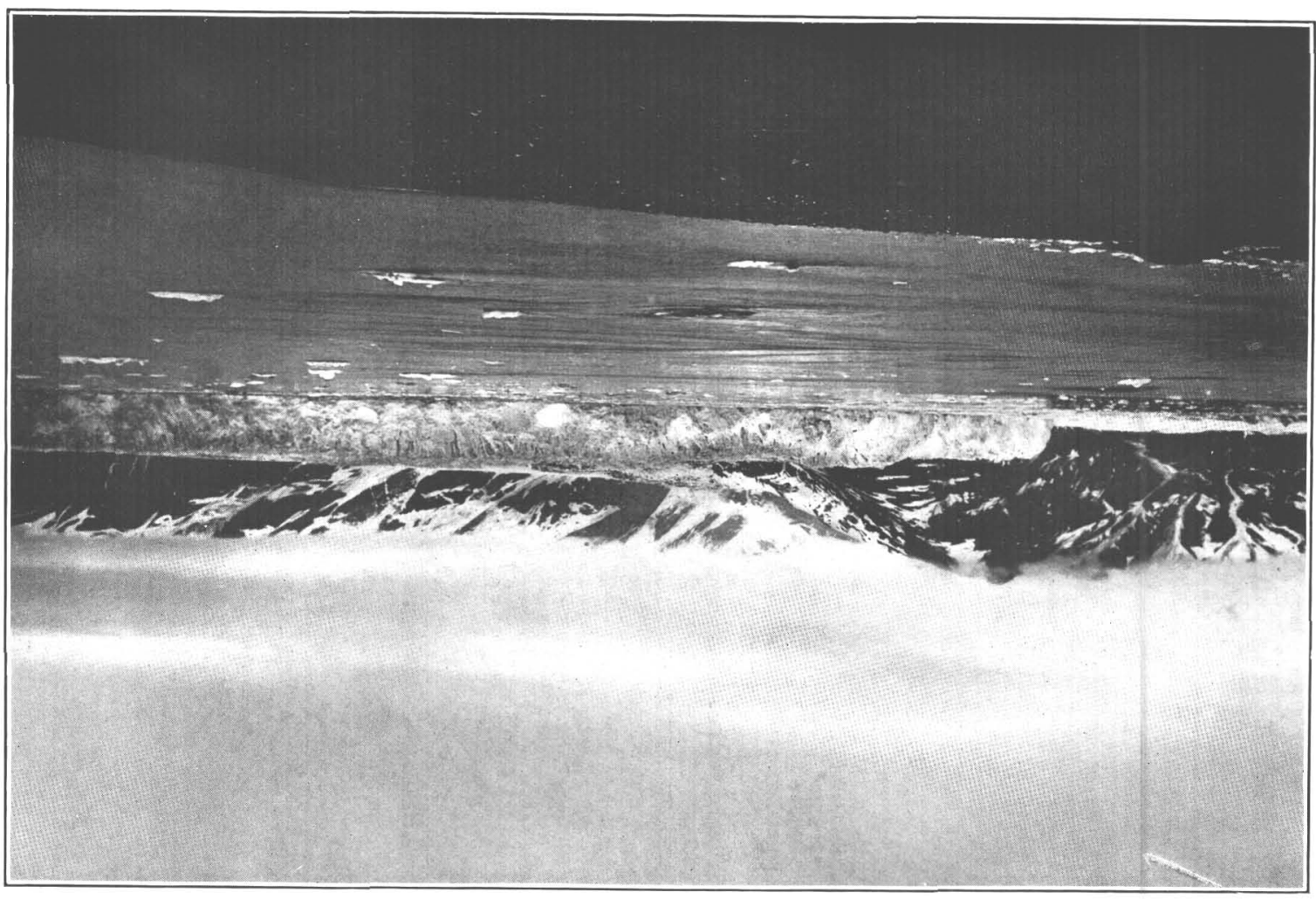

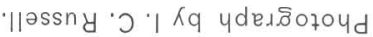

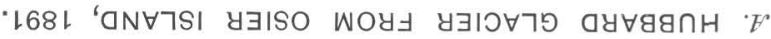

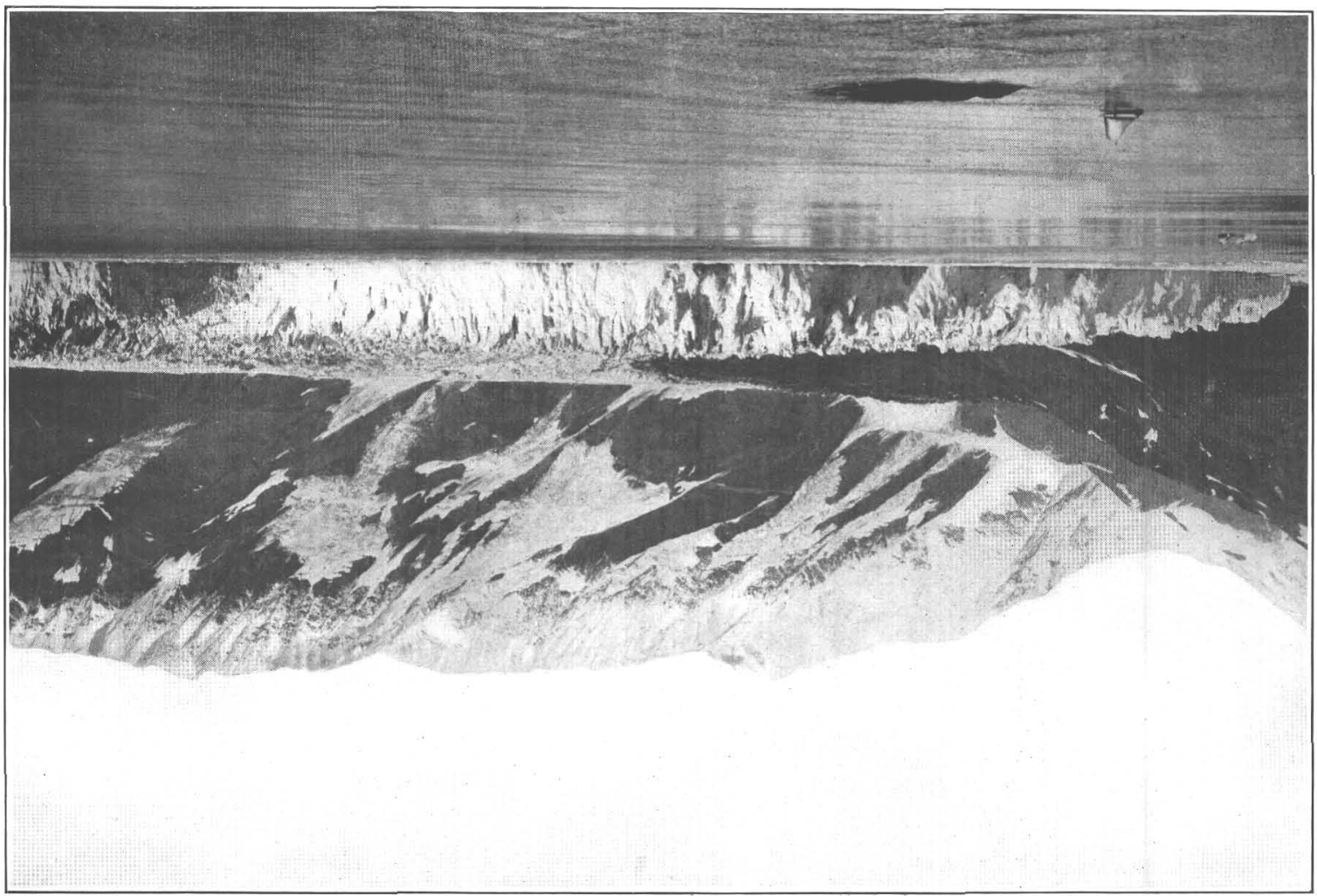


The steepened mountain walls are made of several types of crystalline rock. Near the mouth of the valley both walls are a black hornblendic gneiss. Above this is a green argillite schist, and above that red, orange, and banded gray quartz gneiss, rusting different colors. These rock, beds strike across to Orange Glacier, and in addition there is a white granite on the south side of that valley. These different rocks give rise to bands of variously colored moraines.

Near the end of its valley the glacier was separated from each mountain wall by a gully having moraine-covered ice for one wall and the mountain slope for the other; but at a very recent period the glacier had evidently extended to the mountain walls, for the rock was smoothed and polished. Moreover, there were high-level moraine terraces upon which vegetation, with the exception of a few scattered annual plants, had not yet encroached.

BANDED MORAINES ON EXPANDED ICE FAN (1905).

Passing out of its mountain valley Variegated Glacier expands into a bulb-shaped piedmont area of most interesting character, which in 1905 was apparently completely stagnant (Pl. XVI). This part of the glacier, which extends almost to the sea and westward to Hubbard Glacier, was so covered by moraine that ice showed only in patches where the moraine had slid off. In several places englacial streams were seen flowing into or out of ice tunnels. One excellent ice tunnel, now carry-

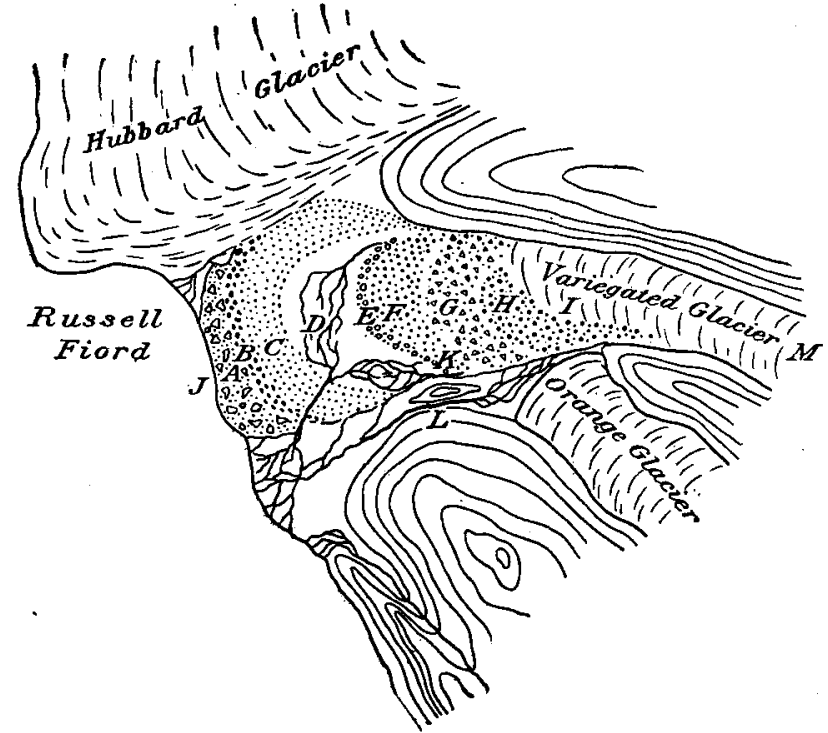

FiGURE 2.-Sketch map of banded moraines of Variegated Glacier, 1905. A, White granite moraine; $B$, red rusted moraine; $C$, hornblende gneiss moraine; $D$, interior flat; $E$, red moraine; $F$, purple moraine; $G$, green moraine; $H$, orange moraine; $I$, ice surface; $J$, beach; $K$, glacial stream, 1905; $L$, glacial stream, 1906; $M$, point reached in 1907 .

ing no stream, was photographed (Pl. XV, D). It was a nearly circular pipe 3 or 4 feet in diameter and several hundred yards long, the tube being revealed at both ends by melting down of the glacier surface.

The moraine is arranged in concentric bands (see figs. 2, 3), of various colors, forming white, black, green, purple, orange, and red loops, or crescentic ridges, with the concave side toward the valley glacier feeder, and meeting the moraines of Hubbard Glacier at an angle. The first and highest of these concentric moraines rises abruptly above the partly débrisveneered end of the valley portion of Variegated Glacier, forming a steep wall fully 100 feet high

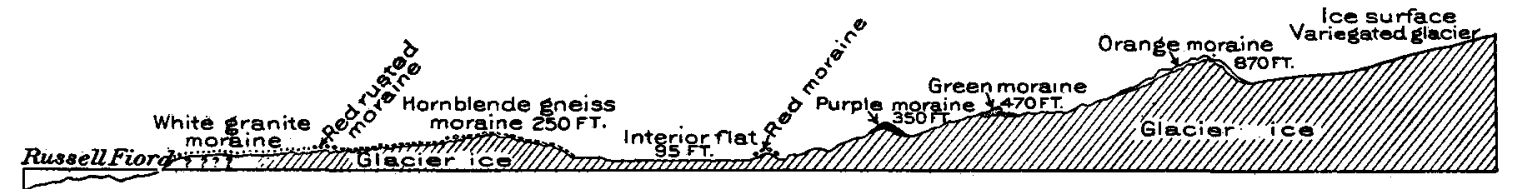

FiaURE 3.-Approximate cross section of banded moraines of Variegated Glacier, 1905.

$(\mathrm{Pl} . \mathrm{XV}, A)$. The rock of which this is mainly composed is a gray quartz gneiss, which rusts to an orange yellow on exposure to the weather, giving to the moraine a distinct orange color recognizable 7 or 8 miles away. This moraine ridge is traceable into the eastern lateral moraine of the valley portion of Variegated Glacier. It first appears up the valley portion of the glacier as a narrow lateral moraine brought to the surface by ablation. Developing rapidly in breadth and depth it soon forms a prominent ridge, with ice everywhere within a few feet of the surface and in places visible.

On emergence from the mountain valley the moraine swings out in crescent form, partly encircling the expanded area of clear ice which, just outside the mountains, is fully half as wide 
again as the width of the glacier within its mountain valley. This gives the ridge somewhat the appearance of a moraine terminal to the expanded ice foot. The angular character of the fragments proves that the moraine is supplied by surface débris concentrated by ablation, and not by bottom moraine brought to the surface by uprising ice currents. That its source is high up the mountain valley is proved by the fact that the lower mountain wall is made of black hornblende gneiss, not of gray, orange-rusted gneiss. The hornblende gneiss is not now supplying débris to the ice surface, since the glacier is separated from it by a deep gully.

The crest of the orange moraine is 870 feet above sea level, and the ice at its inner base 770 feet. $^{a}$ Its outer slope is also steep, descending in less than a quarter of a mile to an elevation of 450 feet. The moraine-covered ice surface then rises again to a ridge, in this case greenish in color, due to a predominance of green schist. Between the green and orange moraine ridges there is a low crescentic area in which ice shows much more frequently than in the ridges. It is, in fact, an ice rather than a moraine area, but is veneered with a thin coating of moraine, which thickens in places, giving rise to low, short ridges and to an indistinct concentric banding, including one linear area of white granite. There is also an area of rounded stones, evidently a stream deposit, either an alluvial fan or lake delta, now spread out and its form destroyed by ablation.

The greenish moraine ridge reaches an elevation of 470 feet, or about 20 feet above the low inner area of thin moraine just described. But its descent toward the west is much steeper, for it rises about 150 feet above its western, or outer, base. Like the orange moraine ridge, this is also crescentic, with the concave side toward the ice supply, but with a larger radius. Ice exists just beneath the moraine veneer, and the ridge is higher near the center than on the ends. Neither of these crescentic moraines extends to the valley margin.

Outside the greenish moraine are several other crescentic ridges, each with increased radius. First, there is a purplish moraine, whose color is due to the presence of a purple gneiss in sufficient quantities to mask the scattered red, orange, and black fragments. Its crest is 350 feet above the fiord, or 120 feet below the green moraine, from which it is separated by a valley where the moraine is thinner. Its width is about an eighth of a mile. On its outer or seaward face it slopes steeply down to an outwash gravel flat (see p. 50) about 250 feet below the crest of the purple moraine ridge. On this descent there are two minor bands, each about 100 yards wide, forming.indistinct ridges. The innermost of these is red in color, owing to the presence of yellow-rusted granite and red-rusted gneiss, with a minor admixture of purple gneiss. The outermost ridge contains enough white granite to give it a distinctly white color.

In places young willows grow on all these moraine ridges except the orange, but none were found that were more than two years old. Individual plants are vainly struggling to gain a foothold in the slumping soil, but in most instances undermining is so rapid that the growth of a year or two is all that can be gained. Many dead plants were seen, their withered roots now lying on the surface where slumping had overturned them. ${ }^{b}$

\section{BANDED MORAINES OUTSIDE THE INTERIOR FLAT (1905 AND 1906).}

Outside the ridges is a broad flat (see p. 50) overspread with alluvial-fan deposits, bounded on the inner side by the purple moraine just described and on the outer or seaward side by a concave moraine ridge rising steeply 100 to 150 feet (PI. XVI, $A$ ). That this also is a moraineveneered ice ridge is proved by the fact that ice shows in its face and on its crest, but the moraine here is thicker and more stable than in the ridges already described. This moraine ridge has a far greater radius than those nearer the valley glacier, and extends much farther, forming fully half a circle. On the southeastern side it swings into an old lateral moraine of Orange Glacier. To the north it extends nearly to the base of the mountain, where it also merges into lateral moraines. Throughout it is characterized by such a predominance of black hornblendic gneiss

a Elevations obtained with aneroid barometer.

$b$ This description of Variegated Glacier applies to the conditions in 1905; but as is shown on p. 51 the conditions in 1906 were totally different. 


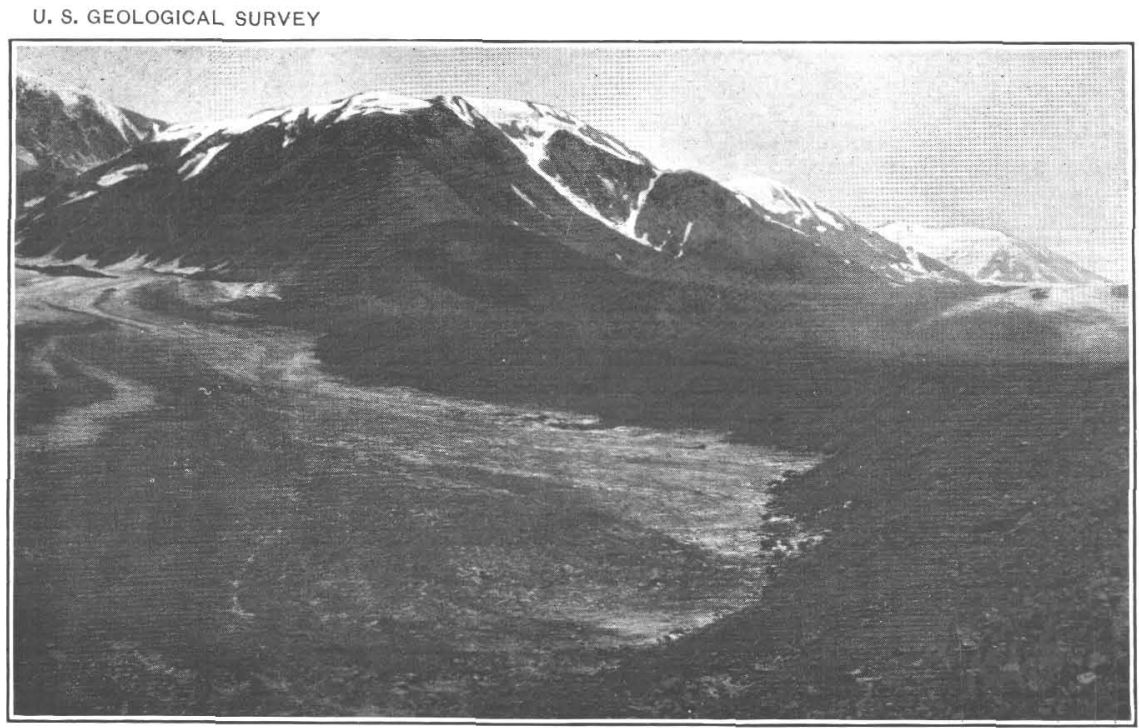

A. WASTING LOWER END OF VALLEY PORTION OF VARIEGATED GLACIER, Orange moraine rising on right, and Orange Glacier still farther east. In 1906 this surface was wholly impassable. Photograph taken August 5, 1905.

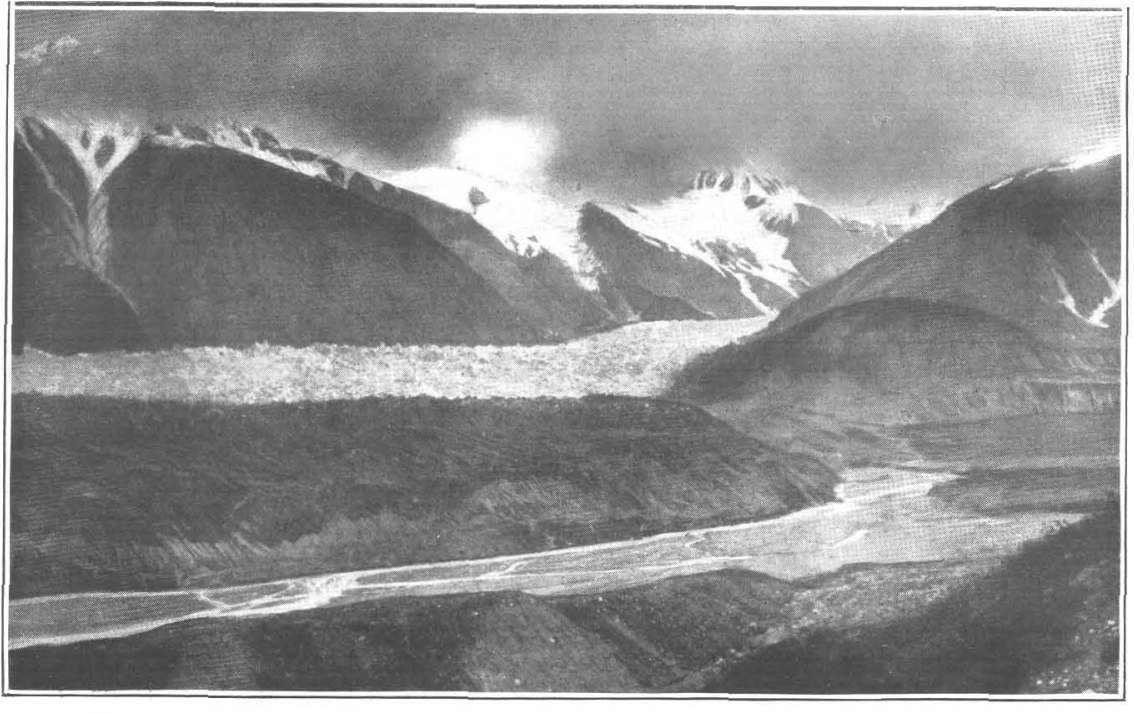

C. VARIEGATED GLACIER FROM THE SOUTHEAST.

Marginal channel of Orange Glacier stream in foreground. In August, 1905, the Survey party walked freely up this glacier to the bend, over a smooth surface like that shown in Plate XV, A. Photograph taken August 18, 1906.

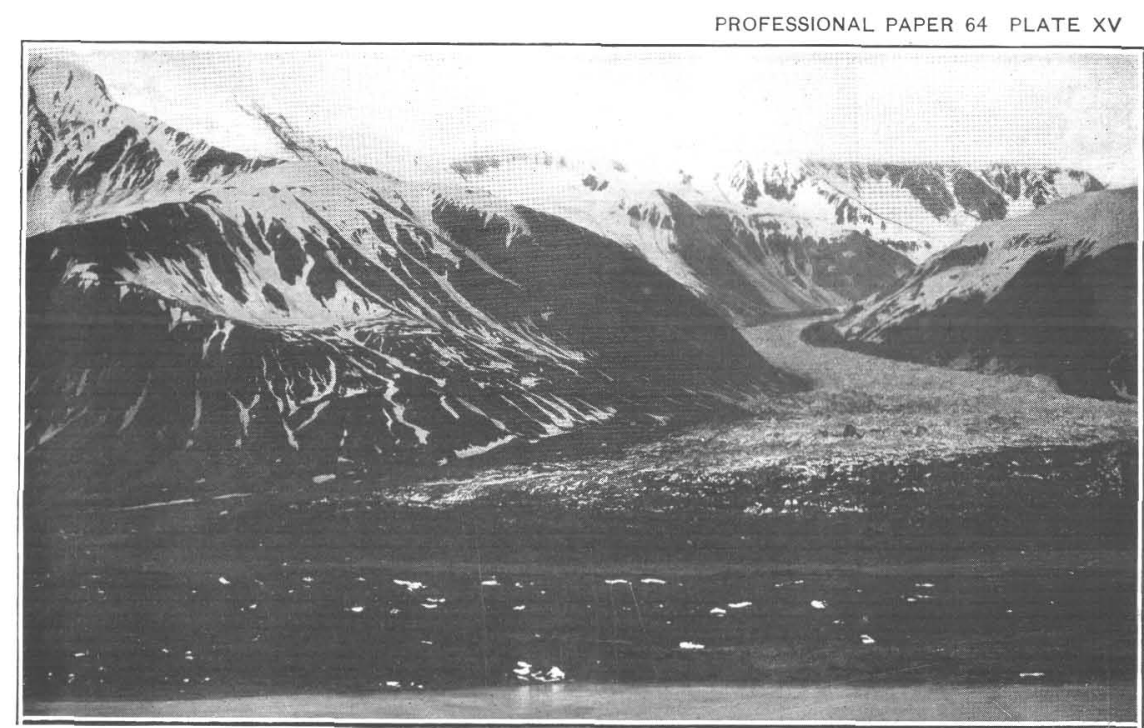

B. LONG-FOCUS VIEW OF VARIEGATED GLACIER FROM GILBERT POINT.

Elevation, 1,000 feet above Osier Island. The surface from the interior flat to the bend, where the Survey party easily walked in August, 1905, was at the time this view was taken (July 3,1906 ) a sea of crevasses. All the banded moraines
inside the interior flat are destroyed.

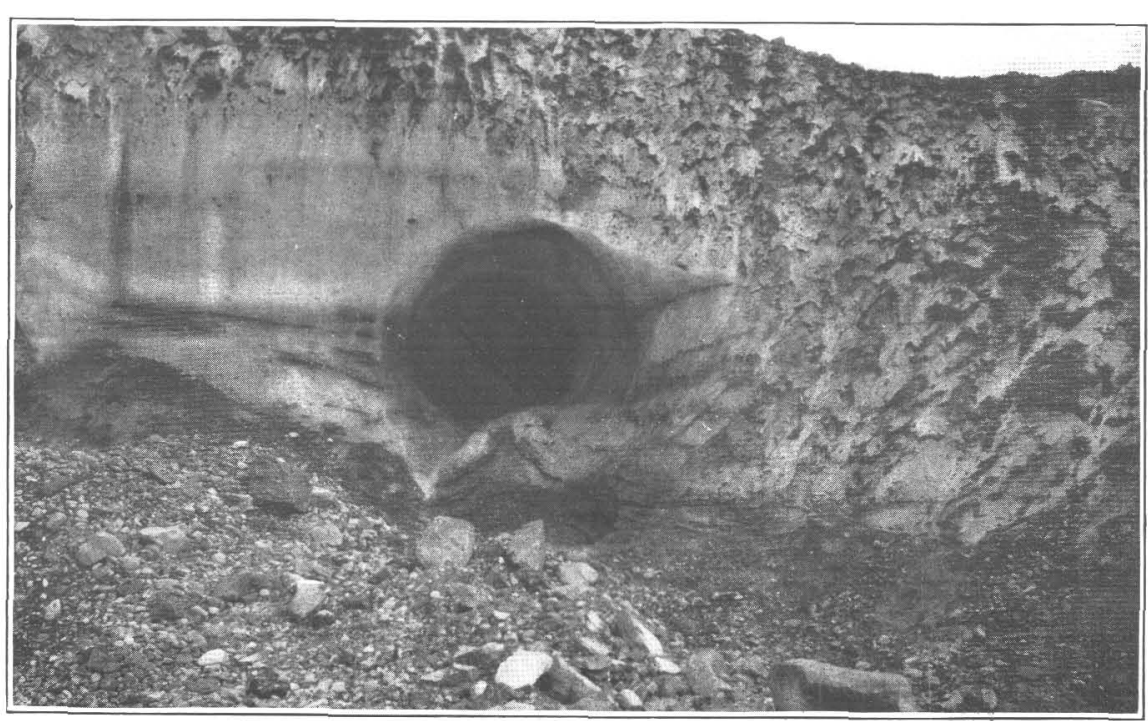

D. WESTERN OR LOWER END OF TUNNEL IN MORAINE-COVERED ICE F VARIEGATED GLACIER.

Length of tunnel, 100 yards. Photograph taken August $6,1905$. 

that it has a somber black color when seen from a distance as well as from close at hand; but there are also scattered fragments of various other rocks, especially purple gneiss, white granite, and red-rusted gneiss. All the fragments are angular, and hence are of surface and not basal origin.

This ridge rises abruptly as an ice cliff, with a fairly thick moraine cover, from an elevation of about 100 feet at its base in the interior flat to 205 feet above sea level. It then rises more gradully, reaching 250 feet at a distance of a quarter of a mile from the base, then sloping moderately toward the sea, with the slope interrupted by numerous hummocks and short ridges. The total width of the black band is about half a mile, but in one place, at least, it is divided by a pronounced belt of red-rusted gneiss about 100 feet in width. Throughout this band of black moraine ice appears here and there in cliffs and kettles. Elsewhere the presence of ice is also shown by the sliding and faulting of the soil and by the abundance of water oozing from the hummocks. Some of this water stands in little kettle ponds, but there are no running streams more than a few.yards in length, for the water quickly sinks into the ice. The last ice actually seen occurs near the outer margin of the black moraine, about half a mile from the sea.

There is almost no vegetation on the black moraine, except a little moss in favorable places and here and there a tuft of grass. Individual willows a year or two old occur scattered over the moraine, and one four years old was found in a protected spot. One willow with ten annual rings was found on the inner edge of the crescentic cliff near the interior flat at a point where slumping of the moraine was slight.

Concentric with and outside of the black moraine is a narrow band of red-rusted gneiss about 200 feet in width. Outside of this, and reaching to the beach, is a belt, somewhat more than a quarter of a mile across, in which there is such an abundance of white granite bowlders, mixed with some black hornblende gneiss and red-rusted gneiss, as to give it a grayish appearance from a distance, quite in contrast to the red and black bands. In detail it consists of a series of short, overlapping bands of white granite, black hornblende gneiss, and red-rusted gneiss, the whole forming a crescentic belt outside of the black-hornblende moraine.

No ice was actually seen in this outer belt of moraine, but its presence was clearly proved in the inner half and is suspected in the outer portion even as far as the beach. Throughout its extent this moraine is so thick, and the quantity of underlying ice so slight, that the melting is retarded and slumping of the surface checked so that prominent ridges are not produced in it and the under ice is not revealed. The presence of ice is, however, indicated by the large amount of water oozing from the hummocks, by the cracking of the surface, and by the general absence of vegetation. These indications decrease toward the sea, and it is possible that no ice remains at the very coast, though there is some slumping even there and more water escaping than seems normal. There are also some shallow lakes in the moraine close by the beach. Ice is certainly present within a quarter of a mile of the fiord; and even if it is now absent from the cliff back of the beach, it has not been many years since it disappeared. On this part of the moraine willow and alder occur in scattered individuals and clusters, the largest seen having usually not more than eight rings of annual growth; but on the ridge directly above the beach there are willows 15 years old.

On its seaward side the moraine is terminated by a bluff 20 to 40 feet high, at the base of which is a beach elevated above the reach of the waves during the earthquake of 1899 . This outer moraine apparently once extended into the fiord, but has been nipped back by the waves. The proof of this is the general shallowness of the fiord at this point, as shown by the grounding of an iceberg 20 feet high a quarter of a mile from shore. Shallowness is also proved by the large amount of seaweed and the abundance of shallow-water shells on this beach, a condition not found on other beaches in the fiord. The only source for these organisms is offshore shoals, for there are no rock shores here, and the beach is bordered on one end by Hubbard Glacier and on the other by a large alluvial fan. 
ALLUVIAL FAN.

The ice-born streams of Russell Fiord reach the sea in two very different ways. In the tidal glaciers they have submarine mouths, and along the ice front the fresh water may be seen boiling up to the surface in muddy masses, doubtless having dropped much of its sediment beneath the water level. Contrasting strikingly with these is the more normal type of glacial streams that flow into the sea over large alluvial fans, upon which they drop their coarser sediment. Alluviation goes on so fast that these streams are visibly changing their channels and rapidly extending their fans, or deltas, into the fiord. The streams from Hubbard Glacier are of the former type, those from the Variegated of the latter, and they have at this point built the largest single fan in Russell Fiord (PI. XXXI). In both cases the waters of the fiord near by are clouded with sediment; and in front of the fans the deposits are rapidly extending the shore line seaward, thus furnishing unfavorable places for marine life.

$$
\text { INTERIOR FLAT (1905). }
$$

The interior flat, mentioned above, has an elevation of about 100 feet above the sea, a width of fully three-fourths of a mile at its widest part, and a length of more than a mile (Pl. $\mathrm{XVI}$ ). It is bordered on the south and west by the concave face of the black hornblende gneiss moraine, and on its inner side by the convex face of the next or red and purple moraine ridge. The shape of the flat is therefore that of a crescent, rather broad in the middle. It forms a distinct depression in the moraine-covered ice, and is inclosed between steep walls which rise 100 or 200 feet above it. On the whole, its surface is smooth and very gently sloping, being made by the building of alluvial-fan deposits supplied by streams from the glacier (Pl. XVI, B). However, some low morainic hummocks and short ridges rise out of the flat. There are also some irregular lakelets; its surface is pitted by recent sinking; and there are cracks and faults, proving that settling is still in progress. These facts demonstrate the presence of ice beneath the flat, but the small amount of settling indicates either thin ice or else thick protecting deposits; and the general levelness of the surface proves absence of forward movement in the underlying ice. This makes it certain that none of the ice between the inner edge of the flat and the sea is now in active movement.

This flat must represent the site of an area of relatively clear ice between concentric moraines, which, when the piedmont portion of the glacier became stagnant, melted more rapidly than the moraine-covered ice on the inner and outer sides. Being thus lowered through ablation, this part of the glacier became the seat of an outwash gravel deposit, which is still accumulating and burying the ice deeply. Two streams have contributed the gravels, one from each side of the ice which rises above the inner part of the flat. The southern, or larger of these (PI. XVI, $B$ ), after emerging from the glacier, tumbled over a fall about 40 feet high, then entered a granite gorge, beyond which it passed for a short distance through the moraine and thence out onto the flat.

The two streams that flowed across the flat spread out over it in several distributaries, then united into a single stream that crossed the outer moraine-covered area in a gorge (Pl. $\mathrm{XVI}, A$ ) in which ice is revealed. On emerging from this moraine-covered ice gorge the stream unites with one from Orange Glacier, and again branches and flows to the sea over its large alluvial fan (fig. 2). Thus we have here the anomaly of two glacial streams having their sources 3 or 4 miles back from the actual terminus of the glacier, flowing over the ice and building alluvial fans on it, then cutting a gorge through the moraine-covered outer expansion of the glacier and building another fan beyond its outer margin.

Since much of the sediment has been strained out in crossing the fans of the inner flat, the rate of building of the extensive fan out into the fiord has necessarily been diminished as the interior flat has developed.

\section{CAUSE OF THE BANDED MORAINES.}

The remarkable banded morainic phenomena furnish striking evidence of the protection even a thin moraine cover gives to ice. They present a series of noticeably colored concentric 


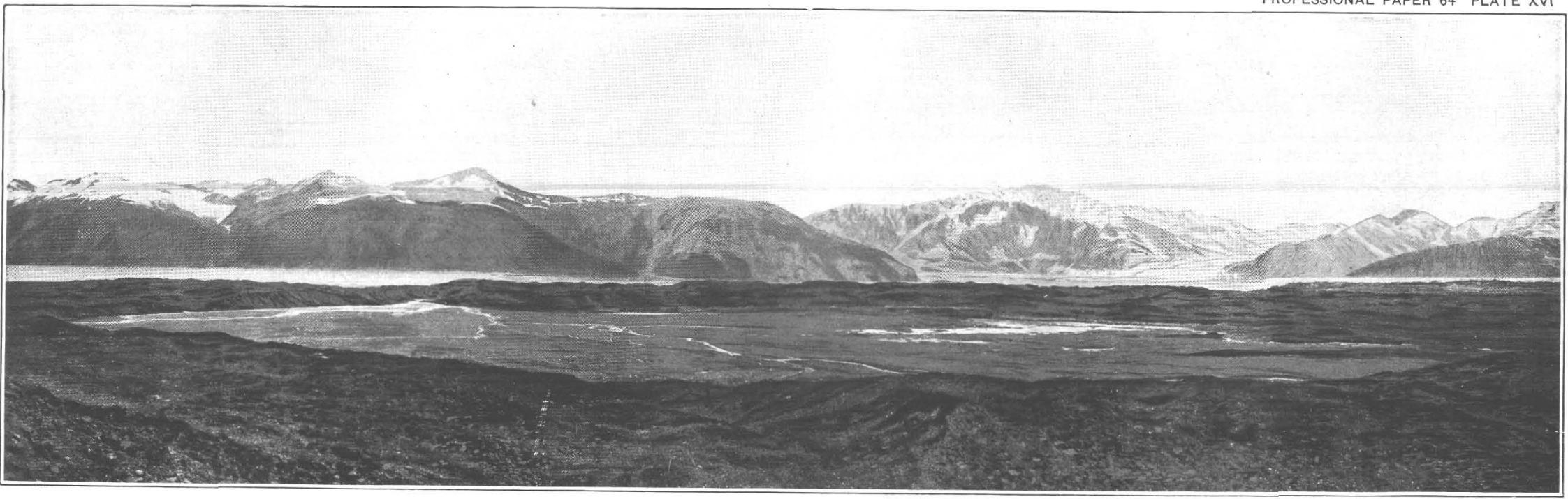

A. PANORAMA OF INTERIOR ALLUVIAL FLAT FROM THE GREEN MORAINE OF VARIEGATED GLACIER, LOOKING WEST.

Ice underlies the crescentic moraine on outer side of flat. Alluvial fan building stream emerges from flat through gorge in the moraine-covered ice in right-hand third of view. Site of this photograph (taken August 8,1905 ) was, in 1906, a bristling, crevassed ice front. (See PI. XVII, B.)

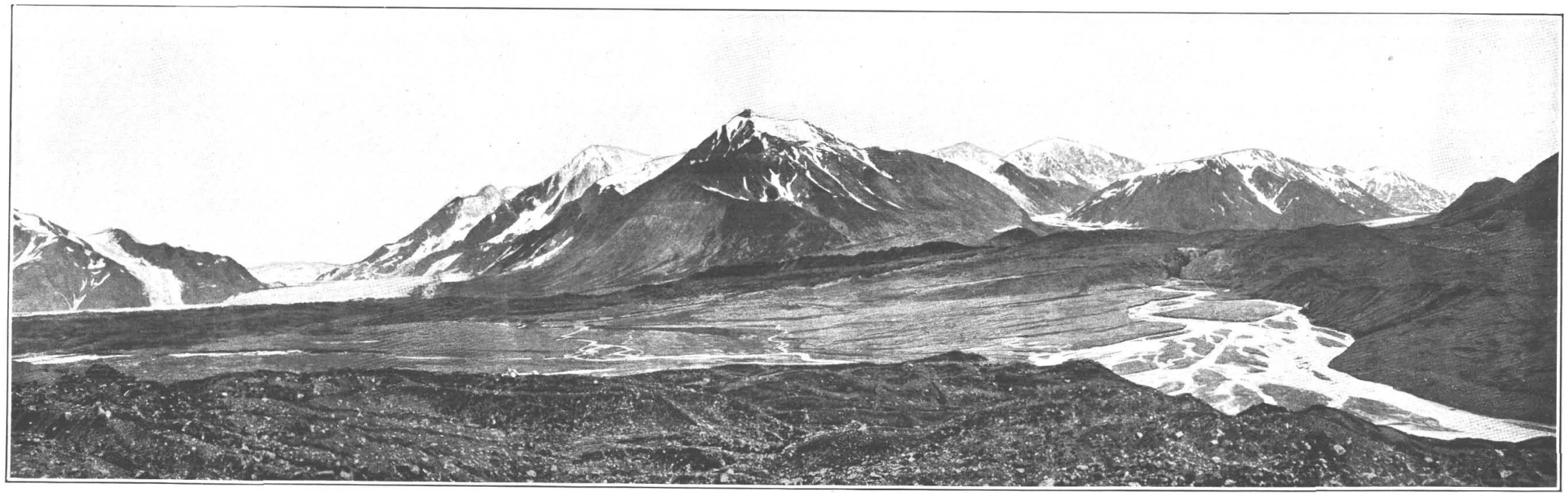

B. PANORAMA OF INTERIOR ALLUVIAL FLAT FROM INNER PORTION OF BLACK MORAINE OF VARIEGATED GLACIER, UNDER WHICH THERE IS ICE. Hubbard Glacier on extreme left; Orange Glacier on extreme right; Variegated Glacier just to the left of it. Moraine-covered Variegated Glacier, with banded moraines, rises with moderate slope on inner side of alluvial flat, and a large glacial stream emerges from a granite gorge on the right of the picture. After spreading out, the distributaries reunite and escape through a gorge in the moraine-covered ice on the right. Photograph taken August 8 , 1905. (Compare PI. XVII, B.) 
bands, now elevated to form prominent ridges; but, since the ridges are really ice with moraine veneer, if the glacier should completely melt away, these moraines would be conspicuous more by their color than by their height. Throughout the area the moraines are clearly of superficial origin, not ground moraine raised to the surface by upturned layers. The ridges are not properly terminal moraines, for they occur as crescentic bands on stagnant ice. Their present position and distribution are evidently due to the fanning out of lateral and medial moraines in a bulb-shaped, piedmont ice mass, though the exact process by which this development of concentric bands is brought about is not clear.

So far as I can interpret the phenomena, the succession of events seems to have been about as follows: At an earlier stage Hubbard and Variegated glaciers were united, and Variegated Glacier entered the fiord. Lateral moraine terraces on the mountain spur between Variegated and Hubbard glaciers, descending at an angle of about $5^{\circ}$ toward the Hubbard, represent the stage when Variegated Glacier contributed ice to the Hubbard and spread out fan shaped over all the area to the southeast of it. At this time the ice in both Variegated and Orange glaciers rose much higher than now, and the high-level lateral moraines, with sparse vegetation on them, which doubtless represent this stage, indicate that this period was not many decades ago. At that stage the two glaciers coalesced and supplied sufficient ice to keep the bulb-shaped ice foot in motion. The ice in the mountain valley of Variegated Glacier then pressed against the mountain walls and received the supplies of white granite and black hornblende gneiss so characteristic of the outer moraines, but not now being contributed to the glacier.

Stagnation followed, and ablation has concentrated the moraine near the margin, but has not completely removed the ice from beneath it. Following the stagnation of the outer part of the ice fan, the individual glacier arms maintained activity, at first coalescing and contributing moraine, later becoming independent. Variegated Glacier then began to dominate that part of the ice fan which was still active, while the broader Orange arm, being a dying "through glacier," has recently ceased to contribute to it either ice or moraine. With the shrinking of the glaciers the white granite supply diminished, then the black hornblende; and now the purple, green, and red gneisses from the upper valley, where the ice is in contact with these ledges, are the rocks which the glacier is bringing down on its back to the active portion of the expanded ice foot. The low area of the interior flat probably represents the clear ice of the bulb back of the moraine-veneered terminus of the combined glaciers, and the moraines on the inner side of the flat evidently represent the newly developed terminus of the ice bulb of the recently separated Variegated Glacier. This interpretation of 1905 was strikingly borne out by the observations of 1906.

When the ice is all gone from beneath these moraines their concentric pattern will suggest them to be terminal moraines; and they might then well be interpreted as marking the successive positions of the former fronts of a receding glacier. In reality, as already stated, they are ice-surface phenomena due to varying supply of rock fragments, the fanning out of a bulbshaped ice foot, and the surface concentration of débris through ablation. They deserve to be distinguished from ordinary recessional moraines, and for them I propose the name "ablation moraines."

\section{CONDITION IN 1906.}

My last viow of Variegated Glacier in 1905 was obtained near the middle of August, and when I again saw it, late in June, 1906, I was astounded at the remarkable change in its condition. The outer moraine, outside the interior flat, was unaltered; the flat itself was changed only by being slightly narrowed on the inner side; but all beyond that was totally altered. All the colored mornines had been destroyed and their places taken by a maze of jagged pinnacles and deep crevasses into which so much of the morainic débris had fallen that where, in the previous summer, no ice could be seen from a distance, now fully half the surface was clear ice $(\mathrm{Pl}$. XV, $B$ ). The only sign left of the prominent colored moraines was a faint tinge of color here and there on the broken ice surface. 
Beyond the moraine-covered area of 1905 , where the smooth wasting glacier came out of its mountain valley, a labyrinth of crevasses extended from one side of the valley to the other, at least as far up the valley as the point reached in our excursion in August, 1905. The ice was again in contact with the black hornblende gneiss from which it was separated by a deep valley in 1905. Attempts were made to climb the outer margin of this crevassed lobe, in order to reach a position from which the surface over which we so freely traveled ten months before could be photographed, but so profound was the crevassing that the attempt utterly failed. The surface so easily traversed for many miles in a single day in 1905 had in less than a year become wholly impassable (Pl. XV, $C$ ).

The crevassed area expanded in a bulb shape outside the mountain front, and accompanying the breaking were a forward movement and a thickening of the expanded terminus. (Cf. Pls. XVI, $B$, and Pl. XVII, B.) There was no means of determining the amount of thickening, but from a comparison of the photographs of the two seasons it is evident that the ice front is not less than 200 to 300 feet higher than in 1905 . Nor is it possible to state the exact amount of forward movement. The ice had advanced far enough to perceptibly narrow the interior alluvial flat, and it had completely overridden the gorge through which the glacial torrent flowed in the previous summer. From a comparison of photographs the amount of advance was estimated to be not less than 100 yards.

The effect of the forward push of the ice was not apparent in the alluvial flat, where the substratum of ice is undoubtedly very thin. Probably it was this thinness that prevented the thrust from reaching the outer area of stagnant, moraine-covered ice. Apparently the advancing glacier is overriding the flat, but the ice beyond it will probably not be affected unless the advance pushes the crevassed front completely across the interior flat.

\section{CHANGE IN DRAINAGE.}

The overriding of the granite gorge and the destruction of the drainage which flowed into it (see Pls. XVI, $B$, and XVII, $B$ ) has robbed the interior flat of the larger of the two streams which formerly flowed across it. The volume of the stream emerging through the ice gorge is, therefore, correspondingly diminished and the rate of upbuilding of the interior flat is temporarily decreased. This has withdrawn from the great alluvial fan on the shores of the fiord the large volume of water which was formerly flowing over its western half.

This enormous fan attracted attention in 1905 partly by the fact that it was the largest in the fiord and partly because its eastern half was covered with an alder thicket. It was inferred that some previous condition of drainage, which had built up this part of the fan, had so changed as to withdraw the water from it, and that this change was due to a recession of the glaciers, which gave a new locus for the emergence of the subglacial waters. The alders were mature, some of them being not less than twenty-five years old, indicating that at least a quarter of a century had elapsed since this change of drainage occurred. I little suspected that when I should again see it, after the short lapse of ten months, this alder-covered portion would again be the site of a fan-building stream.

By the advance of the glacier and the accompanying destruction of the old drainage on the margin of the interior flat the subglacial waters of Variegated Glacier have been turned to the east. In 1906 several good-sized streams were emerging from the crevassed eastern margin of Variegated Glacier into the valley which separates it from Orange Glacier, a valley in which one wall is the crevassed Variegated Glacier and the other the front of Orange Glacier. Here, uniting with the drainage of Orange Glacier, the waters from Variegated Glacier flow first along the glacier margin and then cut across a rock spur against which the crevassed Variegated Glacier is pressing.

In this part of its course the torrent flows with great velocity through a gorge cut in the granite (Pl. XXXVI, B); then, on its emergence, it spreads out upon the great alluvial fan, down the east side of which it flows in a series of branching distributaries through the alder thicket, which the floods are rapidly destroying. Many of the bushes are torn up; others are dying 


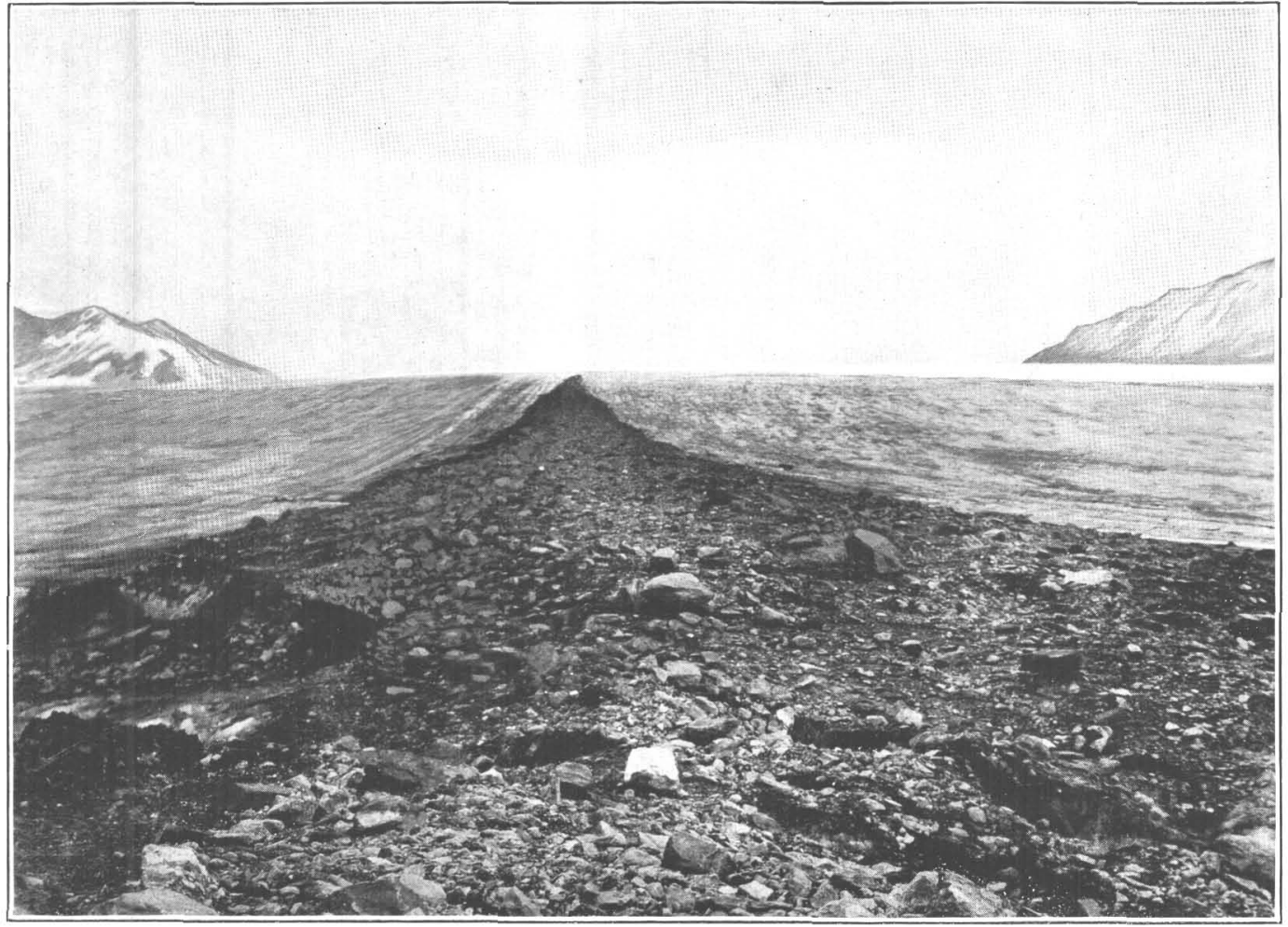

A. VIEW LOOKING EAST UP TO THE SNOW-COVERED DIVIDE OF ORANGE GLACIER, ALONG THE MEDIAL MORAINE.

Elevation, 1,650 feet. Beyond the divide the ice descends eastward toward Nunatak Fiord.

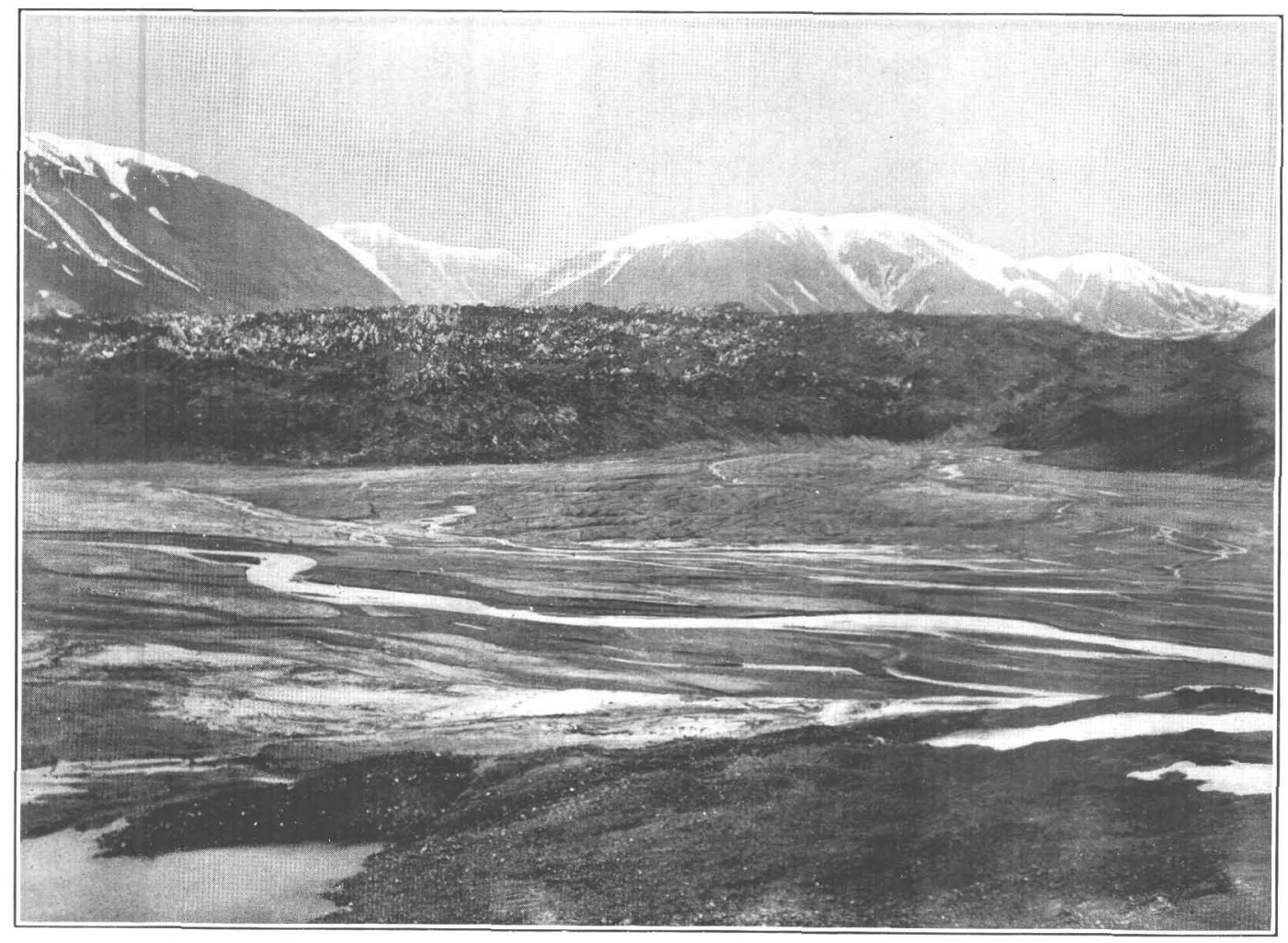

B. CREVASSED BULB OF VARIEGATED GLACIER RISING ABOVE INTERIOR FLAT.

Photograph taken August 17, 1906, from nearly same site as Plate XVI, B. Note the increase in height, the development of crevassing, the appearance of clear ice, the destruction of the moraine, the overriding of the granite gorge, and the consequent destruction of the large glacial stream. 
from submergence in the icy waters; still others are being buried beneath the deposits which the stream is rapidly making over their roots. The bushes were in full leaf, proving that this change had all occurred during the growing season of 1906.

\section{ORANGE GLACIER.}

Orange Glacier was not ascended in 1905, but in 1906 I went out upon it for the purpose of obtaining views of the crevassed Variegated Glacier. It is a typical example of a small wasting through glacier, occupying a valley somewhat more than a mile in width (Pl. XVII, $A$ ). The surface is everywhere smooth, with an angle varying from $5^{\circ}$ to $15^{\circ}$, but rarely attaining the latter slope. There is some crevassing, but none that makes travel across its surface diffcult. It rises to a broad, flat divide, about 2,500 feet above sea level, which on August 18 was snow covered. From this divide a tongue also descends eastward to Nunatak Fiord, where it terminates in a stagnant, moraine-covered end.

So far as could be seen from either side, the inclosing mountain walls were not indented by any deep valleys, and no pronounced tributary glaciers were seen. The glacier is joined by two or three small tributaries, which, however, seem incompetent to supply the large amount of ice of the main tongue. The mountain walls are steep, but rise to no great height. In all these respects Orange Glacier is different from Variegated Glacier, which heads back among lofty mountains and receives numerous tributaries from them.

The glacier is remarkably free from morainic material. There are marginal moraines near the lower end, and there is a well-defined medial moraine (Pl. XVII, $A$ ); but even the lower wasting terminus, which lies well within the mountain valley, has little morainic débris upon its surface. The medial moraine, which lies very near the exact middle of the glacier, is a very striking phenomenon. It is composed of angular fragments, on none of which scratches were seen, and the great majority of which are of orange-rusted gneiss, giving it a distinct color, noticeable at a distance. This moraine emerges as a narrow band just below the snow line and broadens toward the terminus, at the same time standing out more and more prominently as a morainic ridge. Since there are no visible large tributaries to this glacier, the origin of such a pronounced medial moraine is difficult to explain.

The cause for such a large glacier in this position is a puzzle. With its highest portion not far above the snow line, with few tributaries and limited snow supply from the mountain sides, and with flowage in both directions from a flat divide, it presents characteristics. which seem to demand special explanation. The following hypothesis is proposed: At the time when ice filled the Yakutat Bay Inlet, and when the glaciers rose high above the level of the present fiord waters, a stream of ice moved freely across this divide, connecting the enlarged Nunatak and Hubbard glacier areas and by its active erosion lowering and flattening the divide. This part of the hypothesis is supported by the evidence of profound glacial erosion on the walls of the mountains inclosing Orange Glacier. In no other way than by the vigorous passage of ice through this valley could the mountains have been so thoroughly scoured and the small tributary valleys have been left so well hanging.

The hypothesis proposed involves the assumption that the wasting away of this through glacier has not yet been completed; that is to say, the ice at present occupying this valley is a remnant of the former great through glacier. It is, however, still maintained as a glacier, with a slow forward movement and slight crevassing, primarily by the downsliding of snow from the mountain sides, and by the heavy winter snowfall upon the broad, flat divide, whose very breadth and width are the result of the glacial erosion of the former great through glacier.

Earlier higher stages of this glacier are clearly indicated along its margin by the presence both of marginal drainage channels, now abandoned (p. 142), and of high-level moraine terraces on the valley slopes. These all indicate a movement from the east, and may be due either to a pushing of ice through from Nunatak Fiord or to a former higher level of Orange Glacier itself. On the latter theory, however, it is difficult to understand how there could be enough ice accumulation in such a valley to cause so great a thickening of the glacier. 
That Orange Glacier is not now advancing and is not newly crevassed, like its neighbor the Variegated, is not difficult to understand in view of its small supply ground for snow and ice. If the theory proposed (pp. 90 et seq.) to account for the advancing glaciers is correct, Orange Glacier would not be expected to show much, if any, advance.

\section{NUNATAK GLACIER.}

\section{THE NUNATAK.}

Nunatak Glacier (figs. 4, 5) was named by Russell; ${ }^{\text {a }}$ who viewed it in September, 1891 , from Cape Enchantment, opposite the mouth of Nunatak Fiord. In his description of the glaeier Russell says: "Near where it enters the bay it is divided by a rounded butte of bare rock that rises through it like an island and that suggested the name Nunatak Glacier." $b$ When mapped by the Canadian Boundary Commission, in 1895, the glacier was separated into two distributaries, the larger one ending in a sea cliff, the smaller terminating on the land in a valley behind the nunatak (PI. III). Since that time the two distributaries have receded still farther.

The nunatak which separates the two termini of this glacier is a double-crested hill, approximately 2 miles in length, and at its highest point reaching an elevation of 1,440 feet. Its longer

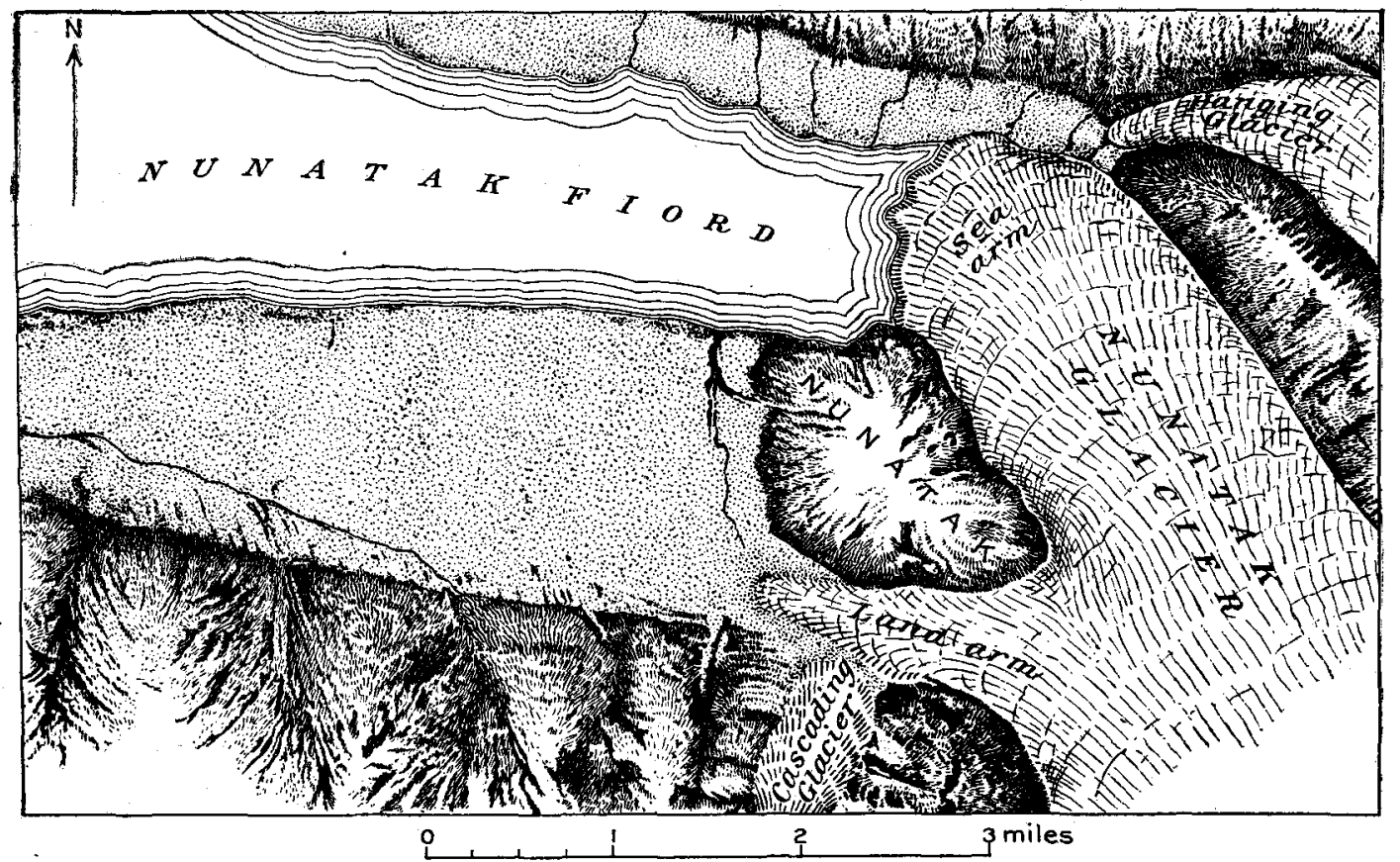

Figure 4.-The Gannett map of Nunatak Glacier, based on surveys in June, 1899. Reproduced from Gilbert's Glaciers and gtaciation: Harriman Alaska Expedition, vol. 3.

axis extends a little south of east, and it is evidently continued still farther eastward under the ice, this being clearly indicated by the presence of a crevassed ice dome in the direction of the axis of the nunatak for at least a mile. The main part of the nunatak consists of crystalline rocks, including several varieties of gneiss and schist. It dies out westward in a low, ice-scoured tail composed of schist near the higher part of the nunatak and of slate farther westward. The entire nunatak, including the tail, shows clear evidence of powerful ice erosion; and the general absence of vegetation on it, as well as in other parts of Nunatak Fiord, clearly proves recent recession of the glacier.

\section{TRIBUTARY ARMS.}

Three or four miles from the sea front Nunatak Glacier splits into two diverging branches (P1. VIII). The southern branch heads upon a broad, flat divide, as already described. Appar-

a Russell, I. C., Second expedition to Mount St. Elias: Thirteenth Ann. Rept. U. S. Geol. Survey, pt. 2, 1892, p. 86. $b$ In Greenland a mountain peak rising like an island out of the great ice flood is called a nunatak. 


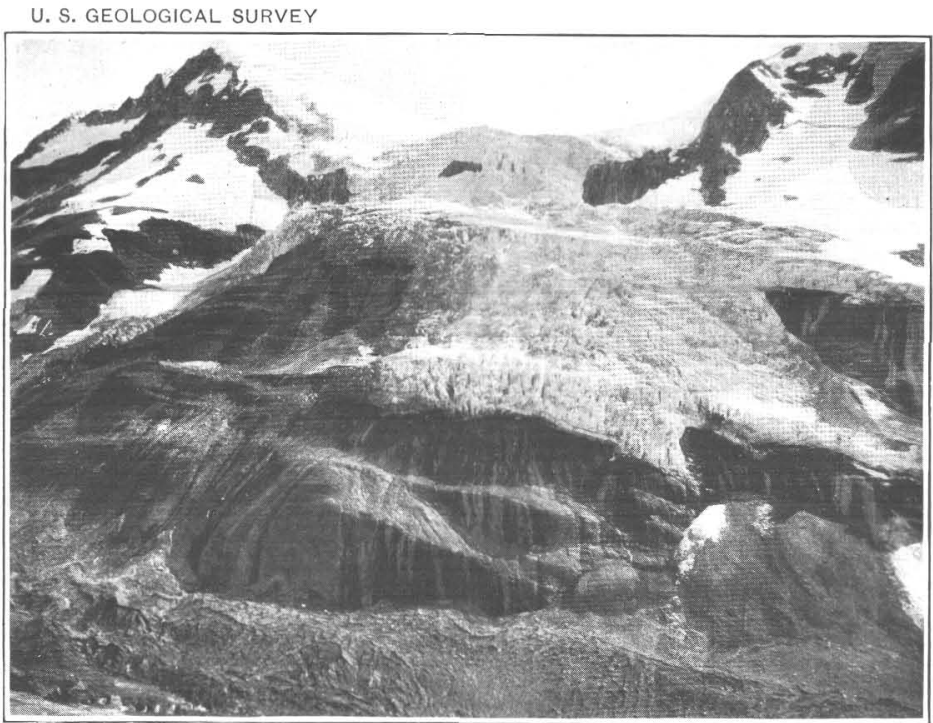

A. CASCADING GLACIER FROM THE NUNATAK.

Showing hanging-valley conditions, the cascading of ice from ledge to ledge, and the ice sculpturing of the steepened valley slope, down

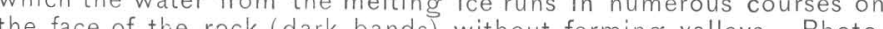
the face of the rock (dark bands) without forming valleys. Photograph taken July 24, Igo5.

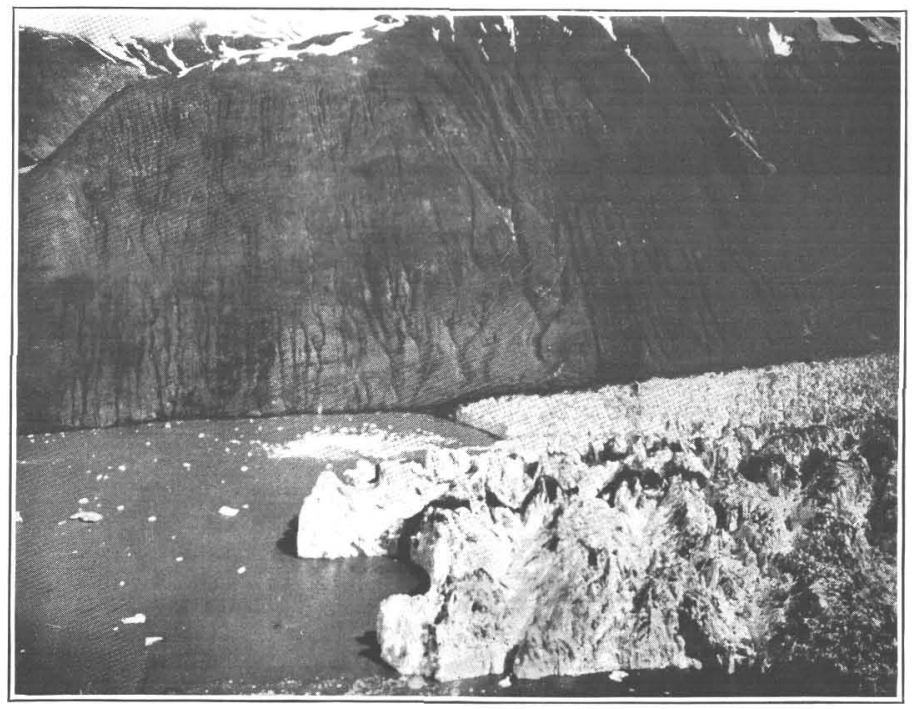

c. SEA END OF NUNATAK GLACIER FROM POINT NEAR CREST OF THE NUNATAK.

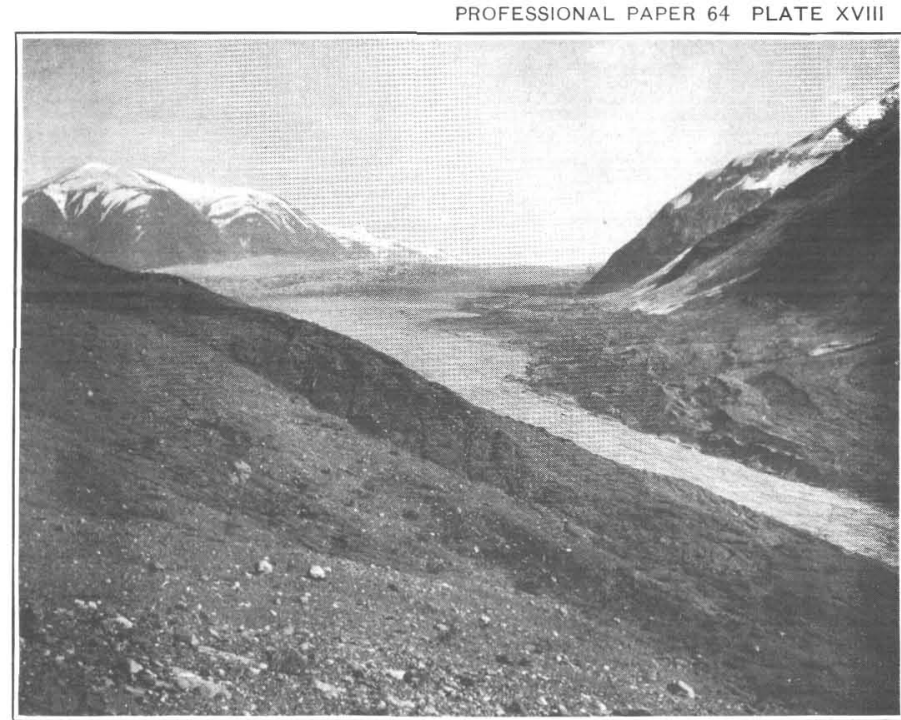

B. LAND TONGUE OF NUNATAK GLACIER FROM SOUTH SIDE OF THE NUNATAK.

Showing pronounced lateral moraine and wasting ice; also, in distance, the broad, flat divide of the through glacier. Photograph taken July 29, 1905

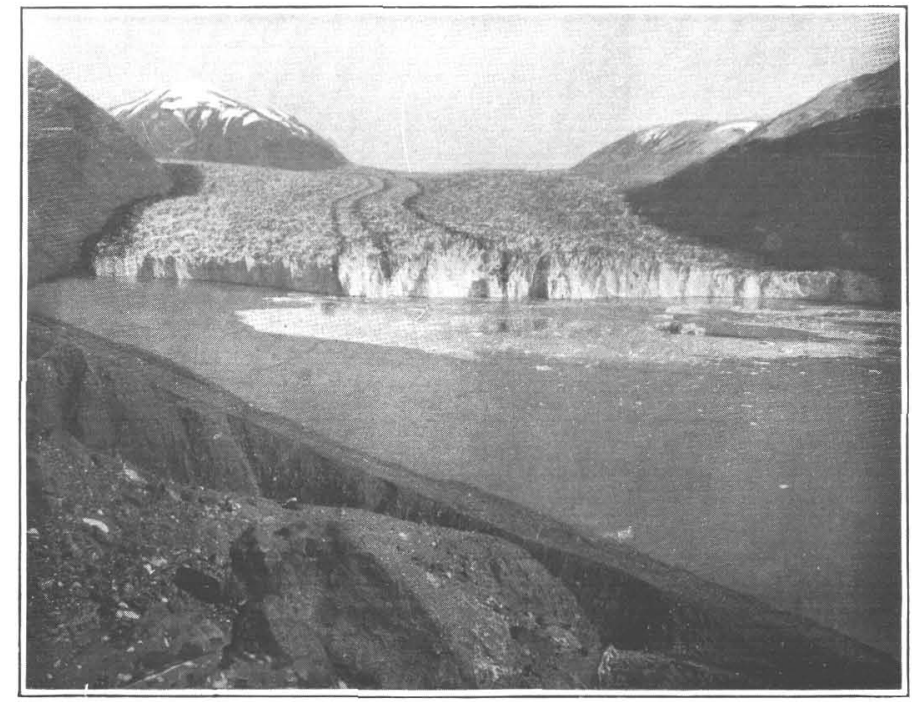

D. NUNATAK GLACIER FROM GRAVEL TERRACE 450 FEET ABOVE FIORD. 
ently it is not greatly crevassed, save in the dome alluded to, where the east end of the nunatak is emerging. The northern branch, which is evidently the larger and more active of the two, bends northward so that from the nunatak its sources are hidden from view; but it is evidently made by the union of at least two pronounced tributaries, the southenmost of which, like the southern arm of the main glacier, appears to head in a through valley sloping toward Alsek River.

\section{MORAINES.}

The presence of other tributaries, hidden from view, is indicated by the medial moraines. Five parallel medial moraines, rather close together, are visible about 3 miles from the terminus of the northern tributary; but these dwindle rapidly in the crevassed areas, and by the time the northern branch unites with the southern these five moraines are reduced to two. A third medial moraine is anded by the union of the lateral moraines of the main sawh and worth branches, and the three extend to the sea face as parallel morainic ribbons, rather close together. The lower end of the sea terminus of Nunatak Glacier is so badly crevassed that these moraines lose intensity as they approach its front (PI. XVIII, $C, D$ ).

The two medial moraines contributed by the north branch are gray in color, but that made by the union of the north and south branches is black, evidently due to black hornblendic gneiss. That the northern tributary is more powerful than the southern is clearly indicated by the bend in these medial moraines, which, below the junction of the two branches, are pushed well over toward the axis of the southern tributary (Pl. VIII). The pronounced crevassing of all of the north branch visible from the nunatak is also proof of greater activity. "The thrust from the weaker south branch, combined with the effect of the inclosing mountain walls, finally turns the moraines, which thence pass on to the sea in a fairly straight course. The significance of such a deflection of moraines in its bearing on the direction and velocity of ice currents, and of this upon the question of differential ice erosion, is evident.

There are fairly well defined lateral moraines on both sides of the trunk glacier, that on the south side being much broader

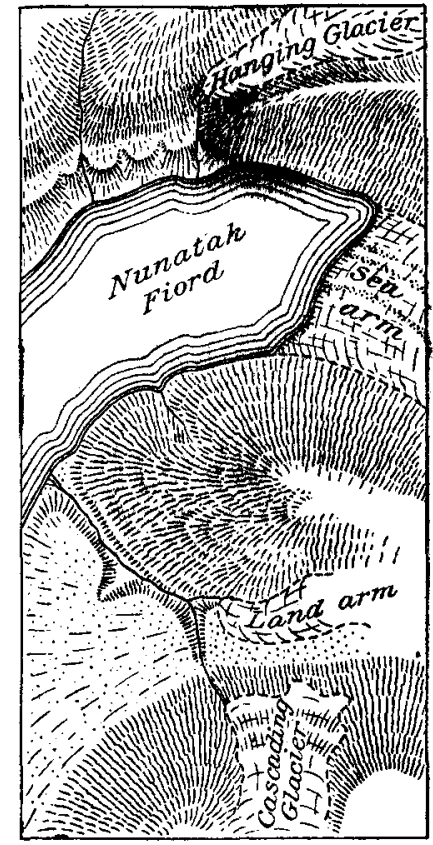

Figure 5.-Sketch map of Nunatak Glacier, from plane-table survey by B. S. Butier, August, 1905 . than that on the north side, evidently because of the fact that the southern or land arm is dwindling (PI. XVIII, $B$ ). In each case the protection from ablation furnished by the lateral moraine causes the surface to rise perceptibly above that of the main glacier.

\section{THE TWO DISTRIBUTARIES.}

The great bulk of the ice passes down the broader valley to the sea, and a much smaller supply is contributed to the distributary which ends on the land (fig. 4). The sea end is moving rapidly and is crevassed from side to side (PI. XVIII, $C$ ); but the land tongue is much smoother, slightly crevassed, and evidently almost stagnant. Its ice supply is now being diminished by the interference of the subglacial extension of the nunatak, and if recession continues much longer it can not be many years before this distributary will have its supply cut off.

Indeed, in 1899, Gilbert, who saw only the lower end of the land tongue, inferred that it had already been cut off. He states: ${ }^{a}$

In the hollow separating this knob [the nunatak] from the south wall lay a mass of ice of uncertain relations. It was seen only from the west, and was supposed to be a tongue or distributary arm of Nunatak Glacier. The fact that it lay several hundred feet higher than the tidal arm has raised doubts as to the correctness of the first impression, and I now suspect that it was only the remnant of a former arm of the glacier, stranded as a motionless and slowly wasting summit mass. On the map of the Canadian Boundary Commission (1895) it is represented as a distributary of the glacier. 
Some years ago prospectors made use of this distributary in entering the glacier highway to the Alsek Valley, but a prospector who was familiar with this route informed me that it had to be abandoned because of the development of crevasses, which interfered with sledging.

THE SEA END.

The sea face of Nunatak Glacier is approximately a mile wide, and both sides of the glacier rest against steeply rising and quite inaccessible walls (Pl. XVIII, $C$ and $D$ ). Both sides are bordered by narrow lateral moraines, that on the southern or nunatak side being the smaller. Partly because of the influence of these moraines in retarding ablation, and partly, no doubt, because of the shallowness of the fiord water along the valley margins, the glacier front projects slightly on each side, especially on the southern. Except for these lateral moraines and the three medial moraines, the ice surface is fairly clean. The ice front projects decidedly near the middle, probably as a result of the more rapid movement near the middle of the valley.

The ice cliff rises more than 200 feet above the water, and from it there is an almost constant discharge of icebergs (Pl. XVIII, $C$ and $D$ ), often large, which generate great iceberg waves whose effects are felt several miles down the fiord. That these waves are important agents of erosion near the ice front is evident from their frequency and from the violence of the surf to which they give rise. The icebergs discharged from Nunatak Glacier, while not nearly so numerous as those from Hubbard and Turner glaciers, are nevertheless sufficiently abundant - to obstruct the fiord with a procession of moving bergs, mostly small, but including some which rise 20 or 30 feet above the water. On the whole they are remarkably free from débris, and in this respect contrast decidedly with many of the icebergs from Hubbard Glacier.

Two streams emerge from the ice front beneath the sea, one, the larger, about 200 yards from the northern side, the other about an equal distance from the southern side. Each of these streams gives rise to a swirling current of muddy water which keeps the near-by front of the ice cliff fairly free from icebergs at all times except immediately after a fall. The larger northern stream clears away the floating ice for a distance of nearly a mile from the front. Opposite the center of the glacier the fiord water is much freer from sediment, and a mass of floating ice is usually present there.

It is evident that the subglacial streams are pouring enormous quantities of sediment into the fiord, the greater part of which settles close to the ice front; and if the glacier should remain stationary for any length of time an extensive deposit would necessarily accumulate there.

THE LAND END:

The terminal slope of the land distributary of Nunatak Glacier (Pl. XVIII, $B$ ) is about $10^{\circ}$ near its edge, changing to $5^{\circ}$ a few hundred yards from the front. The ice is now rapidly melting and apparently nearly if not quite stagnant, for there is no significant crevassing in at least the lower mile of its course. The melting gives rise to short streams which soon cascade into moulins, some with a diameter of more than 30 feet.

Near the lower end the ice surface is discolored by a thin film of mud, sand, and bowlders, which in places is thick enough to form pyramids with ice cores varying in height from an inch to 6 or 8 feet. These are evidently due to thicker deposits, formed in earlier depressions, and now brought into relief by ablation. There are also numerous ridges of similar character, apparently deposits in former crevasses. There is no moraine-covered terminal portion, the outer edge of the ice being very indistinct; in fact, the exact terminus is evidently very thin and flat and is buried beneath stratified deposits.

Fringing the ice front, and on the site where the glacier terminated during Gilbert's visit in 1899 , there is a depression containing a small lake. A fairly large glacial stream emerging from the ice has built an alluvial fan in this lake, all since 1899. Deposits of clay prove that the lake is the remnant of a formerly more extensive one, possibly one that is formed in spring when snow and ice have dammed the gorge through which the glacial waters escape. In the depression also there is a flat-topped, delta-like deposit, forming a gravel plain fully 100 yards 


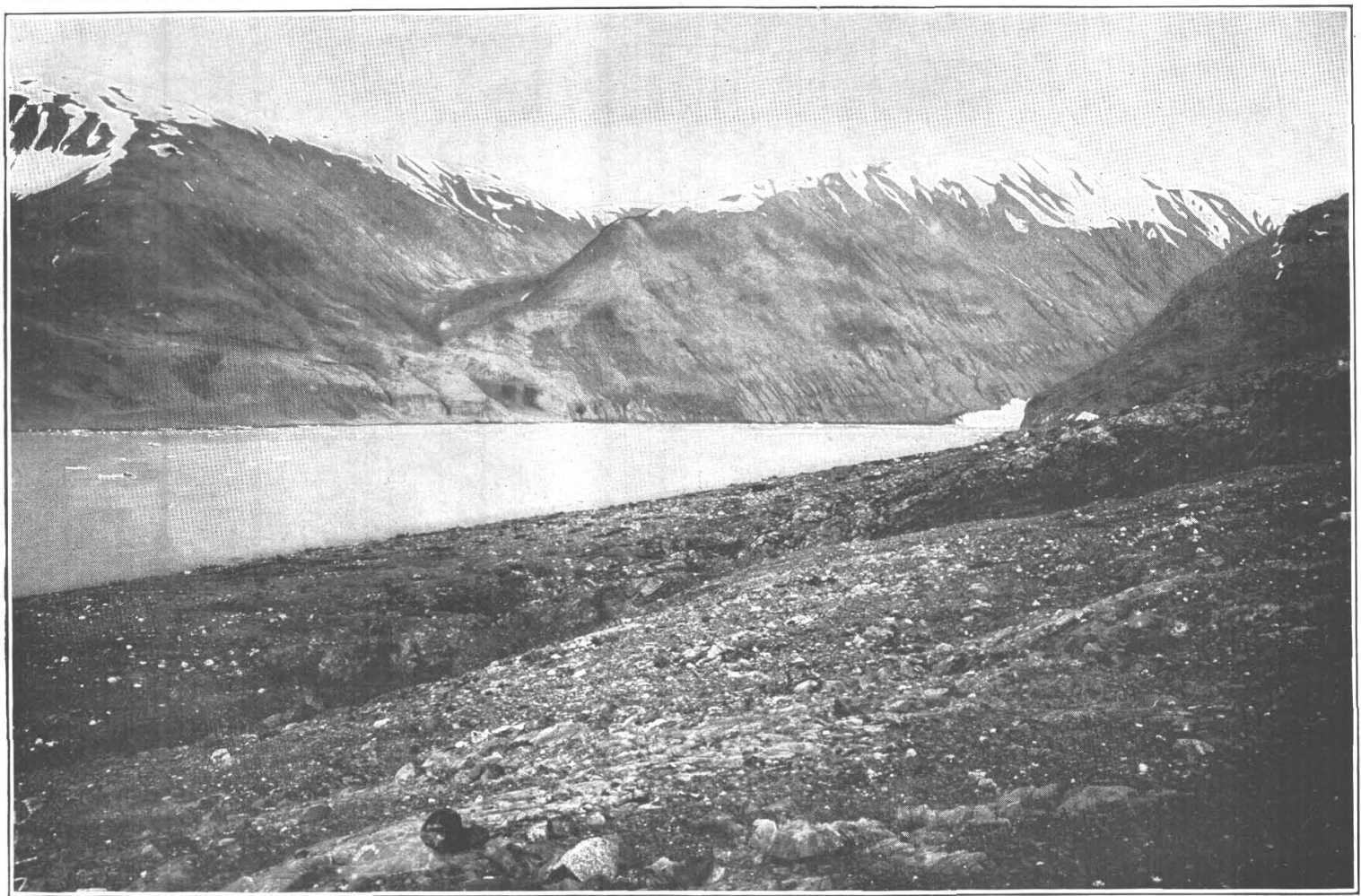

A. SEA END OF NUNATAK GLACIER, JULY 5, 1906.

Photograph, taken from same site as Plate $X I X, B$, shows slight recession since 1905. Note glaciated north wall of Nunatak Fiord.

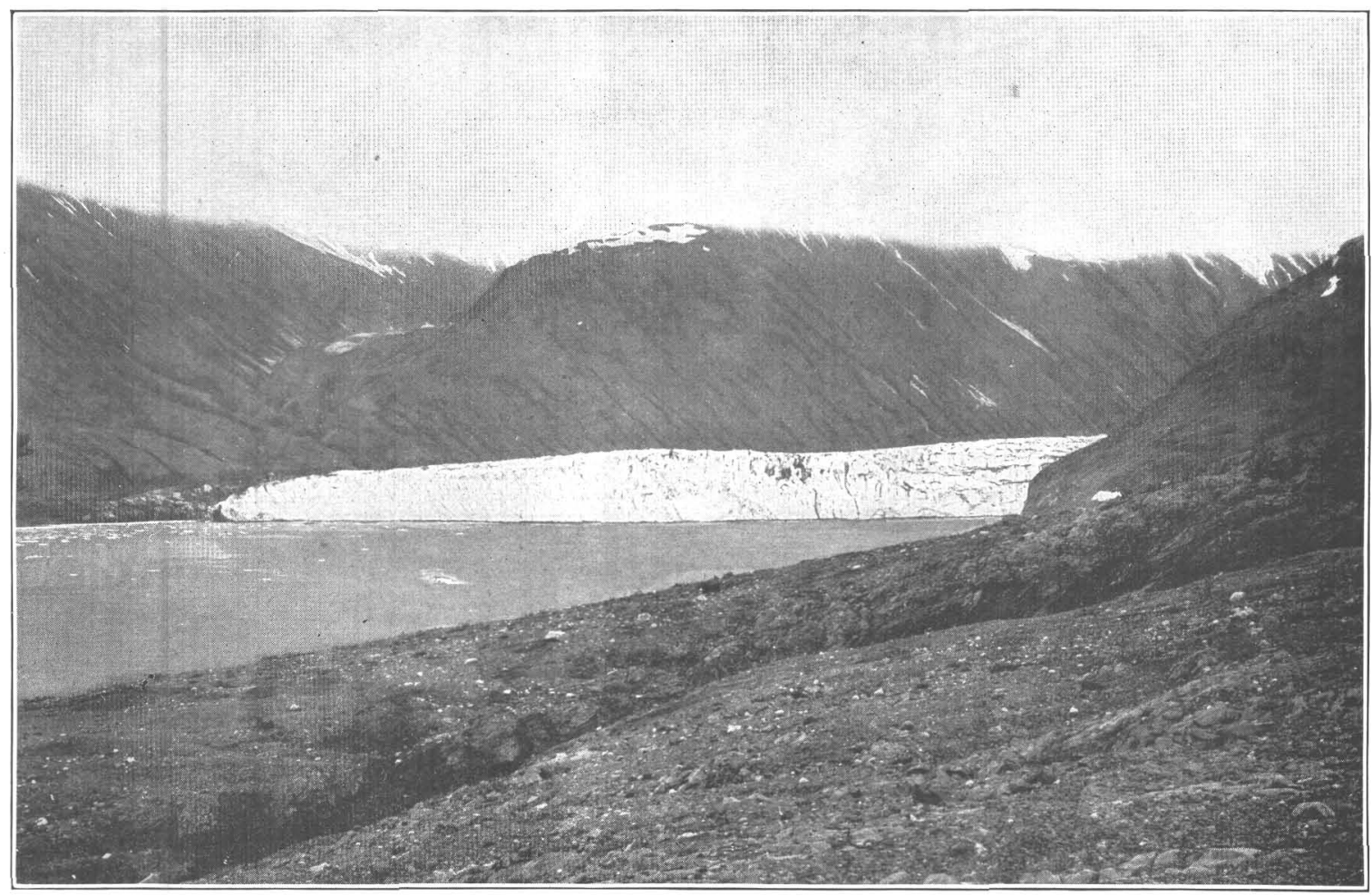

B. SEA END OF NUNATAK GLACIER, JUNE, 1899.

Note hanging valley occupied by a glacier on opposite side of fiord and Nunatak Glacier stretching across it. (Compare with PI. XIX, A.) Photograph by G. K. Gilbert. 
across in its longest diameter. Viewed from a distance it has the appearance of a sand plain; but it is, in fact, merely an ice remnant on which stratified gravels were deposited during the higher lake stage.

There is a pronounced lateral moraine on both sides of this tongue, in places completely hiding the ice. It looks like an irregular ridge of débris, rising in places to a height of 75 feet above the glacier surface (PI. XVIII, $B$ ); but in reality the morainic deposit is thin, the elevation and irregularity being due almost wholly to irregular ablation of dirt-covered ice. The southern lateral moraine varies greatly in breadth from place to place as a result of the fall of talus from the mountain sides. It is evident that if the tongue were not stagnant, or nearly stagnant, this irregularity would be greatly reduced by transportation of the talus to the ice terminus.

After passing through the depression described above, the waters of the land tongue of Nunatak Glacier enter a profound gorge, cut in the friable schists and slates of the nunatak tail. It seems hardly conceivable that this gorge can be the product of water erosion in the brief period of fourteen years between 1905 and 1891, when, according to Russell, the two tongues were united over this very tail. It may, of course, be due in part to subglacial stream erosion during the period when the land tongue swung into the fiord to join the sea tongue; or it may, in part, represent stream erosion during or before the last ice advance; or, as is suggested below, it is possible that the period of union of the two tongues was earlier than that which Russell's description suggests.

\section{RECESSION OF NUNATAK GLACIER.}

The notable recent recession of Nunatak Glacier is proved by the freshly smoothed and polished rock slopes of Nunatak Fiord, by the general absence of vegetation in the fiord (p.128), by Russell's description of the condition in 1891, and by the Boundary Commission map and photographs of 1895. Gilbert's description ${ }^{a}$ and photographs, taken in June, 1899, and Gannett's map (fig. 4), ${ }^{b}$ made at the same time, give a much more exact basis for estimating the recession.

It was not found possible to reoccupy the exact sites whence Gilbert took his photographs of the land tongue of Nunatak Glacier, but photographs were taken from approximately the sites occupied in two of his pictures. These photographs show a decided recession of the front, a narrowing of the clear-ice portion of the glacier, and a lowering of the surface.

At the time of Gilbert's visit the sea tongue of Nunatak Glacier extended across the mouth of a hanging valley on the northern wall (Pl. XIX, B), within which a glacier with a morainecovered end descended to the very lip. Along this northern wall the glacier was extended still farther westward by a narrow, moraine-covered tongue resting on gravel deposits. This moraine-covered ice still remains, but is much smaller and is now completely separated from the glacier, whose front is fully a mile farther east. The stagnant ice mass lies somewhat less than a quarter of a mile west of the stream that now descends into the fiord from the hanging valley glacier. Little ice now appears in it, though ice was revealed in a number of places, and its presence elsewhere was proved by the slumping of the moraine and by the emergence of water from its base. The preservation of this detached mass of ice, and the absence of other remnants between it and the present glacier front, are due (1) to the fact that the ice at this point rested on a gravel deposit above sea level, while between it and the present glacier front the steep mountain wall descends precipitously beneath the fiord waters; and (2) to the fact that at this point a large amount of débris was poured upon the ice by the glacial stream which descends from the hanging valley.

About a quarter of a mile farther west, on the eastern side of the next large alluvial fan, there is another mass of considerable height, also evidently underlain by ice. No ice was actually seen in it, but its surface was freshly cracked, and it was evidently slumping in 1905 .

The exact site of Gilbert's 1899 photograph of the sea front of Nunatak Glacier was occupied, even to the extent of locating the same small bowlders in the foreground.c (Cf. Pl. XIX,

a Gilbert, G. K., Glaciers and glaciation: Harriman Alaska Expedition, vol. 3, 1904, pp. 53-63.

$b$ Gannett, Henry, idem, PI. VII.

c Tarr, R. S., and Martin, L., Glaciers and glaciation of Yakutat Bay, Alaska: Bull. Am. Geog. Soc., vol. 38, 1906 , fig. 14. 
$A$ and $B$.) The amount of recession in six years is striking, being not far from a mile; but it is possible that a portion of this recession is to be attributed to the effect of the earthquake shock of September, 1899, since there was much shattering of the rocks of the nunatak at that time.

The interval between Gilbert's visit and mine was six years, and the map of the Boundary Commission shows the front of Nunatak Glacier four years earlier than Gilbert's visit. The recession in this earlier period was also striking, and apparently at about the same rate as that between 1899 and 1905 . If the same rate of recession had prevailed for the interval between 1891 and 1895, it would not carry the two tongues out far enough for union, as Russell's description indicates was the condition. This has led me to question Russell's conclusion that the nunatak was surrounded in 1891 . He might easily have been mistaken in this instance, for he saw the glacier only from a distance, at Cape Enchantment. The position of his point of observation was such that the two tongues might well have appeared to completely wrap around the nunatak, although actually separated by a considerable gap, and, in fact, with the sea ends no farther out than in 1895 . It should perhaps be pointed out that Russell does not specifically say that the nunatak was actually surrounded, though the name "nunatak" and the statement that it. "rises through" the glacier "like an island" warrant this interpretation of his description.

\section{CONDITION IN 1906.}

The photographic site of 1905 was reoccupied in July, 1906 (PI. XIX, $A$ ), and in the interval of less than a year there had been noticeable though slight recession. Viewed from the crest of the nunatak it was found that there had been a notable change in the outline of the front.

\section{CASCADING GLACIER.}

GENERAL DESCRIPTION.

Under the name Cascading Glacier Gilbert ${ }^{a}$ describes an interesting glacier which heads in a high mountain valley of moderate size, with snow-clad peaks at its head and on either side (Pl. XVIII, $A$ ). The valley is a typical hanging valley with its lip approximately 1,500 feet above the fiord. The glacier passes out over the lip of the hanging valley and descends the steep south wall of Nunatak Valley for a thousand feet, terminating on the mountain slope above the end of the land tongue of Nunatak Glacier. Beyond the lip the glacier is not inclosed in valley walls, but rests on the very face of the mountainous wall, descending so steeply that it seems a marvel that it can cling there at all.

That the ice is able to remain on so steep a slope is due to a series of rock terraces, descending westward, which were seulptured by glacial erosion during a higher stage of Nunatak Glacier. These terraces form steps upon which the ice rests, giving the appearance of an ice cascade, and their westward inclination deflects the ice slightly in that direction. That Cascading Glacier is in actual movement below the hanging valley lip is indicated by the pronounced crevassing, but that its present movement is not causing effective ice erosion is proved by its not having destroyed the east-west grooving and striation produced when the westmoving Nunatak Glacier rose that high on the valley wall.

From the ragged lower edge of the perched glacier a multitude of small streams flow straight down the hillslope, but they have existed for so short a time that they have not yet perceptibly gullied the glaciated rock surface over which they descend (PI. XVIII, $A$ ).

Cascading Glacier is rapidly wasting back, partly by ablation and partly by the falling of ice blocks from its terminus. A number of these falls were seen during our visit. The result has been to form a fan of ice blocks, really an ice-block talus, at the base of the cliff. That this change has been in progress since the time of Gilbert's visit is proved by the very notable change in form of the lower margin of Cascading Glacier which the photographs of 1899 and 1905 show. In one section of the margin the recession has amounted to about 200 feet vertically. 


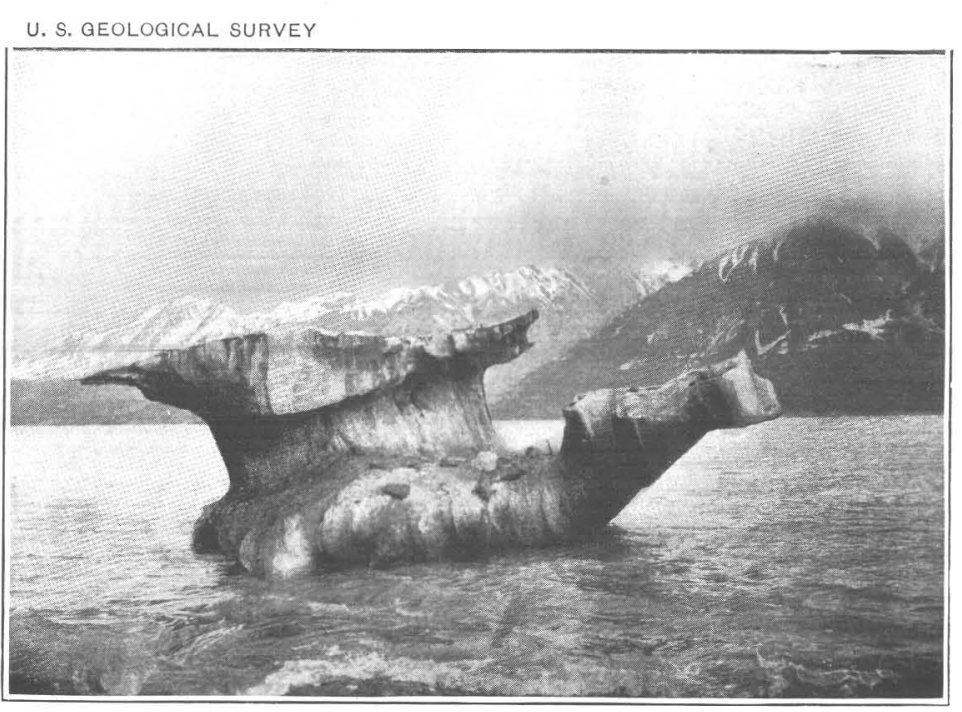

A. DÉBRIS-CHARGED ICEBERG IN DISENCHANTMENT BAY, BEARING BOWLDERS.

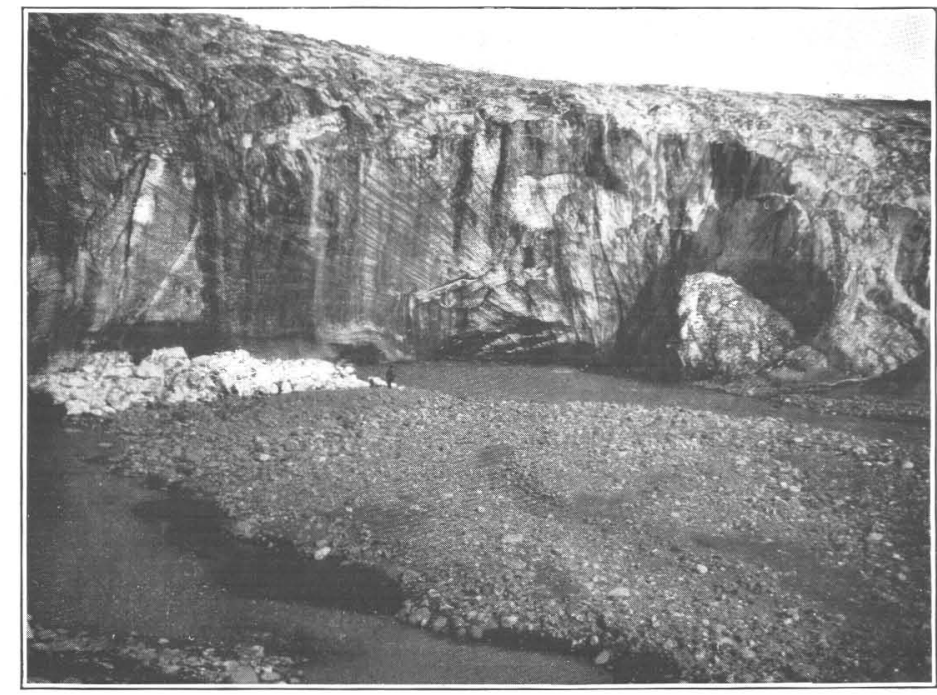

C. ICE CAVE neAR SOUthern EDGE OF HIDDEN GLACIER, FROM WHICH MAIN STREAM ISSUED JULY 25, 1905.
PROFESSIONAL PAPER 64 PLATE $X X$

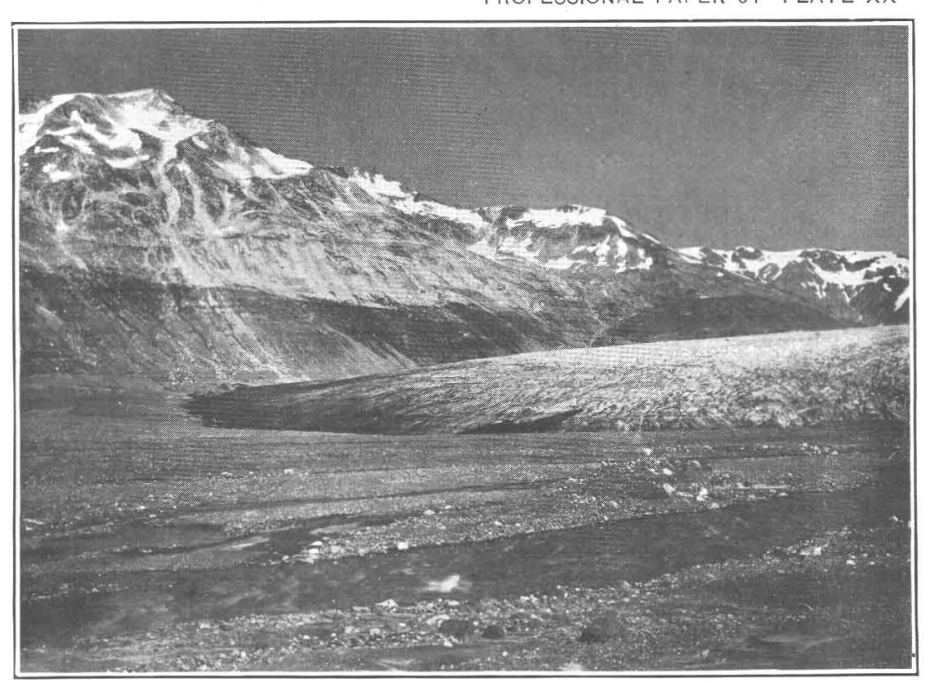

B. VIEW OF END OF HIDDEN GLACIER, LOOKING NORTHEAST.

Hidden Glacier stream in foreground, pitted gravel plain beyond, and in distance northern margin of glacier resting on older gravels. Note strong glacial erosion of mountains on north side of valley.

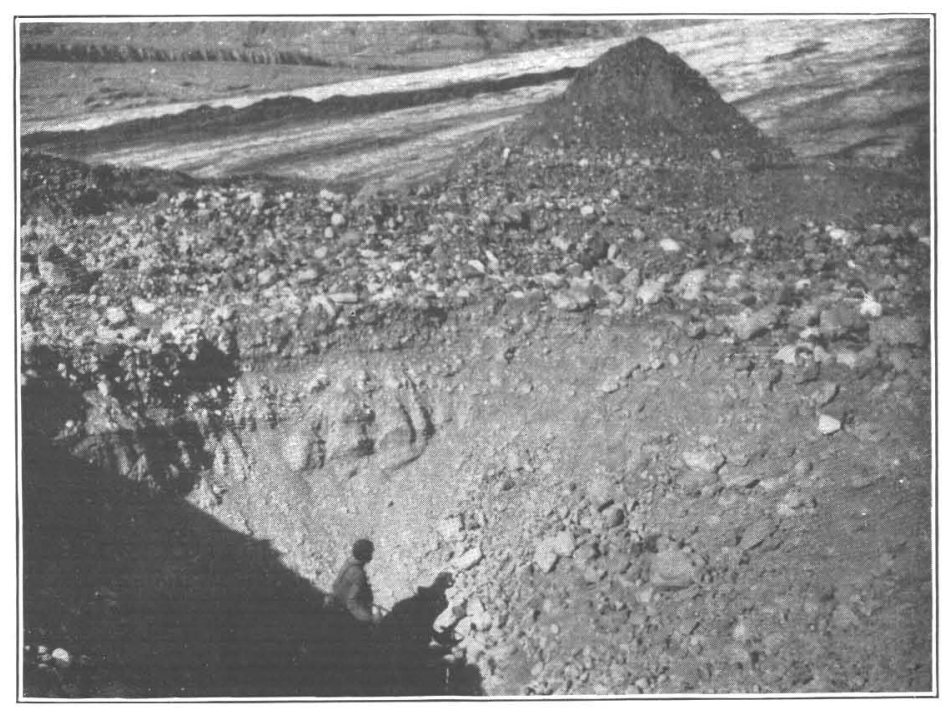

D. SMALL DRY KETTLE NEAR FRONT OF HIDDEN GLACIER. The gravel cone is on the glacier. The site of this kettle was occupied by Hidden Glacier in 1899. Photograph taken July 25, 1905. 

ORIGIN OF CASCADING CONDITION.

Cascading Glacier evidently represents a stage in the recession of hanging-valley glaciers. If the cascading end could be entirely removed, there would be left merely a glacier occupying an upland valley and descending to the lip of the valley. It would be separated from the main valley by a steep, glaciated surface, down which, in place of a series of small streams, a single glacial stream would cascade; and this would, in time, notch the valley wall and form a gorge.

Almost directly oppesite Cascading. Glacier, en the north wall of Nunatak Fiord, there is - nother large hanging valley whe lip is not so high above the fiord (PI. XIX). It is occupied by a glacier which extends to its very lip, and from it a stream flows down the valley side in a gorge of considerable depth, cut mainly in the glacial gravels. The valley next west of Cascading Glacier is also hanging high (about 700 feet) above the fiord ( $\mathrm{Pl}$. XXX, $C$ ); but in this case the glacier ends about a mile back from the edge of the hanging valley. The stream emerging from it has notched the steepened slope below the lip of the hanging valley with a distinct though not very deep gorge.

About a mile east of Cascading Glacier, and on the same side of the Nunatak Valley, there is another hanging valley, over the lip of which a glacier cascades, descending fully 1,500 feet and actually uniting with the land tongue of Nunatak Glacier (Pls. VIII, XVIII, $B$ ), mingling with it in an area of pronounced lateral moraine. Its lower slope is smooth and thin, and it is evidently about ready to be disconnected and given separate existence.

In this fiord there are, therefore, gradational stages between the hanging valley occupied by a mere glacier remnant and the hanging valley whose ice is still tributary to the main glacier, the series progressing, as might be expected, up the trough of a large receding glacier, and varying somewhat, also, according to the height of the hanging valley. Elsewhere in the inlet there are other stages; in fact, one of the most common of glacier features in this region is the abrupt descent of the lower end of a tributary to a larger glacier (Pl. XIII, $B$ ), or one entering a larger valley.

When such hanging valley glaciers were tributary to the main glacier, in its higher stage, the steepened slope down which they now extend was occupied by the ice of the main glacier, moving powerfully at right angles to the direction of present ice movement in the tributaries, and completely dominating the movement below their junction. By the withdrawal of this high-level ice the tributaries have been given independent existence; and, in some instances at least, the cascading ends may be mere remnants of an earlier flood stage, which, owing to the elevation and consequent slow ablation, have not yet been destroyed.

\section{HIDDEN GLACIER.}

GENERAL DESCRIPTION.

South of Nunatak Fiord, at the head of a small bay called Seal Bay by the natives (Pl. $\mathrm{XXXV}$ ), is a delta deposit fed by one large glacial stream and several smaller ones, all flowing from the melting ice of Hidden Glacier. (See figs. 6, 7.) This delta, or outwash gravel plain, extends from one side of the valley to the other and runs back from the sea for a distance of somewhat more than 2 miles, where it is terminated by the end of Hidden Glacier, whose front is about a mile wide, filling the whole valley from wall to wall. At the glacier front the outwash gravel plain has an elevation of about 150 feet. Both walls of the valley, above as well as below the end of the glacier, are profoundly smoothed, grooved, and otherwise greatly modified by ice erosion. Between these glaciated walls and the outwash gravel plain are some low gravel terraces showing clear evidences of former overriding by the ice.

Hidden Glacier resembles the southern tributary of Nunatak Glacier, rising up to a broad, flat, snow-covered col, across which, according to the Boundary Commission map, it is continuous with Nunatak Glacier. Snow-capped mountains rise above it on either side, and small tributaries descend the valleys of these mountains; but, so far as could be seen, there are no large 
tributaries to Hidden Glacier, much of whose supply, as in the case of Orange Glacier, apparently comes from snow accumulations on the broad ice-submerged divide. Several facts indicate that the supply ground is not at present contributing enough ice to Hidden Glacier to give it much activity. The Boundary Commission map indicates other supply ground, but these sources were out of sight.

The front of Hidden Glacier has a moderate slope, ranging between $10^{\circ}$ and $20^{\circ}$, but back of the terminal slope this perceptibly decreases $(\mathrm{Pl}$. XX, $B$ ). The ice is only slightly crevassed

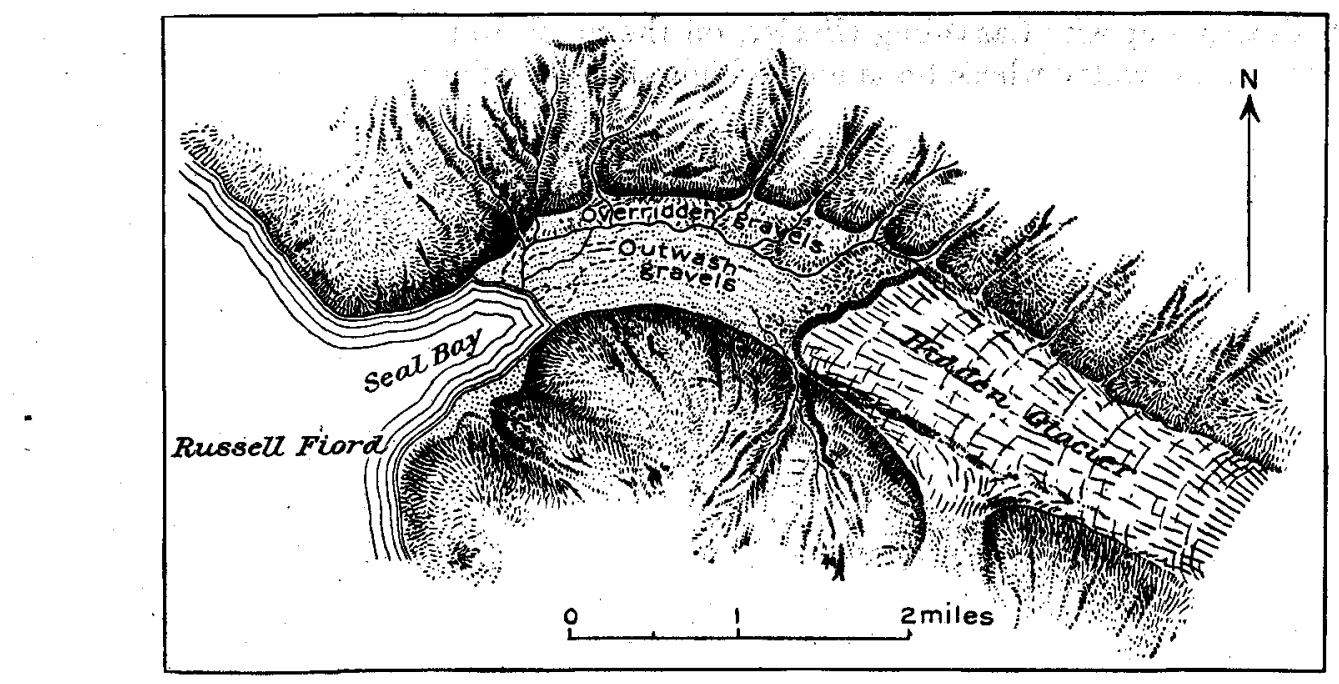

Frgure 6.-Gannett map of Hidden Glacier, based on surveys in June, 1899. From Gilbert's Glaciers and glaciation: Harriman Alaska Expedition, vol. 3.

and is evidently moving very slowly. As a whole, the glacier surface, like that of Orange Glacier, is remarkably clear of débris, in this respect differing from most of the Yakutat Bay glaciers which terminate on the land, whose ends are usually buried beneath pronounced morainic accumulations. Hidden Glacier has the appearance of coming down to the outwash gravel plain and terminating abruptly with the normal slope of a glacier front, with clear ice to its very terminus. This appearance is somewhat deceptive, however, since, as is shown below, the ice in reality extends under the outwash gravel plain. Because of this peculiarity in the terminus of Hidden Glacier no terminal moraine of the normal kind is being accumulated.

There is a well-defined lateral moraine on each side of the glacier, which by protecting the ice causes its surface to rise decidedly on both margins. One fairly well defined medial

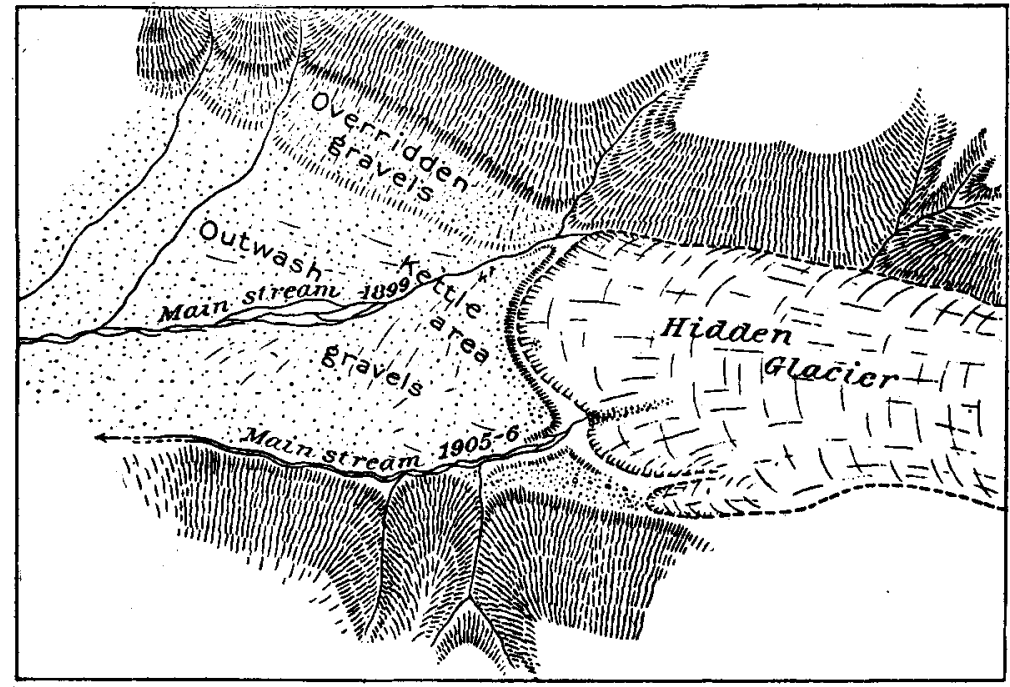

Figure 7.-Sketch map of Hidden Glacier, from plane-table survey by B. S. Butler, July, 1905 . moraine comes down to the ice front in the southern third of the glacier, being evidently supplied by the entrance of some small, weak tributary from the south side. The absence of other medial moraines testifies to the lack of important tributaries higher up. 


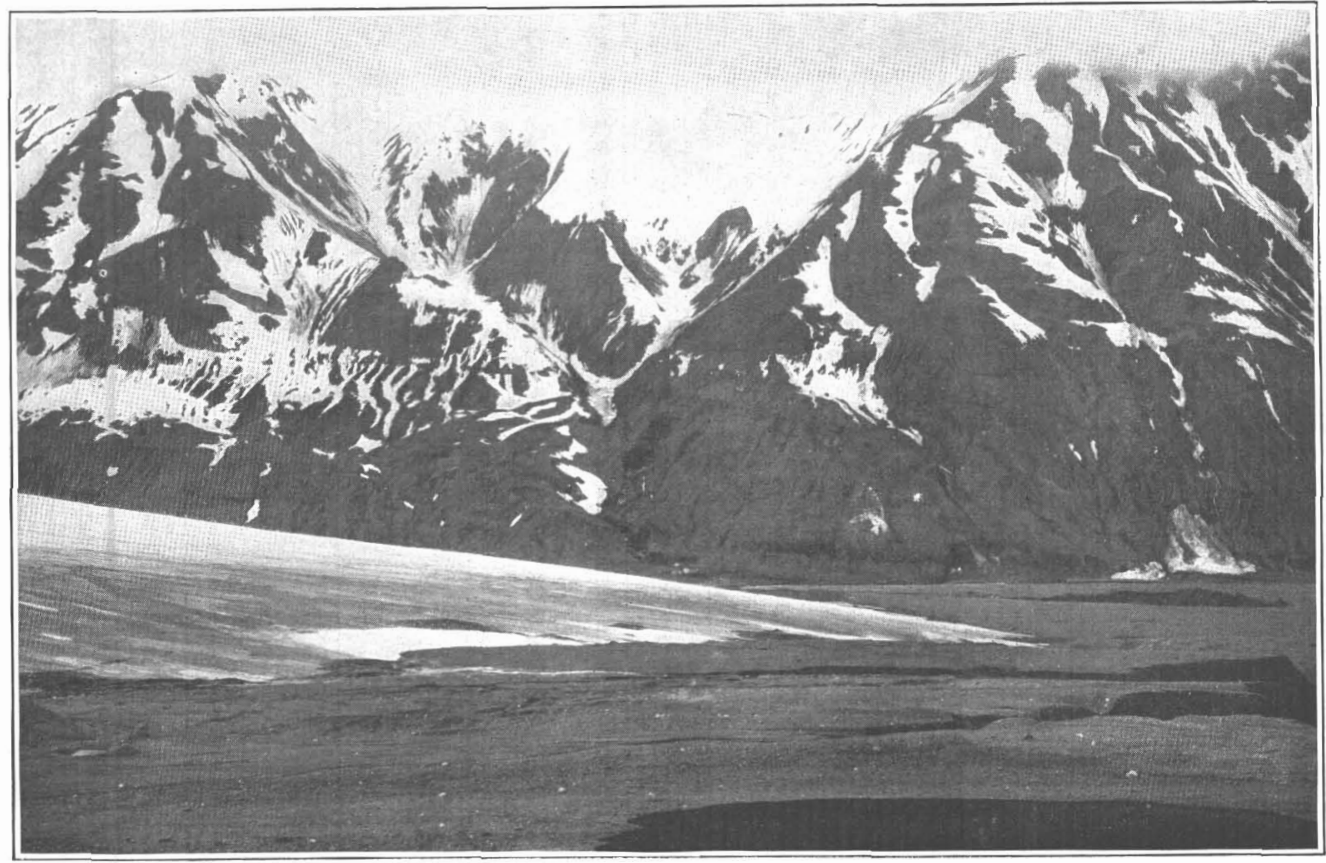

A. END OF HIDDEN GLACIER FRoM GRAVEL TERRACE ON NORTH SIDE OF VALLEY JUNE, 1899.

Photograph by G. K. Gilbert.

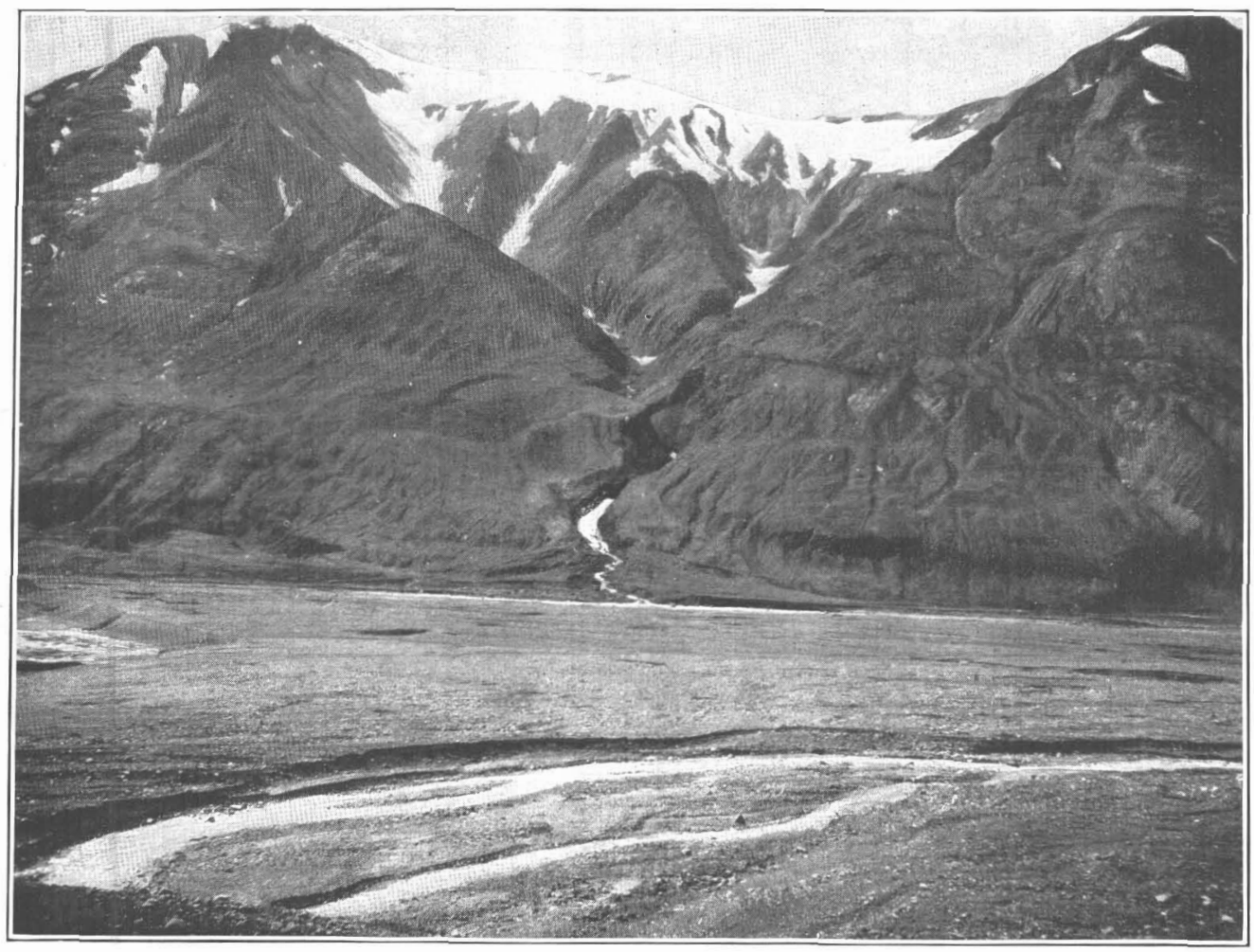

B. END OF hIDDEN GLACIER FROM NEARLY SAME SITE AS PLATE XXI, $A$, JULY 26, 1905. Note pronounced recession. Northern stream in foreground, hanging valley on south side of valley, glacier end just to left of fosse, and gravel plain in front on site of glacier end in 1899 . 

RECENT RECESSION.

A comparison of the photographs and maps made by the Harriman expedition of 1899 with the condition in 1905 shows that there have been material changes in the front of Hidden Glacier in six years. (Cf. Pl. XXI, $A$ and $B$.) There is a more marked development of the lateral moraine on the south side, but whether this is due entirely to the difference in season (my visit being made July 25 to 30 and Gilbert's on June 20), or whether it may be partly assigned to recession, is not clear.

The outline of the front is also distinctly changed. Gannett's map (fig. 6) shows the snout of the glacier close to the southern wall of the valley, but at the time of my visit it was not far from the middle (fig. 7). His map represents a stream issuing from the north side of the glacier, and none from the south side. A photograph by Brabazon, of the Canadian Boundary. Survey, who made the excellent maps of this region, shows this stream in the same position in 1895, near the north wall, with no noticeable drainage on the south side of the valley; his map represents the same condition of drainage. But in 1905, although the northern stream still flowed, a large stream emerged from the south side, with a volume several times as great as that from the north, being, in fact, an impassable glacial torrent. The point of emergence was an ice cave in a pronounced indentation in the ice front close by the medial moraine ( $\mathrm{Pl} . \mathrm{XX}, C$ ).

In addition to these changes along the ice front there has been a pronounced general recession. The Gilbert photographic sites were approximately located, and from them the evidence both of change in outline of the ice front and of notable recession is clear. The snout of Hidden Glacier has receded more than a quarter of a mile (PI. XXI, $A$ and $B$ ), and its 1899 site is now occupied by an extension of the outwash gravel plain.

Seal Bay was revisited by the Survey party in 1906 and the glacier viewed from a distance. There had been no pronounced change in its form or condition during the year.

\section{GLACIAL STREAMS.}

On emerging from the ice, the stream on the northern side of the valley enters a pronounced gorge cut in the older gravel terraces, and, escaping from it, flows over an alluvial fan which grades down into the outwash plain.

The far greater stream on the southern side pours out from a large tunnel ( $\mathrm{Pl} . \mathrm{XX}, C)$, at the head of an ice embayment having precipitous walls, and flows with great velocity down to the sea. It is clouded with sediment and drags along its bed both pebbles and bowlders, the noise of whose movement is plainly audible above the roar of the torrent. Like some of the other large glacial streams of the region, it carries so much sediment as to be yellowish rather than milky in color. The stream hugs the southern wall of the valley, branching only slightly until near its terminus, where it subdivides into numerous distributaries. Like other glacial streams entering the Yakutat Bay inlet, it discolors the waters of the bay for some distance off shore.

The northern stream branches much more freely, and long before the sea is reached its distributaries are scattered over a large part of the outwash plain. It was clear, however, that both streams had varied their positions even during the season of 1905 . The surface of the outwash plain is crossed by an intricate series of anastomosing stream courses, many of which were dry at the time of our visit. These streams have built up the remarkable outwash gravel plain in front of Hidden Glacier, which is still in progress of rapid growth, both upward and outward (fig. 8).

THE FOSSE.

The gravel plain does not begin exactly at the ice margin, but is separated from it by a valley or fosse about 20 yards wide (Pl. XXII, $B$ ), with the glacier front, rising at an angle of about $15^{\circ}$, for one wall, and with a gravel-veneered ice cliff about 20 feet high, with an angle of slope of somewhat more than $30^{\circ}$, for the other. That this western wall of the fosse is ice, veneered with gravel, is proved by the presence of a number of caves with vertical ice sides, into which 
the drainage of the ditch escapes. During our visit the fosse was partly occupied by a very shallow lake and partly by branching streams, but shore-line terraces along the west wall of the fosse clearly proved that a lake 5 or 6 feet higher had occupied this depression during the season of 1905. Ice, veneered with gravel, forms the floor of the fosse, and therefore the apparent terminus of the glacier is not the real end; the ice extends continuously into and under the outwash gravel plain.

At either end of the fosse, but notably at the south end, there is a very irregular kamemoraine mass whose form is due to the melting out of ice beneath a thin gravel veneer. The present form is primarily that of the underlying, irregularly melted ice, which in most places we could readily reach with our ice axes, and which was visible in numerous cliffs. The gravel was constantly sliding.

The explanation of the fosse and its kamelike termini is believed to be as follows: In the spring the snout of Hidden Glacier reached to or beyond the crest of the western wall of the fosse,

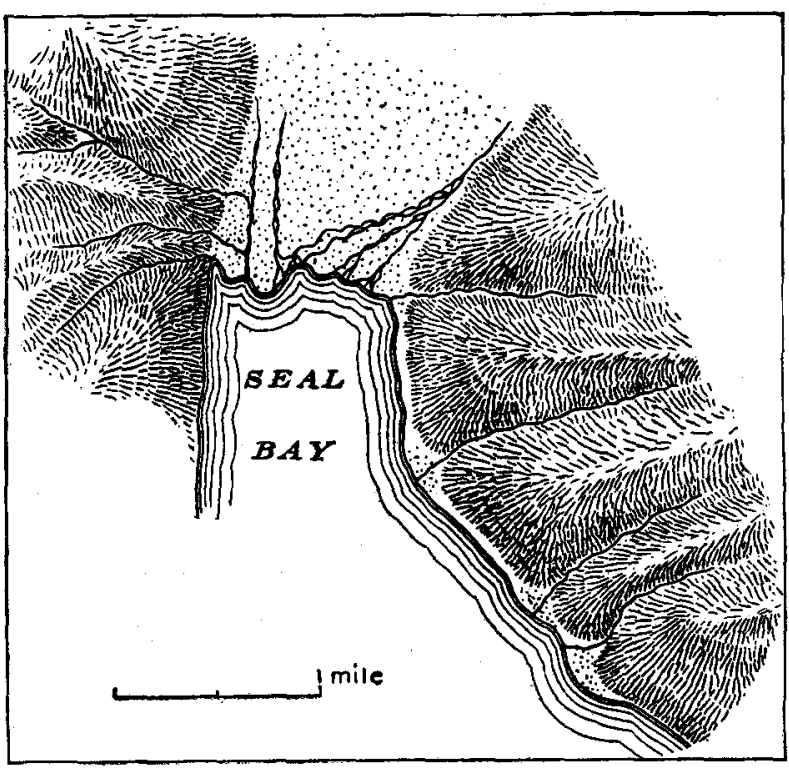

FIGURE 8.--Map of outer portion of outwash gravel plain, Hidden Glacier, showing position of delta margin in July, 1905. From plane-table survey by B. S. Butler. rising from that point with the normal slope of the glacier front. With the first melting of the snows that covered the end of the glacier and the contiguous gravel terrace, alluvial fan building streams, some of them from the ice, deposited gravels upon the end of the glacier, thus protecting it from rapid melting. When these streams diminished in volume and the gravel deposit ceased, there existed a continuous ice slope, the lower part of which was covered with gravel. Ablation, proceeding much more rapidly on the clear ice portion and working with especial rapidity on the westward-facing glacier, developed a fosse, or valley, between the clear and the gravel-veneered ice. In this depression water naturally gathered, forming a lake which was ultimately drained by the development of ice tunnels beneath the outwash gravels. The thinner gravel deposits at the ends have not protected the ice there as thoroughly as have the thicker deposits near the fosse, and consequently, by its more rapid melting, slumping has given rise to the kame-moraine topography. If, now, without a repetition of this process, the glacier should rapidly recede, there would be developed here, as the stagnant ice beneath the gravels melted, a crescentic kame-moraine area with its steep face toward the glacier. Beyond this would be a fairly level pitted outwash gravel plain. Such a condition is not uncommonly present among Pleistocene deposits.

\section{OUTWASH GRAVEL PLAIN.}

Between the fosse and the sea the outwash gravel plain occupies the entire valley floor (Pl. XXII, $A$ ), being built up on the south side to the base of the mountain wall, and on the north side to the gravel terraces which exist in the upper $1 \frac{1}{2}$ miles of the valley, and to the very mountain base in the lower three-quarters of a mile. This plain, made of fairly well-rounded gravels, has many abandoned channel ways upon it, some with banks 30 or 40 feet apart and 5 to 10 feet in height, formerly occupied by large streams. The plain is almost barren of vegetation, even individual annual plants occurring in only a few places, proving that it is being built up so rapidly that plants can not find a foothold. 


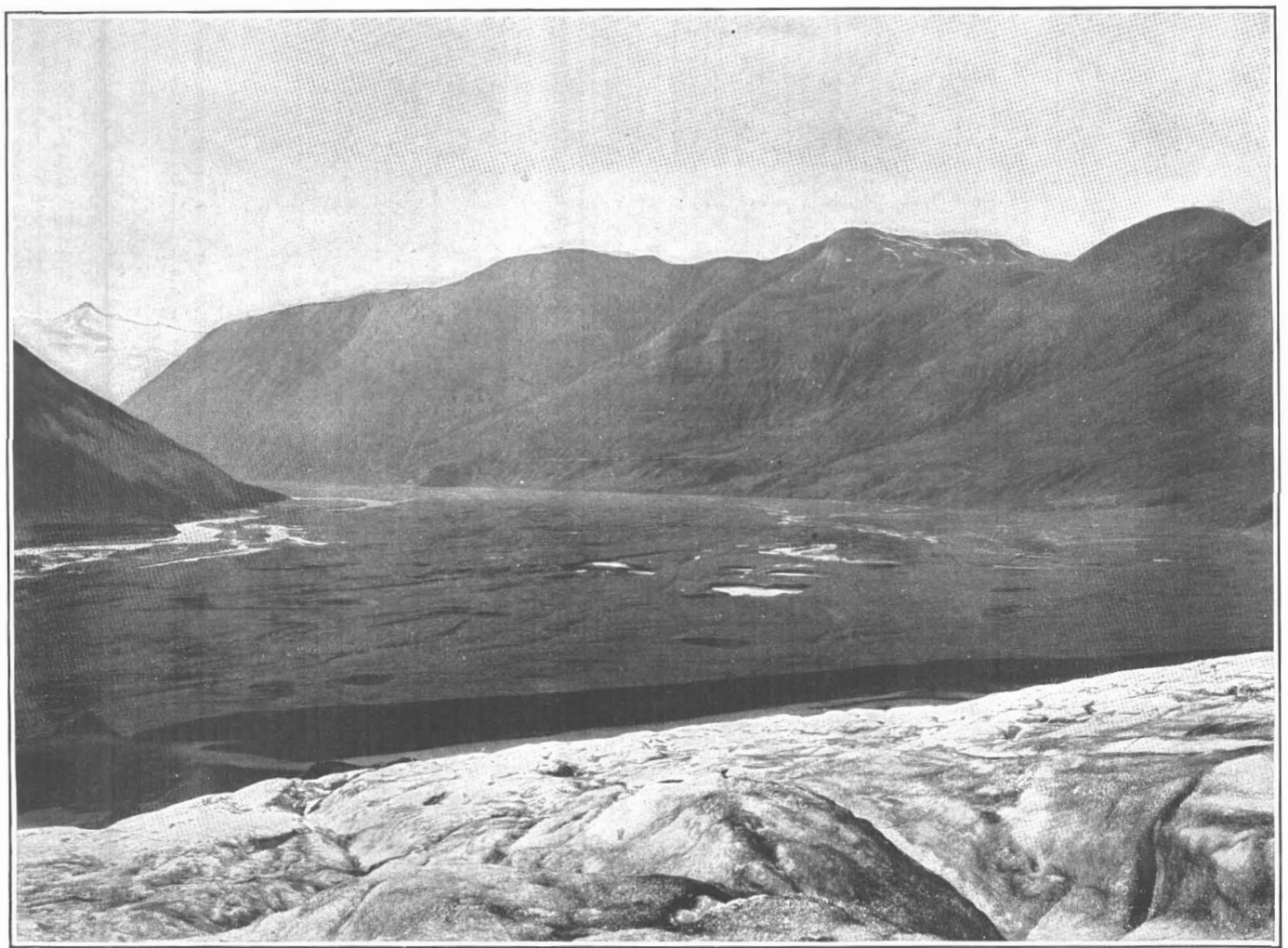

A. VIEW LOOKING WEST FROM HIDDEN GLACIER, SHOWING THE FOSSE AND THE PITTED PLAIN.

Large stream on south side also appears. Photograph taken July $26,1905$.

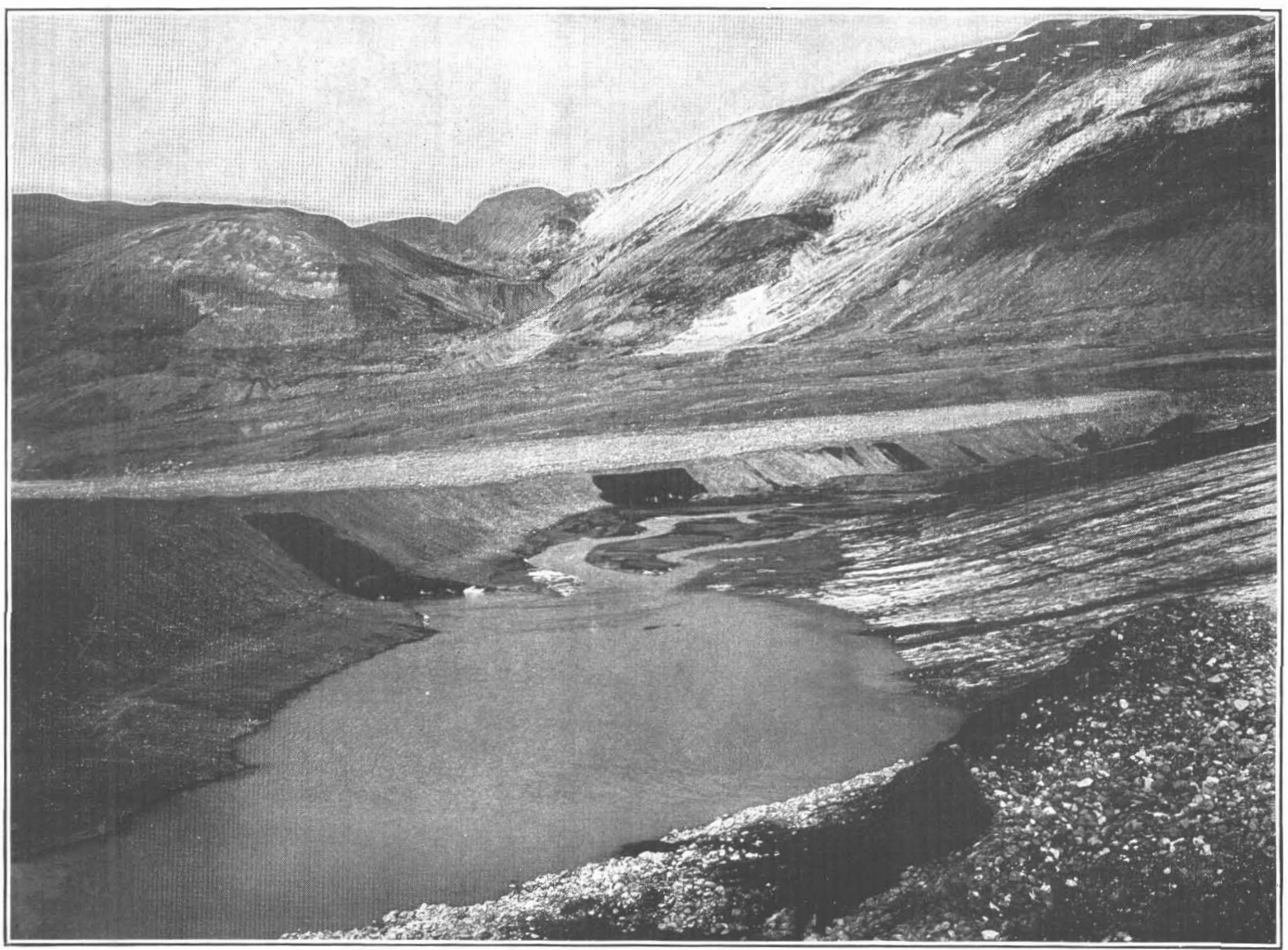

B. VIEW LOOKING NORTH ALONG THE FOSSE.

Hidden Glacier on right; low gravel-veneered ice cliff on left, with several caves through which drainage escapes. The glacier is continuous across the fosse to the cliff. Overridden gravel terraces in background at mountain base. Photograph taken July 26, 1905. 

The most notable feature of this gravel plain is its pitted surface. ${ }^{a}$ For a distance of more than a mile from the fosse the surface is pitted with abundant kettles (Pl. XXII, $A$ ) whose diameters vary greatly. The dimensions of a number of the larger kettles were measured; one was 65 feet across, but it formed part of a linear group of connected kettles whose total diameter was 95 feet (Pl. XXIII, $A$ ). The largest seen was 250 feet in length by 50 in width, and from this the size varies down to shallow pits a few feet in diameter $(\mathrm{Pl}$. XX, $D$ ). The depth varies from a foot or two up to 15 or 18 feet. Many of the kettles are dry, especially the shallow ones, but a large number contain pools of clear, cold, deep-blue water, the greatest depth measured being 10 feet. The color of the water contrasts strikingly with the muddy water of the near-by glacial streams. Some of the kettles have shallow water and muddy bottoms, and in some the water has only recently disappeared, leaving a muddy floor. The water in the larger kettles is flowing and streams emerge from them. A number of the smaller streams on the outwash gravel plain derive their supply wholly from the melting of the ice beneath the plain, and these are clear, quite in contrast to those derived from the glacier. No attempt was made to count the kettles, but it was estimated that there were more than a hundred good-sized pits in an area of about a square mile.

Proof is conclusive that these kettles were developing at the time of our visit, and that their development is due to the melting out of ice from beneath the plain, although in no case was ice actually seen. The great volume and the coldness of the water emerging from the gravels demonstrate the presence of ice at its source. The steep slopes and the constant downsliding of the stratified gravels on the sides of the kettles, together with the presence of much marginal faulting, due to the slumping and inslipping of the gravels, are still further proof of ice beneath. If the kettles had not been forming during the season of 1905 it is certain that they would have been partly destroyed by the erosion and deposition of the braided streams, which are building. up the plain at such a rate as to keep the gravels barren of vegetation. A few of the kettles had, in fact, received sand and silt deposit by recent overflow, probably during the season of 1905; and faulting of these sediments shows continuation of the settling since their deposit. The fact that, notwithstanding the numerous deep kettles, no ice was seen, clearly proves that the protecting deposit is thick.

That for at least a part of the distance this buried ice is directly continuous with Hidden Glacier is proved by the extension of the ice out under the western wall of the fosse. The abundance of kettles throughout the area, for at least a mile from the ice front, leaves no reason to doubt that most if not all of the buried ice is also actually continuous with the glacier; and it is noteworthy that the portion within a quarter of a mile of the present glacier front was occupied by the terminus of the glacier when seen by Gilbert in 1899 (Pl.XXI). There is a continuous diminution in size of kettles and amount of slumping for about a mile out from the ice front.

The continuity of the buried ice with the glacier makes it certain that the terminus of Hidden Glacier is not at present in active movement, for if it were its thrust would of necessity disturb the gravels resting on it. Even at the very edge of the fosse the gravel shows no sign whatever of faulting, with the exception of that due to subsidence. This indicates that Hidden Glacier is a dying glacier, whose continued recession may be looked upon as a probability.

If the glacier should entirely disappear from the valley, it would leave below the fosse a level gravel plain with well-defined stream channels upon it and with numerous kettles of varying size, a condition well known among Pleistocene deposits of eastern United States. The stream channels would head in the air, there being no visible source of supply for them after the glacier had melted away. The steep walls of the kettles would disappear by crumbling, and the smaller , kettles would become partly filled by the sliding down of the sides; in fact, this change is all the time in progress, even during the formation of the kettles, and some of the smaller ones are partly filled.

It is obvious that, so long as ice is present up the valley, supplying aggrading streams with sediment, no great and permanent development of kettles may be expected, for the anastomosing streams will fill up irregularities nearly as fast as they are formed. Once these alluviating

a Gilbert, G. K., Glaciers and glaciation, Harriman Alaska Expedition, vol. 3, 1904, p. 54. 
streams are gone, however, the kettles and pits that are formed as the foundation ice slumps will remain and grow in size. Applying this principle to Pleistocene outwash gravel plains, it is evident that, even with a foundation of ice, permanent kettle development need not necessarily follow the melting out of the buried ice.

\section{OVERRIDDEN GRAVELS.}

The ice-eroded slopes of the Hidden Glacier Valley are, on the whole, too steep for moraine and gravel accumulation (Pls. XX, $B$; XXI; XXII, $A$ ); but on the north side, for a distance of about $1 \frac{1}{2}$ miles below the glacier front, the mountain base is faced by gravel deposits up to an elevation of 200 or 300 feet above the outwash plain (Pl. XXIII, $A$ ). These gravels are in the form of a series of indistinct terraces descending gently westward. They are cut by a number of streams, revealing well-stratified deposits, inclosing fragments of trees. The nature and origin of these terraces are considered in a later chapter, which deals with similar deposits found elsewhere in the Yakutat Bay Inlet. (See p. 125.)

Near its northern margin the glacier rests directly upon these gravels (PI. XXIII, B). The grade of the glacier surface is from $10^{\circ}$ to $15^{\circ}$ westward, while the gravel surface slopes southeastward, toward the axis of the valley, at an angle of about $5^{\circ}$. This double slope causes the ice to wedge out into a thin edge. That the glacier is overriding these gravels was plainly visible in the field, and may be seen in the illustration (Pl. XXIII, $B$ ); and that it is also eroding them is evident from the smooth surface and the broadly truncated gravel strata. That the ice erosion is faster in the middle of the valley than on the sides is indicated by the dip of the overridden gravel surface toward the valley axis.

That this overriding has formerly extended down the valley is proved by the smooth, rounded, ice-sculptured surface of the terraces (Pls. XXII, $B ; \mathrm{XXIII,} A$ ) and by the presence of a thin veneer of till and glacially transported bowlders ${ }^{a}$ on the gravels. Evidence associated with the extensive gravel deposits in the main Russell Fiord indicates that a recent extension of Hidden Glacier led to its coalescence with a Russell Fiord glacier. It is noteworthy that even with such marked extension of the glaciers ice erosion was incompetent to completely remove the gravel deposits from the Hidden Glacier valley. The significance of this is considered later. (See p. 127.)

Below the point where the edge of the glacier overrides the gravels a stagnant, morainecovered ice mass rests on the overridden gravels. It is the unconsumed northern edge of the glacier, protected from rapid melting by its lateral moraine cover. This stagnant ice remnant, which projects about one-eighth of a mile from the main glacier, clearly illustrates the difference in rate of melting of moraine-covered and clear ice. Near the glacier, where ice appears at numerous points in the moraine, it has a remarkably perfect kame topography, with differences in elevation of fully 50 feet between kettle bottoms and hummock tops. Near its western or outer end it is much lower and no ice is visible; but the kame topography is still pronounced, and there are small lakelets in the kettles. When the ice is completely melted out from beneath this lateral moraine it will undoubtedly still retain a kame topography, though with much less pronounced irregularities; and the kamelike lateral moraine will then rest directly on ice-eroded gravels of earlier age.

The front of Hidden Glacier thus presents two very interesting phenomena of opposite types. In the first place, the glacier margin is resting on gravels, formed during an earlier period, which later glacial erosion has been unable to remove completely. In the second place, the glacier terminus, near the middle of the valley, is buried beneath gravels of modern date, which are still encroaching on the receding ice front.

a This point was made by Gilbert (Glaciers and glaclation: Harriman Alaska Expedition, vol. 3, 1904, p. 58), who detected the overriding without the aid of the clear proof furnished by the ice visibly resting on the gravels. 


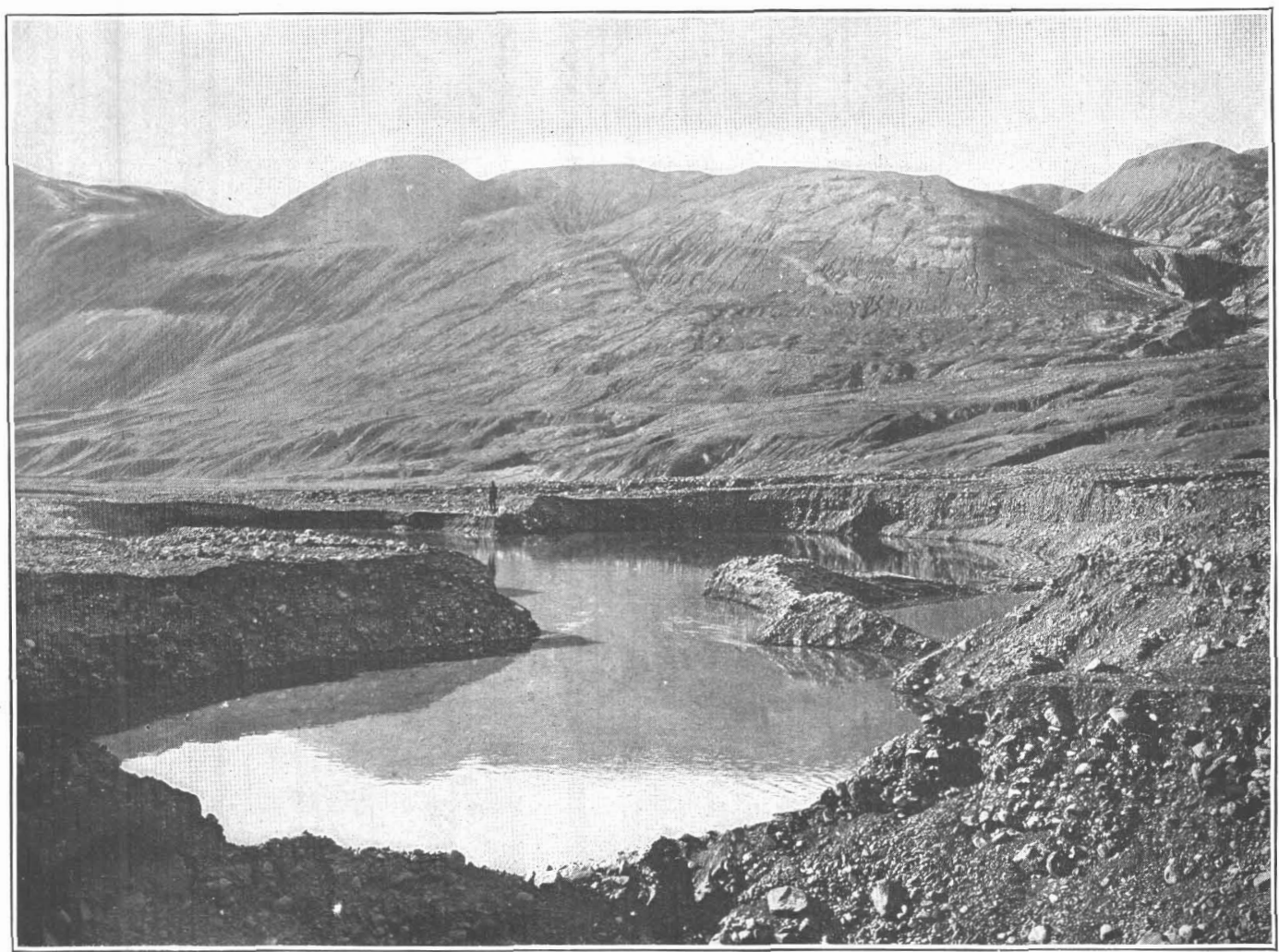

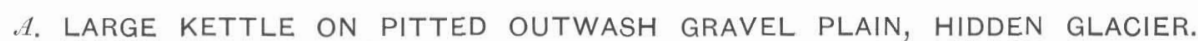

This kettle lies 300 yards from front of glacier at a point where the glacier stood in 1899 . Note overridden older gravels at mountain base. Photograph taken July 25, 1905.

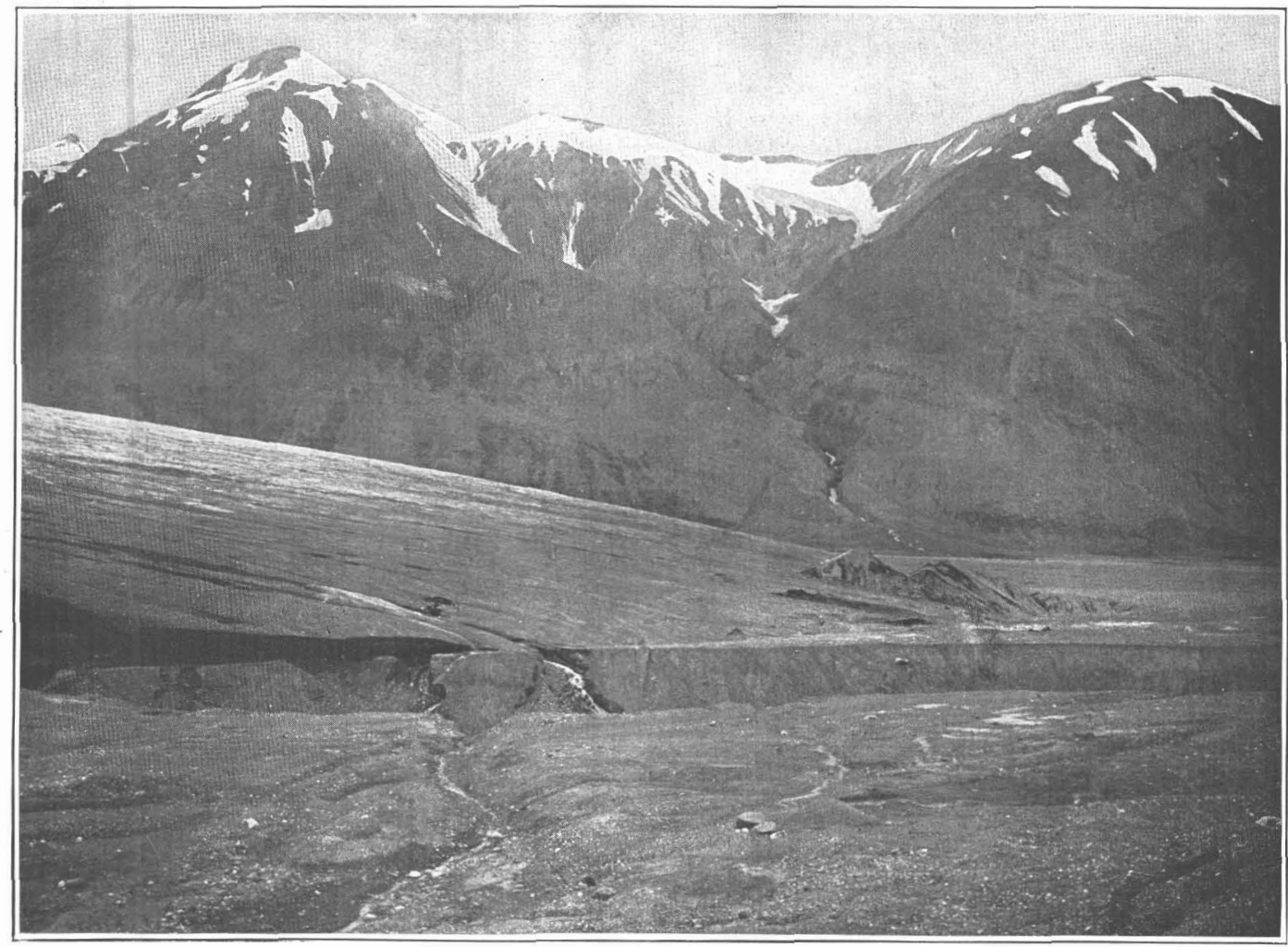

B. NORTH EDGE OF HIDDEN GLACIER RESTING ON OLDER ICE-ERODED GRAVELS.

The gash in the foreground is formed by a stream from the ice. Photograph taken July 25, 1905. 



\section{MINOR GLACIERS OF THE PENINSUIAA.}

Small glaciers exist at the heads of all the larger valleys of the peninsula between Yakutat Bay and Russell Fiord, for the mountains forming the central axis of the peninsula rise well above the snow line. I am not able to state how many of these minor glaciers there are, though, including the small cirque glaciers, there must be several score. The Survey party noted upward of fifty which were not previously mapped. A detailed description of one of these may serve, in general features, for all.

\section{DETAILED DESCRIPTIONS.}

Latouche Glacier.-Latouche Glacier lies in a small valley south of Latouche Point. Its lower end is hidden by a great avalanche which completely covers the ice and moraine, except at the very sides of the valley. A small glacier stream, not heavily charged with rock flour, emerges from below the avalanche, flows down the valley, and enters the sea near the Indian summer camp. That this glacier is receding is proved by the fact that for a distance of a quarter of a mile below its terminus there is a bare moraine with only scattered annual plants upon it, and the valley sides above the glacier are also bare of vegetation for some distance.

Back of the avalanche, and probably because of it, the glacier has developed a new front with an angle of slope of $17^{\circ}$. The foot of this front is 1,000 feet above tide, or about 150 feet above the point of emergence of the stream just mentioned.

Less than a quarter of a mile back from the new front the glacier receives from the north a small tributary which supplies a faint medial moraine. Very few crevasses appear, and there is little surface moraine, merely a small, low, medial moraine and two narrow lateral moraines with scattered fragments between. The glacier surface rises in a series of steps or undulations, some having a slope as great as $25^{\circ}$. Apparently, when a little thinner, this glacier will develop into a cascading glacier. On August 12 the snow line in the middle of the glacier, with a shaded northwestern exposure, was at an elevation of 1,850 feet. The glacier heads in a low divide at an elevation of 2,420 feet, with steep mountains rising to no great height on either side. There is no extensive snow field, and no glacier is developed on the opposite side of the divide because this slope is exposed to the full effect of the noonday sun.

The stream which flows from the terminus of this glacier has cut a narrow rock gorge from 100 to 200 feet wide and more than 50 feet deep. Below this the stream flows through morainic materials with its bed encumbered by many bowlders; farther down it is building an outwash gravel plain. Its valley is evidently hanging in relation both to the main Disenchantment Bay valley and to the larger Indian Camp valley, which lies just north of it.

Henry Glacier.-The broad, U-shaped, glaciated valley just south of Haenke Island (Pls. II, XXIX, B) receives a number of hanging tributaries, in each of which a small glacier ends well back from the lip. The heavily laden streams which flow out from these glaciers have cut shallow gorges in the steepened valley slope and have piled their coarser sediment in extensive alluvial fans on the margin of the flat-bottomed main valley.

Henry Glacier ${ }^{a}$ is formed at the head of the valley by the union of two large branches, which head upon low divides from which glaciers also descend southeastward toward Russell Fiord, giving rise to a through-glacier condition. The end of this glacier is completely covered with moraine, which causes the surface to rise in irregular hummocks with intervening kettles. There is a well-defined medial moraine, also lateral moraines, which, by their protection to the ice, cause the surface to rise in pronounced ridges.

The entire valley shows clear signs of former occupation by a large glacier, the walls being profoundly ice sculptured to a broad $U$ shape and breached by excellent types of hanging valleys (Pl. XXX, $A, B)$. It is believed that at the highest stand of the Yakutat Bay Glacier

$a$ Named after our efficient Indian guide, T. J. Henry. 
the ice streamed through this valley from Disenchantment Bay to Russell Fiord, and that the glacier was later given independent existence, receiving tributaries from the numerous valleys left hanging by the pronounced ice erosion. A stage in the recession of this independent glacier is clearly shown by a prominent crescentic moraine ridge across the valley about $1 \frac{1}{2}$ miles from the sea. An area barren of vegetation immediately in front of the glacier proves recent recession.

The outwash gravels from Henry Glacier and from the glaciers in the hanging tributary valleys have built up a flat floor for the main valley, over which the glacial stream flows in a braided course; but where it crosses the moraine it occupies a single channel in a rather pronounced canyon, in which rock is revealed beneath the moraine. Below this, clear to the fiord, the flat valley floor is covered by an outwash gravel plain which is:advancing seaward as a delta.

Alexander Glacier.-A group of small glaciers radiate from the highlands near Mounts McCarty and Alexander. The largest of these is Alexander Glacier, ${ }^{a}$ which extends northward, and whose recent recession is proved by a barren zone in front. This glacier heads on a broad, U-shaped divide leveled up with and deeply buried beneath snow, from which a glacier also descends into the valley south of Cape Enchantment. The terminus of Alexander Glacier is about 600 feet above the fiord and is moraine covered in its lower portion. A smaller glacier, just south of this, also heads in a snow divide with a glacier descending in both directions, the divide in this case being 2,700 feet above the fiord.

Glaciers on east side of Russell Fiord.-South of Cape Enchantment there are a number of glaciers in broad, U-shaped valleys which hang above the fiord. Most of these glaciers head in flat snow divides and receive small tributaries from the steep inclosing mountains. Almost all of them are covered with broad fields of irregular, hummocky morainic débris and are nearly stagnant in the lower portions. Two or three descend to within less than a mile of the sea, and all are rapidly wasting. In front of the moraine-covered termini stagnant patches of ice are occasionally found completely separated from the main glacier. This is especially noticeable on the valley margins, where either exceptionally heavy lateral moraines or avalanche falls have protected the ice from melting.

Below these moraines is a broad zone in which at present there is little vegetation. Nearest the ice even annual plants are very scattered, and farther away young willows and alders begin to appear. Evidently these glaciers have very recently been much more expanded than now, and pronounced recession is still in progress. In the second glacier south of Cape Enchantment there is evidence of more recent recession than is found in those farther south. The sparse flora at the mouth of this valley indicates that at no very remote period its glacier extended to the fiord, probably uniting with the expanded Nunatak Glacier. The stagnant northern lateral margin of the terminus of this glacier rests upon an ice-eroded gravel deposit at a distance of considerably less than a mile from the sea.

\section{DÉBRIS-COVERED ENDS.}

The extent of the débris-covered areas in these small valley glaciers is often very great, the ice being covered from side to side and from the terminus nearly to the head of the valley. In this respect these glaciers are in harmony with the Lucia, Atrevida, Galiano, Black, Variegated, and many other glaciers in the Yakutat region. It is, in fact, generally true of the glaciers ending on the land in this region that their termini are moraine covered and that they have recently retreated perceptibly and are still (1905) wasting. The chief exception to this statement is Hidden Glacier, whose visible lower end is not moraine covered. It is a notable fact that in all these areas of moraine-covered stagnant ice no extensive superglacial streams were found, with the single exception of the glacial stream which flows over the lower portion of Variegated Glacier in the interior flat. 
POSSIBLE GLACIER-FLOOD REMNANTS.

In numerous places glacier ice is present at levels above 2,000 feet where there seems to be neither source of supply nor evidence of present movement. This ice sometimes exists as terraces on north-facing mountain ledges, and even in August was covered with snow. In seeking for an explanation of these peculiar isolated masses of glacier ice we have been led to interpret: them as remnants of the former ice-flood stage. At or just above the snow line ablation would proceed at such an exceedingly slow rate that glacier remnants might be expected to linger long after the disappearance of the ice at lower levels. Of necessity there would be a level where the snow supply and melting would be in exact balance, and some of the ice patches on the peninsula have the appearance of being glacier remnants in such situations.

\section{FALLEN GLACIER.}

On the western wall of Disenchantment Bay, between Black and Turner glaciers, three small glaciers were perched in short, steep hanging valleys. Their slope was so steep and they had such an appearance of instability that they attracted particular attention. The southernmost of these was estimated to have a length of approximately a mile, its chief supply coming from a steep mountain crest from which the snow slides into a cirquelike amphitheater about halfway down the slope. The glacier was photographed from the crest of Haenke Island by Russell in 1890; by Brabazon, of the Canadian Boundary Commission, in 1895; and by Gilbert in 1899. Attracted by the steep inclination of the three perched glaciers, the Survey party photographed this mountain side from the bay on July 3, 1905, which happened to be the last day in the life of the southernmost of the three.

This glacier, which I will call Fallen Glacier, lay for the most part in a cirquelike amphitheater with steeply rising mountain walls at its head. The amphitheater has a narrow mouth, out of which the crevassed terminus of the glacier protruded, the lower end terminating at an elevation of about 1,000 feet above the fiord, from which it was separated by an ice-steepened rock slope. Aside from its apparently instable position, there was so little to attract special attention to this glacier that no detailed observations were made on it.

A moderate rain fell during the night of July 3 and continued during July 4. On the latter day, when working in Russell Fiord, about 15 miles from Fallen Glacier, I was surprised by the appearance of a series of waves far too pronounced and lasting far too long a time to be ascribed to iceberg origin. The water rose and fell from 15 to 20 feet, and the disturbance lasted for fully half an hour. At the time I could think only of earthquake origin for the waves, but the next day one of the Indian guides, returning from Yakutat, reported the falling of a glacier in Disenchantment Bay. Later in the season, returning to the west side of Disenchantment Bay, it was found that the glacier which had fallen was the southernmost of the three small glaciers described above.

The valley was almost completely emptied of ice, there remaining only a mere remnant of the steeply perched névé area and some minor ice fragments near the edge of the cirque. The entire glacier had evidently shot out of its valley, tumbled a thousand feet down the steep slope, and entered the fiord, generating a series of pronounced waves. The walls and bottom of the cirque were bare of ice and distinct evidence of the avalanche was present on the sides of the narrow throat of the amphitheater out of which the glacier shot. Emerging from this throat the avalanche had spread out fan shaped, sweeping all soil away, and near the fiord killing the alders over an area half a mile in width. Since the fiord is evidently deep at this point, only a small remnant of the avalanche was visible at the time of visit, most of the ice having floated away and the débris sunk to the bottom. The coast was pushed out slightly, with a new shore line of angular rock débris, beneath which ice evidently remained, since in places the surface was freshly faulted by slumping.

The water wave generated by this avalanche was of great height near its source. A half mile south of Fallen Glacier the wave rose 110 feet, breaking off alder bushes at that height. Three miles north of it, near Turner Glacier, vegetation was killed by the wave to a height of 
65 feet. About an equal distance, on Haenke Island, the wave swept to a height of 50 or 60 feet on the north end, and 115 feet on the northwest end of the island, washing out good-sized alders at that level; but the latter unusual elevation was due to an especially favorable topography which developed high breakers.

Besides breaking off and uprooting bushes, the waves did much erosion wherever they came in contact with unconsolidated materials, cutting small cliffs and gullies in the till and alluvial fans. A mile northeast of Haenke Island, near the point whence the glacier had been photographed on the day before its fall, the waves gullied the till and uprooted bushes to an elevation of 30 feet. In addition, annual plants were uniformly killed, up to the height reached by the water wave, as a result of the salt bath which their roots received. The height reached by the wave could almost everywhere be seen by the zone of parched brown grass and other vegetation. Small icebergs were also left stranded above high tide in several places.

The Indians stated that this was the third time the glacier had fallen; but on questioning them it was evident that the tradition merely referred to a glacier falling from the west side of the bay, and not specifically to this one. The last fall, which is said to have occurred about sixty years ago, is reported to have destroyed a hundred Indians who at the time of the fall were at, the summer sealing camp a few miles south of Haenke Island. It is said that only one of the Indians in the camp was saved. It is fortunate that in 1905 the Indians had left the bay before the glacier fell, for it is hardly conceivable that their canoes could have lived in the floating ice during the passage of such waves as this glacier avalanche generated in their sealing ground.

\section{BLACK GLACIER.}

Black Glacier occupies a short, broad southward-facing valley on the west side of Disenchantment Bay near its entrance, and a short distance below Fallen Glacier. Its lower end is nearly flush with the mountain wall, and from that point far up its valley it is covered with a veneer of fragments of black shale of the Yakutat group which give it the dark color that suggested the name Russell applied to it. ${ }^{a}$

CONDITION IN 1890 AND 1905.

In his description Russell states ${ }^{b}$ that for a height of 200 to 300 feet the valley walls are bare of vegetation, indicating recent shrinking. He photographed this glacier in 1890, and when in 1905 the Survey party visited the approximate site of his picture I was unable to detect any notable difference in its appearance. Its face was still about a mile from the sea, and its front extended only a few score of yards beyond the end of the mountain valley, without expanding. The glacial stream still emerged from an ice cliff near the western margin, and the alluvial fan still spread out between the inclosing forests of cottonwood. On this alluvial fan the glacial stream has not only shifted its position but has sunk a trench to a depth of 10 or 15 feet, this being made possible by the rejuvenation resulting from the uplift of the land accompanying the earthquake of 1899 .

A close examination shows some differences in the ice front, indicating a moderate recession and a slight lowering of the surface; but the retreat is of very minor importance. The mountain wall on the southwest side of the valley, however, shows very material change. Large sections of mountain slope which in 1890 supported vegetation are now bare rock; altogether very nearly half a square mile of vegetation-covered surface has been replaced by barren rock. Correlated with this is a visible increase in the size of the talus slopes. It seems hardly probable that this is the result of mere weathering, and I interpret it as one of the effects of the 1899 earthquake shocks, which at this point must have been intense, since one of the fault lines extends along this mountain base, and the near-by shore line was raised 47 feet.

The Black Glacier alluvial fan, which is about a mile in length, reaches an elevation of 250 feet at its apex. The stream that forms it emerges from a cave beneath an ice cliff fully

a Russell, I. C., An expedition to Mount St. Elias, Alaska: Nat. Geog. Mag., vol. 3, 1891, p. 101.

Idem, p. 104 . 
100 feet in height, down which stones are continually rolling. At other points the frontal slope of the glacier varies from $20^{\circ}$ to $50^{\circ}$.

Fringing the steep ice front on both sides of the stream to a distance of about 100 feet is a low, stagnant ice mass veneered with moraine. In its southern portion this stagnant ice rests on a polished, scratched, roche moutonnée surface, and just above the rock the lower layers of the ice are charged with débris, including bowlders fully 20 pounds in weight. Immediately in front of this moraine-veneered ice foot-in fact, within a few feet of it-is an alder growth with bushes ten to fifteen years old. It seems probable that this moraine represents the position of the glacier front during Russell's visit, and the recession in fifteen years, thus indicated, is not more than $\mathbf{1 0 0}$ feet. Two hundred yards farther seaward is a mature cottonwood forest, which appears in Russell's photograph; it is therefore impossible that Black Glacier can have advanced far since his visit.

\section{GENERAL DESCRIPTION.}

The ice cliff, where the stream emerges, shows a definite upbending of layers toward the southern margin of the glacier. Although from top to bottom there are débris-charged layers, the ice is not especially full of débris, and there is no noticeable increase in amount toward the bottom. Where the stream emerges the glacier is resting on rock with a steep stoss slope and a smooth, rounded surface, to which the ice is molded; but just east of this it rests on till, apparently a deposit in the lee of the rock just mentioned.

Back of the precipitous front the ice rises at an angle of about $20^{\circ}$, and in less than half a mile attains an elevation between 700 and 800 feet. In this portion the glacier is a single, rather narrow, débris-covered axial ridge sloping steeply toward both sides of the valley. The southwest slope is so steep, being often $30^{\circ}$ or $35^{\circ}$, that the ice frequently shows in it, and stones loosened by melting roll down to its base. Very little ice is revealed along the center of the ridge, the moraine being so deep that we could at many places thrust our ice axes down their full length without reaching ice. Alders grow almost all over this deep moraine, in places forming small thickets. The largest alder that we cut had thirteen rings of annual growth. The growth of the alders is subject to some disturbance, apparently due to slumping rather than to motion of the ice, for there is no visible crevassing. As a result of this slumping, bushes were occasionally found that had fallen over and died.

The slope of the moraine-covered glacier ridge extends down to the talus which is falling from the precipitous mountain side, thus giving rise to a steep-walled $V$-shaped valley, especially well developed on the southwestern side of the glacier. Although a number of streams descend from the mountain slopes, no visible stream flows along this valley, for all the water sinks into its talus-moraine bottom. The mountain wall is weathering with great rapidity and the immense talus accumulation hides any moraine which may exist.

For a distance of about a mile up from the glacier terminus there is no crevassing in the central ridge, though occasional crevasses appear on its sides. Beyond this, there is a small area of crevassing, and there the alder belt is absent. Above this crevassed area alders again grow, but of smaller size and nowhere in thickets, the age of the largest being estimated at six or seven years. Somewhat over a mile from its end the glacier has an elevation of 1,100 feet and still supports alders. These disappear a short distance above, however, and at the same time the ridge form, and consequently the marginal valley, are gradually lost. At a distance of 2 miles from its terminus, at an elevation of about 1,600 feet, the slope of the glacier flattens to a grade of $7^{\circ}$ to $10^{\circ}$. But the moraine veneer continues, and in fact rock débris covers the glacier from side to side clear to its head, at a distance of 3 miles from the terminus. It is the most completely moraine-covered glacier observed.

Two steeply descending tributaries enter Black Glacier from the precipitous mountain wall at the valley head; another from the southwest joins it near the head; and two enter from the northeast. At the base of the steep mountain walls there are also numerous fan and talus glaciers, as well as large snow patches, which must contribute materially to the supply of ice. This supply is doubtless greatly increased in winter, when the snowfalls must completely fill 
the marginal valleys and allow both snow and rock to be shot out upon the glacier surface. Even in August the snow had not entirely disappeared from the marginal valleys, its presence being proved by the slumping of the talus in the valley bottom.

GLACIAL EROSION.

Like the valley of its neighbor, Galiano Glacier, the Black Glacier valley is remarkable for its $U$ shape, steep sides, steeply-rising upper end, and absence of accordant tributary valleys. Such a valley can hardly be the result of normal stream erosion and weathering. During the time of greater expansion of the glaciers of this region, when the main glaciers reached an elevation of about 2,000 feet, these short valleys, of which the valley of Black Glacier may be considered typical, were necessarily filled with a great depth of ice. At that time these small tributaries must have had decided power of erosion. The greatly steepened valley walls and the absence of tributaries at grade, although there are many well-developed valleys above the zone reached by the ice flood, testify to the vigorous glacial erosion in these troughs.

That the short Black Glacier valley is not more distinctly hanging above Disenchantment Bay seems remarkable, notwithstanding the fact that the rocks in which it is cut are easily worn away. Without doubt it is actually a hanging valley, with the lip near sea level. - This is indicated by the presence of bed rock under the glacier end, but the clearness of the evidence is obscured by the gravel deposits in front of it and by the water of the fiord. The same remarks apply to many other valleys tributary to the Yakutat Bay inlet.

\section{GALIANO GLACIER.}

Looking northward from out on Yakutat Bay one sees into a broad, U-shaped valley of no great length, inclosed at the head as well as the sides by precipitous mountains whose crests and slopes are deeply clothed in snow. The bottom of the valley is occupied by a glacier of fairly steep grade, which extends well beyond the mountain face, where it spreads out in a bulb-shaped ice fan. Its form suggests that of a frying pan, with the handle in the valley and the pan outside the mountain base.

EXPANDED ICE BULB, OR FAN.

The expanded, stagnant, moraine-covered ice bulb outside of the mountain front swings eastward until it reaches to within 100 yards of the sea; but since it does not expand so far in a westerly direction, this ice fan is one sided, being distended eastward. Water is escaping from the entire edge of the fan, though less comes from the eastern than from the western portion. A small stream flows from the east side, and a much larger one emerges from an ice cave on the west side near the entrance to the mountain valley; the latter stream receives numerous minor tributaries on its way to the sea.

The face of the expanded ice fan is everywhere steep, but at no point is ice visible in the very front, though the abundance of water issuing from it, together with the slumping of the moraine, clearly proves that ice is present under the very end. Near the center of the fan ice is revealed beneath the moraine at a distance of less than 100 yards from the front.

Speaking of this glacier, Russell ${ }^{a}$ says:

"Débris-covered ice streams, too small to reach the water, are typical of a large class of glaciers in southern Alaska, which are slowly wasting away and have become buried beneath debris concentrated at the surface by reason of their own melting. The Galiano Glacier is a good example of this class.

As far as could be seen by comparison with Russell's photographs, the ice fan had practically the same shape in 1905 as it had in 1890, and the glacier itself shows no marked change in form.

The steeply rising, moraine-covered ice fan is black with shale of the Yakutat group, though there are light patches and bands of graywacke here and there. Vegetation is almost completely absent, though scattered individuals and clumps of willows, with five or six annual rings, occur on the very face. 
VALLEY PORTION.

The entire expanded foot of the glacier is a moraine-covered desert with ice frequently revealed, but evidently almost if not quite stagnant. For a distance of approximately 2 miles within the mountain-walled valley, also, the glacier is almost completely moraine covered. This valley is about three-quarters of a mile wide, maintaining its great breadth almost uniformly to the head, where the mountain wall rises as precipitously as the valley sides. Rock fragments and landslides are so frequently falling down these steep slopes that during the day the Survey party was on this glacier the sound of landslides was heard every few minutes. At the head of the valley, whose total length is more than 4 miles, there are at least five cascading glaciers, two of them of fair size. They appear to have been essentially the same in 1905 as in 1890; but one large patch of glacier, which in 1890 clung to the precipitous northeast slope, had entirely disappeared, and there was a diminution of both snow and ice in other parts of the valley head.

The Galiano Valley, like the Black Glaciẹr valley, is notable for its great breadth as compared to its length, for its uniformly precipitous sides and head, and for the absence of accordant tributary valleys. It has somewhat the appearance of a greatly deepened and elongated cirque. From the valley mouth to the mountain wall at its head the slope, as indicated by the glacier surface, is fairly uniform and not very steep; but, as already stated, the grade abruptly changes at the valley head, and the trough is terminated by a precipitous mountain wall.

The outer mile of the glacier, within its mountain valley, has the form of a moraine-covered ridge with a deep valley on each side between the ice and the mountain. Above this the glacier becomes slightly more crevassed, the ridge form disappears, and the ice extends up to the valley sides without the presence of an intervening valley. In its middle course the glacier gradually loses its moraine veneer, finally becoming fairly clear of débris. In this part of the glacier the surface has an angle of slope of $12^{\circ}$. Still higher up the ice surface is more irregular, becoming decidedly crevassed near the points where the steeply descending tributaries join it.

AVALANCHES.

The first valley on the western side rises very steeply and at its head holds a glacier whose lower end is at an elevation of about 1,500 feet above sea level. Below it there is much granular ice, but no continuous glacier. Between the terminus of this small glacier and the Galiano there is a bare rock wall from which both soil and bushes have been swept by a recent avalanche, doubtless due to the falling of the lower end of this small glacier. The recency of this fall is indicated by the torn and dead alders still clinging to the rock above the barren zone.

Apparently contemporaneous with this avalanche is a fairly well-developed alluvial fan, half a mile long and a quarter of a mile wide, near the middle of Galiano Glacier, contrasting strikingly, both in form and in materials, with the angular-block moraine which elsewhere covers the ice. This fan was apparently built against the avalanche. Wherever this material comes to rest there will be a mixture of moraine and water-assorted drift.

As pointed out above, a comparison of the conditions in 1905 with those of 1890 , as revealed by Russell's photographs, shows clearly that in the interval there have been other great ice falls in the Galiano Valley.

\section{CHANGES IN THE GLACIER.}

Alder-covered moraine.-Russell, describing Galiano Glacier and vicinity, states ${ }^{a}$ that " $\mathbf{A}$ little way back from the shore, clumps of alders, interspersed with spruce trees, marked the beginning of the forest which covered the hills toward the west and southwest." Near this a" densely wooded hill rose "about 300 feet high, with a curving outline, convex southward." It lay "at the mouth of a steep gorge in the hills" (Galiano Valley). After forcing his way "through the dense thickets," Fussell reached the top of the hill and "found a large kettleshaped depression, the sides of which were solid walls of ice 50 feet high." Continuing toward 
the gorge in the mountains, he forced his "way for nearly a mile through dense thickets" before reaching the "broad open fields of rock and dirt," or morainic desert, which "completely conceal the ice and form a barren, rugged surface, the picture of desolation." $a$ His photographs clearly show the alder thicket on the ice fan and extending well within the mountain valley.

Russell's description and pictures make it clear that in 1890 the entire ice fan, as well as the outer part of the glacier within the mountain valley, was covered with an almost continuous mature alder thicket now entirely destroyed.

In 1905 there was an abundance of dead wood on and near the front of the ice fan, and at two points the dead trunks of the destroyed thicket were seen in place. The clearest case was on the southern face of the fan, near its center, at an elevation of 60 feet. Here several score of trunks of small trees were found in place, the oldest having twenty-five rings of annual growth. At first sight these tree remnants appeared to be turned upside down, for they rapidly increased in size upward; but roots, all pointing downward, grew from the trunks to a height of 3 or 4 feet above the moraine. That the upward expanding tree remnants were not tap roots was proved by the presence of shaggy bark out of which the roots extended. The fact that there were several score of trunks in a limited area, all upright and all showing the same general features, makes it certain that they were actually in place.

Evidently these trees were growing under adverse conditions of soil encroachment, which caused roots to be sent out at higher and higher levels as the lower portions were buried: From 1 to 3 feet above the uppermost roots the trees are terminated with a ragged break, as if torn, and the bent, frayed shreds were almost uniformly turned southward, as if broken by a thrust from the north, which is the direction from which the glacier flows.

Alluvial fan.-Russell's photographs show a broad alluvial fan between the forest-covered ice fan and a low gravel knoll 2 miles or more south of it. This alluvial fan is not now present, and, moreover, no such continuous and extensive fan as his picture clearly shows now exists anywhere between Galiano Glacier and the alluvial fan of Kwik River. Instead of this there are many low, irregular moraine hills and groups of hills strewn with angular bowlders, and the glacial streams from both Galiano and Atrevida glaciers flow in branching courses among these moraine hills, which they have partly submerged beneath alluvial fan deposits. Farther back from the sea, however, on the inner side of the moraine hummocks, toward Atrevida Glacier, Esker Stream has built an extensive and very perfect alluvial fan; but the fan form is lost among the moraine hills nearer the sea, where the surface consists primarily of low moraine hills with small patches of alluvial deposit between, over which the distributaries flow in ever-changing threads.

The moraine which now occupies the site of the old alluvial fan consists of a large number of low, conical hills and some broader patches. These moraines are arranged in roughly concentric bands, extending down to the seashore, with the concave side facing Galiano Glacier. That they extend out into the fiord is indicated not only by the fact that they reach to the shore, but also by the evident shallowness of the water offshore, on which icebergs are stranded at a considerable distance from the beach. There seems little doubt that these moraines are in some way associated with a former and not very remote extension of Galiano Glacier.

Overridden gravels.-Three gravel knolls, remnants of an earlier stratified deposit overridden by the ice, rise well above the level of the moraines. Overriding is proved by the presence of a moraine veneer on these gravels and also by the glacially sculptured surface, the gravel layers being truncated by a series of broad, swinging grooves.

Former forest.-It is noteworthy that at an elevation of 1,280 feet on the glacier surface and far back in the mountain valley a good-sized cottonwood log was found, high above the level at which any cottonwoods are now growing in or near this valley.

Recent changes in the vegetation of this region are indicated by still another line of evidence. Scattered over the moraines is a great abundance of tree trunks and branches, ${ }^{b}$ many

a Russell, I. C., An expedition to Mount St. Elias, Alașka: Nat. Geog. Mag., vol. 3, 1891, pp. 88-89.

$b$ Some of these have evidently been drifted inland by the earthquake waves of 1899; but for others this explanation seems impossible. Even those brought by the earthquake must have been of local origin in a region where no forest now grows near the sea. 
of them badly torn. Only scattered annual plants and young willows and alders are now growing on the moraines, and none of those cut down showed more than five or six annual rings. Yet a mature spruce forest grows on the margin of the Esker Stream alluvial fan just beyond the area of morainic hummocks.

It is evident from these facts that there has been a pronounced change not only in the front of Galiano Glacier but on the flat for a distance of 4 or 5 , miles southwest of it. This change has destroyed an alluvial fan which existed in 1890 and also a forest growth which previously covered a portion of the area. That the forest was destroyed after Russell's visit is further indicated by the fact that only young bushes now grow there. It is inferred, therefore, that the change was contemporaneous with the destruction of the forest on the ice fan of Galiano Glacier.

Underlying ice.-A careful search was made to find definite evidence of the presence of ice in the moraine knolls, but this was unsuccessful. Nevertheless, it is believed that ice still exists there and that the surface is still slumping, though very slightly. In a few places minor cracks in the surface were found, and in a number of places there were shallow kettles, in the bottom of which clay had not yet accumulated, although within reach of the flood stage of the fan-building streams.

More important than either of these evidences, however, was the presence of a great number of cool, clear springs in the low moraine areas. The amount of water oozing from the morainic soil and the frequency of springs are altogether out of proportion to what would be expected from the normal seepage of rainfall in a low moraine of this character. Nowhere else in the region was such a condition found except where there were other reasons for suspecting the presence of buried melting ice.

Interpretation of phenomena.-The phenomena outlined above puzzled us greatly in $1905 .^{a}$ It was perfectly evident that there had been a remarkable and pronounced change since Russell's visit in 1890, and that this change was unquestionably local, for Black Glacier presented no evidence of marked variation, and the ice fans of the neighboring Lucia and (in 1905) Atrevida glaciers still possessed their forests. Both these facts, together with the concentric character of the moraine, crescentic toward Galiano Glacier, pointed to a change associated with that glacier; and this conclusion was further supported by the unquestioned destruction of the forest which in 1890 covered the ice fan of Galiano Glacier.

At the time of Russell's visit the glacier terminus was in a state of stagnation which had been of such duration as to permit the growth of a dense alder thicket and in places a forest on the moraine-covered ice fan. That this was a mature growth was proved by the size of the broken trunks found in place and by the large recumbent logs on the face of the ice fan. In one of these logs, near the eastern end of the ice fan, seventy-five rings were counted. This period of quiet had also permitted a perfect development of the Esker Stream alluvial fan above the moraine and of a lower fan both of this creek and of the Galiano stream close by the seashore. Small morainic areas evidently rose high enough above this fan to support a growth of alders and trees, some of which, now overturned, had fifty and sixty rings of annual growth.

This long period of quiet had evidently been followed by an abrupt change which had completely destroyed the forest, not only on the expanded terminus of Galiano Glacier but also throughout the moraine-dotted flat for a distance of 4 or 5 miles toward the southwest. It moreover broke up an alluvial fan which existed in 1890 , and introduced above its level a series of hummocks and moraine patches through which the glacial streams were wandering. That the upthrust of these morainic areas was recent was shown by the absence on them of any other than very young plants, although there were extensive and mature forests close at hand in the undisturbed areas just to the north and west of the new moraines.

It seemed scarcely possible that mere slumping of the surface could account for these changes. It was not probable that, after fifty or seventy-five years of forest growth, through absence of slumping, during which a mature forest developed, ablation should suddenly begin 
and proceed with such rapidity as to absolutely destroy the forest in a period of fifteen years. Further, the broken and torn nature of the forest remnants demanded active movement. Shattering of buried ice by earthquake shaking might account for part of the change, but not for the entire result, and especially not for the breaking of the forest trees.

It could not be supposed that Galiano Glacier had actually advanced for a distance of 5 miles over this flat; and in any event the testimony of the natives was conclusive against this suggestion. The only satisfactory hypothesis that we were able to advance to account for these conditions was that the expanded terminus of Galiano Glacier did actually reach 5 miles beyond the visible ice fan, which so clearly appears in Russell's photographs and which was present also in 1905. Through ablation the outer part of this stagnant ice mass became so lowered that the glacial streams encroached upon it and buried its moraine-covered surface beneath alluvial fan deposits, bringing about the conditions present in 1890. With so deep a cover of moraine and alluvial fan the underlying stagnant ice almost ceased melting and assumed such stability that alders and trees grew upon those parts of the moraine which rose above the alluvial fans. The forest-covered ice fan, just outside the mountain valley, was directly connected with this buried ice, but, being practically stagnant, did not cause any forward movement in it. Later, for some reason, Galiano Glacier began to move forward, so disturbing the moraine on its lower end as to destroy the forest. This thrust was also extended out to the buried ice, pushing some of the moraine above the alluvial fan and destroying both the alluvial fans and the small forest patches. Since the occurrence of this forward thrust, which admitted water and air to the longburied glacier, melting proceeded more rapidly in this outlying, buried ice area, thus giving rise to the peculiar morainic conditions observed.

Seeking in 1905 for a cause for such an advance, we were able to find but one rational explanation-the effect of the 1899 earthquake. As shown later (pp. 91-93); the second season of field work, in 1906, furnished ample and convincing proof of the possibility of this explanation, which in 1905 seemed almost an impossibility, although it was the only hypothesis against which there were not fatal objections.

\section{ATREVIDA GLACIER.}

GENERAL DESCRIPTION.

A few miles west of the Galiano is Atrevida Glacier (Pl. XXXVII). Like the Galiano, it occupies a broad, U-shaped valley with precipitous mountain walls, and expands beyond the mountain front, terminating on the land. Its mountain valley is much longer than that of the Galiano, its supply ground is greater, and consequently its expanded terminus extends much farther from the mountains. On the western side it coalesces with the still larger Lucia Glacier, which comes down a great valley from the slopes of Mount Cook.

Russell ${ }^{a}$ calls attention to the fact that many Alaskan glaciers show a striking difference above and below snow line. Rocks previously concealed in the névé become concentrated at the surface at lower altitudes by ablation, forming sheets of débris, often many miles in extent. He finds no evidence that these débris fields are due to uprising currents, and with this conclusion $\mathrm{I}$ am in thorough agreement. Although many of the glaciers of the region illustrate this débris-laden condition, none do so better than Atrevida (in 1905) and Lucia (in 1905 and 1906) glaciers.

CONDITION IN 1905.

Moraine desert.-From Amphitheater Knob, whose elevation is 2,275 feet, one obtains an excellent bird's-eye view of Atrevida Glacier and of its relation to its larger neighbor, the Lucia. Each of the glaciers, on extending beyond the mouth of its mountain valley, expands somewhat, forming a bulb-shaped terminus whose exact extent could not be determined because of the moraine cover, which supports forest growth in its lower portion. At the point where the glaciers emerge from their mountain valleys they are separated by a series of descending terraces, one above the other, tied to the mountain spur which separates the glaciers. This V-shaped point, called Terrace Point by Russell, adds to the mountain a nose in the form of an acute 


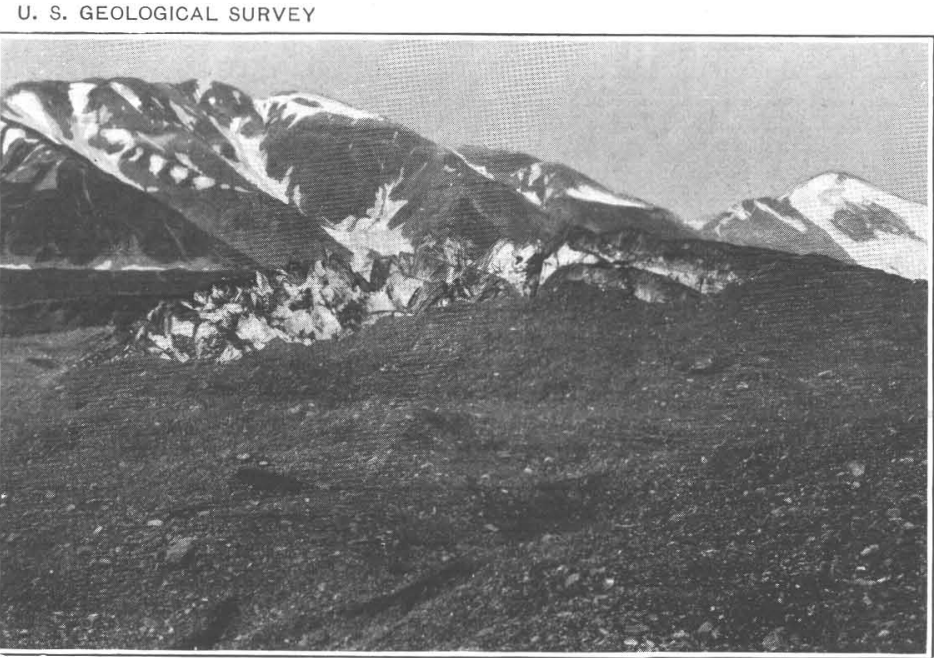

A. SURFACE OF ATREVIDA GLACIER, SHOWING AREA OF CREVASSING.

Photographed because of the exceptional feature of a dome of crevassed ice in the midst of the moraine desert. The morainic waste extends to PI. XXY

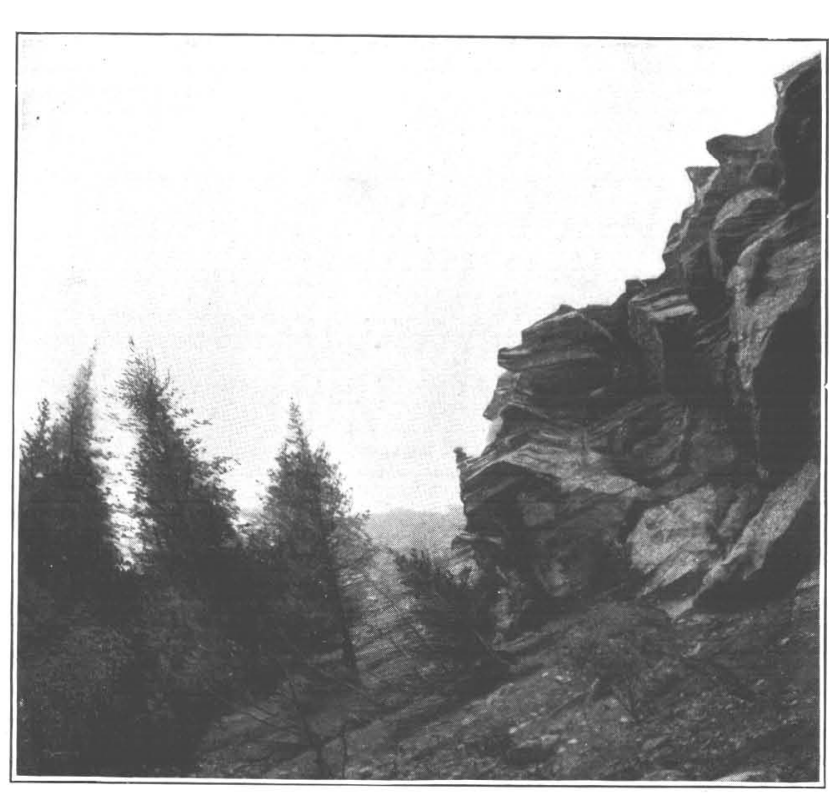

C. MARGIN OF ATREVIDA GLACIER WEST OF ESKER STREAM.

Jagged ice cliff on left where, in 1905, it was easy to ascend, over moraine waste, up a moderate slope. From this cliff blocks of ice and bowlders were constantly falling while the photograph was being taken. Note the trees bein buried in the morainic débris and overturned by the ice shove. Photograph taken July 10, 1906.
FROFESSIONAL PAPER 64 PLATE XXIV

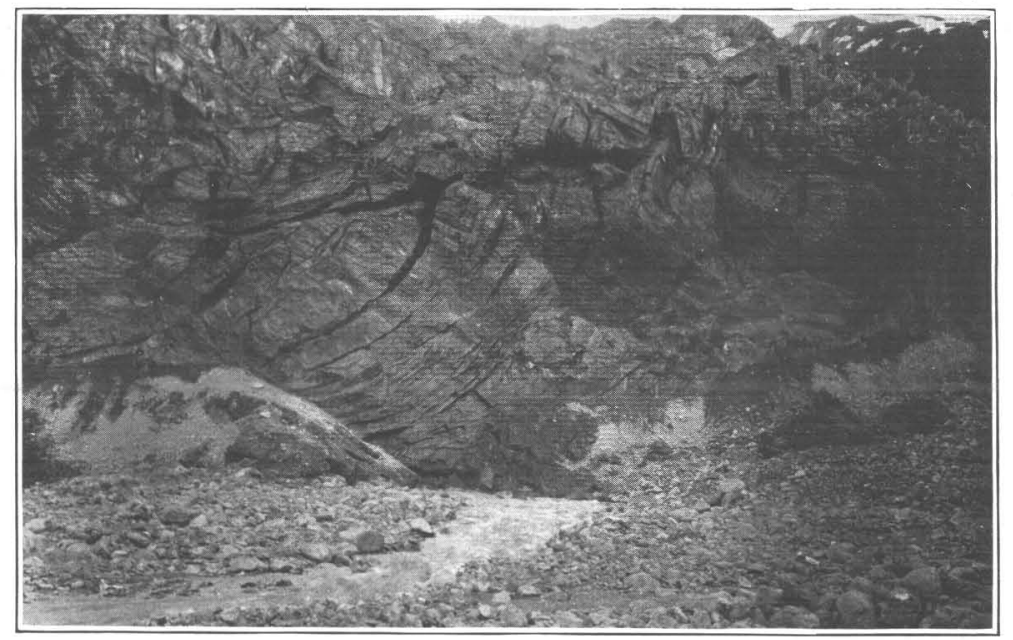

B. POINT OF EMERGENCE OF ESKER STREAM, JUNE 29, 1906.

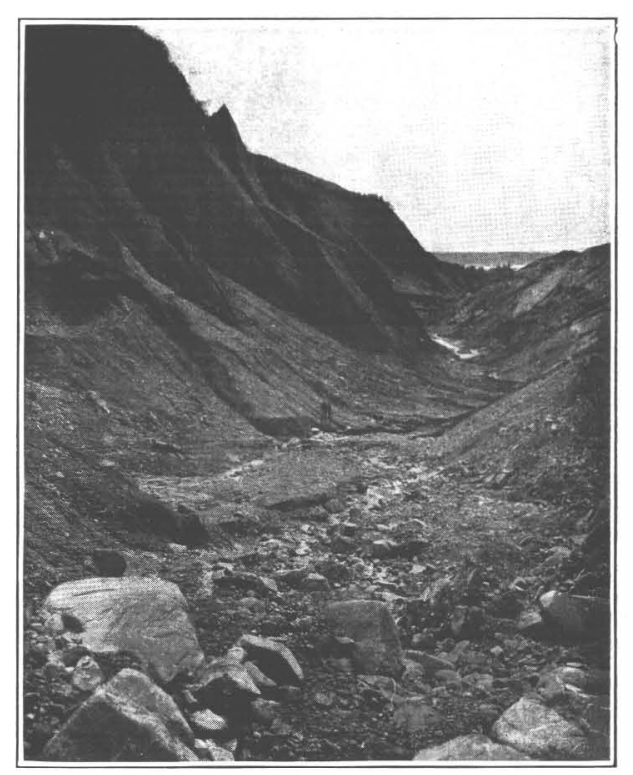

D. VIEW LOOKING DOWN MARGINAL VALLEY OF HAYDEN GLACIER AT SOUTHWEST END OF FLORAL HILLS, 2 OR 3 MIL

Moraine-covered Hayden Glacier on right; sculptured older gravels on left; débris-covered ice in valley bottom. In a seven-day rain the detail in this valley bottom was absolutely altered. Photograph taken July 18,1906 
. 


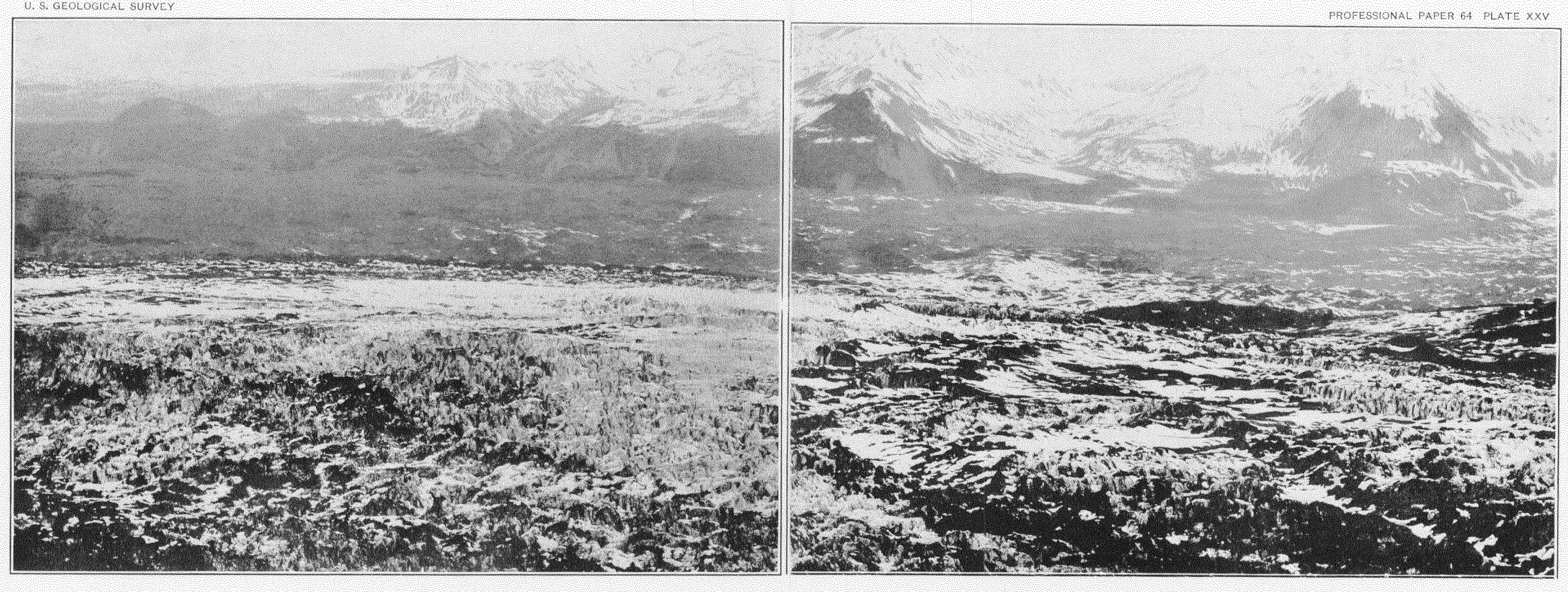

1. PART OF PANORAMA oF ATREVIDA GLACIER, From CREST OF AMPHITHEATER KNOB,

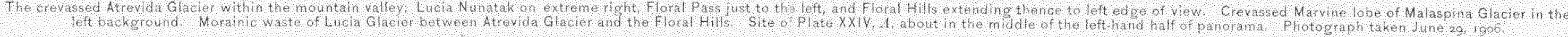

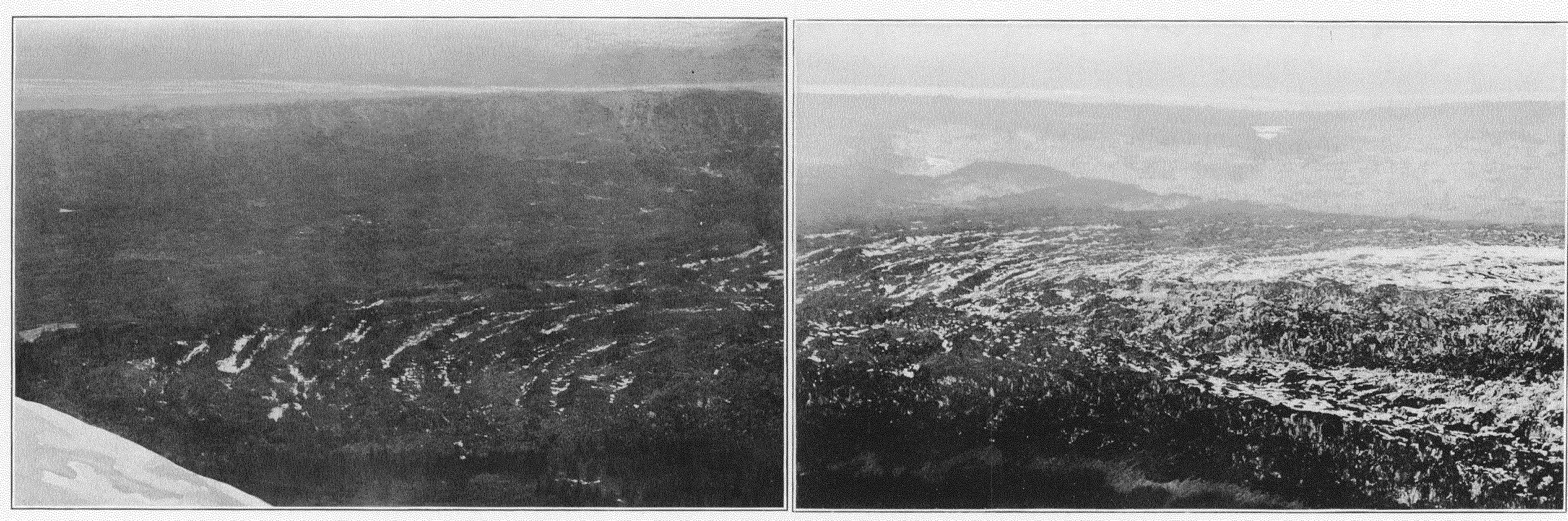

8. Part of panorama of atrevida glacier, From crest of amphitheater knob.

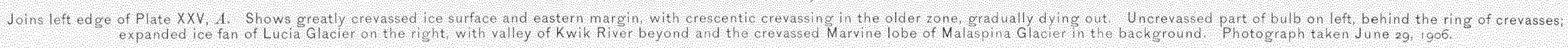


triangle, pointing southward. By it the two glaciers are separated for at least a mile beyond the end of the mountain spur. The terraces are in the nature of interlobate deposits formed during higher stages of the ice, and represent successive stages in glacier recession.

In 1905 a narrow band of alder extended from the apex of Terrace Point, forming an oasis in the midst of a barren moraine desert, and marking the line of division between the coalesced termini of the two glaciers. For a distance of a mile or a mile and a half within its mountain valley the Atrevida Glacier surface showed an expanse of hummocky moraine almost completely covering the ice (PI. XXIV, $A$ ). At the upper limit of the moraine desert clear ice predominated, and at the lower limit vegetation covered the moraine. The wooded section is for the most part covered with a dense and almost impenetrable alder thicket, with here and there small patches and scattered individuals of cottonwood and spruce. Ice could be clearly seen at one point near the inner margin of the wooded moraine, and its presence elsewhere was proved by patches bare of vegetation where destroyed by slumping. The forest-covered stagnant glacier terminus extends clear to the Kwik River valley, where it rises as the eastern wall in the form of a low, undulating, wooded slope.

Esker Stream and neighboring ice cliff.-At the extreme eastern margin of the glacier, at the base of Amphitheater Knob, a good-sized stream emerges. It leaves the ice base at an elevation of 750 feet, flows for a distance in a rock gorge, crossing the coal-bearing Tertiary strata, and emerges upon a broad fan (Pl. XXXIII, $B$ ), whose area it is constantly extending by encroachment on the neighboring forest. Above the surface of the alluvial fan, on the northern border, numerous dead trees rise, and others are being rapidly buried in the fan deposit.

Russell reproduces a photograph of the ice terminus where Esker Stream emerges, ${ }^{a}$ and, so far as could be seen, the condition during the 1905 visit was almost identical with that which his photograph records. Good-sized alders, estimated to be at least fifteen or twenty years old, grew within a few yards of the ice edge both at the front and on the east side of the glacier, and west of the creek the mature spruce forest extended to the very base of the moraine-covered glacier slope. These facts prove that there had been no perceptible retreat since 1890, and no reason was observed for suspecting an advance.

The stream emerged from a low cave in a vertical, and in places overhanging, slope. Above this the inclination of the glacier front was about $35^{\circ}$, and down it stones were almost constantly falling. The glacier section revealed showed many débris layers, increasing in number toward the base and including some good-sized bowlders; but the ice was nowhere heavily or uniformly débris-laden. Above the stream a number of nearly horizontal crevasses, dipping at an angle of $5^{\circ}$ to $10^{\circ}$ into the ice, indicated that there was differential movement along nearly horizontal planes rising toward the terminus. ${ }^{b}$

The steep ice front rises about 200 feet above the glacial stream. At its very crest there was a dense alder thicket, difficult to pass through, with bushes estimated to be not less than fifteen or twenty years old. At the time of visit, in 1905, one of these bushes had passed beyond the edge of the ice and was resting in an unstable position at the very top of the ice cliff. These alders formed a tree moraine, growing in a bowlder moraine, which in turn rested on living ice.

Journeys over the glacier surface.-The survey party climbed up on Atrevida Glacier just west of Fsker Stream, easily ascending to its crest, and spent half a day wandering over its morainic desert. Nowhere was other difficulty encountered than that presented by the alder growth and the hummocky surface of unstable moraine, over which walking was tedious. Later, two of the party, Messrs. Martin and Butler, with two Indians, crossed the glacier to Terrace Point, carrying a camp equipment. They encountered no areas of crevassing and found the journey easy.

For upward of a mile from the Esker Stream ice cave toward the valley head the glacier was covered by a confusion of hummocky moraine with only a few scattered alder bushes growing on it. On the lower end of this moraine desert there were a number of lakelets from 200 to 300 yards in diameter, the best defined occurring on the east side near the alder zone.

a Russell, I. C., An expedition to Mount St. Elias, Alaska: Nat. Geog. Mag., vol. 3, 1891, P1. X.

This phenomenon may represent a beginning of the striking changes discovered when this glacier front was revisited ten months later, as recorded on p. 76. 
In the moraine-covered section there was almost no crevassing and evidently not very active movement. Ablation was greatly retarded, but was nevertheless proceeding with sufficient rapidity to give rise to a hummocky surface and to a shifting soil on which vegetation could not develop successfully.

Above the moraine desert, at a distance of a little more than a mile from the Esker Stream cliff, the ice was somewhat more crevassed and there was a decided diminution in the amount of moraine, although the ice was by no means clear of rock débris. In one section only was there notable crevassing-on a dome-shaped area which was so exceptional that it was photographed, the only feature on Atrevida Glacier photographed in 1905 (Pl. XXIV, $A$ ). We then interpreted it as the result of a protrusion on the valley bottom, probably the site of a future nunatak; but in the light of the observations of 1906 it seems probable that the crevassing was a forerunner of the remarkable breaking up of the glacier witnessed at that later date.

Source of moraine.- The great abundance of moraine on this and other glaciers similarly situated is evidently due to the downfall of rock debris from the inclosing mountain walls, concentrated near the lower edge by ablation. Its angular character and the absence of striation furnish clear proof that it is not bottom débris raised to the surface. The development of these moraine wastes is far greater in this region than is common in other regions of valley glaciers that $I$ have seen or read descriptions of.

In a number of glaciers in the Yakutat Bay region, notably Atrevida, Lucia, Galiano, and Black glaciers, as well as in some of the smaller glaciers of the peninsula, the great amount of débris may be due in part to the crumbly condition of the rocks of the Yakutat group, which include a feldspathic graywacke and a friable black shale, both of which weather with remarkable rapidity. But some even of the glaciers heading among the crystalline rocks, like Variegated Glacier, have débris fields covering their termini. In these cases the conclusion seems warranted that the prime cause for the abundant supply, which operates also in the valleys cut in the Yakutat beds, is the greatly. steepened mountain slopes which glacial erosion has given these valleys. These exceptionally steep slopes naturally invite rapid weathering, and with it, of course, the tumbling down upon the glaciers of a great supply of rock fragments

\section{CONDITION IN 1906.}

Interval between visits.--It was on August 23, 1905, that Messrs. Martin and Butler returned from their expedition across Atrevida and Lucia glaciers. This was the last view we had of Atrevida Glacier until June 26, 1906, when Mr. Butler and I approached its edge for the purpose of laying out in detail a route for packers westward to Blossom Island along the general line followed the previous summer by Messrs. Martin and Butler and in 1890 by Professor Russell. We were stopped at the very margin of the glacier by a remarkable change in its character.

Eastern margin.-At the point where Esker Stream emerges the glacier front had pushed forward some distance, though the exact amount could not be determined. The ice margin was also crowded eastward against Amphitheater $\mathrm{Knob}$, overriding and destroying the alder thicket which covered the mountain base. This margin of the glacier, which in 1905 was uncrevassed, moraine covered, and moderately sloping, was now transformed to a jagged precipice with projecting blocks and overhanging cliffs, from which stones and fragments of ice were almost constantly rattling down. We passed along the base of this ice cliff for a quarter of a mile amid a scene of destruction of the most striking character. On one side rose the precipitous slope of the knoh, on the other a ragged ice crag stained with black débris; and in the valley between, alders were battered, torn, and partly buried beneath morainic débris and fallen masses of ice, still rapidly accumulating.

Esker Stream ice cave.-At the point where Esker Stream issued from its ice cave the previous summer the conditions were also entirely altered. The ice cave itself was completely destroyed, the stream issuing in a broad sheet at the very base of the glacier (Pl. XXIV, B). Above it rose a precipitous, blackened cliff, faulted by numerous thrust planes. In the previous 


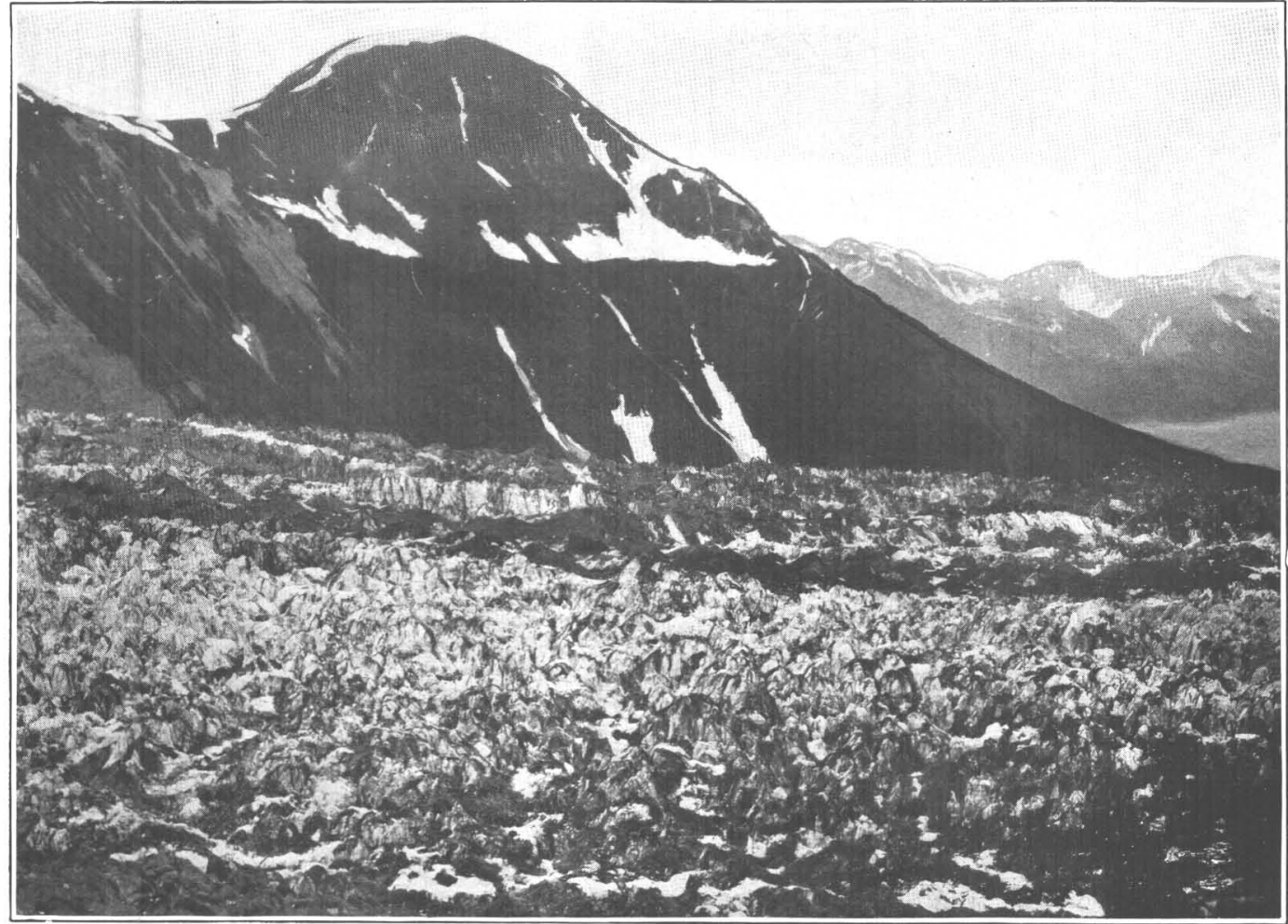

A. LONG-FOCUS VIEW OF CREVASSED SURFACE OF ATREVIDA GLACIER, LOOKING EAST FROM TERRACE POINT.

The mountain peak in the background is the site of the panorama, Plate XXV. Plate XXIV, A, was taken from a point very near center of this view, looking toward camera site. Photograph taken August 2, 1906 .

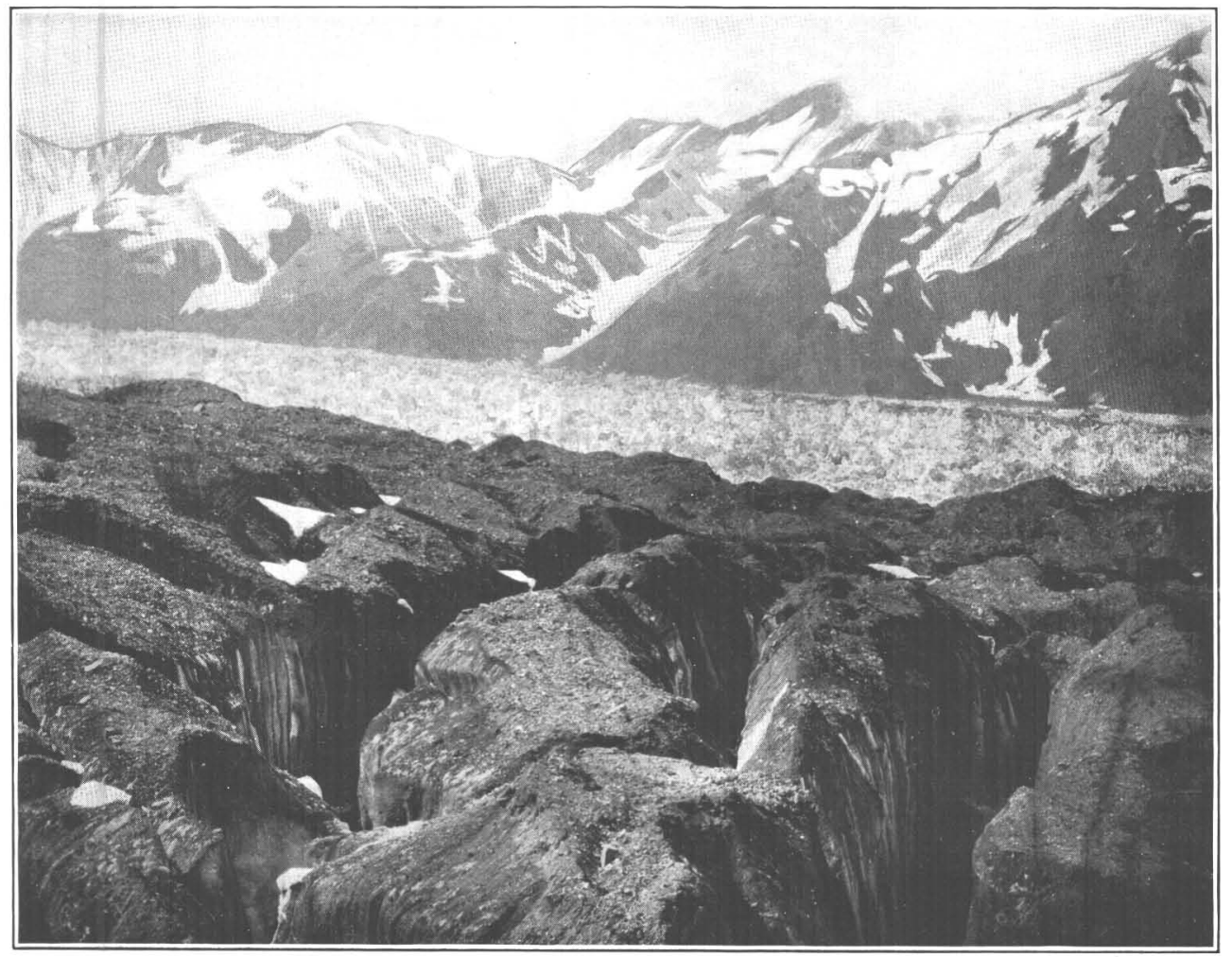

B. CREVASSED SURFACE OF MARVINE GLACIER FROM SMALL GLACIER NORTHWEST OF BLOSSOM ISLAND.

Showing its crevassed condition where emerging from its mountain valley. Russell crossed at this point in 1890 . Photograph taken July $30,1906$. 

summer it was possible to ford Esker Stream just below its ice cave, as Russell had done in 1890; but in 1906 its volume was so greatly increased that it seemed unsafe to attempt a crossing.

West of Esker Stream.-West of the creek also the glacier was advancing and was fringed by a faulted, pinnacled ice cliff, instead of the easily climbed moraine-covered slope of the summer before. A journey of half a mile along this newly formed ice precipice showed the ice rising everywhere precipitously, gashed by deep crevasses, and faulted along nearly horizontal planes, giving rise to shattered blocks and overhanging ice cornices. In one place only was it found possible to ascend this ice slope, and even there, before sufficient elevation was reached to overlook the glacier surface, progress was checked by the system of deep crevasses.

We followed this ice cliff well down into the alder-covered portion of the glacier bulb. There the recent breaking of the ice had undermined the thicket, and the bushes were tumbling down the face of the cliff and into the crevasses that opened beneath them. The morainic soil and the vegetation which it supported were fast disappearing.

Along the ice face there was an almost constant downsliding of moraine, including large bowlders and fragments of alder bushes which the previous summer had been firmly rooted in the soil above. Added to this were falls of ice, in some cases involving scores of tons in a single avalanche. This sudden downsliding of débris and ice blocks, together with the forward movement of the glacier, had wrought and was still working great destruction in the mature spruce forest along the ice margin. Trees fifty years old were inclined at all angles by the ice shove; and both bushes and trees were battered and overturned by the avalanches which had descended from the advancing ice front (Pl. XXIV, $C$ ). Mighty forces were at work, and the evidence of their power not uncommonly forced us to move away from the base of the cliff into the forest, at a safe distance from the frequent falls of rock and ice.

For a long period of time, certainly more than a quarter of a century, and probably more than half a century, this glacier bulb had been so nearly stagnant that a deep morainic soil had accumulated and a mature alder thicket developed. Thus protected from sun and rain, the melting of the ice had been so nearly checked that in 1905 only small streams of pure water trickled from this wooded moraine slope. Now, as a result of the operation of titanic forces, the ice, so long blanketed, had been rent asunder and lay open to the weather, melting so rapidly that innumerable streams, heavily charged with débris, were emerging from its margin and rushing through the mature spruce forest, submerging its mossy bed in an icy flood and burying its tree roots beneath muddy deposits. Where the slope steepened these streams were cutting new gorges in the moraine, and in several localities were even carving rock gorges. This new supply of water, entering Esker Stream, was adding to its already increased volume.

The eastern margin of Atrevida Glacier was evidently being subjected to a sudden thrust by which it had been profoundly broken and its whole character utterly changed. This movement had been entirely accomplished in the period of ten months between August 23, 1905, and June 26, 1906, though it is possible that the horizontal crevassing noticed in 1905 in the ice cliff above Esker Stream, and the crevassed dome out in the middle of the glacier, were the forerunners of this remarkable change.

Bird's-eye view.-In order to obtain a bird's-eye view of this advancing glacier, the Survey party ascended to the crest of Amphitheater Knob and looked down upon it from the same point of view as that chosen in 1905 . The nature and extent of the change were almost incredible. From far above the snow line, across the desert of morainic waste, well down into the alder-covered terminus, the ice was broken into a waste of crevasses. The moraine desert was almost entirely destroyed, and its formerly undulating surface was replaced by a series of pinnacles and sharp ridges separated by yawning crevasses ( $\mathrm{Pl}$. XXV, $A$ ). Moraine still clung to the tops of the broader ridges, but more than half the surface was clear ice, whereas in the previous summer scarcely any ice appeared in the morainic waste when viewed from a distance.

The crevassing extended far down into the alder zone, but not to its outer end ( $\mathrm{Pl}$. XXV, $B$ ). In that zone the crevasses formed a series of crescentic rents, with increasing radius toward the margin of the broken area, paralleling the bulblike expansion of the glacier terminus itself. Toward the outer margin the crevasses gradually died out, the outermost ones being short, 
narrow rents revealing clear ice in the midst of the dark-green alder thicket, where in 1905 no ice whatsoever was visible.

Within the area of crevassing the alder thicket is doomed. Whether that on the outer side of the crevassed zone will also be destroyed depends on how far the rigid forward thrust reaches into the outer stagnant bulb of the glacier. There is no means of telling whether the effects of the thrust had reached their maximum at the time of observation; but it does not seem probable that this was the case, for the breaking off of projecting ice masses along the margin indicated that the ice was then still moving forward.

Western margin.-Later in the season-that is, late in August, 1906-I again approached Atrevida Glacier, this time from its western side, looking down upon it from Terrace Point (Pl. XXVI, $A$ ). This nearer bird's-eye view amply verified the conclusion that passage across it was totally impossible. Where in 1905 there was a débris waste, over which travel was easy, there now lay a wilderness of crevasses and pinnacled ice, fully half of which was pure marble white. The crescentic crevassing was even more clearly shown from this point of view, and it was evident that the advancing ice had pushed westward well into the area dominated in 1905 by Lucia Glacier. At this point the advance was accompanied by a great thickening of the glacier, causing its surface to rise at least 200 feet above the Lucia surface, with which, in the previous summer, it coalesced without any notable change in level. The alder belt, described in a previous section (p. 75) as marking the boundary between the two glaciers, had been entirely destroyed by the forward movement of Atrevida Glacier.

The ice was crowding up against the base of Terrace Point, overriding the gravels and pushing them up in front of the ice foot-a true instance of a "shoved" moraine. By itsforward movement the ice had advanced over and destroyed the camp site at its western base, occupied by Messrs. Martin and Butler in 1905; and the moderately sloping, moraine-covered western margin over which they easily traveled, was transformed to a high, crevassed, inaccessible ice precipice similar to that on the east side. In at least one place the forward movement of the glacier, pushing against a gravel spur of Terrace Point, had formed a lake which did not exist in 1905 .

From the comparative observations of the two seasons it is evident that a long period of quiet, and, in the lower portion of the glacier, essential stagnation, had been followed by a profound breaking of the ice; and that this had been accompanied by a distinct forward movement and, in the western portion at least, by a thickening of the glacier. The advance is of the same general character as that discovered in Haenke and Variegated glaciers. It probably is of the same nature as that through which Galiano Glacier passed in the interval between 1890 and 1905.

\section{LUCIA GLACIER.}

Lucia Glacier, though both broader and longer, closely resembles the Atrevida in its $1905^{\circ}$ condition. It is the best example in the Yakutat Bay region of a wasting valley glacier essentially stagnant near its terminus. (See Pl. XXV.)

\section{BULB-SHAPED TERMINUS.}

Like the Atrevida, Lucia Glacier spreads out at its lower end; but the mountain spur, known as Floral Hills, prevents it from expanding toward the west. As also in the case of the Atrevida, the outer edge of Lucia Glacier is a low wooded slope forming the eastern wall of the Kwik River valley. Spruce grows on its outer portion, but back from the front the plant growth is mainly alder thicket. This condition extends for somewhat more than a mile from the outer margin of the glacier, and in that area no ice appears from a distant view. The aldercovered, bulb-shaped terminus of the Lucia is fully twice as wide as the upper, mountain-valley portion.

\section{MORAINIC WASTE.}

Toward the mountain valley the alder cover gradually disappears, its place being taken by a desert of moraine which extends for a distance of 3 or 4 miles, reaching well up the moun- 
tain valley, at least 1 mile above Terrace Point on the east and Floral Pass on the west. In this morainic desert section fully nine-tenths of the surface reveals no ice when viewed from a distance. Only here and there does ice appear in small bands or in depressions holding lakelets, at least a score of which dot the moraine-covered portion of the glacier.

In the outer part of the morainic waste the surface is a confused series of hillocks and depressions with no definite system. But farther up the glacier, notably between Floral Pass and Terrace Point, the moraine consists of a series of crescentic ridges arranged concentrically. These appear to be continuations of longitudinal ridges, parallel to the axis of the valley, which, after extending down the glacier for a distance, turn out into it and sweep in crescentic curves across the surface.

The moraine ridges vary greatly in height, having undulating crests, in some cases rising fully 100 feet above the intervening valleys. Small crevasses occur, but these are all nearly filled with rock fragments that have slid down into them. On some of the ridge faces ice is occasionally revealed, giving rise to slopes so steep and slippery as to make crossing difficult. Some of the ridges are rendered distinct by the predominance of certain kinds of rocks, such as conglomerate, black shale, and gray feldspathic graywacke-all rocks of the Yakutat group, proving that this glacier and its tributaries receive their supply from mountains composed of strata of this age.

With a single exception the valleys between the moraine ridges are covered with morainic débris, which is steadily sliding down into them; but it is evident that the moraine filling can not be so thick in these valleys as on the ridges; otherwise the valleys would soon change to ridges as a result of differential melting. Drainage, as well as morainic débris, descends into the valleys, and in their bottoms finds escape down huge moulins. Possibly it is this drainage and the accompanying removal of débris that permits these valleys to develop so notably.

As in the case of other débris-covered glaciers in this region, the source of supply of the morainic material is evidently from the valley sides, through weathering and avalanches, rather than from the uprising of bottom layers; for all the fragments are angular, and nowhere was glacial polishing or striation detected.

The concentric arrangement of the morainic ridges and the difference in the rock material covering them remind one of the remarkable series of banded moraines that covered Variegated Glacier in 1905 . One of the valleys between the morainic ridges, contrasting strikingly with the others, also suggested a comparison with that glacier. This valley, which runs approximately east-west for nearly a third of the distance across the glacier, lies directly between Floral Pass and Terrace Point. It has a nearly flat floor, almost entirely free from morainic débris, and the drainage that descends into it escapes down three enormous moulins. Its outline is crescentic, and it is concentric with the inclosing morainic ridges. There was no visible reason for this débris-free ice in the midst of the morainic desert. If the glacier should melt down far enough this ice flat might well become the seat of alluviation similar to that in the interior flat on the expanded bulb of Variegated Glacier.

UPPER VALLEY PORTION.

About a mile above Floral Pass the débris fields gradually disappear, but a prominent medial moraine extends far up the glacier. Numerous tributaries descend from the steep mountains, some entering the valley within a mile or two of Terrace Point on the east and Floral Pass on the west. Several of these tributaries have steepened lower slopes, and those nearest the end of the mountain valley are débris covered in their lower portion.

\section{LUCIA NUNATAK.}

Almost opposite Floral Pass, Lucia Glacier is divided by a hill rising 600 or 700 feet. The main glacier sweeps around the east side, while a small, nearly stagnant, débris-covered tongue - is protruded part way down the west side, transforming the hill into a seminunatak. On the northern slope of the nunatak the ice rises more than half way to the top and high above the 
level of the main glacier, being so completely covered with a thick coat of débris that it is melting with extreme slowness. It seems inconceivable that this ice can be pushed up and maintained at its present high level by the existing thrust of Lucia Glacier. It is inferred, therefore, that it is a remnant of a higher stage of ice, still clinging to the mountain slopes because of the slowness of ablation under the moraine cover. That this ice collar has recently stood even higher is proved by the fact that the mountain slope is bare of vegetation at least 100 feet above its present level.

\section{GLACIAL STREAMS.}

A small stream emerges from the minor western tongue of Lucia Glacier, passing through a gorge between the nunatak and Floral Hills. This gorge is a true marginal channel, caused by the ice pushing up against a spur of the Floral Hills. Still smaller streams are supplied from the stagnant ice mass which rises against the northern spur of the nunatak. Near the southern base of the nunatak a great glacial torrent issues from a high ice cave, and for a short distance flows in an ice gorge. Its gravels are well rounded, indicating long travel under the ice. This, the largest stream emerging from Lucia Glacier, swings past the southwest end of the nunatak and is shortly joined by a creek from Floral Pass, which has received as tributary the glacial stream from the western tongue of the glacier. The combination of these tributaries makes a veritable river of muddy water, which flows with great velocity along the eastern base of Floral Hills, receiving occasional accessions from smaller streams issuing from the stagnant bulb of the lower Lucia Glacier. Owing to the fact that Lucia Glacier crowds up against the Floral Hills, this river is forced, in several places, to cut across the mountain spurs in deep, steep-walled rock gorges, alternating with more open stretches where the glacier forms one wall of the valley. On emerging from the outermost gorge the torrent spreads out over an alluvial fan, at the base of which its waters unite with Kwik River.

POSSIBLE COMing CHANGe.

Both in 1905 and in 1906 members of the Survey parties crossed Lucia Glacier from Terrace Point to Floral Pass. No notable change in the ice condition in the interval was noted. Mr. Butler, who was present on both these expeditions, is of the opinion that, while in its general characteristics the upper Lucia Glacier was the same in 1906 as in 1905 , there had been a distinct increase in the amount of crevassing far up the valley. The fact that the nature of crevassing was not particularly observed in 1905 may possibly account for the apparent difference, since in 1906 we were all keenly on the outlook for indications of a coming change in glacier condition. If it be true that there has been an increase in crevassing, as Mr. Butler suspects, we may with safety predict that within a year or two the lower Lucia Glacier will be subjected to the same paroxysmal thrust as that which so altered the condition of the Atrevida and other glaciers in the interval of ten months between our two visits. If the explanation offered to account for the changes in the advancing glaciers is correct, a forward movement of Lucia Glacier is to be expected; but in this longer glacier it would normally be expected to appear later than in the shorter Atrevida Glacier. 


\section{CHAPTER V.}

\section{MALASPINA GLACIER.}

\section{GENERAL DESCRIPTION.}

From the clear and accurate description of it by Russell, ${ }^{a}$ Malaspina Glacier has come to be recognized as the type of piedmont glaciers. Fed by numerous valley-glacier tributaries, some of them very large, it spreads out as a broad ice plateau at the base of the St. Elias Range, covering an area fully equal to that of the State of Rhode Island. It was so nearly stagnant that Russell, Abruzzi, and others freely crossed it, drawing their outfit over its surface on sleds.

Ablation along the margin has developed broad débris fields of hummocky moraine; and along portions of the margin the degree of stagnation has been so great that alder thickets, and even cottonwood and spruce forests, have developed in the moraine soil which deeply mantles the glacier. None of the explorers mention crevassing sufficient to interfere with easy sledding.

Numerous glaciers contribute to the supply of this great ice plateau, each of the largest dominating one section or lobe. My studies are confined to the two easternmost of these glaciers-Hayden Glacier and its much larger neighbor immediately to the west, Marvine Glacier. As these two contributing glaciers are different in character and behavior they will be considered separately, but no attempt will be made to describe Malaspina Glacier farther west, for which reference may be had to Russell's descriptions, referred to above, and to the account of the Abruzzi expedition to the summit of Mount St. Elias. ${ }^{b}$

\section{HAYDEN GLACIER.}

GENERAL FEATURES.

Hayden Glacier was crossed along two lines in 1906, and in both 1905 and 1906 was viewed from neighboring low mountain spurs. In the latter season, also, its entire eastern margin up to Floral Pass was traversed and its western margin visited at and near Blossom Island.

Fed by many tributaries among the lofty mountains, and heading back on the western slopes of Mount Cook, Hayden Glacier descends with moderate slope through a broad valley, its upper portion mantled in snow and having no visible areas of crevassing. The snow line descends about half a mile below Floral Pass, and beyond that point clear ice is revealed, bearing morainic ribbons of irregular pattern and covered on either margin with a broad belt of lateral moraine. Below Floral Pass, where the Floral Hills and the mountains near Blossom Island flare apart, the valley broadens; within the mountains the glacier is 3 to 4 miles broad, but it rapidly expands beyond the Floral Hills, ultimately reaching at least 6 to 7 miles.

\section{RELATION TO MALASPINA GLACIER.}

Hayden Glacier coalesces with Marvine Glacier near Blossom Island, thus becoming tributary to Malaspina Glacier. It does not, however, notably supply this great piedmont ice plateau. Where it joins the Malaspina the Hayden Glacier bulb pushes distinctly out into the crevassed Marvine ice, well beyond the line of Marvine Glacier as it descends past Blossom Island. In addition to forming this ice bulb, Hayden Glacier flows southward along the southwestern

a An expedition to Mount St. Elias, Alaska: Nat. Geog. Mag., vol. 3, 1891, pp. 53-203; Second expedition to Mount St. Elias: Thirteenth Ann. Rept. U. S. Geol. Survey, pt. 2, 1892, pp. 1-91.

$b$ Filippo de Filippi, The ascent of Mount St. Elias by H. R. H. Prince Luigi Amedea di Savoia, Duke of the Abruzzi, 1900. 74228-No. 64-09-6 
base of the Floral Hills, forming a wedge-shaped addition to the eastern margin of the Malaspina at this point. This practically uncrevassed ice, welded to the greatly broken Marvine Glacier lobe, shows with diagrammatic clearness the extent to which the two coalescing glaciers supply ice to the main Malaspina.

From these features it is clear that Hayden Glacier, though a tributary to the Malaspina, does little more than coalesce with it. A moderate recession would disconnect it and give it independent existence, such as Atrevida and Lucia glaciers, once tributaries to the Malaspina, now have. That such separation is imminent, if the recent recession of the glaciers continues, is indicated by the presence of a long, undulating, somewhat crevassed valley along the line of junction between Hayden and Marvine glaciers, and by the fact that the outer portion of Hayden Glacier bears a great burden of débris, though not a continuous morainic waste like the Lucia. It is therefore not stagnant; but moving so slowly that ablation has concentrated much débris on the surface.

\section{SURFACE FEATURES.}

Where the Survey party crossed it Hayden Glacier is only moderately crevassed, and no special difficulty was encountered in several journeys along different lines. The eastern margin is covered with lateral moraine for a distance of more than half a mile, giving rise to a very hummocky surface, gradually rising toward the center of the glacier, where the ice surface rises and falls in a series of broad swells. Below the snow line, a number of medial moraines appear. The surface moraine increases in quantity, and the area covered grows larger toward the lower end where the glacier coalesces with the Marvine. There is a downward grade toward this junction, as well as a gentle slope from the center of the glacier toward each margin.

The ice surface is too rough for sledding, but the irregularities are due mainly to melting rather than to crevassing. This melting gives rise to many streams, all short and quickly disappearing into moulins. In the morainic areas, both along the margin and in the center, there are some lakelets on the ice surface. The details of the ice surface are interesting, but of the usual character, including crevasses and moulins in great variety, morainic ridges, sand cones and ridges, rock tables, short muddy streams, and clear streams of icy water.

\section{RATE OF ABLATION.}

Excellent opportunity was found at Hayden Glacier for measuring the rate of ablation. Late in July a cache of provisions was left on a level part of the glacier. On returning seven days later (July 28) it was found perched on an ice pedestal well above the glacier surface, and almost ready to slide off. Measurements indicate that at this point the glacier surface was lowered $2 \frac{1}{2}$ feet in seven days, or more than 4 inches a day. It had been raining almost steadily during the seven days. Changing the position of the cache to another level surface near by, it was left five days longer, during which the days were almost uniformly clear, while the night temperatures always descended well below the freezing point. During this period also the rate of ablation was found to be approximately 4 inches a day, which is therefore assumed to be the rate for this part of the glacier during the warmest summer weather.

\section{SUBGLACIAL STREAM.}

On the west side, near Blossom Island, a large glacial stream enters beneath Hayden Glacier, and the ice surface near by is greatly crevassed by slumping (Pl. XXVIII, $A$ ). Out near the center of the glacier the fall of ice, far underfoot, was distinctly heard and felt, being evidently from the roof of the subglacial tunnel of this stream, which, as is shown later (p. 85), had found this course only shortly before.

\section{EASTERN MARGIN.}

The eastern margin of Hayden Glacier presents some interesting features. Above the snow line it extends with fairly even surface up to the mountains. Where the through valley of Floral Pass causes a break in the eastern mountain wall, a small tongue of Hayden Glacier 
ice protrudes a few hundred yards into the valley; it has a steep slope down the valley, but at the time of visit (July 30 and August 2) was snow covered. A very small stream emerges from it, at first flowing beneath the snow banks of the upper part of Floral Pass.

To emerge from Floral Pass westward one must ascend this protruding glacier tongue to the main Hayden Glacier. The presence of lateral moraine on the main glacier at the entrance to the pass shows clearly that the amount of ice entering the Floral Pass valley is very slight and that its motion is very slow, yet the surface of the main glacier, where it flows across the entrance, rises several hundred feet above the rock floor of the pass. If Hayden Glacier should rise much higher it would necessarily send an active tongue into this valley, as it undoubtedly did at a former period.

Below Floral Pass a marginal valley is developed with a small stream flowing in it, but at one point the ice presses against a low spur of the mountain, forcing the marginal drainage into a narrow rock gorge for an eighth of a mile. The stream then emerges into a broader valley, with one ice wall, and within a quarter of a mile disappears in an ice tunnel, which has recently collapsed, forming a temporary lake whose fresh deposits are easily recognized. From these deposits it is evident that the lake was of brief duration and quickly drained. Its escape must have caused a sudden rise in Kwik River, to which this marginal drainage is tributary. For upward of 2 miles this stream flows under the glacier, receiving numerous tributaries, partly from land drainage and partly from the ice.

Below the ice tunnel for more than a mile there is no visible stream in the marginal valley, whose bottom is hummocky, moraine-covered ice, into which drainage disappears. Near the end of the marginal valley a small stream appears, fed mainly from land streams; but the stream that entered the ice tunnel does not again reappear, evidently uniting with Kwik River as a subglacial tributary. The Kwik emerges as a rushing torrent, of great volume, from a huge ice cave near the southeastern end of the Floral Hills, and shortly below is nearly doubled in size by the entrance of the Lucia glacial stream.

Above the Kwik ice tunnel, where the ice is supplied by Hayden Glacier, Malaspina Glacier is not crevassed along its margin, but below the tunnel the crevassing caused by the advancing Marvine Glacier appears. Therefore it is inferred that the river emerges almost at the very boundary between the Hayden and Marvine ice. For 3 miles above this ice tunnel the marginal valley (Pl. XXIV, $D$ ) is inclosed on its western side by a steeply rising wall of hummocky, moraine-covered ice, in several places overriding gravels, while a precipitous and greatly dissected gravel cliff forms the other valley wall. During our stay in this region the details of the form of this valley were rapidly changing by the melting of the ice on one side, the gullying and downsliding of the gravels on the other, and the slumping of the ice in the valley bottom. In an interval of three weeks the change in details of form was striking, and during a seven-day period of heavy rain there was a remarkable alteration on both sides of the valley and in its bottom.

\section{AVALANCHE MORAINE.}

No sign of an advance in Hayden Glacier was discovered, and it appeared to be the same in 1906 as in 1905 . On the west side, nearly opposite Floral Pass, a great area of moraine on the glacier, with a form somewhat like a delta, apparently represents an enormous avalanche, possibly precipitated during the 1899 earthquake. Lying as it does at the snow line, it can not be a stream deposit, and both its great area and its form prohibit classing it as a normal lateral moraine.

\section{MARVINE GLACIER.}

NATURE OF OBSERVATIONS.

In 1905 the Survey party did not go actually to Malaspina Glacier, our nearest approach being the western slope of Floral Hills, directly above Hayden Glacier, where Messrs. Martin and Butler looked out over the Malaspina on a clear, bright day late in August. With the aid of field glasses the glacier was also viewed on clear days from Amphitheater Knob, from Point 
Latouche, and from the western slopes of Mount Tebenkof. In 1906, from at least two of these points of observation, the crevassed condition of the eastern margin of Malaspina Glacier was easily seen with the naked eye, and was very evident with the aid of field glasses. Therefore, although in 1905 we were not looking for change in condition of the glacier, I believe the fact that we did not see any change is proof that there had been no notable change since Russell and Abruzzi crossed it in 1890-91 and 1897, respectively. This conclusion receives additional support from direct evidence, as stated below.

Besides obtaining bird's-eye views from several points directly above its margin, in $1906 \mathrm{I}$ traveled along the eastern edge of Malaspina Glacier to a point about 2 miles above Blossom Island, where the Marvine tributary emerges from its mountain valley and where Russell crossed it in 1890. I also saw the entire sea front of the glacier on the Yakutat Bay side as far out as Point Manby-that is, the portion which Russell crossed in his retreat of 1891 and the point of entrance of the Abruzzi and Bryant expeditions of $1897 .^{a}$

THE BROKEN GLACIER SURFACE.

The entire broken section, except a small portion where Hayden Glacier enters, is dominated by Marvine Glacier (Pl. XXXVII). From the point where Marvine Glacier emerges from its mountain valley clear to the sea Malaspina Glacier is a labyrinth of crevasses and is utterly impassable. The crevassed area, 4 miles or more wide at the mouth of the mountain valley, broadens seaward, ultimately attaining more than double this width.

From the southern slopes of the Floral Hills, as well as from the summit of Blossom Island, the entire eastern half of Malaspina Glacier, from the mountains to the sea, is plainly visible. Viewed from these points Marvine Glacier, where it emerges from its valley where Russell crossed it in 1890, is a maze of pinnacles, a veritable wilderness of crevasse from side to side $(\mathrm{Pl}$. XXVI, $B$ ). The pinnacles and sharp ridges are plainly due to shering rather than melting, for the surface is above the snow line. I have never before seen so broad a glacier surface so completely broken, with no path either across it or along its margin.

Seward Glacier, the next large tributary to the Malaspina toward the west, is also badly crevassed where it emerges from its mountain valley and thence down to its junction with the Marvine; but its surface is not nearly such a labyrinth of crevasses as that of Marvine Glacier. From a distance it seems impossible to sled across this part of Seward Glacier; and Benno Alexander, one of the party, who was with the Abruzzi expedition, assures me that in 1897 it displayed no such crevassing as he could plainly see from the summit of Blossom Island Hill in 1906. He sledged freely across Seward Glacier in 1897, making numerous trips over the part now so crevassed. It thus seems probable that the Hitchcock Hills are now inaccessible; they surely can not be reached by crossing the Marvine, and approach from the west would certainly be difficult, if not impossible.

Outside its mountain valley Marvine Glacier, though still impassably crevassed, is less pinnacled. It is true that there are many pinnacles and sharp ridges, but, except at the very margin (Pl. XXVII, $A$ ), the general pattern of the ice surface is that of table-top areas surrounded by broad, deep crevasses extending in all directions. It is evident that the breaking force in this expanded piedmont section has been far less intense than in the mountain valley; and it is further evident that the broken ice has not long been exposed to ablation. The surface has the appearance of a level area so recently cracked open that melting has not had time even to round off the corners of the unbroken table-top areas between the crevasses. Snow covered some of the glacier, thus protecting it from ablation; but the lower areas had lost their snow cover, and yet were not greatly modified by melting except at the glacier margin. This fact points to the season of 1906 as the period of breaking of this glacier, as we know it to have been in the three other advancing glaciers previously described.

Opposite Blossom Island the crevassed area dominated by the Marvine ice is estimated to have a width of about 5 miles. West of this, areas of crevassing appear in that part of the

a By two accidents in crossing glacial streams the small survey camera was lost, and later, through wetting, the plates for the larger camera and many pictures already taken were ruined. Therefore the photographic record of parts of this expedition is incomplete. 


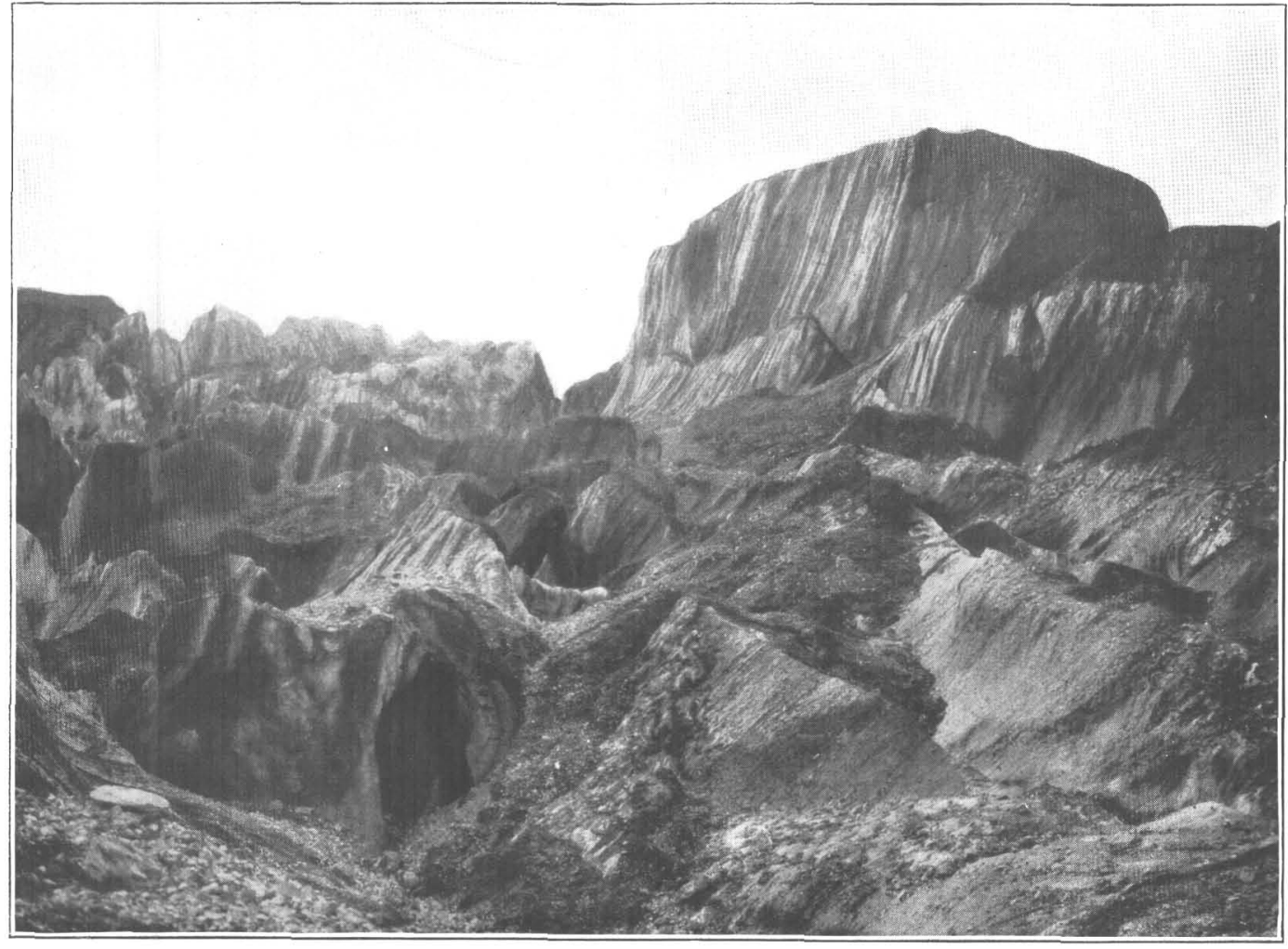

A. A DETAIL IN THE CREVASSED EASTERN MARGIN OF MARVINE GLACIER NEAR BLOSSOM ISLAND.

Moraine was constantly sliding into the crevasses so recently opened here. Photograph taken July 29, 1906.

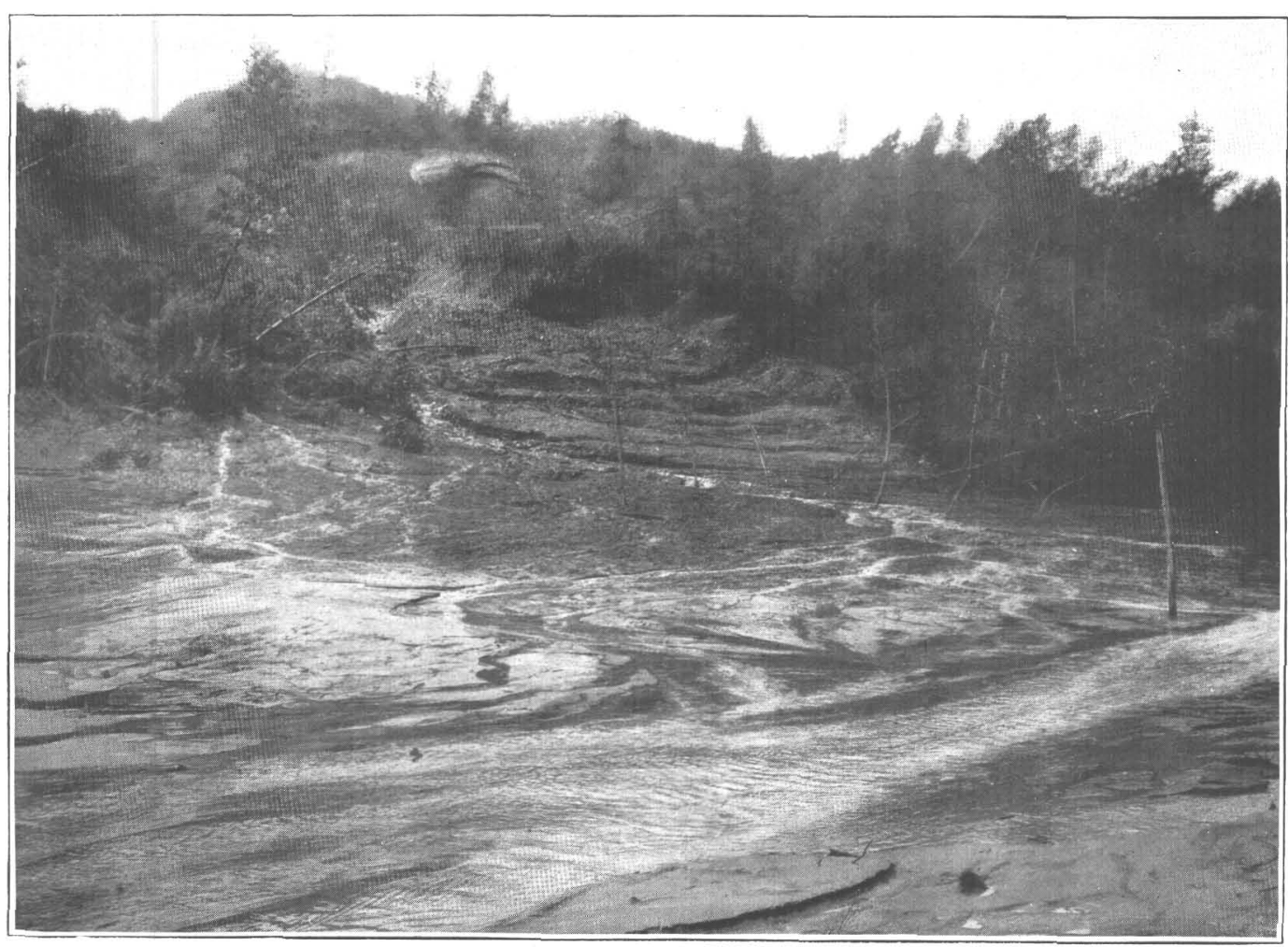

B. MORAINE-COVERED FORESTED EASTERN MARGIN OF THE MARVINE LOBE OF MALASPINA GLACIER.

The ice, recently thrust forward, has protruded through the soil; the trees are tilted at various angles and overturned; and the underlying ice, exposed to air and rain, is rapidly melting. Streams of water and of liquid mud descend the slope. In early July the foreground was occupied by a lake upon which the alluvial fan had encroached, the stream, in the meantime, being greatly increased in size. Photograph taken August 9, 1906. 

Malaspina supplied by Seward Glacier; but on the whole this part of the ice plateau is smooth and unbroken. Part of this apparent smoothness may be due to the heavy coat of snow which covers that portion of Malaspina Glacier; but, even granting this, it is certain that the underlying ice can not be nearly so broken as in the portion dominated by the Marvine ice. From a distant view it seemed probable that one could enter upon Malaspina Glacier at some point between Sitkagi Bluffs and Point Manby and, by going around areas of crevasses, sledge over to the Samovar Hills; but possibly a nearer view would show that even this is impossible.

From these observations it is clear that Marvine Glacier has been recently thrust forward, breaking into an impassable condition that part of Malaspina Glacier which it supplies. Seward Glacier has apparently also advanced, but not yet with sufficient force to profoundly break the ice beyond the mountain base.

\section{BROKEN MARGIN AT BLOSSOM ISLAND.}

The margin of the advancing Marvine Glacier presents many features of interest. Exactly at Blossom Island it is not greatly broken, for the ice is protruded into a little bay in which it is protected from the forward thrust by a small tributary which joins Marvine Glacier from the northeast, about 2 miles above Blossom Island. This small tributary, which Russell crossed, is now badly shattered by great rents, as if by the pull of the Marvine Glacier thrust. One could hardly carry packs across it now.

Just below Blossom Island, near Blossom Island Lake, the effect of the ice shove begins to be felt at the very margin. Here alders in full leaf, growing on the moraine-covered ice, were being overturned, and the morainic soil was tumbling into the crevasses. Standing on the edge of this crevassed margin one constantly heard the rolling of stones and sliding of morainic avalanches into the crevasses, which were being rapidly widened by ablation (Pl. XXVII, $A)_{\ldots}$. So broken was the ice, so deep the crevasses, so steep the slippery slope formed by crevassing and melting, and so frequent the falls of bowlders, that entrance into this broken ice area was difficult and dangerous, and a journey of any length quite impossible.

Still farther down, nearer Hayden Glacier, where the evidence clearly showed that there was formerly a moraine-covered slope, the ice margin rose as a steep cliff on whose face numerous thrust faults were clearly visible. Along this part of the ice margin rock fragments and bushes had recently tumbled, forming a talus at the base; and newly formed streams were overwhelming the alder growth on the older moraine in front of the ice with their floods of icy water and by the growth of their rapidly extending alluvial fans.

\section{INTERFERENCE WITH SUBGLACIAL DRAINAGE.}

For several miles below this point the crevassed Marvine ice swings in a gentle, crescentic curve around the outer end of the expanded and uncrevassed Hayden Glacier which coalesces with it. Formerly the drainage of the Blossom Island region escaped under the end of Hayden Glacier, almost at the exact point where it unites with the Marvine. A long, narrow bay in the ice, with steep walls, marks the site of this former outflow. The advance of the Marvine has closed this subglacial course, and for awhile the waters gathered behind the ice barrier, forming a large lake whose deposits cover a wide area. That this lake was formed in the spring of 1906 was proved by the fresh lacustrine deposits; by the fact that alders and willows, which the lake water covered, were just beginning to burst into leaf late in July; and by unmelted, stranded icebergs above the present lake level. In fact, at the time of visit, in the last half of July, the Blossom Island Lake was still shrinking.

The waters had found a new outlet under Hayden Glacier more than a mile north of the old outflow. Into this a muddy torrent was rushing, not into a well-developed ice cave, but as a broad sheet at the very base of the glacier, which was constantly slumping into the river that was undermining it. For an eighth of a mile the glacier was crossed by a series of faults (Pl. XXVIII, $A$ ) due to settling resulting from the weakening caused by this new stream course. Where the torrent enters, a vertical ice cliff, in places overhanging, rose above the 
stream. Every few minutes fragments of ice fell from this cliff, and now and then enormous masses, weighing thousands of tons, tumbled forward with a great crash into the river. The base of the cliff was littered with these fallen blocks. In the interval of ten days between my first and last view of this outlet its outline was entirely changed, and one great ice fall which I witnessed was estimated to include fully 10,000 tons of ice.

These facts confirm the other evidence that in July, 1906, this stream, the principal headwater source of Kwik River, was just finding a new subglacial course, having been forced to abandon its old one by the forward movement of Marvine Glacier. It had as yet cut only a short gorge in the ice, but was still extending it to a more stable position. In a part of this gorge one bank was a gravel terrace, and this too was rapidly tumbling into the stream, furnishing further proof that the stream was newly located there.

GLACIER MARGIN IN THE KWIK RIVER VALLEY.

From the Hayden Glacier to Yakutat Bay, Malaspina Glacier forms the western wall of the Kwik Valley. Formerly this entire margin was moderately sloping and moraine covered, for most of its length supporting alder thickets and cottonwood forest. In 1906 its condition was absolutely transformed. In was rent by a multitude of crevasses and broken into a maze of pinnacles, ridges, and tables. Not only was the ice broken by vertical crevasses, but thrust faulting had pushed it forward along nearly horizontal planes, giving rise to a broken ice cliff with numeraus projecting blocks (Pl. XXVIII, B). Stained by included débris and by a wash of mud over the surface, these ice cliffs looked so like a frost-riven cliff in the Adirondacks that, in other situations, they might readily be so classed if passed without close inspection. The resemblance was heightened by the presence of trees standing on the cliff face, as trees grow in the clefts of a jagged rock cliff.

Along this strange glacier margin blocks of ice were frequently heard to fall from the cliffs, suggesting that the motion was still in progress. There was a constant rattling of avalanches and falling bowlders, and every now and then the crash of an undermined tree. Cottonwood trees, some fully half a century old, were resting at all angles, from prostrate to vertical, and all in full leaf (PI.XXVIII, $C$ ), proving that the advance all occurred in the growing season of 1906 . Evidently the trees had started the season well, but for many of them it was their last season of life. Early in August some, though still standing, had assumed the yellow tints of autumn; others, overturned, bore only dead leaves. Frequently trees were seen to fall down the ice front or into the yawning crevasses, especially during rainstorms, when the supporting soil was most rapidly washed away.

The soil revealed along the glacier margin varied in depth from 2 to 15 feet or more, and was shown in many sections resting on the dirty ice it had so long protected. The cracking of the ice had proceeded so far that much of this soil was already gone, and the rest was rapidly washing away. Wet by the rains and by the melting ice, it was sliding down the glacier front, formin mud streams so dense that large stones were easily borne along, and building mud fans at the ice foot, into which it was dangerous to step. Change was very active along this ice margin, and its end must be to replace the verdure-covered slope by a fairly clean ice wall.

Some of the streams were already emerging from ice caves, and between early July, when I first passed along this glacier margin, and the middle of August, when I returned, a number of new caves had developed, while all the large streams had greatly increased in volume. Evidently a system of drainage was developing by headwater extension in and under the ice. These changes, together with variations in cliff form and the falling of trees, had given rise to noticeable modifications in the ice front during the interval of five or six weeks.

INCLUDED SOIL AND FOREST BEDS.

Along both the Atrevida and the Malaspina Glacier margins the glacier and glacial deposits are advancing in forested regions and overspreading old soils, peat beds, and forests. When the process of present change is at an end there will be in this region soil beds and plant beds 


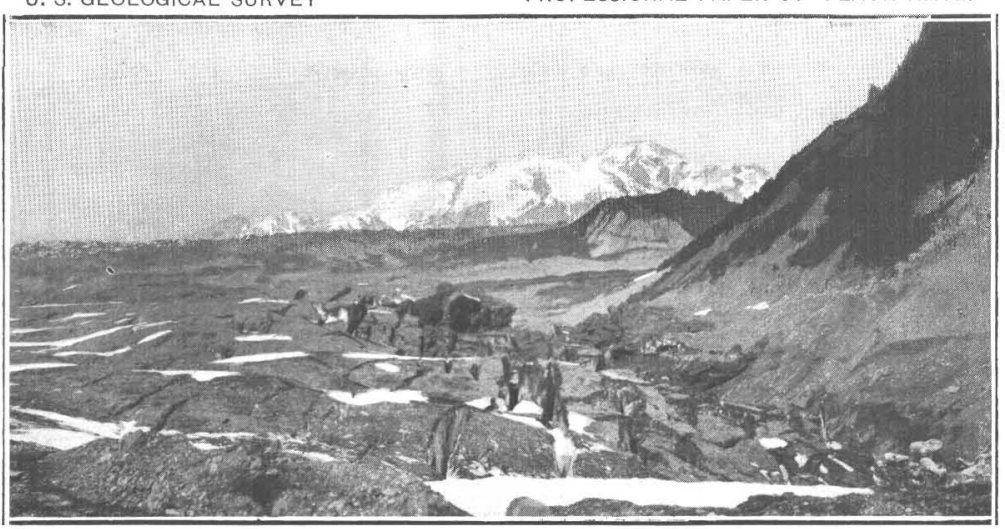

A. VIEW SHOWING BLOSSOM ISLAND HILL IIN THE MIDGROUND ON THE RIGHT), THE CREVASSED MARVINE GLACIER (BEHIND IT AND TO THE LEFT), THE BLOSSOM ISLAND DEPRESSION BETWEEN MARVINE AND HAYDEN GLACIERS (TO THE LEFT OF BLOSSOM ISLAND HILL), AND THE FAULTED HAYDEN GLACIER (IN THE FOREGROUND).

The faulting of Hayden Glacier is due to the recent establishment of a subglacial drainage channel beneath it to carry off the waters of the Blossom Island region, whose former escape a mile to the left had been cut off by the advance of the newly crevassed Marvine Glacier. Hitchcock Hills in the distance. Photograph taken July 19, 1906.

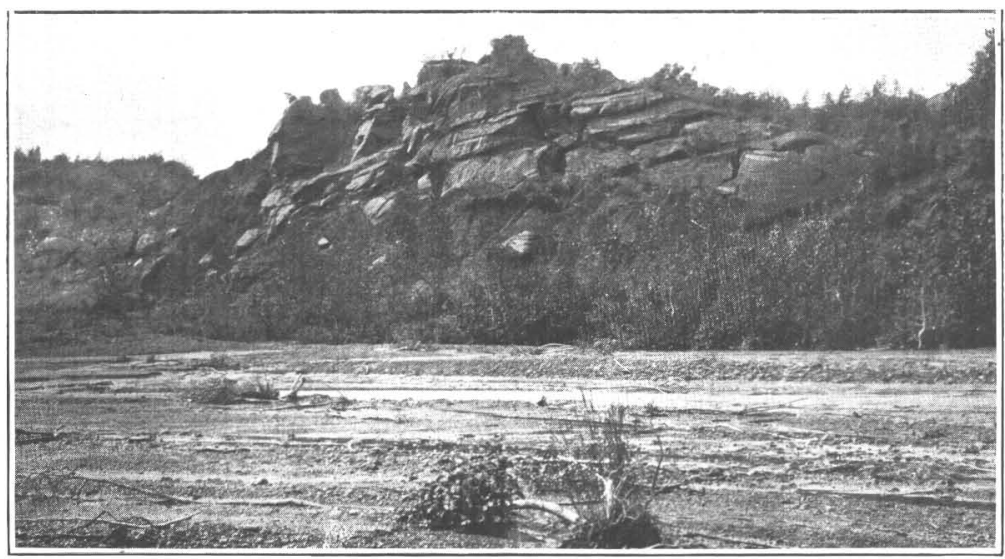

B. BROKEN EASTERN MARGIN OF THE MARVINE LOBE OF MALASPINA GLACIER, FROM ALLUVIAL FAN OF KWIK RIVER.

The broken ice cliff has protruded through the morainic soil and the forest Blocks of ice fell from this cliff as the Survey party passed, trees crashed down, and the morainic soil was constantly sliding down. Photograph taken August 11, 1906

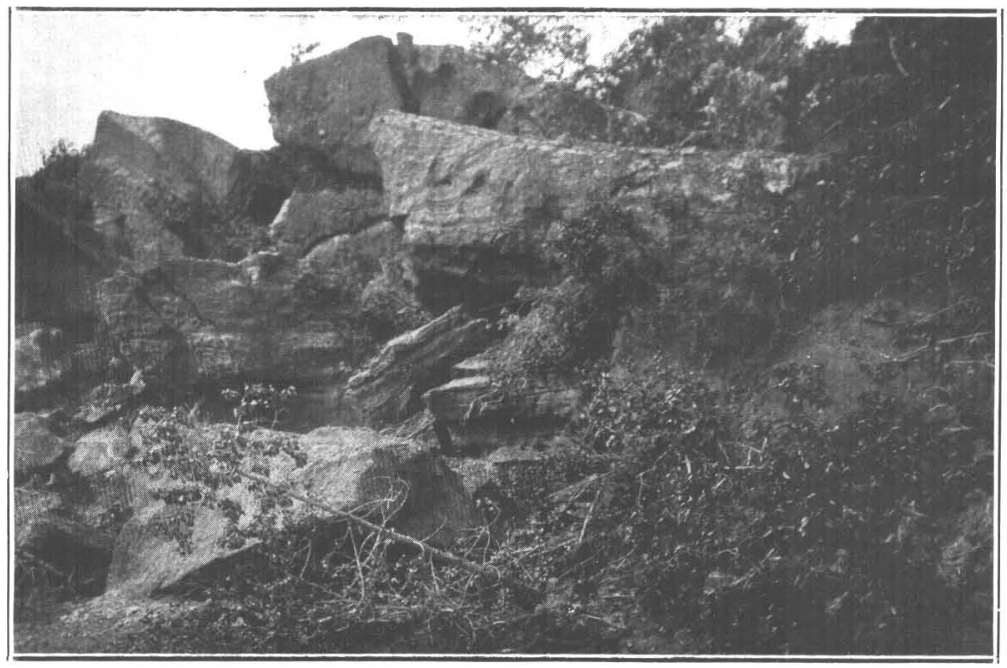

C. BLOCKS OF ICE PROTRUDING THROUGH MORAINIC SOIL AND FOREST COVER, EASTERN MARGIN OF MALASPINA GLACIER.

Cottonwood trees, in full leaf, overthrown by the recent thrust that broke the glacier margin. Photograph taken August 11, 1906. 
interbedded with glacial deposits, and all as the result of a sudden change in glacier-margin conditions. - It requires no elaboration of this subject to make it clear that here is a hint of great significance in the interpretation of Pleistocene deposits. In view of such phenomena as those described above it is evident that the interpretation sometimes placed upon plant beds and soil heds intercalated in Pleistocene deposits - namely, that they prove separate, glacial epochs-can hardly stand without the support of other and convincing evidence that the plant or soil bed interval was of long duration.

\section{RAPIDITY OF CHANGE.}

The nature and speed of the variations may be inferred from the following description of a single instance. Near the middle of August the party camped close to the ice base, by the side of a stream emerging from a depression in the glacier, whose face was a jagged cliff and whose crest bore a cottonwood forest. The stream entered a small lake, in which it was building an alluvial fan (Pl. XXVII, $B$ ). Between early July and the middle of August the stream had increased notably in volume and the fan greatly in height and breadth. The lake had nearly disappeared by filling, and the face of the glacier had changed materially by the appearance of much more ice and by the increase in breadth and depth of the valley out of which the stream flowed.

Camping here in the middle of August, during a three-day rain, I often saw and heard falls and slides of trees, moraine, and ice. The details of the ice cliff were totally changed in those three days. A cache of provisions left on an older gravel terrace, in what seemed to be a safe spot, was found two days later to be nearly overwhelmed by the stream, which had increased several fold in that length of time.

The conditions developed along this ice face are peculiarly favorable to rapid change. A latent supply of water, long blanketed and almost sealed by a coat of débris and forest, has been suddenly opened to the sun and rain, not only at its surface but, by rending and crevassing, in its very interior, along a multitude of planes. Under these conditions the ice is quickly changing to running water and is carrying away the great abundance of débris residually accumulated by the long-continued and very slow ablation of the underlying ice. An interval of at least half a century of exceedingly slow change has been abruptly terminated by a period of remarkable activity and rapid change.

It will be interesting to note what the end of this new cycle will be. Probably it will end in a treeless and perhaps moraineless glacier margin. Another season of exposure to melting should destroy most of the forest and remove much of the moraine. The débris thus removed is in part carried out into Yakutat Bay, but most of it, and all the coarsest, accumulates near the ice base, encroaching on and destroying the forest growing there.

\section{YAKUTAT BAY MARGIN.}

Along the shores of Yakutat Bay, from Kwik River to Point Manby, the margin of Malaspina Glacier was seen from a boat. Throughout this entire distance the glacier is greatly broken and quite impassable; yet it was over this very ice front that Russell easily walked in 1891. Evidently there has not as yet been a marked forward advance, but only a continuous breaking of the ice front. Thus Kame Stream still emerges from a pronounced ice tunnel, as it did when Russell saw it; but it is flanked and backed by badly crevassed ice.

The breaking up of the ice front extends at least a mile beyond Osar River and how much farther can not be stated. Where Osar River flows out from the ice, along the route followed by Abruzzi and Bryant on their entrance upon the Malaspina ice plateau, the glacier front is so badly. crevassed that packing supplies up the ice slope would be utterly impossible; and it seems doubtful if a man unburdened could ascend it without cutting ice steps all the way. Except for the absence of forest, the condition along this part of the ice front is quite like that in the $K_{w i k}$ Valley; already described. From Point Manby eastward along the route followed by Russell 
in 1891 , the ice is everywhere crevassed, and a man could not possibly traverse it except with the utmost difficulty, cutting ice steps all the way.

Northwest of Point Manby, toward Sitkagi Bluffs, the crevassing diminishes, and it seemed that one might possibly enter upon Malaspina Glacier by that route; but the view of this part of the glacier front was too distant to make certain of this. On one point, however, there is certainty-Malaspina Glacier can not now be entered upon from the Yakutat Bay side either at or east of Point Manby. Its utility as a highway is, therefore, gone until such time as the present remarkable advance of Marvine Glacier is at an end and its effects are healed by ablation.

\section{BLOSSOM ISLAND REGION.}

Hayden and Marvine glaciers meet at a high angle, leaving a triangular depression between the mountain base and the ice, above which rises a low hill called Blossom Island by Russell (PI. XXVIII, $A$ ).

SMALL GLACIERS.

The mountains to the north of the depression support small glaciers, one of which, a very small one, is a typical talus glacier. It is a well-developed, débris-covered glacier, extending to the outlet of its valley; but it is separated from its very definite névé by a steep, high rock cliff.

The largest glacier from these mountains occupies a broad, U-shaped valley directly north of the Blossom Island hill. This glacier splits against the northern slope of Blossom Island, sending a small tongue to the west, where it comes within a quarter of a mile of joining a small glacier just northwest of Blossom Island, and a larger tongue eastward toward Hayden Glacier. Morainic deposits in the depression, still nearly barren of vegetation, prove a recent marked recession of this glacier, particularly of its eastern tongue; and its stagnant, morainecovered terminus shows that the recession is still in progress. At no very remote period the entire Blossom Island depression was evidently occupied by ice, which accounts for its not having been already filled with glacial deposits.

\section{BLOSSOM ISLAND LAKE.}

The streams from these small glaciers, together with the drainage from the Marvine and Hayden glacier margins, unite in a shallow lake with an area of somewhat more than half a square mile. The water, thence emerging as a large, muddy torrent, disappears under Hayden Glacier, as described on page 85. Hayden Glacier forms the southeastern shore line of Blossom Island Lake, Marvine Glacier the western shore, while the remaining portion is bordered by alluvial fans and by overridden gravels coated with a thin morainic veneer. A sparse growth of willow and alder, with bushes at least twenty years old, covers these gravels.

On July 19 these bushes had not fully leaved out, and the annual and perennial plants were just sprouting. A film of fine glacial mud coated many of the bushes and overspread the ground up to a fairly definite level of 20 to 25 feet above the then existing lake level. There were many pools of muddy water in the depressions, and stranded icebergs were found several feet above lake level. These facts proved conclusively that the Blossom Island Lake had been much higher that spring. covering an area of not less than 4 or 5 square miles. In fact, on July 19 the lake had not been lowered to its normal level, for willows were still partly submerged in it.

Such a rise can not be of common occurrence, for it has so set back mature bushes that it is doubtful if they will survive; and they certainly could not endure many such floods. As stated in a preceding section, this rise was due to the blocking up of an old subglacial outlet by the advancing Marvine Glacier; and the lowering of the lake has resulted from the development of a new outlet, in an abnormal position, a mile away from the former one.

The deposits of this higher lake stage are interesting. Being charged with rock flour, supplied from many streams, a sheet of fine-grained clay was spread over the lake bottom, presumably in a fairly uniform sheet. At the time of visit, however, the clay was entirely 
absent from some areas, and was running rapidly off from others in little streams of liquid mud, which flowed down even moderate grades and showed a strong tendency to run off from the gentle slopes of the ridges and accumulate in the shallow depressions.

This phenomenon throws light on the peculiar distribution of the lake-clay deposit in the area formerly covered by the expanded Finger Lakes of central New York. It had puzzled me greatly to account for the fact that some areas of very gentle slope have no lake clay, while near at hand the clay is 10 to 20 feet deep. Here was an exposition of the process in actual progress.

Where streams had entered the expanded lake there was a variation in the sediments. At the highest lake stage clay was deposited offshore, to be buried, when the lake shrunk, by beds of sand or gravel, or both. Consequently one would frequently step on what seemed to be compact sand or gravel, and sink through it into a layer of liquid, sticky mud often a foot or two in depth. Scattered over the lacustrine deposit were occasional large rock fragments, doubtless brought by icebergs; and in a few places the clay layers were seen to be disturbed by the push of a grounded berg.

MARGINAL DEPOSITS.

The combination of lacustrine, stream, and glacial deposits, in ever-changing relation, introduces the possibility for a complex marginal accumulation. At present débris is failling from the glacier front, forming a talus resting on an ice base. In time this will rise to a pronounced lateral moraine, like one or two bands of earlier origin which skirt the ice base at a distance of 50 to 100 yards. Innumerable streams of various sizes are descending through this moraine, cutting here and depositing there, in some cases having built good-sized alluvial fans. Between the earlier morainic ridges are numerous lakelets, some fed by clear-water streams and others by turbid streams which create local clay pockets in the moraine.

In addition to these causes for variety in deposit, there is the large Blossom Island Lake, close at hand, in whose fluctuating area clay, sand, and gravel are accumulating, while extensive alluvial fans are building out into it. If any or all of these deposits happened to be accumulated on the ice, its melting would give rise to an irregular moraine of very complex character, including much stratified deposit. If the ice should override the deposit, still different characteristics would be introduced; but, if undisturbed by ice push or slumping, there would ultimately be an extensive gravel plain, underlain by and in part interstratified with clay, terminating on two sides against ice walls. Subglacial stream courses along at least two lines would extend from this plain, possibly being represented by eskers 4 or 5 miles in length.

Many of the glaciers of the Yakutat Bay region possess marginal conditions favoring similar complex deposit, and in no two are the conditions exactly alike, presenting, as they do, ever-varying combinations of erosion and deposition by both ice and water. From a study of such conditions, of which the Blossom Island area may be taken as a type, one readily understands the vast degree of complexity in morainic deposits left along the margin of the ancient continental glaciers. 


\section{CHAPTER VI.}

\section{ADVANCE OF THE GLACIERS. \\ GENERAL STATEMENT.}

The facts stated in the preceding descriptions of individual glaciers show that there is a remarkable change in progress in at least four of the many valley glaciers of the Yakutat Bay region-the Variegated, Haenke, Atrevida, and Marvine. This change is in the nature of a paroxysmal thrust, as a result of which the ice is badly broken, as if a push from behind had been applied with such vigor as to break the rigid resisting ice mass in front. In each case the effect of this thrust is felt from far up the mountain valley well down toward the terminus of the glacier, and in the Haenke and Marvine glaciers to their very end.

In Variegated and Atrevida glaciers the ice has been broken for a distance of 5 to 7 miles; in Marvine Glacier the breaking extends fully 15 miles. The crevassing in all cases extends completely across the valley portion of the glacier and down into the stagnant, or nearly stagnant, moraine-covered margin. In all cases, too, the thrust is accompanied by a forward movement of the margin; and in at least three cases-the Variegated, Haenke, and Atrevida-there has been a distinct thickening of the ice as a result of the forward thrust. It is probable that there has also been a thickening of the Marvine Glacier margin; but as it was not visited in 1905 there are no comparative observations on which to base a definite statement.

This remarkable advance of these glaciers is recent, and occurred mainly, if not entirely, in the ten months preceding June, 1906. Not only is the movement recent, but it was actively in progress at the time of the second visit, in the summer of 1906 . In at least one case, that of Galiano Glacier, a forward movement occurred and died out during the interval between 1890 and 1905. There are indications that an advance is beginning in some of the glaciers, notably the Lucia and the Seward; but there are others which show signs neither of the approach of such an advance nor of its having already come and gone.

From these facts it appears that, for some reason, a remarkable and rapid change is in progress in at least a number of the glaciers of the Yakutat Bay region, interrupting a period of long quiet, in some instances fully half a century, and affecting different glaciers at different times One glacier (Galiano) has passed completely through a cycle of change; others (Variegated, Haenke, Atrevida, and Marvine) entered upon it in 1906; still others (Lucia and Seward) show signs of the beginning of such a cycle; and in other cases there are, as yet, no indications of its approach.

\section{CaUSE OF THE ADVANCE.}

Such a remarkable change in the condition of glaciers as to transform long-stagnant, unbroken, moraine-covered valley glaciers into a labyrinth of crevasses in the short interval of ten months - a phenomenon, so far as known, not elsewhere recorded-calls for a special explanation. Further, as the phenomena in the field clearly prove that there has been a wave of advance passing through the glaciers with such rapidity as to break the ice, instead of causing a slow forward movement such as commonly results from normal variations in supply, this explanation must postulate a cause sufficient to start a rapid wave.

\section{CLIMATE.}

In seeking an explanation for the advance of a glacier one naturally, first of all, considers climatic causes. In the attempt to apply this explanation to the case in hand, two serious difficulties have arisen. In the first place, no such profound result from climatic variation has ever 
before been noticed. In the second place, it seems impossible that the amount of additional snowfall required to start such a tremendous wave of advance could be supplied by seasonal variations; for it would mean a sudden and great increase, interrupting half a century of fairly uniform conditions. There is no direct evidence against this hypothesis, since we have no rainfall records for this region; nevertheless, one seems warranted in dismissing it merely on the basis of improbability, for such a profound and sudden change in climate would of itself be more remarkable and more difficult of explanation than the phenomenon which it is called upon to explain.

UPLIFT.

A second hypothesis that has been considered is that of uplift. Concerning this also there are no definite facts to advance, but against it may be argued the improbability of so decided a change in so short a time as to profoundly disturb the glaciers radiating from a mountain center. To produce such an effect an uplift would need to amount to at least hundreds of feet, and to take place in a brief interval of time. In fact, since the glaciers all head in lofty, snow-covered mountains, up whose slopes damp ocean winds rise, and on which the snow cover descends to within 2,000 or 3,000 feet of sea level, it is very doubtful if the amount of snowfall upon the mountains would be greatly increased even if there could be an uplift of hundreds of feet. This hypothesis is so utterly improbable that it also may be dismissed without further consideration.

CHANGE OF GRADE.

A change of grade in the valley glaciers as a result of alterations of level accompanying the earthquake of 1899 has been suggested, but lacks probability; for a change in grade suffcient to transform a nearly stagnant, smooth-surfaced valley glacier to one as badly crevassed as an ice fall is wholly unlikely. Moreover, in the case of Atrevida and Variegated glaciers, at least, direct observation proves that the grade was essentially the same in 1906 as in 1905; and in both cases it was far too low, in 1906, to account for movement rapid enough to break the ice. It is evident that the cause of the crevassing must be sought, not in the influence of grade, but in an acceleration of motion due to a push from upstream, acting upon low-grade glaciers whose forward motion, up to 1905 , had been so slight as to permit the concentration of broad fields of morainic waste upon their surfaces.

\section{EARTHQUAKE SHOCKS.}

Two hypotheses involving earthquake effect were considered and quickly dismissed. One of these was that some very recent earthquake had so shaken the region as to break the ice into the condition observed in 1906 . This hypothesis was readily disproved on inquiry, when it was found that there had been no notable earthquake in the Yakutat Bay region since 1899.

The second earthquake hypothesis was that the shock of 1899 was responsible for the conditions of 1906 by actually breaking the ice, though the effects are only just now appearing at the surface. Numerous facts disprove this hypothesis, the most fatal being the convincing evidence that a forward movement was actually in progress in the summer of 1906 . As has been shown above, the change is associated with, and apparently the result of, a forward push, so that any hypothesis which does not account for this is necessarily eliminated.

SNOW SUPPLY RESULTING FROM EARTHQUAKE SHAKING.

Statement of hypothesis.-There remains only the hypothesis of a great increase of the snow supply due to earthquake shaking. This hypothesis is, in a word, that during the earthquake of 1899 the mountains from which the snow supply of these glaciers is derived were so vigorously shaken that great avalanches of snow and rock were thrown down to the névé, starting a vigorous wave of advance whose effects have now reached the glaciers described above. Of all the hypotheses which have suggested themselves, this alone seems capable of explaining the phenomena. No facts opposing it have been discovered, while there is much in its favor. 
Earthquakes.-The earthquake of $1899^{a}$ was of unusual vigor. Throughout a period of seventeen days the region was subjected to a succession of earthquake shocks, some of which were of exceptional vigor, notably those on September 10 and September 15. The most violent shocks were of such strength that they were recorded on the seismographs in Europe, Japan, and at the Cape of Good Hope. During these earthquakes the coast line of Yakutat Bay was greatly deformed; in one place, on the western side of Disenchantment Bay between Turner and Black glaciers, the beach was hoisted 47 feet above sea level. The people living at Yakutat, the nearest inhabited point, report long-continued and terrifying shaking of the ground. Some prospectors camping near Variegated Glacier make a similar report, adding to it the statement that the most violent shakings were accompanied by noises like thunder, as huge avalanches of snow and rock descended the neighboring mountain slopes.

Proof of unusual avalanches.-There can be no question but that during these shocks immense quantities of snow and rock were thrown down from the steep mountain slopes. The snow line descends to within 2,000 or 3,000 feet of sea level, and the mountains rise to elevations of 10,000 to 15,000 feet. By glacial erosion and other forms of denudation the valley slopes have been greatly steepened, so that over large areas the snow lies in very unstable positions. Even under ordinary conditions snow avalanches may be seen at almost any time among these lofty mountains. This is especially true during and after snowstorms, which are unusually heavy in September, the month during which the earthquake of 1899 occurred. When to this heavy snow blanket, which mantles the steep mountain slopes (Pls. V, VI, XI), is added a repeated shaking of the mountains, it follows that a great and sudden addition to the névé must have taken place.

In addition to the testimony of the prospectors mentioned above and of other men at various points in the Alaskan coast ranges, direct evidence of heavy downfall of snow, ice, and rock avalanches from the mountains is obtained by a comparison of present conditions with photographs taken by Russell. In two cases where these comparisons were possiblethe valleys of Black and Galiano glaciers-there have been notable changes. In the Black Glacier valley areas which in 1890 were covered with vegetation are now bare rock (p. 68). In the Galiano Valley large patches of snow and ice which in 1890 clung to the steep slopes have disappeared (p. 71).

A third line of evidence consists of the remains or scars of actual avalanches observed. All around the shores of the Yakutat Bay inlet there are far more evidences of the occurrence of avalanches of recent date than are normal in a mountain region, and more than are seen along the inside passage. The Yakutat natives declare that in places the "face of the mountains was totally changed," and my observations lead me to accept this statement as essentially true. Evidence of such avalanches occurs not only along the shores of the bay, but also in the mountain valleys. For example, there is a great avalanche scar on the southern face of Amphitheater Knob between Galiano and Atrevida glaciers; evidence of a recent great avalanche is plainly visible in the Galiano Glacier valley (p. 71); another on Latouche Glacier (p. 65); and an enormous mass of recently fallen débris still lies on Hayden Glacier (p. 83).

Adequacy of the cause.-That there was abundant cause for an unusual downsliding of snow, ice, and rock in 1899, and that this downfalling actually did occur, the above facts amply prove. A notable accession of supply in the névé region, such as these facts demonstrate, must of necessity start a wave of advance in the glacier, and this wave would naturally be a great one, far more powerful and sudden in its effects than is liable to be produced by normal climatic variations. One possible difficulty in the way of acceptance of the explanation here proposed is the briefness of time for the transmission of this great wave; in fact, this difficulty has at times led me to question whether it may not be necessary to seek the explanation in an earthquake of more remote date. Facts bearing upon this question are not at hand.

Probable effects of unusual avalanche supply.--It is well known that normal climatic variations cause a slow wave of advance in glaciers; but exactly what would follow a sudden and

a Tarr, R.S., and Martin, L., Recent changes of level in the Yakutat Bay region, Alaska: Bull. Geol, Soc. A merica, vol. 17, 1906, np. 29-64. Also Report on the Yakutat Bay earthquakes of September, 1899, in preparation. 
abnormal accession of snow supply is not so clear, for, so far as known, no similar phenomenon is reported from other regions for comparison. So far as I am able to consider the question, however, I am led to believe that it would not be proper to make use of the results of normal climatic variations, as an exact parallel, in the consideration of the effects which would follow a sudden accession of enormous quantities of snow and ice in the glacier reservoir. As in rivers there are both moderate rises and floods, so in glaciers there may be gentle fluctuations and vigorous glacier floods. It seems probable that so great an increase in supply would start a wave of such power as to crowd upon the rigid and nearly stagnant ice of a wasting glacier. Such a crowding, by applying a rapid thrust against the ice, might well push it so hard and fast as to force it to slide forward and cause it to find relief from strain by massive breaking instead of by interstitial movement. It is even conceivable that the effects of such a wave might advance faster than the wave itself.

To state the latter point more fully, when a great wave of advance, starting in the névé region, reaches the glacier proper, it may exert sufficient pressure to push forward the ice in front of it and thus cause it to break, pile up, and advance even down to the very margin. In this way the effects of a great wave of advance might well extend clear to the end of the glacier suddenly and long before it would be possible for a normal wave to reach the terminus. Some such process as this is indicated by the fact that in a period of not more than ten months miles of ice were rapidly changed from a surface easily traversed to one consisting of a labyrinth of crevasses.

If the lower portions of a glacier are moving as a result of viscous flowage, it is possible that a great increase in pressure, such as might result from a sudden addition of enormous quantities of snow and ice to the néve field, might cause so decided a forward movement in the viscous body as to break the more rigid upper layers into a condition like that observed in these glaciers. Even this process does not seem competent to account for the breaking up of the relatively thin; stagnant outer portions of the glacier without some rigid forward thrust and accompanying piling up along the margin thus thrust forward.

Lack of previous recognition of phenomenon.-That such a phenomenon as this has not hitherto been described is not remarkable in view of the fact that regions of both large glaciers and violent earthquakes are not common, and, furthermore, that those which do exist are remote and not yet closely studied. It is a mere chance that this particular case was detected. Had it occurred twenty years ago, probably nothing would have been known of it; and even if it had occurred between 1904 and 1905, instead of 1905 and 1906, the evidence would have been very difficult of discovery and interpretation. The fact of two expeditions going to the same remote region in successive seasons, at the very time most favorable to a study of the phenomenon, accounts for its discovery.

Possible application to other regions.-One is led to question whether some other instances of advancing glaciers may not be explained by the same cause. For example, may not some of the advancing Alpine glaciers be moving forward as a result of a moderate thrust from a slight increase in the névé due to earthquake shaking of no great intensity? Even moderate shaking would add to the névé more snow than the excess resulting from a series of severe winters under ordinary climatic variations; and the wave from such an accession would not be powerful enough to break up the ice, as in the case of these Alaskan glaciers. One is also led to question whether some of the earlier advances of glaciers in this very region may not be due to former earthquakes of unusual intensity. giving rise to glacier floods of large proportions.

\section{GLACIERS THAT ARE NOT ADVANCING.}

That some glaciers are advancing and others are not suggests the possibility that there is some selective action, as a result of which certain glaciers are immune from the effects which have caused so remarkable an advance in others; but this seeming immunity may be only apparent.

If the cause for the advance is earthquake shaking, as here suggested, it ought in time to affect most, if not all, of the glaciers of the region. But there is no reason to expect that the 
glacier flood would occur at the same time, or to the same degree, in the different glaciers. There are, in fact, at least three important reasons why it should vary in time, or in intensity, or both.

Of these, one of the most prominent is the length of the glacier; and in this connection it is notable that one of the smallest glaciers, the Galiano, has already passed completely through a period of advance, and that Atrevida Glacier now shows the full effects of the advance, while its longer neighbor, the Lucia, has not been affected, except possibly in its upper valley portion. On the other hand, the long Marvine Glacier, a far greater ice stream than even the Lucia, has entered upon the maximum development of the effects, while some very short glaciers, like the Black, just south of the Haenke, show signs neither of having passed through the period nor of its approach.

These contrasts, however, may be due to one or both of the other two possible causes for variation in the effects of the earthquake shaking. One of these is the steepness of the valley walls, especially in the snow-field areas; the other is the amount of snow available. Obviously there must be great differences in the steepness of the mountain slopes and in the amount of snow available in unstable position; and, according as these conditions favor or oppose a sudden increase in the snow supply to the névé, under the impulse of earthquake shaking, there will be marked variations in the rate and the amount of consequent advance.

A possible fourth cause for variation in the effects of the shaking is difference in intensity of shocks from place to place. While undoubtedly the entire region was severely shaken again and again, it is probable that some portions of the area escaped with far less shaking than others, and consequently with a much smaller addition of snow to the névé.

There are, therefore, adequate explanations for the differences observed in the condition of the various glaciers. Some, quite certainly, will never show the effects of the earthquake shaking; others, which have not yet advanced, may be expected to push forward later. It can not be definitely predicted when this will occur in any individual case; but, from the rapidity with which the advance has swept throughout the entire length of some of the glaciers, it seems probable that in all cases where the cause for the advance has operated, the effect of the wave will become manifest within a very short period of time. Therefore, it may be predicted that, in all probability, this region will be one of great interest to glacial geologists in the next few years. It is highly probable that Malaspina Glacier, for so long a period a nearly stagnant ice plateau, will become crevassed throughout its entire length, and, advancing along its margin, possibly enter the sea, discharging icebergs both into Yakutat Bay and into the open Pacific, along a coast where, at present, the glacier front is faced by strips of alluvial fan and beach.

\section{FUTURE CONDITION.}

In addition to the possible future advance of other glaciers, it is interesting to consider what may be expected to follow the advance of those glaciers already affected. On this point Galiano Glacier throws much light. From the results in this case it may be inferred that in each instance the wave of advance will soon die out, that stagnation will speedily follow, and that ablation will proceed to again man'tle the glacier margins with a cloak of morainic débris. Much of the moraine formerly available for this mantle will have been lost as a result of the breaking due to the recent advance. Some of it will have tumbled to the bottom of the glacier through crevasses, and much of it will have been carried away by the new-born streams. The removal of this material will leave less to blanket the ice and to prevent it from wasting. For this reason a more decided recession of the margin of the glaciers should be expected in the immediate future. This more rapid recession may be expected to be increased by a diminution in the supply of ice; for, since the shaking down of quantities of snow in the supply ground has removed the accumulations of many years, until such time as its place is taken by additional snow accumulation there should be a decided deficiency in supply. One may, therefore, fairly predict a distinct recession following the notable present advance. 


\section{GEOLOGIC EFFECTS.}

The sudden breaking of extensive areas of glacier ice and the accompanying advance of the broken glacier margins give rise to some striking geologic changes, most of which have been so fully described under the individual glaciers that only a summary is called for here. By the advance, in at least two instances, the course of good-sized glacial streams has been completely altered. The cracking of the glaciers opens to ablation an enormous area of ice hitherto either protected by débris or buried beneath the surface of the previously smooth glacier. The accumulated moraine on the glacier surface, and particularly along its margins, furnishes an immense quantity of débris, so that not only is the volume of the glacial streams greatly augmented, but, by the increased sediment supply, their activity in transporting and depositing sediment is increased manyfold.

The advancing ice pushes against and overrides deposits previously made. It also buries and mixes with the deposits of débris the battered fragments of both bushes and trees which grew in front and on the surface of the glaciers. Under the variable and ever-changing conditions accompanying this deposition and overriding there is being accumulated a remarkable deposit of stratified and unstratified material, mixed with plant fragments. The significance of this phenomenon in relation to the interpretation of plant beds in Pleistocene deposits is evident. ${ }^{a}$

\section{Possible ECONOMIC EFFECTS.}

In this unsettled region the economic effects of the sudden advance of the glaciers have not been of marked importance. But if the advance extends to the entire Malaspina Glacier and to Hubbard and Turner glaciers, there may result some effects of distinct significance to man. Already the ice cliff of Turner Glacier has been extended fully a mile, and the area of iceberg discharge has thereby been greatly increased. If Turner and Hubbard glaciers also push forward, the amount of ice discharged into Yakutat Bay may so far exceed that of the present as to produce a distinct effect on the seal-hunting industry in the bay, upon which the Yakutat natives depend. If Malaspina Glacier advances far enough to enter the bay and the ocean, as it may possibly do, the discharge of icebergs will constitute a menace to navigation along this coast.

Farther to the northwest the city of Valdez is situated on an alluvial fan directly in front of Valdez Glacier. If earthquake effects should start a wave of glacier advance there similar to that witnessed in the Yakutat Bay region, Valdez would be in danger both from the advancing ice and from the increased volume of water discharged from it.

In several places the Alaska trails extend over glaciers, and such an advance as that in the Yakutat Bay region would of course destroy these. In the consideration of routes for railroads it is proposed, in some instances, to lay the tracks close by the ends of glaciers, and even over stagnant glacier termini. Such a sudden advance of glaciers as has occurred in the Yakutat Bay region would, of course, completely interrupt travel along such routes. In this region of frequent earthquakes it is not at all unlikely that glaciers of other sections may, during the present century, receive an impulse of advance similar to that which has visited the Yakutat Bay region. It is certainly a possibility which ought to be taken into consideration in building towns, roads, and railways.

a Tarr, R.S., Some phenomena of the glacier margins in the Yakutat Bay region, Alaska: Zeitsebrift für Gletscherkunde, III Band, 1908 , p. 105. 


\section{CHAPTER VII. \\ MORAINIC DEPOSITS OF FORMERLY EXPANDED GLACIERS. EVIDENCE OF FORMER EXPANSION.}

RECENT RECESSION.

It has been shown by Russell (1890-1891) and by Gilbert (1899) that at the time of their studies the glaciers of the Yakutat Bay region had long been in a state of general recession. A comparison of the descriptions and photographs of these observers with the conditions in 1905 shows that the ice retreat had, in general, continued to that date, after which definite advance had occurred in some of the glaciers. The evidence is also clear that the recession of the fifteen years between 1890 and 1905 was only a part of a longer period of retreat. As Russell pointed out, " the "broad débris fields, which cover all the lower ice streams not ending in the sea," and "the absence of vegetation on the smooth rocks recently abandoned by the ice" furnish distinct proof of recent recession of the glaciers.

The descriptions of Malaspina and Puget were long considered conclusive proof that Hubbard Glacier extended 5 or 6 miles farther down the bay a hundred years ago than it does at present, but this conclusion has recently been questioned on the basis of an analysis both of the evidence in the field and of the descriptions of these explorers. ${ }^{b}$ Nevertheless, while it seems that an appeal can not be made to historic evidence on this point, and while the field evidence points rather clearly to the conclusion that Hubbard Glacier was not as far out as Haenke Island in the latter part of the eighteenth century, there is abundant evidence that there has been a great, long-continued, and geologically recent recession of the glaciers of the Yakutat Bay region. There is little doubt that the recession of the last iffeen years is only a part of this great retreat. The sparseness of vegetation in Disenchantment Bay, in Nunatak Fiord, and in contiguous parts of Russell Fiord is explicable only on this hypothesis.

FORMER EXTENT OF GLACIERS.

That the ice at one time extended throughout the entire Yakutat Bay inlet is proved by several lines of evidence: (1) There are extensive morainic deposits outside of the mountain front, both at the head of Russell Fiord and at the mouth of Yakutat Bay, these being included under the general name Yakutat foreland; (2) submerged morainic topography is clearly indicated by the soundings in Yakutat Bay, notably in the crescentic ridge which sweeps across its mouth (fig. 1); (3) transported rock fragments and morainic deposits high on the sides of the inlet and on the neighboring mountains definitely establish the former presence of a great ice flood; (4) no less definite are the undoubted effects of powerful glacial erosion, which are very pronounced throughout the inlet; (5) many marginal drainage channels, no longer occupied, prove the former presence of ice.

These several lines of evidence will be considered separately, and the more extensive glaciers of the ice-flood period will be called, respectively, Yakutat Bay Glacier, Nunatak Fiord Glacier, and Russell Fiord Glacier.

$a$ Russell, I. C., An expedition to Mount St. Elias, Alaska: Nat. Geog. Mag., vol. 3, 1891, p. 100; Climatic changes indicated by the glaciers of North America: Am. Geologist, vol. 9, 1892, pp. 328-330.

b Tarr, R. S., and Martin, L., Position of Hubbard Glacier front in 1792 and 1794: Bull. Am. Geog. Soc., vol. 39, 1907, pp. 129-136. See also pp. 21-22 of this report. 


\section{YAKUTAT FORELAND.}

Owing to the dense forest which clothes the margin of the Yakutat foreland it was very difficult to examine its detailed characteristics, but it was entered at several points, and a good bird'seye view of it was had from the slopes of Mount Tebenkof, and a fair idea was thus obtained of its general features.

\section{GENERAL FEATURES.}

A bird's-eye view.-As viewed from the slopes of Mount Tebenkof it was evident that the Yakutat flat was composite in character. For a distance of 3 or 4 miles from the shores of the bay, near Knight Island, the surface was rough and hummocky, with many ponds and small lakes and some small prairie areas, the last apparently filled ponds. The roughened surface was forest covered and extended eastward as a fringe along the mountain base, projecting seaward in a crescentic bend near the head of Russell Fiord.

Between this forest-covered morainic area and the ocean the surface was evidently much smoother, and this level area was, on the whole, free from forest. Here and there slightly higher, drier portions support forest; but such places are exceptions, being islands in an expanse of swampy prairie.

From this bird's-eye view the distinct appearance was that of a looped moraine deposited as a fringe to an expanded Russell Fiord Glacier, to numerous smaller minor glaciers descending the mountains between Russell Fiord and Yakutat Bay, and to a great glacier occupying Yakutat Bay as far out as Ocean Cape-all these moraines being united in a complex whole with an outer border of outwash gravels. The flat area outside the moraines is roughly triangular in form, as if a great outwash gravel plain had been deposited in the interlobate area between the two moraines of the expanded Russell Fiord and Yakutat Bay glaciers.

Foreland southeast of Yakutat.-The interpretation based on the bird's-eye view was tested and verified by a number of short excursions into the interior of the foreland and by one journey of $9 \frac{1}{2}$ miles southeastward from Yakutat to the terminus of the Yakutat and Southern Railway, at the mouth of Situk (see-tuck) River. Wherever examined at Yakutat the surface of the foreland was distinctly morainic, with numerous hummocks and ridges inclosing kettles, in many of which there were ponds and swamps. Wherever cuts revealed the nature of the morainic material it was found to be stratified gravel, though in places confusedly stratified. Both in the gravels and on the surface were many large bowlders of crystalline rocks, including a great number of white granite and white marble, whose only possible source is far back among the mountains.

Along the line of the railway the morainic condition extended for a distance of less than $a$ mile from Yakutat; then the surface became more regular, and soon developed into an evensurfaced plain, with no ridges, no kettles, and no bowlders. This plain is made of gravel and sand, becoming steadily finer toward the Situk, evidently a perfect example of an outwash plain grading into the moraine of the Yakutat Bay Glacier. It is so level that streams flow across it with sluggish current, and its surface is too damp for tree growth except in small insular patches on slightly higher ground. This outwash gravel plain, which was crossed for a distance of more than 8 miles, from northwest to southeast, is apparently the dominant feature in the Yakutat foreland.

The moraine border is clothed by a mature forest in which there are not only living trees of enormous size, but also great numbers of fallen trunks of old trees. It seems certain that the age of this forest is to be estimated in centuries and that the ice has been absent for at least that period of time.

The outer border of the Yakutat foreland is the ocean beach of the open Pacific, behind which are dunes, and often inclosed lagoons or sloughs, navigable for small boats. In these and in the mouths of the streams flowing into them the salmon are caught.

74228-No. $64-09-7$ 
In the course of a study of the salmon fisheries, Ensign C. R. Miller crossed the Yakutat foreland from a point near the head of Russell Fiord to the mouth of Situk River in July, 1901. ${ }^{a}$ After leaving the mountains he passed first through a lake $1 \frac{1}{2}$ miles in length, 200 to 700 yards in width, and 190 feet above sea level, nestled at the mouth of a mountain valley, with walls rising 500 to 2,000 feet. This lake receives the drainage of a small glacier, which gives the water a greenish color and a low temperature $\left(45.5^{\circ}\right.$ at the surface on July 3$)$.

An outflow at its south end connects this lake with a second one, which I have named Lake Miller. ${ }^{b}$ The stream is 20 feet wide and 2 feet deep, flowing with a "very swift current over a rocky and bowlderous bed, having in places small areas of sand and gravel." These bowlders indicate that the surroundings of the stream are morainic. Lake Miller, which is roughly circular, with a diameter of about 2 miles, stands 110 feet above sea level, with clear water and, on July 3, a temperature of $60^{\circ}$, evidently not receiving direct contributions from glaciers. The mountains on the northern shore rise 2,500 feet.

Situk River flows from the southern side of the lake with a width of 50 feet and a depth of 2 feet, flowing first with a strong current of very clear water and a temperature of $60^{\circ}$ to $62^{\circ}$. "The bottom at first is rocky and bowlderous, quickly changing to gravel, and finally to sand and mud, as the sea is reached." The distance from lake to sea is 13 miles in a straight line, but the river flows across the flat in a winding channel.

From Miller's description it is evident that Lake Miller is also surrounded by morainic topography, but that the outwash gravel plain begins a short distance below it: It seems probable that these two lakes occupy depressions in terminal moraines of the minor expanded valley glaciers, representing on a small scale the conditions which have given rise to the expansion at the head of Russell Fiord. This conclusion is supported by the fact that the lakes have fairly regular shore lines, and are apparently deep, while the other lakes on the foreland, lying at a distance from the mountains, are very irregular, with many islands, and are evidently shallow.

Foreland at head of Russell Fiord.-Where Russell Fiord extends beyond the mountains it expands to form a great lakelike bay, which Gilbert ${ }^{c}$ compares in form to the terminus of Davidson Glacier. It has every appearance of marking the site of an expanded glacier end. Twelve miles to the southeast Yakutat Glacier projects from the mountains, and, in size and position, presents an excellent picture of what Russell Fiord Glacier must have been when it occupied the site of the present head of Russell Fiord.

The Boundary Commission's map does not exactly represent the actual conditions. The bay is in reality more expanded than appears on the map, and its coast line is far more irregular, consisting of alternate headlands and bays. For some distance beyond the mountains the platform of the foreland, revealed in the headlands, consists of rock, planed off to near sea level either by marine erosion or by subaerial denudation; but elsewhere the headlands are entirely of drift, at least above the water. Near the head of the bay, on the western side, there is a low gravel island, half a mile from shore; and between it and the foreland is another gravel island, connected to the mainland by a spit. Both these islands are being rapidly cut away by the waves.

These irregularities of the coast line are evidently constructional, so far as they concern the unconsolidated beds, and in form they bear close resemblance to the topography produced by ice contact with terminal deposits. For these reasons Gilbert's interpretation is accepted with confidence. By this interpretation it is inferred that during the greatest expansion of Russell Fiord Glacier the ice extended 3 or 4 miles beyond the mountain front, expanding slightly and depositing moraine upon the old planed-down rock platform which fringes the mountain front. This terminal moraine, roughly crescentic in form, extends 4 or 5 miles beyond the mountain front, being faced on its outer side by an outwash-gravel plain, sloping gently seaward and coalescing with a similar plain built by streams from the expanded Yakutat Bay

a Bull. U. S. Fish Comm., vol. 21, for 1901, pp. 382-390.

b After Ensign C. R. Miller, its discoverer and first explorer.

$c$ Gilbert, G. K., Glaciers and glaciation, Harriman Alaska Expedition, vol. 3, 1904, p. 51. 
Glacier and with smaller fans supplied from minor mountain valley glaciers between Russell Fiord and Yakutat Bay.

The foreland has not entirely ceased to grow. Between Russell Fiord and Yakutat Bay it is receiving only minor contributions from small valley glaciers, forming deposits at the very mountain base; but east of Russell Fiord it is receiving notable contributions from a number of glaciers, particularly from the great Yakutat Glacier, which expands on the foreland beyond the mountain front and is still contributing moraine as well as outwash gravels.

On the beach near the very head of Russell Fiord, as pointed out by Russell, ${ }^{a}$ and on other beaches near by, a submerged forest proves that there was a forested land area fringing the mountain front before the deposition of these moraines, and that subsidence has since occurred in this region.

One or two short excursions were made into the forest at the head of Russell Fiord. After ascending the gravel bluff, which is revealed wherever the waves are cutting into the foreland, there was found to be a level terrace, back of which the topography was everywhere distinctly morainic, with pronounced hummocks and kettles, and the surface strewn with huge crystalline bowlders. This moraine is interpreted as the marginal deposit of the expanded Russell Fiord Glacier, but the fringing gravel terrace is associated with a later lake stage. (See p. 133.)

Foreland along eastern margin of Yakutat Bay.--Along the eastern shore of Yakutat Bay, between Yakutat and Knight Island, evidence of morainic topography is everywhere present. No rock was found in place, but it seems difficult to explain the deep channels between the maze of islands on any other hypothesis than that of an irregular rock platform. The shore line, both of the foreland and of the islands, has many headlands and bays, giving rise to a topography which is evidently constructional and which bears close resemblance to the topography of ice-contact deposits. Wherever cut by the waves the material is found to be water-worn gravel, but the main topography is morainic, and the surface is strewn with huge crystalline bowlders.

If one were to interpret the conditions here solely on the evidence of the wave-cut cliffs, he would consider this region to be merely a great gravel deposit; but excursions into the forest back from the shore clearly prove that the surface conditions are different from those which the cliffs alone reveal. Whether this combination of stratified gravels and morainic topography is the result of a single stage of deposition, or whether it is due to a deposition of gravel, afterwards. overridden, could not be determined in this densely forest-covered region in the short time at our disposal. The latter condition is, however, strongly suspected, both in view of the great abundance of gravel and of the broad surface undulations suggestive of ice erosion.

The irregular topography of the eastern shore of Yakutat Bay, shown by the great number of islands there, is even greater than appears from the map, for it also comprises numerous shoals, some directly connected with the islands, some lying at a distance from them. Where these shoals rise above low tide they are covered with an abundance of large bowlders, indicating their morainic character. Shallow water extends several miles above Knight Island along the east. side of the bay. There has been some postglacial modification of the irregular topography by the ocean, high cliffs being cut on exposed headlands at various places by the waves, while tidal action, coupled with wave work, has built a long sand spit on Khantaak Island. In the main, however, the irregularity is due to glacial action in some one of its phases.

On the peninsula near Knight Island there are two terraces, the lowest of which rises to an elevation of 150 to 200 feet. It swings along the base of the mountain and out into the moraine of the foreland, bearing a general resemblance to a beach. Where we crossed it, however, its surface is irregular, hummocky, and morainic, and strewn with a great quantity of large crystalline bowlders; consequently I interpret it as a moraine terrace, formed during a recessional stage in the ice flood. It is assigned to a recessional stage for two reasons: (1) It is so low that the ice which formed it could not be expected to slope so gently as to extend as far as the outer moraine at Yakutat, and (2) there are other morainic deposits at a much higher level.

a Russell, I. C., Second expedition to Mount St. Elias: Thirteenth Ann. Rept., U. S. Geol. Survey, pt 2, 1892, p. 89. 
RELATION OF THE EXPANDED YAKUTAT BAY AND MALASPINA GLACIERS.

That the moraine of the islands and foreland on the east side of Yakutat Bay is the result of a former expansion of glaciers admits of no doubt; but there are several questions of detail on which it has not been possible to reach a definite conclusion. The first of these is the relation of Yakutat Bay Glacier to the expanded Malaspina Glacier. With the extension of the great Hubbard, Turner, and other glaciers into Yakutat Bay there must have been a corresponding expansion of Malaspina Glacier, causing it to coalesce with Yakutat Bay Glacier. High-level moraine terraces at Blossom Island and elsewhere are undoubtedly to be correlated with this extension, but it is not at all certain that by it the piedmont Malaspina ice would be given sufficient power to cause it to dominate the great valley glacier which descended southward through the mountain trough of Disenchantment Bay. It seems more probable that Yakutat Bay Glacier, on emerging from Disenchantment Bay, expanded, coalescing with Malaspina Glacier, but maintaining its ice currents clear to the ocean.

I was unable to find distinct proof of this in the forms of the marginal moraines; but the crystalline bowlders which occur in the moraine from Logan Beach to Yakutat are of the same general character as those found in Disenchantment Bay and Russell Fiord. They include a great number of white marble and white granite bowlders, which are also numerous throughout the inlet. No such bowlders are now being borne on Atrevida, Lucia, Hayden, or the eastern margin of Marvine Glacier, while they are being carried by the large glaciers tributary to inner Yakutat Bay. Although not absolutely conclusive proof, these facts strongly support the theory that the ice which built the moraines along the eastern margin of Yakutat Bay, as far as Yakutat, was supplied from Disenchantment Bay and not from Malaspina Glacier.

ORIGIN OF THE GRAVELS.

A second point upon which a final conclusion has not been reached is the relation, already referred to, of the gravel deposits to the moraine topography. The hypothesis which is considered most probable is that, with the advance of Yakutat Bay Glacier, extensive deposits of outwash gravels were laid down, which the ice later overrode, partly removing them and depositing upon them a veneer of moraine.

\section{ISLANDS AND DEEP CHANNELS ON EASTERN SIDE OF YAKUTAT BAY.}

A third point of uncertainty is the origin of the deep channels between the islands, which often reach a depth of 400 or 500 feet. Three hypotheses suggest themselves in explanation of this feature: (1) They may be due to an irregular rock platform which the gravel deposits failed to obscure; (2) during the stand of the ice near the edge of the foreland the glacier margin may have oscillated, leaving stagnant ice blocks upon which the gravels were deposited, and which, on melting out, gave rise to the depressions; (3) an extensive and uniform deposit may have been made in front of the advancing glacier and, when later overridden, have been partly removed by erosion, leaving an irregular topography, part of which now rises above the bay, while the more extensively eroded portions form the maze of channels.

Facts which would establish or entirely eliminate either of these hypotheses were not obtained, but of the three the first seems most probable. The long, narrow channels and the intervening flat-topped areas, often of large size, as well as the great depth of the depressions, do not resemble the forms produced either by ice erosion or by the subsidence due to the melting out of buried ice blocks. That they can be erosional channels excavated by streams from the glacier does not seem probable, for this would not only make a pronounced recent subsidence necessary in a region where the evidence of outwash gravels a short distance away is opposed to such an interpretation, but it would make necessary the assumption that degradation was accomplished by streams which are normally aggrading. Furthermore, opposed to such a theory is the fact that, so far as soundings show, both the pattern and the location of the channels are not in harmony with stream-origin interpretation. 


\section{SUBMERGED MORAINES IN YAKUTAT BAY.}

Gilbert ${ }^{a}$ calls attention to the existence of irregularities, apparently morainic in origin, on the bottom of Yakutat Bay (fig. 1). Near Point Latouche, at the entrance to Disenchantment Bay, there is a sounding of 1,000 feet, but between this and Knight Island the bay shallows decidedly, the deepest sounding being no more than 420 feet. Outside of this shallow area, toward the ocean, the bottom is irregular, with soundings usually between 300 and 400 feet, and nowhere more than 600 feet except in the neighborhood of the islands. (See pp. 14-15.)

Between Ocean Cape and Point Manby there is a pronounced shoal, which is described in the Coast Pilot in the following words: "Outside of a line between Ocean Cape and Point Manby, at a distance of 2 or 3 miles, there is a remarkable ridge, with depths of $8 \frac{1}{2}$ to 16 fathoms. This ridge is very narrow on top, and the water deepens rapidly to over 30 fathoms on either side except near Point Manby." The submerged ridge has a slightly crescentic form, concave toward the bay, and, as suggested by Gilbert, is probably an outer moraine of the expanded Malaspina-Yakutat Bay glacier. Doubtless it is to be correlated with the ice stage during which the moraine and outwash gravel plain of the Yakutat foreland were built.

\section{HIGH-LEVEL MORAINES.}

It requires only a cursory glance to detect evidence of the former presence of a great ice flood which rose to considerable elevations above the Yakutat Bay inlet. This evidence is double, consisting, first, of distinct morainic deposits high above the fiord, and, secondly, of a zone below which the mountain slopes are evidently ice worn, while the topography above is distinctly that resulting from subaerial denudation (Pls. II; XIX, $A ; \mathrm{XX}, B$ ). At several points the elevation to which the ice flood reached was determined, and studies of the highlevel deposits were made. The details of these studies follow.

\section{CAPE ENCHANTMENT.}

The first locality examined was on the mountain slopes immediately northwest of Cape Enchantment. Here distinct morainic deposits were found up to an elevation of 1,350 feet, with many foreign bowlders and clear evidence of powerful glacial erosion. Above this level the evidence of former ice invasion becomes much less distinct, though undoubted foreign fragments of crystalline rocks, resting on Yakutat beds, were found as high as 2,000 feet. Above this level the mountain ridge has been glaciated to an elevation of 2,800 feet, but among the numerous transported rocks none were found which could be proved to have come from outside the peninsula.

From this evidence it is certain that the ice flood in this part of the fiord rose to an elevation of at least 2,000 feet. It is possible that the higher glaciation (above 2,000 feet) was due entirely to minor glaciers generated in the upland of the peninsula and extending across the 2,800-foot ridge to join the main Russell Fiord Glacier. An alternate hypothesis is that the ice flood of the main glacier itself reached as high as 2,800 feet, but that the local thrust from the tributary glaciers prevented the transportation of foreign fragments to the edge of the valley wall. This inference receives support from the fact that in a valley just east of the 2,800 -foot ridge a foreign granite bowlder was found at an elevation of 2,200 feet. To have come to this position it must have passed either over the 2,800 -foot ridge or else across the divide at the head of the valley, whose ice surface is now 2,690 feet, but whose rock surface is doubtless 100 or 200 feet lower. This is the highest unquestioned foreign fragment found in this region.

The evidence at Cape Enchantment, therefore, demonstrates an ice flood at least as high as 2,000 feet, with a possibility that it reached 2,800 feet. 
POINT LATOUCHE.

A second point selected for determination of the upper limit of former glaciers was on the ridge which extends southward from Point Latouche, and on which high-level morainic terraces are plainly visible from the west side of Yakutat Bay, opposite Point Latouche. This ridge was ascended to an elevation of 2,900 feet without finding any sign of ice action in the upper portion. At an elevation of 2,120 feet scratched stones were found, rapidly increasing in size and quantity lower down. The highest distinctively foreign crystalline fragments were found at an elevation of 1,920 feet, associated with an excellent moraine showing a distinct hummocky topography.

From these facts it is inferred that the main ice flood on the eastern side of the mouth of Disenchantment Bay reached an elevation of at least 1,920 feet, receiving from the peninsula a tributary which swung around the nose of the mountain ridge at an elevation of 2,120 feet, supplying only local fragments. Thus the level of the ice flood in the main valley must have been over 1,920 feet, and perhaps as much as 2,120 feet, the ice being prevented from transporting foreign fragments to this elevation because of the thrust from the tributary. Since the fiord off Point Latouche is 1,000 feet deep, Yakutat Bay Glacier at this point, where now there is no ice, must at its flood stage have attained a thickness of not less than 3,000 feet. That this ice flood was not of recent date is proved by the fact that a mature spruce forest, with trees fully a century old, occupies the lower slopes of the ridge on which the high-level moraines occur.

WEST SIDE OF HEAD OF YAKUTAT BAY.

The third point of observation on the level of the upland moraine was between Black and Atrevida glaciers, where there are distinct morainic terraces on the more gentle slopes. In the Black Glacier valley, for instance, there is a morainic terrace at an elevation of 1,020 feet, and a still higher one estimated to lie at upward of 2,000 feet above sea level. Between Black and Galiano glaciers the higher moraines are absent, owing to the steepness of the mountain slope, the highest moraine terrace visible being at an elevation of only 800 feet. Its noticeable westward descent, at an angle of $5^{\circ}$, evidently represents the angle of slope of the Disenchantment Bay ice as it swung around the mountain front toward Galiano Glacier.

On the west side of the Galiano Glacier valley there is a very pronounced morainic terrace extending over to Amphitheater Knob, a portion of which was briefly described by Russell. ${ }^{a}$ This moraine starts on the western side of the Galiano Glacier valley at an elevation of 500 feet above the present ice surface and 1,900 feet above sea level. It has the form of a distinct moraine terrace, hummocky and ridged, and since no foreign fragments were found above its level it is assumed to represent the highest stand of the ice at this point. Near where the moraine is first noticeable, well within the Galiano Valley, a large alluvial fan extends from a small mountain ravine, being graded up to the base-level of the terrace. It probably began at the ice-flood stage, but has not yet succeeded in rising above the moraine terrace.

The moraine is distinctly traceable around the nose of the mountain on the west side of the Galiano Valley, descending to an elevation of 1,800 feet in about 2 miles. It extends as a series of hummocky ridges, inclosing kettles, but sometimes has the form of a single ridge. Farther on it assumes the character of a broad, undulating terrace, 100 to 200 feet in width and 1,675 feet above sea level, descending toward the southwest, where it is tied onto Amphitheater Knob.

In this portion the moraine terrace has a distinctly crescentic form, with the concave face eastward (Pl. XXIX, $A$ ). It has a general resemblance to a crescent beach, but its hummocky form, its westward descent at an angle of $5 \frac{1}{2}^{\circ}$, and the great abundance of large angular bowlders it carries prove that this is not its origin. That it is not the moraine of a local glacier is proved by the fact that there is no source of supply for such a glacier, and, moreover, because its concave face is on the side away from the mountains. It is unhesitatingly correlated with the

a Russell, I. C., An expedition to Mount St. Elias, Alaska: Nat. Geog. Mag., vol. 3, 1891, p. 91. 


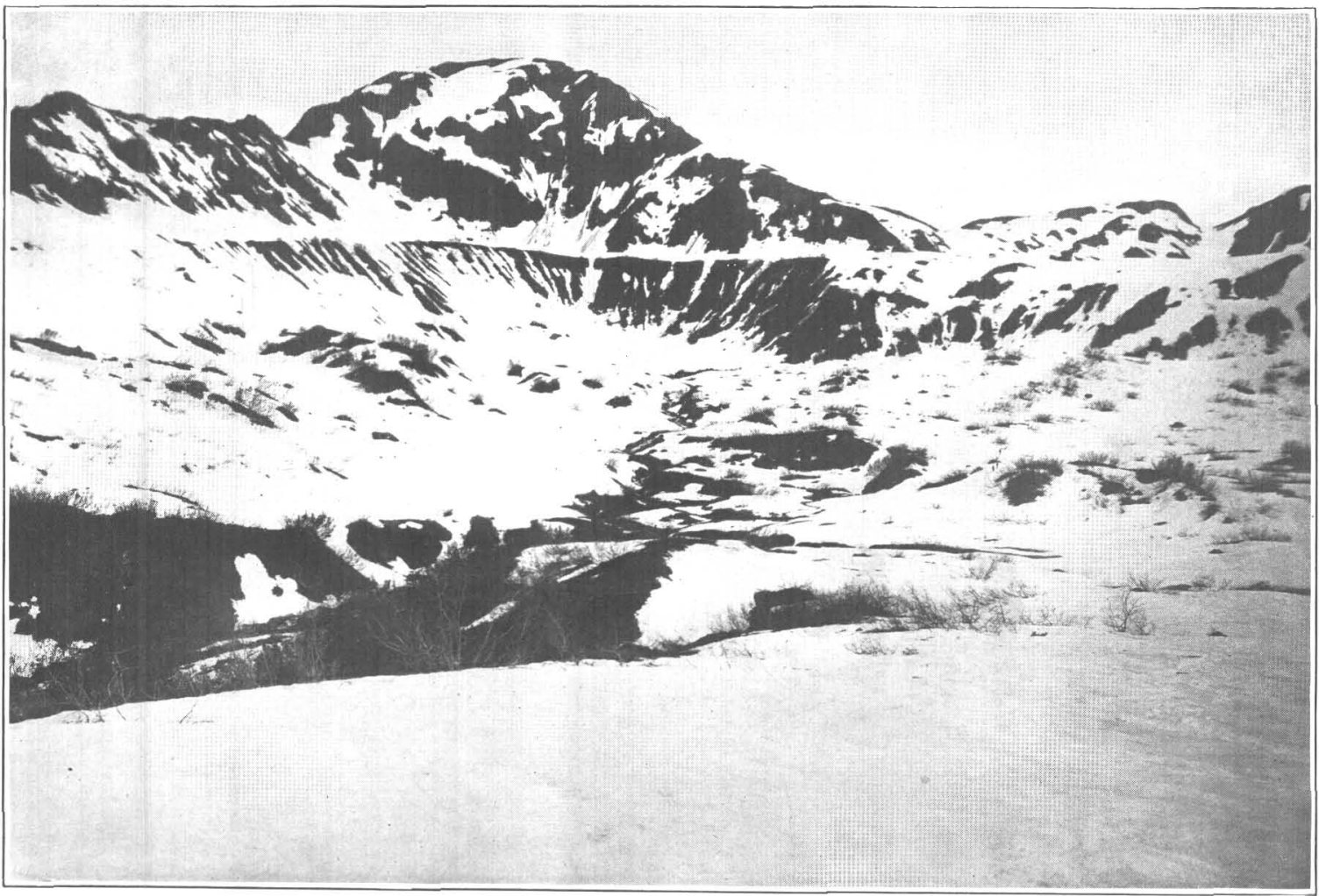

A. MORAINE TERRACE IN THE AMPHITHEATER ON AMPHITHEATER KNOB.

View looking west toward concave or ice-contact face of moraine. A good-sized lake lies behind the right-hand end of the terrace. Photograph taken June 29, 1906.

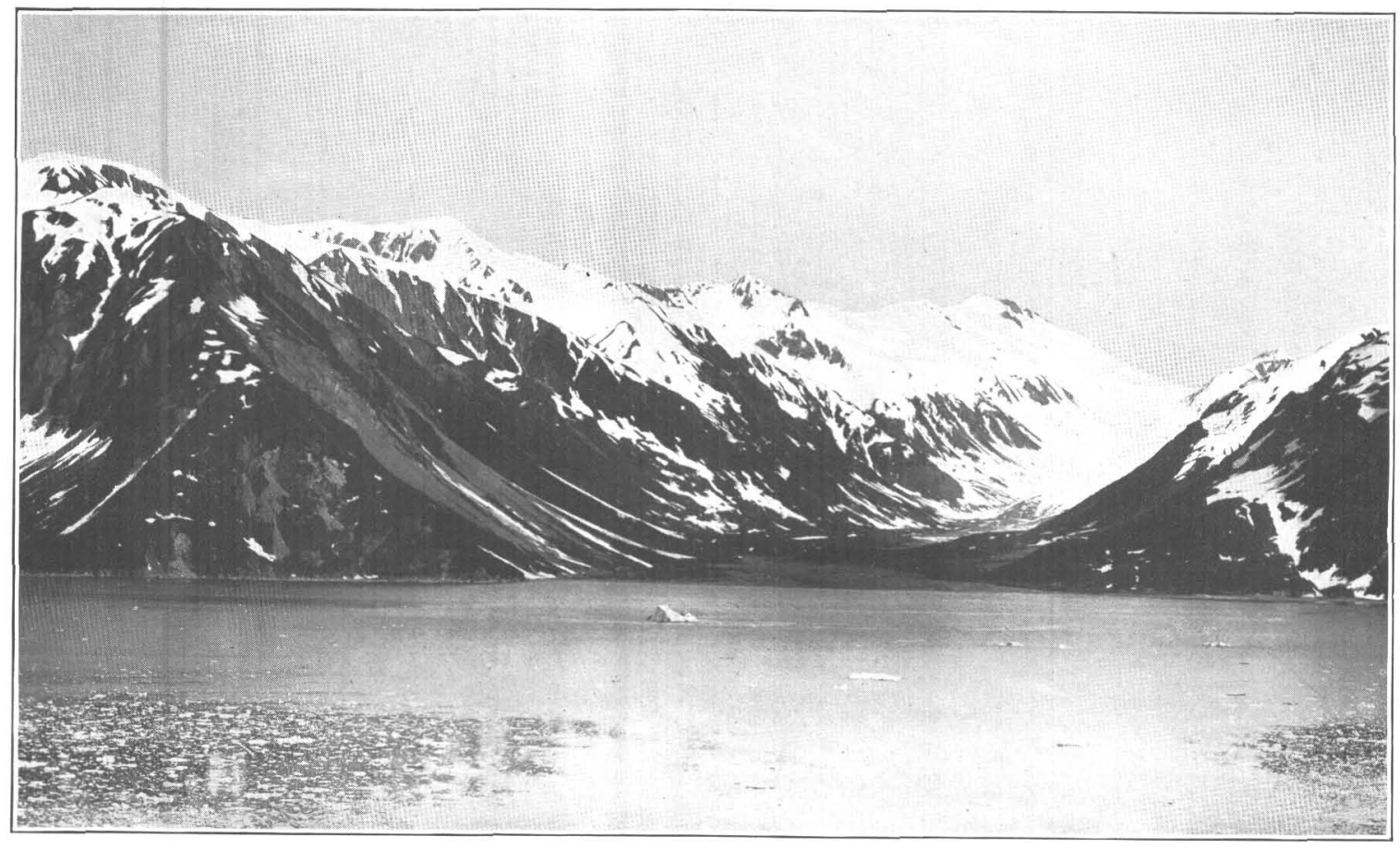

B. LONG-FOCUS VIEW OF CALAHONDA VALLEY, FROM WEST SIDE OF DISENCHANTMENT BAY. Henry Glacier, buried in snow, at head of valley. Note broad $U$ shape, steep walls with talus slopes developing; and flat bottom veneered with outwash gravels. Rock outcrops in the center of this valley in the wooded strip. The hanging valleys in Plate XXX, $A$ and $B$, are on the right-hand side of the valley. Photograph taken June 28,1906 . 
main Yakutat Bay Glacier, which apparently protruded a small lobe into the amphitheater between the knob and the main mountains. Strangely enough, although there are immense numbers of bowlders in this moraine, no foreign fragments were found. This, however, is doubtless the normal result of the fact that the three nearest tributary glaciers of Yakutat Bay Glacier (the Black, Galiano, and Turner), supplied to the main glacier only rocks of the Yakutat group.

This morainic ridge is separated from the mountains by a valley more than a quarter of a mile in width, in which lies a lake whose longest axis is approximately a quarter of a mile. It receives some small streams; which have built alluvial fans, but which do not bring water enough to cause the lake to fill completely the basin behind the terrace; in fact the lake does not rise to within 150 feet of the lowest point of overflow, its water seeping through the coarse moraine. That the water surface of this lake fluctuates decidedly is proved by a barren zone, with a vertical range of about 15 feet, probably representing the height of the lake in the spring. At the time of our visit it was apparently above its lowest level, for one of the alluvial fans extended beneath the water and was crossed by a submerged channel. Distinct, though narrow, shore lines, now grass covered, are visible on the slopes of Amphitheater Knob behind the terrace. There are several score of these abandoned strands at different levels, the highest reaching above the crest of the moraine, thus proving that they were formed during the stand of the ice which built the moraine, when there was a large marginal lake completely filling the amphitheater behind the moraine.

Where it crosses the cirquelize amphitheater between the knob and the mountains this moraine terrace, with a steep face, rises as a flat-topped ridge, approximately 150 feet above both the inner and the outer base. At its center this crescentic terrace has an elevation of 1,675 feet, but it descends toward the southwest. Its front is slightly terraced, indicating halts in the recession of the ice; and between it and the bay there is an area of well-defined, hummocky, moraine topography, with one good-sized pond and several swampy areas, proving later stands of the ice at these lower levels.

The height of the moraine at this point, outside of the mouth of Disenchantment Bay, shows clearly that during the period of former glacier expansion there must have been a coalescence of the Disenchantment Bay ice with the neighboring Atrevida, Lucia, and Malaspina glaciers. That the interval of time between the recession of this ice flood and the present is not great is proved by the fact that the old shore lines in the amphitheater have not been destroyed nor the pond in the amphitheater more completely filled with alluvial-fan deposits.

TERRACE POINT.

Morainic terraces were observed and studied at several points west of AmphitheaterKnob. A series of moraines cling to the western face of the knob high above Atrevida Glacier. On the west side of this glacier the prow-shaped point called Terrace Point, which lies between Atrevida and Lucia glaciers, consists of a series of terraces, the highest being between 500 and 600 feet above the neighboring glacier surface and from 1,500 to 2,000 feet above sea level. ${ }^{a}$ So far as could be seen in the cuts, these terraces are all of gravel, but on their tops they are distinctly morainic, with many hummocks and kettles, often holding lakes, and with their surface strewn with many bowlders.

On the margin near Lucia Glacier the terraces are sculptured by present-day streams, which have both cut and built small terraces, some of the latter having been formed of gravel deposits in marginal lakes, dry at the time of visit, but apparently occupied in the spring when the subglacial outflow channels were obstructed by freezing. In early August there were numerous outlets under the ice, but the freshness of the deposits and the absence of vegetation on the lower terraces prove conclusively that these lower terraces are of recent origin and are probably still in process of formation. 
The higher terraces all bear vegetation, including thickets of mature alder and scattered spruce trees at least a half century old. These terraces are evidently interlobate moraine deposits, built in the lee of the mountains, between Lucia and Atrevida glaciers, at a former period when the ice stood at least 500 feet higher than it now stands and, flowing around the end of the mountain, met below the point. The abundance of stratified gravels, as well as the situation of the terraces in the angle between two converging glaciers, proves that water deposition bore a a prominent part in their formation. As the glaciers recede the terrace area naturally extends, and the smaller terraces described above are doubtless a part of the process by which this great prow-shaped point has been added to the mountain nose.

FLORAL HILLS.

At Floral Pass some interesting morainic deposits tell a complex history of change in the relations of the glaciers. At present Hayden Glacier protrudes a small tongue into the head of the pass (pp. 82-83), and at a former period of greater elevation it must have sent a much longer tongue down the valley. To-day Lucia Glacier flows well outsjde the lower end of the Floral Pass valley, but at a former high-level stage, when the Lucia nunatak was covered, it also must have sent a tongue into the valley. At that period the lower and upper ends of the Floral Pass valley were occupied by ice tongues. Doubtless at one period these two tongues united to form a through glacier across the pass, but at a later period of recession they were separated.

The evidence of the latter condition is the presence in the lower part of the valley of thick beds of clay overlain by massive gravel deposits. These accumulations are now deeply dissected by the main Floral Pass stream and its tributaries which have cut gorges often a hundred feet in depth. With the oncoming and recession of the ice floods this valley, owing to its peculiar situation, has doubtless been the seat of a succession of interesting changes, passing from glacial erosion to glacial deposition, and then to stream erosion. Among Pleistocene deposits in hilly countries, like central New York, similar combinations of conditions have doubtless at times existed.

That Lucia Glacier once actually rose to the level necessary to permit the extension of a tongue westward into the Floral Pass valley is proved, not only in that valley itself but in the one next southwest of it, which is not a through valley, but is separated from the Hayden Glacier by a high divide. Into this valley a tongue from Lucia Glacier extended fully a mile, building one of the most perfect morainic ridges seen in the entire region. As in the case of the terrace on Amphitheater Knob, this moraine forms a crescentic loop across the valley, holding a goodsized lake behind it. Scattered young spruce trees grow on its surface, proving it to have been built long ago; and lower moraines, between it and the glacier, demonstrate halts in the ice recession. This terrace is 1,500 feet (by aneroid) above sea level, and when Lucia Glacier was at that height it must have been an active tributary to Malaspina Glacier, from which it is now entirely disconnected.

On the southwestern and western slopes of the Floral Hills, between Lucia and Hayden glaciers, and also directly above the latter, there are extensive deposits of gravels and wellmarked moraine terraces up to an elevation of 1,400 feet (by transit measurement) above sea level.

\section{BLOSSOM ISLAND.}

Farther west, in the Blossom Island region, high-level moraines are also present. On the mountain slopes near Blossom Island morainic terraces occur 700 to 800 feet above the present glacier surfaces. ${ }^{a}$ During the accumulation of these higher moraines Blossom Island itself was entirely submerged beneath the ice flood. In later stages of recession the ice stood against the slopes of this hill, and some remarkably perfect recessional moraine ridges were deposited. These have the form both of level-topped terraces and of pronounced ridges, the latter often being backed by narrow channels of marginal-stream origin. Still other channels slope both ways, proving them to be of constructional origin. One of the best of the ridges, contouring

a An accident to the barometers made it impossible to determine these elevations more closely, or to tell the elevation above sea level. 
the hillside, is continuous for 300 or 400 yards, rising about 5 feet above the marginal stream valley, whose width at the bottom is about 30 feet.

Farther west the high-level terraces on the Hitchcock Hills, far above the present ice surface, could be plainly seen. Thus the evidence is convincing that during an ice-flood stage Malaspina Glacier, as well as Yakutat Bay Glacier, was greatly expanded by the increase in supply of ice from its enlarged tributaries, and even from tributaries now cut off. At that time Malaspina Glacier must have pushed far out beyond its present position, and while we are not able to prove definitely that the ice-flood stages of Malaspina and Yakutat Bay glaciers were contemporaneous, there is no reason to doubt that they were, and that the expanded Malaspina Glacier coalesced with the great Yakutat Bay Glacier.

\section{MOUNT TEBENKOF.}

At two points near the outer portion of the mountainous peninsula observations were made on the former height of the glaciers, one near Knight Island, on the slope of Mount Tebenkof, directly above the Yakutat foreland, the other near the head of Russell Fiord.

On the slopes of Mount Tebenkof, at an elevation of 800 feet, there is a pronounced morainic terrace on which foreign fragments are abundant. Striated pebbles were found as high as 1,060 feet, but no signs of glaciation could be discovered above that level. This elevation is sufficient, however, to account for the extension of Yakutat Bay Glacier out to the ocean, especially if, as seems probable, the ice in outer Yakutat Bay was influenced by the thrust from Malaspina Glacier.

HEAD OW RUSSELL FIORD.

Near the head of Russell Fiord, Mr. Butler ascended an unnamed mountain just northwest of Cape Stoss, from which he could look down on the Yakutat foreland. Foreign fragments were found up to 1,040 feet, and a lake, evidently due to morainic deposits, lies at an elevation of 1,100 feet. The mountain slopes are smooth, as if by ice scouring, up to 1,200 feet. From these observations it appears that Russell Fiord Glacier rose higher on the outer mountain slopes than Yakutat Bay Glacier. This might well be expected from the narrowness of the fiord, as contrasted with the broadening, V-shaped outer portion of Yakutat Bay west of Mount Tebenkof.

\section{FORMER THROUGH-GLACIER CONDITION.}

Besides the localities described above, high-level moraines were seen at many points on the mountain slopes of the Yakutat Bay inlet and in the tributary valleys both of the peninsula and the mainland. Although the elevations of these were not determined, it was evident that they were to be correlated with those studied, and that the whole series constituted a record of a former great ice flood in which both tributary and main valleys were deeply submerged (fig. 9). In several places-for example, in the Orange Glacier and Russell Fiord valleys-moraines were seen at such an elevation that during their formation the ice must have streamed across present-day divides as through glaciers. Thus the peninsula must have been crossed by more than one tongue connecting Russell Fiord and Yakutat Bay glaciers; and it seems probable that the great glaciers of the Yakutat Bay inlet were then directly connected with expanded glaciers of valleys farther east.

\section{GRADE OF ANCIENT GLACIER SURFACE.}

From observations on the high-level moraines it is possible to make a rough calculation of the slope of the ice surface during the flood stage. This calculation can not be made with exactness because there is some uncertainty as to the exact height of the ice in several places.

Taking the height of the ice at Cape Enchantment as 2,000 feet and on the mountain near Cape Stoss as 1,040 feet, and the distance between the two as 17 miles, the grade of the surface of Russell Fiord Glacier was about 50 feet to the mile. For the calculation of a grade between Point Latouche and Mount Tebenkof, a distance of about 15 miles, the ice surface at the former 
point may be assumed as 1,920 feet and at the latter as 800 feet, giving a grade of 75 feet to the mile. From the moraine terrace at Amphitheater Knob, whose elevation is 1,900 feet, to the sea level at the submerged moraine across the entrance to Yakutat Bay, the distance being about 27 miles, the grade was about 70 feet to the mile. From the 800 -foot moraine on Mount Tebenkof to the submerged moraine at the entrance to Yakutat Bay, a distance of about 19 miles, the grade was 42 feet; but in this case the elevation assigned to the ice on the slopes of Mount Tebenkof is undoubtedly too low.

Although these grades can not be accepted as definitely accurate, it is interesting to note that they are closely like the grades on Malaspina Glacier and on the broader, outer portions of its larger

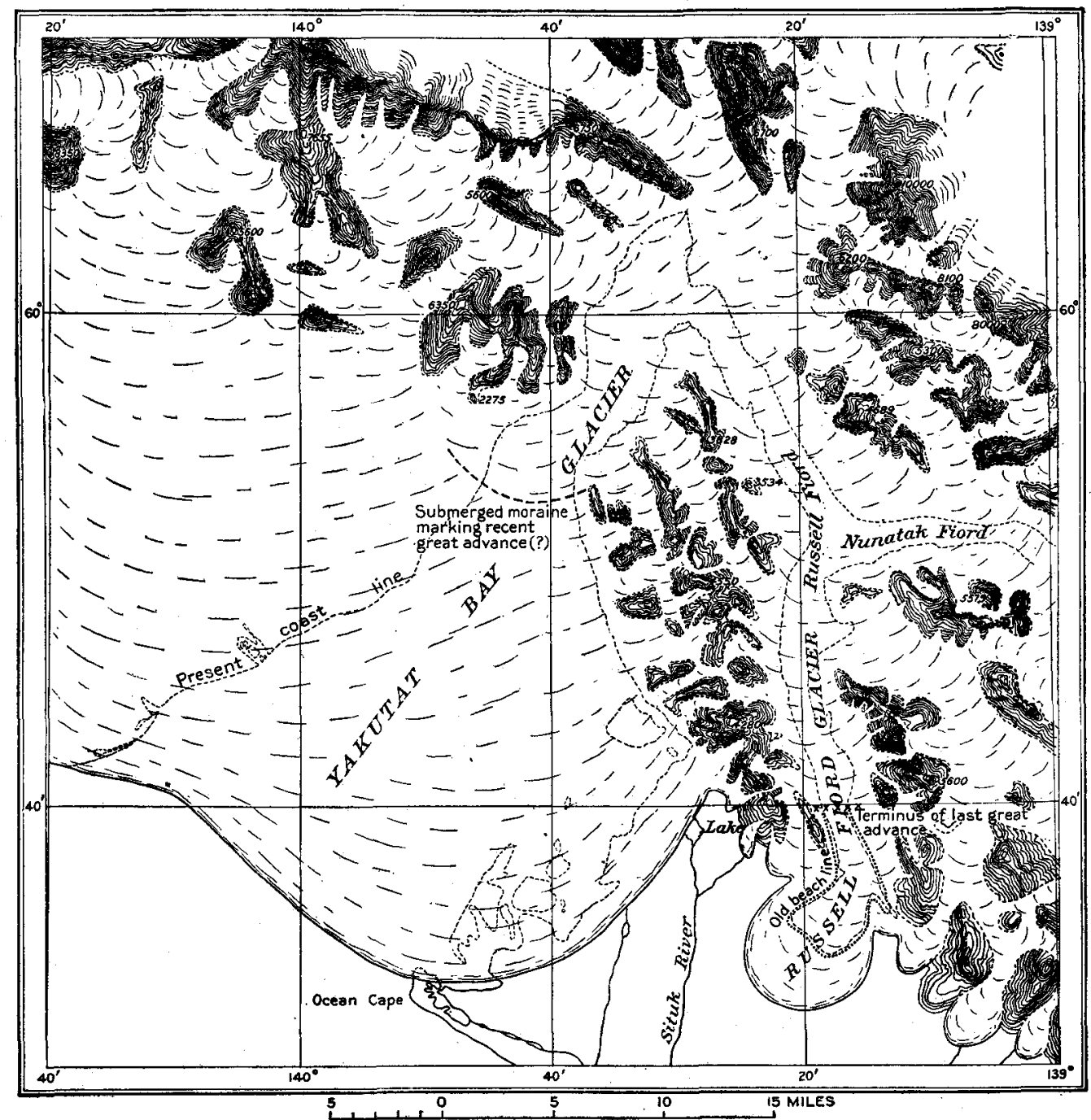

FIGURe 9.-Map showing hypothetical former extension of glaciers during ice-flood stage, based on observations of the height reached by the glaciers at a number of points.

tributaries. These grades vary greatly from one part of the Malaspina to another, so that without a careful survey it would be impossible to determine an exact average. So far as can be told from the data at hand, the average grade from the mountain base to the sea is not far from 70 feet per mile, the slope being steeper near the seaward end and at the mouths of the tributary glaciers. 


\title{
CHAPTER VIII.
}

\author{
GLACIAL EROSION.
}

PREVIOUS STUDIES.

RECOGNITION BY RUSSELL.

In his description of the Yakutat Bay region Russell refers to the evidence of pronounced glaciation in the inlet. For example, he states ${ }^{a}$ that the shores of Disenchantment Bay and its extension, now called Russell Fiord, bear evidence of recent glaciation "up to an elevation of over a thousand feet." He calls attention ${ }^{b}$ to the fact that "there are no rounded domes or smoothed and polished surfaces to suggest that higher summits have ever been subjected to general glacial action." Describing the Northwest Arm of Russell Fiord, Russell states ${ }^{c}$ that its lower slopes "have the subdued and flowing outlines characteristic of glaciated regions." Describing the same region in the report of his second expedition, he states: "On the northern side rises a remarkably even mountain slope, along which the horizontal grooves left by an ancient glacier flowing westward are plainly visible. Crossing these grooves at right angles are recent drainage lines, showing the amount of erosion that has taken place since the glacier disappeared." Farther on in the same report, $e$ speaking of the topography in general, Russell says: "The angular outlines of crests and peaks, due to the action of running water, and the rounded and flowing contours of the lower slopes which have been ground away by ice are brought into sharp contrast."

\section{RECOGNITION BY GILBERT:}

Gilbert $f$ calls attention more definitely to the striking evidence of glacial erosion in the Yakutat Bay inlet. Describing the valley of Hidden Glacier, he says:

As in Russell Fiord and its appendages, the valley walls exhibit the flowing contours of glacial sculpture in magnificent development. There are many places where the smooth curves of the mountain side, carved out in harmony with the flow lines of the ice, suggest the sweeping contours of a gigantic ship, rather than the billowy backs of a flock of sheep described by the word moutonnée. A system of flutings can often be traced in simple curvature for a half mile, and no one familiar with the topography resulting from stream erosion can fail to be impressed with the profound modification here wrought by the ice.

On other pages Gilbert calls attention to the evidence of profound glacial erosion, both in this inlet and elsewhere along the Alaskan coast. He describes and shows illustrations of hanging valleys, and in fact makes one of the clearest cases for glacial erosion so far published.

My observations completely verify the work of Russell and Gilbert in this respect, differing only in carrying the subject into further detail. In order to show the nature of the evidence of profound glacial erosion, the features of various parts of the inlet will be described by geographic divisions, commencing in outer Yakutat Bay and proceeding to the head of Russell Fiord. $g$

\section{OUTER YAKUTAT BAY.}

The shallowness and irregular bottom of Yakutat Bay, the morainic ridge across its mouth, and the extensive deposits in the Yakutat foreland all suggest a large measure of glacial erosion. Without knowing the thickness of these several deposits, the full significance of this evidence

a Russell, I. C., Mount St. Elias and its glaciers: Am. Jour. Sci., 3d ser., vol. 43, 1892, p. 173.

b Russell, I. C., An expedition to Mount St. Elias, Alaska; Nat. Geog. Mag., vol. 3, 1891, p. 191.

c Russell, I. C., tdem, p. 100 .

d Russell, I. C., Second expedition to Mount St. Elias: Thirteenth Ann. Rept. U. S. Geol. Survey, pt. 2, 1892, p. 85

e Russell, I. C., idem, p. 90.

$f$ Gilbert, G. K., Glaciers and glaciation, Harriman Alaska Expedition, vol. 3, p. 57

$g$ Tarr, R. S., and Martin, L., Glaciers and glaciation of Yakutat Bay, Alaska: Bull. Am. Geog. Soc., vol. 38, 1906, pp. 153-160. Tarr, R. S., Glacial erosion in Alaska: Pop. Sci. Monthly, vol. 70, 1907, pp. 99-119. Tarr, R. S., Glacial erosion in the Scottish Hignlands: Scottish Geog. Mag., vol. 24, 1908, pp. 575-587. 
can not be determined, but even if they are of no great depth they testify to enormous transportation, and at least indicate great glacial erosion.

In outer Yakutat Bay, where the glacier flared out after passing beyond the mountain front, there is little reason to expect extensive vertical erosion. At this point the ice should have been moving slowly and depositing rather than eroding. Farther up the bay, between Point Latouche and Knight Island, the features of the mountain face prove clearly that there was at least lateral ice erosion along the mountainous eastern coast of outer Yakutat Bay. When viewed from out in the bay, all the valleys are seen to be perceptibly hanging, the one nearest Point Latouche having a spruce-covered lip 200 to 300 feet above sea level, while the hanging-valley level steadily diminishes toward Knight Island. The hanging valleys themselves are U-shaped, evidently having been smoothed, rounded, and broadened by ice erosion, but the glaciers which occupied them did not succeed in lowering their mouths below the waters of the bay. At higher levels (1,000 feet or thereabouts) there are hanging cirque valleys, below which the mountainous coast has evidently been so ice sculptured as to remove the preglacial stream valleys.

These conditions are interpreted to be the result of the powerful lateral erosion of Yakutat Bay Glacier under the influence of the thrust of the Malaspina ice; and it harmonizes with the theory that ascribes the morainic phenomena between Knight Island and Yakutat to Yakutat Bay Glacier (p. 100) pushed vigorously eastward by the Malaspina thrust. The glacial erosion along this coast is older than that farther up the inlet, described below, for the steepened and truncated mountain spurs, as well as the $U$-shaped tributary valleys, are weathered and eroded far more than is the case up the inlet; and, moreover, there is a growth of mature spruce on the glacially eroded slopes.

It is noteworthy that the truncated spurs and hanging valleys of this coast terminate along one of the best-marked fault lines, along which distinct uplift occurred in 1899 . In this case, therefore, one might interpret the phenomena as a result of uplift. This must be considered as an alternate hypothesis; but it appears weaker than that of glacial erosion, because the forms produced are so like those farther up the inlet where faulting is out of the question, because ice as well as faulting was present here, because the hanging cirques are so high and the slopes below so free from stream erosion, because the tributary valleys are so definitely and unquestionably ice eroded, and because the hanging tributary valleys hang at such different levels.

\section{DISENCHANTMENT BAY.}

WEST SIDE.

In Disenchantment Bay the evidences of glacial erosion are very pronounced. On the west side two of the largest tributary valleys are occupied by glaciers, Turner Glacier in the larger and Black Glacier in the smaller. As has been shown in the description of these glaciers (pp. 39,70 ), both of these valleys are hanging.

Between the Turner and the Black Glacier valleys the mountain wall is abrupt, profoundly grooved, and greatly ice scoured. Some of the glacial grooves are so pronounced as to be visible at a distance, even though the slopes are covered by vegetation. These great grooves have an angle of inclination southward of $5^{\circ}$ to $10^{\circ}$.

In this area there are several spoon-shaped valleys occupied by hanging glaciers, out of one of which Fallen Glacier tumbled in 1905 . These valleys are fairly broad and cirquelike above, and are terminated below in the steep rock slope of the mountain wall. They are therefore distinctly hanging, the streams that descend from them leaping in a series of cascades down the glaciated rock slopes below their lips.

The broad, U-shaped hanging valley occupied by Black Glacier has been profoundly scoured by glacial erosion. This is clearly proved by the fact that, although the rock walls are crumbly and easily eroded, the steep western wall is cut by no distinct valleys below 1,800 feet. Above this level there are fairly broad valleys and cirques, but the water which emerges from them tumbles down the valley walls usually in threads on the very surface of the rock slope, though in some instances in shallow gorges. 



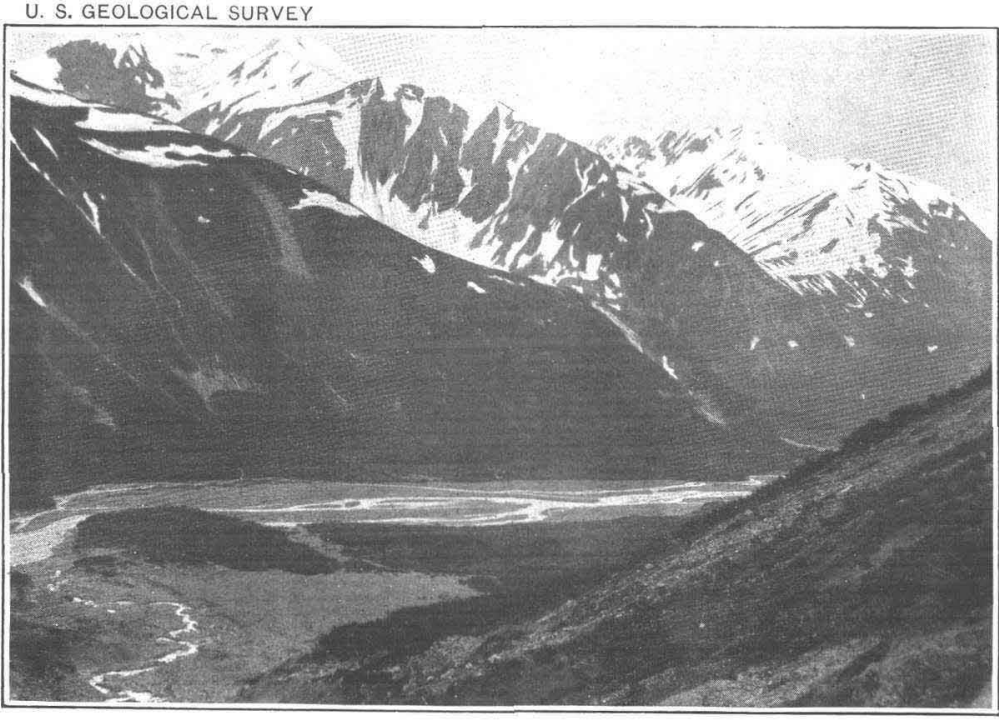

A. TWO HANGING VALLEYS ON NORTHEAST WALL OF RUSSELL VALLEY, LYING AT DIFFERENT LEVELS.

In the nearer of the two the stream descending the steepened slope is almost flush with the mountain wall. Rock outcrops near the center of the valley just beyond (to the left of) the area shown in this view. Photograph taken June 24,1905 .

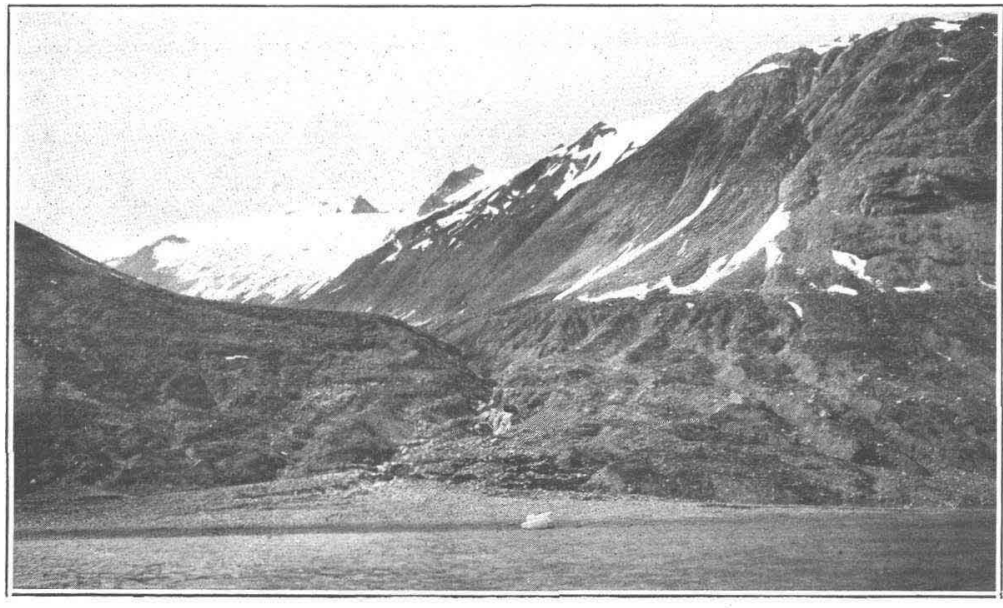

C. HANGING VALLEY ON SOUTH SIDE OF NUNATAK FIORD, JUST WEST OF THE NUNATAK.

View from point out in fiord. (See also PI. XXXIII, A.) The lip is entirely of rock with a thin but irregular veneer of gravel. Photograph taken
PROFESSIONAL PAPER 64 PLATE XXX

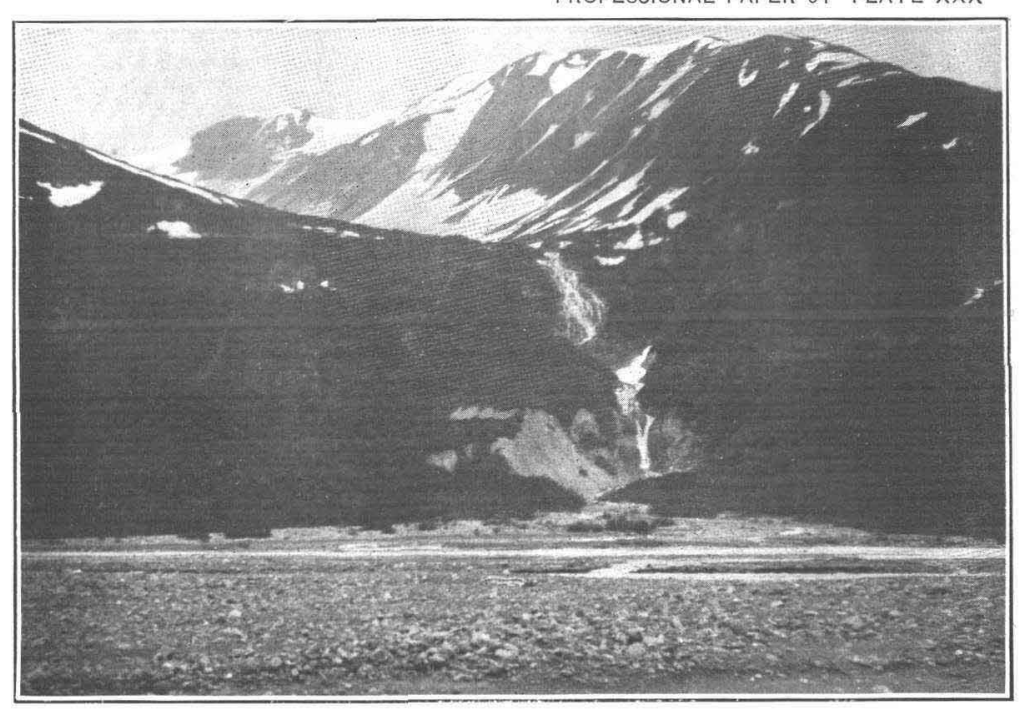

B. NEARER OF THE TWO HANGING VALLEYS SHOWN IN PLATE $X \times X, A$.

The stream from this hanging valley, after passing over the lip, descends on the very face of the rock wall of the steepened valley slope, cutting a gorge in only the lower portion, where it crosses glacial deposits. Photograph taken June 24,1905

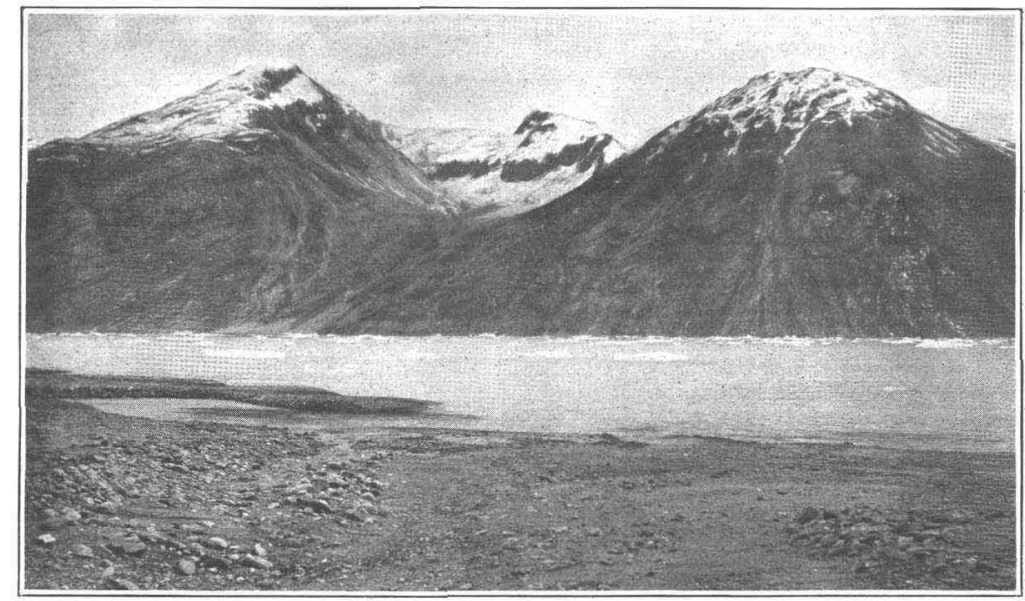

D. HANGING VALLEY ON SOUTH SIDE OF NUNATAK FIORD, LYING NEXT EAST OF VALLEY SHOWN IN PLATE $X X X, C$,

A small glacier lies at its head. The hanging valley is broadly U-shaped; the steepened slope below the lip is entirely of rock, and the stream descending it flows in a shallow rock-walled gorge. In a nearer view the steepened slope shows excellent phenomena of plucking. Photograph
taken July 8,1905 . 
EAST SIDE.

The eastern wall of Disenchantment Bay also bears signs of powerful glacial erosion. The rock walls are smoothed and grooved, and in places chipped into the irregular forms which result from plucking.

The tributary valleys of Disenchantment Bay from the east are likewise profoundly glaciated. The Indian Summer Camp Valley (Aguadulce), which enters just north of Point Latouche, is made by the junction of three prominent tributaries, each of which is notably ice eroded. The middle tributary is much the largest and is joined by a third branch from the south in which lies Latouche Glacier. Near the point of junction of these two valleys, and about 2 miles from the sea, there is a rock bench across the mouth of this southern tributary, which, when viewed from the seaward side, has the appearance of a terminal moraine. The profile of the valley bottom steepens on the seaward side of this bench, but flattens down again a short distance below. The relation of this tributary to the main valley indicates that it has been left hanging by the erosive action of the greater glacier which descended through the larger valley.

It is not to be inferred, however, that the Latouche Valley is not also deepened and broadened by ice erosion. The valley is U-shaped, the walls are smooth and grooved, and the small mountain streams that join it rise in hanging valleys or cirques. Up to an elevation of 1,500 feet the valley walls are strikingly smooth, with no gorges cut in the slopes, although many small streams are descending from the cirques and hanging valleys. A stream, fed from the small Latouche Glacier at the head of the valley, has cut a narrow rock gorge, about 50 feet deep, where it crosses the steep descent from the hanging upper portion.

At all elevations above 2,100 feet the ridge which forms the southern wall of this valley is angular, with topographic features characteristic of subaerial work. From this ridge a view across the three uniting valleys shows a condition of general glaciation up to a level of more than 2,000 feet. This evidence of glacial erosion extends across the divides which separate the three branches, giving the general appearance of a single preglacial valley with three minor U-shaped trenches cut in its bottom. The contrast between this rounded topography of the lower divides and the angular topography above 2,100 feet is most strikingly brought out.

\section{CALAHONDA VALLEY.}

Calahonda Valley, which enters Disenchantment Bay from the southeast above the valley just described, also shows the clearest evidence of glacial erosion (Pls. II, XXIX, $B$ ). It is extremely broad and gently eurving in cross section, with the bottom flattened in the middle by a deposit of outwash gravel. The curve of the cross section increases rapidly near each mountain wall where it merges into the precipitous mountain slope of the valley sides. The valley walls are so steep that in most places it is impossible to ascend them, their slope being not that of a broad, mature valley, but of a young stream valley, and therefore totally out of harmony with the breadth of the valley bottom and the low grade of the longitudinal profile. No known process of stream erosion could have produced a valley of such form, and its association with an existing glacier remnant is, therefore, significant.

The covering of outwash gravels, which becomes more extensive toward the sea, so hides the rock of the valley bottom as to obscure the evidence that it is hanging in its relation to Disenchantment Bay, whose depth just below this point is known to be more than a thousand feet. To assume that it is not hanging requires nearly a thousand feet of deposit in the lower part of the valley. Less than 2 miles from the bay there are rock outcrops near the middle of the valley, and extending the profile of the upper valley to the lower 2 miles, below the rock outcrops, would locate the lip of the valley just below sea level. It seems certain, therefore, that there is a decided change in grade of the lower part of this glaciated valley, making it a hanging valley with the lip probably just below sea level.

The steep walls of Calahonda Valley are smoothed and striated, and bear every evidence of powerful ice abrasion. At varying elevations, estimated to be from 300 to 1,000 feet above the valley bottom ( $\mathrm{Pl}$. XXX, $A, B$ ), the smooth walls are broken by broad, U-shaped tributary 
valleys, in the upper portions of which lie small glaciers. The glacial streams emerge from these valleys and tumble down the valley sides, in some cases in shallow gorges, in others as a series of cascades and magnificent falls almost flush with the steepened valley slope ( $\mathrm{Pl}$. XXX, $B$ ).

Nèar the head of Calahonda Valley three small glaciers coalesce to form a dwindling ice tongue, evidently inactive and with its lower end covered by morainal deposits. A rock knob rises out of the lower end of this, the Henry Glacier, and there are also bed-rock irregularities in the valley bottom several miles below the glacier. It requires but a glance to see that this dwindling glacier is not now powerfully eroding at its terminus, and a person, basing his conclusions on observations at this point, might infer that, because this glacier is not eroding, extensive glacial erosion is everywhere an impossibility. Such a conclusion has been drawn from observations in similar situations in other parts of the world.

The fallacy of such an argument against glacial erosion is readily proved by an inspection of Calahonda Valley below its dwindling glacier of the present day. Instead of nearly stagnant and wasting ice, there was formerly a glacier 2,000 feet or more in depth, moving down the valley to join a still greater glacier in Disenchantment Bay. Comparison between the work now being done by this dwindling glacier and that of the former glacial flood is not greatly different from the comparison of a meadow brook with Colorado River, both as to possibilities of work and as to results accomplished.

HAENKE ISLAND.

Although the evidence of profound erosion along the line of Disenchantment Bay is convincing, it is a noteworthy fact that this ice erosion failed to remove prominent parts of the valley bottom, which now rise above the surface as Haenke Island and smaller adjacent reefs. This island shows evidence of powerful glacial scouring (Pl. IX), and at first thought its presence may seem distinctly opposed to the inference that Disenchantment Bay has been greatly deepened by ice erosion. As is shown in succeeding pages, however, this condition, which is not uncommon in the inlet, is in reality a normal result of powerful ice erosion.

\section{NORTHWEST ARM OF RUSSELL FIORD.}

In the Northwest Arm of Russell Fiord, between Cape Enchantment and Hubbard Glacier, the evidence of glacial erosion is most striking. This is one of the regions to which Russell specifically refers in the quotations given.

It has already been shown (p. 43) that the two arms of Hubbard Glacier have an increased slope just above their junction, which is interpreted as an indication of the hanging condition of the valleys occupied by these glaciers. The mountain walls of both arms of Hubbard Glacier $(\mathrm{Pl}$. XIII, $B)$, and of Variegated and Orange glaciers are smoothed, steepened, and grooved, and possess hanging tributaries.

The rock walls on the two sides of the Northwest Arm of Russell Fiord are entirely different in character. On the northeastern side are steeply dipping slates with a strike roughly parallel to the fiord. The southwest shore is made of the friable Yakutat shales and sandstones with outlying masses of crystalline rock. These differences in rock structure have given rise to an entire difference in the forms produced by glacial sculpturing on the two sides of the fiord.

On the northeast side the slate hill has been rendered smooth and regular by the scouring which it has received. All the ancient drainage lines below the level of 700 or 800 feet have been erased, and the mountain side is fluted with a regular system of nearly parallel rock grooves, often amounting to a terrace form, descending gently northwestward (Pl. XXXI). Upon this smoothed mountain slope are innumerable parallel stream courses, mostly dry in summer. They have been cut through the thin veneer of glacial deposit, but only the largest trench the weak slate rock, the others flowing almost flush with the hill slope. The streams descend the slope in straight courses, spaced at distances of a few yards. There is no development of lateral streams, and the whole appearance of the drainage is youthful in the extreme. This youthfulness is indicated both by the fact that the streams have not yet cut gorges and by the lack of development of tributaries and the consequent lack of union of the closely spaced streams. 


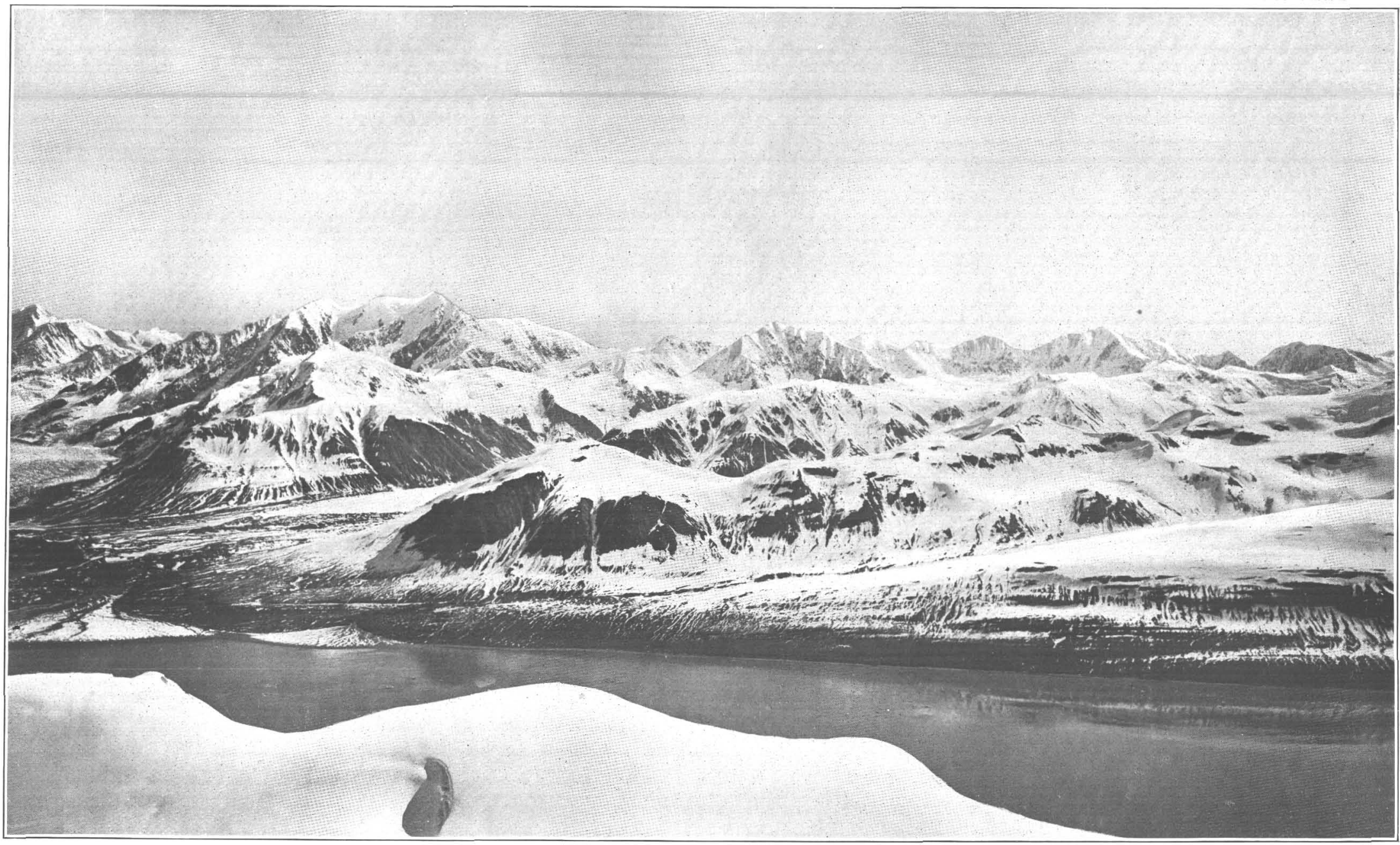

DESCENDING ROCK GROOVES ON NORTHWEST END OF SLATE HILL, ON NORTHEAST SIDE OF NORTHWEST ARM OF RUSSELL FIORD. Alluvial fan of Variegated Glacier on extreme left. Photograph by Brabazon, Canadian Boundary Commission, 1895. 

This same feature of youthful hillside drainage on the lower mountain slopes is seen in many other parts of the inlet, but nowhere so clearly as in this region of profound ice sculpturing, which was made possible, in large part, by the weakness and uniform texture of the slate rock.

A single valley has survived the ice erosion on this slate hill (Pl. III). This valley, which comes down near the middle of the hill, is broad and well defined above the level of 700 feet, having doubtless been occupied by a small glacier at an earlier stage. The form of the valley, which is clearly hanging, changes at about the 700-foot contour, and its stream descends the steepened lower slope in a broad gorge, cut by a postglacial stream in the weak layers of slate which form the lower part of the hill at this point.

On the south side of this arm of the fiord, opposite the slate hill, the topography is much less regular because the rocks are more variable in their power of resistance (Pl. XXXII). There are, however, well-defined hanging valleys at varying levels, and a complete destruction of the ancient drainage lines in the lower 500 feet of the valley wall. Some of the hanging valleys contain glaciers, and out of all of them water pours down the steepened lower slope in a succession of leaps, usually confined in shallow gorges, but sometimes almost on the very face of the valley wall.

Near the middle of this stretch of Russell Fiord there are some off-lying hills connected with the main peninsula by alluvial fans. They rise 200 or 300 feet above the water surface, and for some reason have resisted the glacial erosion which has deepened the rest of the fiord. These outliers are made of crystalline rock, somewhat more resistant than the shales and graywackes of the Yakutat Group. Their occurrence presents a problem similar to that of Haenke Island, but in this case it is possible that the greater resistance to ice erosion offered by the crystalline rocks may be sufficient explanation for their prominence. That they have been powerfully eroded is clearly proved by their roche moutonnée form, their smoothed and grooved surfaces, and by the presence of a rock tail on their lee or northwest end.

\section{NUNATAK FIORD.}

No part of the Yakutat Bay inlet shows clearer evidence of glacial erosion than the Nunatak Fiord arm (Pls. III, VIII). This evidence is rendered all the more clear by reason of the almost total absence of vegetation.

East of the terminus of Nunatak Glacier the valley walls on both sides are steep, and there are excellent hanging valleys with lips at different levels (Pl. VIII). In all these hanging valleys small glaciers remain, those on the southern side descending below the hanging-valley lip, as in Cascading Glacier. West of the glacier terminus the nature of the northem ralley wall changes perceptibly, its slope becoming much more gentle and the underlying rock topography being obscured by gravel deposits. The south wall remains steep-in fact, for the most part, too steep for gravels to cling. The moderate slope of the northern wall is due to two facts-the convergence of several valleys and the presence toward the west of the weak slate rocks. On the south side the rocks are massive crystallines.

The steep southern wall is polished and grooved in a striking manner, the last touches having been given so recently that the polished surfaces glisten in the sun, while vegetation has not yet taken hold on the cliffs. Where the rocks are much jointed, as in the case of an area of granite with well-developed sheet jointing, the mountain slope has a hackly surface, consisting of alternate smoothed surfsces and broken, angular slopes, the characteristic form produced by glacial plucking. In the less jointed rocks farther east, in the neighborhood of Cascading Glacier, there is a remarkable development of lateral grooving, giving rise to the succession of rock terraces on the upper of which rests the lower end of Cascading Glacier (Pl. XVIII, $A$ ). These grooves descend toward the west.

Associated with this evidence of pronounced glacial erosion is a series of the most perfect broad, U-shaped hanging valleys (Pls. III, XIX, XXX, $C, D$ ), terminating in a steepened slope down which the glacial torrents cascade in shallow gorges. In the lower thousand feet of the southern valley wall there is an almost complete absence of valleys, except where an unusually low hanging valley forms a break in the glaciated wall, or where the larger streams have cut 
shallow gorges below the hanging-valley lips. In contrast to this condition on the lower slopes is the excellently developed system of mountain valleys above the hanging-valley level. Between the hanging valleys small streams, draining a system of valleys on the upper mountain slopes, run down the steepened lower slope, almost on the surface, in innumerable parallel courses, only about one-tenth of which carried water at the time of visit in July, the remainder being occupied during the spring period of snow melting. In this peculiar parallel downhill drainage, as on the slate hill in the Northwest Arm of Russell Fiord, there are no master valleys with lateral tributaries, but every few yards a little trench extends straight down the hillside, indicative of an exceedingly immature stage of drainage.

One of the Nunatak Fiord hanging valleys, that which lies just west of the nunatak on the southern side, may be taken as typical $(\mathrm{Pl}$. XXX, $C$ ). The lip has an elevation of 700 feet and rock outcrops completely across it. Its bottom lies well below the level up to which the ice flood profoundly scoured the main valley wall, and both its sides and floor prove that it, too, was greatly deepened and broadened by ice erosion (Pl. XXXIII, $A$ ). At the head of the valley lies a dwindling glacier, moraine covered in its lower portion. From it emerges a stream, which, flowing with moderate grade at first, abruptly changes its grade on reaching the lip of the hanging valley and cascades down the steepened slope in a shallow rock gorge ( $\mathrm{Pl}$. XXX, $C$ ). Other hanging valleys in this arm of the fiord have higher and lower lips, and in some the glaciers extend to the very lip, or even out beyond it, as in Cascading Glacier.

Whether Nunatak Fiord is itself hanging above Russell Fiord can be told only by a series of soundings; but owing to its width, the evidence of powerful erosion along its axis, and the fact that its glacier extended freely out into Russell Fiord, it does not seem probable that it is hanging. It is more probable that the South Arm of Russell Fiord would be found hanging.

\section{SIGNIFICANCE OF NUNATAKS.}

Between the steep mountain slope and the southern wall of the nunatak of Nunatak Fiord there is an excellent example of an ice-eroded valley, the upper part of which is occupied by the land tongue of Nunatak Glacier. The $U$ shape of this valley, its scoured and grooved sides, and its relation to the hanging valleys above it are proof that it was a line of free ice movement. That the valley on the north side of the nunatak, occupied by the sea tongue of Nunatak Glacier, was also the seat of a freely moving glacier is proved by its steepened, smoothed slope, its depth, and the hanging valley, occupied by a glacier almost to its lip, which cuts the steepened northern wall just west of the ice cliff of the Nunatak Glacier front (Pl. XIX). The evidence is clear that this northern, larger branch of the valley was formerly subjected to much more powerful ice erosion than the smaller southern arm, as is still the case.

Between these two troughs the nunatak rises to a height of 1,410 feet (PI. VIII), extending eastward under the glacier at a lower level. The nunatak is a double-crested hill, sloping steeply in all directions, and terminated toward the west, or lee side, by a long tail. The nunatak itself is made up of rather resistant gneisses and schists, though apparently no more resistant than the other rocks in this part of the fiord. The tail consists of weaker schists and slates protected from ice erosion by the nunatak knob. This tail gradually dies out toward the west, where the two arms of the valley again unite near present sea level, the northern and broader channel, now occupied by the fiord, having been so much overdeepened that the other hangs above it.

The question naturally arises: Why should portions of the bottom of an ice-eroded valley stand up so prominently as is the case with the nunatak, Haenke Island, and the outlying hills at and near Marble Point? (See Pl.XXXII.) The answer is not in all cases clear, but the phenomenon does not, as has sometimes been argued, present any obstacle to the acceptance of the other very clear evidence that the valley in which the knob stands has been profoundly deepened and broadened by ice erosion. In fact, in the situations where these islands occur it would be utterly impossible to consider them as arguments against the ice-erosion explanation, for the fact of profound deepening of the valleys above whose bottoms they rise admits of no question. 


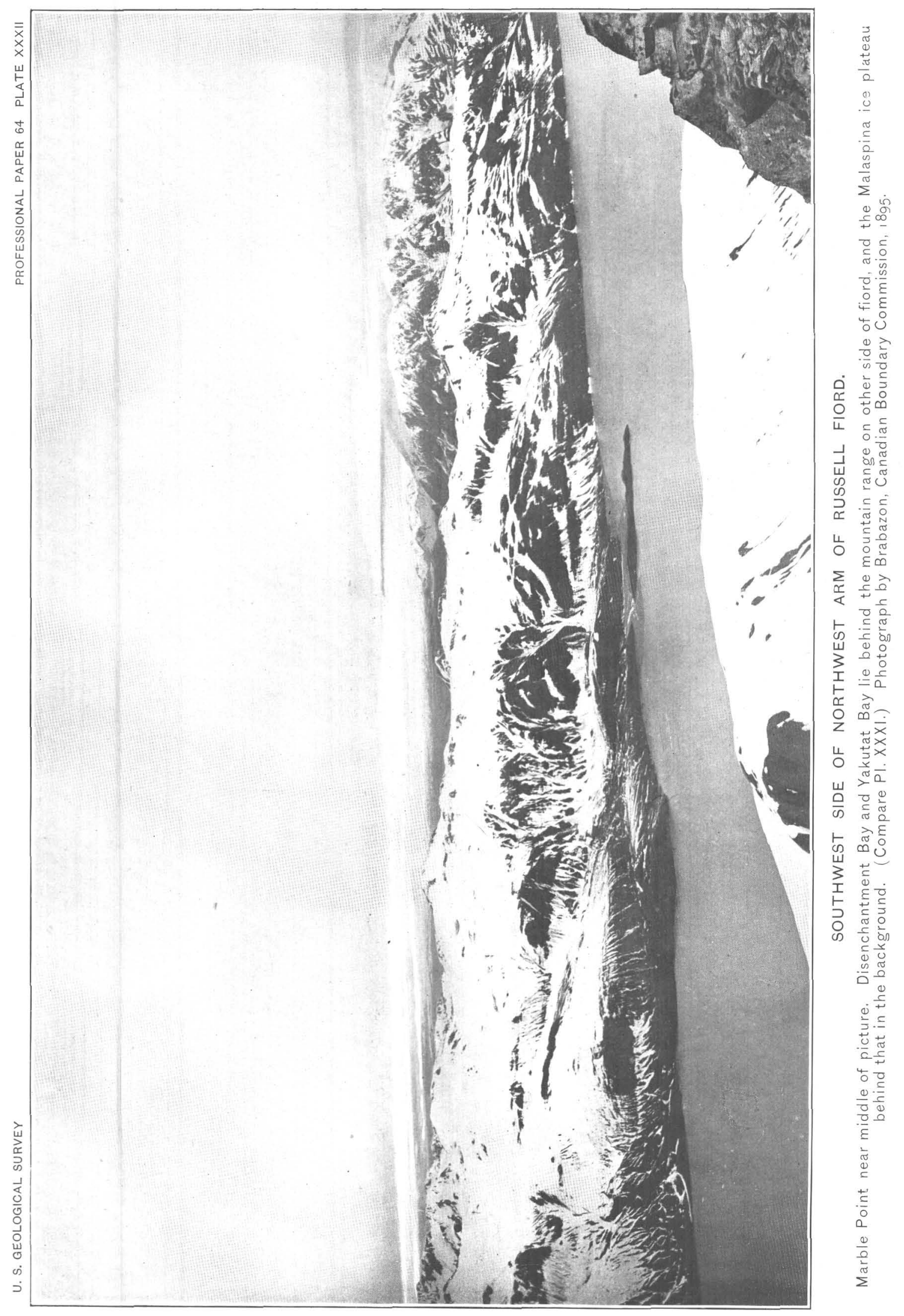



Doubtless the exact cause for such hills in a valley varies from place to place. Three prominent reasons for such apparent anomalies suggest themselves: (1) Taking for granted the fact of glacial erosion, the ice acts in a selective manner, as other agents of erosion act. Those rocks which offer greatest resistance to ice erosion will be the last to be removed; consequently, where the rocks possess different degrees of resistance, the bottom of an icedeepened valley should normally be irregular. (2) The ice may inherit a preexisting valley whose form was produced by subaerial denudation. Such a valley necessarily possesses irregularities; therefore, even if ice erosion be uniform all over its bed, the ultimate result may bn an irregular valley floor. It is fair to assume, however, that ice erosion would not be regular, and that conditions would occasionally be present as a result of which the original irregularity would be actually increased by ice erosion. (3) Ice currents, like river currents, are necessarily more or less irregular in direction and strength. A main ice stream, flowing through a valley of perfectly regular curvature and uniform rock texture, might be assumed to erode with regularity, having its greatest current in the middle; but if, for any reason, the current be deflected from the center of the valley, irregularity of erosion is necessarily begun. Variation in the width of a valley, the influence of projecting spurs, and the effect of incoming glacier tributaries, would all tend to cause a deflection of ice currents from the valley center.

Let the last reason be applied specifically to Nunatak Fiord. It has been noted in an earlier part of this paper (p. 55) that the southern tributary of Nunatak Glacier is distinctly deflected by the thrust of the northern branch (Pl. VIII). When the expanded Nunatak Glacier completely filled Nunatak Fiord, it received large tributaries from the north, now completely disconnected and dwindling. It may fairly be inferred that these thrust the axis of ice movement over to the southern side of the fiord. This would readily explain the prominence of the hanging valleys and steepened slope on the south side of Nunatak Fiord, and it may also in part explain the presence of the nunatak itself.

The localization of erosion would depend not solely on the more rapid flow of the currents, but in part on the greater effectiveness of the cutting tools carried. The knob might even rise above the level of the débris-charged bottom layers, and consequently the ice which passed over it would have less material with which to scour. In addition to this, a knob which lay away from the valley wall, as all the instances under consideration do, would be less influenced by the supply of cutting tools which fall from the valley wall upon the surface of the ice and, descending to the base of the ice, become agents of erosion in the bottom layers. A still further point favoring weaker erosion on the crests of the elevations is the fact that the depth of the ice is less there, and consequently its power is decreased.

From these considerations it is clear that irregularities are to be expected under the bed of an eroding glacier. Granting the initial development of an irregularity, due to any one of these causes, the normal action of ice erosion is such as not only to preserve it, but even to accentuate it. Even before the nunatak stage, the ice currents tend to spread around rather than over an elevation rising above the main bed on which the glacier rests. The effect of this would be to deepen the valley on either side of the elevation more rapidly than the reduction of its crest.

Altogether, therefore, elevations above the main floor of an ice-eroded valley are to be expected. Indeed, it seems probable that, when the phenomenon of glacial erosion is as well understood as that of river erosion, the presence of nunataks in ice-eroded valleys will seem no more anomalous than a sand bar in a river, or than Goat Island between the two cataracts of Niagara. Even further, it is not at all improbable that, when properly considered, the presence of nunataks is to be reckoned as an evidence for, not against, ice erosion, to be classed with hanging valleys, steepened slopes, and truncated spurs. Indeed, it is even less difficult to account for a hill rising above the level of a glaciated valley bottom than it is to account for such a condition in a normal river valley.

In the Yakutat Bay inlet there are a number of nunatak knobs. There are the nunatak of Nunatak Fiord, imperfect knobs on the east side of Russell Fiord south of Cape Enchant- 
ment, Cape Stoss, Cape Enchantment itself, Marble Point and a knob southeast of it, Osier Island, Haenke Island and the reefs north of it, Lucia nunatak, and numerous smaller knobs in minor valleys. In a number of these there are well-defined tails on the lee side, notably where the main nunatak is of a more durable rock, thus standing up prominently and protecting the weaker rock in the lee. Such nunatak tails testify clearly to the fact that the nunataks themselves were being lowered, as well as the valleys in which they lie, but that their reduction lagged behind that of the deeper parts of the valley bottom.

The opposite topographic feature to the nunatak in glacial sculpturing is the rock basin, located where ice erosion is locally more active instead of less so. This topographic feature was not clearly represented in the Yakutat region, but doubtless a series of soundings would reveal such depressions on the floor of the fiord.

\section{DISCORDANCE OF HANGING VALIEYS.}

In Nunatak Fiord, as well as elsewhere in the Yakutat Bay inlet, the elevation of the lips of hanging valleys varies in an irregular, nonprogressive way (Pl. II). Neighboring valleys hang at strikingly different levels. This fact is in perfect harmony with the theory of glacial erosion, for at least three causes are operating to bring about such discordance, as follows: (1) Two. tributary glaciers of equal strength, descending through valleys in rocks of different texture, will deepen their valleys to different degrees, that in the weaker rock being most deepened; (2) two glaciers of different degrees of activity, but in rocks of uniform texture, will likewise lower their valleys by different amounts, the stronger glacier deepening its valley the most; (3) the production of hanging valleys is not wholly the result of vertical erosion; to a notable and variable degree, the elevation of the lip of a hanging valley is the result of lateral planing back of the main valley wall by the trunk glacier. As has been pointed out above, glacial currents are frequently thrust over to one side of the valley, and for this reason it may be expected that the lateral planing of a tributary valley mouth will vary in degree according to the difference in the ice currents.

All three of these causes, at least, have been in operation in the Yakutat Bay region; and the difference in erosion resulting from their combination has introduced a great variety in the level of even adjacent hanging valleys. Some are perched at an elevation of 1,000 or even 1,500 feet above the fiord water; others are only slightly above the level of the fiord; and still others are evidently hanging with their lips below the level of the fiord surface. Such differences are the normal results of the operation of glacial erosion; they are difficult to explain on any other hypothesis.

\section{SOUTH ARM OF RUSSELL FIORD.}

In the South Arm of Russell Fiord the evidence of glacial erosion is very striking as far down as Shelter Cove. Below this it becomes much less marked, and in the extreme southern portion the mountain walls have such irregular outlines and such angular rock outcrops as to suggest very weak glacial erosion.

The best evidence of glacial erosion in this arm of the fiord is near its north end, where the mountain slopes are well rounded and grooved, but nowhere so thoroughly as in Nunatak Fiord and the Northwest Arm of Russell Fiord. Between Nunatak Fiord and the Hidden Glacier valley there are distinct hanging valleys and other signs of powerful glacial erosion. (See H, Pl. XXXVII.) In the Hidden Glacier valley itself the evidence of glacial erosion is very clear (Pls. XX, B, XXI). The valley walls are polished, scoured, and fluted with grooves and rock terraces descending westward. Hanging 200 to 500 feet above the valley floor, broad mountain valleys appear, with gorges below their hanging lips; but profound glacial sculpturing of the main valley walls extends much higher than this. Whether Hidden Glacier valley is hanging above the bottom of Russell Fiord is not certain, for its mouth is occupied by Seal Bay, and we have no soundings to determine its relation to the main fiord.

On the west side of the South Arm of Russell Fiord a number of broad, U-shaped valleys enter from the peninsula. All of these are profoundly glaciated, and at present all bear small 
dwindling glaciers. Several are hanging distinctly above the surface of the fiord water, but all such are low, their lips being no more than 100 or 200 feet above sea level. They are so low and form such a contrast to the high hanging valleys of the region that at first sight they might not appear to be hanging at all, but examination shows the presence of a rock lip above the fiord level in each valley.

\section{CASCADING GLACIERS.}

Besides the evidences outlined above, striking proof of profound glacial erosion is seen in all the valleys formerly occupied by glaciers. The walls above the glacier surfaces are all steepened and scoured, and the tributary glaciers almost uniformly enter the main valley with an abrupt descent whose height is, roughly, inversely proportional to the size of the glacier occupying it. These steps in the lower reaches of tributary glaciers, often producing ice falls and cascading glaciers, are interpreted as the result of the hanging condition of the valleys out of which they descend (p. 50).

\section{CIRQUES.}

There are also abundant cirques, both on the peninsula and on the mainland. They exist at various levels, some of them hanging pronouncedly, some forming the heads of branches to larger valleys, some existing as depressions on the steep mountain slopes. They vary greatly in size, form, and position. Many of them are at so high a level as to be still occupied by glaciers, but others are well below the present snow line. No careful study was made of any of these cirques.

\section{THROUGH VALLEYS.}

On pages 35-36 mention has been made of the presence of through glaciers, resulting from the lowering of divides by glacial erosion at the former flood stage, and of their relation to the peculiar condition of the through valley. Many of these through valleys are still so deeply buried beneath ice that their form and relation can not be clearly determined. Even these are, nevertheless, out of harmony with the surrounding mountain topography, and are strongly suggestive of ice erosion. In some cases there is so little ice in them that their form is evident, and in all such cases the divides are found to be broad, U-shaped, and flattened, harmonizing with the U-shaped, glaciated valleys with which they are connected. Their character may be inferred from a description of two instances.

One of these extends from Nunatak Fiord to Variegated Glacier, being occupied from end to end by a through glacier heading on a flat divide, one end descending to Nunatak Fiord, the other forming Orange Glacier (PI. XVII, $A$ ). The valley has a nearly uniform breadth throughout, and, judging from the surface profile of the glacier, its bottom, even at the divide, is of the same nature as the other glaciated valleys, such as.Calahonda Valley. Above it rise smooth, steep-sloped mountain walls, breached high up by small hanging valleys.

A second through valley lies just south of this, behind the slate hill, in the Northwest Arm of Russell Fiord. On the southern side its wall is slate, on the northern apparently white granite. The divide is approximately 1,500 feet above the fiord level, and no ice was seen in it. It is broadly U-shaped throughout, and bears clear evidence of profound ice scouring. Lying as it does along the line which the expanded Nunatak Glacier must have followed when it was tributary to the Hubbard, it is in an excellent position for ice scouring. This, considered together with the valley form, suggests ice-erosion origin, and no other hypothesis seems applicable to this particular instance. At one stage in the recession of the ice flood the slate hill must have risen as a nunatak above the glacier surface.

If this explanation of through valleys is the correct one, the amount of glacial erosion performed during the flood stage of the ice is far greater than one would infer from a mere examination of the partly drowned fiord valleys. Among the mountains of this region are many through valleys, extending in all directions. It is a form of topography to be expected in regions of profound glaciation, and one, so far as I have been able to learn, not described as occurring in unglaciated regions. 
While stream erosion and faulting seem totally incapable of explaining this through-valley condition, it is entirely possible that a part of it is due to retrogressive cirque erosion at the glacier heads. When the ice flood was beginning, the development of cirques near the valley heads would have a tendency to lower the divides and push them back, opening up connections between opposing valleys, and thus providing a way for later free passage of through glaciers during the flood stage of the ice. The introduction of this possible initial influence of cirque erosion does not materially alter the general proposition that the present form of the through valleys is the result of profound ice erosion due to the movement of through glaciers across divides now so broad, flat, and low.

\section{Y-SHAPED VAILEYS.}

The evidence is clear that during the last advance of ice in the Yakutat Bay region Nunatak Glacier split at Cape Enchantment, sending a tongue southward to join the expanded Hidden Glacier and northwestward into the Northwest Arm of Russell Fiord. There is little doubt also that Hubbard Glacier split against the point back of Osier Island at an earlier period.

The $Y$ shape of valleys is not uncommon in regions of former glaciation, and in many cases the evidence is convincing that the glacier split at the point, sending distributaries into each branch of the $Y$. The $Y$ of Lake Como may be taken as an example of such a condition in another region. In such cases ice erosion has so profoundly modified the topography that it is now often difficult to reconstruct the ancient valley condition out of which the present $Y$ form has been evolved. While it would be possible to offer hypotheses for the cases in Yakutat Bay, a discussion of this question would be fruitless, since the facts are too meager to support any of them. Suffice it to say, therefore, that the $Y$ shape does not seem a probable result of stream work, but that it might readily have resulted from the enlargement by glacial erosion of a tributary (Northwest Arm of Russell Fiord) to a main valley (Disenchantment Bay). -

An analogous case, very much to the point, occurs at the head of Lake Cayuga; in the town of Ithaca, N. Y. The continental glacier, moving southward along the Cayuga trough, split against South Hill, one current passing on southward up the Inlet Valley, the other southeastward up Sixmile Creek valley, lowering both and leaving tributary valleys hanging above the ruunded, U-shaped valley bottoms of the main troughs. Passing on southward, the ice streamed across the divides of both the Inlet and Sixmile Creek valleys, lowering each to a through-valley condition. If the sea could rise up to the 1,100-foot contour, drowning these valleys, a condition closely analagous to that in the Yakutat Bay region would be produced. It seems highly probable, also, that the cause known to have operated in the Ithaca region is responsible for the similar case in Yakutat Bay. The Y-shaped valley seems to be a form normal to regions of pronounced glacial erosion.

\section{ALTERNATIVE HYPOTHESES.}

In the above description glacial erosion has been assumed throughout as the agency by which the peculiar topographic forms have been produced. This has been done principally because it is believed that the glacial-erosion explanation of such forms is now established. At the same time it may not be out of place to consider the question of alternative explanations as applied to this particular region.

\section{PROTECTION BY LATERAL VALLEY GLACIERS.}

One explanation that has been offered to account for phenomena similar to those so clearly developed in this inlet is that the tributary valleys were occupied by glacier tongues, while the main valleys were free, and that the overdeepening of the main valleys was accomplished by stream erosion, while the glaciers protected the tributary valleys. Aside from the improbability that such glaciers would linger in scores of places, at exactly the proper position, for so long a time as to permit such great deepening of the main valleys, there are insuperable objections to this hypothesis. 
No known action of streams forming a youthful valley with steep slopes could at the same time make the valley broad and flat bottomed and without projecting spurs. If there is such a process, it should be clearly stated, with instances, by the advocates of this hypothesis. Moreover, the steepened valley slopes are now unstable in position, indicating clearly that they were developed in such a situation as to be protected from weathering, as would be the case under a glacier. Now that they are exposed to the weather they are crumbling rapidly and talus slopes are developing at their bases. Had they been formed by normal stream work, in attaining such breadth weathering would most certainly have lessened the slopes, whose instability in relation to weathering processes is now so clearly evident.

Again, tributarv glaciers, even in such remarkable situations as those postulated, should develop pronounced gorges below the lips of the hanging valleys, and the streams between the hanging valleys, descending the steepened slopes from the higher mountains valleys, should likewise have intrenched themselves. In the meantime there should have developed on the muuntain slopes a system of valleys with branching tributaries. Any one of these objections is almost fatal to the theory proposed, and the combination of all is sufficient to eliminate it absolutely.

\section{REJUVENATION.}

A second hypothesis for the condition of hanging valleys is that of rejuvenation. To this explanation most of the objections outlined in the preceding section apply with equal fullness and with sufficient force to render it an hypothesis without foundation so far as this region is concerned.

\section{FAULTING.}

A third hypothesis is that of block faulting. It is true that this region is one of recent faulting, and therefore one to which this explanation might seem possibly applicable, but objections to it even here are as strong as to any of the other rival hypotheses. No known process of block faulting would give rise to the curve of the typical glaciated valley, which is a convex curve on the mountain walls and a concave curve in the valley bottom, the two uniting to form a broad U.

Block faulting along so many lines and with such great and recent throw as would be demanded in this region seems most improbable. This of itself may not seem a strong objection, but when it is considered that the peculiar valleys to be accounted for are found in all parts of the region, and extend in all directions, it is evident that a remarkable complexity of block faulting would need to be postulated, and one would seem warranted in demanding at least some definite evidence of its existence before accepting so improbable an hypothesis. There is no such evidence even in this region of pronounced faulting.

A much stronger objection to the hypothesis of faulting is the fact that neighboring hanging valleys, for example, those on the south side of Nunatak Fiord, are hanging at distinctly different levels, and without any uniformity of difference in level which could be correlated with faulting. (See also Pl. II.) Furthermore, in some instances main valleys have hanging tributaries, which themselves have minor hanging tributaries; and in some of these instances the rock face of the secondary tributary is clearly exposed below the lip of the hanging valley, without showing the least evidence of recent faulting.

Another objection to the hypothesis of faulting is the necessity of assuming, as a part of the hypothesis, that the faulting occurred recently, abruptly, and in great amount. Had it occurred slowly, drainage lines would of necessity have developed on the steepened slope during the periods intervening between the uplifts.

\section{OTHER HYPOTHESES.}

Stream capture, lateral ice erosion instead of vertical, and other hypotheses have been put forward; but to all fatal objections can be and have been urged. In a recent arraignment of the glacial erosion "fallacy" no more definite alternate hypothesis was put forward than that the phenomena are to "be explained as normal product of atmospheric and stream work under 
conditions not yet understood." Such an hypothesis can not, of course, be specifically considered. ${ }^{a}$

\section{EFFICIENCY OF GILACIAL EROSION.}

Of all the hypotheses proposed, glacial erosion alone appears capable of explaining all the facts. It accounts for the broadened and greatly overdeepened main valleys, with truncated spurs, spurless walls, steepened slopes, and immature drainage lines; the $U$ shape of the hanging tributary valleys; the nonprogressive, irregular discordance in the hanging level of these; the difference in erosion from place to place; the irregularities of the valley bottoms, and the through valleys-a combination of features which has never been described except from a region which has been, or still is, occupied by glaciers. Any rival explanation must also account for these facts, and since none of those so far proposed do this, is seems rational to accept the glacial-erosion explanation for the phenomena.

Against glacial erosion little has been urged further than the argument that ice is not a powerful agent of erosion, and that it acts to protect rather than to erode. This conclusion has been based largely on observations along the margins of weak, 'dwindling valley glaciers. In a similar way, a generation or two ago, it was argued that rivers could not cut great canyons. It required convincing evidence that rivers actually accomplished such erosion before it was agreed that they could do it. The facts set forth in this chapter prove conclusively that ice has eroded in this inlet to a remarkable degree; and, by similar evidence elsewhere, others have shown that glaciers have eroded profoundly during previous flood stages.

In the face of such evidence that ice actually has eroded, it is hardly demanded that one shall show that it really can erode. Nevertheless, it may not be amiss to point out several facts bearing directly on this question. In the first place, there was an enormous thickness of ice, supplied from many tributaries and without doubt flowing with comparative rapidity through the valleys. Second, there is direct evidence that this ice was actually eroding. The roche moutonnée surfaces, the evidence of plucking, the polished, scratched, grooved, and fluted rock exposures in all parts of the inlet (Pls. IX, XXXI), and the extensive morainic deposits, all testify to the fact of erosion by the glaciers; and the existing glaciers add another evidence, namely, that of rock flour issuing from the ice fronts in the glacial streams.

Whether one assumes that this erosion amounts to an inch a year or an inch in a score of years, the fact of ice erosion must be accepted. It is then necessary only to haye time enough in order to obtain the results so clearly indicated in this field. The problem is the same as that of a river. One might see a small stream of clear water in the bottom of a deep gorge and say, correctly, that such a stream can not have formed so profound a gorge; he might even go so far as to say that such a stream does not erode at all, or practically not at all. But the flood stream, like the ice flood, is a different agent in degree. Give it time and it can cut the gorge, just as the ice flood, given time, can deepen mountain valleys even thousands of feet. This proposition seems incontrovertible on the face of it; and in the light of the peculiar topographic features in regions of former glaciation, it seems necessary to assume that what is possible is what has actually taken place. Those who oppose vigorous glacial erosion are in the position of those who opposed river erosion long after the majority of workers accepted it-that of ultraconservatism.

A recognition of the topographic forms resulting from glacial erosion makes it possible to determine the area formerly occupied by ice. Applying this to the Yakutat Bay region, we find that both the main valleys and the tributaries were occupied by streams of ice compared with which the present-day glaciers are mere pygmies. The evidence of the topographic forms produced by glacial erosion harmonizes with and verifies that derived from the study of highlevel moraines. It adds, however, three new points. (1) It tells plainly that these great ice streams were moving with rapidity and great power, and (2) the great amount of erosion

a For further consideration of the arguments against glacial erosion, see Tarr, R. S., Glacial erosion in Alaska: Pop. Sci. Monthly, vol. 70, 1907. pp. 99-119, and Tarr. R. S., Glacial erosion in the Scottish Highlands: Scottish Geog. Mag;, vol. 24, 1908, pp. 575-587. 
performed clearly testifies to a long period of ice occupation. Furthermore, (3) the freshness of the evidence, in this region of active weathering, conclusively proves that the period of ice occupation was not very remote.

\section{DIRECTION OF ICE MOVEMENT.}

Descending moraine terraces and descending ice-grooved rock terraces prove a movement of the ice westward out of the Hidden Glacier valley and Nunatak Fiord, and southward out of upper Russell Fiord and Disenchantment Bay. In that part of Russell Fiord between Nunatak Fiord and Disenchantment Bay the evidence is very clear that the latest ice movement was northwestward. On the northeast side of the fiord there is a series of remarkably perfect rock grooves and terraces descending northwestward at an angle of about $5^{\circ}$ (Pl. XXXI). On the opposite side of the fiord, in the area of crystalline rock near Marble Point, a northwestward movement is demonstrated by the presence of a crag-and-tail form of striation, where quartz nodules have resisted the ice erosion better than the inclosing minerals.

These evidences are all associated with the last ice movement, whose erosive action must have been exceedingly powerful to have produced such prominent grooving. This is indicated not only by the sculpturing of rock cliffs so prominent that it is possible to show the grooving in photographs taken at a distance of several miles (PI. XXXI), but also by the deep, though minor, grooves and flutings. Nowhere are the latter shown better than in the crystalline limestone at Marble Point, where the fluting, though on a minor scale, reminds one of the remarkable instances at Kelley Island, Lake Erie.

The recency of this period of ice erosion is proved by the perfect preservation of the polishing and the delicate striæ, even where the rock has no soil cover, as well as by the general absence of vegetation. The freshness of the glaciated surfaces is preserved even on exposed areas of the weak graywacko of the Yakutat group, as on Osier and Haenke islands (Pl. IX).

That the ice molded itself to the larger irregularities of its bed is evident. This was clearly shown in the case of Haenke Island, where, on the north side, striæ rise out of the fiord and ascend the northern slope with an inclination of about $5^{\circ}$. On the south or lee side of the island descending striæ occur.

Evidence concerning the direction of ice movement in the earlier flood stage is not so conclusive as that of the later movements. Two facts suggest an earlier movement of the ice through the Northwest Arm of Iussell Fiord in the opposite direction from that of the last movement--that is to say, a period during which Hubbard Glacier, reenforced by many valley glaciers now greatly shrunken, or even absent, sent one tongue down Disenchantment Bay and another eastward through I.ussell Fiord, joining forces with Nunatak and Hidden glaciers in the South Arm of -ussell Fiord. The first indication of this is the fact that the upper groovings and moraine terraces are approximately horizontal and in.strong contrast to the northwestwarddipping lower and later grooves and terraces. In the second place, among the high-level deposits on the ridge west of Cape Enchantment occurred rusted gneissic rocks of the same type as those now present near Hubbard and Variegated glaciers. It is of course possible that there may be a source for this same type of rock among the tributaries to Nunatak Glacier. This evidence is, therefore, not advanced as conclusive, but as merely suggestive. A much more careful study of the bed-rock geology and of the rock contents of the moraines will be required to definitely determine the direction of the earlier ice currents.

The evidence of the through valleys, together with the fact that the higher moraine terraces are well above the level of the present divides of some of these valleys, indicates that in the flood stage the ice streamed in a complex network (fig. 9) along valleys now either abandoned by ice or else occupied by glaciers descending both ways from a central divide. In the ice-flood stage this mountainous land was literally submerged, with only the peaks and higher ridges projecting above the network of glaciers. 


\section{CHAPTER IX.}

\section{GRAVEL DEPOSITS.}

\section{GENERAI STATEMENT.}

Throughout the Yakutat Bay region gravel deposits occur in various situations. Alluvial fans are at present developing in front of all the glaciers which terminate on the land; for example, Hidden Glacier (p. 62), Galiano Glacier (p. 72), Atrevida Glacier (p. 75), and Malaspina Glacier. Gravels are also being deposited in marginal lakes, as, for example, in the Blossom Island lake (p. 88) and in the lake near the margin of Hubbard and Variegated glaciers (p. 44); and gravel deposits are even accumulating on some of the glaciers themselves, as in the case of Variegated Glacier (p. 50).

Besides these gravels now being deposited there are extensive areas accumulated at various levels during an earlier stage of glaciation. These earlier gravels present some interesting features and furnish a clue to certain phases in the recent glacial history of the region. For this reason they will be deseribed in some detail, after a preliminary consideration of the gravels now accumulating.

\section{MODERN ALLUVIAL FAN GRAVELS.}

In front of Hidden Glacier, as already described (p. 62), there is an extensive outwash gravel plain filling the valley from side to side, and still in process of both outward growth and upward building.

ALLUVIAL FANS IN NUNATAK FIORD.

In Nunatak Fiord there is no alluvial fan in front of the sea end of the glacier, but with continued recession and consequent shallowing of the bay the ultimate development of an outwash gravel plain similar to that in the Hidden Glacier valley may confidently be predicted. In the meantime alluvial fans are rapidly developing on both margins of the fiord, opposite the mouth of each of the valleys in which dwindling glaciers still exist. The rate at which these fans are growing out into Nunatak Fiord is remarkable and shows the great possibilities in the way of extensive gravel formation along the slowly shifting base-level of a receding ice sheet.

There is a progressive series of such fans increasing in size away from the end of Nunatak Glacier. The fan nearest the glacier front is being built by a stream which descends from the glacier that occupies the hanging valley on the northern side of the fiord just below the ice cliff of Nunatak Glacier. When Gilbert photographed Nunatak Glacier, in 1899, the ice extended below the site of this fan, which, of course, did not then exist; but by 1905 a small alluvial fan had been created, the product of less than six years' work. Over this fan flowed a vigorous stream, which had cut a gorge in older, higher level gravels, evidently accumulated against the ice margin when Nunatak Glacier extended below the mouth of this hanging valley.

Just west of this are two dwindling glaciers whose fans are coalesced, forming at the sea margin a gravel deposit fully half a mile across and projecting several hundred yards into the fiord. The absence of even young alders and willows upon the older gravel terraces above this double fan proves that it has not been many years since the ice left the site now occupied by the alluvial fans. The lower terraces have not yet acquired even the distinct coating of moss such as is found on the higher and older gravels. With such rapid development of lateral fans, and with the outward growth of a fan at the valley head, terminal to the main ice tongue, it could not be a task requiring a great period of time to fill a considerable part of Nunatak Fiord from side to side with gravels, as in the Hidden Glacier valley. 


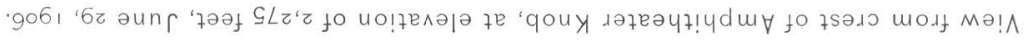

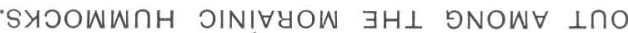

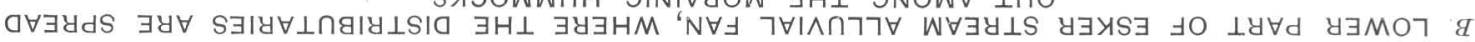

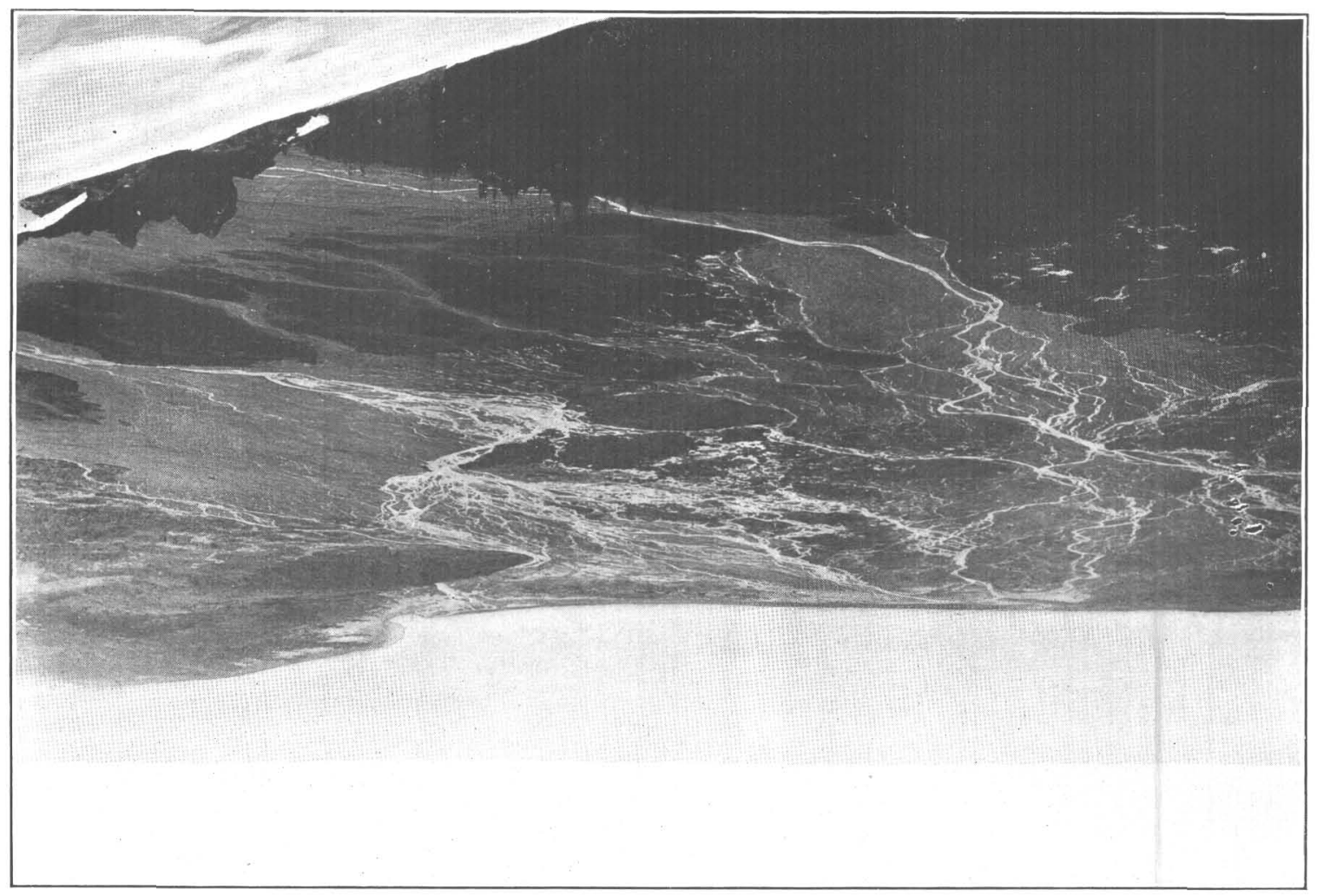

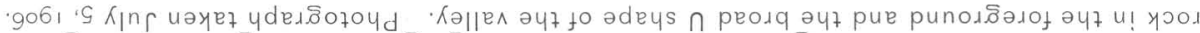

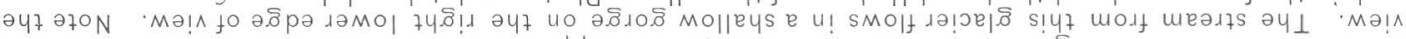

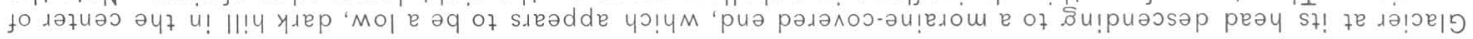

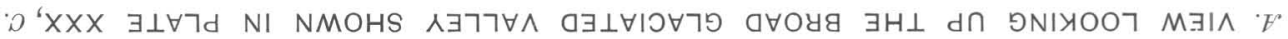

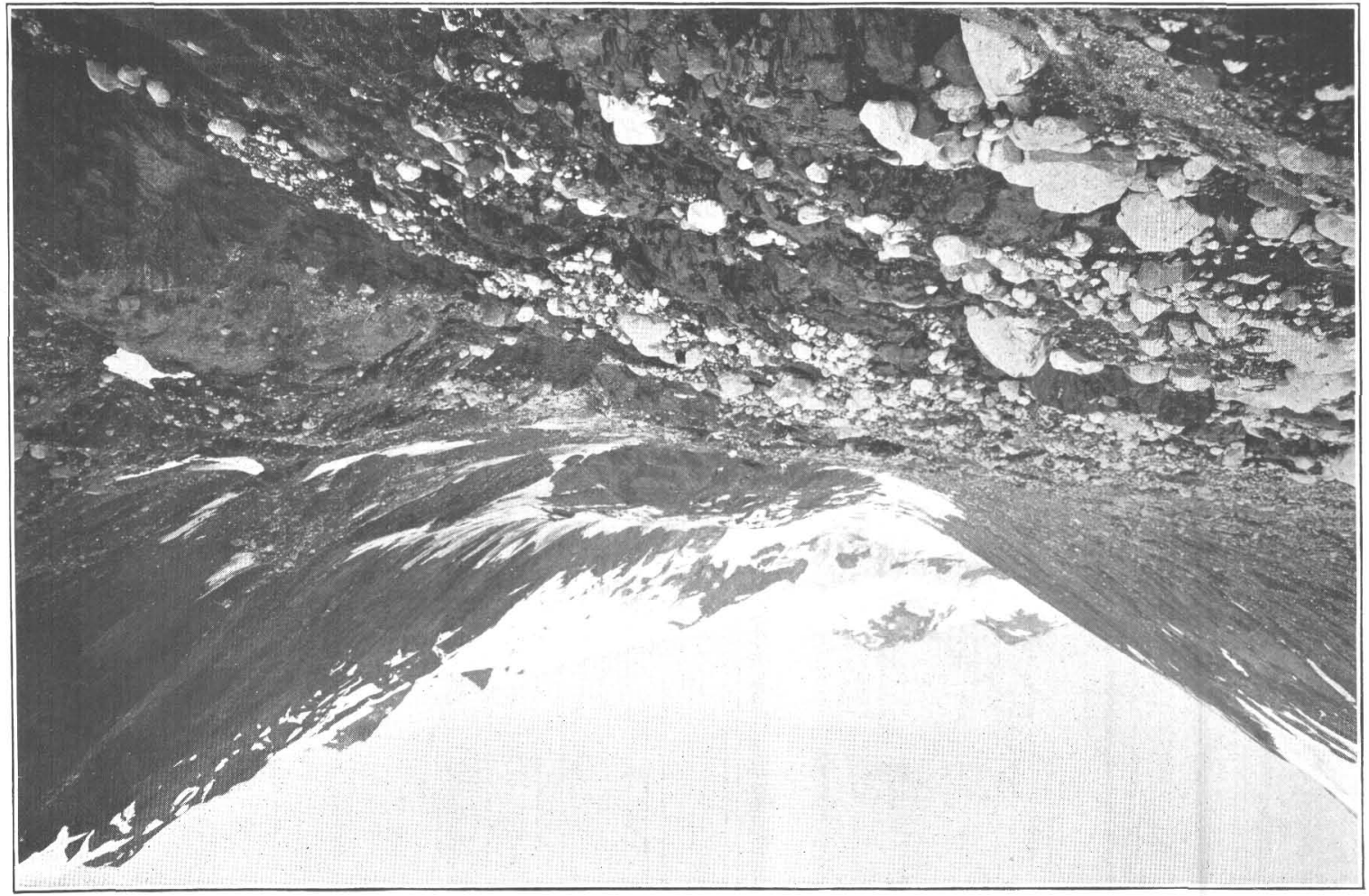

IIIXXX $\exists \perp \forall 7 d \quad t 9$ y $\exists d \forall d \quad 7 \forall N O I S S \exists \sqsupset O Y d$

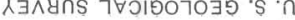


The rapidity of growth of the alluvial fans decreases rapidly with the diminution of the glacier that supplies the fan-building stream with water and sediment, but even with such a dwindling glacier the fan growth is rapid if the stream is removing higher level gravels, as is the case on the north side of Nunatak Fiord in the area between the alluvial fans already described.

VARIEGATED GLACIER ALLUVIAL FAN.

The diminution in rate of growth of alluvial fans, due to decrease in sediment supply, is in some cases very clearly demonstrated. This is well illustrated in the alluvial fan of the Variegated Glacier stream, the largest fan in Russell Fiord (Pl. XXXI). Ordinarily the constant shifting of the braided streams prevents the growth of vegetation on the alluvial fans. The eastern half of the Variegated Glacier fan, however, is covered with a mature alder growth, and on the western half there is more vegetation than is normal on an actively developing alluvial fan. This fan was evidently built during a period of more powerful water action than now, probably when the stream of Variegated Glacier was larger and it brought all of its gravel supply to the sea. At present not only is the volume of the stream diminished, but much of its gravel is strained out by deposit in the interior flat of Variegated Glacier (p. 50). It is evident that if there should come a readvance of the ice, after such a period of relative inactivity, the continued growth of the fan would involve the destruction and partial burial of the alder growth. ${ }^{a}$

ESKER STREAM ALLUVIAL FAN.

The variation in conditions associated with the development of an alluvial fan during the dwindling of the supplying glacier is exceedingly well illustrated in the case of the fan of Esker Stream, whose source is in the eastern margin of Atrevida Glacier (p. 75). The head of this alluvial fan lies more than 4 miles from Yakutat Bay at an elevation of 250 feet above sea level. It is a perfectly developed fan, containing many large, rounded stones, and, since it is barren of vegetation, is evidently growing at the present time. There is a progressive change in the size of the fragments forming the fan, from the upper to the lower part. Near the glacier there are many good-sized bowlders, while at the seacoast the materials are mainly gravel and fine sand.

This fan is encroaching in places on the spruce forest, and both dead and living trees, still standing, rise above it in various stages of destruction. The forest is mature, containing trees certainly more than a century old, thus proving that the region between Atrevida and Galiano glaciers has not been occupied by moving ice within that period at least.

About a mile from the sea the fan becomes imperfect, and, as already described (p. 72), is being built among and over moraine hummocks (Pl. XXXIII, $B$ ). This is interpreted as proof that an ice barrier, evidently an expanded stage of the adjacent Galiano Glacier ice bulb, recently stood across the path now followed by this fan-building stream.

Between these moraine hummocks and Atrevida Glacier, and fringing the base of Amphitheater Knob, is an earlier, higher fan, dissected to a depth of 50 feet by the present Esker Stream. It is believed that this older fan was developed during a still earlier and higher level of Galiano Glacier, when the drainage from the Atrevida was deflected along its bulb-like expansion and turned southward toward Kwik River.

A small stream descending from Amphitheater Knob and dissecting this older fan reveals a buried forest in jts gravels. The stream has cut a broad, deep trench in the higher-level fan, in which aggradation is now in progress, and as the stream undermines the older high-level fan it is both overturning mature living trees which are growing on the top of the fan and unearthing huge spruce trees buried within it. While many of these buried trees are overturned, numerous instances were found of trunks still standing in place. Both the trees growing on the fan and those buried in it include individuals fully a century old. Thus in this single area there are two instances of forest burial in alluvial-fan deposits of widely separated dates, one now.

a This paragraph is left as it was written in the winter of 1905-6. As is stated in previous pages of this report (p. 52), the advancing Variegated Glacier has given greater volume to this stream, and the alder thicket is being destroyed. Observations in the summer of 1906 show also that a change in position of the outflow of this stream occurred in the interval of ten months between the two visits. 
being buried in a fan at present growing, the other in a higher fan, built certainly not less than a century ago, apparently during an earlier period of expanded glaciers.

CLAY DEPOSIT IN ALLUVIAL FANS.

It is a significant fact, bearing on the interpretation of the older gravels of the inlet, that the formation of these alluvial fans involves also a deposit of clay layers, in favorable situations sometimes even interstratified with the gravels. Near the sea both Esker Stream and the Galiano Glacier stream are flowing in braided courses behind a barrier beach. In this situation, as elsewhere on the fan, the major deposit is gravel, but layers of clay are also being accumulated in the more quiet water and in the lower portions of the fan. Far more extensive clay deposits are, however, being made in the depressions between neighboring alluvial fans.

DEPOSITS OF KWIK RIVER.

The largest alluvial fans in the region are those connected with Malaspina Glacier. Russell notes ${ }^{a}$ a series of coalescing alluvial fans fringing Malaspina Glacier, so that if the ice should disappear there would be left a large number of "great bowlder washes" "unsupported at their apexes." Of all these fans the largest is that of Kwik River, which was studied with some care by the Survey party in 1906 .

Water and sediment supply.-Kwik River, after entering beneath Hayden Glacier, in the manner previously described (p. 85), flows in a subglacial course for upward of 5 miles (Pl. XXXVII). It enters the glacier at an elevation of about 900 feet and emerges 400 feet above sea level, thus having a fall, in its subglacial course, of about 100 feet to the mile. It then flows for about 7 miles to the sea with a rapidly decreasing grade.

The Kwik emerges as a rushing torrent from a large cave on the eastern edge of Hayden Glacier near its junction with the Marvine. Its volume swells quickly with every rain and with every clear summer day. At night it shrinks, especially on clear nights, when its supply from the melting glacier is diminished by freezing. Normally the river is at its highest stage between 4 and 6 o'clock in the afternoon, and at its lowest between 8 and 10 in the morning.

What the river is accomplishing under the glacier there is no means of telling, though it may well be engaged in the building of an esker. On its emergence it is heavily sediment laden, carrying not only clay and sand, but even good-sized cobblestones. A pail of water dipped from this torrent has fully an inch of sediment after settling, and the stones dragged along its bed make a noise, as they strike together, which can be heard above the roar of the rushing water.

At first the stream flows in a single course between low gravel banks, but in less than half a mile it divides into a dozen branches, each flowing on the surface of the fan and constantly shifting in amount and position. The volume of the Kwik is nearly doubled by the great Lucia Glacier stream which comes from the east. After emerging from its marginal channel, where it crosses a spur of the Floral Hills, the Lucia stream branches and descends over a steep alluvial fan in a number of distributaries. The great volume of water supplied by the Lucia stream pushes the $K$ wik waters over to the west against the base of the crevassed Malaspina Glacier margin, from which further additions of water and sediment supply are received.

Changes in the distributaries. - The distributaries that flow over the alluvial fan of the Kwik are ever changing their course and volume. When the Survey party ascended the fan early in July we could pass up its western side, near Malaspina Glacier, with only small streams to cross; but on our return, in the middle of August, a large stream, difficult to ford, swept the very ice base for nearly a mile. On every trip up or down this fan a different assemblage of distributaries was encountered. In fact, by watching for half an hour the change could be actually seen in progress.

One of the most striking changes is that in the position of sand and gravel waves in the stream bed. Ordinarily the deeper, swifter streams are ridged in the center, so that the water in the middle is actually higher than the gravel border or bank. One can sit down beside such 
a stream and not be able to see the other bank. Frequently, however, this ridge is broken into a series of choppy waves, from 1 to $2 \frac{1}{2}$ feet in height, which mark the site of river-bottom ripples of sand or gravel. Areas of these "saw-teeth" waves move progressively downstream, and often pass by the observer in procession, so that for an hour or two the stream is thus disturbed, then, in the same place, there is fairly quiet water, the entire area of sand waves having moved on downstream. Later another procession passes by. This is an important method of transportation of sand and gravel by these swift glacial torrents.

A less common variation brought disaster to a part of our outfit early in July. A cache of provisiors, placed in what seemed a safe position, was suddenly overwhelmed and swept into the flood. It is believed that this was due to an abnormal rise in the stream caused by the bursting of an ice-dammed lake, possibly by the opening of the new subglacial outlet of the Blossom Island Lake (p. 88). It is commonly reported that sudden rises of this great glacial river are not of infrequent occurrence.

Lower fan.-Below the junction of the Kwik and the Lucia streams, each of which flows in distributaries over high-grade fans of coarse gravel and even bowlder washes, the united waters flow to the sea over a common fan of lower grade. Pebbles are the coarsest fragments borne, the cobbles of the upper course having been left behind. At times of high water, after heavy rains, this lower fan is almost completely covered with a sheet of water, with very small areas of uncovered gravel bars, and many swift, deeper currents. At other times more land appears, but even then the surface of the fan seems to be more than half water.

In one journey over the 7 miles of this fan, during such a stage of low water, upward of 150 streams, varying in depth from 2 or 3 inches to $2 \frac{1}{2}$ feet, were crossed, the larger ones flowing swiftly enough to transport gravel, and all heavily charged with mud. These streams branch and subbranch, reunite and branch again, and each individual stream is evidently changing constantly both in volume and in position. Standing beside one of these, even for only a few minutes, it can be seen to either diminish or increase in volume, and new threads can be seen to start over the dry areas of gravel, while others shrink to nothing. The quantity of sediment transported is enormous, and in its overburdened condition the river is rapidly aggrading its entire alluvial fan, on which there is not a vestige of vegetation, not even annual plants finding a foothold.

Nearer the sea the grade of the alluvial fan so diminishes that, finally, even small pebbles are no longer carried, and sand and clay are deposited. In the lower reach the divided currents come together for escape through the barrier beach to the sea. In this portion of the river the current is so slackened that it is possible to ford it, as Russell did in 1891, and as one of our packers did, though with great difficulty, for he sank to his neck in water and quicksand.

Lagoon section.-A A barrier beach skirts this coast near the mouth of Kwik River, being breached by the outrushing current. Behind this beach is a long lagoon, into which the high tide enters, backing up the current of the Kwik for more than a mile from the sea. Thus, twice every day there is a change in the velocity of the sediment-laden waters of the lower $K$ wik. In addition, there is a variation in volume, velocity, and amount and coarseness of sediment of a more irregular nature, due to variation in supply from day to night, and from rainy to clear spells. There must also be variations of longer period due to seasonal changes in water supply.

The effect of these variations is plainly seen in the lagoon deposits, which are thinly bedded with layers markedly different in texture. In general, these layers consist of alternate beds of a fine-grained, oozy clay (rock flour) and sand, but there are some layers of fine gravel. In places these deposits give rise to quicksands, the oozy clay and thin layers of sand sinking under the feet, sometimes in an alarming manner. Experience with this treacherous deposit, however, always showed a hard bottom at a depth of 1 to 3 feet, possibly due to the coarser gravel deposited during the floods of early spring.

This lagoon deposit is not absolutely lifeless, though only a few forms of mud-living organisms thrive in it. Its surface is tracked with the footprints of birds, foxes, wolves, and bears, and it is grooved by icebergs that float over it at high tide. Here and there a stranded berg introduces a little pocket of gravel in a depression in the clay and sand layers, and in numer- 
ous places tree fragments are lodged. Altogether an interesting deposit, later to be covered with alluvial fan gravels, is accumulating.

Outgrowing coast.-The beach whose barrier makes this lagoon possible is newly formed, for it bears only a sparse vegetation of sand-loving plants. Where the waters of the $\mathrm{K} w \mathrm{ik}$ escape the gap through the beach is faced by a crescentic bar, over which the breakers dash even at high tide, while at low tide small bars appear here and there.

This mighty current of heavily mud-laden water is supplying enormous quantities of sediment to the sea, far more than can be effectively disposed of by the waves and currents. Strong floods undoubtedly carry gravel clear to the sea, for gravel appears in cuts beneath the lagoon quicksands. For at least a mile off the mouth of the Kwik the bottom has been so shallowed by deposition that the ocean swells of ordinary summer weather frequently rise almost to the point of breaking. Because of the sediment supplied by the $\mathrm{K}$ wik, the coast is being rapidly pushed outward, and in this section projects as a distinet, rounded point.

The process of outgrowth of this coast has long been in progress, for there are two distinct barrier beaches of older date than the present, and a third, more dissected, still farther inland. All of them are cut into fragments by the Kwik, but the amount of dissection increases away from the sea. The outer abandoned strand, less than half a mile from the present barrier beach, supports a growth of mature cottonwood in clusters or groves, with the individual trees in some cases three-quarters of a century old. A mile farther inland is the second abandoned barrier beach, more thoroughly forest covered, and bearing mature spruces. Still farther inland, about $2 \frac{1}{2}$ miles from the present coast, is the third, so dissected that only small fragments remain.

Thus in the conflict between the sediment supplied by the current of Kwik River and the ocean waves and currents the latter are given more to carry than they can dispose of, exactly as the $\mathrm{K}$ wik itself is overburdened. Therefore the coast is being built outward, evidently at a rapid rate. Within a very few centuries it has been pushed out for a distance of fully $2 \frac{1}{2}$ miles, and another step in the outgrowth has been begun in the crescentic bar off the mouth of the rivor.

\section{IMPORTANCE OF GLACIAL STREAM DEPOSITS.}

From the above description it is evident that the glacial streams of the Yakutat Bay inlet are bearing enormous amounts of sediment, and are consequently rapidly making deposits over large areas. The materials forming these deposits are of all grades of texture from the finest clay to good-sized bowlders. Besides the visible alluvial fans and the outgrowing coasts, there are the invisible deposits in front of the tidal glaciers, as well as extensive offshore deposits, mainly of the finer clay. The amount of this clay contribution to the marine sediments is striking. In the Yakutat Bay region there are scores of glacial streams, and opposite the mouth of every one of them the waters are constantly clouded with the heavy burden of sediment that is being poured into the sea. In some of the largest of the streams the muddy water extends fully a mile from the coast. Thus, both the visible and the invisible sediments are forming extensive deposits. In few situations is there more rapid sedimentation than in association with such glacial torrents.

\section{OLDER ALLUVIAL FANS.}

At no point was it possible to find extensive alluvial fans of perfect form in situations indicating their deposition marginal to the former expanded main ice tongues, although this origin is suspected for many of the higher-level gravels described below. It happens, also, that neither conditions favoring the development of marginal lakes nor topographic features favoring the accumulation of high-level marginal gravels are now present near the termini of the existing glaciers. For the accumulation of such deposits there should be lateral tributary valleys not high above the fiord level, whereas near the present termini of the glaciers the lateral valleys are all hanging high above the fiord. As will be shown later, the evidence is very clear that such 
marginal topographic conditions did occur at numerous points during the former expansion of the glaciers.

While no such gravel deposits were found actually in process of formation, instances were discovered where this kind of deposit was evidently made during a late period in the recession of the glaciers. The best of these cases are on the west side of Russell Fiord, just south of Cape Enchantment. Here occur a series of higher-level gravels which were overridden by the glacier but not completely worn away. These gravels were later trenched by broad gullies, in which extensive alluvial fans have been built, and these fans are themselves cut to a depth of 20 to 30 feet by channels in which modern alluvial fans are now growing.

The modern fans are distinctly smaller than the older dissected fans, often not one-third as extensive. Their surfaces are barren of vegetation, while the truncated older fans support a growth of moss and scattered alders. Tree fragments, evidently washed out of the older ice-eroded gravel terraces, occur on top of the older fans many feet above the present reach of the waves and at the mouths of valleys in which no trees now grow.

There is no evidence to indicate that the older high-level fans were made during a former lower.stand of the land, and this hypothesis was therefore rejected. They were doubtless accumulated in lake waters ponded back in this arm of the fiord during the late stages of recession of Nunatak and Hubbard glaciers, perhaps starting as deposits in marginal lakes and continuing their growth in the expanded, ice-dammed lake which must have occupied the southern part of Russell Fiord during the last recession of the ice. That they are to be correlated with the period of recession rather than advance of the glaciers is proved by the fact that they have not been overridden.

\section{EARLIER GRAVELS.}

\section{GENERAL DISTRIBUTION.}

At various levels, even well up toward the highest limit of former ice extension, gravel deposits cling, in favorable situations, to the mountain sides. These gravels are distinctly different from the ordinary till of glaciated regions, which is not particularly abundant in this field. At the higher levels the gravels are ordinarily thin, scattered, and much eroded by postglacial stream work (Pl. XXXIV, $A$ ). These facts, together with their inaccessibility, rendered it impracticable for us to study carefully the highest-level gravels.

Lower down the mountain slopes both the extent and the perfection of development of the gravels increase, their best development being reached within 400 or 500 feet of the fiord level. They are not everywhere present, naturally being entirely absent from the steepened fiord walls, to which they could not cling, and also from any of the more moderate slopes on which they may once have existed but from which they have been removed by glacial erosion.

Where the gravels occur they are evidently remnants of far more extensive deposits, and they frequently have the appearance of terraces, although in most cases closer examination shows this appearance to be deceptive. The characteristics of these gravels will be best understood by a description of some of the localities of typical occurrences.

\section{GRAVELS OF HIDDEN GLACIER VALLEY.}

Summary of previous descriptions.-Both walls of the Hidden Glacier valley show clear evidence of powerful ice scouring. The outwash gravel plain, in its upper part, covers the end of the glacier. Along its northern margin the glacier rests upon gravels which the ice has overridden without succeeding in removing them. Beyond the end of the ice, on the northern side of the valley, a series of irregular gravel terraces rise to various levels (Pl. XXIII, $A$ ), the lowest of which is directly continuous with the gravel on which the living ice now rests. (See p. 64.)

Observations by Gitbert.-Gilbert ${ }^{a}$ presented convincing evidence that the terraces just mentioned had been overridden by the ice, although he did not find the ice actually resting on the 
gravels in 1899. My observations do not differ from those of Gilbert, but as the Survey party spent somewhat more time in this valley than he, it was possible to discover more details, which are fully set forth below.

Structural features.-The materials forming these gravel benches are, in the main, stratified gravels. The layers vary, however, from clay to coarse gravel, and include occasional large bowlders of white granite and other rocks. While the average dip is toward the valley axis, the beds less commonly show inclinations in various other directions. Since their deposition the gravels have been deeply gullied by numerous small, wet-weather streams, so that the structure is easily studied. No sign of slumping of the layers due to the melting out of ice blocks was found in any of the numerous cross sections.

Viewed from the south side of the valley these gravel benches have a fairly regular appearance, with a gentle westward inclination of the surface. They seem also to represent remnants of extensive accumulations of gravel, but, as rock was revealed in a number of the gorges, it is evident that the appearance of great depth of the gravels is somewhat deceptive. Nevertheless, nearest the valley center some cuts more than 100 feet in depth showed gravel from top to bottom.

Presence of tree fragments. - That the gravels include plant fragments was early made evident by the fact that numerous pieces of wood, including sections of good-sized trees, were found on the surface of the outwash gravel plain between Seal Bay and Hidden Glacier, in situations to which it was perfectly clear that they could not have been washed from the fiord. This evidence did not show whether the plant fragments were brought by the glacier and thence supplied to the fan-building stream, or whether they were unearthed by the dissection of the gravel terraces themselves. In one place, however, about three-quarters of a mile north of the edge of the outwash gravel plain, and about 75 feet above it, a piece of wood was found in place in the gravels of the terraces. This tree fragment, which was recumbent, was the only one found in the Hidden Glacier valley, with the exception of those on the modern outwash gravel plain.

These facts clearly demonstrate that a forest growth existed in or above this valley, which is now treeless, at a period preceding the last ice advance, and that remnants of this forest were incorporated in the gravels deposited at some stage prior to the last ice advance.

Overriding.-While the westward-descending gravel benches, when viewed from a distance, appear to have a fairly regular form, closer examination of the surface reveals a swinging, undulating surface characteristic of ice erosion. The undulation most commonly assumes the form of broad, smooth grooves, with the longer axis extending westward; but there are also rounded, dome-shaped forms, bearing a close resemblance to roches moutonnées. It is a perfectly characteristic topographic form, clearly recognized by Gilbert, and not to be confused with any other type.

A rolling surface of this sort, common enough in unstratified drift, could not be developed by the deposit of stratified gravels; and, furthermore, the gravel layers are clearly seen to be truncated by the undulations, which are therefore due to some form of erosion later than the deposition of the gravel. That this erosion is not the result of stream work is proved by the broad, swinging slopes, by the position and direction of the depressions, and by the marked contrast between these topographic forms and the steep-sided gullies now developing in the benches as a result of normal stream erosion.

In some parts irregularities on the gravel terraces have been formed by subsequent deposits of two kinds-alluvial fans and glacial deposits; but these irregularities are in most instances easily capable of detection, and are not to be confused with the broadly undulating, ice-eroded surface, whose broad, troughlike depressions are usually parallel to the direction of last ice movement, which is at right angles to most of the stream courses.

Glacial deposits occurring on the gravel benches are to be correlated with the evidence of overriding revealed in the topography. The surface of the benches is strewn with abundant bowlders, some of huge size. In many instances these are arranged in lines, apparently marking the sites of crevasses in the ice margin. These bowlder lines are very noticeable, especially if they are, as frequently happens, of one sort of rock, such as white granite. There are also occasional thin deposits of till. 
That the overriding of these gravel benches is of recent date is proved by the general absence of vegetation upon their surfaces. For a mile from the ice front there is practically no vegetation on the terraces, and nowhere in the Hidden Glacier valley are dense alder thickets developed on the gravel surfaces. As shown below, similar gravel benches, with ice-sculptured surface, morainic veneer, and general absence of vegetation, occur in Russell Fiord, in the neighborhood of the Hidden Glacier valley. From this evidence it seems not at all improbable that this valley was occupied by the glacier clear to its mouth less than a century ago.

The recession of the ice from the gravels is still in rapid progress. This is proved not merely by actual observation of the glacier terminus resting directly on the gravels (Pl. XXIII, $B$ ), but also by an isolated patch of moraine-veneered ice one-eighth of a mile west of thi point. This ice patch is nearly covered by moraine which, by slumping, has assumed a kamelike topography with differences in elevation, between kettle bottoms and hummock tops, of fully 50 feet. When the ice has entirely melted out from beneath this moraine the topography will be greatly subdued, but there will still be left a distinct kame deposit on the gravel surface.

Failure of ice erosion to remove gravels.- The failure of the ice to remove these overriden gravels is noteworthy. It can not be imagined that the gravels have resisted ice erosion throughout the entire period of occupation of the region by glaciers, for in many places they extend along the valley wall below the mouths of the hanging valleys whose origin is undoubtedly due to profound deepening of the rock bottom of the valley on which the gravels rest. The presence of the gravel benches indicates either a brief period of ice erosion or a relatively weak condition of the expanded glaciers, which had been much stronger in an earlier advance, or stayed longer, as the hanging valleys testify. The evidence is clear, however, that the ice was actively engaged in carrying away these gravels and that it had actually succeeded in removing a large share of the previous deposits. The sculptured form of these proves that erosion was in progress, and their complete absence from many places is probably also proof of erosion. In some instances, at least, the gravel remnants lie in protected situations, and in the Hidden Glacier valley they occupy but one side of the valley, and that for only a part of the distance.

One naturally thinks of unconsolidated gravels as weak and easily eroded materials, but it is by no means certain that the erosion of gravel beds by a glacier may not be a more difficult task than the erosion of some hard rocks. They must be carried away grain by grain by the process of abrasion, for the absence of jointing precludes the possibility of plucking on a large scale, which is such an important factor in the erosion of many hard rocks. If the gravel was cemented by frost, as was probably the case, its erosion by the slow process of abrasion might well be much less rapid than that of ordinary indurated jointed rock.

High-level alluvial fans. - On the upper margin of the ice-eroded gravel benches in the Hidden Glacier valley there are high-level alluvial fans deeply cut by present drainage. They have distinctly the appearance of having been built against the margin of a decreasing ice tongue. Since their form is not destroyed and they bear no morainic débris, they are interpreted as phenomena associated with the present recession of Hidden Glacier.

GRAVELS OF NUNATAK FIORD.

General distribution and form.--Owing to the steepness of the mountain walls which inclose the tidal arm of Nunatak Glacier, gravels are not now being deposited along its margin, and the ice has not stood in one position long enough for gravel deposits to accumulate in the deep water at its terminus. Farther down the fiord, however, there are extensive gravel deposits, formed during an earlier stage of ice advance. These are far better developed on the north than on the steep south side of the fiord, being especially well defined in the area of gentle slopes where two broad tributary valleys, occupied by dwindling glaciers, enter the fiord from the north. My examination of these gravels did not extend higher than 740 feet above the fiord, but scattered, dissected gravel deposits occur fully twice as high as this on the more gentle mountain slopes.

In the lower 740 feet the gravels form a series of somewhat irregular benches, descending at a low angle toward the west and more rapidly, in a series of steps, southward toward the 
fiord (Pl. XXXIV, A). Viewed from a distance, their form might be supposed to havi resulted from some constructional agency, such as deposit marginal to the glacier; but when examined in detail their general regularity is found to be modified by numerous broad, sweeping curves, such as are characteristic of ice erosion.

Structural features.- These terraces are cut by streams in many places and by waves in one place, so that their internal structure is clearly revealed in numerous excellent sections. The wave-cut cliff lies less than a mile from the glacier front (1905), at a point just west $c^{\bullet}$ the stream which descends from the hanging valley on the northern wall of the fiord, and ai nost exactly at the point where the ice front stood in 1899. This cliff is from 75 to 100 feet in $h$. and nearly vertical. The lower half consists of a rudely assorted till-like deposit, inclu ling horizontal bands of well-assorted materials; the upper half is well-stratified gravels.

In all the other cuts examined the stratification is very distinct, the layers dipping, on the average, from $5^{\circ}$ to $15^{\circ}$ toward the valley axis. There are layers of sand and gravel, with individual bowlders of large size here and there, and with occasional beds of bowlders. While most of the layers are gravel, there are also numerous beds of sand and, still more rarely, layers of clay. No wood fragments were found in any of these beds. The pebbles in the gravel layers are well rounded and varied in character, and include a large percentage of foreign fragments. No disturbance of the strata such as would have resulted from either ice thrust or slumping was seen. These gravels attain great thickness, being revealed in some of the stream cuts to a depth of more than 150 feet.

Overriding.-That the gravels of Nunatak Fiord, like those of the Hidden Glacier valley, have been overridden by ice since their deposition is clearly proved not merely by the topography, which is that characteristic of ice erosion, but also by the well-defined morainic deposits on the benches. On the whole, these deposits are thin, forming a mere veneer upon the eroded and truncated gravel beds. Over much of the area a thin bed of till veneers the gravels; but more striking than this are the numerous small patches of morainic hummocks and ridges, evidently former superglacial moraines.

Some of these morainic deposits are distinctly kamelike in both composition and form. There are also numerous short, narrow ridges, arranged in rectangular fashion, apparently marking the sites of crevasses in the ice. In one place on these overridden gravels a distinct esker was found, with a length of nearly half a mile and an elevation nowhere greater than 8 or 10 feet. It extends in a north-south direction, with a meandering course, and, so far as could be seen, was composed entirely of gravel with fairly well-rounded stones, some of them of good size. Two or three small tributary eskers join the main one at nearly a right angle.

Besides these deposits the gravel terraces bear many angular bowlders of crystalline rock, some very large. These bowlders are far too numerous to be explained as the result of concentration due to removal of the inclosing gravels.

This veneer of varied deposits on the irregularly ice-eroded surface of the gravels has given rise to numerous small basins in which there is standing water. All these facts combined demonstrate beyond question that since their deposition the gravels of the north side of Nunatak Fiord have been overridden by ice up to an elevation of at least 740 feet.

As in the Hidden Glacier valley, the time that has elapsed since the recession of the ice from these gravels is very short. Even down as far as the mouth of Nunatak Fiord there is little vegetation on the terraces. At this point the till cover of the gravels supports a moss growth, in which occur scattered individuals of creeping willows. A single small cottonwood was also seen. Nearer the ice even these forms of vegetation are practically absent, the flora consisting solely of scattered individuals, mainly of annual and perennial plants. From this evidence it is inferred that Nunatak Glacier, whose recession is now so rapidly in progress, at no very distant time extended to the mouth of Nunatak Fiord. Assuming a rate of recession as fast before 1895 as that from 1895 to 1899 , and from 1899 to 1905 , this need not have been more than fifty years ago. A very old Yakutat native, without knowing my interest in glacial recession, stated to me, as translated by my boatman Henry, that he remembered the time when this glacier extended as far as Marble Point. The general absence of vegetation between Marble Point and the tidal end of Nunatak Glacier indicates that this story may well be correct. 


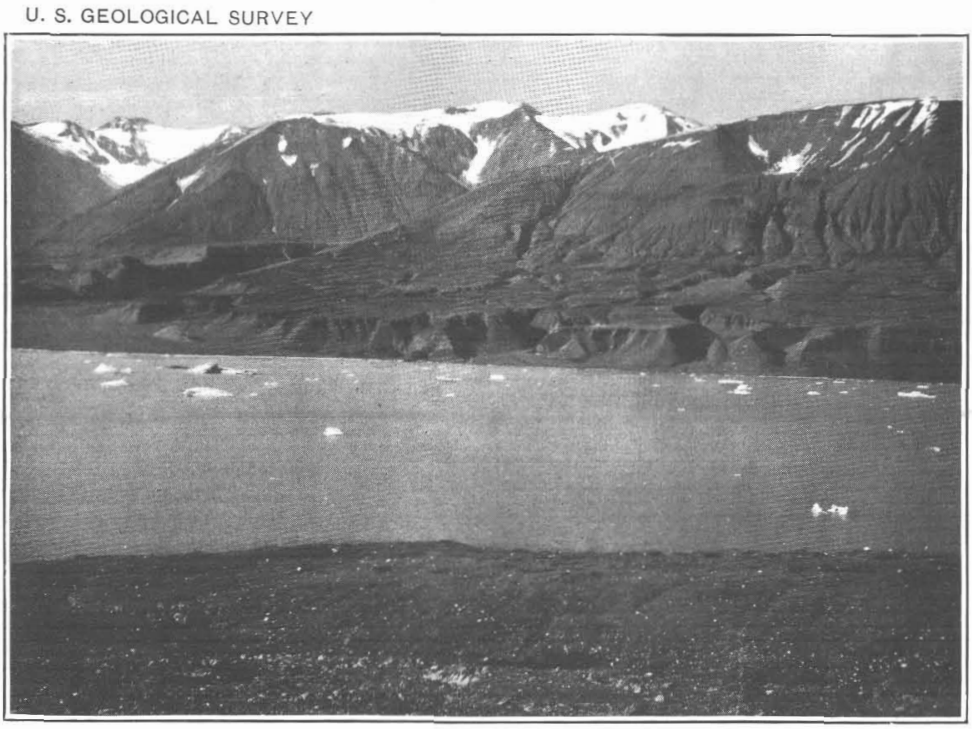

A. DISSECTED, ICE-SCULPTURED GRAVEL BENCHES ON NORTH SIDE OF NUNATAK FIORD.

Shows also gullied higher-level gravels on steeper mountain slope. Note absence of vegetation. Photograph taken July $8,1905$.

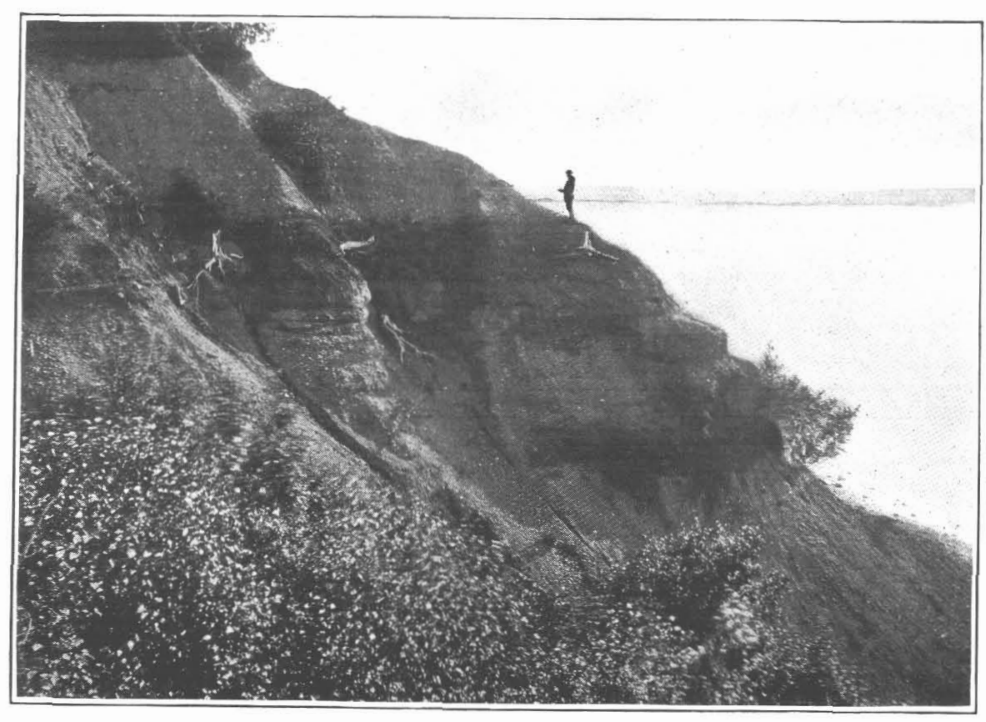

C. TREE TRUNKS STANDING IN PLACE IN A CLAY LAYER IN GRAVELS ON EAST SIDE OF RUSSELL FIORD.

Near head of fiord, at elevation of 75 feet. Photograph taken July 31, 1905.
PROFESSIONAL PAPER 64 PLATE XXXIV

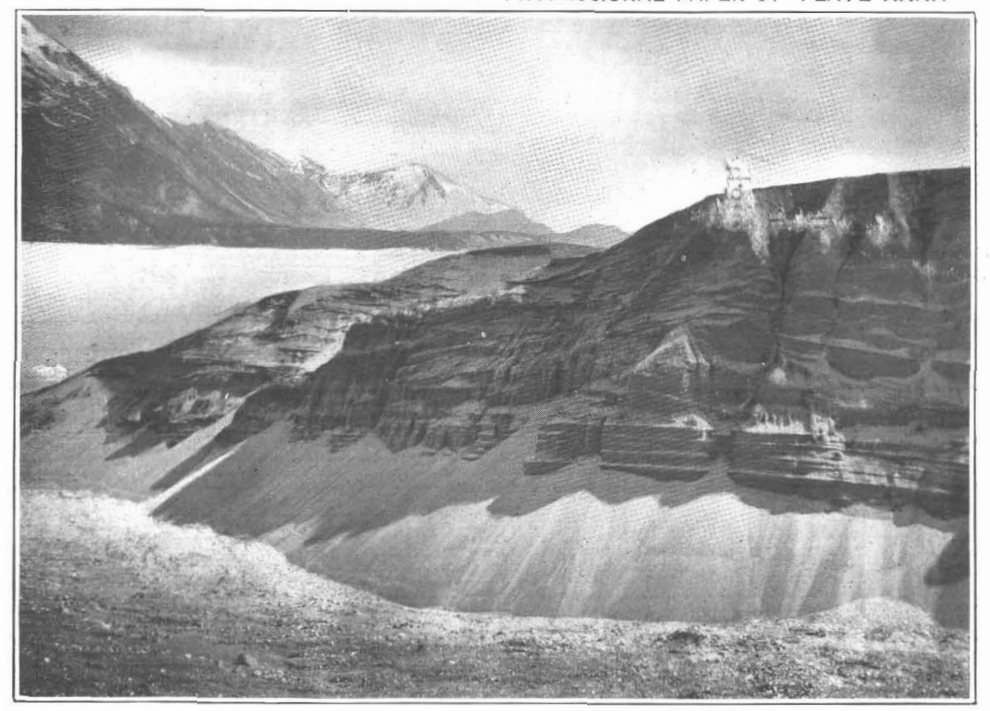

B. STREAM CUT IN OVERRIDDEN GRAVEL BENCH ON WEST SIDE OF RUSSELL FIORD, JUST SOUTH OF CAPE ENCHANTMENT.

The surface is ice eroded and veneered with glacial deposit, on which vegetation has scarcely begun to advance. On the opposite side of the fiord is seen the ice-sculptured gravel terrace between Seal Bay and Russell Cove. Photograph taken July 10, 1905.

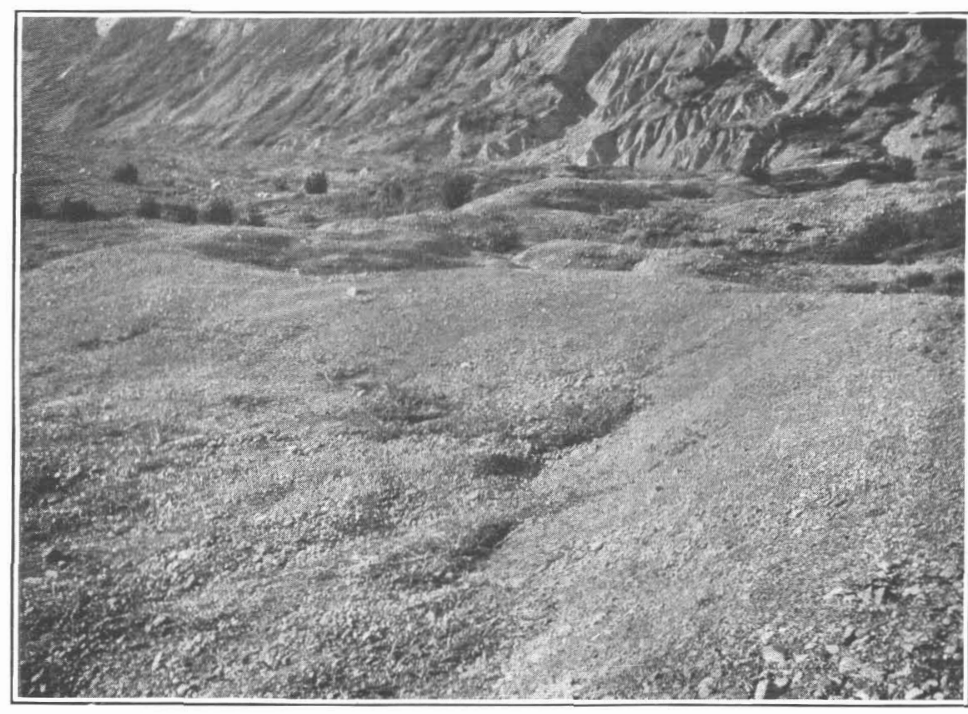

1). ESKER ON OVERRIDDEN GRAVELS SOUTH OF CAPE ENCHANTMENT, ON WEST SIDE OF SOUTH ARM OF RUSSELL FIORD.

Note general absence of vegetation. Photograph taken July 23, 1905. 

Deposits on the nunatak.--In a few places on the south side of the fiord gravel clings to the steep mountain slope; but the most extensive deposit on that side occurs on the lee or western base of the nunatak, where the gravel deposit is fully 40 feet thick, thinning rapidly westward. This is evidently a remnant protected from erosion by the nunatak knob.

Farther west, on the rock tail of the nunatak, there is little drift and much evidence of ice erosion on the outcropping bed rock. On this rock tail there are one or two winding, eskerlike ridges of rounded gravel, and a thin, irregular veneer of angular slate stones, partly frost riven, partly glacial. There are also numerous trains of white granite which extend diagonally across the glacial grooves and flutings on the bed rock. These bowlder trains evidently represent surface material which fell upon the ice from a granite cliff a short distance above. Besides these white granite trains there are numerous crevasse deposits, consisting of fairly straight ridges of gravel and stony drift, ranging in length from a few to several score of yards, in height from 1 to 3 feet, and in width from 2 to 5 feet.

The difference in distribution of gravels on the two sides of Nunatak Fiord is apparently due to two causes: (1) Less gravel was deposited on the steeply rising south side; (2) the vigorous ice erosion on that side, indicated by the prominent hanging valleys, was more competent to remove gravels there than on the north side.

Origin of gravels. - All evidence that is obtainable points to the conclusion that the gravels of Nunatak Fiord are remnants of marginal accumulations. That they did not originally form a continuous sheet across the fiord valley is indicated by the great height $(1,500$ feet $)$ to which they rise, for in that case the volume would have been enormous. Their composition, form, position, and elevation indicate marginal accumulations along a shifting base-level, such as either an advancing or a receding glacier would furnish. That they are waterlaid is evident from their stratification; and that, to some extent, at least, they were deposited in standing water is proved by the large bowlders scattered through the gravels, which are too large to have been brought by a glacial torrent but might have been transported in icebergs. So they were probably accumulated, in part at least, in local marginal lakes.

The slope of the layers toward the valley axis suggests that the gravels are alluvial-fan deposits from land streams, but this theory is clearly disproved by the well-rounded character of the pebbles and by the large number of varied crystalline rocks, which could not have come from so local a source. It is inferred, therefore, that the gravel supply came largely from glacial streams issuing from the main ice tongue, and that the dip of the layers toward the valley axis is due to the removal of a substratum of ice on which a thick blanket of gravel was deposited.

It is probable that the gravels at different levels and in different positions have originated in more than a single way. In the nature of the case, along a shifting ice margin against an irregular land contact there would be a complex series of conditions favoring marginal-lake deposition, the building of marginal gravel terraces by glacial streams, and the formation of alluvial fans by marginal streams. It is possible, also, that the lower terraces may represent the remnants of a fairly extensive gravel deposit, similar to that which now fills the Hidden Glacier valley from side to side, though this seems hardly probable in view of the evident great depth of the fiord.

Glacial erosion has so sculptured these gravels that their exact origin is now difficult to determine. It is believed, however, that, with the possible exception of the lowest benches, these gravels are remnants of earlier deposits whose original area was not greatly in excess of that of those now found. It seems certain that they were not accumulated either in a single high-level lake or in the sea during a lower stand of the land. Had either of these conditions prevailed, extensive beds of clay should be found beneath the gravels at persistent horizons, and in them one would also expect to find evidence of marine or lacustrine life.

GRAVELS IN NORTHWEST ARM OF RUSSELL FIORD.

The ice-eroded slate hill in the Northwest Arm of Russell Fiord bears only a thin veneer of glacial deposit. Much of this is distinctly morainic, evidently lateral moraine accumulated as the ice was melting, and later lowered to form a veneer on the bed rock. Some gravel is revealed, 74228-No. 64-09-9 
but no extensive areas or benches. Both the freshness of the glacial striation on the exposed bed rock and the moderate development of vegetation prove a recent recession of the ice from the eastern half of this arm of the fiord, even up to an elevation of 500 feet. The alder is so scattered that passage through it is easy, and the individual bushes are not mature; but in the western part of this arm of Russell Fiord there are dense thickets of mature alder. There is, therefore, a progressive increase in the development of vegetation from Nunatak Glacier northwestward nearly to Hubbard Glacier, but not to the extent of the development of the cottonwood or spruce forest of the Alaskan coast. This is what a recent retreat of the glacier toward the east would lead us to expect.

On the southwest side of this arm of Russell Fiord there is much more gravel than on the northeast side. This is doubtless due to the fact that the southwestern wall is more irregular, thus furnishing opportunities for the accumulation and preservation of marginal gravel deposits. These gravels nowhere form extensive benches, like those of Nunatak Fiord, but are in scattered and separated patches, particularly well developed in and near the tributary valleys. There are, however, some patches even on the steeper mountain slopes. These gravels are so greatly

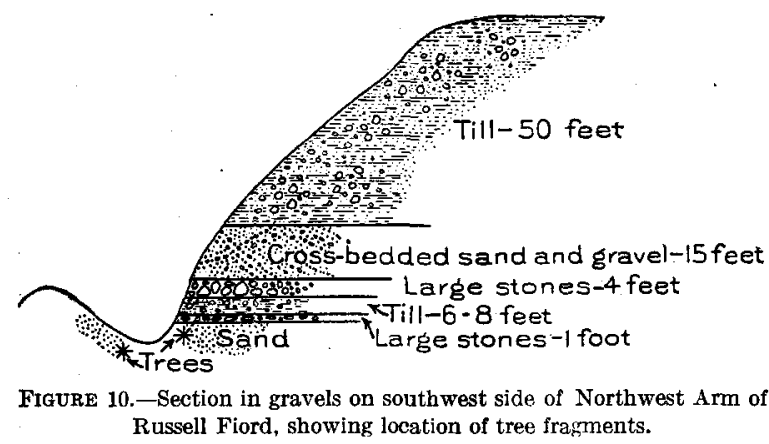
gullied, up to a height of several hundred feet, that in many places their erosional forms simulate badland topography.

In the hanging valley just southeast of Osier Island and several hundred feet above the fiord, recumbent logs were found embedded near the base of a gravel cliff. The gravel bench in which these logs occurred is doubtless a delta deposit in a marginal lake on the side of the ice tongue. In a region where trees no longer grow the presence of logs in gravels is of distinct interest. The section in figure 10 shows the position and associated deposits in which these logs occurred.

Gravel deposits were found in some of the tributary valleys here and elsewhere in the region; but as these were nowhere studied in detail it must suffice to merely mention their existence.

GRAVEL RIDGES ON WEST SIDE OF YAKUTAT BAY.

In the area south of Galiano Glacier, already described as being the site of a series of remarkable morainic hummocks, among which the fan-building streams from the Galiano and Atrevida glaciers are now flowing and depositing, there are two remnants of older overridden gravels. The southernmost of these is much the larger, and a description of it will serve for both. It lies just south of the Esker Stream alluvial fan and less than a quarter of a mile from the sea, rising above the general surface as a gravel ridge fully three-quarters of a mile long and about 70 feet high. It is only 100 to 200 feet in width, and its longer axis extends southward.

At one point this ridge is being cut into by a small distributary of Esker Stream, and here its gravel character is clearly revealed. Near the base there is a clay layer with scratched stones and some indefinite plant fragments. The surface of the ridge has the sweeping curves of ice erosion, and it is veneered with morainic deposits, including small ridges, hummocks, and kettles and a few good-sized bowlders. Evidently, therefore, it was formed at an earlier period and has since been overridden by ice and partly removed; it may, in fact, be a remnant of a much more extensive deposit now buried beneath the alluvial fan.

There are many tree fragments upon this ridge, as there are on the neighboring morainic hummocks. This fact, together with the absence of a growth of trees in so favorable a situation, greatly puzzled me. It can not be supposed that in its recent advance Galiano Glacier actually overrode this terrace, nor is it possible that the upward thrust of the ice could affect its tree growth. The only alternative that has suggested itself is that it was swept by the earthquake water wave in 1899. 
GRAVELS WEST OF YAKUTAT BAY.

Gravels occur in many places west of Yakutat Bay. There is, for example, an extensive development of gravels in the valleys near the southern end of the Floral Hills, where in some cases the beds, underlain by clay, attain a depth of 200 or 300 feet, being revealed by the extensive dissection of the present drainage (p. 83).

Between the south end of the Floral Hills and Hayden Glacier there are also extensive, deeply dissected gravels (Pl. XXIV, D). The lowest beds are in contact with the present ice, and in places are overridden by it; as a result they occasionally show evidence of the ice shove in crumpled layers. The higher gravels form a part of the morainic terraces previously described (p. 104). Throughout these beds wood fragments and tree trunks occur, proving a former period of ice recession.

At Blossom Island, in addition to the gravels at present accumulating along the glacier margin and in the lake, there are older gravels at various levels, some of the lower beds having been overridden. Huge spruce logs, far larger in size than anything now growing in that vicinity, occur plentifully in these gravels.

GRAVELS ON EAST SIDE OF YAKUTAT BAY.

Older gravels occur on the eastern side of Yakutat Bay in the foreland and the off-lying islands (p. 99). There is also an almost continuous fringe of gravel from Knight Island northward for 3 or 4 miles. At its northern end this fringe is low (15 to 20 feet above sea level), ice eroded, and moraine veneered. Its forest cover was swept off by the tidal wave accompanying the earthquake of 1899 .

This terrace fringe attains its best development at Logan Beach, where it reaches an elevation of more than 100 feet. It is covered by a dense spruce forest, has a swinging surface indicative of ice erosion, and has at least two small lakes. It is faced by a high sea cliff, revealing well-assorted gravels with pebbles of a great variety of crystalline rocks from the mountains to the north. Gold from these gravels, concentrated by the waves, occurs in small quantities in the beach at the base of this cliff (p. 166).

On the beach there is a submerged forest whose roots are at least 10 feet below the level of high tide. A line of huge crystalline bowlders, just off the beach, may possibly have been derived by concentration from the wearing back of the bluff through wave attack, though there seem to be scarcely enough bowlders in the gravels for this purpose. They may therefore be a part of a basal moraine on which the forest grew before the deposit of the gravels.

All the wave-cut cliffs at Knight Island are of gravel, but the surface of the island is distinctly morainic. The surface is broadly undulating and has many kettles and hummocks, and these bear large numbers of crystalline bowlders; but the whole island is covered with a mature forest, proving that the overriding of these gravels is of remote date. That they extend out beneath the water of Yakutat Bay is proved by the bowlder-covered shoals that stretch far out from the shores of the island.

Each of the other islands fringing the Yakutat foreland, and the foreland itself, reveals the same characteristics as Knight Island. A striking feature is the scarcity of fragments of rocks of the Yakutat group, clearly indicating a distant source, which the abundance of crystalline rocks proves to have been the mountains near the source of Hubbard Glacier, or tributaries joining the expanded Yakutat Bay Glacier from the east. Gold occurs in the beach sands at several points, the best-known locality being at the base of the gravel bluff near the southeast end of Khantaak Island, which is exposed to the full force of the ocean waves.

GRAVELS IN SOUTH ARM OF RUSSELL FIORD.

Observations by Russell and Gilbert.-In the description of his expedition through Yakutat Inlet in $1891^{a}$ Russell says that, after rounding Cape Enchantment, horizontal terraces were visible up to an elevation of approximately 150 feet above present water level. He further 
states $^{a}$ that the gravels develop southward and extend all around the head of the bay. Again, Russell ${ }^{b}$ reports that around the southern arm of what is now called Russell Fiord there are "conspicuous gravel terraces, which score its sides in even, horizontal lines up to a height of about 150 feet. These terraces sweep about the bluffs of gravel inclosing the lakelike expansion at the south, showing that the water body which made them did not find an outlet in that direction. As the entrance of the bay was blocked with ice when visited by Malaspina and Puget, it seems reasonable to suppose that the water body in the southern arm owed its existence to the ice dam thus formed. The terraces are therefore about one hundred years old."

Gilbert ${ }^{c}$ also mentions terraces, indicating the former presence of an ice-dammed lake in this part of Russell Fiord, but states that "The discharge of the lake must have been southward over the gravel lowland." He further says ${ }^{d}$ that "At various points, but especially south of Hidden Glacier, there are marginal banks of gravel similar to those about Muir Glacier, characterized by horizontal bedding, but showing by their surficial forms that they have been overridden and molded by a glacier."

It will be noted that while Russell classes all these gravels together, Gilbert distinguishes between ice-eroded gravels in the north and lake-beach gravels in the south. My observations agree with this interpretation. In the northern two-thirds of the fiord the gravels everywhere show signs of overriding since deposit; in the southern third there is no evidence of this (Pl. XXXVII). The two sections, whose boundary lies about midway between Shelter Cove and Cape Stoss, will therefore be described separately.

Overridden gravels.-These gravels are extensively developed on both sides of the fiord, but more perfectly on the west side than on the east. On the west side they are found all the way from Cape Enchantment to a point nearly opposite Mount Ruhama; on the east side they occur from Shelter Cove northward nearly to Seal Bay. These gravels were examined in a number of places, both on their surface and in stream-cut (Pl. XXXIV, $B$ ) and wave-cut cliffs, many of which reveal sections from 100 to 150 feet high.

Here and there small clay layers appear, especially near sea level; but most of the materials exposed in the cliffs are sand and gravel, with the latter predominating. Some of the gravel layers are coarse, and beds of bowlders are found persisting for several hundred yards. These gravels include a very large proportion of foreign fragments, far more than occur in the alluvial fans now developing near by. Moreover, the pebbles are much better rounded than in the modern alluvial fans. These facts are interpreted as proving that the gravels were accumulated by glacial streams associated, not with the small glaciers of the peninsula, but with an expansion of a great trunk glacier through this fiord.

In some of the clay layers plant fragments were found. Usually these were carbonized leaves, cones, and fragments of indistinguishable character; but there were also tree fragments. At a number of points fragments of trees were found on the gravel surface, where now no trees grow, at such an elevation as to preclude the possibility of transportation by tidal waves.

The surface of these gravels is carved into a series of broad, swinging curves (Pl. XXXV), truncating the layers and producing a topography exactly like that in Nunatak Fiord and the Hidden Glacier valley, already described and confidently assigned to ice erosion. In addition to this topographic evidence of overriding, which by itself seems conclusive, in every place that the terraces were studied distinct confirmatory evidence was found in the form of surface deposits of till or bowlders, or both. Usually these deposits were thin, but in some places they were thick enough, together with the sculptured surface of the gravels, to give rise to basins in which ponds, often of good size, were standing.

While the best-defined gravel terraces occur at elevations of less than 300 feet, there are distinct gravel patches up to an elevation of 500 feet, and these, like the lower ones, are both ice sculptured and moraine veneered. At these higher levels the moraine cover on the gravels

a Russell, I. C., Second expedition to Mount St. Elias: Thirteenth Ann. Rept. U. S. Geol. Survey, pt. 2, 1892, pp. 88-89.

$b$ Russell, I. C., Mount St. Elias and its glaciers: Am. Jour. Sci., 2d ser., vol. 43, 1892, p. 173.

c Gilbert, G. K., Glaciers and glaciation: Harriman Alaska Expedition, vol. 3, 1904, p. 48.

a Idem, p. 51 . 


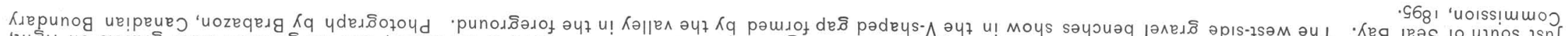

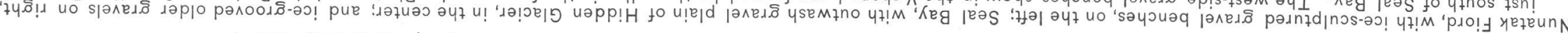

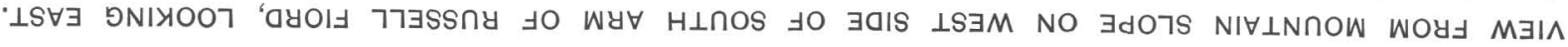

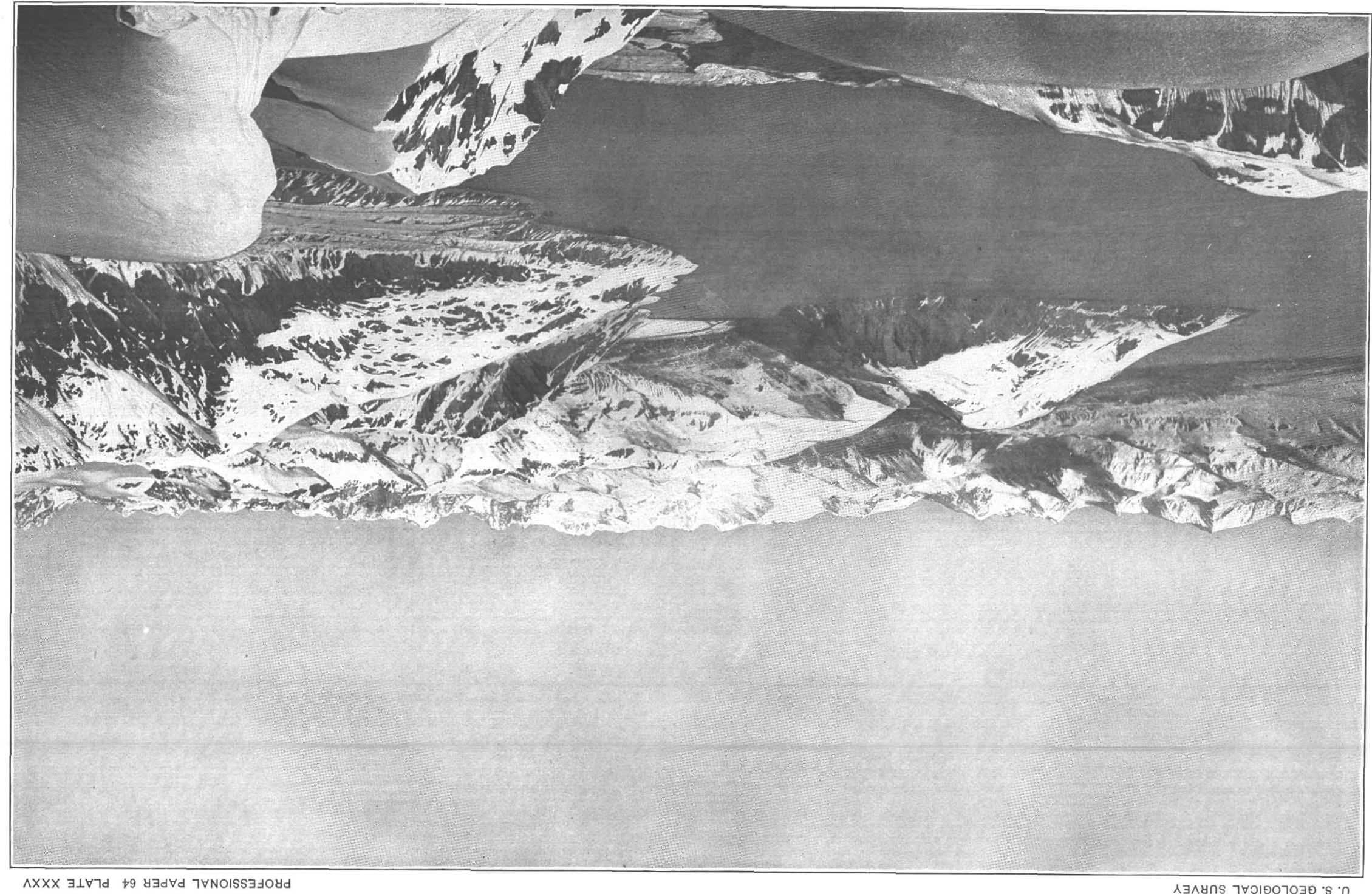




$$
y^{x}
$$


is thicker and more varied in character. At one point, just below Cape Enchantment, and nearly opposite Seal Bay, a distinct esker (Pl. XXXIV, D), 150 yards long and 10 feet high, was found at an elevation of 500 feet, associated with a small area of kame gravels.

- That the recession of the glacier from these overridden gravels is of recent date is proved by the condition of vegetation. Toward the south, below Shelter Cove, the gravels are covered with dense and almost impenetrable thickets of mature alder, and farther south by cottonwoods. On the west side, for a distance of several miles below Cape Enchantment, the gravels are almost bare of vegetation, but toward the south this zone grades into the area of dense alder thickets.

The barren zone extends farther south on the west than on the east side of the fiord, doubtless because of the more recent recession of the valley glaciers on the west side; in fact, these glaciers are still far down their valleys, stagnant at their ends, and rapidly retreating. This is particularly well illustrated by Hendrickson Glacier, whose end is within three-quarters of a mile of the sea and whose stagnant ice is still resting on an overridden gravel deposit, the internal structure of which, beneath the glacier itself, is revealed in the gravel-walled gorge of a glacial stream.

Old lake-beach gravels.-Around the head of Russell Fiord there is a very distinct terrace, bearing a type of vegetation different from that on the land behind it.

A cross section of this area on the east side of the fiord, near the yalley which descends from the area between Mounts Ruhama and Pinta, shows a pronounced wave-cut gravel cliff, 107 feet high (by Locke level), rising above the beach. Stratified gravels extend nearly to the top, where a local clay bed containing wood fragments was found. Back of the edge of the cliff the surface still rises perceptibly, and is covered with a dense alder and cottonwood growth. At an elevation of 115 feet the surface, for a breadth of about 75 yards, was strewn with rounded pebbles, apparently an abandoned pebble beach. The area occupied by these pebbles was free from forest growth, being in this respect quite in contrast to the surface both east and west of it. Behind this pebble area the surface rises, becomes distinctly irregular, and is again wooded, but in this case with spruce.

A second section, near the head of the fiord on the east side, reveals, 4 feet above high tide, a clay layer bearing leaves, bark, and small pieces of wood. Above this are cross-bedded sands and gravels, interrupted at an elevation of 55 feet by a clay layer carrying logs, mostly recumbent, but some still bearing roots. In this clay, cones and wood fragments also occur. At an elevation of 75 feet there is another clay layer with logs and with six upright trees in place, each broken off at the top (Pl. XXXIV, $C$ ). At 95 feet another log-bearing clay layer was found, in this case with all the logs recumbent. Each of these wood-bearing layers was from 5 to 10 feet thick and made of clay and fine sand.

The steep cliff terminates at an elevation of 112 feet, and behind it lies a gently rising plain, densely covered with alder, willow, numerous cottonwood trees, and a few scrub spruces. The surface is very level and rises gently inland, being underlain apparently by the same fine gravel as that in the cliffs. At 145 feet this plain is terminated by an absolute break in both topography and vegetation. From it rises abruptly a low, irregular cliff, back of which rises a perfect moraine topography with many hummocks and kettles and a surface strewn with large bowlders, all covered with a typical Alaskan spruce forest, relatively easy to pass through and contrasting strikingly with the dense alder tangle on the narrow frontal plain. In places near the contact there is a zone of fairly open vegetation covered with grasses, strawberry plants, and other annuals and perennials.

There are, therefore, three distinct zones of flora in this short section of about an eighth of a mile. Near the contact of the two inner zones of vegetation there are many large bowlders on a level terrace, apparently accumulated residually during the wearing back of the moraine by waves which built a beach and off-shore gravel plain. A third section south of this reveals similar conditions, with the contact of the plain and moraine at 140 feet.

All around the head of the bay a distinctive marginal fringe of cottonwood forest and alder thicket borders the spruce-covered moraine on the side toward the fiord. It is surprising 
that with such an abundance of mature spruce close at hand the spruce forest should not have encroached upon this wave-formed terrace, even in the brief period since the lake was drained.

The fact that around the head of the bay the spruce forest is not now growing close up to the edge of the gravel cliffs which the present-day waves are cutting renders it impossible for large quantities of driftwood to be supplied to the fiord by the undermining action of the waves; nevertheless the head of the bay is fringed by a great mass of driftwood, including many large spruce logs. This abundance of driftwood, which far exceeds in quantity that found elsewhere in Russell Fiord, can not have been supplied by stream transportation from the spruce forest on the moraine, because only very small and sluggish streams enter this part of the inlet; nor can it have been brought from lower down the fiord, because there is no spruce forest in that section to furnish the supply. From these facts the conclusion seems warranted, therefore, that this abundance of driftwood has been furnished to the beaches from the gravel terraces themselves, and is therefore older than the last ice advance. This conclusion is supported by the fact that logs were seen in the gravels in a number of places, one of which has already been described (p. 133).

The logs embedded in the gravel were no doubt in part supplied from the spruce forest growing on the moraine when it was being cut back by the waves of the higher water level which formed the terrace; but doubtless a portion of the supply came from farther down the fiord at the time of the greater expansion of the ice which formed the lake, being removed by the advancing glacier and discharged into the ice-dammed lake. The wood seems altogether too abundant for the single cause first mentioned; and, moreover, we know that logs occur in the gravels at various points in the fiord outside of the beach-terrace area. A third probable source for some of the driftwood is the submerged forest at the head of the bay, now revealed on the beaches, with some of the stumps still standing upright in place (p. 99).

\section{INTERPRETATION OF PHENOMENA.}

The interpretation of the glacial oscillations, in the light of the deposits they have left, has been partly stated as the subject has been developed. It therefore remains to round out and summarize this interpretation.

\section{RECENT ICE ADVANCE.}

The proof is definite that Hidden Glacier, Nunatak Glacier, and the small glaciers near Cape Enchantment are receding, and that as they recede they are uncovering extensive gravel deposits which were not made by the ice sheet which is now resting on them. Similar gravel deposits occur far up Russell Fiord; and to a point well south of Shelter Cove these gravels bear evidence of an overriding by ice of so recent date that vegetation has not yet advanced over them to the fullest extent. As far south as Shelter Cove the overridden gravels and associated moraine deposits rise fully 500 feet above present sea level.

It is believed that the recession of the glaciers now in progress has been going on for a long time, and that during the greatest expansion of this period of ice advance Nunatak Glacier, receiving Hidden Glacier as a tributary and also the smaller glaciers from the sides of the fiord, advanced to a point south of Shelter Cove (fig. 9).

As this expanded glacier advanced it passed over a forest-covered land, destroying the forest and incorporating portions of its débris in marginal and terminal deposits. With the advance of the ice extensive gravel deposits were accumulated in favorable situations, especially in the marginal lakes formed between the glacier and the land, where lateral valleys entered at low levels. It is possible, of course, that in places the gravels may have filled the fiord from side to side; but this is not a necessary assumption, and no facts were discovered which supported such an hypothesis. Local gravel areas, similar to though more extensive than those now accumulating, would account for all the facts.

With this expansion of the glaciers the upper part of Russell Fiord was shut out from its connection with the ocean, as Russell suggested, and an ice-dammed lake was formed, in which log-bearing gravels were deposited and around the shores of which a wave-cut terrace was 
made. At the same time a tongue of Nunatak Glacier extended down the Northwest Arm of Russell Fiord, and Hubbard Glacier reached well down Disenchantment Bay.

That this ice advance was a later one than the great expansion of glaciers during which the Yakutat foreland was built is demonstrated by the fact that the recent ice advance failed to remove the gravels that it overrode. If the evidence brought forward to prove great ice erosion during the maximum advance of the glaciers is accepted, this conclusion is certainly warrarted; for it is inconceivable that the rock of the fiords could have been removed and the tributary valleys left hanging while at the same time gravels were not scoured away even at the base of the hanging valleys. This advance, therefore, is interpreted as a late episode in the glacial history of the region. What the cause of the advance may have been is wrapped in the same obscurity as the question why the glaciers are now receding so rapidly, but the fact of a recent advance and present recession seems established.

\section{ACCUMULATION OF GRAVELS.}

The exact conditions under which the gravels were accumulated is not proved beyond question. It is possible, of course, that they were in part, or even wholly, deposited during the recession of the earlier great ice flood. The gravel deposits on the eastern shore of Yakutat Bay seem certainly to have been related to that ice period, for the later advance did not reach that far.

The morainic gravels near the head of Russell Fiord are also apparently to be correlated with the earlier great advance. This conclusion is based on the evidence of the buried trees in place, both those which occur below tide level at the head of the bay and those in the gravel cliff described on page 133. These trees could not have been growing during the deposit of the gravels in the ice-dammed lake, for in both instances they would have been below the level of the lake waters. The submerged forest at the head of the bay may very well represent the old forest that grew on the land during or before the advance of the earlier and greater ice flood. Those trees which are standing in place in the gravel bluff were evidently growing during the deposition of the gravels, probably under conditions similar to those at present existing on the Esker Stream alluvial fan.

Of the other gravels no evidence was found to determine the period of their accumulation, further than that they antedated the last ice advance and were overridden by it. It is not at all improbable that some were formed during the recession of the great ice flood, but this does not seem possible for those now clinging to the steeper mountain slopes, for the rapid rate at which they are at present being removed makes it improbable that they could have survived a long interglacial period of denudation. Even the lower gravels would have been so gullied that it would seem probable that evidence of interglacial stream erosion would be easily detected in the ice-eroded remnants. The fact that no such evidence was found makes it probable that most, if not all, of these gravels were accumulated during the period of last advance of the glaciers. The evidence is clear that the gravels are not in any large measure due to deposition by fan-building streams from the land, but rather to glacial streams receiving their sediment from glaciers heading in the area of crystalline rocks.

\section{COMPARISON WITH MUIR INLET REGION.}

It is noteworthy that the conditions described by Wright, ${ }^{a}$ Reid, ${ }^{b}$ Cushing, ${ }^{c}$ and Russell ${ }^{d}$ in the Glacier Bay region are almost identical with those described above. In Muir Inlet the ice was found resting on gravels, the surface of which was sculptured by ice erosion and veneered with a thin layer of morainic deposit. Buried forests, with trees of existing species

\footnotetext{
a Wright, G. F., Ice age in North America, 1891, pp. 57-62.

$b$ Reid, H. F., Studies of Muir Glacier, Alaska: Nat. Geog. Mag., vol. 4, 1892, pp. 19-84; Glacier Bay and its glaciers: Sixteenth Ann. Rept. U.S. Geol. Survey, pt. 1, 1896, pp. 434-438.

$c$ Cushing, H. P., Notes on the Muir Glacier region, Alaska: Am. Geologist, vol. 8, 1891, pp. 207-230.

$d$ Russell, I. C., Origin of the gravel deposits beneath Muir Glacier, Alaska: Am: Geologist, vol. 9, 1892, pp. 190-197; Glaciers of North America, 1897 , pp. $86-87$.
} 
in place, occur in the gravels. High-level gravels are found up to an elevation of 1,000 to 1,500 feet, but these differ from the low-level gravels both in characteristics and in origin. Reid presents evidence in proof of the conclusion that the advance of the ice in this bay occurred about one hundred years ago, at the time when Vancouver's officers saw the region. The fact that the gravels were not completely removed by ice erosion be considers to be evidence of the brief duration of the ice stand at this advanced position.

It is an important fact that in two widely separated inlets on the Alaskan coast the same succession of events should be recorded in the glacial deposits.

\section{CAUSES OF ICE ADVANCE AND RECESSION.}

That in both the Yakutat and Muir inlets there should have been a period of pronounced advance of the glaciers so recently that vegetation has not yet encroached upon the land formerly occupied by the ice, and that in each case the period of ice occupation was so brief that glacial erosion was incapable of removing the gravel deposits, is noteworthy. The advance must have been due to some general cause, operating for a brief period but with great effectiveness over an area at least 150 miles in extent. The distance covered by the advance of Nunatak Glacier can not be estimated at less than 15 miles.

Two causes suggest themselves in explanation of the phenomena of ice advance and recession in this region, one topographic, the other climatic. The assumption of a general uplift might account for the advance, but would fail to explain the subsequent recession, which is still in rapid progress. Moreover, the evidence clearly proves that these mountains are still rising, so that if the cause were elevation of the mountains the advance of the glaciers should still be in progress.

It is conceivable that a period of brief but rapid rising of a mountain area would in due time be succeeded by a sympathetic advance of the glaciers and a subsequent recession. Such an uplift, accompanied by frequent and vigorous earthquakes, would throw great quantities of snow into the valleys, and in time this cause would necessitate a movement of the ice fronts. Although this cause, resulting from a single brief period of earth shaking in 1899, has started a forward movement in some of the glaciers of this region, it seems hardly probable that it can be appealed to in explanation of so great an advance, operating over so large an area, and causing glaciers to advance so many miles into the fiord.

It does not appear probable, therefore, that topographic explanations are capable of accounting for the facts in this region; consequently the vague hypothesis of climatic variations, for the cause and nature of which it is not at present possible to suggest any reason, is proposed. It is a subject which can not be discussed with any prospect of solution until more is known of the meteorologic conditions and the possible causes for changes in rainfall. The present observations form merely a contribution toward the final solution of this interesting and difficult problem. ${ }^{a}$

\section{DIFFERENCE BETWEEN GLACIERS}

Malaspina Glacier and its tributaries, although clearly influenced by the same kind of oscillation, and probably at the same date, show decided differences of advance and retreat from those of the glaciers now entering Yakutat Bay. The Malaspina at present resembles more closely the condition of the Yakutat Bay Glacier at the period of its greatest expansion. Why Malaspina Glacier at the present time retains characteristics which at an earlier age belonged to the glaciers that built the foreland south of Yakutat Bay is a question of decided interest. At present this is a subject on which speculation only is possible, and since the facts bearing upon the problem are meager, it will not be fully discussed at this time. It may be due merely to the higher mountains and consequent greater snow fields; but, even granting this, there still remains to be explained the recent oscillation of this great glacier.

a For a discussion of this same question, including observations over a wider area, see Gilbert, G. K., Glaciers and glaciation: Harriman Alaska Expedition, vol. 3, 1904, pp. 102-112. 
One point bearing on the subject, however, is evident, namely, that the glaciers ending in the fiord will, once the sea water is admitted to their fronts, show results of recession more quickly and effectively than those which end on the land. The morainic cover of the land glaciers effectively protects them from rapid melting, while the action of the fiord water not only melts the glaciers back rapidly and carries away the ice faster than mere melting could, but also prevents the accumulation of a protecting blanket of débris on the ice surface. For this reason it would be expected that, even if the same cause for ice recession is now present on the Malaspina ice plateau as in the glaciers of Yakutat Bay, its progress will not have gone so far there as in the glaciers ending in the fiord.

In this connection it is noteworthy that the great Yakutat Glacier, southeast of Russell Fiord, still spreads out beyond the mountain base in a nearly stagnant ice foot on the Yakutat foreland. It is also noteworthy that the expanded Nunatak-Hidden Glacier extended farther than the expanded Hubbard-Turner Glacier. The reason for this is undoubtedly that the latter glacier terminated in a tidal bay, while the former ended in an ice-dammed lake, whose cold waters could have had little influence on the ice front. 


\section{CHAPTER X. \\ DISTRIBUTION OF PLANTS AND ANIMALS; RECENT GEOLOGIC CHANGES. VEGETATION.}

TIMBER LINE.

According to Coville, ${ }^{a}$ who bases his conclusion on collections made by Funston, the flora of this region, in its general geographic relationship, "shows an almost exclusively circumpolar origin, while in its differentiation from the circumpolar flora it conforms with that of western British America and the mountains of Washington and Oregon."

Funston states that the timber line of the Sitka spruce reaches an altitude of 2,200 feet on Mount Tebenkof, while that of the red alder extends up to 3,000 feet. The upper limit of spruce descends to sea level in Disenchantment Bay, but the alder continues to grow high up on the mountains. Discussing the distribution of the forest in the Yakutat Inlet, Coville ${ }^{a}$ writes as follows: "The conditions which favor the northward progress of the forest are: The low elevation of the coast region, the warmth of the ocean currents, and the prevailing southeasterly winds; while the opposing conditions are: The higher elevation of the mountains, the snow and ice which cover them, and the occasional northerly winds." To the opposing conditions must be added, as a still more important factor, the recency of the withdrawal of the ice.

ANCIENT FOREST.

Evidence has already been presented to prove that forest covered at least a portion of the treeless part of this region before the last advance of the glacier, which swept the forest entirely away from Nunatak Fiord, the Hidden Glacier valley, and a large part of Russell Fiord and Disenchantment Bay. It is further evident that the forest occupied regions from which the glaciers have not yet receded.

A fragment of evidence bearing on the question of the ancient forest was discovered in the amphitheater on the eastern side of Amphitheater Knob near Galiano Glacier. Here, at an elevation of 1,500 feet above sea level, and just below the morainic ridge already described (p. 102), a single dead spruce trunk stands. It is fully 15 feet high and more than 2 feet in diameter at the base, the top being broken off, though not lying near at hand. It is not only upright but evidently in place, and is the only tree of any kind in the neighborhood, being high above the limit of spruce growth in this vicinity. That it has not been buried in glacial deposits and later revealed by their stream erosion is proved by the morainic form of the ground on which it stands and by its remoteness from any stream which could have eroded the gravels from around it.

The only apparent explanation of the presence of this isolated trunk in place is that it is a remnant of a forest which occupied this amphitheater and was removed by the advance of the glacier upon it. Standing as it does in a protected bay in the mountains; it may have escaped removal by that ice erosion which carried away the rest of the forest. If it had been destroyed by the cold of neighboring ice, which did not reach quite to it, other remnants of the forest should be present. The withdrawal of the ice which destroyed the tree can not have occurred at a very remote period, otherwise the trunk could not still remain upright. Therefore the destruction of this tree is correlated with the recent advance discussed in the previous section.

The peculiar distribution of the spruce in the Blossom Island region seems capable of explanation only on the hypothesis of a former great extension of forest. On Blossom Island itself there are clusters of spruce trees on the northern slope, although the crest and south side

$a$ Coville, F. V., Contributions from U. S. Nat. Herbarium, vol. 3, No. 6, 1895, p. 335 
support only alder. This northern slope seems less favorable to forest growth than the sunny southern and western slopes, but it is favorable to preservation from removal by higher ice levels.

Mature spruces of good size also grow in clusters on the mountain slopes north and northeast of Blossom Island. Some of the spruces are dead; others do not appear to be in healthy condition; and all are several hundred feet above the base of the mountains, none growing either on the lower mountain slopes or in the depression above which Blossom Island rises. Therefore the spruces occupy a narrow belt, both above and below which forest is now absent.

The following hypothesis is proposed to explain these peculiar conditions. At a period not very remote, the glaciers being greatly shrunken, this entire region was forested up to a level at least as high as the remnant clusters mentioned above. The ice advanced, carrying away trees up to a certain level, but, owing to the débris-covered margin, not lowering the air temperatare sufficiently to destroy the forest near the glacier margin. Nevertheless, the expansion of the glaciers caused such a refrigeration of the air that the snow line descended toward the glacier, killing the upper portion of the forest. There was left, therefore, a band of trees in clusters between the snow line and the ice level, and some of these have survived to the present time.

In support of this hypothesis the following points may be noted: The glaciers have recently been higher, their high-level moraines occurring near the lower limit of tree growth. Former extensive forest growth is proved by the abundance of large tree trunks in the neighboring gravels. It would be exceedingly peculiar if spruce cones or seeds should be carried across the broad wastes of Hayden Glacier and find root, not in the lowest ground, but well up on the mountain slopes. That trees can live in such a situation as postulated is proved by the fact that at present, not far distant, spruce grows not only near but actually on the glaciers.

This hypothesis is, therefore, fairly well supported. It appears to be rational; it explains the facts; it is opposed by no known facts, and no other rational hypothesis suggests itself to account for the peculiar distribution of tree growth in this region. Moreover, it is in harmony with the evidence of change in vegetation conditions in the Yakutat Bay region.

\section{ADVANCE OF THE MODERN FOREST.}

Evidence that the modern forest is advancing into the region from which the glaciers have recently withdrawn, and is therefore reoccupying the territory from which it was previously removed, is both abundant and varied. In the first place, throughout the entire Yakutat Bay inlet the climate on the lower slopes seems suitable to forest growth. The summer is both warm and long, and the severity of the winter is greatly moderated by the open waters of the fiord. It is possible that some portions, especially those shady slopes exposed to the glacier winds, are incapable of supporting forests; but even of this there is strong reason for doubt.

More direct evidence on this question is furnished by the nature of the forest at its innermost limit, both in Russell Fiord and in Disenchantment Bay. In each place a fringe of cottonwoods grows in advance of the spruce forest; and both the cottonwoods and the spruces have straight trunks and do not, in any particular, partake of the characteristics of trees which have reached the limit of their possible advance. Were they occupying their northernmost limit, owing to opposition from glacier-chilled winds, these trees would of necessity become stunted and irregular in their growth.

The forest is evidently still advancing into its old territory. The alders and willows have preceded in the march; the cottonwoods come next; and the heavy-seeded spruces and hemlocks are slowly pushing onward. As has been already shown, even the alder has not been able fully to occupy the ground from which the glaciers have most recently withdrawn, although it often grows in far less favorable situations, even on the stagnant glacier ends. The spruce and cottonwood forest has advanced down Russell Fiord nearly to Shelter Cove; and in outer Yakutat Bay it has advanced to Point Latouche on the eastern side and up to Black Glacier on the western side. The spruce forest also grows on the lower slopes of Amphitheater Knob, and to the very edge of Atrevida Glacier. Scattered spruce growth occurs also on Terrace Point, the Floral Hills, and in the Blossom Island region. 
Elsewhere in the Yakutat Bay inlet there is no regular forest cover, but that both spruce and cottonwood are capable of occupying this region is proved by the presence of scattered individuals in advance of the main forest and by the fact that the alder growth itself is now advancing to reoccupy the region from which the ice is now receding. This condition will be best understood from a description of specific instances.

The crest of Haenke Island was occupied as a photographic station by both Russell and Gilbert, the former in 1890 and 1891, the latter in 1899. Since their photographs were taken the growth of alder has been sufficient to materially alter the foreground shown in their pictures. On this island two spruce trees are found, estimated to be not more than twenty years old, these being farther north than any other spruces seen in the inlet. On the peninsula between Haenke and Osier islands there is a good-sized cottonwood tree at least 3 miles from the northern limit of the cottonwood forest near Black Glacier.

Both in Disenchantment Bay and in lower Russell Fiord, as well as in the tributary valleys, alder grows high up on the mountain sides. There are dense thickets on both sides of Russell Fiord between Osier Island and Marble Point, but from this point eastward the alder begins to grow less thickly, and finally is entirely replaced by scattered clusters and by low willow bushes. This change in vegetation occurs near the descending morainic terraces which are correlated with the recent advance of Nunatak Glacier, and the decrease is in the direction of the last retreating ice tongue.

On the north side of Nunatak Fiord there are no alder thickets and only a few small scattered clusters; indeed, up to about 500 feet there is almost no woody vegetation, but above this there is a moss sod with willows and other small plants. In about the middle of this area a small cottonwood was found growing on the gravels, and individual young cottonwoods occur at numerous points farther west.

On the north side of the Hidden Glacier valley several small cottonwoods were found, and one fairly good-sized tree. Near the western end of the outwash plain in this valley, and about 100 feet above it, a small spruce was growing in a spot with a good southern exposure. All of these trees are far from the northernmost limit of the spruce and cottonwood forest.

From these facts the inference is drawn that the Yakutat Bay inlet furnishes an excellent instance of the advance of vegetation upon an area from which glaciers are still receding, and it is believed that if this recession continues the lower slopes of the inlet will ultimately be again clothed in forest.

The forest peculiarities at the head of Russell Fiord, where only cottonwood and alder (with the exception of individual spruces) have advanced onto the beach of the former lake, present an interesting ecological study, for it is one of the most pronounced features in the vegetation of the region.

PLANT GROWTH ON THE GLACIERS.

Russell called special attention to the remarkable occurrence of mature alder, cottonwood, and spruce on the stagnant ends of the glaciers of the Yakutat Bay region. These forests are found on Malaspina, Lucia, and Atrevida glaciers, and are as dense and luxuriant as on the land. Remarkable though the growth in such a situation undoubtedly is, it is a normal result of long-continued stagnation and ablation of a débris-laden glacier.

On many of the other moraine-covered glaciers woody plants are beginning to gain a foothold, as described in the chapters on living glaciers. The struggle in which these plants are engaged is clearly shown by the frequent uprooting of the plants, their general youth, and their scattered occurrences. Such plant life can not successfully occupy those moraine deserts in which the soil is so thin that slumping is actively in progress. Even on the areas of greater stagnation and deep moraine, soil slumping is in progress and much destruction of trees is always resulting.

The advance of the glaciers between 1905 and 1906 has begun a destruction of the forest growth on the margins of some of the glaciers, as already described; therefore plant growth on glacier margins is subjected to the possibility of widespread spasmodic destruction, as well as to local destruction through slumping. 
ECOLOGIC PROBLEMS.

The Yakutat Bay region offers a remarkable field for the ecologist. Besides the conditions of flora described in this section, each of which is of sufficient interest to warrant a careful botanical study, there are many minor problems. There is the question of the advance of flora on the abandoned beaches of the outgrowing coast; the struggle of the flora for a foothold on the upgrowing alluvial fans; the advance of the flora on the beaches uplifted in 1899; the nature of the flora in the bogs caused by the outflowing of ice-cold water from buried ice tongues like that of Galiano Glacier; and doubtless many others. It is to be hoped that some student of the subject will undertake such a study in this peculiarly interesting region, for not only would it have a present-day interest, but it would serve as a basis for a future comparative study. It is certain that some of the changes now in progress will continue, while others will cease to operate, and for future work it would be highly important if the actual present conditions were known. It has of course not been possible to make such a study in the present instance.

\section{FAUNA.}

Facts bearing on the advance of the fauna are rather meager, but nevertheless striking. They confirm the other evidence of recent marked recession of the glaciers.

The stretch of coast line between Nunatak and Hubbard glaciers is even now isolated from other parts of the region by excellent barriers to the advance of larger mammals, as it has undoubtedly been for some time past. To the south are the waters of the fiord; to the north, lofty snow-capped mountains with glaciers in all the valleys; to the east, the much crevassed Nunatak Glacier, whose northern edge rests against an inaccessible mountain wall; to the west, the profoundly crevassed and practically impassable Hubbard and Turner glaciers.

Although the tracks of foxes, wolves, and bears were abundant both on the mainland and on the peninsula, we saw none in the region between Nunatak and Hubbard glaciers. That these animals can not be abundant in that region is further indicated by two facts: (1) This coast is occupied by great numbers of ptarmigan, far in excess of any found in other parts of the inlet; (2) the gulls nest directly on the moraine, whereas elsewhere in the inlet their nests are placed on steep cliffs. With an abundance of such cliffs in the region, it is inconceivable that the gulls should choose such nesting places if there were numerous carnivorous enemies in the same area.

On the Yakutat foreland conditions are favorable to the existence of the deer, which is so abundant in the coastal forest region farther southeast; but the deer is absent from the foreland. This fact is doubtless due to the glacier and water barrier to the southeast, which during a former period of more extensive glaciation was even more effective than it is now.

There is probably an interesting problem concerning the distribution of bear in the Malaspina Glacier region. This animal is very abundant there - in fact, far more so than in other parts of the Yakutat Bay region. It is reported, too, that there is a blue glacier bear, quite different from the ordinary brown bear. The conditions might well favor isolation and variation. The great abundance of the bear is undoubtedly due to the quantity of food and to the protection from man. The off-lying mountain spurs are quite isolated and have been visited only by explorers, for the natives never go out on the glacier.

\section{RECENT GEOLOGIC CHANGES.}

In the preceding chapters some of the recent geologic changes have been discussed, but there remain a number of others on which a few words are necessary in a consideration of the physiography of the region.

\section{MARGINAL CHANNELS.}

Streams flowing along the margin of living glaciers have often cut channels, which, when the ice disappears, will no longer be occupied by water. Two or three specific instances may serve to illustrate this phase of glacial stream work. 
The eastern margin of Hayden Glacier is bordered by a valley, through portions of which a stream flows. For most of the distance this valley has ice for one wall and gravel bluffs for the other (Pl.XXIV, $D$ ). These bluffs are sometimes from 200 to 400 feet high, and are greatly dissected; but when the ice wall disappears there will be no visible cause for their steepness. Elsewhere the land wall of the valley is bed rock, often trimmed to a precipitous cliff; and in one place the stream has cut a gorge across a rock spur. When Hayden Glacier has disappeared, this gorge will form a gulch on the mountain slopes high above the valley bottom. The course of the valley elsewhere will be marked by a precipitous, trimmed slope and by a complex of stream and marginal lake deposits with irregular topography; but the other valley wall will be missing.

Other glaciers present similar phenomena, and short gorge sections are not uncommon where the glacier, by crowding against rock spurs, has forced the streams across them. One of the best instances of such a gorge is that on the northern slope of Blossom Island, where a small glacier crowds up against its base.

The most complete series of marginal channels found in association with living glaciers in this region are those developed by the drainage of the streams from Orange and Variegated glaciers. In 1905 there was a gorge in the granite on the inner edge of the interior flat (Pl. XVI, $A$ ), but in 1906 this was covered by the advancing glacier, and the drainage from the ice was forced to find escape farther southeast. This drainage, united with that from Orange Glacier, flows in a marginal channel with ice for one wall and a gravel cliff for the other; then, where the ice crowds up against a granite spur, it enters a rock gorge more than half a mile long and 200 feet deep $(\mathrm{Pl}$. XXXVI, $B$ ). In this granite gorge the glacial torrent rushes with great velocity and in a succession of falls.

Higher up on the mountain side is another marginal channel, now abandoned. For some distance it has only one wall, and its bed is composed of a complex of deposits, with many channel ways, now occupied by vegetation. The channel then enters a gorge having gravel blufis for both walls and a bed of bowlders and well-rounded cobbles of large size (Pl. XXXVI, $A$ ). This valley joins the granite gorge described above. There is a still higher and older marginal channel, also tributary to the granite gorge lower down its course.

The granite gorge of the interior flat, described above, now covered by the advancing Variegated Glacier, is a common type of gorge in this region, where glacial streams with steep slope tumble over rock lips. They are present on the lips of several of the hanging valleys in which glaciers still lie. One of the best instances is the profound gorge across the tail of the nunatak, through which the waters of the land tongue of Nunatak Glacier now escape.

Each of these types of marginal drainage channels is found at various points on the mountain slopes of the inlet. They form part of the evidence of former occupation by glaciers. In some cases the rock slopes of the inlet are deeply notched by a succession of rock gorges, as, for example, on the east side of Russell Fiord, south of Shelter Cove, and on the western wall of Disenchantment Bay just below Turner Glacier (Pl. IX). Individual instances will not be described, for they differ in no important respect from those now forming and already described. There are scores of instances of such marginal channels, often one above the other, and frequently deeply snow filled. These channels clearly prove that water erosion, as well as deposition, was an important factor along the former glacial margins, and they are useful in determining the direction of movement of the glaciers which gave them birth.

\section{WEATHERING.}

The damp climate and the sharp frost action in this region combine to cause rapid weathering. This is further aided by the abundant steep slopes, many of which have an unstable steepness due to ice erosion, which has also removed the earlier products of decay and left very little glacial débris in its place to protect the bed rock from frost action. Talus slopes are accordingly being rapidly formed, and some are already extensive. The crumbling of the rocks, especially those of the Yakutat group, is in such rapid progress that the sound of falling fragments is heard with great frequency, especially in the morning when the frost is melting. 


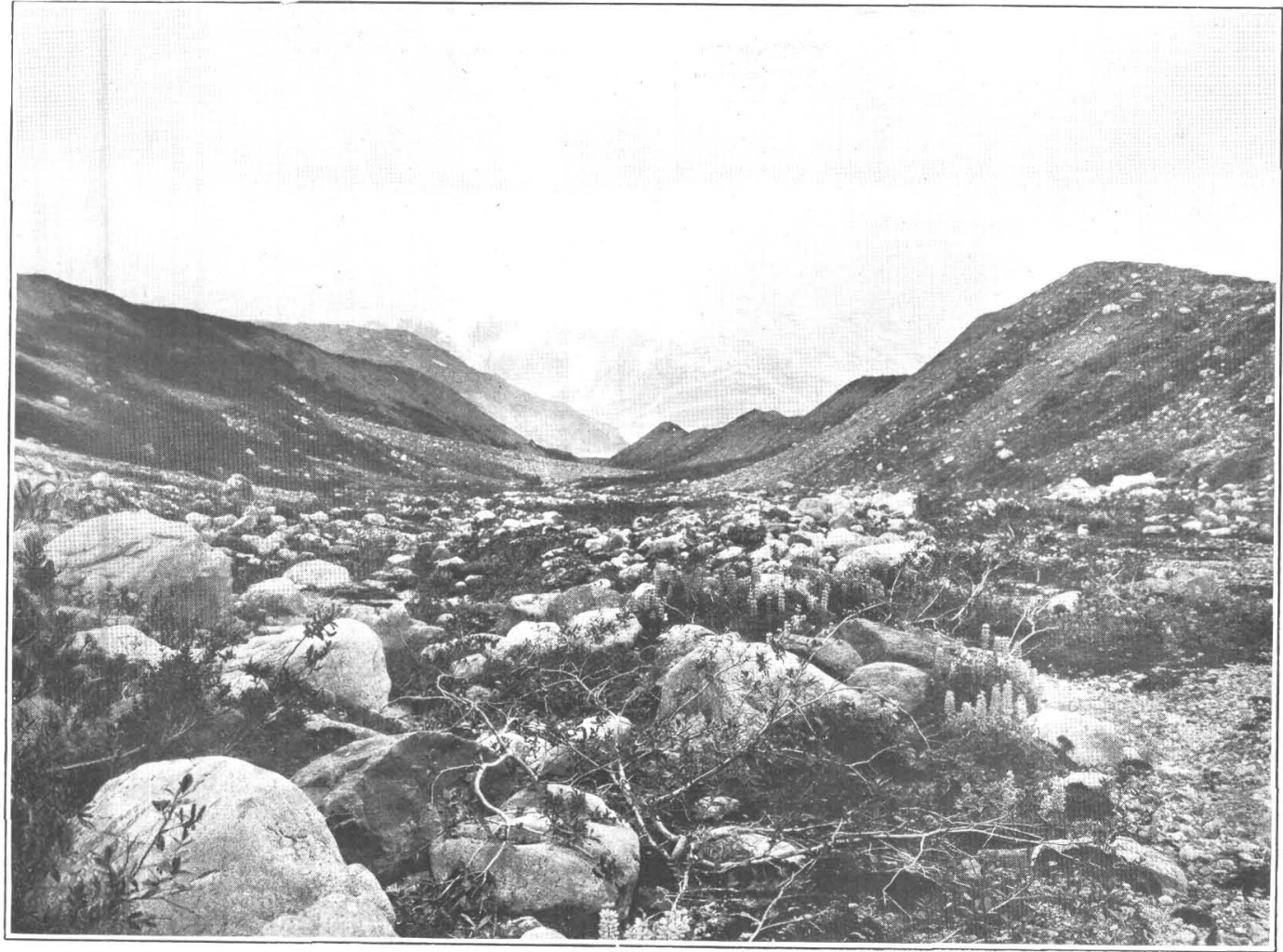

A. VIEW LOOKING DOWN MARGINAL CHANNEL OLDER THAN THAT SHOWN IN PLATE XXXVI, $B$, AND AT A HIGHER LEVEL.

Both walls are of drift, the bowlders in the bottom are waterworn, and numerous channel ways are visible on the floor of the valley. At the lower end, just below the lowest point visible, this channel enters the granite gorge shown in Plate XXXVI, B. Photograph taken August 18, 906.

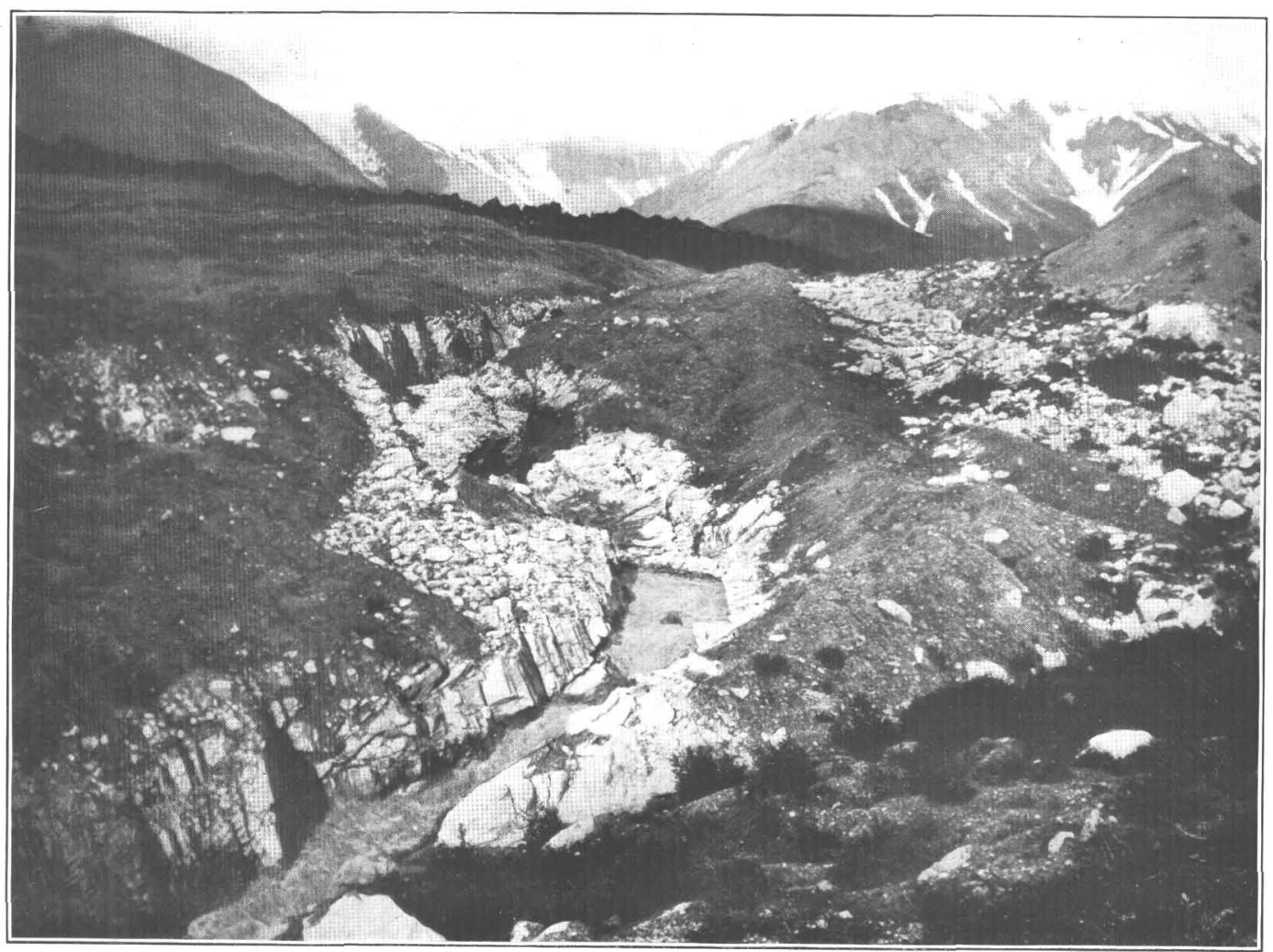

B. MARGINAL CHANNEL ACROSS SPUR OF WHITE GRANITE SOUTH OF TERMINUS OF VARIEGATED GLACIER.

Crevassed dark moraine-covered surface of glacier appears just beyond the gorge. An earlier marginal channel of briefer duration is seen on the right. Photograph taken August $18,1906$. 
On the mountain tops, particularly above the zone of former glaciation, the effect of frost action is very apparent. The surface consists of a series of huge angular bowlders, and the smaller cliffs are reduced to a mass of tumbled, frost-riven blocks. The rate of weathering in these higher altitudes is further increased by the absence of plant protection. There seems to be little difference in the rate of weathering of the friable black shale, which yields readily to frost action, and the massive graywacke, which is more open to decay. There are apparently as many peaks of the black shale as of the harder, more compact graywacke, though along the coast the former is worn back by the waves much more rapidly than the latter.

The influence of the earthquake of 1899 as an agent of weathering was especially noticeable. By it vast quantities of rock were thrown down the steep mountain slopes, so that the mountain faces are scarred far more by avalanches than is normal in similar mountain regions. Moreover, the earthquake has broken the rocks along a multitude of cracks, some of which form yawning crevasses. Into these water enters and freezes, prying apart great slices, which on the steeper slopes are made ready for falling into the valley.

Some of these rock crevasses are evidently due to the earthquake, but others, especially those near the steepened slopes of the ice-eroded valleys, appear to be due to normal processes of weathering, which is evidently an important factor in the broadening of glacial valleys. A glacier, occupying either a cirque or an elongated valley, deepens and widens it by erosion, producing a steep wall. Frost action, working along joints and inclined bedding planes, pries apart masses above the glacier level, which, loosened on an oversteepened slepe, fall upon the glacier surface and are removed by it. Thus in two ways ice erosion cooperates with weathering to more rapidly enlarge the valley, one by the removal of fragments as they fall, the other by under. mining cliffs and supplying steep grades for the downsliding of the weathered fragments. The same process applies to cirque recession.

A peculiar minor influence of weathering was also noticed. In some parts of the mountain slopes snow banks linger long after the disappearance of snow elsewhere at that level. These snow banks were found to occupy shallow pockets, whose origin was a puzzle until it was found that they were actually burrowing into the mountain slope. The lingering snow mass prevents the growth of regetation because of the short season during which the snow is absent. After the snow begins to disappear these bare patches become the seats of active frost action because the rock is exposed, abundant moisture is present each day, and the elevation guarantees freezing every night.

\section{STREAM TERRACES.}

Ordinarily glacial streams are depositing, not eroding; but in some places local conditions have favored the excavation of gravels previously deposited, and in such places stream terraces are being formed. Only one instance of this seems worthy of special description, namely, that in the lower course of the Lucia Glacier stream, near the point where it emerges from its lower gorge.

There is an older alluvial fan, of high level, into which the present stream is now sinking its channel, building a lower fan in the gash thus cut. As a result of the dissection of the gravels there are two well-defined terraces at different levels, each held up by rock spurs; one terrace is so old that it now supports a mature spruce forest; the other, which is lower, about 30 feet above the stream, is occupied only by scattered young alders. On the east side of the stream there are a number of minor terrace steps, of a pattern strikingly like those of the Connecticut Valley, the lowest being defended by a rock spur, over which the stream tumbles in a rapid, not yet having had time to cut into it.

These conditions clearly show that there was first extensive fan building, then cutting, followed by a long rest with the building of a new fan in the gash, and finally renewed cutting now in progress. These variations are in harmony with evidence elsewhere in the region, pointing to the conclusion that the glacier history has been complex. Here, however, uplift by the earthquake of 1899 may have been the cause of the latest rejuvenation by which the terrace is being trenched. 
Complexity of glacial phenomena is further indicated here by the presence of two sets of marginal channels farther up the Lucia stream, where Lucia Glacier has, at an earlier high level, crowded its marginal stream over against the Floral Hills, causing it to cut a gorge across mountain spurs. One of these marginal channels is of ancient date and is gravel filled. In the other, now being formed along nearly the same line, the stream is engaged in removing the older gravel filling, but locally has been deflected across small spurs buried by the gravel filling. The older gorges are much broader than those now forming.

COAST LINE.

The coast line of the Yakutat Bay inlet is everywhere immature. In some parts, where elevated during the earthquake of 1899 , it has only just begun to develop new forms; but even the raised beaches, wave-cut benches and cliffs, and the shore lines where no elevation has occurred are all characterized by the features of youth.

Throughout most of the region the shore lines call for no special description, the only noteworthy feature being the rapid outward growth of the coast where glacial streams enter and pour their heavy burden of sediment into the sea (p. 50). In the protected waters of the fiord these streams have built perfect alluvial fan deltas, many of them of steep slope and composed of pebbles and even bowlders, clear to the seaward margin. In outer Yakutat Bay, where ocean waves beat on the coast and where only finer sediments are deposited by glacial streams, the results are different, as may be illustrated by describing the coast line between Esker Stream and Kwik River.

This coast line is rapidly growing outward, not as a fan does, by steady growth, but by successive steps, or leaps, as offshore bars develop. Offshore, near the stream mouths, there is a bar on which the waves break and behind which there is more protected water (p. 123). Then comes the present beach, over which the storm waves break, so that there is as yet little or no vegetation on it. Ordinarily, however, this beach is out of water and forms a continuous barrier except where broken by the outflowing glacial streams. This barrier beach projects in long, sweeping curves into the bay, having flat points, somewhat cuspate in form, opposite the stream mouths.

Behind the beach is a long line of lagoons, navigable by canoe at high tide, but at low tide exposing a broad flat of fine-grained sticky glacial mud, with areas of quicksand and extensive marshes not reached by ordinary tide. Back of this is an older beach with associated sand dunes, behind which is a sandy, level, swampy area-an old lagoon, now raised by deposit above sea level. Back of this, as already described (p. 124), are other older beaches and intermediate lagoons. Altogether there are three beaches in different stages of dissection and regetation growth. In time the inner beach will become dry land; the barrier beach will become what the inner now is; the bar will become a barrier beach; and a new bar will develop out in the ocean.

The vast quantity of sediment pouring into Yakutat Bay is rapidly modifying its coast line. It is also causing extensive clay deposits offshore. There is an abundance of water from the melting snows and glaciers, and enormous supplies of sediment for transportation, for glacial erosion keeps the mountain slopes steep, and weathering is active, while little of the débris remains behind to blanket the rock. This rock débris is borne slowly to the glacier margins near the sea, and there, in rapid torrents, is hurried toward and into the sea. The extent and rapidity of accumulation, both on the alluvial fans and in the sea at the stream mouths, are remarkable. This is one of the most active regions of sediment deposit in the world and is to be compared with great river deltas.

\section{EARTHQUAKE OF 1899.}

Undoubtedly the most notable recent geologic changes in this region are those wrought by the earthquake of 1899 , with the accompanying phenomena of faulting and uplift and depression of coast lines. These recent changes are not discussed here because they are to be taken up in another publication. ${ }^{a}$

a Tarr, R.S., and Martin, L., Yakutat Bay earthquakes of 1899, U. S. Geol. Survey (in preparation). Earlier sccountsof this earthquake will be found as follows: Recent change of level in Alaska: Science, vol. 22, 1905, pp. 879-880; Recent changes of level in the Yakutat Bay region, Alaska: Bull. Geol. Soc. America, vol. 17, 1906, pp. 29-64; Recent change of level in Alaska: Geog. Jour., vol. 28, 1906, pp. 30-43. 


\section{PART II.-AREAL GEOLOGY.}

By Ralph S. Tarr and Bert S. Butler.

\section{CHAPTER I.}

STRATIGRAPHY AND STRUCTURE.

\section{GEOLOGIC INVESTIGATIONS.}

EARLIER WORK.

The earliest reference to the bed-rock geology of the Yakutat Bay region so far discovered is in Dall's report; ${ }^{a}$ but, the expedition having totally different objects, the geologic data gathered were evidently fragmentary and throw little light on the bed-rock conditions.

Russell gathered much more information, a great deal of which our expeditions were able to verify. Russell states ${ }^{b}$ that all the mountain region inclosing Yakutat and Disenchantment bays is made up of brown sandstone and black slate belonging to the Yakutat "system;" but on the southern shore of the Northwest Arm of Russell Fiord white limestone occurs in the neighborhood of heavy outcrops of quartz-mica diorite and green metamorphic rock resembling serpentine.

He further states " that the gray and brown sandstone and nearly black shales are "uniform in lithological character over a large area, and are usually greatly crushed and seamed. So great has been the crushing to which they have been subjected that it is difficult to work out a hand specimen with fresh surfaces. Fragments broken out with the hammer are almost invariably bounded by planes of previous crushing, and are usually somewhat weathered." Except where greatly disturbed near fault lines, the Yakutat rocks, wherever seen, dip northeastward, east of Disenchantment Bay at angles of $15^{\circ}$ to $20^{\circ}$, more steeply toward the west, and nearly vertically near Knight Island.

Although the Yakutat rocks are stratified, it is impossible to determine their thickness, which is abnormal, for the reason that they have been greatly crushed and overthrust. This is well illustrated in the Hitchcock Range, where, were the rocks in their normal position, their thickness would be incredible. ${ }^{d}$

Exceptions to the prevailing dip occur along the immediate shores of Yakutat Bay, northwest of Knight Island, and at the southern extremity of each of the mountain spurs between Yakutat Bay and Blossom Island. At these localities the rocks are frequently vertical or nearly so, owing their high dip to the proximity of lines of displacement.e

The several geologists of the Harriman expedition made further observations on the bedrock geology. $f$ Emerson describes numerous varieties of crystalline rocks from the moraine of Hubbard Glacier. The rocks of Russell's Yakutat system he describes under the name

a Dall, W. H., in Ann. Rept. UJ. S. Coast Survey for 1875, p. 162

$\checkmark$ Russell, I. C., Second expedition to Mount St. Elias: Thirteenth Ann. Rept. U. S. Geol. Survey, pt. 2, 1892, p. 90.

c Russell, I. C., An expedition to Mount St. Elias, Alaska: Nat. Geog. Mag., vol. 3, 1891, pp. 167-174. Mount St. Elias and its glaciers: Am. Jour. Sei., 3d ser., vol. 43, 1892, pp. 173-175.

d Russell, I. C., An expedition to Mount St. Elias, Alaska: Nat Geog. Mag., vol. 3, 1891, p. 168

$\varepsilon$ Idem, p. 169.

$f$ Geology and paleontology: Harriman Alaska Expedition, vol. 4, 1904; B. K. Emerson, pp. 23-24, 44-4i, 49-50; E. O. Ulrich, pp. 125-146. $74228-$ No. $64-09-10$ 
"Vancouver series," a name employed in 1886 by Dawson for beds in the northern part of Vancouver Island and in the Queen Charlotte Islands, with fossils characteristic of the Alpine Trias. The series consists of "dark slates, sandstones, graywacke, tuffs, and subordinate calcareous beds, often strongly cleaved or jointed all to pieces, and filled with quartz veins, but otherwise not greatly advanced in metamorphism." In describing the rocks of the Yakutat region he says that the black shale is "much shattered, and kneaded with coarse sandstone."

Ulrich discusses the age of the Yakutat "formation," which elsewhere in the volume Emerson calls the Vancouver series, describing the fossils and concluding that it is of Liassic age.

Professor Russell discovered at Pinnacle Pass, west of Yakutat Bay, a series of conglomerates, sandstones, and limestones containing fossil shells and leaves of plants belonging to species still living. These beds of the "Pinnacle system" a are said by Knowlton to be not older than Miocene, and from the strong resemblance to existing flora likely to be much younger. ${ }^{b}$ From the relative position of the different series of rocks Russell inferred that the Yakutat "system" was younger than the "Pinnacle system," and, "more than this," that "the upheaval of the mountains, the formation of numerous fault scarps, have also occurred since Pliocene times."

Although our work did not cover the section on which Russell based this inference, the observations made elsewhere in the region led us to entirely different conclusions as to the relative age of the several series of rocks. The reasons set forth by Russell in support of his interpretation are not convincing; and it is noteworthy, also, that the Abruzzi expedition ${ }^{c}$ not only failed to verify it, but brought forward reasons for doubting the succession as stated by Russell.

EXPEDITIONS OF 1905 AND 1906.

One of the principal objects of the expedition of 1905 was to make a reconnaissance study of the stratigraphic and areal geology of the region contiguous to the Yakutat Bay inlet. For this purpose almost the entire coast line was traversed on foot and practically all the outcrops were examined. The recent uplift of the land, during the earthquake of 1899, had revealed an excellent chain of outcrops, as fresh and unweathered as when the waves were beating against the upraised strand. Moreover, the wave-planed bench offered a good highway of travel along the coast. For these reasons the rocks of the region could be easily examined along a very long and excellent outcrop.

In addition to the coast-line section, traverses were frequently made up the cliffs and into the valleys. Several journeys were made into the mountains of the peninsula, and some also into the mountains of the mainland. The more important of these side trips are indicated on the map (Pl.XXXVII). In a reconnaissance way, therefore, the region was fairly well examined. ${ }^{d}$

On the second expedition, in 1906, less attention was paid to the bed-rock geology. A boat trip was made to the head of the inlet, however, and another to Variegated and Orange glaciers. The Floral Hills and the region round about Blossom Island were also examined.

\section{THE ROCKS.}

\section{GENERAL STATEMENT.}

The problem of the stratigraphy of the Yakutat Bay region was found to be a most difficult one. The rocks are mostly barren of fossils, and except in the youngest beds none were found that promised to throw definite light on their age. This rendered it difficult to fix upon beds which could be used as a datum plane in determining the order of succession or the thickness of the strata. Moreover, the region has been subjected to profound" disturbance, including both

\footnotetext{
a Knowlton, F, H., An expedition to Mount St. Elias, Alaska: Nat. Geog. Mag., vol. 3, 1891, pp. 131 and 167-185.

b Idem, pp. 199-200.

c Filippi, Filippo de, The ascent of Mount St. Elias; report on the geology by I. V. Novarese. Appendix E., 1900, pp. 232-239.

d A brief preliminary report on the geology of the first Survey expedition to Yakutat Bay appeared in U. S. Geol. Survey Bull. No. 284, 1906, pp. 61-64.
} 


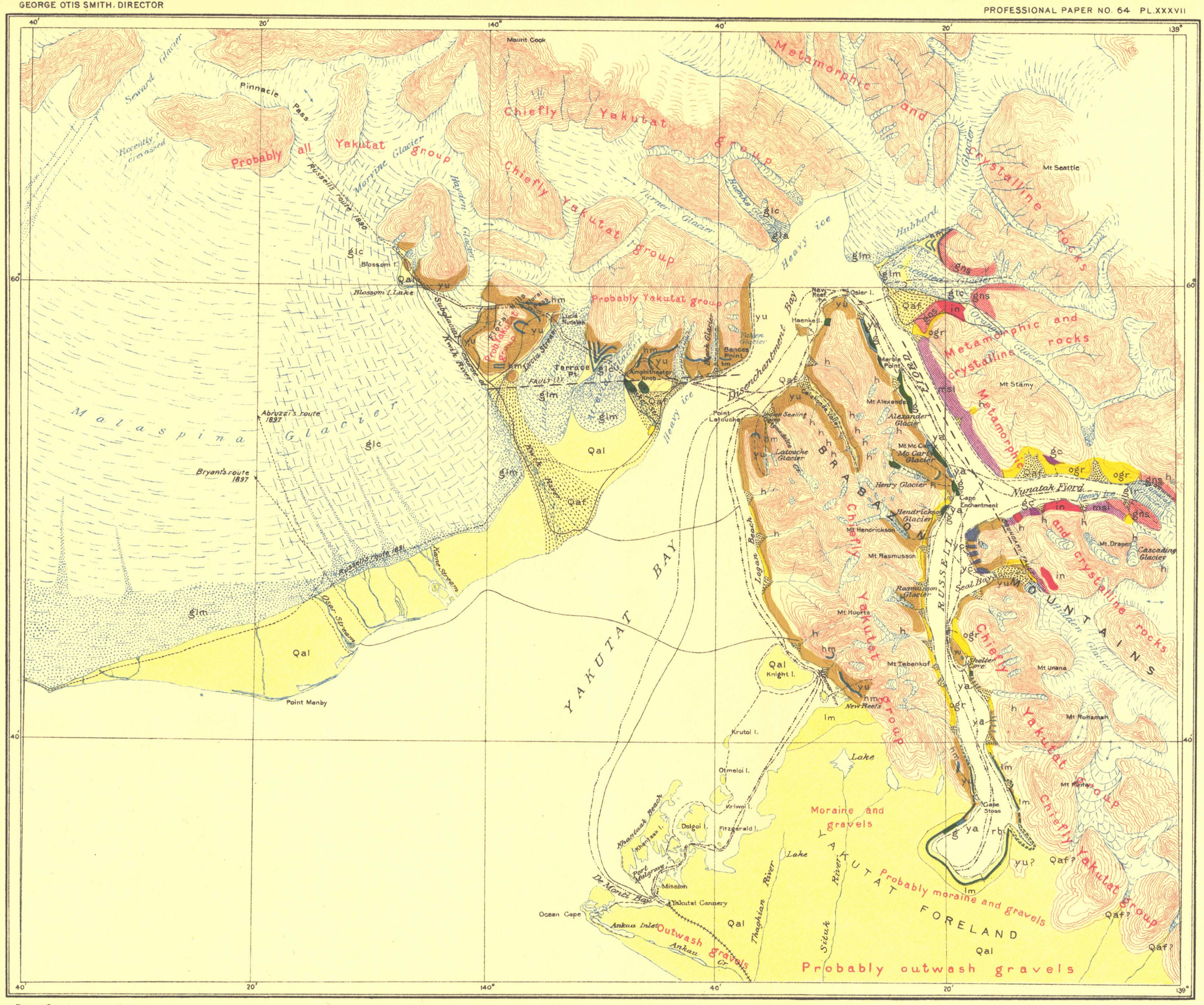

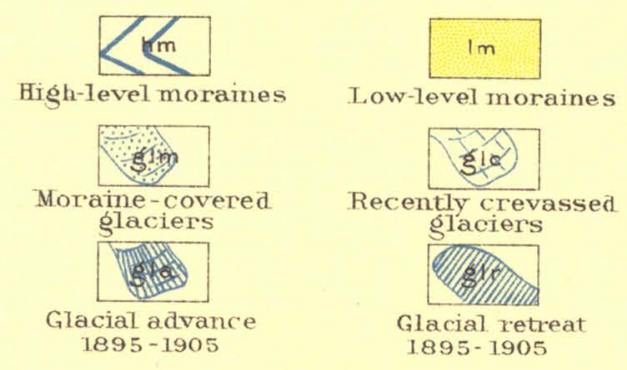

ogr

Overriaden gravels

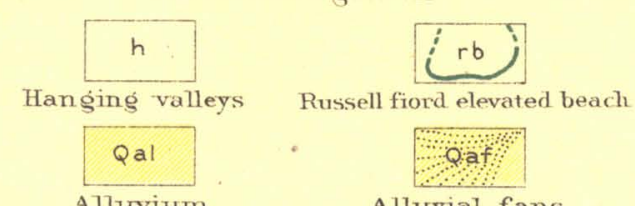

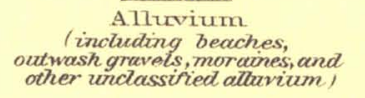

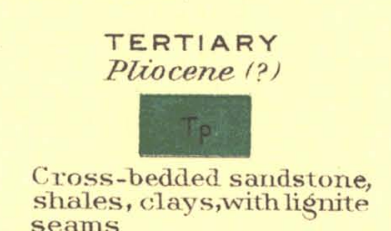

MESOZOIC (?)

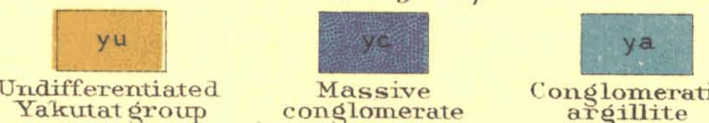

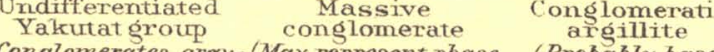

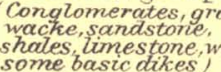

PALEOZOIC OR OLDER (?)

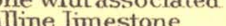

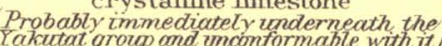

Ninis

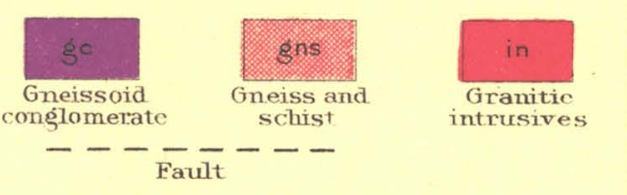

Boat trip, 1890 and 1891 , Russell

Rurssell's, Abruzzi's, and Bryant's routes, 1890, 189, and 189 ?

\begin{tabular}{c} 
Gibert's route, 1899 \\
$--\frac{\text { Route of party. } 1905}{}$ \\
\hline
\end{tabular}

_._. Route of party, 1906 
folding and faulting. Many of the faults are thrust faults, and many of the folds are overturned. This disturbance of the layers is on both a large and a small scale, introducing an extrnordinary degree of complexity in the structural features of the region. Scores of faults and small folds could be seen in a single small outcrop. Under these conditions it was utterly impossible to hope to work out with definiteness an order of succession of strata in the limited time at our disposal. Some conclusions were reached, however, and facts were observed that indicated others.

The strata throughout most of the region are an assemblage of sedimentary beds complexly folded and faulted, but ordinarily not notably metamorphosed. These beds are included under the term Yakutat group; they are very barren of fossils, but there are reasons for assigning them tentatively to Mesozoic age, as is shown in a later section. The Yakutat beds consist in the main of a peculiar graywacke, in part, at least, a tuff; very fragile and fissile black shale; and rapidly alternating thin-bedded black shale and sandstone. There is also a blue limestone in one or two places; and there are two different kinds of conglomerate, one a massive conglomerate of normal kind, though often including large bowlders, the other a conglomerate whose matrix is black shale and whose pebbles are often bowlders of very large size. This we have called a black conglomeratic argillite. It appears to be the basal member of the Yakutat . group.

The beds of the Yakutat group form practically the entire peninsula, the mountains west of Disenchantment Bay as far at least as Blossom Island, and the mountains east of the South Arm of Russell Fiord south of Hidden Glacier. The only exceptions discovered are the basement crystalline rocks, mentioned in the next paragraph, and some basic dikes.

The basement crystalline rocks appear at several points along the coast, as indicated on the map, and also were found in the interior of the peninsula. So far as could be seen, the black conglomeratic argillite rests on these crystalline rocks unconformably, but in a complex relation, evidently due to faulting and folding. Both large and small fragments of the crystalline rocks are included in the black argillite. The basement rocks are mainly greenstone and white crystalline marble; but there are also quartz diorite and granodiorite, besides other rock phases. These rocks were found over so wide an area that it is believed they form the platform on which the strata of the Yakutat group were deposited.

A fault separates the Yakutat group from a complex of metamorphic and crystalline rocks. This fault was definitely located on the southern shore of Nunatak Fiord, and its extension, as plotted on the map, would carry it to Hidden Glacier and down the Northwest Arm of Russell Fiord. On one side of this fault line the Yakutat group and the greenstone-limestone series only were found; on the other, crystalline rocks only, and no beds like those found south of the fault line.

The metamorphic and crystalline rocks include clay slates with cleavage parallel to the . bedding, gneissoid conglomerates, a great variety of gneiss and schist, and intrusive granites, both in dikes and in large masses. The slate outcrops along the entire northeastern shore of the Northwest Arm of Russell Fiord, and also in smaller area on Nunatak Fiord and in the Hidden Glacier valley. Back of the slates are gneisses, schists, and granites, which also form the main rocks on the two sides of Nunatak Fiord; but here, on both sides, gneissoid conglomerate was found.

These beds of metamorphic and crystalline rock are tentatively assigned to the Paleozoic era; they are certainly older than the Yakutat group. In all probability, too, they include beds of more than one age. It seems reasonably certain, for instance, that the clay slates and gneissoid conglomerates are younger than the gneisses and schists.

By far the greater part of the region is made up of rocks of these kinds. In one place, however, along and near Esker Stream, on the west side of Yakutat Bay, near Bancas Point, rocks of Tertiary age were found. These, which are probably Pliocene in age, consist of crossbedded sandstones, clays, shales, and lignitic beds. They are far less disturbed than the strata of the Yakutat group, from which they are apparently separated by a fault. In these beds a 
fairly good flora was found. The Tertiary strata outerop in but a small area, evidently extending westward under Atrevida Glacier.

On the map these several groups of strata are represented by different symbols. Only those places actually observed are marked, the remaining area being indicated as probably of one group or another. However, in many cases this probability might almost be stated as a certainty, since the rocks were seen from only short distances, and, moreover, the glaciers descending from the area show very clearly the nature of the rock through which they flow. The map errs, perhaps, in overconservatism.

The succession of strata, as indicated by our studies, is represented in the following table, being the same as that used for the legend of the map (Pl. XXXVII):

Quaternary:

1. Beaches.

2. Alluvial fans.

3. Outwash gravels.

4. Overridden gravels.

5. Moraines.

6. Unclassified alluvium.

Tertiary (Pliocene ?):

Cross-bedded sandstones, shales, clays, with lignitic-coal seams.

Mesozoic (?) (Yakutat group):

1. Undifferentiated Yakutat group: Conglomerates, graywacke, sandstone, shales, limestone, with some basic dikes.

2. Massive conglomerate: May represent phase of basal conglomerate.

3. Black conglomeratic argillite: Probably basal member of Yakutat group.

Paleozoic or older (?) (metamorphic and crystalline rocks of undetermined age):

1. Greenstone, with associated crystalline limestone: Probably immediately underlying the Yakutat group and unconformable with it. Separated from other crystalline rocks by fault, but relative age of two unknown.

2. Clay slate and phyllite.

3. Gneissoid conglomerate.

4. Gneiss and schist.

5. Granitic intrusives.

METAMORPHIC AND CRYSTALLINE ROCKS.

Varieties of rocks.-Nunatak, Orange, Variegated, and Hubbard glaciers bear a burden of crystalline rocks of great variety, including granite, gneiss, and schist, indicating clearly that the valleys through which they pass are walled by these crystalline rocks. No attempt has been made to study the characteristics of these transported rocks, but their general nature and great variety may be inferred from the following list of rocks gathered by the Harriman expedition from the moraines of Hubbard Glacier: ${ }^{a}$ Glaucophane-quartz schist, amphibolite, hornblende gneiss, epidote-quartz schist, quartz-biotite diorite, and gneissoid biotite granite. On the shores of the bay were found coarse crystalline marble with black veins, coarse pegmatite with felted actinolite needles, poikilitic mica diorite, and fine-grained epidote-chlorite schist.

Hubbard and Variegated Glacier valleys.-Besides studies of the crystalline rocks in the Northwest Arm of Russell Fiord, in Nunatak Fiord, and in the Hidden Glacier valley, three excursions were made in 1905 into the crystalline area, one along the eastern margin of Hubbard Glacier, the second up the valley of Variegated Glacier, and the third up the valley of Orange Glacier. Schist, slate, and gneiss were found in the mountains east of Hubbard Glacier, the beds having a steep dip $\left(70^{\circ}\right)$ northward and a strike about northwest-southeast parallel to the axis of the mountains. In the Variegated Glacier valley the strike was about the same and the dip toward the north, usually at a high angle, though in some places as low as $45^{\circ}$. The outermost ledge in this valley was black hornblende gneiss, followed up the valley by a green argillite schist, and this by a gray quartz gneiss rusting red and vellow. In the Orange Glacier valley occur similar gneisses and also, on the south side, an extensive area of white granite.

a Emerson, B. K., Geology and paleontology: Harriman Alaska Expedition, vol. 4, 1904, p. 23. 
, Nunatak Fiord. -A more detailed section of the crystalline rocks was made in Nunatak Fiord. All the mofainic material brought by that glacier is crystalline, clearly indicating that the upper portion of the valley is entirely within the crystalline belt. The easternmost outcrop studied in place was the nunatak, where there is a mixture of several gneisses which we did not attempt to differentiate. Among these was hornblende gneiss, which, together with hornblende schist, also forms the bulk of the rock on the north side of the fiord opposite the nunatak. South of the nunatak the main mountain wall includes, besides gneisses, a large mass of white granite. Granite dikes of marked irregularity, and with great variation in width and texture, gross the gneisses of the nunatak.

The tail of the nunatak is composed of a series of slates and slaty schists, whose greater weakness accounts for the erosion which has given rise to the valley between the southern wall of the fiord and the nunatak. The slate becomes more schistose near the nunatak, and the general strike is about N. $60^{\circ} \mathrm{W}$. (magnetic), with a dip of $70^{\circ}$ to $80^{\circ} \mathrm{S}$. This slate belt strikes out into the fiord, and is succeeded westward, along the shore line, by a white granite with remarkably well-developed sheeted joint planes, giving it the appearance, when viewed from a distance, of a gneiss or a series of stratified beds. These joints strike about north and south (magnetic) and dip $45^{\circ} \mathrm{E}$. Underlying the granite is a hornblende gneiss with the gneissic structure alnost at right angles to the joints of the granite-that is, with a dip of about $45^{\circ} \mathrm{W}$. One fragment of the hornblende gneiss was found included in the granite.

Immediately adjoining the hornblende gneiss on the west, and probably of later age, is a metamorphosed conglomerate with large stretched pebbles. The conglomeratic character is clearly seen in the feld but is difficult to detect in the hand specimens, which appear to be true gneiss. Some of the layers were so metamorphosed that even in the field it was difficult to detect the original sedimentary characteristics. Associated with the conglomerate is a thin layer of gneissoid sandstone, or possibly a stretched conglomerate originally of fine grain.

The conglomerate is succeeded on the west by what is probably a later series of slates and less slaty fine-grained sandy beds, with the slaty cleavage parallel to the bedding, the rocks having a general northwest strike and a dip of $70^{\circ}$ to $80^{\circ} \mathrm{NE}$. Toward the west the slate rocks become blacker and more fissile. Near the point of transition there is a small granite intrusion including. llate fragments.

The rock outcrops on the north side of the fiord were not so carefully plotted, for on this side thick gravel deposits obscure the bed rock. Enough was seen, however, to show that there are gneiss and schist toward the east, then metamorphosed conglomerate, and finally slate. The moraine deposits along the shore indicate also the presence of white granite on this side of the fiord.

Slate belt.-In the Northwest Arm of Russell Fiord there are continuous slate outcrops on the northeastern side, all the way from the mouth of Nunatak Fiord to the Variegated Glacier stream, with a remarkably uniform strike, about northwest and southeast, and a northeast dip of not far from $30^{\circ}$. There is some crumpling, but no faulting was detected. Numerous quartz veins cross the strata, and occur between the layers and in knobby masses, some of them containing pyrite. There are also several dikes of highly altered diabase crossing the slates.

The cleavage is remarkably perfect, and the rock splits like a roofing slate, though in places it is rather more micaceous than common roofing slate. Everywhere the cleavage is essentially parallel to the bedding. In some places the beds grade into a very fissile chloritic slate. Most of the slates are vert fine grained, but some beds are sandy; and toward the east the slate is not only fine grained but black and crumbly, making a very weak rock.

No fossils were found, though carefully looked for; nor was the thickness of the slate belt determined. Its strike is slightly diagonal to the axis of the fiord, and it forms the shore line for several miles. In two or three trips up the mountain slope slate was found to reach an elevation of several hundred feet, so that the apparent thickness is great, probably several thousand feet; but since the beds are evidently folded it did not seem worth while to make careful 
measurements in this reconnaissance unless we could take time to work out the system of folds as well.

The slates on the northeastern shore of Russell Fiord are apparently identical with those on the southern shore of Nunatak Fiord. Not only are their characteristics the same, but they strike toward each other, the gap being only about a mile. What rock lies outside the slate belt on the northern shore of Russell Fiord is unknown, for the strata strike out into the water; but on the south side of Nunatak Fiord the slates end abruptly against the unmetamorphosed rocks of the Yakutat group, from which they differ not only in degree of metamorphism but also in lithologic character. The slates are wholly unlike the black shales of the Yakutat group, and, moreover, do not include any of the graywacke so characteristic of that belt.

Boundary fault.-The two belts of diverse rocks are separated by a profound fault. The fissile black slate is traceable into a small valley on the south side of Nunatak Fiord, on the western side of which, less than 20 yards away, occur the typical black shale and graywacke of the Yakutat group. The slate strikes N. $40^{\circ} \mathrm{W}$. and dips $70^{\circ} \mathrm{E}$., while the rocks of the Yakutat group are greatly contorted and faulted, with a general westward dip. In the gap of a few yards between the recognizable rocks of the two diverse series there is a faulted, slickensided dough of black shale.

This fault line, if extended, would pass along the axis of Russell Fiord, on the northeast side of which is the slate belt, on the southwest side the Yakutat group. Extended southeastward it cuts diagonally across the mountains to the Hidden Glacier valley near the terminus of that glacier. On visiting this valley it was found that slate and slaty schist, with gneiss and granite-behind, strike into the valley near the glacier end, while the south side of the valley and the northern wall nearly to the glacier are made up of rocks of the Yakutat group. Although the position of the fault line was not exactly located here, its position was determined within a few hundred yards, and it is in line with the fault line on the south side of Nunatak Fiord and with its prolongation along the axis of the Northwest Arm of Russell Fiord.

Summary.- The crystalline and metamorphic rocks are older than those of the Yakutat group, from which they are separated by a fault. The conclusion that the crystalline rocks are older than the Yakutat rocks is based on the fact that, though the two belts are in close proximity, one set is highly metamorphosed, the other not. Moreover, granite is intruded into the crystalline rocks and not into the Yakutat rocks. It is inferred, therefore, that there was a period of mountain folding, granite intrusion, and profound metamorphism before the beds of the Yakutat group were laid down. Further proof of the accuracy of this interpretation is presented in the discussion of the rocks of the Yakutat group.

It is noteworthy that the metamorphic and crystalline rocks include three quite different groups: (1) Gneisses and schists of uncertain origin, and with extreme development of metamorphism; (2) metamorphosed sediments-slates, sandstones, and conglomerates; (3) granites, intruded into both the gneiss and the metamorphosed sediments. While other and more definite proof was not found, the profound difference in degree of metamorphism between the gneiss-schist beds and the contiguous metamorphosed sediments suggests the probability that there are rocks of at least two quite different ages in this metamorphic and erystalline complex.

GREENSTONES AND LIMESTONES BENEATH YAKUTAT GROUP.

At a number of points there are outcrops of crystalline rocks upon which the beds of the Yakutat group evidently rest unconformably. These basement rocks may be an otherwise unexposed part of the crystalline complex described in the previous section, but the fact that they are separated from it by the fault between the Yakutat group and the crystalline belt, and the further fact that the two kinds of crystalline rocks are quite unlike, render it desirable to consider them apart and make it impossible to definitely correlate them.

The greenstones and limestones are best revealed along the southwest shore of the Northwest Arm of Russell Fiord, between Osier Island and Cape Enchantment. The first outcrop is exposed near low-tide line about 2 miles southeast of Osier Island in close association 
with and beneath a black conglomeratic argillite. This outcrop is a greenstone varying from fine to coarse grain, at times as coarsely crystalline as diorite. In it are included small areas of white marble, apparently introduced by faulting. Numerous similar outcrops occur along the coast to the southwest at and near mid-tide level. In places the marble is surrounded by the greenstone, but ordinarily the inclusion was evidently the result of faulting, and it was nowhere certain that it was the result of igneous intrusion. If the greenstone is igneous and the marble not faulted in, it is hard to understand the unaltered character of the included marble along the contact. Possibly, however, some of the greenstone is a tuff and some intrusive, but facts were not discovered which would determine this.

One fairly large outcrop of white marble, closely associated with coarsely crystalline greenstone, had a strike about northwest and a nearly vertical dip, parallel with a schistosity developed in the greenstone. These rocks have been much faulted since the development of the metamorphic banding, and the marble is crossed by a network of veins.

Just southeast of this, at and beyond Marble Point, the coast line projects well beyond the main fiord wall. This projection is due to a low off-lying mass of basement crystalline rock which has resisted the glacial erosion that has deepened the main fiord and given it extraordinarily steep and even walls. It is separated from the sedimentary Yakutat strata of the southern wall of the fiord by a valley in which there are glacial gravels and alluvial fans. At Marble Point there is a great mass of coarsely crystalline greenstone and a long, narrow band of white marble, which extends for fully a mile. The relation of the marble to the greenstone is confusing, for stringers of greenstone enter it, and bowlder-like masses of the marble are included in the greenstone. In places the appearance is that of greenstone intrusion, but on the whole the evidence was opposed to this interpretation. The marble has been much crumpled and faulted since the production of the pronounced banding which has developed in it. In the greenstone there are areas of metamorphic banding and much evidence of crushing and faulting. At many places it is so veined, and its decay so rapid owing to the crushing, that it is difficult to get fresh specimens.

Besides these two rocks there are lesser quantities of other rock phases. At one place there is a narrow outcrop of quartz diorite, or granodiorite; and there are outcrops of a redbrown crystalline rock, resembling a diabase, and of a black rock so slickensided that it resembles a black shale. It would require a prolonged study of this area in the field, followed by a careful petrographic study, to work out the differences in these rocks and their relations.

Similar outcrops occur along the coast as far as Cape Enchantment, which itself is greenstone, with faulted inclusions of white marble. Between Marble Point and Cape Enchantment there is a long, narrow band of faulted marble in the greenstone, traceable for fully a quarter of a mile. A small area of greenstone associated with black conglomeratic argillite occurs along the coast just south of Cape Enchantment.

Similar rocks were found in place on the peninsula just east of the north end of Haenke Island, where there is a very small outcrop of pyritiferous greenstone with white marble inclusions. The black shale of the Yakutat group wraps around this outcrop, as if it were either upfolded or faulted to its present position in the Yakutat sedimentaries. Greenstone was also found in a small outcrop south of Shelter Cove, but without white limestone, though pebbles of this rock occur in the overlying black conglomeratic argillite.

In our excursions into the interior we found these rocks in only one place-high up in a small valley occupied by a glacier, 2 or 3 miles west of Cape Enchantment, at an elevation of about 1,500 feet. Here the typical greenstone occurs, but the limestone is bluish, and far less coarsely crystallized than in the localities mentioned above. The limestone is, however, distinctly crystalline, and is crushed and crossed by innumerable veins. It is correlated with the crystalline basement series. A small outcrop of greenstone was also found just below the end of Hidden Glacier, under a gravel terrace near the northern edge of the outwash gravel plain.

Near the head of Russell Fiord the coast line on the west side is diversified by numerous headlands and little coves. On these headlands and around the shores of some of the coves, except where covered by pocket beaches, there are outcrops of quartz diorite and of a coarse 
crystalline rock with a quartzless phase, resembling the greenstone of the region between Marble Point and Cape Enchantment. In it are large inclusions of white, coarsely crystalline marble.

There seems little doubt that these rocks near the head of the fiord are the same as the basement rocks along the southern shore of the Northwest Arm of Russell Fiord; and the fact that they occur at such widely separated points, and also near Haenke Island, and high above sea level west of Cape Enchantment, proves that the basement crystalline rocks underlie a large part, if not the whole, of the Yakutat group of this region. In the next section further evidence is presented to prove that the limestones and greenstones underlie much of the Yakutat group, and that they are not only unconformable beneath it but also of far earlier age.

\section{YAKUTAT GROUP.}

Above the basement beds the rocks are all unmetamorphosed, though greatly folded and faulted. It is to these that Russell gave the name Yakutat system (p. 145). Owing to the profound disturbance of this series of strata, we could not be certain that there are not unconformable relations between the different members, but in the absence of evidence of such unconformity they will be treated as a conformable series. A number of very different members comprise this belt, and each of these will be considered separately. Apparently the lowest member is a very peculiar black conglomeratic argillite which in a number of places is found resting unconformably upon the greenstone and white marble basement rocks.

Black conglomeratic argillite.-The black conglomeratic argillite occurs all through the region, and was studied in innumerable outcrops, mainly along the seacoast, but also in the valleys away from the coast. Everywhere it shows the same general characteristics, being a mashed, closely folded, and greatly faulted conglomerate, with a fine-grained black-shale matrix, which in many places exceeds in quantity the pebble content. Wherever the basement crystalline rocks outcrop the black conglomeratic argillite occurs either resting directly on it or in close proximity, but it is also present in many places where the basement series is not uncovered.

The pebbles of the conglomerate are mainly graywacke, greenstone, white marble, and a granitic rock, but some other rocks are also present. There are not, however, any pebbles of gneisses, schists, granite, and slate, so characteristic of the crystalline belt, even where these rocks outcrop within a distance of a mile or two, on the northeast side of the fault line between the Yakutat and crystalline rocks. The conglomerate appears to be of local origin, with the pebbles mainly, if not entirely, of rocks from the basement series, moved only a short distance from their source. Besides pebbles there are many bowlders, some of them several tons in weight. Many of the pebbles and bowlders of the conglomerate are distinctly angular.

Where the black conglomeratic argillite rests on the basement crystalline rocks the relations of the two are very complex. Great masses of the argillite are included in the greenstone, and narrow, dikelike extensions of the greenstone extend into the argillite. In a number of places these relations could be definitely shown to be due to faulting, and in others it was suspected; but in some no proof of faulting was found, though the fact that the apparent intrusions of greenstone nowhere reached more than a few feet above the basement is opposed to the theory that the greenstone is an intrusion later than the deposit of the argillite, as the lack of contact metamorphism also indicates.

This peculiar argillite was found also where the basement rock does not outcrop, but the fact that it contains the same pebbles and possesses here the same characteristics as in the localities where it visibly rests on the basement rocks leads to the inference that the basement limestones and greenstones lie buried at no great depth. This inference receives support from the fact that the basement rock is exposed in widely scattered localities, and even in the interior of the peninsula high above sea level.

It is this remarkable argillite for which Blackwelder, ${ }^{a}$ from studies in the mountains southeast of Russell Fiord, suggests glacial origin. But the local origin of the fragments and their

$a$ On the probable glacial origin of certain folded slates in southern Alaska: Jour. Geology, vol. 15, 1907, pp. 11-14. 
relation to the basement crystalline rocks, which was not seen in Blackwelder's area, lead us to another explanation. Nowhere in our area did we find bowlders as large as those described by Blackwelder, though some of those seen in the Yakutat Bay inlet were very large. Some of the largest of these were found to be faulted blocks of the underlying rock, brought up into the argillite. In fact, in its basal portion, some of the black conglomeratic argillite has been distinctly brecciated by crushing and faulting.

Our theory for the origin of this peculiar argillite is that it is derived from the underlying crystalline rocks and was accumulated after a very short journey, during which the pebbles and bowlders were only slightly rounded. There is in many places a greenish phase to the matrix, which further indicates local origin. To the causes for the peculiarities of the rock is added faulting, by which large fragments of the basement limestones and greenstones have been incorporated in the overlying argillite. By faulting, also, some of the overlying rock has been included in the basement rocks.

The wide extent of the black conglomeratic argillite, which outcrops throughout the region, and the fact that in places several bands are parallel to one another and close together, have raised the question whether there is more than one stratum of this peculiar rock. Owing to the profound folding and faulting of the entire series of rocks of the Yakutat group, it is impossible to answer this question definitely; but the probabilities are against a recurrence at different horizons of conditions favoring so peculiar a deposit. We are therefore inclined to consider it more probable that the repetition, such as is evident south of Shelter Cove, where there are several bands of black conglomeratic argillite with intermediate beds of black shale and graywacke, is due either to a series of compressed isoclinal folds or to faulting.

Relation of the Yakutat strata to the basement crystalline rocks.-Observations on the relation between the black conglomeratic argillite and the basement rocks warrant certain conclusions. A conglomerate of local origin, with angular fragments of the basement rock inclosed in a stratified clay matrix, usually black but locally greenish, apparently from the influence of the adjacent supply from the greenstone, was deposited on a far older series of crystalline rocks, including greenstone, granodiorite, and white marble. These basement rocks were in essentially their present degree of crystallinity when the conglomerate was deposited, for its pebbles and bowlders are identical with those of the basement series, though included in an unmetamorphosed clay matrix. This clearly points to a profound unconformity.

This argillite is younger than the latest plutonic intrusion in the neighborhood, for, while quartz diorite occurs in contact with the argillite, and granite is present in great abundance in the crystalline belt not far away, no granite dikes were found in any of the sedimentary beds of the Yakutat group.

The argillite occupies a wide area, appearing on or near all the outcrops of the basement rocks and occurring at many points where these rocks do not now outcrop; but inasmuch as large fragments of the basement rocks are found in the argillite at all points, the rocks from which they were derived are believed to lie buried near at hand. Our inference is, therefore, that the entire Yakutat group in this region is underlain, at no great depth, by the basement crystalline rocks.

Subsequent to the deposition of the black conglomeratic argillite and of the other Yakutat beds there was a period of profound disturbance during which the entire series was complexly folded and faulted. This also affected the basement rocks, against which the less massive Yakutat rocks were pressed; and along the contact, mainly in the black conglomeratic argillite, there was a crushing and brecciation, by means of which fragments of the unmetamorphosed Yakutat strata were faulted down into the basement rocks, and large masses of these rocks were incorporated in the lower layers of the black conglomeratic argillite. By this mutual interchange there has arisen a very peculiar basal layer resting on the basement crystalline rocks.

Massive conglomerates.-The Yakutat group includes another conglomerate of entirely different character. It was nowhere seen to grade into the black conglomeratic argillite, nor was it found resting on the basement crystalline rocks. Whether it occurs above the Yakutat strata or in the higher horizons of this group or whether it is itself a basal conglomerate locally 
at a different horizon from that of the black conglomeratic argillite was not determined. This conglomerate occurs at many places in intimate association with the black shale and graywacke, increasing in abundance toward the northwest, but without showing at any point where we studied it definite evidence of its relation to the other members of the Yakutat group.

One of the most extensive areas of this conglomerate in the region is on the west side of Russell Fiord, between Seal Bay and Nunatak Fiord. Here it outcrops in massive beds separated by strata of black shale and graywacke. It has the appearance of being in several strata, but this repetition may well be due to faulting or folding.

The matrix of the massive conglomerate differs greatly from that of the black conglomeratic argillite in forming a far smaller proportion of the rock, in being sandy instead of a clay, and in being brown or gray in color instead of black. The pebbles are well rounded, and among the fragments are some very large bowlders. The rock fragments are varied in character, including granite, white marble, greenstone, sandstone, black shale, and some gneisses. The presence of the sandstone and shale might indicate that this conglomerate is of later age than the Yakutat beds, but on this point our field study was not conclusive. We did not definitely identify the sandstone and shale fragments with the Yakutat rocks, and specimens were not collected for microscopic study and comparison. The relations of this conglomerate can not, therefore, be considered definitely established, though from the evidence at hand it seems to be a constituent part of the Yakutat beds, and not improbably a basal conglomerate of different phase from the black conglomeratic argillite.

A similar conglomerate occurs at various points along the shores of Yakutat Bay and its branches, in the valleys of the peninsula, and among the mountains northwest of Disenchantment Bay. Judging from the numerous outcrops of this rock in the latter area, and from the abundance of conglomerate fragments in the moraines, notably of Lucia Glacier, we infer that this conglomerate attains a greater development toward the northwest.

Blue limestone.-Near the coast, about a mile south of Cape Enchantment, a low hill of blue limestone, slightly crystalline, contains thin bands of blue, green, and black flint. The beds are decidedly crumpled. Another outcrop of similar rock was found on the mountain slope 2 or 3 miles farther south, and a similar outcrop was discovered on the south side of the Calahonda Valley, near the shore. No fossils were found in this limestone. It appears to be conformable with the Yakutat beds, but may possibly form a part of the basement rocks, representing a slightly metamorphosed phase of the white limestone. Against this interpretation, however, is the presence of the abundant flint, which was not found in the coarsely crystalline white marble of the basement rocks near by.

Black shale and sandstone.-The remaining rocks of the Yakutat group are assemblages of black shale, sandstone, and graywacke. Ordinarily the black shale is fine grained, but it has sandy phases. It is exceedingly fissile, apparently due more to cleavage than to bedding. As a result it crumbles rapidly under the influence of frost, and in the outcrops can be dug away with the fingers. Some of the thinner beds are rather sandy and might be classed as fine-grained black sandstone; but all the thicker beds are true shale. Some of the shale layers are highly calcareous, as is shown by specimens collected on Osier Island.

The black shale occurs in massive beds and in thin layers. The latter is bedded with gray and brown sandstone, the individual alternating layers being commonly from 6 to 12 inches thick.

Graywacke.-The massive beds of graywacke are perhaps the most characteristic rocks of the Yakutat belt. They are everywhere gray, but vary in texture, some outcrops being fine grained, others very coarse. In the latter condition the graywacke often appears in the field to be a true igneous rock with a texture as coarse as a fine-grained granite. Feldspar crystals, quartz, and basic silicates are visible to the naked eye, and the rock crumbles rapidly on exposure to weather.

In its more massive crystalline phase the graywacke shows no stratification, and for a long time its actual character could not be determined in the field. It sends stringers into the black shale, includes black-shale fragments, and, owing to complex folding and faulting, has 
ill-defined relations to the associated beds. In many outcrops, however, its sedimentary origin is clear, and the study of thin sections likewise proves this origin.

The field evidence of the sedimentary character of the graywacke consists of the conformable bedding with the black shale in places, and in the presence here and there of stratification. The best stratification is that caused by a very peculiar breccia of black shale. Angular, elongated chips of black shale lie in bands parallel to the stratification of the graywacke and associated black shale. Sometimes these fragments are very scattered; elsewhere the rock is closely peppered with them. Ordinarily the black-shale fragments are only an inch or two long, but some pieces 2 or 3 feet long and from 1 to 3 inches wide were seen.

It is possible that all the larger shale inclusions are faulted into the graywacke, as some of the largest certainly are; but the breccia with smaller fragments undoubtedly represents bedding. It is exceedingly difficult to understand how such a number of angular fragments of a friable shale could be deposited in such a graywacke. Transportation should have readily either rounded them or reduced them to the clay constituents, and water transportation. should have mixed finer particles of the black shale with the graywacke and in places colored it black. Another difficulty is that the shale fragments are apparently of exactly the same character as the associated black-shale layers with which the graywacke is bedded. If derived from these beds, as seems to be the case, they must already have been sufficiently consolidated for transportation before the graywacke was deposited. A further problem is to account for the fresh, angular crystal fragments visible in the graywacke, for which no near-by source is now known, but whose angularity shows that they were not carried far before deposition.

As shown in the chapter on petrography (pp. 171-172), microscopic study reveals evidence of volcanic origin for at least a portion of the component particles of the graywacke. This gives support to the theory that the rock is, in part at least, a volcanic tuff, and that the shale fragments, as well as the crystalline minerals, were derived by volcanic explosion followed by rough assortment by water. In our field study the tentative name for these beds was "tuff," and the laboratory study supports this usage. If it is a tuff, supplied from volcanic vents which passed through the Yakutat beds, the origin of the angular shale fragments is clear. In that case the graywacke is of later origin than the black shales from which the angular breccia fragments were derived.

Whether there is more than one bed of graywacke we could not be certain, though there are such differences from outcrop to outcrop, and the rock occurs in so many places, that even in the face of convincing evidence of faulting and isoclinal folding it seems necessary to assume the existence of two or more beds.

Large, perfect concretions, many of them as round as a ball, and ordinarily several inches in diameter, are a prominent feature in this rock. Some were a foot or more across. They are merely more perfectly cemented portions of the graywacke, and owing to this fact weather out of the ledges like pebbles from a conglomerate. Since they are often faulted, it is evident that at least some of the movement to which the Yakutat strata have been subjected has occurred since the consolidation of the graywacke.

Like all the rocks of the Yakutat group, the graywacke presents abundant evidence of profound disturbance since deposition. It is crushed and broken and crossed by a network of small veins filling the planes of breakage. In many places the crushing and veining have so aided weathering that the rock is deeply decayed and crumbled.

Osier Island section.- The Yakutat rocks were studied in a number of sections, and while innumerable differences in detail were found the general features are alike throughout most of the area. It will suffice to describe in some detail one of these sections in order to show the relations. The minor details discovered in other sections do not call for special mention. For the purpose of presenting these general relationships, the section at Osier Island is selected.

On the east end of this island there is an extensive outcrop of crumbling crystalline rock, massive and unstratified, and with very confusing relations. In the field it was called a tuff, but in this paper it is classed as a graywacke. Being one of the weakest of the rocks, it crumbles readily, forming a talus at the base of a low sea cliff and having a disintegrated surface from 
which most of the glacial grooves have disappeared. Crossing it are a great number of small veins occupying planes of crushing and extending in all directions, so that, altogether, it was difficult to secure a fresh specimen. The rock contained many rounded concretions a few inches in diameter.

The east side of this outcrop ends in the sea, but the west side is in contact with black shale, conformably, so far as could be seen. A small dike of the graywacke enters the black shale, giving the appearance of an intrusive, which is heightened by the fact that many thin wedges of the graywacke enter the black shale parallel to the bedding, and by the presence in the graywacke of bands of angular, included, black-shale fragments, giving rise to the breccia described in the previous section. There are also numerous long, angular bands of black shale included near the contact, the field evidence pointing to faulting as the explanation for these. The dikes and intruded wedges, which so closely simulate igneous intrusion, are now interpreted as sandstone dikes, but in the field the contact of the black shale was found to be so impregnated with the graywacke that it then seemed almost necessary to assign an igneous origin to the graywacke. Field studies elsewhere led to the conclusion that the apparent evidence of igneous intrusion is the result of mechanical intrusion, faulting, and sedimentary inclusion of small angular fragments.

The black shale west of the graywacke is not very thick, and it is soon followed by a series of nearly vertical layers of sandstone and black shale, the individual beds being commonly from a few inches to a foot in thickness. It is estimated that about 90 per cent of this section is sandstone. Fucoids were found on the face of the sandstone layers, and worm tubes (Terebelina) in the black shale. A small area of massive graywacke, apparently of the same nature as that farther east, outcrops about midway in these black shale and sandstone beds.

Here, as elsewhere in the region, the futility of attempting to measure sections in the Yakutat group was clearly proved. The vertical face of the cliff in which the black shale and sandstone beds outcropped had the appearance of being a normal succession of nearly vertical beds, but where planed off horizontally by the waves, at the cliff base, there was revealed a. close fold, with the strikes on the two sides of the axis almost exactly parallel except at the very nose of the fold, and the dip ranging between $30^{\circ} \mathrm{E}$. and $80^{\circ} \mathrm{W}$. This fold could not be detected in the vertical cliff, and there were doubtless others that were not seen.

Other rocks farther west repeat the phenomena already described. It was found utterly impossible here, as elsewhere, to locate either the top or the bottom of the series or to work out a definite succession. Evidently the beds are plicated in a most complex fashion, so that they are repeated again and again in the same section. On Osier Island, as elsewhere, the beds are complexly folded, with many close folds, some overturned and crossed by numerous small faults. On a single acre there are dozens of dips and strikes, and it is no exaggeration to say that on the small area of Osier Island there are hundreds of visible faults. They are seen every few feet, and extend in all directions.

There are peculiar phenomena of detail also. Several of the layers, themselves fairly uniform, have intercalated contortions of complex character in the laminæ of which they are composed. There are also numerous narrow dikes extending from the sandstone beds into the black shale. That these are not igneous intrusions, as at first suspected, is proved by the fact. that they extend from distinct sandstones in which fucoids occur. This phenomenon throws light upon the similar dikes, described above, which extend from the graywacke into the black shale.

Slaty phase of shales of Yakutat group,-Aleng the western shore of Disenchantment Bay and in the mountains to the west the rocks, when viewed from a distance, all have the appearance of being typical of the Yakutat group. They include black shale, graywacke, sandstone, black conglomeratic argillite, and the massive phase of conglomerate. On closer inspection, however, they are found to be far more metamorphosed than the normal Yakutat rocks.

The shale has a slaty appearance and in places is even schistose. This was, however, found to be a phenomenon of slickensiding rather than a general characteristic of the rock. 
Where broken across the stratification, the appearance is typical of the normal black shale; but where broken along the planes of division, the surface is that of an imperfect chlorite slate. In both the Black Glacier and the Galiano Glacier valleys there is a graduation in metamorphism, diminishing up the valley. The metamorphosed phase also disappears farther west in the Floral Hills.

The graywacke associated with the slaty shale is more broken and veined than normal, and contains far more pyrite than common. Weathering gives rise to yellow and reddish-brown stains, so that the graywacke often seemed a different rock from that of the rest of the region. The abundance of pyrite gives rise to a number of sulphur springs near Bancas Point, marked by the characteristic odor and by white and blood-red flocculent deposits.

There is no reason for considering this slightly metamorphosed series of strata anything else than a slightly altered phase of the rocks of the Yakutat group. The resemblance is too close, and the gradation too clearly apparent, for separation of the two phases into different formations. Why this metamorphism should be absent in all the rest of the region is not clear. It is evident, however, that for some reason there is a more intense plication here, especially in folds and faults on a large scale. In seeking an explanation for this local metamorphism it is noteworthy that this area lies between two fault lines, one between the Yakutat rocks and the later Tertiary beds, the other along the axis of Disenchantment Bay. Along at least one of these fault lines distinct movement took place as late as 1899. It is possible that the local metamorphism is related to this close association with fault lines, and to a consequent intense folding of the adjacent Yakutat beds.

Diabase dikes.-Diabase dikes cross the Yakutat beds at numerous points, cutting both the black shale and the graywacke. They vary in width from a few inches to 10 feet. South of Point Latouche and on the west side of Disenchantment Bay there are some large dikes, and in the latter locality there is a mass of similar rock which could not be definitely shown to be a dike. One of the dikes on the west side of Disenchantment Bay differs considerably in mineral composition from the others of the region; this may be due to different physical conditions rather than to a different magma. The petrographic character of the dikes is described in the chapter on petrography (pp. 176-177).

While the dikes are somewhat faulted, their normal vertical position and the fact that they are neither contorted nor greatly faulted prove conclusively that they have been intruded since the major part of the profound disturbance of the Yakutat beds occurred.

Age of the Yakutat rocks. - It has not been found possible to determine the age of these rocks. That they are younger than the metamorphic and crystalline rocks is clear, and that they rest with a profound unconformity on the crystalline basement is also evident. It will be shown below that the Yakutat rocks are older than those containing the coal beds, which are of late Tertiary age. From the stratigraphic evidence, therefore, they may lie anywhere between the late Tertiary and the early Paleozoic. Associated as they are with a mountain range which, both to the northwest and southeast, has undergone repeated foldings, in the course of which the Paleozoic rocks have been very generally metamorphosed, it seems probable that these unmetamorphosed beds are of later age than the Paleozoic.

In his description of the fossils collected by the Harriman expedition, ${ }^{a}$ Ulrich says that "a fossil species of definite character, Terebelina palachei," belonging to a new genus, is common to various localities along the Alaskan coast. Ulrich concludes his discussion of the origin of these rocks as follows: "After weighing, as we have, the evidence of all its known fossils, no other decision seems justifiable than that the slate of the Yakutat series is of Liassic age." The evidence on which this conclusion is based is, however, rather meager.

The lithologic resemblance between these widely separated strata is striking, and taken in connection with even the meager paleontologic evidence, gives some basis for a long-range correlation. From the description by the Wright brothers, and from a glimpse of the beds near Sitka, we are inclined to accept the correlation at least as far as that point. 
Our search for fossils in the Yakutat rocks was almost fruitless. Most of the beds are quite barren, and the others yielded only a very scanty assemblage of forms, all of which were of too indefinite a character to warrant conclusions concerning the age of the rocks. Many specimens of Terebelina (identified by T. W. Stanton) were seen in widely separated localities. They could almost always be found in the black shale where it was not too much crushed. Some of the specimens submitted to Stanton, and possibly all, are specifically identical with Terebelina palachei as described by Ulrich from Columbia Glacier.

Unquestionable wood fragments and other organic forms were collected at Osier Island. Of these last Stanton says: "There are some other slender bodies with rough surface that are probably trails or burrows of some small animal;" and "there are larger irregular bodies that may be either burrows or fucoids." In conclusion, Stanton states: "There is nothing in this collection that gives satisfactory evidence of the age of the rocks. The evidence for correlating these beds with the slates on Woody and Pogibshi [Near] islands, near Kodiak, is by no means conclusive, and the reference of the latter to the Lias is still subject to serious doubt." $a$

A specimen containing an echinoid was found on the moraine of Atrevida Glacier. Since this glacier occupies a small valley, which both from the evidence of the moraine fragments and from a distant view of the entire valley wall is evidently completely walled by rocks of the Yakutat group, this specimen, though not found in place, would properly serve as fair suggestive evidence of the age of the Yakutat rocks, if it were distinctive. Of it Stanton says:

It is a distorted imprint on dark shale showing about 20 connected plates of an echinoid, with numerous fine tubercles. It is believed to represent a part of the under surface of an irregular echinoid, but it does not show the diagnostic features that are used in the classification of genera. It is certainly later than Triassic and may possibly be as recent as Tertiary.

Another and better specimen of similar general appearance was found on the moraine of Hayden Glacier. This Stanton stated orally to be post-Paleozoic; but in this case it is not so certain that the specimen comes from the Yakutat beds, although it occurs in a shale that is indistinguishable from that of the Yakutat group and is associated with other typical Yakutat rocks on a moraine containing no rocks of other type.

From the above discussion of the evidence it is clear that we are not in position to assign even an approximate age to these rocks; but with all the facts in mind there is suggestion of early Mesozoic age, and if it were necessary to tentatively assign a place to these rocks this would seem to us the most probable.

Structural features.-The most striking structural feature of the Yakutat rocks is the extraordinary complexity of the folding and faulting. The beds are twisted, contorted, folded, overturned, faulted, and, as another has well put it, even "kneaded." Folds are faulted and faults folded, and the fault lines extend in all directions, with all hades from horizontal to vertical, and with throws from a fraction of an inch to many feet. The entire region is a veritable museum of faults and folds in which all varieties are present.

Naturally it is in the thin-bedded sandstones and black shales that the clearest evidence of small faults and folds is presented. Here the disturbance often amounts to brecciation. In single outcrops, with an area of only a few square yards, a dozen folds and faults are often to be seen.

There are also many large folds visible on the mountain sides, frequently overturned folds with the strata dipping at low angles, from the horizontal up to $40^{\circ}$ or $50^{\circ}$, and with such minor crenulation as to produce synclinoria and anticlinoria. More commonly, however, the dips are at a higher angle, and in many places almost exactly vertical. In such cases there are numerous folds with highly inclined pitch, so that the limbs of the folds have nearly vertical dip, as seen on Osier Island.

The black conglomeratic argillite and thick-bedded black shale are greatly crushed, and the same is true of the massive graywacke. In the massive beds there is less proof of minor folding, partly, no doubt, because the evidence is less clear than in the thin-bedded rocks, but 
partly also because the massive rocks were broken and crushed under the stresses that folded the thinly bedded strata.

There are many small thrust faults, and in one or two instances large faults of the same character. In fact, some of the structural features seem to imply extensive thrust faulting.

With such complex structural features it is evident that any attempt to work out the relation of beds and the thickness of the series was wholly impossible in a reconnaissance, and could only be undertaken in the course of an extremely detailed survey. In the early field work many observations of dips and strikes were made and measurements of thickness undertaken, but the utter futility of this soon became evident. Within limited areas there are all dips up to $90^{\circ}$, and even reverse dips of high angle, and there are strikes toward all points of the compass. The average dip, if such a term can be used under such conditions, seems to be northeast at an angle of about $50^{\circ}$, and the strike northwest; but there are too many departures from this to make it of much value even as a general average.

The difference in the amount of faulting in the Yakutat beds and in the adjacent crystalline rocks, notably the slates, and the absence in the latter rocks of similar complex folding, are striking. The slates run along for miles with uniform strike and with no great variation in dip, whereas the black shale and sandstone strata frequently change dip and strike every few feet. The only explanation of this difference that suggests itself is that the younger, yielding Yakutat strata have been crushed against the massive, resistant crystalline rocks.

As has been stated, the conglomerates and notably the black conglomeratic argillite seem to be basal, while the graywacke appears to be one of the youngest beds; but we can not prove anything more definite than this in regard to the relative order of deposition of the several beds. Nor can we state the thickness of the series, except that the apparent great thickness is doubtless very deceptive owing to the unquestioned repetition of the same beds through complex folding and faulting.

All the facts discovered could be harmonized on the assumption that there are only five, or at most six, closely folded and greatly faulted beds above the crystalline basement. These beds are (1) conglomerate - black conglomeratic argillite in places and more normal massive conglomerate elsewhere; (2) flint-bearing blue limestone, perhaps only local lenses; (3) massive black shale; (4) thin-bedded black shale and sandstone; (5) one or two beds of graywacke. If this is the actual succession the thickness of the entire series need not be more than 2,000 or 3,000 feet.

The absence of fossils, other than the few kinds discovered, is remarkable, and clearly points to unfavorable conditions for life during deposition. There is no evidence of the nature of these unfavorable conditions. The general absence of fossils is not due to subsequent metamorphism, for the rocks, notwithstanding their profound disturbance, are generally quite unaltered. It is, indeed, rather remarkable that there has been so little alteration of this complexly folded and faulted series. In places crushing and slickensiding have so mashed the rock that no fossil forms could be retained, but there are plenty of other places where they would be uninjured. Indeed, the delicate form of Terebelina and the worm tracks and fucoids are sometimes quite perfectly preserved.

Area covered by Yakutat rocks. - The entire shore of the Yakutat Bay inlet south of the fault between the Yakutat and the crystalline rocks, and as far seaward as the mountain front, is bordered by the Yakutat rocks, except in those relatively small, scattered areas where the basement crystalline rocks outcrop.

Judging from the excursions made into the crystalline area and from the moraines of Hubbard, Variegated, and Nunatak glaciers, the Yakutat rocks do not occur within the valleys of these glaciers either north of the Northwest Arm of Russell Fiord or north and east of Nunatak Fiord.

The mountains of the peninsula, those east of the South Arm of Russell Fiord, and those west of Disenchantment Bay as far west as Blossom Island revealed only rocks of the Yakutat type; and from a distant view it seemed evident, as Russell reports, that the same rocks are found in the outer Hitchcock Range on the western side of Marvine Glacier. 
West of Disenchantment Bay the rocks of the crystalline belt were nowhere seen. Galiano, Atrevida, and Lucia glaciers carry no crystalline rocks, all their moraines being composed of fragments which appear to be from the Yakutat beds. From this it is inferred that the rocks of the southeast face of Mount Cook belong to the Yakutat group. The moraines on Hayden Glacier do contain crystalline rocks, and as this is a much longer glacier, heading on the west side of Mount Cook, and possibly having tributaries farther inland, it is believed to prove that the crystalline belt strikes across at least the north side of Mount Cook, and possibly even the upper portion of its south face. A continuation of the fault line observed in Nunatak Fiord would occupy about this position.

\section{TERTIARY BEDS.}

Localities.-Between Galiano and Atrevida glaciers, 3 to 4 miles from Yakutat Bay, rocks outcrop that are evidently different from and younger than the rocks of the Yakutat group. They lie wholly outside the mountain front, at the base of Amphitheater Knob, and thence westward to the moraine-covered terminus of Atrevida Glacier. The outcrops form a part of a densely wooded, low-lying, topographically inconspicuous area, no higher or more irregular than the associated morainic deposits.

In at least two points these beds are revealed in a fairly clear section, and in both cases there has been some prospecting for coal. In both cases, too, coal fragments are found in the alluvial fans below the outcrops. One of these sections is along a small brook which descends through the spruce forest from the southwest face of Amphitheater Knob, about half a mile above its junction with Esker Stream. The other is on Esker Stream, about a mile farther west, and a mile or more below the point where this stream emerges from Atrevida Glacier.

Sections.-There is a fairly complete section along the small brook. The strike varies somewhat, but does not average far from northeast-southwest, while the dip varies between $45^{\circ}$ and $75^{\circ} \mathrm{NW}$. Measured from west to east, this section, revealed in the bed and along the low banks of the brook, is as follows, from top to bottom:

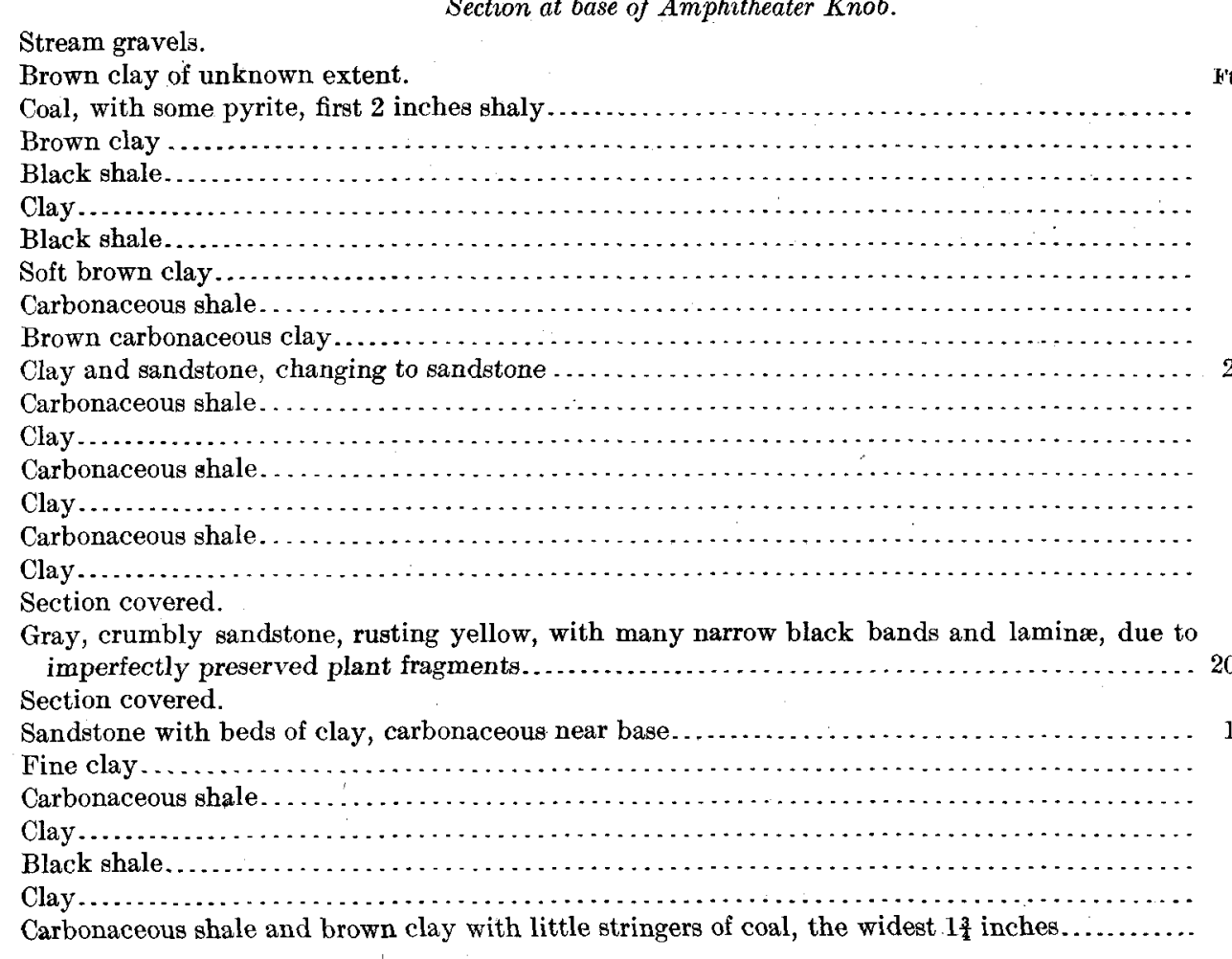




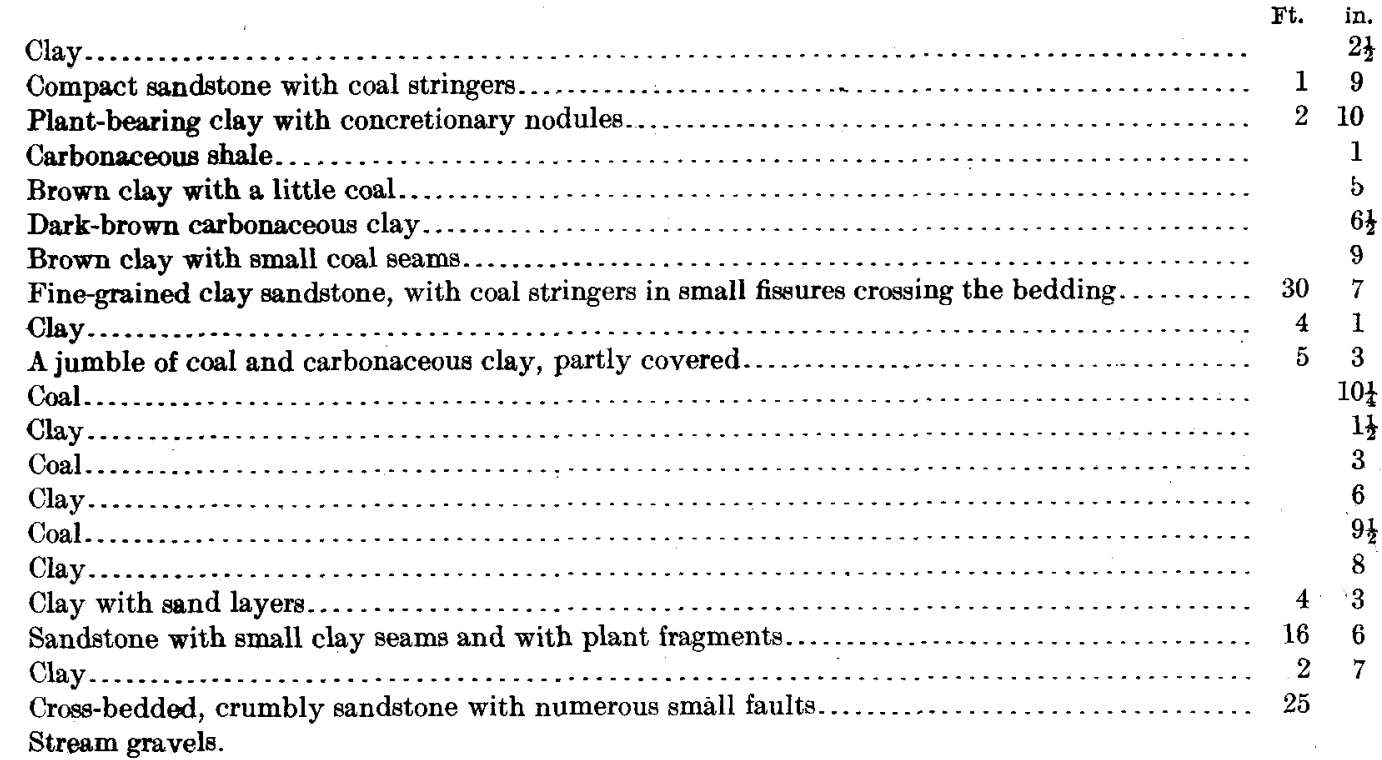

On Esker Stream the rocks outcrop in a bluff upward of 100 yards in length and in places 50 or 60 feet high. Here the strike is northwest and the dip fairly uniform, averaging about $50^{\circ} \mathrm{NE}$. Since the section cuts both the dip and the strike diagonally, and since landslips have covered many of the beds, it could not be obtained in its completeness, but the following portions show the nature of the rocks in two parts of the outcrop.

Section at eastern (upper) portion of Esker Stream outcrop.

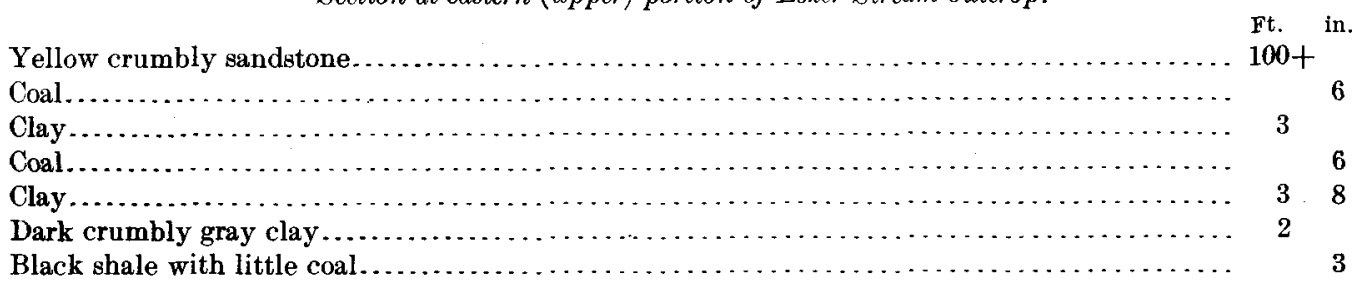

Section at western (lower) portion of Esker Stream outcrop.

Crumbly gray sandsione with small coal veins, and cross bedded $\ldots \ldots \ldots \ldots \ldots \ldots \ldots \ldots .30$

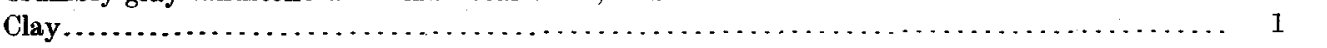

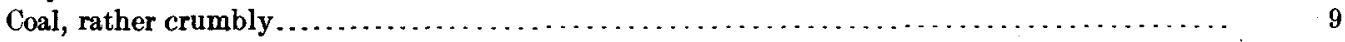

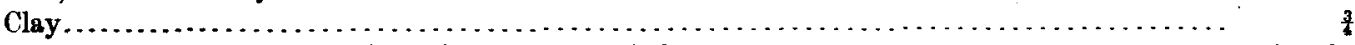

Coal, crumbly, with iron stain and some brown shale......................... 1 . 3

Soft brown clay, thickening downward....................................... 1

Coal, hard and lumpy, with some brown shale............................. 12

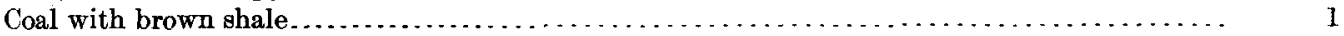

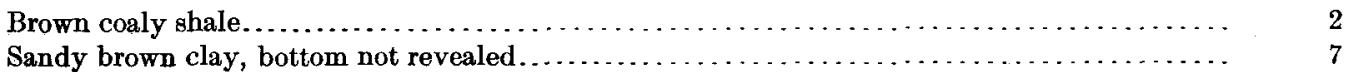

Contrast with Yakutat group.-In these coal-bearing beds the prominent rock is the sandstone, which bears a rough resemblance to the graywacke of the Yakutat group. In places it is evidently a fine-grained arkose. The differences are, however, much more noticeable than the resemblances. It is much less indurated, and it disintegrates so rapidly that bowlders detached from it and carried to the alluvial fans are quickly weathered to sand. The outcrop is veneered with sand, giving the appearance at the surface of unconsolidated sand. Beneath the film of sand the rock is compact and gray, while the weathered face is stained orange yellow.

Unlike the graywacke of the Yakutat group, the sandstone is well stratified and cross bedded, and there are distinct differences from place to place, some of the beds being distinctly micaceous. There are also intercalated lenses of clay. Concretions occur in one of the sandstone 74228-No. 64-09-11 
layers, but they are much larger than any found in the graywacke, some having a diameter of more than 3 feet. There are none of the included black-shale fragments, which in places give the graywacke the appearance of a breccia. Plant fragments are abundant in the sandstone, here parallel to the stratification, there in short, thin coaly plates crossing the bedding; and silicified wood also occurs in at least one of the layers. Thus, notwithstanding the resemblance in color and in the arkose texture, it does not seem possible to consider this sandstone the equivalent of the graywacke of the Yakutat group.

The other beds in these outcrops are wholly unlike those of the Yakutat group. There is none of the typical black shale or black conglomeratic argillite of the Yakutat, and the brown, blue, and gray clays, the brown shales, the coal beds, and the perfectly preserved plant fossils which characterize this series of beds are entirely unrepresented in the older group.

The Esker Stream outcrop, after extending for somewhat more than 100 yards, disappears under the forest-covered moraine which skirts the stagnant margin of Atrevida Glacier. Along a small creek which crosses this moraine the orange-yellow sandstone was again found, and beyond it a conglomerate bed, the full extent and character of which was not revealed. It was found in place at one point, and numerous large bowlders were present in the creek bed, probably resting on the underlying conglomerate. This conglomerate has a matrix resembling the sandstone of the other outcrops, inclosing well-rounded pebbles of a variety of crystalline rocks, many of them 3 or 4 pounds in weight. Both in general appearance and in degree of consolidation it is quite unlike any other conglomerate in the region. On exposure to weather the matrix readily crumbles and the pebbles fall out.

No evidence was found to indicate that this is a glacial conglomerate, though it might possibly have been a glacial stream deposit. The great variety of crystalline pebbles, whose source must have been many miles distant, and the absence of a large percentage of the adjacent Yakutat beds are suggestive of such origin.

A striking feature of these beds is the absence of profound folding and faulting. There is some minor faulting, and the rocks are tilted and doubtless somewhat folded, but there is nothing remotely suggesting the contortion and complex faulting so prominent throughout the entire area of the Yakutat group and even in the Yakutat rocks which outcrop within a quarter of a mile of the Tertiary beds.

Another notable difference between the two contiguous belts of rock is their topographic expression. The rocks of the Yakutat group form prominent mountains, which rival in height and ruggedness the near-by mountains of the crystalline area. The Tertiary beds, on the other hand, outcrop in low, inconspicuous hills, the largest of which are forest covered, resembling the associated moraines in strength of topographic expression. This is doubtless due to two causes-to the fact that the Tertiary beds have not been greatly elevated and to the slight degree of consolidation. The coals and clays weather with great ease, and usually occupy gullies in the outcrops, but even the sandstone crumbles with rapidity. The conglomerate forms the most pronounced elevations, but it also is a weak rock bed. Thus, even if these strata had been notably uplifted, they would have crumbled away rapidly enough to have a far less distinct topographic expression than the Yakutat beds.

It is noteworthy, too, that the Tertiary rocks, so far as discovered, lie entirely outside the mountain front, along the base of which there is apparently a fault plane on which pronounced movement occurred as late as 1899 , and inside of which are the rocks of the Yakutat group. Doubtless these Tertiary beds will be found elsewhere outside the mountain face. There are reports of coal occurring on the inner face of the Yakutat flat southeast of Yakutat, but this locality was not examined.

Age.-No remains of animals were found in these rocks, but fossil plants are abundant. They occur in the clays, shales, coal, and sandstone, and some of them are perfectly preserved. Collections were made from some of the clay beds and submitted to F. H. Knowlton for examination. His report ${ }^{a}$ is as follows: 
There are six or eight species of plants present, among them being minute fragments of a conifer, two ferns, and a number of dicotyledonous leaves. The conifer appears to be a Glyptostrobus or a very slender Sequoia. The ferns both belong to the genus Dryopteris, one of them being in beautiful fruit. This fern is hardly to be distinguished from a species now living in Jamaica. The dicotyledons seem very modern in appearance, among them being one beautifully preserved leaf which I am not able at the moment to distinguish from an undescribed species of Sterculia from Pliocene beds of the Cascades of Columbia River.

So far as this hasty examination shows, none of the plants is referable to the Kenai, and if the exigencies of the stratigraphy demand that they should be referred to the Pliocene there is nothing to contradict it.

From this report the recency of the beds, at least, seems clear. They may possibly be correlated with the Pinnacle system of Russell ${ }^{a}$ and with the Tertiary beds discovered by the Wright brothers near Lituya Bay. Their position in the late Tertiary seems highly probable.

Relation to Yakutat group.-That these Tertiary beds are not a less metamorphosed part of the Yakutat group is evident. - The rocks of the two series differ utterly in character, and the Tertiary beds are far less consolidated. Moreover, while the Yakutat beds are greatly contorted and faulted, the Tertiary strata are only moderately disturbed. All these differences are sufficient to definitely differentiate the two groups.

The exact relation of the Tertiary beds to those of the Yakutat group is not certain, since they were not found in contact, although along Esker Stream there is a gap of less than a quarter of a mile between the two. At this point the Tertiary beds strike about northwest and dip $50^{\circ} \mathrm{NE}$, both the strike and the dip throughout the outcrop being fairly uniform. The Yakutat beds, on the other hand, in a much smaller outcrop, have a multitude of dips and strikes, the average strike being northeast and the dip about vertical.

The relation of the two sets of beds and their utter diversity suggest that they are separated by a fault, and our study of the phenomena associated with the earthquake of 1899 supports this inference. There is a fault line along the mountain base to the southeast which, if extended, would pass along the line of contact between the two sets of strata. On the seaward side - that is, the side occupied by the Tertiary beds-there was no uplift; but on the landward side - that occupied by the Yakutat strata-there was pronounced uplift. Exactly along the line of separation between these two sets of strata no evidence of recent movement was discovered; but 3 miles southeast of it, on the west side of Disenchantment Bay, the line of inferred faulting separates a region of no change of level from one of pronounced uplift. There is therefore good reason for inferring not only a fault here, but one along which movement is still in progress.

\section{STRUCTURE.}

Folding and faulting.- The field evidence in the Yakutat Bay region clearly proves at least three periods of diastrophism. In the crystalline and metamorphic complex mountain building has brought about not only great deformation but a high degree of metamorphism. It is probable that this deformation is of at least two periods, since the metamorphic region includes both a series of gneisses and schists and one of altered sedimentary rocks which still preserve clear evidence of their sedimentary origin.

Assuming the basement crystalline rocks to form part of this crystalline complex, it is evident that there was a long erosion interval succeeding the last period of deformation in the crystalline area. The vast extent of this unconformity is proved by the fact that both plutonic igneous rocks and coarsely crystalline marbles were available for pebbles in the conglomerates of the Yakutat group. The presence of a fault between the Yakutat rocks and the crystalline belt prevents the discovery of the exact relationship between the two groups, except in the case of the underlying basement crystalline rocks.

The deposition of the Yakutat beds was followed by a period of remarkable deformation, at least the second in the region. In this the sedimentary strata were complexly contorted, and even crushed and kneaded; but this deformation did not affect the metamorphic and crystalline 
rocks in the same manner. From this it is inferred that the weaker sediments were deformed by being thrust against the resisting core of crystalline rocks. It is not improbable that the failure of the metamorphic rocks to participate to the same degree in this deformation is due to relief by faulting, perhaps along the same fault line which now separates the two belts.

Following the deformation of the Yakutat beds and the deposition of the Tertiary strata there came a third period of folding and faulting, a movement of less intensity, by which the Tertiary beds have been tilted, folded, and somewhat faulted. It is probable that this period of deformation is still in progress, and that the earthquakes of 1899 were the latest expression of its operation.

Igneous activity.-The history of igneous activity is not fully worked out. It is known, however, that there was a great intrusion of granite into the metamorphic and crystalline rocks, the latest, so far as our evidence shows, being subsequent to the metamorphism of the slates, for there are well-defined slate inclusions in the granite, and the granite dikes that cross the slates show none of the disturbance which they must have experienced if intruded before the early period of diastrophism by which the slates were metamorphosed. There are two distinct granites in the crystalline belt, the lesser in amount occurring as dikes, apparently later than the main white-granite intrusion. There are also intrusions of granodiorite and of greenstone in the crystalline basement, and some of the gneisses also are evidently altered igneous rocks, but the history and relation of these intrusions is not known.

The graywacke of the Yakutat group shows evidence of an important period of volcanic activity during the deposition of the Yakutat beds, but the nature and other results of this period of volcanism are not now known.

Subsequent to the deposition of the Yakutat rocks, and even after the major part of the deformation to which they were subjected occurred, there was intrusion of diabase dikes, crossing the black shale and the graywacke alike. There is no evidence of igneous activity in this region after the deposition of the Tertiary beds.

From this outline it is evident that the history of deformation of this region has been complex. Only a small portion of this history is at present known, for it would require most careful work, over a far wider area, to unravel even the major episodes in this history, to say nothing of the minor details. 


\section{CHAPTER II.}

\section{ECONOMIC GEOLOGY.}

Up to the present time the Yakutat Bay region has attained little importance as a mineral-producing district, and our studies gave little basis for expecting it to become more so. Some gold has been obtained, and coal beds have been discovered. These and other possible mineral resources were investigated with the following results.

\section{GOLD.}

EARLIER WORK.

In the reports of the Eleventh Census ${ }^{a}$ Miss E. R. Scidmore mentions the gold excitement of 1886-87 at Yakutat Bay. According to this report, the miners were realizing $\$ 40$ to the ton from black-sand beaches, when a series of misfortunes befell them. First, thousands of dogfish were cast ashore, and these on decomposing so saturated the sand with oil that mercury could not act on it. Then a tidal wave washed the beach and carried off the black sand. Naturally, the miners left and did not return.

In the same volume ${ }^{b}$ Henry Boursin states that ruby-tinted black sand containing scale gold occurs on the western beach of Khantaak Island. The discovery was made in 1887 and some work was done in 1888 and 1889, when, for reasons stated above, work was abandoned. In July, 1891, three miners sluiced the beach, taking out $\$ 3,000$ worth of gold and realizing as high as $\$ 90$ for about ten hours' work.

\section{EXAMINATION BY STANLEY-BROWN.}

Russell collected a bottle of sand from this beach in 1890 and it was submitted to J. Stanley-Brown for examination. In his report Stanley-Brown c states that "the sand has the appearance of ordinary finely comminuted beach material." Concerning the gold he says:

Among the minerals recognized gold is the most important, though relatively not abundant. It occurs in flakes or flattened grains from a quarter to a half of a millimeter in size. The particles are sufficiently numerous to be readily selected from their associates by the aid of "panning" and a hand lens of good magnifying power, and if distributed throughout the beach as plentifully as in the sample would, under favorable conditions, pay for working. The flakes in their rounded character show the effect of the agency which separated them from their matrix, a separation so complete that no rock is found adhering to the grains. * * The sand is made up of grains of gold, magnetite, garnet, hornblende, pyroxene, zircon, quartz, feldspar, calcite, and mica, associated with fragments of a shaly, slaty, and schistose character. While the information at hand is hardly sufficient to warrant much speculation concerning the rock masses of the interior, still there is no doubt that the sand is derived from the destruction of metamorphic rocks. * * A region of glaciers would seem to be favorable not only to the collection of meteoric material, but also to the destruction of the country rocks, the setting free of their mineralogic constituents in a comparatively fresh state, and their transportation to the sea.

In view of the slight economic importance of these gravels, and of the careful examination previously made by Stanley-Brown, it has not been deemed worth while to study all the samples which we collected in the Yakutat Bay region. An examination of a sample collected from Logan Beach shows it to agree essentially with the above description.

a Volume on Alaska, 1890, p. 53. b Idem, p. $230 . \quad$ c An expedition to Mount St. Elias, Alaska: Nat. Geog. Mag., vol. 3, 1891, pp. 196-198. 
At a number of points along the shores of Yakutat Bay we panned the sands, almost always obtaining colors, but nowhere finding indications of paying deposits except at two points described more fully below.

LOGAN BEACH.

During our stay in Yakutat Bay, in the summer of 1905, three prospectors were washing the sands of Logan Beach, on the eastern shore of Yakutat Bay some distance north of Knight Island. Logan Beach is supplied with sand from a gravel bench of assorted glacial materials-a marginal deposit made during the great extension of Yakutat Bay Glacier, which also supplied the gravels for the islands and foreland along the eastern shore of the outer bay (p. 131).

This gravel bench is made of well-assorted and stratified layers, in which there are many rounded pebbles and even large bowlders. The pebbles are so well rounded that they clearly prove long transportation by water, and the materials of which they are composed are from a distant source. There are some pebbles of rocks from the Yakutat group which form the mountains back of Logan Beach, but far the greater number are crystalline rocks whose source can be no nearer than the mountains north of Russell Fiord. There can be no question that the bulk of the gravel in this terrace has been derived from the borders of Hubbard and other glaciers which formerly entered the outer bay from the region of the crystalline and metamorphic rocks. A collection of pebbles from the gravels shows a great variety of crystalline rocks, some of which contain garnet.

It is probable that a careful study of these gravels and of their crystalline pebbles would show the nature of the rock from which the gold was originally derived, but it is doubtful if this result would be worth the search, since it would probably lead back into the ice-filled valleys, where even a valuable gold mine would be so difficult of access that it might be impossible to work it. One thing is certain, that search for the source of the gold must be among the crystalline rocks, not in the valleys of the peninsula near Logan Beach, where some prospectors have already searched for it.

The waves from the open Pacific enter the flaring mouth of Yakutat Bay and beat with great force on Logan Beach, attacking the gravels so frequently that a high gravel bluff is maintained all along the face of the bench. The gold disseminated through the gravels is concentrated by the waves in sufficient quantity to invite beach-washing operations of a simple character. The amount of gold varies greatly from place to place and from time to time, being especially abundant, according to the prospectors, after a high surf has been attacking the bluff for a while. The richest spots occur in the "ruby" sand, where, besides gold, garnets and magnetite are present in sufficient quantity to color the sand. No rubies are present, the pink garnets giving the basis for the name. Here the gold occurs in small flakes, though pieces as large as a dime are reported. From these richer spots it was possible to pan out a visible quantity of fine grains of gold with an ordinary shovel, and in several instances the gold was actually seen in the beach sand.

The workings conducted in August, 1905, were of a primitive character. The surface sand only was washed, and it was reported that the gold became finer and less abundant both down in the beach sand and out toward low-tide mark. A rocker was employed, the water being brought to the beach in a hose from a small stream on the bluff. When this stream dried up, as it did soon after every rain, operations temporarily ceased. These prospectors claimed that they were making only small wages, and from the amount of time they were idle this seems probable.

Back on the bluff there is a small lake which at slight expense could be made to furnish a steady supply of water, but the prospects of the beach did not seem sufficient to the miners to warrant them in undertaking the task of leading this water supply to their rocker. This beach is occasionally visited and worked in similar fashion for short periods of time, but the general testimony is that it offers only bare wages. There is no means of telling the exact output from 
this beach, but it can safely be stated that, by present methods, it does not exceed more than a few hundred dollars' worth of gold annually.

The question naturally arises whether this beach, and in fact the bluff itself, may not be capable of sustaining a more extensive industry. There is beach sand along a coast line over a mile in length, and there is an enormous mass of gravel back in the bluff. No data are available concerning the amount of gold in the gravel. If, however, examination should show that it contains enough to pay for working on an extensive plan, there is an ample supply of water for hydraulic purposes. Close at hand are large, permanent streams from the mountains which could be utilized. But it seems hardly probable that such a supply of gold will be found, for the beach deposit is narrow and shallow and the entire gold content can hardly be great. There is much more gravel in the bluff, but here, of course, the gold is far more scattered, for the gold in the beach sand is a concentrate due to wave action.

\section{KHANTAAK BEACH.}

The Khantaak Beach sands have been accumulated in a manner similar to those of Logan Beach. The gravels from which the sand is derived were deposited when Yakutat Bay Glacier reached out as far as the mouth of outer Yakutat Bay. In composition these gravels closely resemble those of Logan Beach, being composed of sand and pebbles in which a great variety of crystalline fragments abound; but the layers are less well assorted, and the pebbles are not so well rounded. Among the crystalline pebbles and bowlders were found specimens containing both iron pyrite and garnet. Here also there is a surprising scarcity of fragments of rocks from the Yakutat group, but several varieties of crystalline rock found in place north of Russell Fiord were represented among the pebbles of this gravel deposit.

No one was at work on the beach sands of Khantaak Island at the time of visit (1905), but there were clear evidences that washing had been in progress earlier in the season. Near these places we washed out some fine grains of flaky gold. There is very little water available on this narrow island, and beach washing must be carried on under distinct difficulties. There is only a small strip of sand beach at the southeast end of the island, and northwest of that there is a long pebble beach, against which the waves of the open ocean beat furiously. In this part of the beach the sand is not exposed.

The southeast end of Khantaak Island shows the effects of the earthquake of 1899, the land having been distinctly lowered, either through actual sinking or as a result of settling of the gravels during the vigorous shaking. In consequence, trees are now reached and being killed by the waves, and doubtless the conditions of gold concentration have been materially altered from what they were prior to 1899 .

\section{CONCENTRATION OF THE BEACH GOLD.}

The concentration of the gold in these beach sands has been brought about by a complex process, based on the fact that gold, like garnets (ruby sand) and magnetite (black sand), is a heavy mineral. First disseminated in the bed rock, and unquestionably mainly in the metamorphic and crystalline rocks, the gold was either scoured from the mountain rock during the process of ice erosion or supplied to the glaciers by the weathering of the mountain slopes along which the ice moved.

That portion which fell upon the glacier suffered a rough and incomplete concentration while being borne toward the ice front, for during ablation there must of necessity have been some assorting due to melting on the ice surface and to deposition in crevasses, moulins, and surface ponds.

A more perfect degree of concentration occurred in the alluvial fans and other stream and lake deposits along the ice margin and front. In some localities, by overriding through glacial readvance and by reassorting of the gravels during recession, a further concentration of the gold occurred. Accumulated in the deep gravel deposits, the gold, doubtless greatly scattered, was at rest until reattacked by streams and waves. 
At the gravel bluffs of Logan Beach and Khantaak Island there has been some assortment of the mineral fragments by rain wash and by small wet-weather streams which have accumulated small fans at the cliff base. The final stage in concentration has been accomplished by the waves working over the deposits at the cliff base, and even removing material directly from the gravel beds of the bluffs.

Through these processes gold has been widely spread among the gravels bordering the shores of Yakutat Bay. It seems doubtful if any of these gravels contain gold in sufficient quantity to repay working on an extensive scale. So far as is evident at present the final agency of wave work has been necessary to concentrate the gold sufficiently to pay for washing, and in most places even this has not produced workable deposits; and in the two places where the concentration has been most effective the resulting deposit has so far proved of little economic value. The gold is neither abundant nor present in extensive deposits; for the auriferous sand is a mere surface skin in portions of a couple of beaches of no great size. From these facts it seems justifiable to say that, in the light of present evidence, the Yakutat Bay region does not offer much promise as a gold-producing section.

\section{PLATINUM.}

Platinum has been reported from Yakutat Bay, and in September, 1899, several prospectors were seeking it on an alluvial fan just east of Hubbard Glacier. They met with no success in their search, and at present there is no reason for suspecting the presence of this metal in the region.

\section{COAL.}

\section{OCCURRENCE.}

As stated in the discussion of the Tertiary rocks (p. 160), at least three beds of coal undoubtedly occur 3 or 4 miles west of the head of Yakutat Bay on Esker Stream, and along a small brook which descends the south face of Amphitheater Knob. This coal was prospected with some care by Jack Dalton, and later by the Jewell brothers and associates. Locations of coal land were entered by these prospectors, who have done a small amount of development work. Coal fragments, doubtless derived from the outcrops developed by these men, are found in the alluvial fans of the streams which cross the coal-bearing beds.

Russell $^{a}$ mentioned reports of coal on the western side of Yakutat Bay. He saw lignite seams at the surface, but the shafts opened by Jack Dalton were so filled with water that he could not verify the claims that workable coal occurred there. He also states that fossil leaves were reported to occur with the coal, but he himself saw none.

The mode of occurrence of the coal is described fully in the section on the Tertiary beds in the preceding chapter. Because of caving we were unable to examine the coal where cut by the tunnels and shafts made by Dalton and the Jewells, and it is therefore possible that we did not see the best beds; but the fact that the property is no longer worked suggests that even the beds exposed by underground workings did not offer great promise.

\section{QUALITY.}

Basing our conclusions solely on what is revealed on the outcrops at present exposed, we found little reason for development work. The exposed beds are all thin, and there is much clay and shale parting. Many of the faces show slickensiding, and there is some faulting, though apparently not enough to seriously interfere with mining if other conditions were favorable. The coal is a moderately good grade of black lignite, fairly hard, and in the thicker beds breaks into good-sized blocks, which crumble when exposed to the air. Much sulphur is present, and pyrite is often visible along the seams. No analysis of our specimens has been made. 
TRANSPORTATION DIFFICULTIES.

Should there be a local demand for coal-for example, as fuel on the locomotives of the Salmon Railway, which is being extended southeastward over the foreland from Yakutatit is conceivable that these beds might prove of value; but even if this coal were of the very best quality and occurred in thick beds, it is doubtful if it could be profitably shipped away, for the following reasons:

The coal would need first of all to be transported across an alluvial fan, over which a glacial stream spreads its many distributaries, ever changing in course and in volume, and under which there is evidently a buried glacier end, which in a recent advance has broken the fan and by subsequent melting has caused much irregular subsidence. (See pp. 71-74.)

If the problem of transporting the coal across this fan were successfully met, it would need to be shipped from a harborless coast with shallow water some distance offshore. In summer this coast is not commonly visited by high waves, but in fall and winter it is reported to be open to vigorous surf, which would seriously interfere with shipment. Much worse than this, however, is the barrier of floating glacier ice which hugs this coast at all seasons. Almost the entire discharge of icebergs from Turner and Hubbard glaciers drifts seaward along this coast and accumulates upon it, forming a barrier through which it is commonly difficult to force even a small boat.

Few places on the Alaskan coast are less easily accessible to large boats than this icebound, surf-beaten coast on the west side of Yakutat Bay near the entrance to Disenchantment Bay. For this reason, while it is not at all improbable that larger seams of coal may occur in portions of the coal-bearing rocks underneath the alluvial fans, moraines, and glaciers, exploration in search of them seems hardly worth while, unless it be for local use. If coal were discovered to the southeast of Yakutat the problems of transportation would be far more simple.

\section{COAL IN THE YAKUTAT GROUP.}

Coal was reported at various points in the Yakutat group, but we were unable to find it in place or to discover any evidence of its presence on the beaches, on the alluvial fans, or on the moraines, on all of which careful search was made. In several places short, thin seams were found in the black shale, evidently the result of lignitization of plant fragments embedded in the shale. Coal "smut" was reported in Disenchantment Bay, floating in the fiord off the face of Turner Glacier, but there is no reason for believing that this is anything more than the finely comminuted black shale with which this glacier is burdened.

Even if coal occurred in the rocks of the Yakutat group it would hardly be expected to be of economic value. If it occurred beyond Haenke Island, approach to it could be gained only after a passage through the mass of floating ice which almost constantly guards the entrance to Russell Fiord. Wherever found in the Yakutat group it would of necessity be so contorted, squeezed, and faulted that it is doubtful if even the best of coal could be profitably extracted.

From the facts stated it is evident that the coal beds of Yakutat Bay, so far as at present known, offer no promise of value; and, furthermore, that the difficulties in the way of working and shipping are so serious that even if good coal were found it would have little if any economic worth.

\section{PETROLEUM.}

Several years ago an oil excitement reached Yakutat Bay, and there was such promisouous staking of oil claims that the alluvial fans, the buried termini of glaciers, the earlier glacial gravels, the contorted Yakutat beds, and even the area of the crystalline rocks were staked out; but, so far as could be learned, no underground exploration was undertaken.

The basis for this rush could not be learned definitely, though two explanations were offered, the first being that the discovery of oil at Controller Bay, farther to the northwest, led to the belief that it must also occur in this region; the other, that oil films were found at 
several points around the bay. It is possible that these films were nothing more than the iridescent scum resulting from the decay of vegetation.

In our work we saw no signs of oil. It is, perhaps, needless to say that oil is not to be expected in the region of metamorphic and crystalline rocks, nor in the glacial gravels and alluvial fans, unless, perchance, it is present in the underlying rocks. It is not impossible that oil and gas are developed in the rocks of the Yakutat group, but in its greatly faulted condition opportunity for storage is not generally present, so that no extensive accumulations are to be expected.

The coal-bearing Tertiary beds, having abundant organie remains, might possibly contain oil, for there is little faulting, and there are beds of conglomerate and sandstone for storage; but we saw no signs of oil even here, and heard no reports of any. There is, therefore, no reason to expect petroleum.

\section{MINOR MINERAL DEPOSITS.}

Deposits of other minerals that are of economic importance in more favorable situations were found around this inlet, but in the present state of the mineral industry of Alaska they call for only a passing notice. Among building stones may be mentioned granite and slate, which in places assumes the character of a true roofing slate. There is also much coarsely crystalline white marble. Clays are abundant, and also beach sands. At numerous points iron pyrite occurs in quantities. At Cape Enchantment, in a crushed zone at the boundary between the Yakutat beds and the greenstone of the basement crystallines, a metalliferous zone was discovered containing pyrite, some of which appeared to be chalcopyrite. In at least one place, on the west side of Disenchantment Bay, near its entrance, large sulphur springs occur.

\section{SUMMARY.}

Altogether, Yakutat Bay is not a promising mineral region. The deposits so far discovered are of little value. The floating ice which occupies so much of the inlet, notably Disenchantment Bay, is a serious obstruction to navigation. The valleys in the belt of crystalline rocks, in which there are possibly gold deposits, are obstructed by impassable glaciers, while above an elevation of 2,000 to 3,000 feet the mountains are everywhere clothed in deep snow fields, except on those slopes which are too steep for snow to cling to them.

The region has been thoroughly prospected in the accessible portions, for it attracted attention early, even before the rush to Alaska and the Klondike. Later it became the highway for a stream of prospectors headed for the gold workings of the Alsek region. Many of these spent some of their time in prospecting around the shores of the fiord and in the mountains near by. The failure of these experienced men to discover more than has been found, while not proof positive of the absence of valuable mineral deposits, is suggestive, and leaves little incentive for further search. The region has been rather thoroughly examined, and the results have been almost negative. 
CHAPTER III.

\title{
PETROGRAPHIC STUDY OF ROCKS. ${ }^{a}$
}

\author{
By Bert S. Butler.
}

\section{GENERAL STATEMENT.}

Reference to previous work in the area covered has already been made in the chapter on stratigraphy, and the general field relations of the various rocks, so far as known, are stated there (pp. 145-164).

The specimens from which the petrographic study was made were collected, for the most part, in the summer of 1905 . Circumstances did not permit a detailed study of the field occurrence of the rocks or the making of complete collections, but so far as possible collection was made of type specimens of the igneous rocks and of such of the sediments as promised further facts from microscopic study.

\section{SEDIMFNTARY ROCKS.}

GRAYWACKE OF THE YAKUTAT GROUP.

Field relations.-Because of its peculiar character and its uncertain field relations in many places, the graywacke of the Yakutat group has been studied in thin sections from specimens collected at various localities. Where best developed it occurs in massive beds from a few to 50 or 60 feet in thickness. These beds are generally of uniform texture throughout, and so lacking in stratification that doubt was at times entertained whether they were not igneous masses. The thicker beds are composed of uniform grains of medium size, while the thinner beds frequently have zones that are plentifully sprinkled with shale fragments, usually not exceeding one-half inch in width. Other strata (specimen 75, 1 mile south of Cape Enchantment) are composed largely of small fragments of shale, sandstone, and diabase. Locally, on Osier Island, the sandstone fills the spaces between angular shale fragments, the two being about equal in amount, giving the appearance of a breccia. In this locality the graywacke also occurs as small dikes cutting the shale beds. In numerous localities the rock contains many nearly spherical concretions, varying in diameter from less than an inch to 6 or 8 inches. These readily separate from the inclosing rock, leaving numerous cavities where they have fallen out. When the rock is broken they always separate from the matrix. They are firmly cemented with calcite and are much more difficult to break with the hammer than is the matrix.

In its typical development the rock is light gray, with a slight greenish cast; in the concretions and the finer phases it is darker gray, still with a tinge of green. 'It is cut in every direction by white veins, for the most part calcite, though some quartz veins were seen. So numerous and close set were these that it was often with difficulty that a good-sized hand specimen could be broken out. In the hand specimen the rock appears highly feldspathic and slightly micaceous.

Microscopic study.- Under the microscope the angularity of the component particles attracts attention at once. The shale fragments and some of the quartz grains are well rounded, but

a The author wishes to make acknowledgment to Prof. A. C. Gill, of Cornell University, in whose Iaboratory and under whose direction this study was made. 
the greater part of the quartz and feldspar shows little or no rounding, the feldspar and mica frequently occurring in slender crystals. Locally considerable calcite is present as a cementing material, but in general this is not abundant except in the veins and concretions. In the concretions calcite is very abundant, surrounding nearly every fragment and binding the whole very firmly together.

Quartz is the most abundant mineral occurring in the rock, forming approximately onehalf of the mass. For the most part it is in irregular, angular fragments, but some grains show wear, while a few are well rounded. In some specimens, notably specimen 2, from Osier Island, the quartz grains are shattered, one grain being broken into several fragments which extinguish together. In a few cases secondary quartz occurs in veins and as the filling of spaces between mineral fragments, but this is not common. Fine quartz fragments also form a considerable percentage of the shale fragments contained in the rock.

Both orthoclase and plagioclase are present and together probably form one-third of the mass. The feldspar, like the quartz, is angular, some of the fragments being long and slender. The orthoclase is all clouded with weathering products. In some cases it can be definitely determined; in others determination is based on gradation to less-altered orthoclase. Plagioclase is abundant in nearly all the slides, though the amount varies considerably in the different specimens. It occurs in small, perfect, lathlike crystals and as angular fragments of large crystals. Much of the plagioclase is of a basic character, though some is acidic. In marked contrast to the orthoclase, it shows little alteration, but in some specimens it is slightly spotted or clouded with secondary minerals.

Quartz and feldspar constitute the bulk of the rock, though numerous minerals are present in small quantity. Biotite is present in all the slides in small flakes. Muscovite occurs mainly as an alteration product of the feldspars, though some large flakes are present. Pyroxene is a component of the volcanic fragments described below; several large fragments are also present. Calcite as a cementing material forms a large percentage of the concretions, fills the numerous fissures in the rock, and is present in small quantities in the body of the rock. Chlorite and serpentine occur as weathering products. Magnetite and probably ilmenite are present in most of the specimens. Sphene, zircon, hornblende, epidote, pyrite, and garnet were identified in several of the slides.

Numerous volcanic fragments resembling lapilli are present in specimen 75 , collected about a mile south of Cape Enchantment. One is a fine-grained diabase resembling that of the dikes of the region to be described later. It is composed of plagioclase showing flow structure, augite, and leucoxene, the latter in numerous small grains, probably an alteration from ilmenite.

Nearly all the slides show a greater or less number of volcanic fragments. In some-specimen 42 , for example-they are abundant, while in others few are present. On the whole they form a small percentage of the rock. In most of the specimens weathering has reduced the volcanic fragments to a mass of serpentinous or chloritic matter filled with fine lath-shaped plagioclase crystals.

Although described as a graywacke, the rock appears from the mineralogical composition quite as much like a tuff. Several factors point toward this: First, the large percentage of feldspar in the rock; second, the unweathered condition of the plagioclase; third, the presence of volcanic fragments. However, the abundant shale fragments, with some rounded grains of quartz and other minerals, indicate that the supply of material from older rocks was more important than the volcanic ash.

\section{SHALE OF THE YAKUTAT GROUP.}

The shale of the Yakutat group in its typical development is a soft black rock readily attacked by weathering agents. Locally it grades toward a limestone. A specimen from Osier Island shows a high percentage of calcite and might well be classed as an argillaceous limestone. Fine grains of quartz and mica are the principal minerals besides calcite. Numerous bands of carbonaceous matter give the rock a finely stratified appearance. 
A specimen collected near Galiano Glacier, on the west side of the bay, shows a slight development of slaty structure. Under the microscope it is seen to be a clay rock in which fine quartz grains and mica are abundant. Calcite is present in the fissures and to a slight extent in the body of the rock.

Near Turner Glacier the shale has reached a more advanced stage of metamorphism, having developed a distinct slaty structure. A slide of this phase of the shale was not examined.

\section{METAMORPHIC ROCKS.}

CONGLOMERATE.

Specimens of conglomerate were taken from the north and south sides of Nunatak Fiord. The evidence in the field led to the conclusion that these outcrops belong to the same formation, and the laboratory study tends to confirm this conclusion, though the different specimens were found to vary considerably in the stage of metamorphism.

Specimen 68, from the north side of Nunatak Fiord, is a coarse conglomerate with a sandy matrix, composed of pebbles, some measuring 6 or 8 inches in diameter. The specimen was selected from a fine phase of this conglomerate. It is composed of pebbles varying from a fine shale to coarse shale or fine sandstone. The pebbles have been flattened and stretched, in places showing slickensided surfaces. Under the microscope the rock shows the development of secondary mica throughout and the beginning of a schistose structure.

Specimen 81 , from the south side of Nunatak Fiord, has been highly metamorphosed. It probably originally consisted of sandstone and shale fragments. These have been so flattened and drawn out that in places the rock has a gneissic appearance. The sandstone pebbles are altered to a light-colored quartzite, while the remainder of the rock is dark gray with schistose structure, and in it mica, garnet, and hornblende can be recognized with the naked eye. Under the microscope the quartz is seen to occur in granular crystalline masses, the granules frequently being separated by a thin layer of dark, probably carbonaceous, material. Considerable mica is present in the quartzite areas, and in the section examined light-green hornblende crystals are abundant near the contact of the quartzite and schist areas. The remainder of the rock is a black mica schist, in which garnet crystals 1 millimeter or more in diameter are abundant.

Specimen 82, also from the south side of Nunatak Fiord, is a gneissic rock composed of alternating quartzitic and schistose bands. It is impossible to definitely prove the origin of this rock, but its structure suggests a conglomerate in an advanced stage of metamorphism. Both the megascopic and the microscopic similarity of this to specimen 81 leaves no doubt that they are of the same origin. The white bands, which are in places lenticular, are doubtless stretched quartzite pebbles. The only marked difference in mineral composition is the decrease in garnet crystals in specimen 82 and the considerable amount of calcite, indicating that some of the pebbles may have been calcareous.

SLATE.

The east side of Russell Fiord, south of Hubbard Glacier, is occupied by a slate series in which the cleavage is developed parallel to the stratification. These slates, as exposed near Hubbard Glacier, seem to have been made up of sediments varying from shale to fine-grained arkose, the latter composed principally of microperthitic feldspar. The coarser sediment still retains the form of the fragmentary grains, though it has a banded structure and consequent gneissic appearance. The finer sediments have developed a well-marked schistose structure, the schistosity remaining parallel to the original stratification.

Another member of this series, whose field relations were not carefully studied, has a distinct "greenstone" appearance. The most abundant mineral is a bluish-green hornblende which occurs in large crystals. Epidote is abundant. Orthoclase, sphene, and a black iron mineral are found in the slide. In some specimens the minerals are roughly banded, giving the rock a schistose structure. It is probably an igneous rock that has been greatly crushed and altered during the metamorphism. 
As shown by the above description, this series of rocks has undergone distinctly more metamorphism than the Yakutat strata. This, together with the fact that the two classes of rock are separated by a fault extending through the Northwest Arm of Russell Fiord, leads to the belief that they are not members of the same series. The less altered Yakutat strata are believed to be of later age.

\section{GREENSTONE-LIMESTONE BEDS.}

The specimens from the greenstone-limestone beds were collected, for the most part, on the west side of Russell Fiord, between Osier Island and Cape Enchantment.

The rocks have been subjected to complicated folding and faulting, resulting in slickensided faces and the intermingling of limestone and greenstone. In some places limestone, either in thin films or in lenticular masses, is present in the greenstone; in others the greenstone shows a similar relation to the limestone, giving the appearance of a combination of faulting and kneading. The limestone has been entirely recrystallized to a white marble. The greenstone varies in color from a very dark to a light olive-green, and in texture from a fine conglomerate or tuff to a dense, fine-grained, almost aphanitic mass.

Specimen 48, megascopically, seems to be a green conglomerate. Under the microscope it is seen to be an impure tuff composed of volcanic fragments, apparently lapilli, some fine volcanic material, shale and quartz fragments, together with calcite, most of which is secondary, though some may have been deposited as limestone fragments. The volcanic fragments are considerably altered, but were probably originally composed largely of plagioclase and pyroxene, a composition similar to that of the volcanic fragments in the graywacke of the Yakutat group (p. 171).

In specimens 45 and 50 a fragmental origin is not apparent; they seem rather to have been flows or intrusions, probably the latter, as most of the crystals are coarse. In specimen 45, green, strongly pleochroic hornblende and altered feldspar make up the bulk of the rock. Specimen 50 is composed principally of green pleochroic hornblende and an acidic plagioclase feldspar in about equal amounts. Ilmenite grains are-abundant through the rock, many of them altering to leucoxene. Chlorite and epidote are present as secondary minerals.

These beds have been cut by quartz diorite intrusions (see descriptions below). Like the Yakutat strata, these rocks are separated from the metamorphic belt by a fault. Their relation to the Yakutat group has been discussed in the chapter on geology.

\section{ROCKS FROM THE NUNATAK IN NUNATAK FIORD.}

Specimen 120, from the west end of the nunatak, is a dark-green medium-grained rock containing a number of flattened feldspar crystals which all lie in the same direction, giving the rock a schistose structure. Minerals that can be recognized with the naked eye are hornblende, feldspar, and a few pyrite grains.

Under the microscope the rock is seen to contain the following minerals: Greenish-gray, slightly pleochroic hornblende, which occurs in large crystals and also in fine, needle-like crystals in the altering plagioclase; feldspar, most of which can be determined as plagioclase, some being too badly altered for definite determination, but probably the same; zoisite, associated with the plagioclase, probably as an alteration product; a black iron mineral abundant through the hornblende crystals in small grains and stringers; leucoxene and muscovite in minor quantities as alteration products. This rock is probably the result of the alteration of a coarsegrained igneous rock composed largely of hornblende and plagioclase, somewhat resembling the hornblende "gabbro" of Norway.

Specimen 121 is a green hornblende schist from the nunatak. The slide contains a green, slightly pleochroic hornblende, clouded orthoclase, and a lesser amount of quartz. Numerous fissures are filled with quartz, muscovite, epidote, and some carbonate which does not effervesce with cold hydrochloric acid. Ilmenite grains are scattered plentifully through the slide. These are all altering to leucoxene. The grains are surrounded with a zone of unusually well crystallized leucoxene, which shows the colors of sphene under crossed nicols. 
Specimen 122 is a green hornblende schist from Nunatak Fiord. This is similar to 121, but has a larger percentage of hornblende and is somewhat finer grained.

The material brought down from the mountains by Nunatak Glacier indicates that there is an extensive series of hornblende schists similar to that of specimens 120-122. The advanced stage of metamorphism would indicate that the hornblende schists are of an earlier age than the metamorphic rocks described above.

\section{INTRUSIVE ROCKS.}

QUARTZ DIORITE.

Intrusions of a green dioritic rock are numerous between the Henry Valley and Cape Enchantment. A specimen of a very similar rock was taken from the south side of Nunatak Fiord, and others from the head of Russell Fiord. The rock has suffered considerable alteration and varies somewhat in composition in different localities. The points of resemblance are, however, sufficiently marked to lead to the belief that the differences only represent variations in the same magma.

Specimen 46, from a dike north of Marble Point, is a light greenish-gray rock. In the hand specimen feldspar and biotite are readily recognized. Under the microscope the rock is seen to be made up largely of quartz, feldspar, and biotite.

Quartz is in large crystals, frequently much crushed and shattered. The feldspar, which is considerably altered, is mostly acidic plagioclase, though there is some orthoclase. Biotite occurs in good-sized crystals; it is pleochroic, changing from light brown to dark reddish brown, and is altering to chlorite and a colorless micaceous mineral.

Specimen 47, from south of Marble Point, is a green, medium-textured rock. In the hand specimen feldspar, hornblende, and a micaceous mineral can be recognized. Under the microscope feldspar, hornblende, and small amounts of biotite and quartz are seen to be the principal constituents. The feldspar is considerably altered, but most of it can be determined as plagioclase, though some orthoclase is probably present. The hornblende is very pleochroic, changing from a straw yellow to a dark green. Biotite occurs in flakes so bent and interleaved with alteration products as to give a fibrous appearance in cross section. It is strongly pleochroic, from reddish brown to light yellow. The flakes contain lenses of a colorless micaceous mineral, probably muscovite, derived as an alteration product. Black grains of an iron mineral are numerous, associated with the hornblende. Pyrite, epidote, zircon, and apatite were determined in the slides.

Specimen 72, from the south side of Nunatak Fiord, is a medium-grained rock that has suffered much alteration. Plagioclase was an important constituent of the original rock, but this is now altered to a mass of small, highly refracting grains, which are probably epidote and albite. The hornblende is strongly pleochroic, changing from a bluish green to a light greenish yellow. It occurs in irregular crystals, fraying out at the margin, and in small needle-like crystals in the other minerals. Quartz occurs in irregular grains, probably partly secondary. Small quantities of reddish-brown biotite and ilmenite are present. The latter mineral is altering to leucoxene.

Specimen 104, from south of Shelter Cove, is a coarse-textured dark-green rock spotted with white feldspar crystals. Fine hornblende crystals can also be recognized in the green groundmass. Under the microscope the rock is seen to contain the following minerals: Plagioclase in good-sized crystals, in most cases slightly altered, though some crystals are badly altered; orthoclase in much less abundance; green hornblende scattered plentifully throughout the rock; quartz in fine grains in the groundmass and also as larger secondary crystals; chlorite and epidote as secondary minerals.

Specimen 108, from the head of Russell Fiord, is a medium-grained greenish-gray rock. In the hand specimen quartz, plagioclase, and a dark mineral, probably hornblende, are recognized. 
Under the microscope the rock is seen to contain quartz, acidic plagioclase, and orthoclase as the principal minerals. Several flakes of reddish-brown mica are present. These in most cases are altering to a green pleochroic mica or chlorite. Almost no hornblende is present in the slide. Pyrite, a black iron mineral, and leucoxene were recognized. Chlorite occurs as a secondary mineral in areas of considerable size, doubtless representing the alteration of biotite or hornblende crystals. Several cracks are filled with a fine-grained mineral, probably muscovite.

DIABASE DIKES.

Diabase dikes are present in nearly all parts of the region. They reach their best development, so far as observed, about 2 miles south of Point Latouche, where the largest is 12 to 15 feet in thickness. Specimens were collected from this locality, from the Indian Camp Valley, from Marble Point, from the slate coast north of this point, from Nunatak Fiord, and from Shelter Cove. Dikes, probably of similar rock, were observed on the opposite side of the fiord north of Cape Stoss.

Though the specimens from these localities differ somewhat in composition, their similarity is sufficient to lead to the belief that they are from the same magma.

Two of these dikes are found just to the east of the Indian Camp Valley. One is about 2 feet in thickness, while the other is but a few inches thick. The larger is not badly altered, and may be taken to represent the diabase magma of the region.

This in the hand specimen is a dark-gray fine-grained rock in which feldspar crystals can be recognized.

Under the microscope plagioclase, pyroxene, and ilmenite are determined as the original minerals, the two former being in about equal amounts. The plagioclase, which crystallized before the pyroxene and is included in the latter mineral in the form known as ophitic structure, is in long lath-shaped crystals. The extinction angle shows it to be labradorite. The pyroxene crystallized in irregular forms around the plagioclase. It has a light-pinkish tinge, possibly due to titanium in the magma. Ilmenite occurs in irregular grains fairly uniformly through the rock.

Alteration has not been marked in the specimen, but, so far as it has progressed, is similar to that described below for the smaller dike.

The smaller dike is a fine-grained rock in which only pyrite crystals can be recognized. Under the microscope it is seen to contain porphyritic crystals, with fine crystals in the groundmass, indicating two periods of crystallization. Alteration has been very marked, the pyroxene being entirely changed to secondary minerals, and ilmenite being altered to magnetite and leucoxene, while the plagioclase has suffered much less. Chlorite, serpentine, and calcite are present as secondary minerals.

The dikes south of Point Latouche are very similar to those described above. In specimen 139 the chief difference is in the presence of several large orthoclase phenocrysts, which are probably inclusions.

Specimen 137, from a dike near the above, differs principally in having a few crystals of brown hornblende. This contains considerable clouded serpentinous material in the spaces between the crystals, which may have been glass at the time of consolidation.

Specimen 47, from south of Marble Point, closely resembles the type specimen in both mineral composition and structure. The slide contains one crystal of unstriated feldspar and a brown pleochroic mineral associated with the pyroxene. This is either hornblende or biotite; probably both are present.

Several dikes oceur just to the north of Shelter Cove. Specimen 97, which is the coarsest of these, differs from the type example in containing dark-green masses of secondary material, sometimes showing traces of what was probably the original mineral, olivine, or possibly hypersthene.

Specimen 99, from the same locality, differs from the above in having a much higher percentage of plagioclase and a correspondingly low percentage of pyroxene. The latter mineral is almost entirely altered to a greenish chloritic mass. 
Specimen 100 is from a fine-grained dike, very closely resembling 97 in mineral composition. A few porphyritic crystals of plagioclase occur in this slide. Much alteration has taken . place, secondary minerals, largely carbonates, being abundant through the rock and filling spheroidal cavities.

Specimen $70^{\circ}$ is from a small dike intruded into the metamorphic series 1 mile east of the mouth of Nunatak Fiord. Seen in the hand specimen, this is a fine-grained dark-gray rock in which feldspar and pyrite are recognized, the hatter being scattered plentifully through the roek in small, well-formed crystals.

Under the microscope the rock is seen to be made up largely of plagioclase in fine lathshaped crystals. Calcite, chlorite, and leucoxene occur as secondary minerals, the latter being probably the product of the alteration of ilmenite. The slide contains a few grains of quartz, which are probably of secondary origin.

Specimens 60,61, and 62 are from small dikes cutting the slate strata on the northeast side of lower Russell Fiord. In the hand specimen the rock is light greenish gray, with distinct crystalline structure, but too fine for the minerals to be recognized with the naked eye.

The rock has been so highly altered that its original composition can not be accurately determined, though it seems to be an altered diabase.

At present plagioclase is the only abundant original mineral. Most of this is greatly altered, but some of it can be determined as labradorite. Ilmenite is present in small grains as a primary mineral, though this is largely altered to leucoxene. If pyroxene was ever present in this rock, it has been entirely altered to other minerals. Calcite, chlorite, quartz, epidote, and pyrite are present as secondary minerals.

These dikes being small and highly altered, it is impossible to determine whether or not they should be classed with the diabase dikes of the region.

AUGITE CAMPTONITE (?).

Specimen 149, from a large dike near Turner Glacier, is a fine-grained dark-gray rock with a light-greenish tinge. Feldspar and hornblende are the only minerals recognized in the hand specimen.

Under the microscope feldspar, hornblende, and pyroxene are seen to be the principal. primary constituents, the latter two being in about equal quantities.

Some of the feldspar can be determined as labradorite, though most of it is too badly altered for definite determination. The hornblende is strongly pleochroic, from a very light to a dark reddish brown. It occurs in well-formed crystals and long needles. Some of the crystals have a center, or core, of a light-colored mineral, which in some cases can be determined as feldspar.

The pyroxene, which is nearly colorless, occurs in irregular crystals rather uniformly through the rock. A few grains of a dark iron mineral, probably ilmenite, are present; this has partly altered to leucoxene. Chlorite and epidote are present as secondary minerals. Irregular areas of a colorless material occur through the slide. This has undulatory extinction and index close to Canada balsam. It is probably a zeolite.

This rock is intermediate between diabase and camptonite. Whether it is related to the diabase of the region or was intruded at a different period is uncertain, though the field evidence indicates that it was intruded at the same time.

\section{MUSCOVITE GRANITE.}

On the south side of Nunatak Fiord the metamorphic rocks are cut by numerous lightcolored granite dikes. These are from a few inches to several feet in thickness, and vary in texture from a coarse phase, in which the minerals are readily recognized with the naked eye, to a fine phase in which few of the minerals can be thus determined. 
Specimen 88 , from one of the larger dikes, is a white coarse-grained granite. The rock is so friable that it is possible to pry off fragments from the specimen with the finger nail. The finer-grained dikes are more compact and less easily broken.

The minerals recognized in the specimen are quartz, white feldspar, mica, and garnet. The mica is the most conspicuous of these. It occurs in large well-formed crystals, the largest being 5 or 6 millimeters in diameter and 3 millimeters thick. It is light green in color, but darker than the other minerals, giving the rock a spotted appearance. Garnets can be seen as in small yellowish-brown specks.

In the section quartz seems to form nearly one-fifth of the rock. In the slide examined the feldspar consists of orthoclase, plagioclase, and microcline, the latter two being the most abundant. The order of crystallization was plagioclase, orthoclase, microcline. Most of the feldspar is nearly fresh, though some crystals show considerable alteration. The mica is nearly colorless, with slight pleochroism, medium relief, high interference colors, and parallel extinction. Garnet, iron ore, hornblende, and apatite are present in small amounts.

In the finer phase the mineral composition is essentially the same as that given above. The mica, instead of being in well-formed crystals, appears as slender plumelike forms radiating from centers. In one slide epidote is rather abundant.

\section{BIOTITE GRANITE.}

Biotite granite forms the mountain on the south side of Nunatak Fiord east of the nunatak. The rock is of medium texture, the white mass of quartz and feldspar being spotted with the darker mica crystals. Quartz, feldspar, and biotite are recognized with the naked eye. Under the microscope the primary minerals are seen to be quartz, orthoclase, and plagioclase; microcline, biotite, muscovite, which is possibly primary, occur in lesser amounts; and there are a few crystals of epidote.

The feldspar is slightly altered. The biotite is strongly pleochroic, changing from a straw yellow to a dark brown. Muscovite and calcite occur as alteration products of the feldspar, and epidote as secondary mineral associated with the biotite. Some of the epidote crystals contain sharply bounded cores of brown pleochroic allanite; other small crystals show such low double refraction as to suggest zoisite. 


\section{INDEX.}

A.

Ablation, moraines developed by...........
moraines developed by, description of

Abruzzi, Duke of, explorations by

on geology of region.

Aguadulce Valley, erosion in.

Alexander, Mount, description of.

Alexander Glacier, description of

Alsek Valley, glacial highway to.

Amphitheater Knob, coal on

forest on.

moraine on, view of

section at.

shore lines on

view from.

Atrevida Glacier, changes in ....................... 76-78,90,94

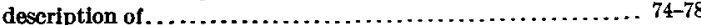

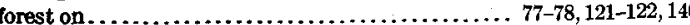

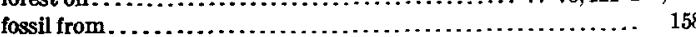

gravels of ...................................... 121-122

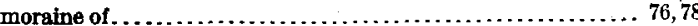

section at. . . . . . . . . . . . .

$160-161$
13

stream from

views of.

Augite camptomite, petrogra.

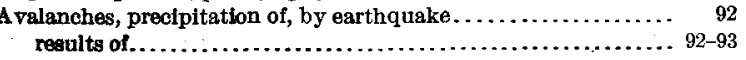

B.

Bancas Point, location of

Beach. See Coast.

Beach gold, concentration of ........................... 167-168 occurrence of. . ...................................... 165-167

Bears, occurrence of

Bering, explorations by .

Blotite granite, petrography of ............................. 178

Black Glacier, changes in...

description of.

erosion at.

70

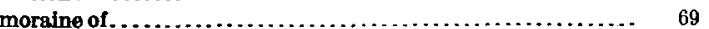

silt from.......................................... 13

terminus of ....................................... $68-69$

valley of, erosion in............................. 108 moraine in

Blossom Island, deposits at . . . . . . . . . . . . . . . . . . . . . .

description of . . . . . . . . . . . . . . . . . . . . . . . . . . . . forest on......................................... 138-139

glaciers of $\ldots \ldots \ldots \ldots \ldots \ldots \ldots \ldots \ldots \ldots \ldots \ldots \ldots \ldots \ldots . .68,142$

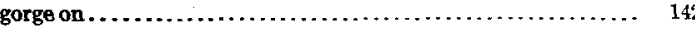

gravels on $\ldots \ldots \ldots \ldots \ldots \ldots \ldots \ldots \ldots \ldots \ldots \ldots \ldots \ldots \ldots \ldots \ldots \ldots \ldots \ldots \ldots, 131$

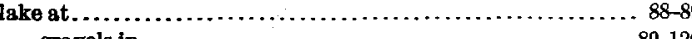

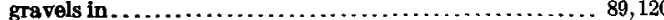

moraine on.................................... 104-105

view ot.

Boursin, Henry, on gold.

on Yakutat region.

Brabazon, A. J., work of.

Brabazon Mountains, roeks of

Bryant, H. G., explorations by

Burroughs, John, work of

Butler, B. B., work ot. c.

Page.

Calahonda Valley, erosion in ......... 109-110

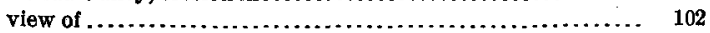

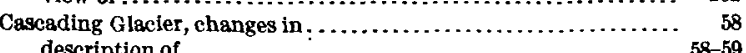
description of. . . . . . . . . . . . . . . . . . . . . . . . erosion at. . . . . . . . . . . . . .

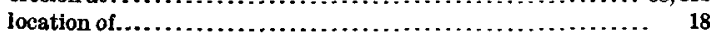

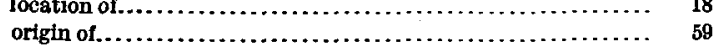

terminus of ....................................... 37,58

Cascading glaciers, valleys of, erosion in .................. 115

view of

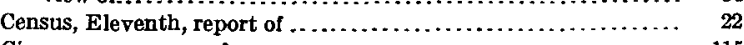

Cirques, occurrence of................................. 115

Clay, deposits of...................................... 122

Cliffs, cutting of, by icebergs . ........................... 33-34

Climate, influence of, on movement of glaciers................ 90-91 influence of, on physiography......................... 30

Coal, markets for.................................... 169 occurrence of. .................................... 168-169 quality of ...................................... 168

Cosst, changes in........................................... 124, 144 description of. . . . . . . . . . . . . . . . .

Coast Survey, work of...

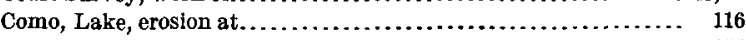

Conglomerate, character and distribution of ................ 153-154 petropraphy of.

Cook, James, explorations by ............................. 20

Coville, F. V., on flora of region . . . . . . . . . . . . . . . . . . 138 Crystalline rock, character and distribution of........... 27-28, 147-152 Cycles of development, evidence of........................ 29

D.

Dall, $\mathrm{W}, \mathrm{H}$, on geology of region $\ldots$ Dalton Glacier. See Turner Glacier.

Diabase dikes, occurrence and character of . . . . . . . . . . . . . 157

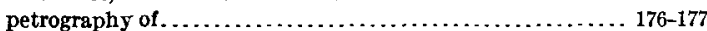

Diorite, petrography of.......................... 175-176

Disenchantment Bay, depth of........................ 19

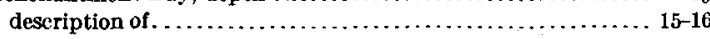
erosion in . ....................................... 108-110

exploration of $\ldots \ldots \ldots \ldots \ldots \ldots \ldots \ldots \ldots \ldots \ldots \ldots \ldots \ldots, 23$

forest near . . .................................... 140

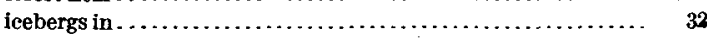

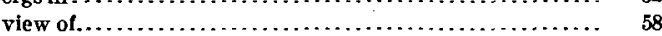

moraines near . . . . . . . . . . . . . . . . . . . . . . . 101-102

rocks near.................................. 27, 147, 156-157

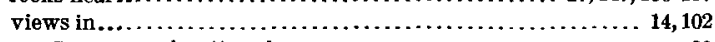

Dixon, George, explorations by ........................ 20

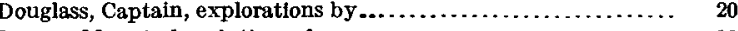

Draper, Mount, description of........................... 18

Dry Bay, location and character of........................

Duffield Glacier. See Turner Glacier.

Dying Glacier, description of.

38

Earthquakes, effects of effects of, on movement of glaciers......................... $91-93$

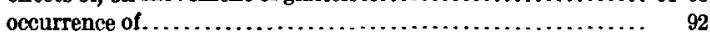

Ecologist, field for................................... 141

Economic geology, description of...................... 165-170

Economic effects of glacial advance, mention of ................ 95

Elevations, character of ................................ 12

Emerson, B. K., on geology of region................ 145-146, 148

work of 
Page.

Enchantment, Cape, gravels near gravels near, view of ......

location and description of

minerals at....

rocks at and near.

Engeln, O. D. von, work of.

Erosion, work of.

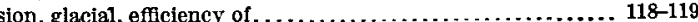
grooves cut by, view of................................ 110 selective action of $\ldots \ldots \ldots \ldots \ldots \ldots \ldots \ldots \ldots \ldots \ldots \ldots \ldots, 113$ work of . .

Erosion, water, work of . . . . . . .

Esker Stream, alluvial fan built by $\ldots \ldots \ldots \ldots \ldots \ldots \ldots \ldots \ldots .121-122$

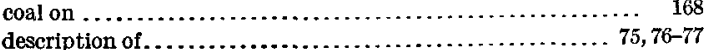
emergence of, view of ....................................... 74

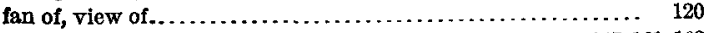
rocks near................................... 147, 161-162

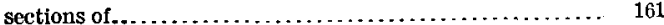

Explorations, notes on ............................... 20

Fairweather Mountain, coast near...................... 11, 12 location and character of . . . . . . . . . . . . . . . . . . . . . . . 12

Fallen Glacier, description of.............................. $67-68$

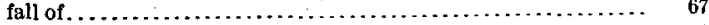
waves caused by $\ldots \ldots \ldots \ldots \ldots \ldots \ldots \ldots \ldots \ldots \ldots \ldots \ldots, 67-68$

Fan glaciers, description of $\ldots \ldots \ldots \ldots \ldots \ldots \ldots \ldots \ldots \ldots \ldots \ldots \ldots \ldots \ldots, \quad 38$

Fans, ancient, oceurrence of ........................... 124-125

Fans, mocorm, desaription of. See also Gravel; particular glaciers, etc.

Faulting, erosion phenomena ascribed to occurrence and character of

Fault lines, coincldence of valleys with.................... 29 location of ............................... 28, 108, 147, 150

Fauna, character and distribution of $\ldots \ldots \ldots \ldots \ldots \ldots \ldots \ldots \ldots, 141$

Fernow, B. E., work of ............................... 24

First Glacier. See Turner Glacier.

Fish Commission, explorations by $\ldots \ldots \ldots \ldots \ldots \ldots \ldots \ldots \ldots \ldots .24$

Floral Hills, gravels on . . . . . . . . . . . . . . . . . . . . 104, 13

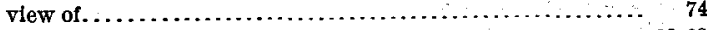

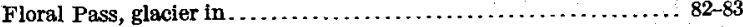

Folding, occurrence and character of ..................... 163-164

Foreland, deseription of . ............................ 97-100

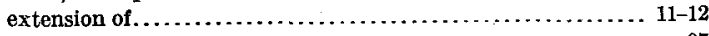

forests on $\ldots \ldots \ldots \ldots \ldots \ldots \ldots \ldots \ldots \ldots \ldots \ldots \ldots \ldots \ldots \ldots, \quad 97$

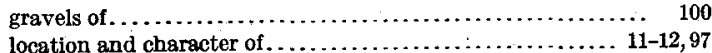

location and character of . ......................... 11-12, 97

view of ............................................ 18

Funston, Frederick, explorations by . . . . . . . . . . . . . . . . . . . 23

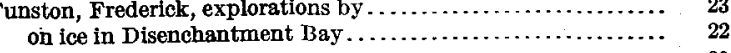

on rain records .................................... 30

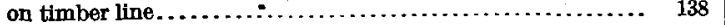

G.

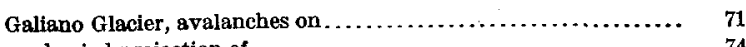

buried projection of $\ldots \ldots \ldots \ldots \ldots \ldots \ldots \ldots \ldots, 74$

changes in .................................. $71-74,90,94$

description of .............................................

fan of $\ldots \ldots \ldots \ldots \ldots \ldots \ldots \ldots \ldots \ldots \ldots \ldots \ldots \ldots \ldots \ldots \ldots \ldots \ldots, 72-73$

moraine of $\ldots \ldots \ldots \ldots \ldots \ldots \ldots \ldots \ldots \ldots \ldots \ldots \ldots \ldots \ldots \ldots \ldots \ldots \ldots \ldots \ldots, 71,72$

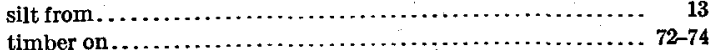

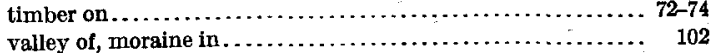

lannett, Henry, work of

Geological Survey, explorations by ..

Geologic changes, explanation of...................... 141-144

Geologic map of region.

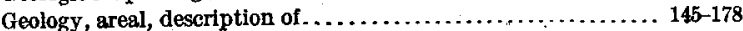

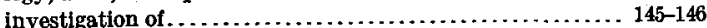
See Stratigraphy; Structure.

Geology, economic, description of . . . . . . . . . . . . . . . . . Geology, glacial, description of . . . . . . . . . .

Gilbert, G. K., on glacial erosion ....................... 107

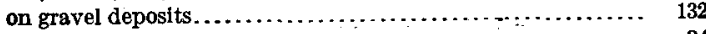
on glaciers of region.

on Hidden Glacier. $125-126$
Gilbert, G. K., on Hubberd Glacier ......... Page. on Nunatak Glacier.

on Turner Glacier . .............................

Glacial erosion. See Erosion, glacial.

Glaclal streams, mouths of, types of ................. . $\quad 50$

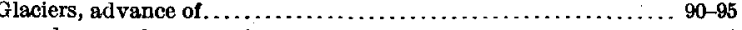

advance of, causes of . . . . . . . . effects of $\ldots \ldots \ldots \ldots \ldots \ldots \ldots \ldots \ldots \ldots \ldots \ldots \ldots \ldots \ldots \ldots \ldots \ldots, \quad 95$ See also particular glaciers.

deposits of $. \ldots \ldots \ldots \ldots \ldots \ldots \ldots \ldots \ldots \ldots \ldots \ldots \ldots \ldots, 124$ See also particular glaciers.

elevation of . . . . . . . . . . . . .

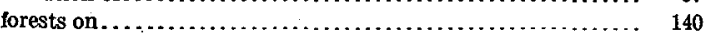

former expansion of ......................

map showing ...................................... 106

grade of ..................................... 105-106

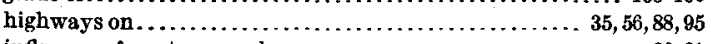

influence of, on topography $\ldots \ldots \ldots \ldots \ldots \ldots \ldots \ldots \ldots \ldots \ldots \ldots \ldots . . .30-31$

movement of direction of ........................... 119

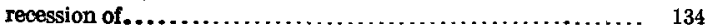

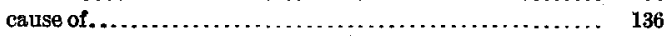

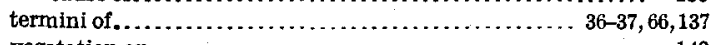

vegetation on .................................... 140

See also Through glaciers; Fan glaciers.

Glaciers, valley, descriptions of..................... $35-80$

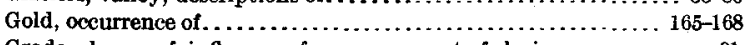

Grade, change of, influence of, on movement of glaciers......... 91

Gravels, glacial, accumulation of . . . . . . . . . . . 26, 30-31, 100,120-137 accumulation of, explanation of . . . . . . . . . . . . . . . . 134-137

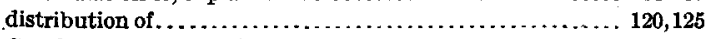
See also particular glaciers.

Graywacke, character and distribution of . . . . . . . . . . petrography of . ................................. 171-172

Greenstones, character and distribution of . ............... 150-152 petrography of $\ldots \ldots \ldots \ldots \ldots \ldots \ldots \ldots \ldots \ldots \ldots \ldots \ldots \ldots \ldots, 174$

Grinnell, C. V., work of. ................................. 24

$\mathrm{H}$.

.............................. 42,90 description of . . . . . . . . . . . . . . .

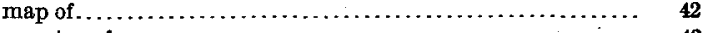

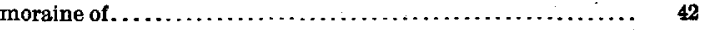

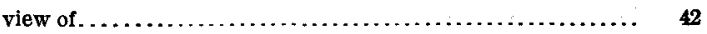

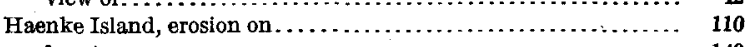

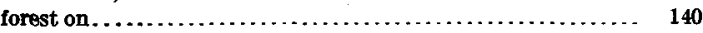

location and character of ............................ 16

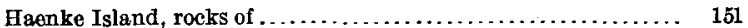

views from................................. 38,42

Hanging valleys, discordance of... . . . . . . . . . . . . . . . 114,117

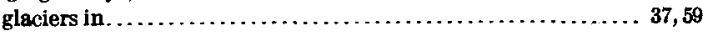
production of, by erosion . . . . . . . . . . . . . . . . . . . . . 109 type of ......................................... 112

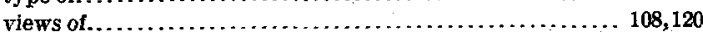

Harriman Alaska Expedition, explorations by ............... 24

Hayden Glacier, ablation on........................... $\quad 82$ avalanche moraine on $. . \ldots \ldots \ldots \ldots \ldots \ldots \ldots \ldots \ldots \ldots \ldots, \quad 83$ description of..................................... 81-83 fan of $\ldots \ldots \ldots \ldots \ldots \ldots \ldots \ldots \ldots \ldots \ldots \ldots \ldots \ldots \ldots \ldots \ldots, 122-123$ relation of, to Malaspina Glacier . . . . . . . . . . . . . . . . . 81-82

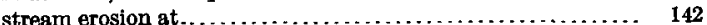

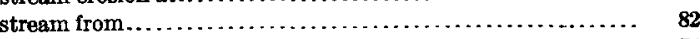

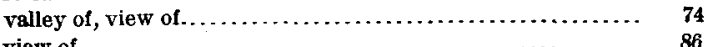

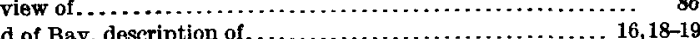

Hesd of Bay, description of . ........................ 105,133,135

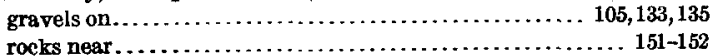

Hendrickson Glacier, deseription of ..................... 133

location of ......................................... 18

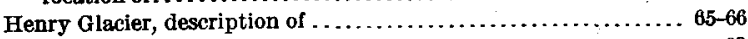

Hidden Glacier, buried extension of........................ 63 description of................................... 59-64

forest in $\ldots \ldots \ldots \ldots \ldots \ldots \ldots \ldots \ldots \ldots \ldots \ldots \ldots \ldots \ldots, 140$

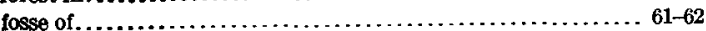

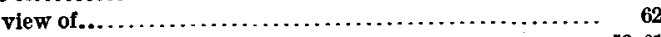

glacial streams from $. . \ldots \ldots \ldots \ldots \ldots \ldots \ldots \ldots \ldots \ldots \ldots, 59,61$

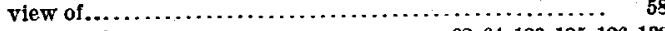

gravels of and near..................... 62-64, 120, 125-126, 132 erosion and overriding of ......................... 126-127 
INDEX.

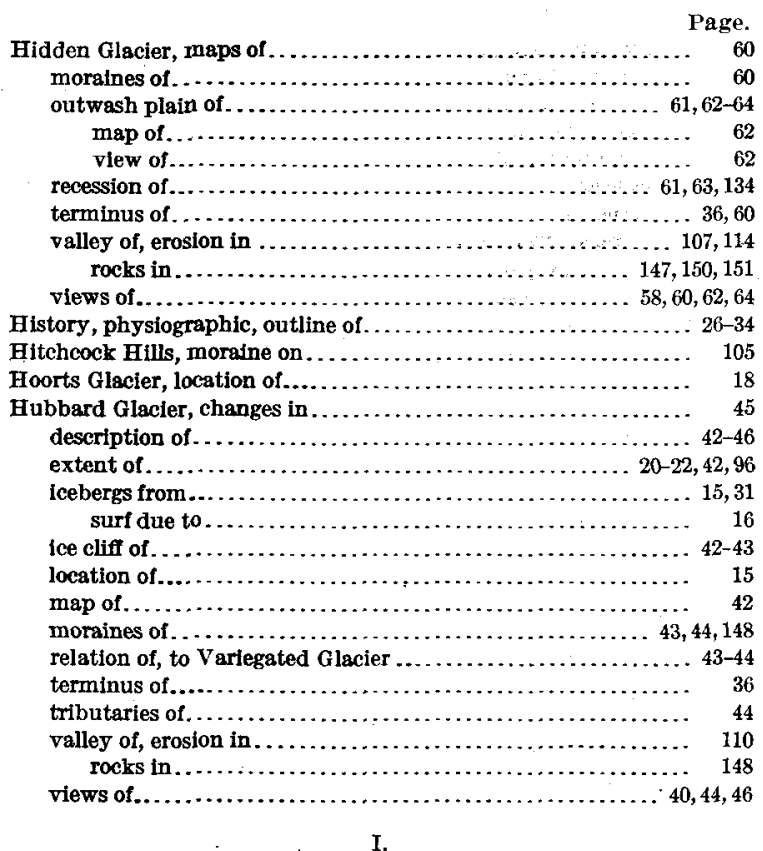

Ice, extent of..

Icebergs, breccias from

calving of....

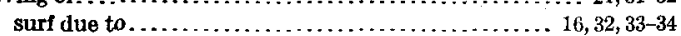

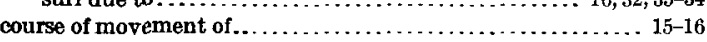

dispersion of . . . . . . . . . . . . . . . . . . . . . . .

geologic effects of $\ldots \ldots \ldots \ldots \ldots \ldots \ldots \ldots \ldots \ldots \ldots \ldots \ldots \ldots, \quad 33$

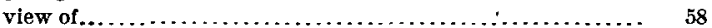

Ice foot, projecting, evidence of . . . . . . . . . .

Ice tunnel, description of.............................. 47

view of...................

Igneous activity, history of.................

International boundary, survey of ........................... 23

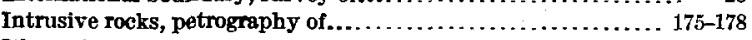

Ithaca, ice erosion near.

K.

Kame Stream, location of

Keeler, Charles, work of

ettles, formation and destruction of...................63 views of.

$131,165,167-168$

hantaak Island, gold on

location of .............. 14

Knight Island, gravels of.................................. 131

location of............

Knowlton, F. H., on Yakutat fossils

Kwik River, distributaries of

gravel deposits of lagoon of ................................... 123-124, 144 location of.

silt in.

sources of.

$83,86,122$

L.

La Perouse, explorations by.

Latouche, Point, moraine on...

valley of, erosion in

Level, subequality of....

Limestones, character and distribution of . . ............. 150-152,154 petrography of..

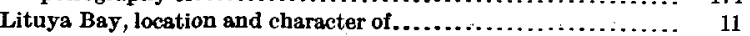

Logan, Mount, elevation of . . . . . . . . . . . . . . . . .

Iogan Beach, gold on.... .......................... 166-167

Lucia Glacier, changes in ......................... 80,90,94 description of.

forest on....

$78-80$

moraine of

numatak in.

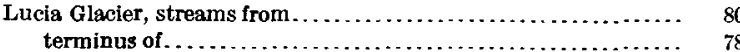

I'age.

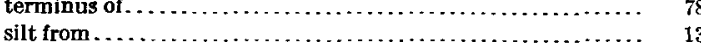
Lucia Stream, description of . . . . . . . . . . fan of $\ldots \ldots \ldots \ldots \ldots \ldots \ldots \ldots \ldots \ldots \ldots \ldots \ldots \ldots \ldots \ldots \ldots \ldots \ldots \ldots, 143$

M.

McCarty, Mount, description of.......... 17

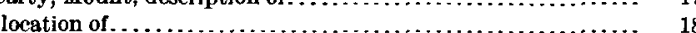

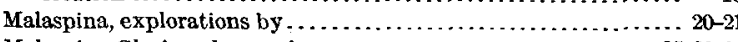

Malaspina Glacier, changes in . . . . . . . . . . . . . . . . . 85-88, 94

débris from ....................................... 13

description of . . . . . . . . . . . . . . . . . . . . . $11-89,136$

explorations of.................................... $81-89,136$

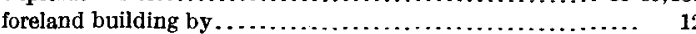

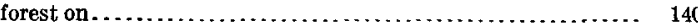

icebergs from . ...

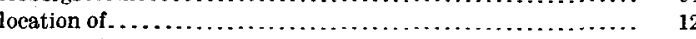

relation of, to Yakutat Bay Glacier................... 100

terminus of $\ldots \ldots \ldots \ldots \ldots \ldots \ldots \ldots \ldots \ldots \ldots \ldots \ldots \ldots \ldots \ldots \ldots \ldots \ldots \ldots \ldots \ldots \ldots \ldots, 37,87$

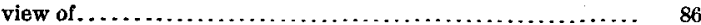

See also Marvine Glacier; Hayden Glacier; Blossom Island.

Map, geologic, of region...

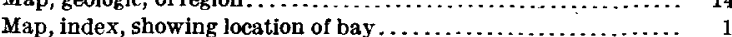

Marble Point, location of ......................................... 16

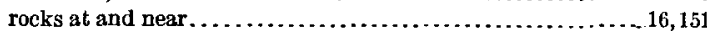

Martin, Lawrence, work of .................................... 11,24

Martin, Lawrence, and Tarr, R. S., papers by, on region..........

Marvine Glacier, changes in ......................... 85-88,90,94

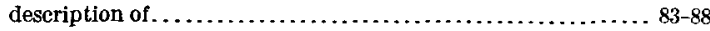

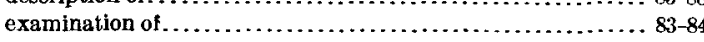

forest on, destruction of .......................... 86

streams from......................................... $85-86$

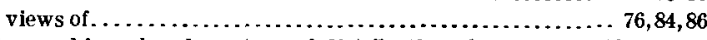

Metamorphic rocks, character and distribution of....... $27-28,147-152$ petrography of................................. 173-175

Miller, C. R., on Yakutat foreland....................... 98

Miller, Lake, description of . . . . . . . . . .................. 98

Moraines, deposition of, by formerly expanded glaciers.......... 96-106

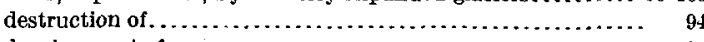
development of ................................... 37 elevations of ..................................... 101-10 occurrence of ........................................ 66

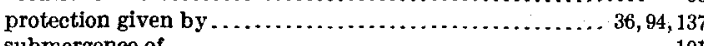
submergence of.................................. 101 See also particular glaciers.

Moraines, banded, cause of ............................. 50-51

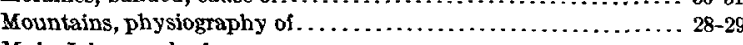

Muir, John, work of................................. 24

Muir Inlet, conditions at . .......................... 135-136

Muscovite granite, petrography of .................... 177-178

$\mathrm{N}$.

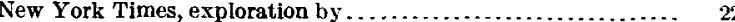

Northwest Arm, description of ............................ 16-17

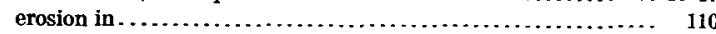
gravels in . . . . . . . . . . . . section of, figure showing ........................ 130 rocks on ............................ 27-28,147, 149, 150,152

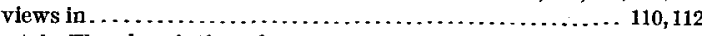

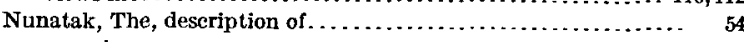
gorge in ...................................... 57,142 gravels on ...................................... 129

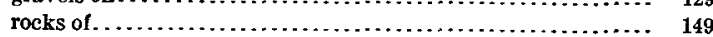
petrography of...................................... $174-175$ views from.......................................

Nunatak Fiord, description of . . . . . . . . . . . . . . . . . . . 16, 17-18

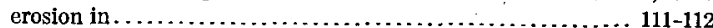

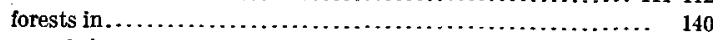

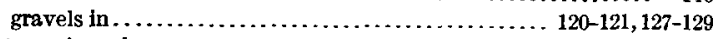

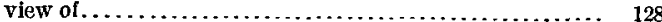
rocks of $. \ldots \ldots \ldots \ldots \ldots \ldots \ldots \ldots \ldots \ldots \ldots \ldots \ldots, 147,149-150$ views in .................................. 16, 108

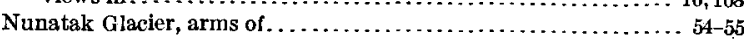
description of ........................... distributaries of.............................. 17, 55-57

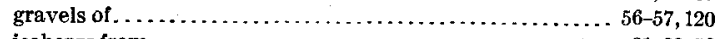

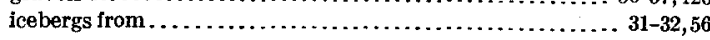




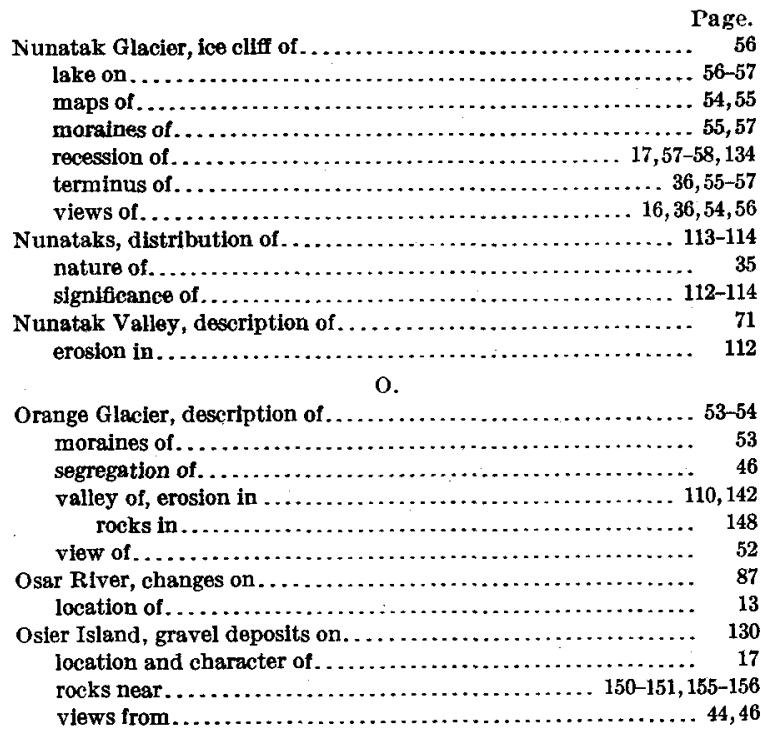

\section{$P$}

Panhandle coast, deseription of

Peninsula minor glaciers of $\ldots .65-67$

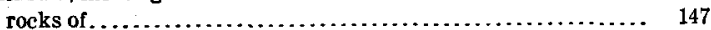

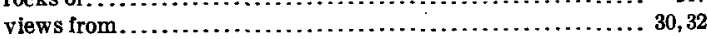

Petrography, study of . . . . . . . . . . . . . . . . . . . . . . . .

Petroleum, oceurrence and character of .................. 169-170

Physiography, description of. . . . . . . . . . . . . . . . . . . . 11-144

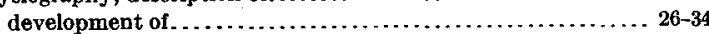

Pinnacle Pass, rocks at..

Pinnacle system, use of term.

Pinta, Mount, gravels near.

Planation, explanation of .................................

Platinum, nonoccurrence of.......................... 168

Powers, R. R., work of .............................. 11,25

Puget, Peter, explorations by

R.

Rain, records of ..................

(18

Reid, H. F., on iceberg formation ......................

Rejuvenation, erosion phenomena explained by .............. 117

Rich, J L., work of...

Ruhamah, Mount, elevation of . gravels near.................................. 132-133

Russell, I. C., explorations by.

on Black Glacier....

on changes in glaciers below snow line................ 37,74

on coal occurrences .

on Galiano Glacier ..................................

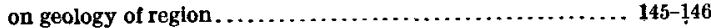

on glacial erosion. . $\ldots \ldots \ldots \ldots \ldots \ldots \ldots \ldots . . .29,107$

on gravel depasits. ........ 131-132

on iceberg formation. . . . . . . . . .

on ice-flooded regions. . . . . . . . . . . . . . . . .

on Malaspina Glacier. . ............................ 81,122

on Nunatak Glacier................................ 57,58

on snow line...................................... 38

on Variegated Glacier.

Russell Fiord, description of........................... 16-19

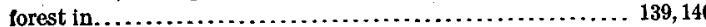

glaciers on east side of ............................... 6

gravels on, view of . ................................ 128

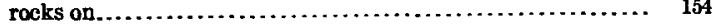

trees in view of $\ldots \ldots \ldots \ldots \ldots \ldots \ldots \ldots \ldots \ldots \ldots \ldots, 128$

views in...................................... 18, 108

See also Northwest Arm; South Arm; Head of Bay.

Russell Fiord Glacier, description of.

Russians, occupation by.
S.

Page.

St. Elias, Mount, cosst near............................ 11, 12 location and character of .......................... 12 Scldmore, E. R., on gold ............................... 165 on Yakutat region......................................

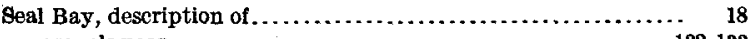
gravels near....................................... 132-133 tributaries to.............................................

Sediment, transportation of, by icebergs...................... 33 Sedimentary rocks, petrography of ...................... 171-173

Seward Glacier, changes in............................. 84, 90 movement of..................................... 85

Shelter Cove, description of . . . . . . . . . gravels near. . . . . . . . . . . . rocks near....................................... 151 Situk River, description of ................................ 98 Slate, character and distribution of. ........................ 149-150 petrography of . ................................. 173-174

Slate Hill, groove on, view of........................... 110

Snow, burrowing effects of ............................. 143 precipitation of, by earthquake......................... $91-93$ Snow line, elevation of .................................. 38 Soll, inclusion of, in glacial deposits..................... 86-87

South Arm, description of $\ldots \ldots \ldots \ldots \ldots \ldots \ldots \ldots \ldots \ldots \ldots \ldots \ldots \ldots \ldots \ldots \ldots, 16,18$ erosion in......................................... 114-115

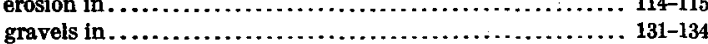
view of............................................... 128 rocks near........................................ 147

vlews on $\ldots \ldots \ldots \ldots \ldots \ldots \ldots \ldots \ldots \ldots \ldots \ldots \ldots \ldots \ldots \ldots \ldots \ldots \ldots \ldots \ldots \ldots, 18,132$

Stamy, Mount, elevation of.............................. 16

Stanley-Brown, J., on beach gold ........................... 165

Stanton. T. W., on Yakutat fossils...................... 158

Stoss, Cape, description of . . . . . . . . . . . . . . . . . . . . . . . 18

Stratigraphy, description of ............................... 146-163

Streams, erosion by ............................ 116-117, 141-142 ridged form of...................................... 123

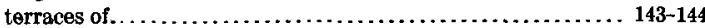
See also Glacial streams.

Striæ, evidence of.................................. 119

Structure, geologic, description of .................. 26-28,163-164

Sumner Glacier. See Turner Glacier.

Surf, iceberg origin of . .................. production of, by falling glacier......................... $67-68$

T.

Tarr, R. S., papers by, on region......................... 25

Tarr, R. S., and Martin, L., papers by, on region.............. 25

Tebenkoff, Mount, moraine on ........................ 105

Terrace Point, moraine on ............................ 103-304

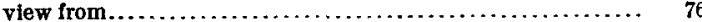

Terraces, formation of. .............................. 143-144 See also Gravels.

Tertiary rocks.................................... 162-163 character and distribution of .................. 26, 147-148,160-163 fossils in ........................................ 162-163

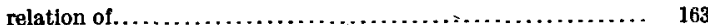
sections of ............................................. 160-161

Through glaciers, alpine type of ........................... 37 existence of ............................................. 105 nature of......................................... 35-36

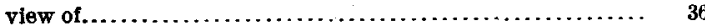

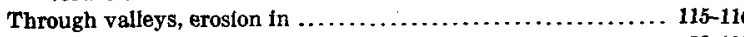

Timber line, elevation of . . . . . . . . . . . . . . . . . .

Topham, explorations by .............................. 22

Topography, influence of glaciers on..................... 30

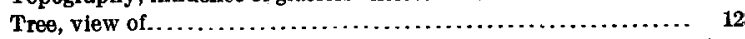

Turner Glacier, changes in........................... $40-41$ description of . . .................................... 39-41

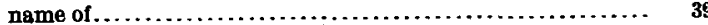
nunatak under............................................

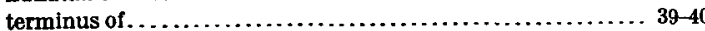

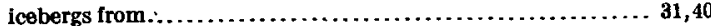

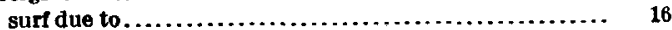

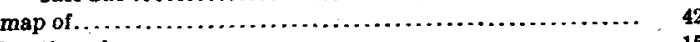
location of............................................ 
Turner Glacier, moraine of

motion of.

views of.

Ulrich, E. O., on Yakutat formation work of.

Tnana, Mount, elevation of

Uplift, influence of, on movement of glaciers. ...................

Valdez, menace of glaciers to

Valley glaciers. See Glaciers, valley.

Valleys, ice-flooded character of

physiography of

See also Through valleys; $Y$-shaped valle

Vancouver, George, explorations by on through glaciers

Vancouver series, use of term.

Variegated Glacier, changes in

description of

drainage of, change in...................

extent of.

fan of....

fan of...

moraines of.

map and section of

relation of, to Hubbard Glacier
Page.

146,157

24
Variegated Glacier, valley of, erosion in

rocks in.

.

views of and near........................................... $148,50,52,142$

Vegetation, distribution of . ............................. 138-141 See also Forest.

Waves. See Surf.

W.

Weathering, work of.

$142-143$

$\mathbf{Y}$.

akutat Bay, bed of, contour of.

bed of, contour of figure showing.................. 14-15, 101

description of ... 14

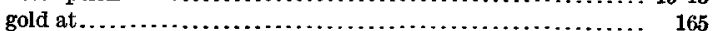

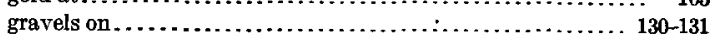

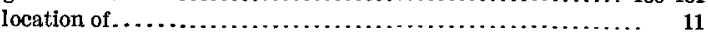

Yakutat Bay Glacier, erosion by .................... 107-108

relation of, to Malaspina Glacier..................... 100

Yakutat Bay Inlet, description of ..................... 12-19

Yakutat group, age of ................................. 157-158 character and distribution of........ 27, 145-146, 147-148, 150, 152-160

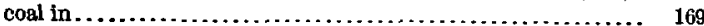

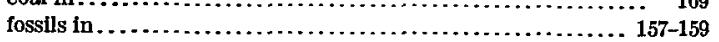

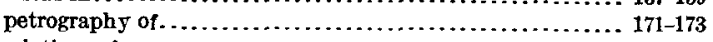

relations of . . . ................................... 153, 163

structure of .................................. 158-159

$Y$-shaped valleys, erosion in ................................. 116 

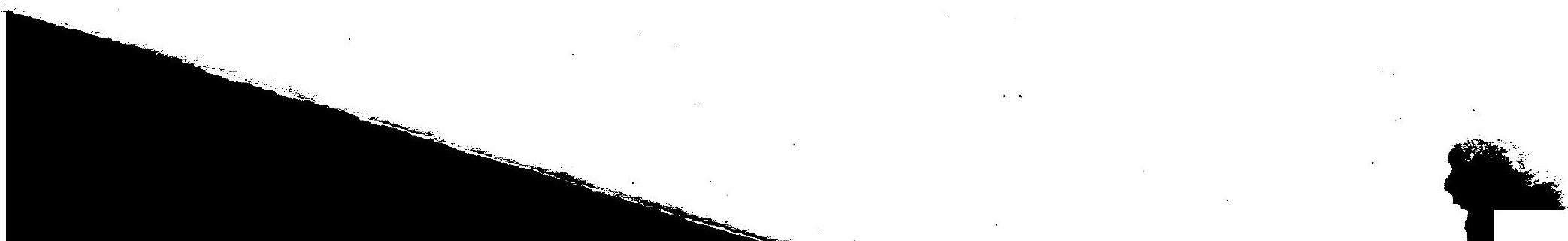